







\subsection{3}

\section{PROCEEDINGS}

OF THE

\section{Biological Society of $W$ ashington}

\section{VOLUME 62}

1949

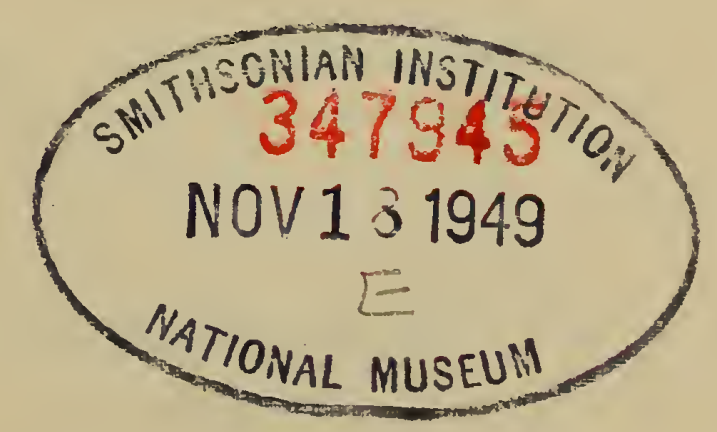

WASHINGTON

PRINTED FOR THE SOCIETY 


\title{
COMMITTEE ON PUBLICATIONS
}

\section{HERBERT FRIEDMANN, Chairman}

\author{
REMINGTON KELLOGG \\ E. P. KILLIP \\ J. S. WADE
}

\section{PUBLICATION NOTE}

By a change in the By-Laws of the Biological Society of Washington, effective March 27, 1926, the fiscal year now begins in May, and the officers will henceforth hold office from May to May. This, however, will make no change in the volumes of the Proceedings, which will continue to coincide with the calendar year. In order to furnish desired information, the title page of the current volume and the list of newly elected officers and committees will hereafter be published soon after the annual election in May.

All correspondence should be addressed to the Biological Society of Washington, c/o U. S. National Museum, Washington, D. C.

Monumantal Printing Co.

BaLtimore, MD. 


\section{OFFICERS AND COUNCIL \\ OF THE \\ BIOLOGICAL SOCIETY OF WASHINGTON \\ (FOR 1949-1950)}

(ELECTED MAY 14, 1949)

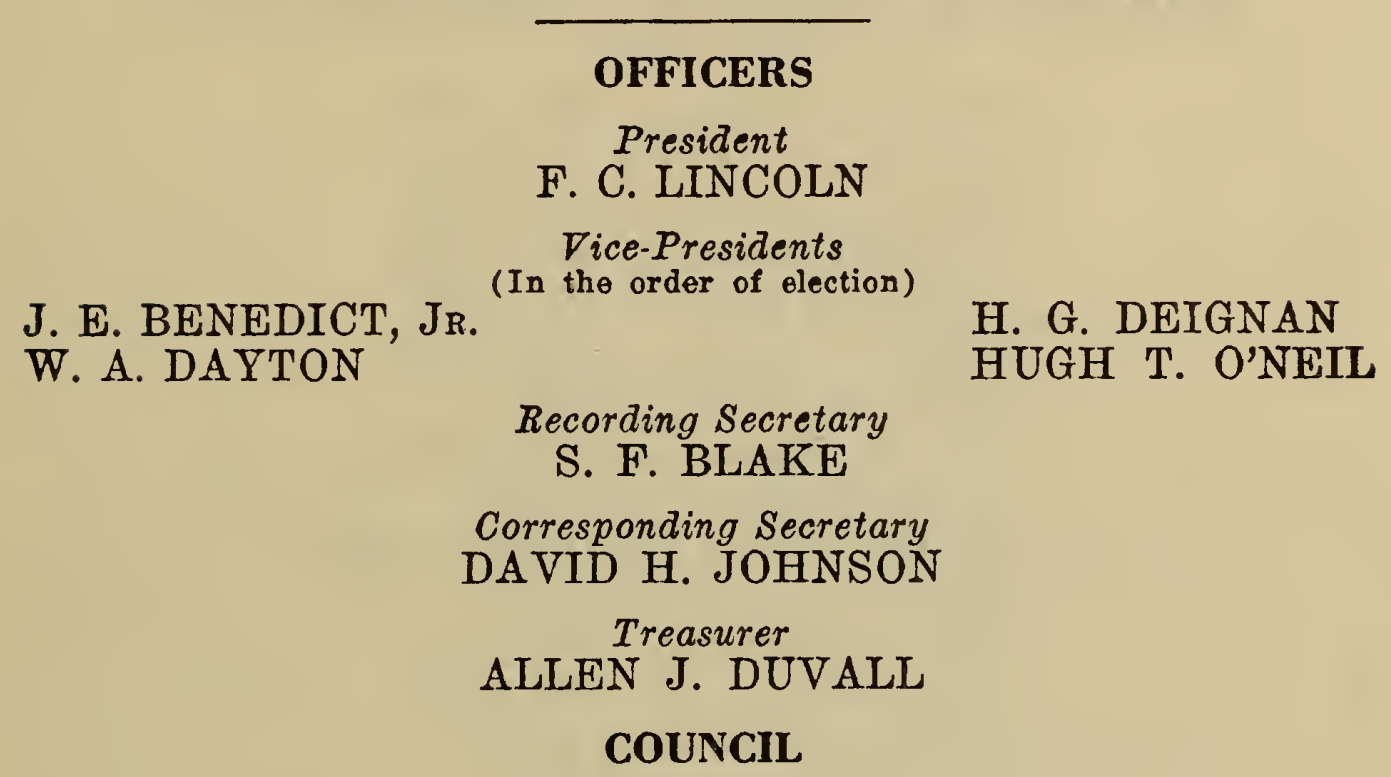

MALCOLM DAVIS

Elected Members

H. A. BORTHWICK

W. H. STICKEL

H. J. DEASON

L. W. SWIFT

J. W. ALDRICH

PAUL BARTSCH

Ex-Presidents

C. E. CHAMBLISS

A. D. HOPKINS

L. O. HOWARD

H. B. HUMPHREY

H. H. T. JACKSON

H. C. OBERHOLSER

T. S. PALMER

S. A. ROHWER

J. S. WADE

E. P. WALKER

A. WETMORE

\section{STANDING COMMITTEES-1949-1950}

Committee on Communications

R. M. GILMORE

MaLCOLM DAVIS, Chairman

HugH T. O'NeIL

LLOYD W. SWINT

Committee on Zoological Nomenclature

Austin H. Clark, Chairman

Paul Bartsch

A. WETMORE
H. H. T. JACKSON

C. F. W. MUESEBECK

Committee on Publications

HERBERT FrIEDMANN, Chairman

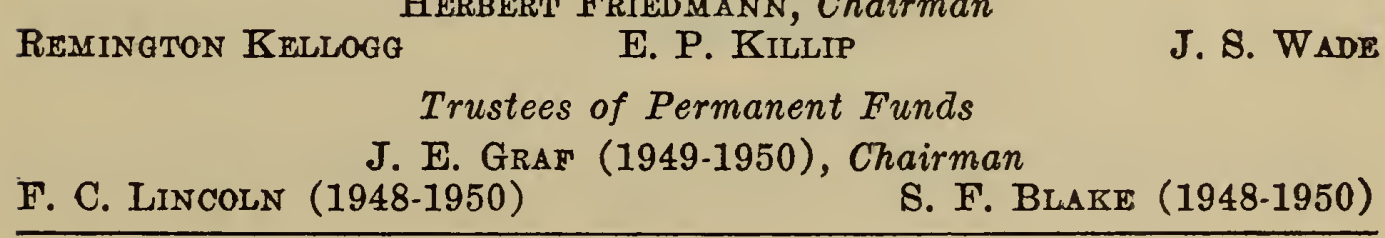




\section{EX-PRESIDENTS}

OF THE

\section{BIOLOGICAL SOCIETY OF WASHINGTON}

*THEODORE N. GiLl, 1881, 1882

*Charles A. White, 1883, 1884

*G. BRown Goode, 1885, 1886

*William H. Dahl, 1887, 1888

*Lester F. Ward, 1889, 1890

*C. Hart Merriam, 1891, 1892

*C. V. RILEY, 1893, 1894

*Geo. M. Sternd berG, 1895, 1896

L. O. Howard, 1897, 1898

*Frederick V. Coville, 1899, 1900

*F. A. LuCas, 1901, 1902

*B. W. EvermanN, 1903, 1904

*F. H. KNowlton, 1905, 1906

"L. STEJNEGER, 1907, 1908

T. S. Palmer, 1909, 1910

*David White, 1911

*E. W. Nelson, 1912, 1913

Paul Bartsch, 1914, 1915

*W. P. HAY, 1916, 1917

*J. N. Rose, 1918

*Hugh M. Smith, 1919

A. D. Hopkins, 1920

*N. Hollister, 1921

* Vernon Bailet, 1922

*A. S. Hitch Cock, 1923

*J. W. GidLex, 1924

S. A. ROHWER, 1925

H. C. OBERHOLSER, 1926-1927

*E. A. Goldman, 1927-1929

AleXander WeTMore, 1929-1931

H. H. T. JACKSON, 1931-1933

C. E. Chambliss, 1933-1936

*H. C. Fuller, 1936-1938

${ }^{*}$ W. B. BeLL, 1938-1940

E. P. W ALKER, 1940-1942

H. B. HUMPHREX, 1942-1944

*F. THONE, 1944-1946

J. S. W ADE, 1946-1947 


\section{TABLE OF CONTENTS.}

Officer's and Committees for 1949

i-iv

Proceedings for 1949

ix-xii

A new Name for the Genotype of Walchia Ewing (Acarina:

Trombiculidae), by Henry S. Fuller

A New Genus and Four New Species in the Diplopod Family Xystodesmidae, by Ralph V. Chamberlin

A New Family in the Diplopod Order Chordeumida, by Ralph V. Chamberlin.

A New Race of the Southern Indian Green Pigeon, by S. Dillon Ripley

Generic Names of the Four-eyed Pouch Opossum and the Woolly Opossum (Didelphidae), by Philip Hershkovitz

Technical Names of the African Muishond (Genus Zorilla) and the Colombian Hog-nosed Skunk (Genus Conepatus), by Philip Hershkovitz

$11-12$

A New Crayfish of the Genus Orconectes from the Nashvilie Basin in Tennessee, with Notes on the Range of Orconectes compressus (Faxon) (Decapoda, Astacidae), by Horton H. Hobbs, Jr.

A New House Finch from the Palouse Country of the Northwestern United States, by John W. Aldrich

Two New Coyotes from the United States, by Hartley $\mathrm{H}$. T. Jackson

Eight New Birds from the Subtropical Zone of the Paria Peninsula, Venezuela, by William H. Phelps and William H. Phelps, Jr.

Descriptions of Some Undescribed Forms Belonging to Two Little Known Species of the Family Aphididae, by F. C. Hottes

Descriptions of the Sexual Forms of Some Species of Aphididae, by F. C. Hottes.

$31-32$

$33-44$

Geographic Variation in the Ribbed Frog, Ascaphus truei, by M. B. Mittleman and George S. Myers

A New Loach of the Genus Acanthophthalmus from Siam, by Robert R. Harry

On a Collection of Sea-stars from the Philippine Islands, by Austin H. Clark

Three New Species of Diplopoda from Virginia, by Richard L. Hoffiman

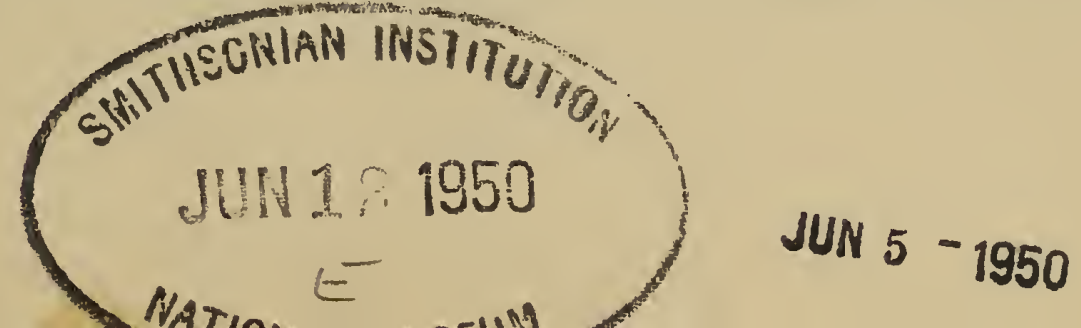


American Caudata. VI. The Races of Eurycea bislineata, by M. B. Mittleman.

Remarks on the Genus Ochetorhynchus Meyen, by Alexander Wetmore

A New Race of Pipilo fuseus from Mexico, by Robert T. Moore and James I. Peters $101-102$

A New Hummingbird of the Genus Lophornis from Southern Mexico, by Robert T. Moore 103-104

A New Species Belonging to the Genus Myzocallis (Aphididae), by F. C. Hottes

Eleven New Subspecies of Birds from Venezuela, by William H. Phelps and William H. Phelps, Jr. 109-124

Some Western Millipeds of the Family Chelodesmidae, by Ralph V. Chamberlin

Cavies of Southern Peru, by Colin Campbell Sanborn $133-134$

Some Recent Collections of Plethodon from Virginia with the Description of a New Form, by Arnold B. Grobman - 135-142

A New Pocket Gopher from Southeastern Utah, by Keith R. Kelson 143-146

A New Drymaria (Caryophyllaceae) from Mexico, by F. R. Fosberg $147-148$

A New Subspecies of Cotton Rat, Sigmodon hispidus, from Michoacan, Mexico, by E. Raymond Hall

A New Brunfelsia from Brazil, by C. V. Morton $151-152$

A New Subspecies of Funnel-eared Bat (Natalus Mexicanus) from Eastern Mexico, by W. W. Dalquest and E. Raymond Hall $153-154$

Two New Orioles from the Philippines, by E. T. Gilliard _... 155-158

Some Obscure Aphid Species, by F. C. Hottes $159-160$

An Additional Form of the South American Grasshopper Sparrow, by Alexander Wetmore 161-162

A New Harvest Mouse from Michoacan, Mexico, by E. Raymond Hall and Bernardo Villa R. $163-164$

A New Trimetopon (Ophidia) Irom Guatemala, by I. C. Stuart $165-168$

A New Subspecies of Harvest Mouse (Reithrodontomys) from Central America, by Emmet T. Hooper $169-172$

A New Race of Rallus nigricans from Colombia, by Boardman Conover

A New Race of Ptarmigan in Alaska, by Ira N. Gabrielson and Frederick C. Lincoln

Two New Species of Saldidae (Hemiptera) from Western United States, by C. J. Drake and F. C. Hottes $177-184$

Seven New Subspecies of Birds from Venezuela, by TVilliam H. Phelps and William H. Phelps, Jr. 
The Committee on Publications declares that each paper of this volume was distributed on the date indicated on its initial page. The contents, minutes of meetings, and index for 1949 (pp. v-xii, 197206) were issued on May 11, 1950. The title page and lists of offcers and committees for 1948-1949 (pp. i-iv) were issued on November 16, 1949.

\section{PLATES.}

Plate I, page 5. New Diplopods of the family Xystodesmidae.

Plate II, page 8. Ergethus perditus.

Plate III, page 25. Orconectes rhoadesi.

Plate IV, page 43. Map of Venezuela.

Plate V, page 87. New Diplopods from Virginia.

Plate VI, page 96. Distribution of Eurycea bislineata.

Plate VII, page 123. Map of Venezuela.

Plate VIII, page 126. Millipeds of the family Chelodesmidae.

Plate IX, page 150. Skull of Sigmodon hispidus atratus.

Plate X, page 181. Two new specimens of Saldidae.

Plate XI, page 193. Map of Venezuela. 
viii Proceedings of the Biological Society of Washington 


\section{PROCEEDINGS}

OF THE

BIOLOGICAL SOCIETY OF WASHINGTON

\section{PROCEEDINGS}

The Society meets from October to May on the second Saturday of each month at 8 P.M. All regular meetings during 1949 were held in Room 43 of the U. S. National Museum except the 984th meeting, held in the National Museum auditorium.

\section{- 979th Meeling-January 8, 1949}

President Aldrich in the chair; 72 persons present.

Informal Communications: Malcolm Davis, Note on the observation of a European ruff; Lorina Wendt, Note on the observation of crossbills at Lebanon, Virginia.

Formal Communication: Richard E. Griffith, Conservation of Alaska's wildlife resources.

\section{0th Meeting-February 12, 1949}

President Aldrich in the chair; 74 persons present.

New members elected: Ethan D. Churchill, E. Thomas Gilliard.

Informal Communications: Mr. Owen, Note on observation of a seal in upper Chesapeake Bay; J. W. Aldrich, Note on the nesting of the barn owl in the Smithsonian tower.

Formal Communication: Reese I. Sailer, The bloodsucking insects of Alaska.

\section{1st Meeting-March 12, 1949}

President Aldrich in the chair; 64 persons present.

Informal Communication: Frank Thone, Exhibition of new books on biological subjects.

Formal Communication: Robert F. Black, Geology of Alaska and its biological significance. 
982d Meeting-April 9, 1949

President Aldrich in the chair; 74 persons present.

Formal Communication: Hugh O'Neill, Vegetation of Alaska.

\section{Special Meeting-April 15, 1949}

Joint meeting with the Washington Academy of Sciences and the Entomological Society of Washington.

Formal Communication: Karl von Fritsch, University of Graz, The language of the bees.

\section{3rd Meeting-May 14, 1949 \\ 70TH ANNUAL MEETING}

President Aldrich in the chair; 20 persons present.

New members elected: Ross H. Arnett, Kenneth C. Parks, William O. Pruitt, Mrs. Anastasia J. Romanoff.

Reports were presented by the Recording Secretary, Treasurer, Committee on Publications, and Committee on Communications.

The following officers and members of council were elected:

President, F. C. Lincoln ; Vice Presidents, J. E. Bendict, Jr., W. A. Dayton, H. G. Deignan, Hugh O'Neill: Recording Secretary, S. F. Blake; Corresponding Secretary, D. H. Johnson; Treasurer, A. J. Duvall; Members of the Council, Harry A. Borthwick, Malcolm Davis, H. J. Deason, Lloyd W. Swift, Wm. Stickel.

The business meeting was followed by an open meeting, at which the records 'of frog and toad voices, prepared by A. A. Allen of Cornell University and sold under the title Voices of the Night, were played on the phonograph.

\section{Special Meeting-June 6, 1949}

Joint meeting with the Society for Parapsychology, Washington section.

Formal Communication: F. C. Lincoln, The homing instinct in birds.

\section{4th Mecting-October 6, 1949}

Joint meeting with the Washington Academy of Sciences and the Entomological Society of Washington.

Formal Communication: H. H. Stage, Observations of an entomologist in Africa and Mauritius ; Nagana, African sleeping sickness of animals (sound film). 
985th Meeting-November 12, 1949

President Lincoln in the Chair; 31 persons present.

New member elected: Abelardo Moreno.

Formal Communication: Lionel A. Walford, Sardines; It's the Maine sardine (color film).

986th Meeting-December 10, 1949

President Lincoln in the Chair; 43 persons present.

New members elected: Robert Rausch, Kenneth E. Stager.

Informal Communications: Clarence Cottam, Note on damage done by squirrels to lead pipe used to protect telephone wire; Malcolm Davis, Note on a turkey buzzard snatching a frankfurter from a small boy at the Zoo and eating it.

Formal Communication: Clarence Cottam, Conservation in New Zealand. 
xii Proceedings of the Biological Society of Washington 


\title{
PROCEEDINCS
}

OF THE

\section{BIOLOGICAL SOCIETY OF WASHINGTON}

\section{A NEW NAME FOR THE GENOTYPE OF WALCIIA EWING (ACARINA : TROMBICULIDAE)}

\author{
By HENRY S. FULLER
}

Trombidium glabrum Dugès dates from January, 1834, Annales des Sciences Naturelles, Seconde Série, Zoologie, 1, pp. 39-40. The description validates the name, but it is not adequate for recognition of the mite according to current standards.

Trombidium glabrum Walch dates from 1927, Geneeskundig Tijdschrift voor Nederlandsch-Indië, 67, pp. 924, 926-927, 932; table I: figs, 4-6. It was made the type of Walchia Ewing by original designation (Proc. U.S. Nat. Mus., 80, no. 2908, Art. 8, pp. 10-11). In mentioning the genotype, Ewing incorrectly referred its original descrip. tion to the genus Trombicula, a combination not used by Walch.

Since Trombidium glabrum Walch is preoccupied, it is rejected as homonym, and the writer hereby proposes for it

\section{Trombidium ewingi nomen novum}

The genus Walchia Ewing contains the following named species: Walchia ewingi nomen novum, genotype; of which $W$. pingue Gater, 1932 , is a synonym, according to Womersley and Heaslip (1943); $W$. enode Gater, 1932; lewthawaitei Gater 1932; W. rustica (Gater, 1932); W. turmalis (Gater, 1932); W. disparunguis (Oudemans, 1929); W. morobensis Gunther, 1939; and $\pi$. americana Ewing, 1942.

This paper is a byproduct of a revisionary study done during the period of tenure of a John Simon Guggenheim Memorial Fellowship.

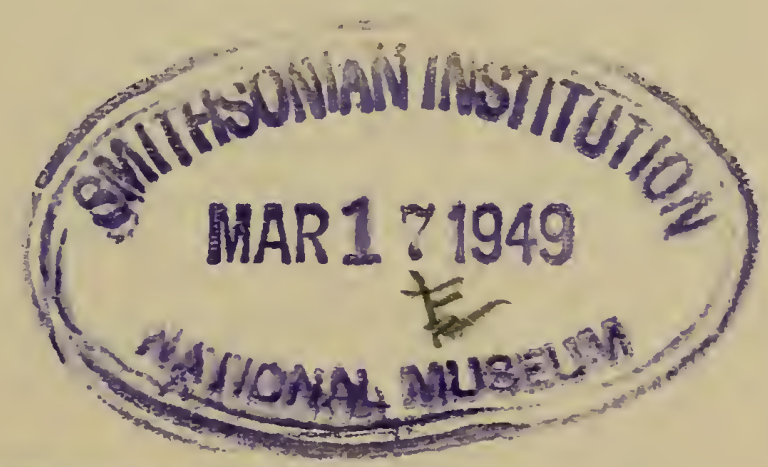

1 -PEOO. Bror. SOO. WАgH. FOK, 62, 1949. 

Vol. 62 , pp. 3.6

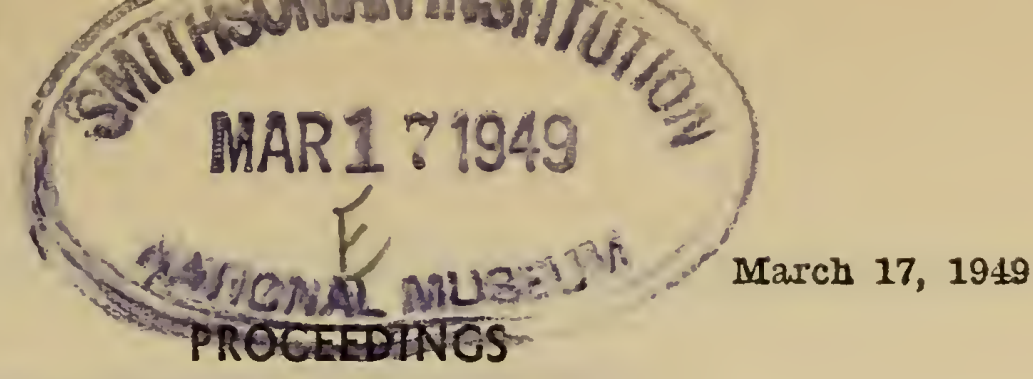

OF THE

BIOLOGICAL SOCIETY OF WASHINGTON

\section{A NEW GENUS AND FOUR NEW SPECIES IN THE DIPLOPOD FAMILY XYSTODESMIDAE}

\section{By Ralph V. Chamberlin}

The types of the new forms here described are in the writer's collection at the University of Utah.

\section{Genus Cherokia new}

Characterized by the structure of the gonopods of the male. In this the telopodite extends forward nearly at right angles to the coxa and is aistinctly divided into two segments of which the first is straight; the second division a blade that is distally furcate, with its terminal branch bidentate at tip. (See accompanying figure 1.) Generotype-Cherokio georgiana (Bollman).

While Bollman's Fontaria georgiana was previously placed by the present writer in the genus Mimuloria, it is now set apart because of the disinctly divided telopodite of the male gonopods, a feature that also distinguishes it from Rhysodesmus and other related genera.

\section{Sigmoria zyga new species}

Field notes record that in life this species has the caudal and lateral borders of the tergites red, with the edges white. In alcohol the red color fades out. The species is best distinguished by the form of the telopodite of the male gonopods, especially at its distal end which is prolonged into a slender curred process as represented in fig. 2.

Length, $35 \mathrm{~mm}$; width, $9 \mathrm{~mm}$.

Locality: North Carolina, between Hot Springs and Paint Rock. Two $\hat{o} \mathrm{~s}$ and one $q$ taken Aug. 7, 1910 by R. V. Chamberlin.

\section{Dynoria medialis new species}

In the preserved holotype the anterior part of the exposed portion of the tergites is chestnut while the keels and a broad band across caudal border are yellow; legs yellow.

Coxae of legs and sternites of middle and posterior segments with conical processes or spines.

Gonopods of $\hat{\delta}$ of same general form as those of icana; the telopodite lamellate, with a narrower proximal stem above which the blade expands as shown in the figures (Figs. $5 \& 6$ ). The supplementary process at the distal end closely applied to the main body, not widely divergent as it is in icana.

Length, about $45 \mathrm{~mm}$; width, $11 \mathrm{~mm}$.

Locality.-Georgia: Atlanta. Nale holotype taken July 12, 1946 by P. W. Fattig. 


\section{Nannaria cayugae new species}

This small form has the keels and a stripe across caudal border of tergites yellow in color, with remaining portion nearly black but lighter each side of middle, this giving appearance of two somewhat lighter longitudinal stripes. Legs light brown or yellow; antennae dark, nearly biack, distally.

Coxae all unspined. Posterior sternite with a pair of subconical processes or teeth at posterior border. Processes of coxae of second legs in male cylindrical, relatively short and stout, distally truncate.

Blade of gonopods of male moderately evenly curved, apically narrowed; with basal spine elongate, curved toward base, the distal portion more nearly straight. (See fig. 3).

Width, $4 \mathrm{~mm}$.

Locality: New York: Ithaca. One male taken in the summer of 1930.

Nannaria equalis new species

Dorsum black or in part deep chestnut excepting the keels, these being yellow; the sides also yellowish. Legs light brown, the antennae darker.

Pores lateral in position as usual in the genus.

Distinguished from other known species in peculiarities of the male gonopods. In these the main branch is straight excepting a short apical portion which is bent at right angles to the main axis. The basal spine nearly equals in length the telopodite proper and is a little clavately expanded distally. See further fig. 4.

Width of ô holotype $5.2 \mathrm{~mm}$.

Locality.-Tennessee: Knoxville. A male and female.

The female allotype is not in full color.

\section{Nannaria castanea (McNeill)}

Polydesmus castaneus MeNeill, 1887, Proc. U.S. Nat. Mus., 10:329, pl. 12 , fig. 8.

Fontaria castanea Bollman, 1893, Bull. U.S. Nat. Mus., No. 46, p. 123.

Mimularia castanea Chamberlin, 1928, Ent. News, 39:153.

Fontaria castanea Williams \& Hefner, 1928, Bull. Ohio Biol. Survey, No. $18: 106$, fig. $9 \mathrm{~B}$.

Nannaria ohionis Loomis \& Hoffman, Proc. Biol. Soc. Wash., 61:53.

Localities: Indiana and Ohio.

Loomis and Hoffman state (loc. sit.) that the form figured by Williams and Hefner "is distinctive in the subterminal tooth on the mesial process" of the of gonopod. However, McNeill in his original description gives a figure of the gonopod in which this characteristic tooth is plainly represented and it is present in all specimens from Indiana and Ohio. It seems obvious, therefore, that ohionis is typical castanea.

\section{Nannaria tuobita (Chamberlin)}

Fontaria tuobita (Cliamberlin), 1910, Ann. Ent. Soc. America, 3:243, P1. $25: 7,8$.

Nannaria ursa Chamberlin, 1938, Proc. Biol. Soc. Wash., 51:207.

Iocalities: Ncw Mexico: Clouderoft, Bear Canyon, Ruidosa, Glencoe, Fort Stanton, etc.

While varying considerably in size and coloration, there is complete intergradation between the extreme forms. 

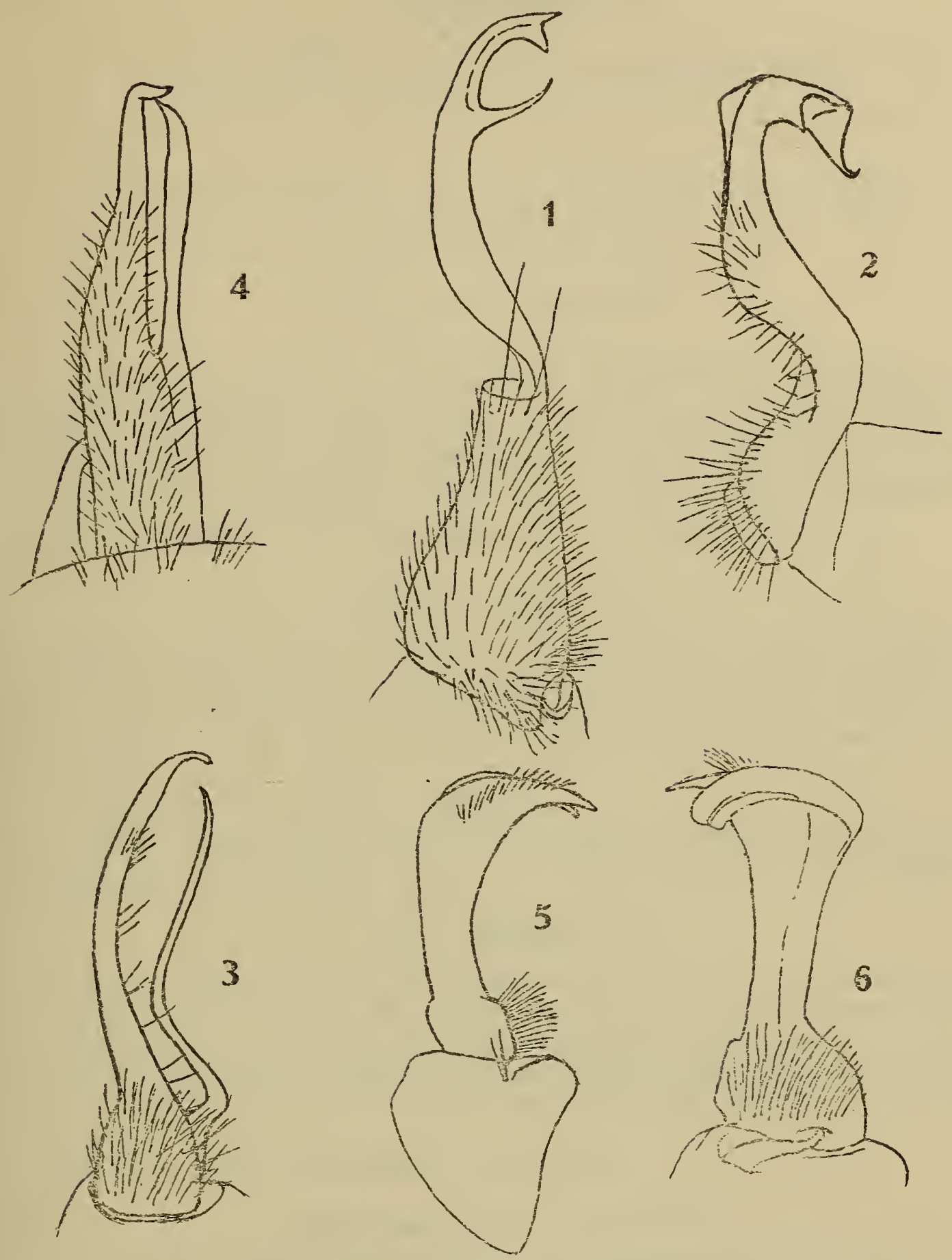

Explanation of Figures on Plate $I$.

Fig. 1. Cherokia georgiana (Bollman). Right gonopod of male, subventral view.

Fig. 2. Sigmoria zyga new species. Gonoped of male, subventral view.

Fig. 3. Nannaria cayugae new species. Right gonopod of male, submesal view.

Fig. 4. Nannaria equalis new species. Right gonopod of male, mesoventral view.

Fig. 5. Dynoria medialis new species. Left gonopod of male, ventral view.

Fig. 6. Dynoria medialis new species. Left gonopod of male, submesal view. 



\subsection{3}

Vol. 62 , pp. $7-8$

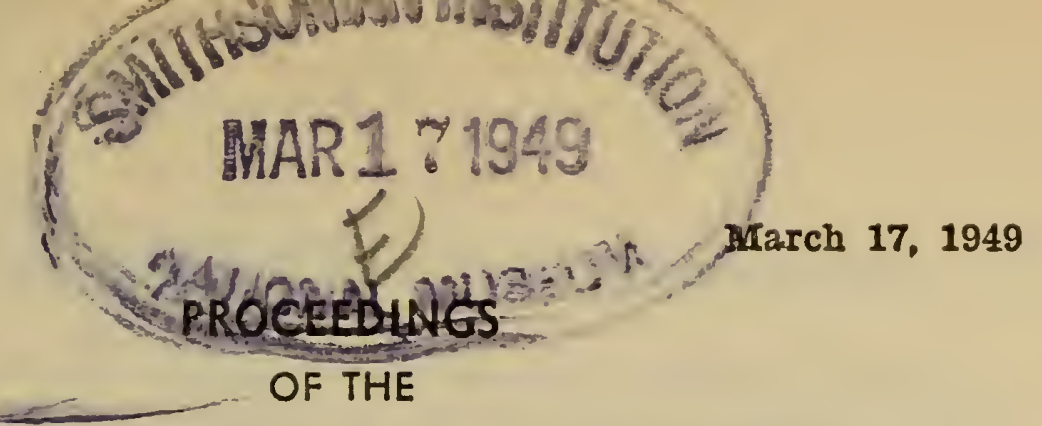

BIOLOGICAL SOCIETY OF WASHINGTON

\section{A NEW FAMILY IN THE DIPLOPOD ORDER CHORDEUMIDA}

By Ralph V. ChaMberlin

Among a number of diplopods collected by Stanley and Dorothea Mulaik, presumably in Texas near Kerrville are a female and two males representing a new genus and a distinctly new family in the suborder Chordeumidea of the order Chordeumida. Pertinent diagnoses are herein given.

\section{Family Ergethidae new}

Body composed of 20 segments. Mentum of the gnathochilarium entire, no promentum being set off; prebasilar sclerite complete, sclerolized entirely across with but very narrow at middle. Ocelli 17 on each side. Second legs of seventh segment in the male not at all modified.

Containing the new genus Ergethus.

Readily distinguished from other families in having the body composed of only 20 segments as well as in the characters of the gnathoehilarium as noted above.

\section{Genus Ergethus new}

With the characters of the family as noted above. Antennae long; first article very short, the second and third long and subequal; the fourth, fifth and sixth somewhat shorter, subequal. Telopodite of gonopods of male curved, distally broad and rather complicated. Second legs of the seventh segment of normal form and size. Surface of tergites smootl.

Generotype-Ergethus perditus new species.

\section{Ergethus perditus new species}

Body attenuated anteriorly and more abruptly posteriorly. Surface of segments smooth, with the segmental sulci fine and distinct. Last tergite with narrowed cauda projecting well beyond the caudal valves. Legs and antennae long.

Body in general brown, paler beneath and in more or less distinct annuli. Legs yellow.

Head depressed behind base of antenna on each side, the ocellus in the depression; retose, the setae longer and more dense in frontal and clypeal region; a fine median scelcus across vertex and down to a point between antennae above which interrupted.

Gnathochilarium with mentum subtriangular in outline, the acute apex extending between the lamellae linguales. 


\section{Proceedings of the Biological Society of Washington}

Collum moderately narrowed down each side; the lower margin nearly straight and the corners rounded, the caudal one more widely so.

Legs long and slender with the ultimate article considerably longer than the penult.

Gonopods of male are represented in figs. 1 and 2.

Length of $\hat{\sigma}$ holotype about $10.5 \mathrm{~mm}$; ; of $q$ allotype, about $12 \mathrm{~mm}$.

Locality: Texas: near Kerrville ( $\xi)$. One female and three males taken in the summer of 1939 by Stanley and Dorothea Mulaik.
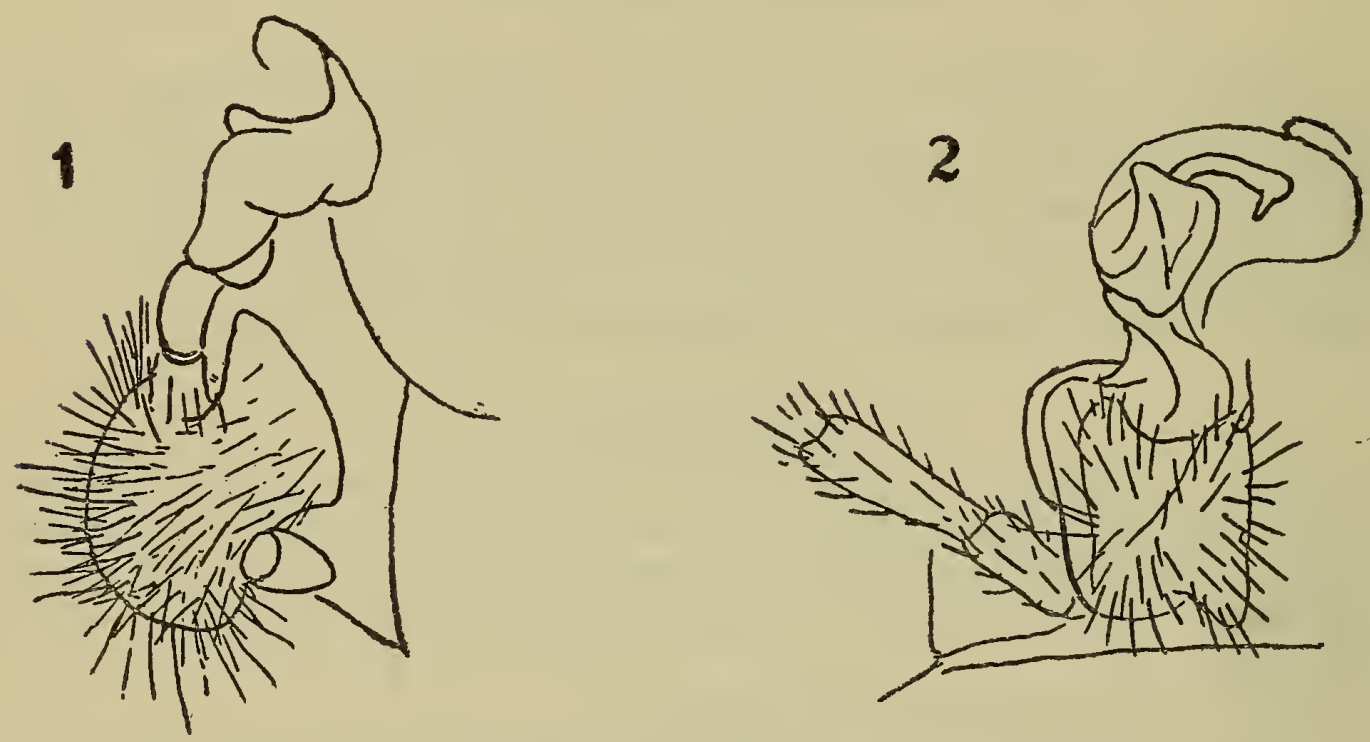

Explanation of Figures

Fig. 1. Left gonopod of male, ectal view.

Fig. 2. Right gonopod of male, ventral view. 
OF THE

\section{BIOLOGICAL SOCIETY OF WASHINGTON}

\section{A NEW RACE OF THE SOUTHERN INDIAN GREEN PIGEON}

By S. Dillon Ripley

Through the kindness of Mr. W. W. A. Phillips, the authority on Ceylon birds and mammals, I have had an oppor. tunity of examining specimens of the Southern Indian Green Pigeon recently secured by him in Ceylon. Mr. Phillips first came on this species in January, 1947 in the forests of Uva Province near Bibile, southeast Ceylon. His note on the occurrence was published in the Journal of the Bombay Natural History Society (47, No. 1, 1947, p. 162.). His record of these pigeons, which have been considered to be rare vagrants, is the first since that of Legge over 60 years ago. Later, specimens have been secured in September, November and February, some in breeding condition. Comparison of these birds with a series from South India reveals at once the presence of a new form which I propose as follows;

Treron phoenicoptera philiipsi subsp. nov.

Type.-of ad. (coll. S. Dillon Ripley No. 1801. Type on deposit in the Peabody Museum of Nat. Hist.), collected February 26, 1948, by W. W. A. Phillips at Nilgala near Bibile, Uva Province, S. E. Ceylon.

Diagnosis.-from chlorigaster of southern India this race differs by being smaller and by being duller yellow on the nape, more greenish, and duller, more grayish-green on the back and wings: below these birds lack the lemon yellow neck and breast. The yellow is confined to a sub-mental spot and to a patch about the vent and thighs. The breast and abdomen are dull greenish-yellow, more infused with grayish-green than in chlorigaster. The vinous shoulder patch also is duller and slightly darker than in chlorigaster. The measurements follow;

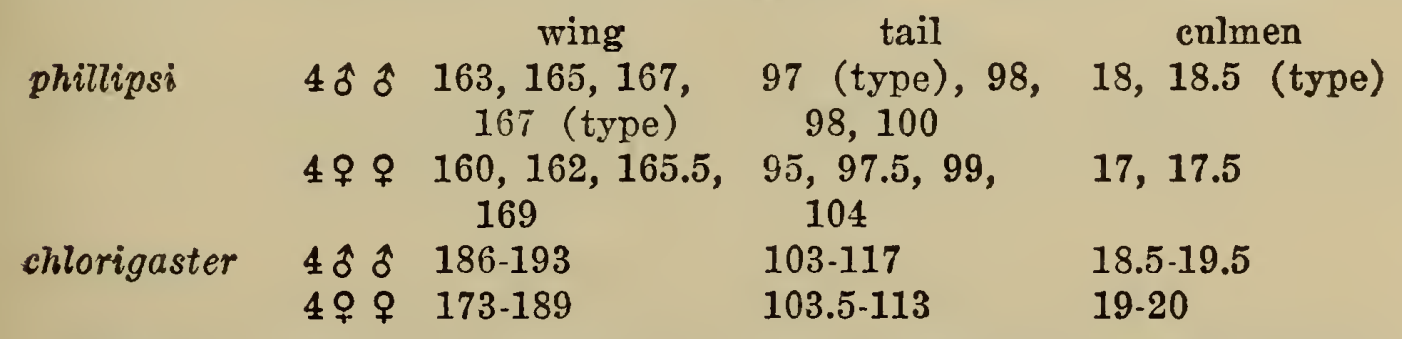

Range.-Ceylon, so far found only in Uva Province in the southeast of the Island.

4-Proo. BIOL. SOC. WASH., VOL. 62, 1949. 


\section{Proceedings of the Biological Society of Washington}

Remarks.-It gives me great pleasure to name this form for my friend who has helped me so much in connection with my studies of Ceylon birds. Mr. Phillips has recently sent me the following notes;

1) color of soft parts; "iris (both sexes), inner ring blue, outer carmine; eyelids bluish gray; bill pale bluish white; legs chrome yellow."

2) notes on occurrence; "In general this Pigeon appears to behave in similar manner to other Green Pigeons. It keeps chiefly to the tops of trees, and normally does not descend to the ground. During the winter period it collects in flocks and feeds on any berries and figs that may happen to be ripe. As they fly these Pigeons may be distinguished by the noise of their wings. A male shot Sept. 23rd was with two or three others and a number of Pompador Green Pigeons feeding in a Ficus. I now think that this Pigeon must be resident in the Bibile jungles as, had the one shot this day been a migrant, it would most probably have been with a flock-also Northeast Monsoon migrants are only just beginning to come in. The gonads of the present bird were fairly well developed. Other specimens collected in late February also had the gonads enlarged. In addition to figs these birds were found feeding on the berries of Vitex altissima, called locally "milla." This bird probably breeds during March and April."'

I am much indebted to Mr. J. D. Macdonald of the British Museum for measurements of a number of specimens of this form in the BM collection. 


\subsection{3}

Vol. 62, pp. 11-12

BIOLOGICAL SOCIETY OF WASHINGTON

\section{GENERIC NAMES OF THE FOUR-EYED POUCH OPOSSUM AND THE WOOLLY OPOSSUM (Didelphidae)}

By Philip Hershrovitz

Published opinions on the status of Philander Tiedemann (Zoologie, vol. 1, p. 426, 1808) are not convincing for lack of evidence that the work cited had been carefully studied or even consulted. Tiedemann's system of classification is Lin. naean with names for all hierarchies recognized (orders, families, genera, species) properly proposed and, for his time, adequately diagnosed. The following abstract from the "Zoo. logie" exposes the nature of the name Philander.
p. 426]
Geschlecht 1. Opossum. Philander (Didelphys L.)
(Sarigue)
[Generic description follows]

p. 427]

[Description continued]

Es gibt gegen 10 bekannten Arten:

1) Das Virginische Opossum. P. virginianus (Did. opossum L.) (le sarique Buff. T. X. p. 279.)

Körper röthlich braun. Ueber jedem Auge ein gelblich weiser Flecken. Schwanz so lang als der Leib.

1 Fuss und 3 Zoll lang ohne den Schwanz.

In Virginien, Mexico, Peru u. s. w.

Schreb. tab. 146, A. B.

Edw. Tyson Carigueya seu marsupiale Americanum or the anatomy of an opossum. Philos. Transact. V. 1698. p. 105, V. 1704, p. 1576.

William Cowper an account of the anatomy of those parts of a male opossum that differ from the female. Ibid. V. 1704. p. 1576.

2) Das mausartige Opossum P. murinus (Did. murina L.) (la marmose Buff. T. X. p. 335.)

p. 428]

[Specific description follows]

3) Das kurzgeschwänzte Opossum. P. brachyarus (Did. brachyuros Penn.) (le touan Cuvier Tabl. Element. d'hist. nat. p. 125.)

\section{[Specific description follows]}

The above three species are all that were included in the genus Philander. It is perfectly clear from the description and the references to Buffon, Linnaeus and Schreber, that the first species $P$. virginianus is merely a new name for the four-eyed pouch opossum, Didelphis opossum Linnaeus. The second species is a Marmosa, the third a Mono. delphis. As $P$. virginianus is virtually tautonymic, it is here designated 


\section{Proceedings of the Biological Society of Washington}

genotype of Philander Tiedemann. Designation of the woolly opossum, Didelphis philander Linnaeus, as genotype by Thomas (Catalogue of the Marsupialia and Monotremata in the collection of the British Museum, p. 336,1888 ) is untenable. In reality, the Philander of Thomas and sub. sequent authors is the homonym Philander Burmeister 1856, with type Didelphis philander Linnaeus.

Arguments presented by Allen (Bull. Amer. Mus. Nat. Hist., vol .13, pp. 188-189, 1900) against usage of Philander Tiedemann stem from a misunderstanding of the original composition of the genus and are not relevant. Nevertheless, Allen's substitution of his own Caluromys (D. philander Linnaeus type) for Philander authors (not Tiedemann), is accidentally valid. Tate's (Ibid., vol. 76, p. 164, 1939) rejection of Philander Tiedemann is based primarily on the misidentification of $\boldsymbol{P}$. virginianus as a Didelphis, and secondarily on the "homonymity" with Philander Brisson, 1762. This last in spite of the fact that Tate (op. cit. p. 161) listed Philander Brisson as an unavailable synonym of Metachirops Matschie! With all due respect for Tate's doubtful endorsement, Brisson's system of classification is non-Linnaean and merits no consideration. Furthermore, it already has been shown by Hopwood (Proc. Zool. Soc. London, vol. 117, p. 533, 1947), that Brisson's generic names are pre-Linnaean and unavailable in any case. Hopwood (op. cit. p. 535) erred, however, in naming "Didelphys philander Linnaeus" the genotype of Philander Tiedemann. In addition, he disinterred Philander Gronovius, 1763 , with the same genotype designated. Names by Gronovius are no better than those of Brisson and need not be revived at this late date ( $c f$. Opinion 89, International Commission on Zoological Nomenelature).

To avoid the possibility of future confusion, disposition must be made of two other and unused generic names each with several species including those under discussion. Genotype of Gamba Liais (Climats, geol. faune et geogr. bot. Bresil, p. 329, 1872) is here designated Gamba palmata Liais (= Chironectes minimus Zimmermann); genotype of Cuica Liais (loc. cit.) is here designated Cuica murina Liais (= Marmosa murina Linnaeus).

Pertinent data presented are summarized in the following synonymies,

Genus Philander Tiedemann (Four-eyed pouch opossums).

Philander Tiedemann, Zoologie, vol. 1, p. 426, 1808 (genotype, $P$ [hilander] virginianus Tiedemann $=$ Didelphis opossum Linnaeus).

Metachirops Matschie, Sitz-ber. Gessellsch. naturforsch. Fr. Berlin, p. 268, 1916 (genotype, Didelphis opossum Linnaeus).

Holothylax Cabrera, Genera Mammalium, (Monotremata, Marsupialia), Mus. Nac. Cien. Nat., Madrid, p. 47, 1919 (genotype, Didelphis opossum Linnaeus).

\section{Genus Caluromys Allen (Woolly opossums).}

Philander Burmcister, Erläuterungen Fauna Brasiliens, p. 74, Berlin 1856 (genotype, Philander cayopollin Burmeister $=$ Didelphis philander Linnaeus; homonym of Philander Tiedemann, 1808).

Caluromys Allen, Bull. Amer. Mus. Nat. Hist., vol. 13, p. 189, 1900 (genotypc, Didelphis philander Linnaeus).

Micoureus Matschie, Sitz-ber. Gesellsch. naturforsch. Fr. Berlin, pp. 259, 269 (genotype, Didclphis laniger Desmarest $=D$. lanata Olfers; homonym of Micoureus Lesson, 1842).

Mallodelphys Thomas, Ann. Mag. Nat. Hist., ser. 9, vol. 5, p. 195, 1920 (snbstitute name for Micoureus Matschie). 


\title{
PROCEEDINGS
}

\author{
OF THE
}

\section{BIOLOGICAL SOCIETY OF WASHINGTON}

\section{TECHNICAL NAMES OF THE AFRICAN MUISHOND (GENUS ZORILLA) AND THE COLOMBIAN HOG- NOSED SKUNK (GENUS CONEPATUS)}

By Philip Hershkovitz

Application of the typical specific name for the Cape Stinkmuishond or Striped Polecat is embroiled with names errone. ously applied to neo-tropical hog-nosed skunks. The Cape Stinkmuishond, currently listed as Ictonyx striatus Perry (cf. G. M. Allen, Bul. Mus. Comp. Zool., vol. 83, p. 179, 1939) is identical with the zorille described and figured by Buffon in 1755 (Hist. Nat., vol. 13, p. 289, 302-303, pl. 41 [misnumbered 29]). Unfortunately, Buffon believed that the animal originated in the New World. This led some authors to compare and even to identify the zorille with the South American mapurito or mafutiliqui mentioned by Gumilla (El Orinoko illustrado y defendido, vol. 2 , p. 276, 1745; Hist. nat., civ. et geogr. l'Orenoque, vol. 8, p. 240, 1758). These blunders were corrected by Cuvier in 1801 (in Azara, Essais Hist. Nat. Quad. Paraguay, French transl., vol. 1, p. 239, footnote a) and in several later works. Cuvier showed that Buffon's zorille, which he termed Viverra zoralla Linnaeus (Gmelin), is a native of the Cape of Good Hope and not related to any American or European mustelid. This correction was sustained until Lichtenstein laboriously attempted to identify the zorille with a representative of the North American genus Spilogale! A. H. Howell, in revising the genus (North American Fauna No. 26, p. 11-12, 1906) was inclined to follow suit but prudently rejected the name for any known form of Spilogale. The white edged ears and the extensively whitened tail of the zorille, clearly figured by Buffon and others (Schreber, Shaw, etc.) are diagnostic of the Cape Stinkmuishond and positively eliminate from consideration all American mustelids.

Of numerous technical names applied to the zorille or Cape Stinkmuishond, the earliest, based solely on Buffon's reference, is Viverra napurito Müller, 1776.

It has already been shown (A. H. Howell, Proc. Biol. Soc. Washington, vol. 19, p. 46, 1906; Hershkovitz, in press, Journ. Mamm., vol. 30, 1949) 


\section{Proceedings of the Biological Society of Washington}

that Oken's vernacular term "zorille" cannot be used as the generic zame for the African polecats. Ictonyx Kaup, 1835, proposed as a substitute, is antedated by Zorilla I. Geoffroy, 1826 (Dict. Class. Hist. Nat., Paris, vol. 10, p. 215, type by monotypy "Le Zorille, Buff., T. XIII, pl. 41; Mustela Zorilla et Viverra Zorilla des auteurs systématiques" = Viverra mapurito Müller). Originally proposed as a subgenus of Mustcla, Zorilla was raised to generic rank by Cuvier (Dict. Sci. Nat., p. 449 , 1829). Accordingly, the scientific name for the zorille or Cape Stinkmuishond, stands as follows, with the partial synonymy included as s supplement to the references given above and by G. M. Allen (op. cit.).

\section{Zorilla mapurito Müller}

Viverra mapurito Müller, Linn. Syst. Nat., Suppl., p. 32, 1776.

Diverra zorilla Schreber, Säugth., Theil 3, p. 445 (description), pl. 123 (name), 1777.

[Viverra] zorilla Erxleben, Syst. Reg. Anim., p. 492, 1777. Shaw, General Zoology, vol. 1. pt. 2, p. 391, pl. 94 (top fig.), 1800 (part; ref. to Schreber and Buffon). Gmelin, Linn. Syst. Nat., ed. 13, vol. 1, p. 88, 1788 (part).

[Viverra] zoriile Boddaert, Elenchus Animalium, p. 84, 1784.

Mustela zorilla, Lacépède, Buffon Hist. Nat., ed. Didot, vol. 13, p. 163, 1799. Desmarest, Mammalogie, p. 181, Atlas pl. 86, fig. 4, 1820 [1821].

Ictonyx striatus striatus, G. M. Allen, Bull. Mus. Comp. Zool., vol. 83, p. 179, 1939 (synonymy).

Type locality. - None given in original description; determined by Cuvier, sup. cit.) as Cape of Good Hope, South Africa.

The named forms of the species include: Zorilla mapurito albescens Heller, Z. m. elgonis Granvik, Z. m. erythreae De Winton, Z. m. intermedius Anderson and De Winton, $Z$. m. lancasteri Røberts. Z. m. maximus Roberts, Z. $m$. obscuratus de Beaux, $Z$. m. pondoensis Roberts, $Z$. $m$. senegalensis Fischer, $Z$. m. shoae Thomas, Z. m. sudanicus Thomas and Hinton.

Shortridge (The Mammals of South West Africa, vol. 1, p. 197, 1934), regards limpopoensis Roberts and shortridgei Roberts as identical with the typical form.

\section{The Colombian Hog-Nosed Skunk}

Notwithstanding published allegations to the contrary, the only basis for the name Viverra mapurito Gmelin, is a Colombian and not a Mexican hog-nosed skunk. This name, as shown above, is preoccupied and cannot be used for any New World mustelid. The first scientific description of the Colombian hog-nosed skunk is due to the celebrated naturalist and eminent botanist, José Celestino Mutis. This scholar, born in 1732, in Cadiz, Spain, sailed for Cartagena, Colombia, in 1760. Until his death in Bogota, in the year 1808, Mutis devoted himself to the study of the natural phenomena of Colombia. It was during a four year expedition to Las Minas de Mantuosa, near Pamplona, Norte de Santander, Colombia, that Mutis discovered the animal in question. A complete description of the skunk under the misnomer "Viverra putorius," was addressed October 6, 1767 to a Swedish friend, Alströmer, who secured its publication in 1770 (Kongl. Vetenskap. Acad. Haudl., Stockholm, 
rol. 31, p. $67-77$ ). In 1771 , Linnaeus included in the Mantissa (2, p. 522) a Latin summary of the original deseription still under the name "Viverra putorius." Schreber (Säugth., Theil 3, heft 26, p. 445-6, 1777) gave a German translation of the description and introduced the Spanish vernacular name mapurito. Schreber continued the use of the misnomer "Viverra putorius," however, and, through a lapsus, assigned both the type locality, Pamplona, and the residence of Mutis, Sante F'e (= Bogotá), to "Mexico." In 1784, Boddaert (Elenchus Animalium, p. 84) disengaged Mutis' skunk from the synonymy of Viverra putorius Linnaeus, a Spilogale, and designated it Viverra semistriata. Unhappily, this author carelessly followed Schreber in eiting "Mexico" as the habitat. The same error was repeated later by Gmelin (Linn. Syst. Nat., ed. 13, rol. 1, p. 88, 1788) who proposed the preoccupied name Viverra mapurito as a substitute for "Viverra putorius Mutis." Hum. boldt (Rec. Obs. Zool. Anat. Comp., vol. 1, p. 350, 1811 [1812] who with Bompland (vide Ann. Mus. Hist. Nat., Paris, vol. 4, p. 476-477, 1804) became acquainted with Mutis and his collections in Bogotá, recognized and redefined the Colombian skunk under the name Viverra mapurito Gmelin. At the same time, Humboldt reasserted the Colombian origin of the type specimen and recorded additional Colombian (Fusugasugá; Santa Fé de Bogotá) and Ecuadorian (Loja) localities for the pecies. Another specimen from Quito, Ecuador, was regarded as distinct and named Gulo quitensis.

The foregoing historical facts are summarized in the following synonymy. A few collateral references are included for disspelling any confusion still remaining in certain quarters.

\section{Coneptaus semistriatus Boddaert}

Viverra putorius Mutis (nec Linnaeus, 1758) Kongl. Vetenskap. Acad. Handl., Sweden, vol. 31, p. 66-67, 1770. Linnaeus, Mantissa, 2 appendix p. 522, 1771. Müller, Linn. Syst. Nat., Suppl., p. 31, 1776. Schreber, Säugth., Theil 3, heft 26, p. 445-446, 1777 ("Der Mapurito," Mexico!).

[Viverra] semistriata Boddaert, Elenchus Animalium, p. 84, 1784 [1785] (based solely on reference to Mutis, 1769 [1770]).

[Viverra] mapurito Gmelin (nec Müller, 1776), Linn. Syst. Nat., ed. 13, vol. 1, p. 88, 1788 (based solely on reference to Mutis).

M[ephitis] mapurito, Lichtenstein, Abh. k. Akad. Wiss. Berlin, phys. K1., 1836, p. 270, 1838 (Colombia).

[Fiverra] conepatl Gmelin, Linn. Syst. Nat., ed. 13, vol. 1, p. 88, 1738 (based solely on "conepatl ... Hernand[ez], Mex[iio], p. 232," 1651).

Gulo quitensis Humboldt, Rec. Obs. Zool. Anat. Comp., vol. 1, p. 347, 1811 [1812] (type locality, Quito, Ecuador).

Mephitis zorilla Fischer, Synopsis Mammalium, p. 162, 1829 (based solely on the "mapurito" of Gumilla; type locality, Río Orinoco, Venezuela).

Y [ephitis] gumillae Lichtenstein, Abh. k. Akad. Wiss. Berlin, phys. K1., 1836, p. 276, 1838 (based solely on reference to the "mapurito" of Gumilla; name antedated by zorilla Fischer).

$\boldsymbol{M}$ [ephitis] amazonica Lichtenstein, Abh. k. Akad. Wiss. Berlin, phys. K1., 1836, p. 275, 1838 (type locality, Rio Amazonas; collected by Mawe, British Museum). 


\section{Proceedings of the Biological Society of Washington}

Conepatus semistriatus, A. H. Howell, Proc. Biol. Soc., Washington, vol. 19, p. 45, 1906. Cabrera and Yepes, Mamíferos sud-americanos, Historia Natural Ediar, p. 154, 1940 (Colombia and Venezuela). Type locality.-Las Minas de Mantuosa, near Pamplona, Norte do Santander, Colombia. 


\title{
74.0673
}

Vol. $62, \mathrm{pp} .17-28$

March 17, 1949

\section{BIOLOGICAL SOCIETY OF WASHINGTON}

\section{OF THE \\ PROCEEDINGS}

\begin{abstract}
A NEW CRAYFISH OF THE GENUS ORCONECTES FROM THE NASHVILLE BASIN IN TENNESSEE, WITH NOTES ON THE RANGE OF ORCONECTES COMPRESSUS (FAXON) (DECAPODA, ASTACIDAE)

By HoRTON H. HoBBS, JR.1
\end{abstract}

Apparently the first specimens of the new species described below were collected by Mr. J. E. Benedict at Nashville, Tennessee, in May, 1897. Faxon (1914:383) mistakenly identified them as Orconectes validus. Fleming (1939), in his report on "The Larger Crustacea of the Nashville Region," was ap. parently unaware of Faxon's record for Orconectes validus, and he included no reference to a form which can be ascribed to this species. It is possible that the range of this new species is somewhat restricted in the Nashville area; however, Dr. C. S. Shoup of Vanderbilt University, and Dr. Mike Wright of Tusculum College have collected it in several localities (see below) south of Nashville.

The Virilis section of the genus Orconectes, of which this species is a member, has a rather large range in the central part of the United States; however, only one member of this assemblage has been previously reported from the Cumberland River drainage. In "The Crayfishes of Kentucky. . "' Rhoades (1944:133) recorded Orconectes compressus (Faxon 1884:127) from the lower Cumberland drainage in Kentucky, but it is not known to oceur in tributaries above the mouth of Little Fiiver in Kentucky.

Since in $\mathrm{my}$ collection there are several new locality records for Orconectes compressus, I am including them below with a brief summary of the present knowledge of this species.

Genus Orconectes Cope 1872

Orconectes compressus (Faxon)

Cambarus compressus Faxon, Proc. Amer. Acad. Arts and Sci. 20:127, 1884.

Faxon 1884: 124, 127-128, 146; Faxon 1885a: 85, 86, 102, 105-107, 161, 167, 174, 178, Pl. V, fig. 6, Pl. X, figs. 2, 2', 2a, 2a'; Faxon 1885b: 359; Faxon 1914: 419; Fleming 1939: 306; Goodnight 1940a: 222-223; Goodnight 1940b: 170; Harris 1903: 60, 83, 146, 151; Hay 1899: 960, 962; Ortmann 1902: 278; Ortmann 1905: 110, 112, 127 ; Ortmann 1931: 90, 94, 95.

orconectes compressus Hobbs 1942: 352 (by implication); Rhoades 1944: 113, 133, 134.

${ }^{1}$ Miller School of Biology, University of Virginia.

7-Proo. BioL. Soc. WAsy., Vou. 62, 1949. 


\section{Proceedings of the Biological Society of Washington}

In the bibliography above only three papers make any contribution to the distribution or ecology of 0 . compressus. In the original description Faxon (1884:128) gives two locality records, but ecological notes are wanting. No new information was published until Goodnight (1940) gave an account of the rediscovery of $O$. compressus in Mississippi. The third contribution was that of Rhoades (1944) who recorded this species from several counties in Kentucky and noted observations he had made on its habits.

Range.-Tributaries of the Tennessee River in Alabama, Mississippi and Tennessee; tributaries of the Cumberland River in Tennessee and Kentucky; and tributaries of the Barren River in Tennessee and Kentucky.

\section{ALABAMA}

Lauderdale County-Tennessee drainage.

1. ${ }^{2}$ Second Creek, Waterloo (Type Locality)-Faxon 1884:128.

2. ${ }^{2}$ Cyprus (sic.) Creek-Faxon 1884:128.

3. Second Creek, Waterloo ( $1 \hat{\delta} I, 1$ ) - L. Stewart, collector, December 7, 1938.

4. Cypress Creek, 3 miles north of Florence ( $4 \hat{\delta} \delta$ III, $12 q \%$ )-I. J. Marchand, collector, June 8, 1941.

Limestone County-Tennessee drainage.

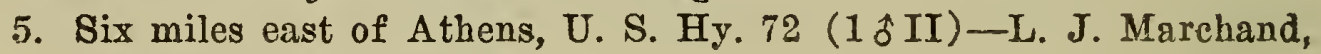
collector, June 8, 1941.

KENTUCKY (Rhoades 1944:133) No localities were cited.

6. Barren County-Barren River to Ohio River.

7. Simpson County-Barren River to Ohio River.

8. Allen County-Barren River to Ohio River.

9. Warren County-Barren River to Ohio River.

10. Trigg County-Little River to Cumberland River.

\section{MISSISSIPPI}

Tishomingo County-Tennessee drainage.

11. ". . small stream between Inka, Mississippi and the Alabama border near U. S. Route 72', (10 of of II, $12 q$ q)-C. J. Goodnight (1940:222), collector, August 22, 1939.

\section{TENNESSEE}

Clay County-Barren River to Ohio River.

12. Big Trace Creek, Hermitage Springs ( $8 \hat{\jmath} \hat{\jmath}$ II, 1 o ) -C. S. Shoup, Mike Wright, and H. H. Hobbs, collectors, April 29, 1945.

Maury County-Duck River to Tennessee River.

13. Creek near Mt. Pleasant (2 $\hat{\delta} \hat{\delta} I I, 1 \%$ )-Fred Campbell, collector, Summer 1945.

Ecology.-The first ecological notes published on 0 . compressus were those of Goodnight. In describing the Mississippi locality cited above he stated "The crayfishes were found in a small rocky stream with a bed of pebbles and sand. The water was clear and cold, apparently spring fed. This observation would tend to indicate that this species is an inhabitant of the clear cold streams of the hills of the area. When disturbed the crayfishes hid by erouching on the bottom of the ereek. Their brown color made them very difficult to detect against the stream

2From the two localities C. L. Herrick collected $18 \sigma^{\circ} \sigma^{\circ} \mathrm{I}, 2 \sigma^{\circ} \sigma^{\circ} \mathrm{II}$, and $19 \% \%$, in October. 1882. 
bottom. . This species is extremely fast and agile in its movements." Goodnight (1940:222).

According to Rhoades, Orconectes compressus "is a common species of the lower Teunessee and tributaries" (1944:133); however, he cites no records except those of Faxon and Goodnight. Further, he states that this "species has crossed the drainage divide between the Cumber. land and Barren rivers. The species is common to abundant through. out the Barren River drainage" (ibid.). Since this species has not been found in the upper Cumberland I judge that Rhoades is postulating the crossing of the divide in Kentucky. With reference to the habits of compressus in Kentucky he points out that specimens are "easily mis. taken for immatures of associated species in seined collections and their color blends so perfectly with the gravelly stream beds that they are difficult to detect for hand collecting. These characters combined with their habit of remaining motionless on the bottom when disturbed may account to some extent for the obscurity of the species"' (ibid).

Cypress Creek is a rock and gravel bottomed, clear, swift stream some 20-60 feet wide with occasional deep holes having muddy bottoms. In writing to me about $O$. compressus in this locality Mr. Marchand stated that they "live in holes in the gravel along edges of quiet shallow pools." About the locality near Athens, he described the creek as a "small, rocky-bottomed creek with a good flow of clear water."

Big Trace Creek at Hermitage Springs where I collected was a very swift, clear, rock and gravel bottomed stream and some three feet deep in the deepest place. The water was so swift at the time I collected there that when I waded in over two feet it was difficult to stand. Here the crnvfish had apparently scooped out shallow burrows under the larger pebbles and stone, and when these stones were turned the crayfish in most instances remained perfectly still until further molested, where. upon they swam away with amazing rapidity. Whereas most of the specimens which escaped my net took advantage of the strong current and went down-stream, a number of them demonstrated their swimming ability by making fairly good headway for short distances upstream.

Thus it seems probable that this species is associated with clear, rock or gravel bottomed streams, and the widely scattered localities suggested a rather widespread distribution in Tennessee.

The morphological differences which exist between the specimens which I hare examined are negligible.

\section{Orconectes rhoadesi, ${ }^{3}$ sp. nov.}

Cambarus validus Faxon, Mem. Mus. Comp. Zool., Harvard Coll., 40 (8) : 383,1914 , (in part). Ortmann, Ann. Carnegie Mus., 20 (2):94, 1931, (in part).

Diagnosis.-Rostrum with margins interrupted, small lateral snines or tabercles may or may not be present; margins not conspicuously thickened, either subparallel or slightly convergent; median carina absent. Chela punctate except for two irregular rows of ciliated squamous tubercles along inner margin of palm; opposable margin of immovable finger bearded at base. Areola approximately 8 or 9 times

sI take pleasure in naming this new species in honor of $m v$ friend and colleague, Dr. Rendell Rhoades, of the Ohio Division of Conservation and Natural Re sourees. 


\section{Proceedings of the Biological Society of Washington}

longer than broad witl two or three punctations in narrowest partlength 32-34 percent of entire length of carapace. In male, hooks on ischiopodite of third pereiopod only. Terminal elements of first pleopod of first form male extending to base of second pereiopod, and separated for some distance proximad of tips; terminals, subequal in length and subparallel, extend almost straight to base of distal third where they bend abruptly caudad so that the distal cephalic surfaces of both are almost at right angles to the main shaft of the appendage. Annulus $v \in$ ntralis immovable (see fig. 9 for surface contour).

Holotypic Male, Form I.-Body subovate, somewhat depressed. Abdomen narrower than thorax (14.9-16.6 mm.). Width of carapace greater than depth in region of caudodorsal margin of cervical groove (16.6-13.4 mm.).

Areola of moderate width (8.3 times longer than broad), with two or three punctations in narrowest part; cephalic section of carapace about 2.1 times as long as areola (length of areola about 32 percent of entire length of carapace).

Rostrum with margins not thickened, slightly divergent at base, but for the most part subparallel. Upper surface concave and with prominent, somewhat crowded punctations. Base of acumen set off by minute corneous tubercles. Acumen short; tip broken in holotype but ending in a long spine in other specimens; this spine reaching distal end of peduncle of antennule. Subrostral ridge moderately developed and evi. dent in dorsal aspect for more than half the length of the rostrum. Weak rostral ridge flanked mesially by a row of setiferous punctations.

Postorbital ridge prominent, grooved laterad, and terminates cephalad iil a small corneous tubercle. Suborbital angle weak and rounded. Branchiostegal spine small but acute. Small lateral spine present on each side of carapace. Surface of carapace granulate laterally and bearing conspicuous punctations dorsally; the usual polished area in the gastric region bearing conspicuous punctations also.

Cephalic section of telson with a single spine in each caudolateral corner.

Epistome with lateral portions raised (ventrally) and a small cephalo. median projection (see fig. 8).

Antennule of the usual form with a small spine present on ventro mesial surface of basal segment.

Antennae broken in holotype but extending caudad to last abdominal segment in other specimens. Antennal scale irregular in holotype but with a broad lamellar portion, broadest in middle; spine on outer cephalic margin moderately strong (see fig. 6).

Right chela somewhat depressed and elongated; palm somewhat in. flated, marked above and below by prominent setiferous punctations. Inner margin of palm with two irregular rows of squamous tuberclesapproxinately seven in each row with a few additional ones at base. Fingers distinctly gaping. Upper surfaces of both fingers with a sub. median ridge devoid of punctations and a somewhat narrower one lying toward the opposable margin. Opposable margin of immovable finger with a single row of 12 low rounded corneous tubercles and a conspicuous tuft of plumose setae on proximal two-thirds of lower opposable surface. Opposable margin of dactyl with a row of 14 tubercles similaz to those nn immovable finger. A single row of minute denticles occurs 
on the distal third of the opposable margins of both fingers. Lateral margin of immorable finger strongly convex and not keeled along basal pcrtion. Mesial margin of dactyl with a few small squamous tubercles on basal third. Lower surfaces of both fingers with a poorly defined slibmedian ridge.

Carpus of first right pereiopod longer than broad with a deep longi. tudinal furrow above. Mesial surface with two tubercles-the distal one large and acute, the proximal one small and obtuse. Lower cephalic margin with a broad, low tubercle near middle, and a somewhat larger cne on lateral angle. Upper surface strongly punctate, scattered punctations on other surfaces.

Upper surface of merus with two small acute tubercles near distal end; lower surface with a mesial row of nine very small tubercles and two laterad of this row, the more distal one of the latter two larger than all the others. Lower distal margin with a broad low tubercle on mesial and lateral angles. Scattered punctations on all surfaces.

Hooks on ischiopodites of third pereipods only; hooks only moderately strong; proximal margin concave and bearing setae.

Coxopodites of fourth and fifth pereiopods not conspicuously orna. mented.

First pleopod reaching coxopodite of second pereiopod when abdomen is flexed. Tip terminating in two distinct parts which are separated for more than half their lengths. Both terminals comparatively slender, and subparallel; their proximal two-thirds relatively straight, and at base of distal third of each, rather suddenly recurved caudad. Mesial process grooved distally on cephalolateral side. Central projection very slender distally and tapering to a point; tip extends almost as far caudad as does mesial process. Both terminals partially corneous.

Morphotypic Male, Form II.-Differs chiefly from the holotype in that most of the tubercles mentioned in the above description are spiniform. Cephalic section of telson with two spines in each caudolateral corner. Hooks on ischiopodites of third pereiopods reduced and knob. like. First pleopod with two terminals in apposition almost to tip; neither terminal slender nor corneous, and distal portions of both directed caudodistad at about a 60 degree angle to the main shaft of the appendage. See measurements for other differences.

Allotypic Female.-Except for body proportions (see measurements) and secondary sexual characters, the allotype agrees with the description of the holotype very well. Annulus ventralis subovate with the greatest length in the transverse axis; narrow deep anteromedian groove extends from midcephalic margin caudosinistrad to midlength where it joins a prominent central depression; in the cephalodextral portion of the latter is the fossa or "orifice"'; suture originates at the dextral margin of the central depression, and extends sinistrocaudad almost to the median line where it turns caudad and terminates before reaching the midcaudal margin of the annulus. (See fig. 9).

Type Locality.-Otter Creek between Granny White Pike and Hills. boro Pike, about seven miles south of Nashville, Davidson County, Ten. nessee. Dr. C. S. Shoup has kindly supplied me with the following in. formation concerning the type locality. This stream drains Radnor Lake, about six miles southwest of Nashville, and is typical of lake drainages in this section of the Central Basin. Ordovician limestone 
underlies the soils of this area, and the stream flows throngh alternating thin woods, pastures, and along a macadam road. "The rather high free carbon dioxide found along most of this stream is indicative of lower (bottoin) lake seepage and drainage.... Food grade for bottom organisms good. Minnows abundant." The following data were ob. tained from two localities in the region from which the crayfish were taken. Station I-200 yards below Radnor Lake; and Station IIabout two miles below Station I. Data taken on September 8, 1948, 1:00 P.M., overeast.

\begin{tabular}{|c|c|c|}
\hline Air Temperature & $\begin{array}{l}\text { Station I } \\
82^{\circ} \mathrm{F}\end{array}$ & $\begin{array}{l}\text { Station II } \\
82^{\circ} \mathrm{F}\end{array}$ \\
\hline Water Temperature & $67^{\circ} \mathrm{F}$ & $70^{\circ} \mathrm{F}$ \\
\hline pH1 & 7.4 & 7.4 \\
\hline $\mathrm{pH}_{2}$, following aeration to remove $\mathrm{CO}_{2}$ & 8.1 & 8.1 \\
\hline Free $\mathrm{CO}_{2}$ & 9.5 p.p.m. & 4.5 p.p.m. \\
\hline Total Alkalinity (bicarbonate) & 150.0 p.p.m. & 150.0 p.p.m. \\
\hline $\begin{array}{l}\text { Rate of flow } \\
\text { General cover grade about }\end{array}$ & $\begin{array}{l}\text { not more than } \\
\left.\qquad L_{2} \mathrm{~S}_{2}\right]\end{array}$ & $1 / 2 \mathrm{ft} . / \mathrm{sec}$ \\
\hline
\end{tabular}

Measurements in Millimeters

\begin{tabular}{|c|c|c|c|}
\hline Carapace & Holotype & Morphotype & Allots \\
\hline Height & -13.4 & 11.7 & 11.0 \\
\hline Width & 16.6 & 13.5 & 13.5 \\
\hline Length & 31.3 & 27.7 & 27.0 \\
\hline \multicolumn{4}{|l|}{ Areola } \\
\hline Width & 1.2 & 1.0 & 1.0 \\
\hline Length & 10.0 & 8.5 & 8.6 \\
\hline \multicolumn{4}{|l|}{ Rostrum } \\
\hline Width & 5.2 & 4.2 & 4.5 \\
\hline Length & 8.3 & 7.9 & 7.5 \\
\hline Abdomen-Length & 34.5 & 31.4 & 31.0 \\
\hline \multicolumn{4}{|l|}{ Right Chela } \\
\hline Length of inner margin of palm & 8.9 & 4.9 & 4.7 \\
\hline Width of palm & 13.0 & 6.6 & 6.4 \\
\hline Length of outer margin of hand & 33.8 & 18.4 & 16.3 \\
\hline Length of dactyl & 23.0 & 12.3 & 10.5 \\
\hline
\end{tabular}

Disposition of Types.-The male holotype and male morphotype (No. 87953 ) and the allotypic female (No. 87954) are denosited in the United States National Museum. Of the paratypes, one first form male and a female are deposited in the University of Michigan Museum of Zoology, and two first form males, one second form male, and two females are in my personal collection at the University of Virginia.

Specimens Examined.-TENNESSEE: Davidson County-Harpeth River to Cumberland-(1) the type locality (1 o I, I ô II, 1 o ) Mav 24, 1945, Mike Wright, coll.; (2) tributary to Harpeth River near Bellevuo (2 ô ô I, 1 o) November 11, 1944, C.S. Shoup, coll.; (3) tributary to Harneth River on Old Hickorv Boulevard near Hillsboro Pike (1 f $\mathrm{I}$. 1 ô II, 2 우 우) November 11, 1944, C.S. Shoup, coll.; (4) Otter Creek (1) June 1, 1945, Mike Wright, coll.; (5) Otter Creek below Radnor Lake (1 \%) June 9, 1945, Mike Wright, coll.; (6) Otter Creek at Hillsboro Pike (2 $q$ ) May 19. 1945, Mike Wright, coll. Mill Creek to Cum- 
berland-(7) Mill Creek near Antioch (1q) November 11, 1944, C. S. Shoup, coll.; (8) Mill Creek at Antioch Pike (1 $\hat{\delta}$ immature) July 19, 1945, Mike Wright, coll. Williamson County-Little Harpeth River to Cumberland-(9) Pond along St. Il lof near Jittle Harpesh River just

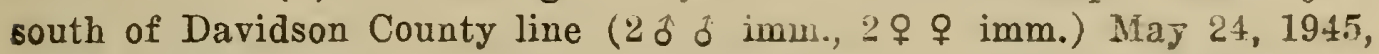
Mike Wright, coll.

Variations.-Among the specimens listed abore I can detect no variations of significance other than the usual difierences associated with age.

Relationships.-Orconectes rhoadesi seems to have its closest affinities with Orconectes validus (Faxon 1914: 382). In fact the two species were confused by Faxon (ibid.: 383); however, they may be easily sepa. rated on the structure of the first pleopod of the male-in validus the cephalic surface is gently recurved through the distal half, while in rhoadesi it is almost straight to base of distal third where it is suddenly recurved caudad; further in valialus the central projection does not ex. tend nearly so far caudad as does the mesial process, but in rhoadesi it extends as far, or almost as far, caudad as does the mesial process. 0 . validus has been reported from the Tennessee River drainage from Huntsville, Madison County, Alabama.

I wish to express my appreciation to the following who have con. tributed most of the specimens on which this report is based: Dr. C. S. Shoup, Dr. Mike Wright, Mr. L. J. Marchand, Mr. Fred Campbell, and Mr. L. Stewart.

\section{Literature Cited}

Cope, E. D., 1872. On the Wyandotte Cave and its fauna. Amer. Nat. 6: 406-422, figs. 109-116.

Faxon, Walter, 1884. Descriptions of new species of Cambarus; to which is added a synonymical list of the known species of Cambarus and Astacus. Proc. Amer. Acad. Arts and Sci. 20: 107-158.

1885a. A revision of the Astacidae. Mem. Mus. Comp. Zool., Har. vard Coll. 10 (4): $1-179,10$ pls.

- 1885b. A list of the Astacidae in the United States National Museum. Proc. U. S. Nat. Mus. 8 (23): 356-361.

-1914. Notes on the crayfishes in the United States National Mu. seum and the Museum of Comparatire Zoölogy with descriptions of new species and subspecies to which is appended a catalogue of the known species and subspecies. Mem. Mus. Comp. Zool., Harvard Coll. 40 (8) : 351-427, pls. 1-13.

Fleming, R. S., 1938-39. The larger Crustacea of the Nashville region. Journ. Tennessee Acad. Sci. 13 (4): 296-324; 14 (2): 261-264; 14 (3) : 299-324, 22 pls., 3 tables.

Goodnight, C. L., 1940a. Rediscovery of Cambarus compressus Faxon in Mississippi. Amer. Midl. Nat. 23 (1): 222-223.

-1940b. New records of Branchiobdellids (Oligochaeta) and their crayfish hosts. Rept. Reelfoot Lake Biol. Sta, 4: 170-171.

Harris, J. A., 1903. An ecological catalogue of the crayfishes belonging to the genus Cambarus. Kansas Univ. Sci. Bull. 2 (3): 51-187, 5 pls.

Hay, W. P., 1899. Synopses of North-American Invertebrates. VI. The Astacidae of North America. Amer. Nat. 33 (396): 957.966. 


\section{Proceedings of the Biological Society of Washington}

Hobbs, H. H., Jr., 1942. A generic revision of the crayfishes of tho subfamily Cambarinae (Decapoda, Astacidae) with the description of a new genus and species. Amer. Midl. Nat. 28 (2): 334-357, 3 pls. 1 table.

Ortmann, A. E., 1902. The geological distribution of fresh-water decapods and its bearing upon ancient geography. Proc. Amer. Philos. Soc. 41 (171) : 267-400.

-1905. The mutual affinities of the species of the genus Cambarus, and their dispersal over the United States. Proc. Amer. Philos. Soc. 44 (180): 91-136, 1 map.

-1931. Crawfishes of the southern Appalachians and the Cumberland Plateau. Ann. Carnegie Mus. 20 (2): 61-160.

Rhoades, Rendell, 1944. The crayfishes of Kentucky, with notes on variation, distribution and descriptions of new species and subspecies. Amer, Midl. Nat. 31 (1): 111-149, 10 figs., 10 maps.

Orconectes rhoadesi, sp. nov.

Explanation of Plate

Pubescence removed from all structures except figure 7.

Fig. 1 Mesial view of first pleopod of first form male.

Fig. 2. Mesial view of first pleopod of second form male.

Fig. 3. Dorsal view of carapace.

Fig. 4. Lateral view of first pleopod of second form male.

Fig. 5. Lateral view of first pleopod of first form male.

Fig. 6. Antennal scale.

Fig. 7. Upper surface of chela of male, form I.

Fig. 8. Epistome.

Fig. 9. Annulus ventralis.

Fig. 10. Lateral view of carapace. 


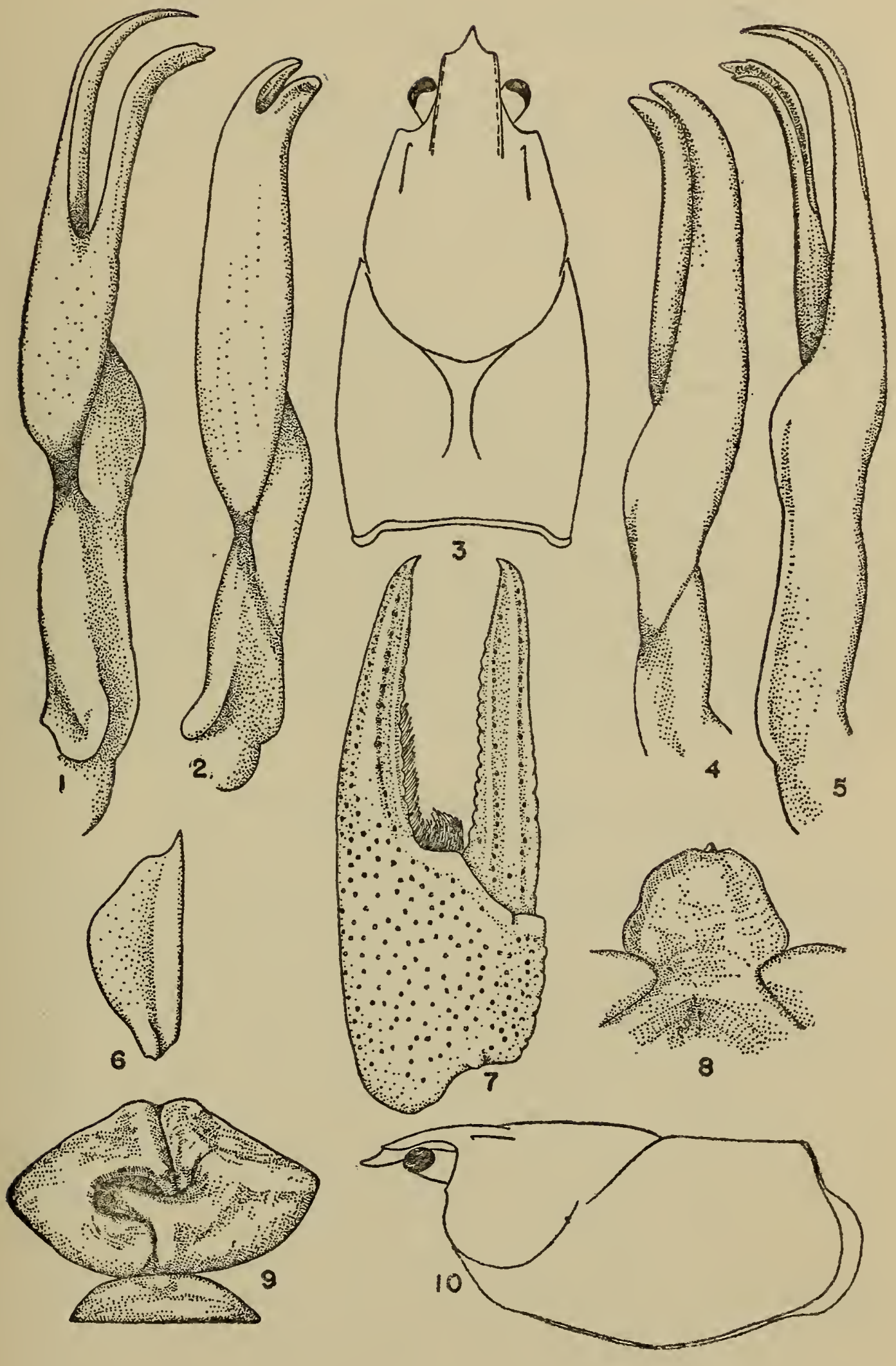





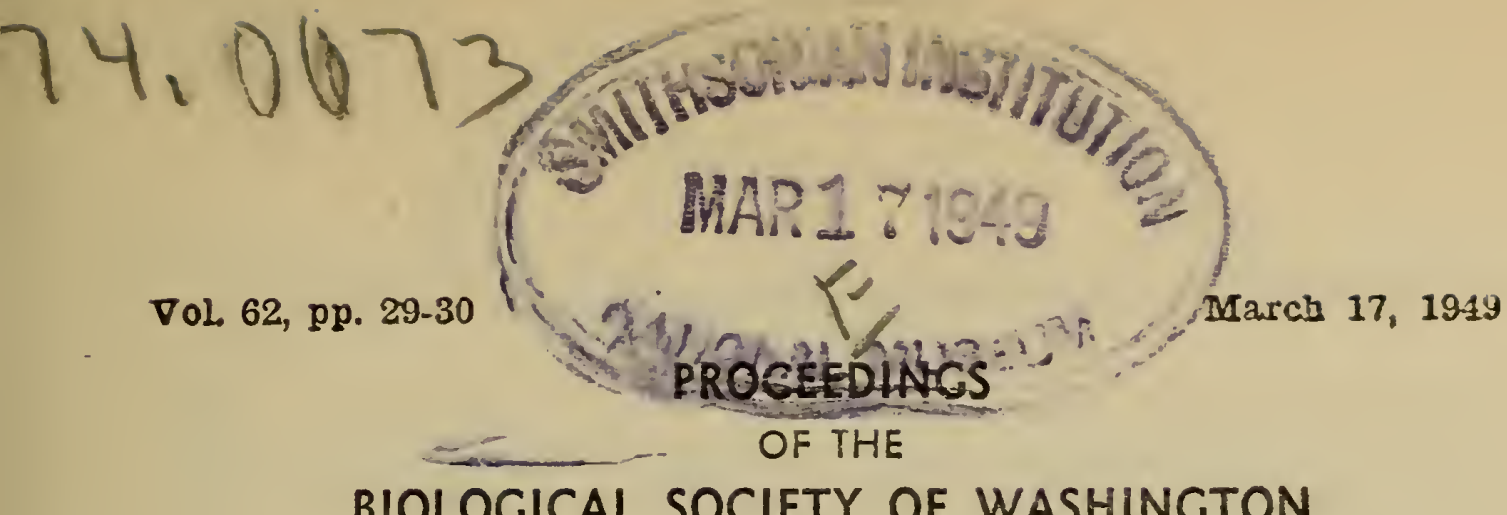

BIOLOGICAL SOCIETY OF WASHINGTON

\section{A NEW HOUSE FINCH FROM THE PALOUSE COUNTRY OF THE NORTHWESTERN UNITED STATES}

\section{BY JOHN W. ALDRICH}

During the course of studying the geographic variation of the birds of Washington State, I have noted a marked racial difference in the house finches resident in the eastern part of that state from adjoining populations on the coast and in the Great Basin. This differentiation seems to be general and constant in the population of house finches occupying the Palouse prairie region of the Columbia plateau, north of the Blue Mountains of Oregon, and between the Cascade Mountains on the west and the Rocky Mountains on the east. So different are these birds in all sex and age plumages and so circum. scribed is their range, that it appears to me they should be considered as a distinct subspecies that may be characterized as follows:

\section{Carpodacus mexicanus sordidus, new subspecies Palouse House Finch.}

Type.-No. 395960, U. S. National Museum (Fish and Wildlife Serv. ice Collection); adult male, Pullman, Washington, July 12, 1948; T. D. Burleigh, original number 11199.

Subspecific characters.-Similar to Carpodacus mexicanus grinnelli of western Oregon and California, but slightly darker and much more grayish, less brownish, abore and below; also less of the reddish wash on back and neck, and red of head, rump, throat, and breast more restricted and deeper less orange in tone, being near spectrum red or carmine rather than scarlet red. It differs from $C$. $m$. solitudinis of the Great Basin region in Nevada to an even greater degree by reason of being much darker as well as more grayish and the reds pnrer and deeper, less scarlet. The combination of characters gives a relatively dusky appearance when compared with other races.

The females differ in the same rray as the males from grinnelli and solitudinis with respect to the brown markings which are more grayish, less brownish, and particularly as regards the ventral streaks which are beavier and darker than in either of the other two races. There is no significant size difference from either of the above-mentioned neighboring forms.

Measurements.-Adult male (14 adult, spring and summer specimens); wing, 77-80 (78.2); tail, 57.5-62 (60.0); exposed culmen 9.5-11 (10.3);

8-Proc. Brox. Soo. Wash., For. 62, 1949. 
tarsus, 15-18 (16.8); middle toe, without claw, 14-15.5 (14.6). Adult female (6 adult, spring and summer specimens): wing, 72.5-75.5 (74.4); tail 55.5-60 (57.3); exposed culmen 9-10.5 (9.8); tarsus 15-18 (16.8); middle toe without claw, 12.5-15.5 (14.1).

Distribution.-Permanent resident in eastern Washington (east of the Cascade Mountains) and northwestern Idaho; probably also adjoining portions of intermontane British Columbia where the species occurs. Specimens of Carpodacus mexicanus sordidus have been identified as follows:

Washington-Eureka, Walla Walla Co., Nov. 3, 1941, ô ; Pullman, Apr.

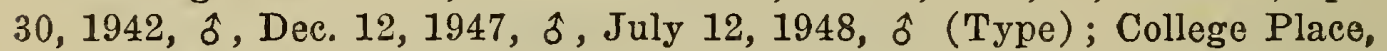
Feb. 18, 1937, ô, Apr. 8, 1937, ô, Oct. 17, 1937; Kiona, Oct. 18, 1916, ㅇ, Dec. 9, 1919, ô, Dec. 11, 1919, , Dec. 11, 1919, ô, (Juv.) ; Wallula, Mar. 27, 1937, ô, Apr. 2, 1939, ô ; Wenatchee, Apr. 29, 1934, 우, July 9, 1933, ô, Aug. 29, 1934, ô, Apr. 12, 1934, + ; White Bluffs, Nov. 1,

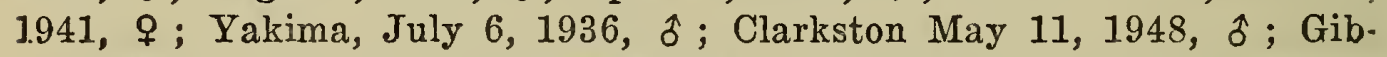
bon, May 18, 1934, + ; Wenas Valley, Yakima County, Cleman Ranch, Sept. 22, 1917, ô (Juv.) ; Zillah, Mar. 8, 1919, ô ; Wawawai, June 12, 1937, of (Imm.), June 12, 1937, -(Imm.), June 12, 1937, 우 (Imm.), Mar. 9, 1941, $q$; Roosevelt, Oct. 29, 1941, ㅇ, Dec. 18, 1942, ㅇ, Dec. 18, 1942, ô ; Harrah, Oct. 25, 1945, ㅇ (Juv.), Oct. 25, 1945, ô (Juv.), Oet. 25, 1945, ô.

Idaho-Troy, June 25, 1948, \& ; Lewiston, Dec. 18, 1947, of ; Moscow,

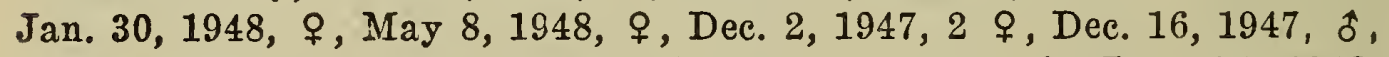

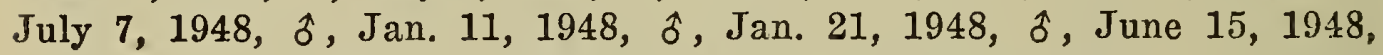
$\hat{\delta}$, June 17, 1948, 2 ô, Aug. 6, 1948, of, July 14, 1948, $\hat{o}$, July 22, 1948 , ô, ㅇ (Imm.), July 27, 1948, ô, July 15, 1948, ㅇ (Imm.), ô (Imm.).

For the loan of pertinent comparative material, acknowledgment is made to Charles R. Conner Museum, State College of Washington; Walla Walla College; State Museum, University of Washington; Mr. John B. Hurley, Yakima, Washington; Museum of Vertebrate Zoology, University of California. For a good series of breeding specimens of this new subspecies from the vicinity of Moscow, Idaho, and Pullman, Washington, I am indebted to the diligent collecting of Thomas D. Burleigh of the Fish and Wildlife Service, who is now stationed in that area for the purpose of making an intensive study of the birds of Idaho. 


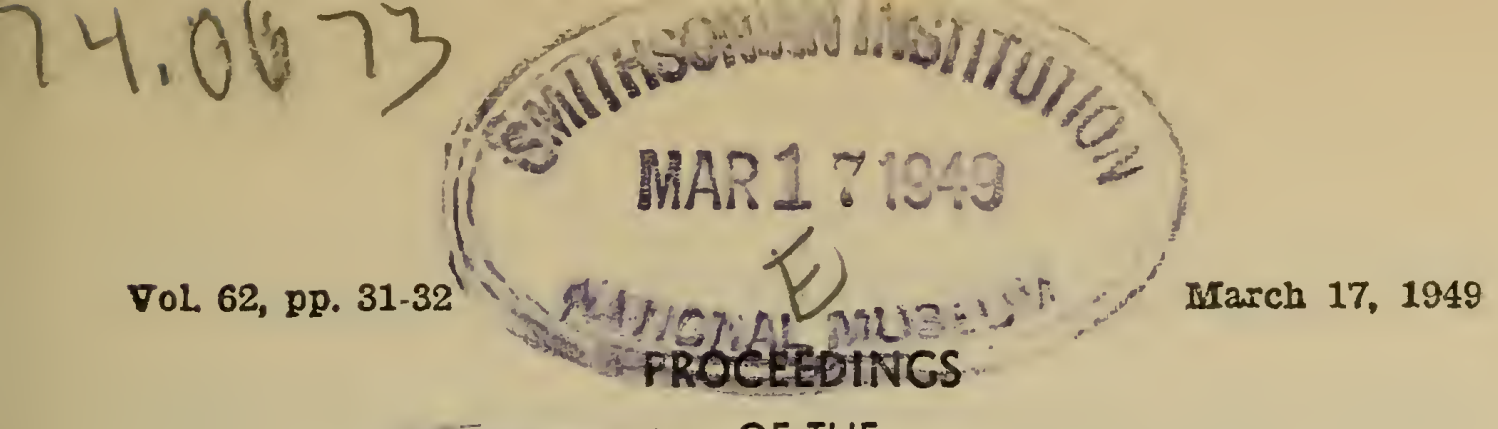

V01.62, pp. 31-32
PROCEETI
OF THE

BIOLOCICAL SOCIETY OF WASHINGTON

\title{
TWO NEW COYOTES FROM THE UNITED STATES
}

\author{
By HaRTley H. T. Jackson
}

Recent taxonomic research on the American species Canis latrans has shown the necessity of naming two new subspecies in order to clarify relationships within the group. These two new forms may be recognized by the following descriptions.

Canis latrans thamnos, subsp. nov.

Northeastern Coyote or Brush Wolf

Type specimen.-No. 233,034, U. S. National Museum, Biological Surreys collection; $\hat{\delta}$ young adult, skin and skull; collected September 4, 1919, by Harry H. Sheldon. Original number 1073.

Type locality.-Basswood Island, Apostle Islands, Ashland County, Wisconsin.

Diagnostic characters.-A large, heavy-set, rather dark coyote, with broad skull, relatively short rostrum, and heavy dentition. About the size of Canis latrans latrans, or larger, but darker in color with more blackish intermixed on the face, back, and tail, and muzzle and back of ears deeper shade, more fulrous; skull relatively broader; rostrum relatively more dished. Darker and larger than Canis l. incolatus, skul] relatively broader, dentition heavier.

Measurements. - Type-specimens: No external measurements from animal in flesh available. Hind foot (measured from dry skin), 180. Skull of type specimen: Condylobasal length, 192.8; palatal length, 99.6; Bquamosal constriction, 62.0 ; zygomatic breadth, 108.4; interorbita] breadth, 35.6 ; maxillary tooth row, 87.3 ; upper carnassial length, 21.2 ; first upper molar length, 13.5; first upper molar breadth, 18.6; lower earnassial length, 23.6.

Geographic range.-East-central Saskatchewan, extreme eastern North Dakota, Minnesota, Iowa, northern Missouri, easterly through Wisconsin, northern and central Illinois, northern Indiana, to eastern and southern Ontario.

Canis latrans umpquensis, subsp. nov. Northwestern Coast Coyote

Type specimen.-No. 216,537, U. S. National Museum, Biological Surveys collection; + young adult, skin and skull; collected March 11, 1916, by W. T. Tison. Original number 16; Biological Surveys miscellaneous number $15,880 \mathrm{X}$.

Type locality.-Five miles southeast of Drew, Douglas County, Oregon.

Diagnostic characters.-A small, rufous-tinged, dark-colored coyote, with distinct black markings on the forelegs and deep fulvous or rufous on both hind and forelegs, usually with cast of rufous on rump; ears 


\section{Proceedings of the Biological Society of Washington}

relatively large; skull comparatively small, dentition weak. Smaller than Canis l. lestes, darker and deeper rufous color on legs; skull smaller, dentition weaker. Smaller and darker than C. $l$. ochropus, deeper rufous on the legs; ears smaller; skull averaging smaller than in ochropus.

Measurements.-No external measurements of type specimen are available. Adult male from Forks, Clallam County, Washington (No. 274,904, U. S. N. M., B. S. coll.): Total length, 1,247; tail vertebrae, 358 ; hind foot, 207 ; ear from notch, 122 ; weight $271 / 4$ pounds. Skull of type specimen: Condylobasal length, 17.1 ; palatal length, 86.4; squamosal constriction, 57.5; zygomatic breadth, 94.0 ; interorbital breadth, 29.5; maxillary tooth row, 78.5; upper carnassial length, 17.3; first upper molar length, 11.9; first upper-molar breadth, 16.1; lower carnassial length, 20.0 .

Geographic range.-West of the Cascade Mountains, in Oregon and Washington.

U. S. Fish and Wildlife Service, Washington, D. C. 


\section{Proceedings of the Biological Society of Washington}

Synallaxis cinnamomea pariae, new subspecies

Type: From Cerro Humo, Irapa, Península de Paria, Sucre, Venezuela. No. 44216, Phelps Collection, Caracas, Venezuela. Adult male collected May 4, 1948, by Ramón Urbano. (Type on deposit at the American Museum of Natural History.)

Diagnosis: Closest to S. c. striatipectus, from the Cerro Turumiquire region, from which it differs by a less prominent superciliary stripe, duller and less prominent dark streaks on breast and abdomen (olivaceous instead of blackish), less striping on abdomen, the black stripes on throat being more prominent than the white ones.

Range: Known only from the Subtropical Zone (900-1200 meters) of Cerro Humo and Cerro Azul on the Paria Peninsula.

Description of Type: Crown Vandyke Brown merging into grayish on forehead close to bill; back and uropygium Vandyke Brown; supereiliary stripe Ochraceous-Tawny; lores dusky; ear-coverts Vandyke Brown; gular region striped Ochraceous-Tawny and black, more narrowly than on breast. Chin and anterior throat striped black and white merging into the Ochraceous-Tawny and black of the posterior throat which in turn merges into the dusky olivaceous and paler stripes of breast; abdomen paler, grayish olive, with buffy white stripes except posteriorly; sides, flanks, shanks and under tail-coverts near to Dresden Brown. Remiges Benzo Brown, outer vanes, except on the two outermost primaries, edged, except apically, with Mahogany Red; inner vanes of tertials tinted with reddish; inner vanes of primaries and secondaries edged with Vinaceous-Fawn, basally on outermost and increasing in extent inwardly; upper wing-coverts Mahogany Red; bend of wing, under wing-coverts and axillaries Tawny. Tail above Liver Brown, below pale brown.

Bill (in life) "black, base of mandible grayish"; feet "greenish gray"; iris "chestnut." Wing, $58 \mathrm{~mm}$; tail, 58; exposed culmen, 15; culmen from base, 17.5; tarsus, 21.

Remarles: Sexes alike in coloration but females have shorter wings. Size similar to striatipectus. Range of measurements: five adult maleswing, 57-59 (58) $\mathrm{mm}$; tail, 58-68 (63); culmen from base, 16-17.5 (16.5); five adult females-wing, 54-56 (54.6); tail, 61-67 (63.6); culmen from base, 16-18 (16.8). Measurements of striatipectus: four adult males-wing, 55-56 (55.5) ; tail, 61-68 (63.2); culmen from base, 16-16 (16); five adult females-wing, 53-55 (54.2); tail, 59-68 (65.2); culmen from base, 15-17 (16.2).

The juveniles have the throat black with white spots and the breast is more spotted, less streaked. May and June specimens have breeding gonads. Specimens were collected: 15 in May, 6 in June, 1 in August, 4 in September and 4 in November.

\section{SPECIMENS EXAMINED}

S. c. cinnamomea.-VENEZUELA: La Sabana, Perijá, 2 ô, 1 . COLOMBIA: "Bogotá," 6(q)."

S. c. aveledoi. ${ }^{4}$-VENEZUELA: Lara, 10; Falcón, 7; Táchira, 3.

S. c. bolivari.-VENEZUELA: Yaracuy, $1^{4}$; Carabobo, $1^{4}$; Dto. Federal, $3^{4}$; Miranda, $17^{4}$; Cumbre de Valencia, ${ }^{3} 1$ o Silla de Caracas, ${ }^{3} 2$ o, 2 우 ; Galipán ${ }^{3}, 2$ ㅇ, 2 오.

S. c. striatipectus.-VENEZUELA: Quebrada Bonita, 3 ô, 3 q, 1(?); 
Cerro El Peonía, 1 q; Cerro Negro, 1 रे, $3 \uparrow, 2(q)$; Quebrada Seca, 1 ô, 1 \%; La Tigrera, ${ }^{3} 1$ \%; Los Palmales, ${ }^{3} 1$ o, 2 \%; Caripe, ${ }^{3} 1(\uparrow)$. S. c. pariae.-VENEZUELA: Cerro Humo, 5 to (incl. type), 8 \&, $3(\xi)$; Cerro Azul, 5 of, 5 q, $4(q)$.

S. c. carri.-TRINIDAD ${ }^{3}: 4 \hat{o}, 2$ \%.

\section{Premnoplex tatei pariae, new subspecies}

Type: From Cerro Humo, Irapa, Península de Paria, Sucre, Venezuela. No. 41041, Phelps Collection, Caracas, Venezuela. Adult male collected November 29, 1947, by Ramón Urbano. (Type on deposit at the Ameriean Museum of Natural History.)

Diagnosis: Differs from $P . t$. tatei of the Cerro Turumiquire region by much more extensive light markings below; almost immaculate buffy throat instead of white with squammations; breast with less distinct squammations; abdomen with wider whitish streaks; crown darker, more dusky.

Range: Known only from the Suttropical Zone (900-1200 meters) of Cerro Humo and Cerro Azul on the Paria Peninsula.

Description of Type: Top of head brownish olive the feathers edged with dusky, giving a faintly scalloped appearance, the feathers of forehead with indistinet pale shaft stripes; a wide dusky nuchal collar, the feathers with prominent pale buffy shaft streaks; back Auburn, feathers with faint dusky shaft streaks; uropygium Auburn; lores dusky; post-ocular superciliary streak, gular region and sides of neck streaked with pale buffy and dusky, continuous with nuchal collar; earcoverts dusky mixed with buffy white. Chin and throat buffy white, feathers very faintly edged with dusky, merging into the pale Cream. Buff breast, the feathers with more accentuated dusky edges giving a faint scalloped appearance; abdomen has a streaked appearance, the feathers uniform with those of breast but with heavy dusky brownish edgings; sides and flanks dusky brown, the feathers with prominent whitish buff shaft streaks; shanks and under tail-coverts Prout's Brown. Remiges Fuscous; primaries narrowly edged with grayish brown, secondaries and tertials broadly with Auburn; upper wing-coverts Auburn, uniform with back, the feathers with dusky shaft streaks; bend of wing, under wing-coverts and axillaries buffy white mixed with dusky. Central rectrices dusky brown, remaining ones Fuscous with dusky brown outer vanes; lower aspect of tail pale brownish.

Maxilla (in life) "black"; mandible "flesh, black tip"; feet "black"; iris "dark." Wing, $60 \mathrm{~mm}$; tail, 56; exposed culmen, 16; eulmen from base, 20 ; tarsus, 20.

Remarks: Sexes alike. Size similar to tatei. Range of measurements: five adult males-wing, 60-62 (61.4) $\mathrm{mm}$; tail, 56-59 (57.4); culmen from base, 20-21 (20.2) ; five adult females-wing, 58-61 (59.8); tail, $51-58$ (54.6); culmen from base, 19-21 (20). Measurements of tatei: five adult males-wing, 59-61 (60); tail, 57-64 (60.8); culmen from base, $19-20$ (19.4); five adult females-wing, 59-61 (59.8); tail, 57-60 (59); culmen from base, 19-20 (19.2).

May specimens of pariae have breeding gonads as have August speci-

\footnotetext{
${ }^{3}$ Snecimens in the American Mnseum of Natural History.

Fon localities see Phelps and Phelps, Jr., Bol. Soc. Ven. Cien Nat., No. 65.66, p. $152,1945-1946$.
} 


\section{Proceedings of the Biological Society of Washington}

mens of tatei. Specimens were collected: 16 in May, 8 in September and 8 in November.

The immature plumage is similar to the adult.

\section{Specimens Examined}

P. t. tatei.-VENEZUELA : Cerro Turumiquire, 1 c ; $;$ Cerro El Peonía, Bergantín, 1 of ; Cerro Negro, Caripe, 11 ô, 7 o, $9(q)$.

P. t. pariae.-VENEZUELA: Cerro Humo, 11 ô (incl. type); Cerro $A z u l, 6$ ô, 3 \&, 2( ().

\section{Grallaricula nana pariae, new subspecies}

Type: From Cerro Azul, Cristóbal Colón, Península de Paria, Sucre, Venezuela. No. 44025, Phelps Collection, Caracas, Venezuela. Adult male collected May 28, 1948, by Ramón Urbano. (Type on deposit at the American Museum of Natural History.)

Diagnosis: Closest to G. n. cumanensis of the Mt. Turumiquire region but darker above, back more purely alivaceous lacking the yellowish brown tinge. Besides other strong characters, olivascens, nana and kukenamensis have much smaller bills than pariae.

Range: Known only from the Subtropical Zone (820-1200 meters) of Cerro Azul and Cerro Humo on the Paria Peninsula.

Description of Type: Forehead, evcept in the center, Orange-Buff $\times$ Cadmium Yellow; center line of forehead, crown and nape Deep Mouse Gray; back, rump and upper tail-coverts Medal Bronze, the long back feathers covering the basal half of tail subterminally white and tipped with pale buff forming a band; orbital ring anteriorly buffy, posteriorly whitish; a dusky preocular lunule. Below Ochraceous-Orange, darkest on breast, sides and flanks and paler on chin and throat; a prominent white spot on anterior breast; entire abdomen white; shanks and under tail-coverts buffy. Remiges Fuscous, outermost edged with pale buff, the others with brownish, most extensively on tertials; remiges edged with buff internally, the outer ones only basally; greater and median upper wing-coverts tipped with dark buffy forming two indistinct bands; primary coverts entirely blackish partly covering a buffy speculum; bend of wing buffy; axillaries and under wing-coverts Cadmium-Orange. Tail darker, browner, than the back.

Bill (in life) "maxilla black, mandible flesh"; feet "purplish flesh"; iris "dark." Wing, $66 \mathrm{~mm}$; tail, 28; exposed culmen, 15; eulmen from base, 18 ; tarsus, 25.

Remarks: Sexes alike. Size similar to cumanensis. Range of measurements: five adult males-wing, $64-70$ (66) $\mathrm{mm}$; tail, 28-30 (28.8); culmen from base, 18-18 (18); five adult females-wing, 64-66 (65); tail, 26-28 (27.2); culmen from base, 18-19 (18.4). Measurements of cumanensis: five adult males-wing, 64-69 (66.6); tail, 27-27 (27); eulmen from base, $17-18$ (17.5); three adult females-wing, 62.66 (64.3); tail, 26-27 (26.3); culment from base, 17-18 (17.7).

May specimens have breeding gonads. Specimens were collected: 36 in May, 1 in June, 1 in August, 8 in September and 6 in November.

The immature plumage is similar to the adult except that the center of forehead, crown and nape is dark brown and the white area of the abdomen is lacking. 


\section{SPECIMENS EXAMINED}

G. n. nana.-VENEZUELA: Boca de Monte, Táchira, $2 \delta, 1$ \&; Quintero, 1 ô; Páramo El Escorial, $3 \hat{o}$; $^{3}$ Páramo de la Culata, 3 ơ ${ }^{2}$ Páramo Cenđé, Trujillo, 1 ô, 1 ㅇ.

G. $n$. olivascens.-VENEZUELA: Colinia Tovar, 2 \&, $1(\uparrow)$; El Junquito, 1 \%; Cerro El Avila, 1 ô, 1 \%.

G. n. cumanensis.-VENEZUELA: Cerro El Peonía, Bergantín, 1 ơ; Cerro Negro, Caripe, 1 ô ; Los Palmales, ${ }^{3} 1 \hat{o}$ (type), 1 $q$; Rincón de San Antonio, 1 \% ; ; Latal, 1 $^{3} .^{3}$

G. n. pariae.-VENEZUELA: Cerro Azul, 11 ô (incl. type), 7 , $10(q)$; Cerro Humo, 14 ô, 8 q, $2(q)$.

G. n. kukenamensis.-VENEZUELA: Arabupá, 1 ô; Cerro Ptari-

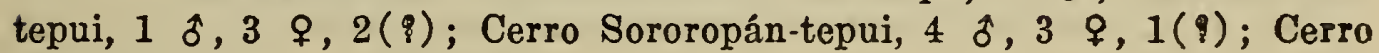
Chimantá-tepui, 1 ơ, 2 ㅇ.

\section{Grallaria haplonota pariae, new subspecies}

Type: From Cerro Azul, Cristóbal Colón, Península de Paria, Sucre, Venezuela. No. 44048, Phelps Collection, Caracas, Venezuela. Adult male collected May 29, 1948, by Ramón Urbano. (Type on deposit at the American Museum of Natural History.)

Diagnosis: Differs from haplonota, of the Caracas region, by much more reddish urder tail-coverts and darker under parts, more ochraceous, less buffy.

Range: Known only from the Subtropical Zone (900-1200 meters) of Cerro Azul and Cerro Humo on the Paria Peninsula.

Description of Type: Above Dresden Brown, paler on rump, feathers faintly edged with dusky on back and more strongly on head; upper tail-coverts reddish chestnut; lores grayish; ear-coverts dusky olivaceous. Chin and center of throat whitish; sides of throat dusky olivaceous; narrow gular stripe whitish buff; breast, sides, flanks and shanks ochraceous, heavily shaded with dusky; abdomen paler; under tailcoverts Xanthine Orange. Wings Benzo Brown, all exposed surfaces uniform with back; outer vane of outermost primary buffy; under wing-coverts Xanthine Orange; axillaries ochraceous. Tail brown, paler or under surface.

Bill (in life) "black"; base of mandible "grayish purple"; feet "purple"; iris "dark." Wing, $98 \mathrm{~mm}$; tail, 40; exposed culmen, 22 ; culmen from base, 28 ; tarsus, 45 .

Remarks: Sexes alike. Size similar to haplonota. Range of measurements: five adult males-wing, 98-101 (99.4) $\mathrm{mm}$; tail, 40-43 (41.8); eulmen from base, 28-30 (29.2); fire adult females-wing, 98-103 (101.2); tail, 39-43 (41.4) ; culmen from base, 28-30 (28.8). Measure. ments of haplonota: five adult males-wing, $99-107$ (102.2); tail, $39-42$ (40.8) ; culmen from base, 28-30 (29.2).

The females have laying oraries. Specimens were collected: 12 in May, 1 in June and 1 in September.

The species has not been encountered in the Mt. Turumiquire region, so the nearest known subspecies is haplonota from the Caracus region.

\section{SPECIMENS Examined}

G. h. haplonota.-VENEZUELA: Mt. Bucarito, $3(\xi)^{3}$; Cumbre de Valencia, 4 ô, $1 \hat{\delta}^{3}$; 5 , 1 o $^{3}, 1$ (१); Paso Hondo, $1 q^{3}$; Hda. Santa 
Clara, 1 of, 1 q ; Colonia Tovar, 4 to, 3 q; Curupao, 1 ; Cerro Golfo Triste, 2 ô.

G. h. pariae-VENEZUELA: Cerro Azul, 7 f (incl. type), 3 \&; Cerro Humo, 1 ô, 3 ㅇ.

\section{Pipreola formosa pariae, new subspecies}

Type: Frim Cerro Azul, Cristóbal Colón, Península de Paria, Sucre, Venezuela. No. 40532, Phelps Collection, Caracas, Venezuela. Adult male collected September 18, 1947, by Ramón Urbano. (Type on deposit at the American Museum of Natural History.)

Diagnosis: Similar to $P$. $f$. rubidior of the Mt. Turumiquire region but the red throat patch is more prominent and more extensive.

Range: Known only from the Subtropical Zone (900-1200 meters) of Cerro Azul and Cerro Humo on the Paria Peninsula.

Description of Type: Forehead and lores black; rest of head, including throat, lustrous dusky blue; nape, back and uropygium Mineral Green. Chin and throat lustrous dusky blue; large prominent Carmine patch on anterior breast; rest of breast orange tinged with Carmine; abdomen Lemon Yellow; under tail-coverts and axillaries Pale Lemon Yellow, sides and flanks more greenish; shanks dusky. Remiges Fuscous. Black edged externally with green except the outermost, more extensively on tertials; inner vanes narrowly edged with yellowish white, more extensively inwardly; remiges, except four outermost, tipped with white, much more broadly on tertials; exposed parts of upper wing-coverts green uniform with black; alula dusky; blend of wing yellowish and dusky; under wing-coverts whitish. Middle rectrices green uniform with back, others dusky; outer vanes green uniform with back; under aspects of tail paler dusky with a faint greenish sheen.

Biil (in life) "reddish orange"; feet "grayish green"; iris "yellowish orange." Wing, $90 \mathrm{~mm}$; tail, 65; exposed culmen, 11 ; culmen from base, 15 ; tarsus, 20.5 .

Remarks: Sexes different in color. Size similar to rubidior. Range of measurements: five adult males-wing, 89-90 (89.4) $\mathrm{mm}$; tail, 62-65 (63.4); culman from base, 14-15 (14.6); five adult females-wing, 81-87 (84.4); tail, 57-65 (60.6); culmen from base, 14-15 (14.6). Measurements of rubidior from the Mt. Turumiquire region: five adult males-wing, 86-89 (87.8); tail, 58-65 (61.6); culmen from base, 15-15 (15) ; four adult females-wing, $84-87$ (85.5); tail, 59-63 (60.7); culmen from base, 14-15 (14.7).

Description of female (no. 40548). Top of head, back, and uropygium Mineral Green; ear-coverts and malar region more olivaceous; lores dusky. Center of chin grayish with faint dusky barring; rest of under parts Greenish-Yellow, darkest on breast and barred with Parrot Green, most densely on breast; shanks greenish. Wings Fuscous-Black, exposed surfaces green uniform with back; inner vanes of remiges narrowly edged with yellowish white, more extensively inwardly; remiges tipped with whitish, except five outermost, more extensively on tertials. Tail dusky, exposed upper surface green uniform with back. Bill, feet and iris as in the male.

May, June and September females have laying ovaries. Specimens were collected: 22 in May, 6 in June, 22 in September and 4 in November. 


\section{SPECTMENS EXAMINED}

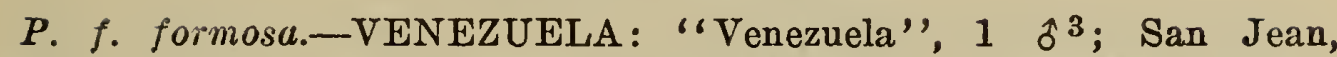
Puerto Cabello, 1 \&; Cumbre de Valencia ${ }^{3}, 3$ o, 1 $\$$; Colonia Chirgua, 2 đิ, 2 q ; Hda. Santa Clara, Carabobo, 1 ô, 1 \& San José de los Caracas, $1 \hat{\delta}$; Cerro Golfo Triste, $6 \hat{\delta}, 4$ $ᄋ$; Cerro Negro, Miranda, 1 ô.

P. f. ribidior-VENEZUELA: Quebrada Bonita, Bergantín, 1 ô, 1 + ; "Cumana", $2 \hat{o}^{3}$; Los Palmales, 3 $\hat{o}^{3}$; Santa Ana Valley, 1 $\hat{o}^{3}$; Carapas, $1 \hat{0}^{\mathbf{3}}$; Cerro Turumiquire, $8 \hat{\delta}^{5}$; Cumanacoa, 1 क 6 ; La Elvecia, 1 ${ }^{6}$; Cerro Negro, Caripe, 8 ô, 3 $q$.

P. $f$. pariae.-VENEZUELA: Cerro Azul, 25 ô (incl. type), 11 $q$; Cerro Humo, $14 \delta, 4$ $\delta$.

\section{Pyrrhomyias cinnamomea pariae, new subspecies}

Type: From Cerro Azul, Cristóbal Colón, Península de Paria, Sucre, Venezuela. No. 44087, Phelps Collection, Caracas, Venezuela. Adult male collected May 30, 1948, by Ramón Urbano. (Type on deposit at the American Museum of Natural History.)

Diagnosis: Differs from other subspecies by being darker brown below and blacker on the crown.

Range: Known only from the Subtropical Zone (800-1150 meters) of Cerro Azul and Cerro Humo on the Paria Peninsula.

Description of Type: Crown dusky Warm Sepia with a partly concealed large Light Cadmium crown patch; forehead, lores and nape Brussels Brown; back Auburn $\times$ Sanford's Brown, more dusky toward rump band; band across rump Raw Sienna; tail-coverts blackish, edged with rufous; sides of neck Amber Brown; ear-coverts more buffy. Chin grayish buff; rest of under parts Amber Brown, paler on under tailcoverts. Wings Fuscous; remiges, except four outermost, externally edged with Sanford's Brown which together with the broad Sanford's Brown tips to the greater wing-coverts and broad edgings to the tertails forms a large wing patch; median and lesser coverts broadly tipped with Sanford's Brown forming two conspicuous wing bands; under wing-coverts and axillaries Sanford's Brown. Upper aspect of tail dusky, outer vane of external rectrices Pecan Brown; lower aspect Pecan Brown except dusky apically; all rectrices faintly tipped with buffy.

Bill (in life) "black;" feet "black;" iris "brown." Wing, $71 \mathrm{~mm}$; tail, 57 ; exposed culmen from base, 15 ; tarsus, 12.5 .

Remarks: Sexes alike. Size similar to spadix. ${ }^{7}$ Range of measurements: five adult males-wing, 70-72 (71.2) mm; tail, 55.60 (57); culmen from base, 14-15 (14.4); five adult females-wing, 67-69 (67.6); tail, 55-58 (56.2); culmen from base, 14-14 (14).

May females have laying ovaries. These specimens were collected: 16 in May, 2 in June, 2 in August, 6 in September and 1 in November.

${ }^{5}$ Specimens in the Chicago Natural History Museum.

'See Wetmore. Smith. Misc. Coll. 98, No. 4, p. 5, 1939. 


\section{SPEOIMENS EXAMINED}

P. c. cinnamomea.-PERU 8 : $40^{3}$.

P. c. pyrrhoptera.-VENEZUELA: Páramo de Tamá, 3 ô, 1 q; Las Delicias, Táchira, 1 ô; PERU8 ${ }^{8}: 28^{3}$.

P. c. assimilis.-COLOMBIA ${ }^{3}$ : Valparaiso, Santa Marta region, 5 ô,

2 (q); Las Nubes, 5 ô, 1 ㅇ, 5 (q); El Líbano, 3 ㅇ.

P. c. vieillotioides.-VENEZUELA: Mt. Bucarito, Lara, 2 ( $(8)^{3}$; Cubiro, 1 $q$; Bucaral, $1 \hat{\delta}$; Cumbre de Valencia, $1 \hat{\delta}, 1$; El Limón, $1 \hat{o}^{3}$; Colonia Tovar, 1 \&, 1 (q) ${ }^{3}$; El Junquito, 2 of, 4 q, 2

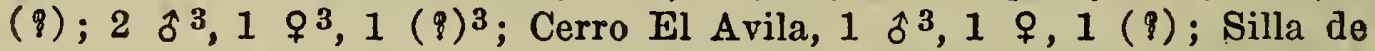
Caracas, $1 \hat{\delta}^{3}$; Hda. Izcaragua, Guarenas, 1 ô; Curupao, $1 \hat{\delta}, 1$ ( $(q)$; Cerro Golfo Triste, $1 \hat{\delta}, 2$; Cerro Negro, Miranda, $1 \hat{\delta}, 2$, 1 ( $q)$.

$P$. c. spadix.-VENEZUELA: Quebrada Bonita, Bergantín, $3 \hat{\delta}, 1$ (१); Caripe, 3 ô; Cerro Negro, 4 ô, 4 ㅇ, 2 (q).

P. c. pariae.-VENEZUELA: Cerro Azul, 12 ô (incl. type), 9 \&; Cerro Humo, 2 of, 3 $q, 1$ (q).

\section{Myioborus brunniceps pariae, new subspecies}

Type: From Cerro Azul, Cristóbal Colón, Península de Paria, Sucre, Venezuela. No. 44106, Phelps Collection, Caracas, Venezuela. Adult male collected June 10, 1948, by Ramón Urbano. (Type on deposit at the American Museum of Natural History.)

Diagnosis: Differs from $M$. $b$. castaneocapillus in having eye-ring, supraloral streak and forehead, against the bill, yellow; superciliary streak and rest of forehead black; back grayish with yellowish olive cast instead of brownish olive; outer tail-feathers more extensively white.

Range: Known only from the Subtropical Zone (800-1200 meters) of Cerro Azul and Cerro Humo on the Paria Peninsula.

Description of Type: Crown Burnt Sienna X Mahogany Red, bordered anteriorly and laterally by-black, the feathers elongated; back and uropygium Deep Mouse Gray tinged with olive, a few feathers on mantlo with dusky shaft streaks, forehead, close to the bill, preorbital region and eye-ring Lemon Chrome; lores and malar stripe black; ear-coverts and sides of head Deep Mouse Gray. Under parts Lemon Chrome, more whitish on under tail-coverts; sides and thighs mixed with grayish. Wings Fuscous-Black; inner vanes of remiges bordered with whitish, more extensively interiorly; bend of wing yellowish; under wing-coverts and axillaries whitish. Six median rectrices Fuscous-Black, very faintly barred with dusky; outer rectrices entirely white, the following pair with a little dusky on the inner vanes basally, and the third pair with dusky region occupying more than one half of inner vanes basally.

Bill (in life) "black"; feet "blackish yellow"; iris "brown". Wing $63 \mathrm{~mm}$; tail, 62 ; exposed culmen, 9 ; culmen from base, 13 ; tarsus, 19.

Remarks: Sexes alike. Smaller than M. b. castaneocapillus. Range of measurements: five adult males-wing, 59-63 (60.2) mm; tail, 59-62 (60.4); culmen from base, 12.5-13 (12.8); four adult females-wing, 57-60 (58.5); tail, 59-61 (60); culmen from base, 12-13 (12.6). Fivo adult males of $\boldsymbol{M}$. b. castaneocapillus-wing, 63-66 (64.4); tail, 59-62

${ }^{8}$ For list of localities see Zimmer, Am. Mus. Nov., No. 1043, p. 2. 1939. 
(60.8); culmen from base, 13-13.5 (13.3); five adult females-wing, 60-61 (60.6); tail, 57-61 (59.4); culmen from base, 13-13.5 (13.2).

May females have laying ovaries. Specimens were collected: 14 in May, 1 in June, 2 in September, 7 in November, 2 in December.

\section{SPECTMENS ExaMiNED}

M. b. brunniceps.-BOLIVIA ${ }^{3}$ : Chilon, 1 of; Pulque, 2 o, 1 ; ; Parotaní, 1 ô, 1 $q, 1$ (q); Tujma, 3 ô; Río Cachimayo, $3 \hat{\delta}, 1$ ‥ ARGENTINA ${ }^{3}$ : San Pablo, 5 ô, 5 \&; Tucumán, 9 ô, 6 \&; Tafí Trail, $1 \hat{\delta}, 1$; ; Quebrada Escoipe, 1 ô, 1 ㅇ.

M. b. castaneocapillus.-VENEZUELA: "Roraima", 3 of ; Philipp $\mathrm{Camp}^{3}, 9$ ô, 5 \&, 1 (१); Rondon $\mathrm{Camp}^{3}, 2$ ô, 4 \&; Arabupú, 1 (१); Cerro Roraima, 1 ô, 2 $\uparrow, 2$ (q); Cerro Ptari-tepui, $3 \hat{o}, 3 q, 6$ ( 3 ; ; Cerro Sororopán-tepui, 1 \&, 3 ( $(q)$; Cerro Chimantá-tepui, $5 \hat{\delta}, 7 q$, 7 ( 8 ); Cerro Uaipán-tepui, 4 ô, 5 $\$, 2$ ( $($ ); Cerro Aprada-tepui, 8 ô, 3 \&, 3 ( $q)$; Cerro Acopán-tepui, 3 \&, 4 (q); Cerro Uei-tepui, 7 \&, 5 $q, 4$ (§); Cerro Auyan-tepui ${ }^{3}, 4$ ô, 4 q, 1 (q).

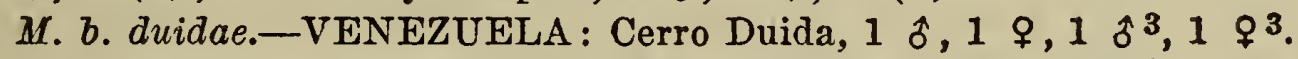

M. b. pariae.-VENEZUELA: Cerro Azul, 5 ô (incl. type), 1 $\$, 1$ (i) ; Cerro Humo, 7 $\delta, 6$ $q, 6(q)$.

\section{Basileuterus tristriatus pariae, new subspecies}

Type: From Cerro Humo, Península de Paria, Sucre, Venezuela. No. 44320, Phelps Collection, Caracas, Venezuela. Adult male collected May 9, 1948, by Ramón Urbano. (Type on deposit at the American Museum of Natural History.)

Diagnosis: Differs from $B$. $t$. meridanus of the Mérida region, and from $B$. $t$. bessereri of the Caracas region, by darker upper parts, brownish olive instead of yellowish olive.

Range: Known only from the Subtropical Zone (800-1200 meters) of Cerro Humo and Cerro Azul on the Paria Penninsula.

Description of Type: Crown and nape with wide lateral dusky stripes; center line pale olivaceous with partly concealed Pale Orange-Yellow crown patch; forehead dusky olive; back and uropygium Citrine-Drab; post-ocular stripe pale olivaceous; ear-coverts grayish, malar region dusky. Throat and breast Naples Yellow, abdomen and under tailcoverts paler; sides, flanks and shanks olivaceous; wings Benzo-Brown $X$ Fuscous; remiges and upper wing-coverts, except primary coverts, cdged with Citrine-Drab, uniform with back; under wing-corerts and axillaries whitish. Tail Benzo-Brown $\times$ Fuscous, paler below, rectrices edged externally with Citrine-Drab uniform with back.

Bill (in life) "black, base sepia"; feet "yellow"; iris "red". Wing, $61 \mathrm{~mm}$; tail, 53 ; exposed culmen, 9; culmen from base, 14; tarsus, 20.

Remarks: Sexes alike. Size of males larger than bessereri. Range of measurements: five adult males-wing, $60-63$ (61) $\mathrm{mm}$; tail, 52-57 (54); culmen from base, 13-14 (13.4); five adult females-wing, 56-59 (57.2) ; tail, 49-52 (50.6); culmen from base, 12.5-13 (12.9). Measurements of bessereri: five adult males-wing, 57-61 (59); tail, $52-54$ (53.4); culmen from base, 12.5-13.5 (13.1); five adult females-wing, $53-58$ (55.2); tail, 48-53 (51.4); culmen from base, 12-12.5 (12.2). 
May females have laying ovaries. Specimens were collected: 29 in May, 1 in June, 1 in August, 3 in September, 7 in November and 2 in December.

Hellmayr ${ }^{9}$ says, referring to $B$. $t$. meridanus: "Specimens collected by $A$. Mocquerys in the Tring Museum are labelled 'Caripé' but this is clearly a mistake." He formed this opinion because the species had never since been collected in the Mt. Turumiquire region. However, now that we know that the species is common in the subtropies of the Paria Peninsula, we can accept the information on the labels of the Caripe specimens. They do not belong to the new subspecies as their backs are similar to meridanus and we shall follow Hellmayr in considering them of that subspecies. Perhaps a good series may show that they represent a distinct race.

\section{SPECIMENS EXAMINED}

B. t. melanotis ${ }^{3}$-CCOSTA RICA: Aquinares, 2 ô; Quebradilla de Azajar, 2 \% ; Azajar de Cartago, 1 ( $($ ). PANAMA: "Chiriquí", 1 (8); Mt. Chiriquí, 1 o ; Boqueti, 1 ô, 1 ㅇ.

B. $t$. tacarunae $^{3}$-PANAMA: Mt. Tacarcuna, E. Panama, 6 ; 2 o.

B. t. tacarunae ${ }^{3}$-PANAMA: Mt. Tacarcuna, E. Panama, 6 ô; Tocarcuna, 3 ô.

B. t. daedalus ${ }^{3}$-ECUADOR: Gualea, $3 \hat{\delta}$; Paramba, 1 ô, 1 q, COLOMBIA : Cical, Cauca, $1 \hat{\delta}$; Cerro Munchique, 1 .

B. $t$. auricularis ${ }^{3}$-COLOMBIA: El Roble, Quindio Andes, $2 \hat{\delta}, 1$ \&; Salento, $1 \hat{\delta}, 1$ ( $q)$; Palmira, Cauca, $3 \hat{\delta}, 1$ q, 1 (q); Gallera, $1 \hat{\delta}$, 1 (q); Las Lomitas, 2 ; San Antonio, $7 \hat{\delta}, 1$ q, 1 (q); La Palma, Huila, 1 $\delta$; La Candela, $7 \hat{\delta}, 1$ $\uparrow$; San Agustín, $1 \hat{\delta}$; Aquadita, 1 ô ; "Bogotá", 6 (q).

B. t. baeza $a^{3}$-ECUADOR: Baeza, 2 ઈ, 2 \% San José de Sumaco, 1 ô; Sumaco, Abajo, 3 ô, 4 o ; Macas, 1 ( $q$ ).

B. t. tristriatus ${ }^{3}$-ECUADOR: Sabanilla, 1 \% ; PERU: Chelpas, 18,1 \%.

B. t. punctipectus ${ }^{3}$-BOLIVIA: Inchacha, 1 of, 2 \&; Locotal, $2 \hat{\delta}$,

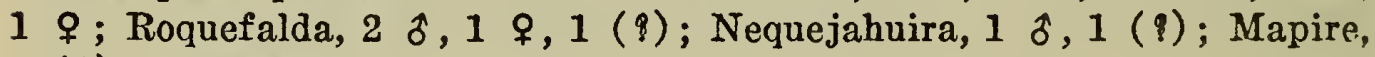

$1(q)$; Yungas, $1 \hat{\delta}$.

B. $t$. meridanus.-VENEZUELA: Queniquea, Táchira, $1 \hat{\delta}, 2$; Seboruco, 1 q; Páramo de la Culata, Mérida, 1 \%; Valle ${ }^{3}, 1$ o; Páramo de Cendé, Trujillo, 1 \%; Cerro Niquitáz, 1 $\delta$; Cerro El Cer rón, Lara, 1 ô, 3 o, 1 (\$); Cubiro, 2 ô, 2 ㅇ, 3 (\$); Bucarito ${ }^{3}, 1$ (१); Bucaral, Yaracuy, 1 $q$; Cumbre de Valencia, $1 \mathrm{o}^{3}$; Caripe, Monagas, $2(8)^{3}$.

B. $t$. bessereri.-VENEZUELA: Colonia Tovar, 3 o, 2 q, 1 ( () ; No León, $2 \hat{\delta}, 2(q)$; El Junquito, 2 $q, 1 \hat{\delta}^{3}$; El Limón, 1 $q^{3}$; Cerro El Avila, 1 o; Silla de Caracas, $1 \hat{\delta}^{3}$; Galipán ${ }^{3}, 2 \hat{\delta}, 1$; Cotiza $^{3}$, 3 o, 2 \&, 1 (\%) ; Hda. Izcaragua, Guarenas, 1 \% ; Cerro Golfo Triste, 2 o, 1 \%, 1 ( ( ) .

B. $t$. pariae.-VENEZUELA: Cerro Humo, 7 ó (incl. type), 11 ㅇ․ 6 (\&); Cerro Azul, 5 \&ิ, 7 \&, 7 ( () .

Cat. Birds Americas, etc. Part 8, p. 496, 1935. 


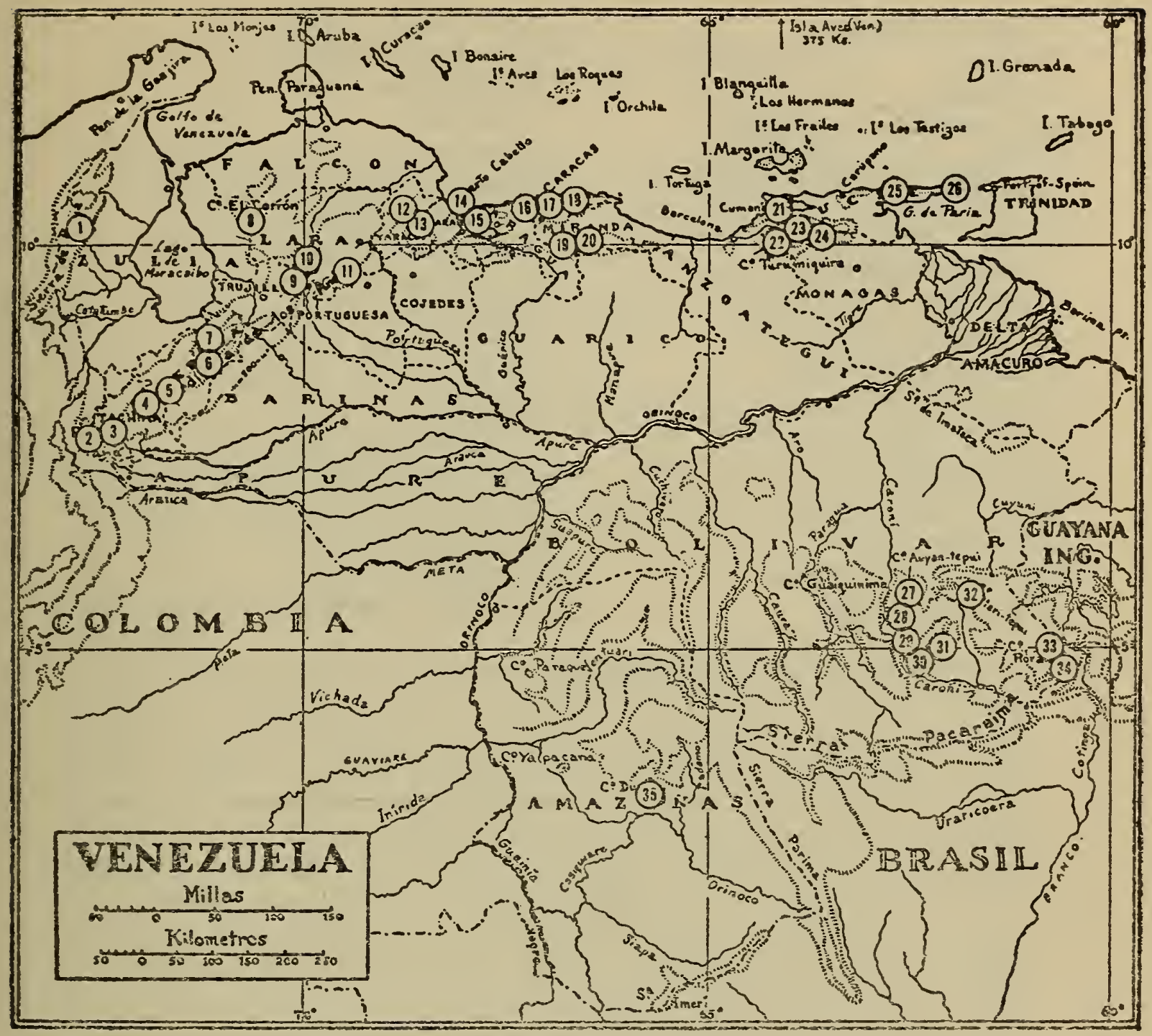

Explanation of Plate IV

31 Acopán-tepui, Cerro

29 Aprada-tepui, Cerro

33 Arabupú

27 Auyán-tepui Cerro

26 Azul, Cerro

22 Bergantín

5 Boca de Monte

12 Bucaral

10 Bucarito, Cerro

17 Caracas

23 Carapas

24 Caripe

30 Chimantá-tepui

13 Colonia Chirgua

16 Colonia Tovar

17 Cotiza

26 Cristóbal Colón

11 Cubiro
21 Cumaná

23 Cumanacoa

15 Cumbre de Valencia

18 Curupao

35 Duida, Cerro

17 El Avila, Cerro

8 El Cerrón, Cerro

16 El Junquito

16 El Limón

17 Galipán

18 Guarenas

19 Golfo Triste, Cerro

25 Humo, Cerro

25 Irapa

18 Izcaragua, Hacienda

22 La Elvecia

1 La Sabana

23 La Tigerera 
44 Proceedings of the Biological Society of Washington

\author{
2 Las Delicias \\ 23 Latal \\ 6 Mérida \\ 24 Negro, Cerro (Caripe) \\ 20 Negro, Cerro (Miranda) \\ 9 Niquitáz, Cerro \\ 16 No León \\ 9 Páramo Cendé \\ 7 Páramo de la Culata \\ 6 Páramo El Escorial \\ 2 Páramo de Tamá \\ 25 Paria Peninsula \\ 14 Paso Hondo \\ 22 Peonía, Cerro \\ 25 Península de Paria \\ 33 Philipp Camp \\ 32 Ptari-tepui, Cerro \\ 14 Puerto Cabello
}

\author{
22 Quebrada Bonita \\ 23 Quebrada Seca \\ 4 Queniquea \\ 7 Quintero \\ 23 Rincón de San Antonio \\ 33 Rondón Camp \\ 33 Roraima, Cerro \\ 3 San Cristóbal \\ 14 San Jean \\ 18 San José de los Caracas \\ 23 Santa Ana Valley \\ 15 Santa Clara, Hacienda \\ 4 Seboruco \\ 17 Silla de Caracas \\ 32 Sororopán-tepui, Cerro \\ 23 Turumiquire, Cerro \\ 28 Uaipán-tepui, Cerro \\ 34 Uei-tepui, Cerro \\ 7 Valle (Mérida)
}


Vol. 62 , pp. $45-52$

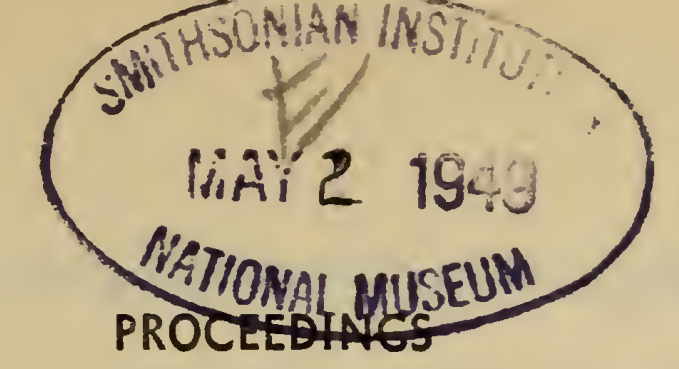

April 27, 1949

OF THE

BIOLOGICAL SOCIETY OF WASHINGTON

\section{DESCRIPTIONS OF SOME UNDESCRIBED FORMS BELONGING TO TWO LITTLE KNOWN SPECIES OF THE FAMILY APHIDIDAE}

Bу F. C. HотTeS

The opportunity is taken to describe several hitherto un. known forms belonging to two little known species of Aphididae and to record some observations concerning their life habits.

\section{Macrosiphum macrosiphum (Wilson).}

Alate male.

This form is described from two specimens. Size and general color.Length from vertex to tip of anal plate $1.04-1.33 \mathrm{~mm}$. Head, first two antennal segments and the prothorax dusky brown with some areas slightly lighter in color, areas around the base of the hair slightly raised and clear. Meso and metathorax on the dorsum rich dark brown with some areas almost black, sides of thorax with some yellow and green. Abdomen rich yellow with dusky markings as follows: four small dark dusky areas or patches on the sides anterior to the cornicles, two rows of lighter dusky areas on the dorsum extending inwardly from the first three lateral spots; just anterior to the cornicles there is an irregular dusky spot which is more or less band-like; posterior to the cornicles there are two rather broken bands of the same dusky color. The cornicles are dusky brown, posterior to their origin the abdomen is dusky brown. The anal plate is dusky, the cauda is more or less yellowish with dusky margins and setulose structures. The antennae are dark dusky brown except for the extreme base of III which is lighter in color. Antennal segment III is darker than the remaining segments. Segments III, IV and V of the rostrum are dusky brown with the tip and margins almost black. Femora yellow at the base shading gradual. ly to light dusky at the apex. Tibiae light dusky with basal and apical portions darker. Tarsi concolorous with apex of tibiae. Gonapophyses dark brown.

Head and appendages.-Antennal tubercles well developed. Vertex with a well developed median tubercle. First antennal segments slightly gibbous on median surface. The gibbous portion of the first antennal segment is slightly rough. Antennal segments with the following proportional lengths: III $.715-.772 \mathrm{~mm}$., IV $.54-.60 \mathrm{~mm} ., \mathrm{V} .58-.60 \mathrm{~mm}$., VI .11-.14 mm + 1.00-1.31 mm. Secondary sensoria on segments III, IV, and $V$ distributed as follows: III 47-53, IV 22-26, V 20-27. On III the sensoria are quite evenly distributed over all but the anterior surface. On this segment the sensoria are uniform in size and slightly tuberculate. Segment IV has the sensoria irregularly arranged, on this 


\section{6 \\ Proceedings of the Biological Society of Washington}

segment the base is almost free from sensoria. From the middle of the segment towards the apex the sensoria are spaced closer and closer together till at the apex they are very much crowded together. Segment $V$ has the sensoria in more or less of a row and like those on IV they are crowded near the apex. III and IV are slightly imbricated, V and VI are distinctly so. Hair on antennae fine, sparse and less than half the width of segment in length. The rostrum fails conspicuously to reach the coaxe of the mesothoracic pair of legs in one case, and almost reaches them in the other.

Thorax.-The forewings of one specimen are missing, and the wings of the other specimen are poorly mounted, hence the only statement that may be made regarding the viens is that they are dark brown and more or less bordered with fuscous. Length of hind tibiae 1.14-1.28 mm. Length of hind tarsi $.114-.128 \mathrm{~mm}$.

Abdomen.-Cornicles typical of species in shape, in length .856-.886 mm. very slightly imbricated, the imbrications being better developed at the base and for the most part lacking on the apical fourth, Cauda $.143-.151 \mathrm{~mm}$. not constricted. One specimen shows two hairs on one side and one on the other, the other specimen shows the sides of the eauda provided with three and four hairs, the hairs on the cauda are long, fine, and sharply pointed. The anal plate is narrow and carries a row of hair on its outer margin. The gonapophyses appear to be further forward than usual, they are short and well provided with hair.

Oviparous female. Wilson confines his description of this form to the color. Size and general color.-Average length from vertex to tip of anal plate $1.69 \mathrm{~mm}$., range in length from 1.53-1.89 $\mathrm{mm}$. Width of head across eyes $.34-.38 \mathrm{~mm}$. Color uniform yellow to light yellowishtan, except as follows: gibbous portion of first antennal segment; apical portion of III and basal and apical portions of IV and V and all of six light dusky to light brown. Basal and apical portions of tibiae and all of tarsi light dusky. Cornicles with apical portions dusky and sometimes entirely so. Cauda light dusky or if not the setulose surface alone is.

Head and appendages.-Antennal segments with the following comparative lengths: III .70-.74 mm., IV .45-.62 ave. .52 mm., V .38-.64 ave. $.54 \mathrm{~mm}$., VI .14-.15 mm. + .57-1.28 ave. $.74 \mathrm{~mm}$. Secondary sensoria confined to third antennal segment and never more than one. The rostrum extends beyond the coxae of the mesothoracic pair of legs but fails to reach those of the metathoracic pair.

Thorax.-The hind tibiae vary in length from $1.35-1.43 \mathrm{~mm}$., the hind tarsi vary from .10-.12 $\mathrm{mm}$. About the basal third of the hind tibiae is very slightly swollen and provided with sensoria, which are very difficult to distinguish.

Abdomen.-The cornicles are typical of the species and vary in length from 1.14-1.28 mm., with the average slightly less than $1.20 \mathrm{~mm}$. The cauda varies in length from $.214-.286 \mathrm{~mm}$. and averages $.26+\mathrm{mm}$. The cauda is not constricted, its sides are uniform and carries from two to three hair on a side and as a rule one on the dorsum near the apex. Its surface is very finely setulose. The anal plate is well rounded, has a setulose surface and carries long pointed hair on its outer margin. About midway between the cornicles and the end of the anal plate the abdomen is considerably narrowed. 
Allotype alate male, Skyway, Colorado, September 14, 1948. Morpho. type oviparous female Skyway, Colorado, September 14, 1948. Both were taken on Amelanchier alnifolia. Both deposited in United States Na. tional Museum.

Wilson described the apterous viviparous female and what he supposed to be the male in the Canadian Entomologist, Volume 44, pp. 155-156, 1912. He placed the species in the genus Illinoia. I described the alate viviparous female in the ProceEdings of tHe BIOLOGICAL Society of Washington, Volume 47, pp. 7-8, 1934. I placed the species in the genus Adactynus. Wilson described the species as occurring in small colonies. I have only taken it solitary on the under sides of the leaves. My experience indicates that it is a very rare species.

Macrosiphum rudbeckiarum (Cockerell).

In 1903, Professor Cockerell, then residing in New Mexico, deseribed from Rudbectia ampla an aphid to which he gave the name Nectarophora rudbeckiarum. Since that time the species seems to have been recorded only in literature. I have been familiar with this species since 1930 and take this opportunity to describe all forms and to record some notes concerning its life history and its possible relationship to another species. Alate viviparous female.

Size and general color.-Length from vertex to tip of anal plate 2.51. 3.47 , ave. $3.02 \mathrm{~mm}$. Width of head across eyes $.54-.57 \mathrm{~mm}$. Head and prothorax light dusky brown. Mesothorax and metathorax brown with darker markings. Abdomen green with a darker median stripe. First antennal segment light dusky with inner margin light brown. Antennal segments II, III, IV, and V light dusky with basal portions of IV and $V$ and apical portions of III, IV, and $V$ darker. VI brown. Femora light dusky with dorsal portion darker. Tibiae light dusky with apical portions light brown, tarsi light brown concolorous with apex of tibiae. Cornicles pale to light dusky, cauda and anal plate the same, cauda with darker setulose surface. Veins of wings brown with a suggestion of a light dusky border.

Head and appendages.-Antenual segments with the following proportional lengths: III 1.02-1.17 mm., IV 1.10-1.24 mm., V .97-1.14 mm., VI .214-.228 mm. + 1.43-1.60 mm. Secondary sensoria confined to the third antennal segment, numbering from $16-33$ average 22 . The sensoria are arranged in more or less of a regular row, any irregularity occuring near the basal portion. The sensoria fail to reach the apical portion of the segment by a distance equal to a little less than the combined lengths of I and II. The sensoria are large and have wide rims, those on the basal half are somewhat oval, the others are round. The surface of III and IV is smooth, segment $V$ is slightly imbricated and VI is distinctly so. On III the hair are for the most part slightly shorter than the width of the segment, they are rather coarse and sharp pointed. The rostrum reaches the coxae of the mesothoracic pair of legs, its tip is almost black, segments III and IV are light dusky. There is a median tubercle on the vertex.

The Thorax.-The metathoracic tibiae are $3.43 \mathrm{~mm}$. long. The tarsi of this pair of legs are $.10-.185 \mathrm{~mm}$. long. The hair on the hind tibiae are rather coarse and sharp pointed. In length the hair near the basal portion are shorter than the width of the segment while those near the apex are slightly long than the width of the tibiae at this point. 
There are no lateral tubercles on the thorax or abdomen. The stigma is pale dusky and has a scale-like surface. Under the stigma there is a faint accessory vien. The racial sector is considerably bowed. The second branch of the media is closer to the margin of the wing than it is to the first branch. All veins are very lightly bordered and none reach the margin of the wing.

The Abdomen.-The cornicles are 1.14-1.43 mm. long. Approximately $.17 \mathrm{~mm}$. of the cornicle at the apex is covered with closed reticulations. The surface of the cornicle not reticulated is imbricated and it is difficult to determine where the imbrications stop and the reticulations begin. The reticulated portion of the cornicle is very slightly narrower than the portion just above. The abdomen has a few rather long sharp pointed hair. The cauda is $.53-.54 \mathrm{~mm}$. long, it is not constricted and has a setulose surface. The cauda has five or six lateral hair. The anal plate is small for an aphid of this size and well rounded.

Apterous viviparous female.

Size and general color.-Average length from vertex to tip of anal plate $3.54 \mathrm{~mm}$., the range is from $2.93-3.93 \mathrm{~mm}$. Half of the females measured have a length of $3.86 \mathrm{~mm}$. or more. Head, thorax, and abdomen light green with the head and first two antennal segments somewhat lighter in color, often very light, abdomen with a darker median stripe. Antennal segments III, IV, and V pale to light dusky, the apical portions darker. Segment VI brown. Some specimens will have antennal segments IV and V dusky brown. Segments IV and V of the rostrum dusky brown. Femora pale greenish. Tibiae pale greenish except for the region near the apex which is light dusky. Tarsi brown. Specimens of this form taken in the fall will have the antennae and legs darker than specimens taken in the summer. Cornicles pale green with the reticulated area light dusky. Fall forms may have the cornicles pale dusky with the apex much darker. Cauda and anal plate pale green.

Head and appendages.-Width of head across eyes $.57-.60 \mathrm{~mm}$. The antennal tubercles are very well developed, each tubercle has two hairs directed inwardly. The vertex has a well developed median tubercle. There are two hairs on the anterior margin of the vertex and rarely three. Comparative lengths of antennal segments as follows: III 1.02. 1.28 ave. $1.17 \mathrm{~mm}$., IV .91-1.28 ave. $1.18 \mathrm{~mm}$., in only two cases out of eight taken at random was antennal segment IV shorter than III. V 1.00-1.14 ave. $1.04 \mathrm{~mm}$., VI .214-.286 ave. .245 mm., + 1.28-1.71 ave. $1.44 \mathrm{~mm}$ Secondary sensoria confined to third antennal segment, numbering from four to ten, most common number seven to nine. The hair on segment III are for the most part as long as the segment is wide, the hair are blunt at the tip but not enlarged. III is smooth, IV is smooth for the basal half and lightly imbricated for the remainder, $V$ is moderately imbricated and VI is very much imbricated. The rostrum extends just beyond the coxae of the mesothoracic pair of legs.

Thorax.-The hind tibiae measure from 3.14-4.07 $\mathrm{mm}$. long and average $3.70 \mathrm{~mm}$. The hind tarsi are $.17+\mathrm{mm}$. long. There are no lateral tubereles on the thorax.

Abdomen.-The abdomen is without lateral tubercles. The cornicles measure from 1.14 in only one case to $1.64 \mathrm{~mm}$. in length. The average length of the cornicles is $1.52 \mathrm{~mm}$. Approximately $.17 \mathrm{~mm}$. of the 
cornicle at the apex is reticulated, the remainder of the cornicle is imbricated. The base of the cornicle is very broad, the remainder of the cornicle is almost straight. The cauda is rather broad and spatulashaped, it is not constricted and earries its width well towards the apex, which is not sharply pointed. There are from four to six hairs on a side, the entire surface of the cauda is setulose. In length the cauda varies from $.57-.71 \mathrm{~mm}$. The average length of the cauda is $.67 \mathrm{~mm}$. Apterous oviparous female.

Size and general color.-Length from vertex to tip of anal plate 2.93-3.50, average length $3.21 \mathrm{~mm}$. Head, thorax, and abdomen similar to that of apterous viviparous female. Antennal segments, legs and cornicles as a rule darker than those of summer apterous viviparous females, and at times much darker, at such times approaching brown.

Head and appendages.-Average width of head across eyes $.54 \mathrm{~mm}$. varying from $.52-.57 \mathrm{~mm}$. Comparative lengths of antennal segments as follows: III .92-1.14 ave. $1.07 \mathrm{~mm}$, most common length $1.14 \mathrm{~mm}$., IV, .92-1.10 ave. $1.03 \mathrm{~mm}$. IV was equal to III in two cases. V .80-.95 ave. $.90 \mathrm{~mm}$., VI .17-.21 + 1.000-1.43 ave. $1.28 \mathrm{~mm}$. Secondary sensoria limited to III and numbering from five to nine, with five the most common number. As a rule there is considerable difference in size of the sensoria which are arranged in a row, on the basal half of the segment. The rostrum commonly extends slightly beyond the origin of the mesothoracic coxae, but two specimens were noted where the rostrum was much shorter.

Thorax.-The hind tibiae vary in length from 2.78-4.07 and average $3.41 \mathrm{~mm}$. The hind tibiae are only slightly swollen and this occurs in a very short distance. In the swollen area and extending slightly beyond, there are about twenty sensoria. The hind tarsi are approximately $.17 \mathrm{~mm}$. long.

Abdomen.- The cornicles are similar to those of the viviparous females, except that the imbrications are less well developed. The anal plate and the cauda are similar to these structures in the apterous viviparous female. The apex of the abdomen is but little drawn out, unlike that of most oviparous females.

Alate male.

Size and general color.-The length from vertex to tip of anal plate varies from 1.40-1.78, the average length is $1.65 \mathrm{~mm}$. As a rule the. length is more than $1.70 \mathrm{~mm}$. Width of head across eyes varies from $.34-.58 \mathrm{~mm}$., arerage width of head $.46 \mathrm{~mm}$. Head dusky with darker brown markings. Antennal tubercles with some greenish-yellow. Median portion of thorax brown with a small amount of black, remainder of thorax green. Abdomen green with a rellowish cast except as follows: three lateral dusky brown patches anterior to the cornicles, small dusky patch surrounding the base of the cornicles; dorsum of abdomen with two rows arranged on three segments of dusky brown to brown areas the second, third rows more or less confluent in the median section. Some specimens have a large dusky brown saddle which overlaps the sides in place of the lateral and dorsal patches. Cornicles pale to light dusky except for the reticulated portion which is dusky. Cauda dusky green. Antennae almost uniform dusky except for one and two and the base of three which are dusky yellow. Femora pale at the base shading to brown at the apex. Tibiae light dusky with the apical portions and 


\section{Proceedings of the Biological Society of Washington}

the tarsi brown. Stigma dusky with a brownish accessory vein beneath. Veins brown surrounded by a light dusky border. Margin of wing light smokey distinctly darker than the more median portion of the wing.

Head and appendages.-Antennal tubercles well developed. Vertex with a median well developed tubercle. Antennal segments with the following proportional lengths: III .78-1.14 ave. $1.03 \mathrm{~mm}$. Most specimens will show III longer than average. IV .85-1.17 ave. $1.07 \mathrm{~mm}$. In six cases out of nine taken at random IV was longer than III and equal to III in another. V .85-1.04 ave. $.94 \mathrm{~mm}$., VI .21-.24 mm. + 1.07. 2.02 ave. $1.74 \mathrm{~mm}$. Secondary sensoria distributed as follows: III 94 119 covering most of surface except for basal and apical regions, the sensoria are uniform in size and have wide rims; IV has from 55-73 sensoria and they appear to cover about three sides of the segment; $V$ has from 27-35 sensoria and on this segment they are for the most part confined to one side of the segment and are closer together near the apex. On III the hair are shorter than the width of the segment and sharp pointed. The rostrum reaches just beyond the mesothoracic eoxae.

Thorax.-The second branch of the media is closer to the first branch than it is to the margin of the wing. The radial sector is long and little bowed. The outer portion of the wing is quite rough as though covered with scales. The hind tibiae are $2.35-2.64 \mathrm{~mm}$. long and average $2.51 \mathrm{~mm}$. The most common length of the tibiae is $2.57 \mathrm{~mm}$. The hind tarsi measure $.143 \mathrm{~mm}$. in length.

The Abdomen.-The cornicles are from $.54-.74 \mathrm{~mm}$. long and average $.62 \mathrm{~mm}$. They are reticulated near the apex for a distance of about .1 $\mathrm{mm}$. The cauda varies in length from $.21-.24 \mathrm{~mm}$., it has from four to five lateral hair. The gonapophyses are dark brown and quite similar to those of other males.

The host upon which I took all forms of this species from the stem mothers in the spring to the sexes in the fall was Rudebeckia montana, a composite which lacks the ray flowers, and it was this that attracted me to it in 1930 when I collected the first specimens from it. The aphids show a preference for the under sides of the leaves. This is especially true of the sexual forms. The alate viviparous forms, if there are any, seem to prefer the flower stem directly under the disk. The immature forms of this species are often pale cream to pale yellow. In the fall immature forms are apt to show a slight frost-like pulverulence. Alate forms of this species key to Macrosiphum laevigatae Essig in all keys known to me. I so determined it for many years until Prof. Palmer called my attention to Prof. Cockerell's description. In 1947 and again in $1948 \mathrm{I}$ was able to follow the complete life cycle on Rudebeckia so I have positive proof that the species need not migrate to a secondary host, although I lack proof that it does not. During the summer of 1948 I tried to colonize apterous viviparous females from Rudebeckia on Salix from which I had collected Macrosiphum laevigatae without success. I also tried to colonize apterous laevigatae on Rudebeckia from June 6 to July 13, after which I could no longer locate laevigatae on Salix. (Prof. Palmer informs me that she has records of Macrosiphum laevigatae on Willow taken August 14, 20-31.) In every case my attempts ended in failure. Another year I shah 
attempt similar transfers making use of alate forms which should be the more normal transfer agents, but these were not available in 1948 when only one alate rudbeckiarum was seen and only two alate laevigatae collected although many pupae of this species were seen on July 13. Macrosiphum laevigatae taken from Salix has a shorter cauda than Macrosiphum rudbeckiarum and also has fewer sensoria, 13-14, to 16-33 in rudbeckiarum. In other anatomical features laevigatae is as a rule smaller than rudbeckiarum but smaller forms of rudbeckiarum will be found to agree except for cauda and sensoria better with lasvigatae taken on Salix.

Until we know more about these seldom-taken forms, it will be well to hold them distinct. On September 14, 1948, I took apterous oviparous females of this species on the under sides of the leaves of Rubus sp. At the time I collected them on Rubus they were mixed in with a species belonging to the genus Amphorophora and it was this species alone that I thought I was collecting. Of this I am positive, and there was no mix-up of species.

Allotype alate male September 3, 1947. Morphotype apterous viviparous female June 25, 1948. Morphotype apterous oviparous female September 14, 1948. (Taken in copulation with male mounted on same slide.) All types deposited in the United States National Museum. Paramorphotypes also taken on the following dates: July 1930, July 1932, June 25,.1948, July 13, 1948, September 3, 1948, September 14, 1948.

All taken on Rudebeckia montana near \$kyway, Colorado. 
52 Proceedings of the Biological Society of Washington 



\section{Proceedings of the Biological Society of Washington}

stigma is dark and has a scale-like surface. Tibiae long rather thin. Hair on tibiae rather coarse, sharp-pointed and about as long as width of tibiae. First tarsal segment apparently with only two hair.

Abdomen.-The cornicles vary in length from .12-.14 mm. In shape they are similar to those of the viviparous females, they are lightly imbricated. Hair on abdomen apparently confined to dusky areas, or arising from small dusky elevations not much wider than the hair itself. The hair on the abdomen is fine and sharp-pointed, very much unlike that found on the abdomen of the female. The cauda is from .12-.15 $\mathrm{mm}$. long, it is wide throughout, it has three lateral hairs and two on the dorsum. All hairs arise posterior to the middle. The gonapophyses are very hairy.

Oviparous female.

Size and general color.-Length from vertex to tip of anal plate 1.79-2.32 $\mathrm{mm}$. ave. $2.08 \mathrm{~mm}$. Color similar to that of apterous viviparous female. In a few females the eggs show through the surface of the body as lighter colored areas. Average width of head through the eyes $.45-.52 \mathrm{~mm}$.

Head and appendages.-Antennal segments with the following comparative lengths: III .48-.65 ave. $.52 \mathrm{~mm}$., IV $.27-.38$ ave. $.31 \mathrm{~mm}$., V .22-.28 ave. $.25 \mathrm{~mm}$., VI .1+.64-.78, most common length $.64 \mathrm{~mm}$. Secondary sensoria on III 8-19, most common number 12 . On this segment the sensoria are confined to the basal half of segment, they are located only on one side of the antenna, are small and quite tuberculate. There are no secondary sensoria on the third or fourth antennal seg. ments. On the third antennal segment the hair are sparse, sharp-pointed, and for the most part longer than the width of the segment. Segments III and IV are lightly imbricated, segments V and VI are conspicuously so. The front of the head has a well developed rather square shaped median tubercle. The rostrum almost reaches the coxae of the metathoracic legs. The hind tibiae have the basal halves much swollen, sensoria occupy this area and extend downwards past the middle of segment. The sensoria are irregular in shape and size. The hair on the swollen portion of the tibiae is less abundant than it is on the lower portions.

Abdomen.-The cornicles and cauda as in the viviparous female. The tip end of the abdomen is somewhat drawn out.

The males and the oviparous females were taken near Skyway, Colo. rado, on the underside of the leaves and on the seed pods of Aconitum columbianum. The complete life history of this species may be followed on this host.

Allotype alate male, taken near Skyway, Colorado, August 18, 1948. Morphotype apterous oviparous female taken near Skyway, Colorado, August 23, 1948. Other sexuals belonging to this species were taken August 3 and on August 11 in the same locality. At the time $I$ described the viviparous forms $I$ remarked at the difficulty of placing this species in a genus. It is just as difficult to do so now. Both the allotype male and the morphotype oviparous female have been placed in the United States National Museum. 


\section{Macrosiphum yagasogae. \\ Alate male.}

Size and general color.-This form is described from two specimens taken with several oviparous and viviparous females. Length from vertex to tip of anal plate $1.52-1.78 \mathrm{~mm}$. Width of head through eyes $50 \mathrm{~mm}$. Head dusky brown with the antennal tubercles lighter. Prothorax concolorous with head meso and metathorax brownish-black on the dorsum and venter, later surfaces dark green. Abdomen dark green with dusky brown spots on the sides. Dorsum of abdomen with much dusky brown in the form of irregular patches, portion of abdomen posterior to cornicles with more dusky brown than green. Cornicles uniform dusky. Cauda and anal plate pale dusky. Gonapophyses brown. First and second antennal segments somewhat lighter in color than the head. Third antennal segment dusky except at extreme base. Fourth antennal segment dusky growing darker towards the apex, fifth segment darker than the fourth, sixth segment dark brown. Rostrum pale green at base, terminal segments light dusky. Femora of all legs pale with a greenish cast basally and with the upper apical surface light dusky. Tibiae pale except for apical portions which are brown. Tarsi brown.

Head and appendages.-Antennal segments with the following proportional lengths: III .68-.77 mm., IV .61-.64 mm., V .68-71 mm., VI $.20-.22 \mathrm{~mm}$. $+1.21-1.30 \mathrm{~mm}$. The antennal tubercles are well developed. The secondary sensoria are distributed as follows: III 38-42, IV 0-2, V 20-22. On III the secondary sensoria are irregularly arranged but for the most part are confined to one side of the segment. On this segment the sensoria are irregular in size and have wide rims. If sensoria are found on IV they are beyond the middle of the segment. The basal portion of $\mathrm{V}$ is free from sensoria but once they begin they are almost in a straight row and placed closer and closer together till at the apex very little if any space separates them from one another. Antennal segments III and IV are lightly imbricated, segments $V$ and VI are conspicuously so. The rostrum fails to reach the mesothoracic coxae. The dorsum of the head has two clear areas suggestive of sensoria.

Thorax.-The hind tibiae are $1.82 \mathrm{~mm}$. long. The hind tarsi measure $.157 \mathrm{~mm}$. The stigma is long and thin, its surface is scale-like. An accessory vein is present beneath the stigma. The first branch of the media is midway between the second branch and the margin of the wing.

The abdomen.-The cornicles are $.50 \mathrm{~mm}$. long. The reticulations at the apex of the cornicles extend for a distance of $.10 \mathrm{~mm}$. The remaining portion of the cornicles is imbricated in a manner to suggest reticulations. The cauda is $.171 \mathrm{~mm}$. long, with from four to five hair on a side and from none to two on the dorsum, the cauda is not constricted. The anal plate is deep and quite narrow. The gonapophyses are shorter than usual and quite hairy.

Allotype male taken at Skyway, Colorado, September 10, 1948, on Solomon's Seal Polygonatum commutatum. Deposited in the United States National Museum. Dr. Frison and I described Macrosiphum kickapoo from material collected on the same host in Illinois. The two species show an unmistakable affinity but at the same time maintain their specific identity. This interesting relationship should be further investigated. 


\section{Proceedings of the Biological Society of Washington}

\section{Kakimia tutigula (Hottes)}

Alate male.

Size and general color.-A Arage width of head through eyes $.41 \mathrm{~mm}$. Average length from vertex to tip of anal plate 1.72, range from 1.68 . $1.78 \mathrm{~mm}$. Head dark dusky brown shading to almost black. Dorsum of thorax dark dusky brown to black, lateral portions of thorax lighter and somewhat green. Abdomen green with dusky brown patches along lateral margins and broken patches of the same color on the dorsum. Antennae with the exception of the extreme base of third segment uniform dusky. Rostrum dusky. Femora with base yellowish-green shading to dusky at the apex. Tibiae dusky at base and apex, remaining portion light dusky. Cornicles and cauda dusky. Gonapophyses almost black.

Head and appendages.-Antennal segments with the following comparative lengths: III .60-.81 ave. $.71 \mathrm{~mm}$., IV $.51-60$ Ave. $.55 \mathrm{~mm} ., \mathrm{V}$ $.48-.52 \mathrm{~mm}$. , VI $.15-.21$ ave. $.17 \mathrm{~mm} .,+.60-.74$ are. $.68 \mathrm{~mm}$. Secondary sensoria on III irregularly arranged but confined for the most part to one side of the segment. The sensoria are irregular in size, have wide rims, and are very little if any tubereulate. The sensoria near the apex of III are few and confined to a row. On $V$ the sensoria are arranged in an irregular row. The sensoria number as follows: III 49-69 ave. 58, V 20-28 ave. 23. All antennal segments are are imbricated V and VI more so than the others. Hair on antennal segments fine, considerably shorter than the width of segment and very sparce. Ocular tubercles small. Rostrum short, failing to reach coxae of mesothoracic pair of legs.

Thorax.-First branch of media as a rule closer to margin of wing than to origin of second branch. Radial sector rather flat, being but little bowed. Stigma narrow. Hind tibiae long.

Abdomen.-Cornicles .20-.21 mm. long, imbricated. Cauda .18-.20 mm. long with from 2-3 hair on a side near the apex and from two to three hair on the dorsum. Gonapophyses very hairy.

Taken near Skyway, Colorado (region of Island Lake, type locality) September 10, 1948, on Capnoides $s p$. At that time there were no oviparous females. On September 17, following a killing frost, one immature oviparous female was taken. The slide bearing the allotype male has been deposited in the United States National Museum. Kalimia tutigula spends its whole life cycle on Capnoides $s p$. 


\section{GEOGRAPHIC VARIATION IN THE RIBBED FROG, ASCAPHUS TRUEI}

\section{By M. B. Mittleman and George S. Myers}

In the Pacific Northwest, from British Columbia and Montana to northern California, occurs the most remarkable of North American frogs. Ascaphus truei Stejneger is not only the most primitive New World frog, but it also possesses a tadpole unique among Nearctic Salientia. Heretofore, but a single named population has been recognized within the genus Ascaphus. While it is the primary purpose of this paper to demonstrate the existence of three recognizable populations of Ascaphus, a brief historical and systematic introduction appears to be useful.

The Ascaphidae, as recognized by Noble (1931: 485, where called Liopelmidae), include but two genera, Leiopelma and Ascaphus. The first-known genus, Leiopelma ${ }^{1}$, is restricted to New Zealand, from whence three forms have been described: L. hochstetteri Fitzinger, L. hamiltoni McCulloch, and L. archeyi Turbott. The primitive nature of Leiopelma was not at first understood, principally because of the then-rudimentary state of frog classification. Fitzinger (1861) compares the genus with Telmatobius and Cyclorhamphus, two neotropical genera now referred to the Leptodactylidae. Steindachner (1867:33) places Leiopelma in the "Bombinatoridae," a heterogeneous group assembled by Günther, and based chiefly on dentition, hympanum, and toe-webbing. Boulenger (1882: 447) appears to have been the first to recognize that Leiopelma belongs with the primitive, ribbed frogs, but his later denial of the presence of rudimentary ribs, and consequent placement of Leiopelma in the "Cystignathidae" (= Leptodactylidae), in 1910 (p. 150, footnote), has never been properly explained. The work of Noble (1922) reinstated Leiopelma among the ribbed frogs, but he separated this genus and Ascaphus from the more advanced Discoglossidae, in which all the ribbed frogs had previously been placed (Noble, 1931: 485).

On the other hand, Ascaphus, unlike Leiopelma, was recognized as a primitive frog from the very first. The unique type specimen was obtained by Cloudsley Rutter of Stanford University, during the course of some ichthyological work he was doing for the U. S. Fish Commission

1This generic name is spelled Liopelma by most recent writers, following Bou. lenger (1882: 447). Myers and Carvalho (1945: 17, footnote 5) called attention to this error, although they did not have Fitzinger's original paper in hand. While the classically correct transliteration of the name would be Liopelma, Fitzinger (1861:218) spelled it Leiopelma, and the International Rules require the retention of this orthography. 


\section{Proceedings of the Biological Society of Washington}

in western Washington State. The type was forwarded to Washington, probably to the headquarters of the Fish Commission, whence it was turned over to the National Museum. The specimen was described by Stejneger in 1899, as Ascaphus truei, and referred to the Discoglossidae. This discovery, the most important in Nearctic batrachology, led Stejneger to write his paper on the geographical distribution of the Discoglossids (1905).

For a number of years Ascaphus remained a very rare frog. However, as its habitat became known, more specimens became available, so that over the course of the fifty years since its original description Ascaphus has become a relatively well-known frog. As early as 1912, Van Denburgh published a detailed note on the skeletal antomy, while Mrs. Gaige wrote at considerable length (1920) on the life-history and ecology, on the basis of her observations in the Olympic Peninsula. Noble (1922, 1931) published some notes on the life-history and breeding of the species from live material and information supplied by Phillips G. Putnam. The cranial anatomy has been investigated by de Villiers (1934), and a number of notes have been published by Storer (1925), Slevin (1928), Myers (1931, 1943), Smith (1932), the Wrights (1933, 1942 ), and at least 23 other writers.

Yet, despite these many contributions to a rapidly-growing literature, the morphological variations of Ascaphus-especially the extent and nature of these variations with respect to geographic distribution-remain scarcely known. In part, this doubtless arises from the fact that there are comparatively few adult (post-metamorphic) specimens in collections, and probably also because the habits of this animal are such that its range is still imperfectly known, with many gaps yet to be filled. Myers has suspected since 1931 that the California population of Ascaphus differs racially from that of Oregon and Washington, but before Mittleman knew of this he already had the present study well under way. He then invited his western colleague to assume joint authorship. All mensural and statistical treatments have been done by Mittleman, but the conclusions expressed herein, as well as the new names proposed, have been authored jointly.

A study of 65 post-metamorphic and 166 larval specimens of Ascaphus, from all parts of the range of this species, indicates that it is composed of three vicarious races: the typical form, occurring in western Oregon and Washington; another race occupying the Northern Rocky Mountain Province in Idaho, Montana, and adjacent British Columbia; a third race restricted to a few counties in northern California. The differences among these three races are quantitative and/or meristic, and although in some cases they are slight in terms of absolute quantities, they are nonetheless of such a constant nature as to permit the positive separation of $88 \%$ of the post-metamorphic specimens studied. No qualitative differences have been found among the populations studied, nor do color or pattern provide useful dichotomous characters.

The distinguishing unitary traits of the three races are the number of vomerine teeth, and the relative dimensions of the eye and head width. No ontogenetic or sexual variations have been found in these characters, so that all tabulations and comparisons are made on the basis of post-metamorphic specimens of all ages and of both sexes. 


\section{VOMERINE TEETH}

The vomerine teeth in Ascaphus truei vary from 1 to 17 per series. There is, as in most amphibians, a considerable variation in the number of teeth per series in individuals, e.g., there is often a considerable discrepancy in the number of teeth on one side, as compared to the other. Thus, in order to facilitate comparisons between individuals and populations, the tooth counts of both sides have been combined to yield a single count reflecting the total number of vomerine teeth in the specimen. The full range of variation in the combined vomerine counts of 52 post-metamorphic Ascaphus from all parts of the range of this species is as follows:

\begin{tabular}{lllllllllllllllllllllllllllllll}
\hline 2 & 3 & 4 & 5 & 6 & 7 & 8 & 9 & 10 & 11 & 12 & 13 & 14 & 15 & 16 & 17 & 18 & 19 & 20 & 21 & 22 & 23 & 24 & 25 & 26 & 27 & 28 & 29 & 30 & $\mathrm{~N}$ \\
\hline$f$ & 4 & 4 & 2 & 3 & 3 & 3 & 2 & 3 & 7 & 3 & 3 & 2 & 2 & 2 & 51 & 1 & 1 & & & & & 1 & 52 \\
\hline
\end{tabular}

\section{Combined Vomerines}

Examination of 13 adult specimens of Ascaphus truei from western Washington and Oregon shows that the combined vomerine counts vary from 8 to 30 . Nine specimens from various southern British Columbia localities have a range of 8 to 21 teeth, while in 13 specimens from Idaho and Montana the spread is from 9 to 22. No significant statistical differences exist between any of these populations so far as the vomerine count is concerned. However, in 17 adult specimens from northern California, the combined vomerine count is much lower, as is also the range of variation, the observed spread being 2 to 8 teeth per specimen. The combined vomerine count is 7 or less in 16 out of 17 Californian specimens, but is 8 or more in all 35 specimens from Oregon, Washing. ton, British Columbia, Idaho, and Montana. Hence, 51 specimens out of $52(=98 \%)$ can be identified as to a Californian or non-Californian provenance on the basis of the vomerine count alone. A chi-square value of 47.5 attests to the highly significant association between the combined vomerine count and geographic origin in these samples.

\section{Relative Size of the Eye}

The diameter of the eye has been taken as the horizontal distance between the anterior and posterior junctures of the lids. Measurements were made with a vernier caliper under low-power $(17 \times)$ binocular magnification. The ratio of the horizontal diameter of the eye to the snout-vent length (hereafter referred to as the eye/SV ratio) shows a small absolute variation, being in 60 specimens of Ascaphus from all parts of the range, as follows:

\begin{tabular}{rc}
$f$ & eye $/ \mathrm{SV}$ ratio $(\%)$ \\
\hline 3 & $10.00-10.99$ \\
14 & $11.00-11.99$ \\
13 & $12.00-12.99$ \\
12 & $13.00-13.99$ \\
13 & $14.00-14.99$ \\
5 & $15.00-15.99$ \\
&
\end{tabular}


As in the case of the vomerine counts, the eye/SV ratios show certain geographic variations. Thus, the 13 Oregon-Washington specimens vary from 11.2 to $13.0 \%$; the British Columbia series shows a variation of 10.44 to $13.60 \%$, while 14 specimens from Idaho and Montana show a range of 10.7 to $13.4 \%$. The California population is again distinctive by virtue of having a proportionately larger eye, since the eye /SV ratio in 24 specimens varies from 12.5 to $15.9 \%$. In 23 out of the 24 Californian specimens the eye/SV ratio is $13.6 \%$ or more, while in 35 specimens out of 36 from other areas this critical ratio is $13.5 \%$ or less. Thus, 58 out of 60 specimens $(=96 \%)$ can be identified as to a Californian or non Californian origin on the basis of the eye/SV ratio.

However, the non Californian specimens are not themselves homogeneous with respect to their eye/SV ratios. Although there is no perceptible difference between specimens from Oregon and Washington in the relative size of the eye, there is a discernable and significant trend toward a higher eye/SV ratio in specimens from Idaho, Montana, and British Columbia. Oregon and Washington specimens have ratios varying from 11.2 to $13.0 \%$, with 10 out of 13 specimens from these states having ratios of $11.85 \%$ or less. In specimens from Idaho, Montana, and British Columbia the eye/SV ratio ranges from 10.44 to $13.60 \%$, with 16 specimens out of 23 having a ratio higher than $11.85 \%(12.31 \%$ or more). A total of 26 specimens out of $36(=72 \%)$ in these two samples can be correctly separated as to their geographic provenance on the basis of the eye/SV ratio. The observed differences in the eye/SV ratios of these two populations are statistically significant (chi-square = 7.19).

\section{Relative Head Width}

The width of the head has been measured at the point of greatest breadth, immediately behind the eyes. Measurements were taken with a vernier caliper under $17 \mathrm{X}$ binocular magnification. The ratio of the head width to the snout-vent length (hereafter referred to as the $\mathrm{HW} / \mathrm{SV}$ ratio) shows a moderate absolute variation, ranging from 32.5 to $42.6 \%$, as follows:

\begin{tabular}{ll}
$f$ & HW/SV ratio $(\%)$ \\
\hline 2 & $32.00-32.99$ \\
5 & $33.00-33.99$ \\
7 & $34.00-34.99$ \\
5 & $35.00-35.99$ \\
6 & $36.00-36.99$ \\
3 & $37.00-37.99$ \\
7 & $38.00-38.99$ \\
8 & $39.00-39.99$ \\
8 & $40.00-40.99$ \\
5 & $41.00-41.99$ \\
4 & $42.00-42.99$ \\
&
\end{tabular}

Each of the various samples discussed heretofore has a characteristic range of variation in its $\mathrm{HW} / \mathrm{SV}$ ratio. Thus, Oregon-Washington specimens show a range of 32.5 to $39.4 \%$, while British Columbia speci- 
mens vary from 33.4 to $37.7 \%$, and the Idaho-Montana samples show a spread of 34.2 to $39.4 \%$. California specimens are again distinctive by virtue of having a relatively wider head, the range of the $\mathrm{HW} / \mathrm{SV}$ ratio being 38.4 to $42.6 \%$.

Despite apparently broad overlaps in the $\mathrm{HW} / \mathrm{SV}$ ratios of the various samples, there are actually very significant differences in the relative head widths of the populations involved. Hence, 23 out of 24 California specimens have HW/SV ratios of $39.0 \%$ or more, while in 34 out of 36 non-Californian specimens the $\mathrm{HW} / \mathrm{SV}$ ratio is $38.7 \%$ or less. These critical ratios will separate 57 specimens out of $60(=95 \%)$, as to a Californian or non-Californian origin. A chi-square value of 47.4 attests to the highly significant association between geographic prove. nance and proportionate head width.

In a similar rein, it is found that 11 out of 13 Oregon-Washington specimens have an $\mathrm{HW} / \mathrm{SV}$ ratio of $35.2 \%$ or less, while 18 out of 23 specimens from Idaho, Montana, and British Columbia have ratios of $35.6 \%$ or more. Again, with 29 specimens out of $36(=80.5 \%)$ being geographically identifiable on the basis of their HW/SV ratios, the significant association between this ratio and geographic origin is reaffirmed (chi-square $=13.3$ ).

\section{LARVAE}

Despite the differences existing among the several populations of Ascaphus truei, as discussed heretofore, the larvae are remarkably stablo in size, proportions, color, pattern, and tooth-row counts. In fact, it has not been possible to determine any dichotomous differences in tadpoles from widely separated parts of the range of the species (sensu lato).

Authors who have had occasion to discuss the larvae of Ascaphus truei have described the tooth rows as being 3/10, except Smith (1932: 100), who reports a specimen from St. Regis Pass, Montana as having the tooth rows 3/9. Careful study of 123 larvae from all parts of the range of Ascaphus shows that the tooth count is either $3 / 11$ or $3 / 12$. The last lower rows, where they encroach on the lower (posterior) lip are exceedingly minute, and occasionally are imperfect. Nonetheless, careful examination under relatively low magnification $(25.5 \mathrm{X})$ will reveal these teeth.

Counts of 11 or 12 lower tooth rows occur with approximately equal frequency throughout the range of Ascaphus, as will be seen in the following tabulation:

Lower Tooth Rows

\begin{tabular}{lrrr}
\hline \multicolumn{1}{c}{ Locality } & 11 & 12 & Total \\
\hline California & 12 & 9 & 21 \\
Washington & 6 & 0 & 6 \\
Idaho & 1 & 0 & 1 \\
Montana & 33 & 39 & 72 \\
British Columbia & 10 & 13 & 23 \\
\cline { 2 - 4 } & 62 & 61 & 123 \\
\hline
\end{tabular}

There is no perceptible correlation or association between tooth-row counts and size in Ascaphus larvae. The full range of size variation (overall length, snout to tip of tail) observed in larrae is from $15 \mathrm{~mm}$. 
(Park Creek, Glacier National Park, Mont.), to $60 \mathrm{~mm}$. (Ole Creek, Glacier National Park).

From our studies of the several populations discussed here, we conclude that Ascaphus truei is a polytypic species composed of three annectant, vicarious races. The population inhabiting the northern parts of the Cascade-Sierra Province and the Pacific Border Province in Oregon and Washington is indistinguishable from Stejneger's type of truei (USNM 25979, Humptulips, Grays Harbor Co., Wash.), whereas the population occurring in the southern parts of these Provinces (in Del Norte, Siskiyou and Humboldt counties, Calif.) is markedly different, as is also the form which ranges through the Northern Rocky Mountains Province in Idaho, Montana (probably also extreme eastern Oregon and Washington), and adjacent British Columbia. Accordingly, we restrict the name truei to the western Oregon-Washington population, and propose that the other two forms be recognized as subspecies. Our definition of truei, and descriptions of the two new races follow.

\section{Ascaphus truei truei Stejneger}

1899 Ascaphus truei Stejneger, Proc. U. S. Nat. Mus., 21: 900, pl. 39. Type locality: Humptulips, Grays Harbor (formerly Chehalis) County, Wash.; Dickerson, 1906, Frog Book, p. 51; Van Denburgh, 1912, Proc. Calif. Acad. Sci., 4 (3): 259 ; Camp, 1917, Copeia: 13; Stejneger and Barbour, 1917, Check-list N. Amer. Amph. Rept., p. 25 ; ibid., ed. 2, 1923, p. 22 ; ibid., ed. 3, 1933, p. 25 (part.); ibid., ed. 4, 1939, p. 28 (part.) ; ibid., ed. 5, 1943, p. 36 (part.); Gaige, 1920, Occ. Pap. Mus. Zool. Univ. Mich., 84: 1; Van Winkle, 1922, Copeia: 4; Noble, 1922, Copeia: 4; Storer, 1925, Univ. Calif. Puhl. Zool., 27 : 143 (part.); Slevin, 1928, Occ. Pap. Calif. Acad. Sci., 16: 79 (part.); Slater, 1931, Copeia: 62; Noble and Putnam, 1931, Copeia: 97; Svihla and Svihla, 1932, Copeia: 38; Svihla and Svihla, 1933, Coneia: 37 ; A. Svihla, 1933, Copeia: 39; Wright and Wright, 1933, Handbook of Frogs and Toads, p. 36 (part.); ibid., ed. 2, 1942, p. 44 (part.); Slater, 1934, Copeia: 140; Graf, Jewett, and Gordon, 1939, Copeia: 102.

Diagnosis: Combined vomerines $8-30$; eye/SV ratio $11.2-13.0 \%$ (11.85\% or less in $77 \%$ of specimens); $\mathrm{HW} / \mathrm{SV}$ ratio $32.5-39.4 \%$ (35.2\% or less in $85 \%$ of specimens).

Range: Oregon and Washington, in the Cascade-Sierra and Pacific Border Provinces.

Specimens studied: 48 , as follows:

\section{OREGON}

Curry County: N. side of Rogue River, 11. mi. above mouth (MVZ2 17162).

Klamath County: Castle Creek, Crater Lake Nat. Pk. (ST 3.20); Copeland Creek, Crater Lake Nat. Pk. (USNM 95230-1); Bybee Creek, Crater Lake Nat. Pk. (USNM 95226-9).

${ }^{2}$ Abbreviations for collections: $M V Z=$ Museum of Vertebrate Zoology: $\mathbf{S U}=$ Natural History Museum, Stanford University; USM = United States National Museum; CNHM = Chinago Natural History Museum: CAS = California Academy of Sciences; PMBC = Provincial Museum of British Columbia; ROMZ $=$ Royal Ontario Museum of Zoology. 


\section{WASHINGTON}

Chelan County: Icicle Creek (USNM 103708; 3 spec.).

Clallam County:Olympic Hot Springs (CNHM 27117-8).

Grays Harbor County: Humptulips (USNM 25979, TYPE).

Jefferson County: Mt. Steel (USNM 63387); Dosewallips River (USNM 64345).

Lewis County: Tilton River (CNHM 27119; 2 spec.).

Mason County: Staircase Camp (MVZ 8497-8); McTaggart Creek (USNM 67121-3; 63388-90); Laundry Creek (USNM 67120).

Pierce County: Mt. Rainier (USNM 62434, 62436, 62438, 62450); Tacoma Creek (USNM 104423-4); Sterens Creek (USNM 104425); Nickel Creek (USNM 104426).

Snohomish County: No locality (CNHM 41298; 2 spec.).

Yakima County: Outlet of Dewy Lake, S. of Naches Pass (SU 9285-7).

No specific locality: "Western Washington", (SU 3091-5, 3761; 3 spec.).

\section{Ascaphus truei californicus, n. ssp.}

1917 Ascaphus truei Grinnell and Camp, Univ. Calif. Publ. Zool., 17: 140 ; Stejneger and Barbour, 1923, Check-list N. Amer. Amph. Rept., p. 22 (part.); ibid., ed. 3, 1933, p. 25 (part.); ibid., ed. 4,1939 , p. 28 (part.) ; ibid., ed. 5, 1943, p. 36 (part.) ; Storer, 1925, Univ. Calif. Publ. Zool., 27: 143 (part.); Slevin, 1928, Occ. Pap. Calif. Acad. Sci., 16: 79 (part.) ; Myers, 1931, Copeia: 56; Wright and Wright, 1933, Handbook Frogs and Toads, p. 36 (part.) ; ibid., ed. 2, 1942, p. 44 (part.); Shapovalov, 1937, Copeia: 234; Wood, 1939, Copeia: 110; Myers, 1943, Copeia: 126. Diagnosis: Combined vomerines $2-8$ ( 7 or less in $94 \%$ of specimens); eye/SV ratio $12.5 .15 .9 \%$ ( $13.6 \%$ or more in $96 \%$ of specimens); $\mathrm{HW} / \mathrm{SV}$ ratio 38.4 to $42.6 \%$ ( $39.0 \%$ or more in $96 \%$ of specimens).

Range: Del Norte, Humboldt, and Siskiyou counties, California.

Holotype: MVZ 19142 \&, near Klamath, Del Norte County, Calif; collected by W. F. Wood, November 4, 1933.

Paratypes: See list of specimens studied.

Specimens studied: 50, as follows:

\section{CALIFORNIA}

Del Norte County: Klamath (CNHM 31909); Wilson Creek, near Klamath (CNHM 31912); tributary of Wilson Creek, $8.5 \mathrm{mi}$. N. of Klamath (MVZ 29790-3, 29795, 29797-8, 29801-3); $8 \mathrm{mi}$. NE of Crescent City (CAS 80135).

Humboldt County: Ascaphus Creek, $0.5 \mathrm{mi}$. N. of road to Holmes, on Redwood H'way (SU 7371-2, 7390-9); Prairie Creek, $11 \mathrm{mi}$. N. of Orick (CNHM 31910-11); $8.6 \mathrm{mi}$. N. of Weott (SU 4636-42); near Scotia (USNM $93779 ; 4$ spec.) ; $10 \mathrm{mi}$. N. of Orick (CAS 80159-62); $10 \mathrm{mi}$. W. of Orick (CAS 78812-3).

Siskiyou County: French Creek (SU 2190); "Siskiyou Mits." (USNM 45362); Mill Creek Park (CAS 81297-300).

Remarks: While it may seem strange that a political boundary, the California-Oregon line, should separate two races (truei and californicus), it should be pointed out that this particular political boundary is, to some extent, a biogeographical one as well. The Siskiyou Moun- 


\section{Proceedings of the Biological Society of Washington}

tains and associated ranges, which rise along the state line, form a barrier which can be seen in the distribution of a number of animal populations. These mountains delimit the northern range of Batrachoseps and of Aneides flavipunctatus (see Myers and Maslin, 1948, Proc. Biol. Wash., 61: 127), and come very close to marking the division between the subspecies of Bufo boreas and Rana aurora. It may be noted that these mountains limit the southward extension of Rana pretiosa (west of the Cascade-Sierra range), and the northward extension of Scaphiopus in the Sacramento Valley. In addition, this natural barrier seems to mark a subspecies boundary in Triturus granulosus, and $T$. rivularis is not known to pentrate it from the south.

\section{Ascaphus truei montanus, n. ssp.}

1932 Ascaphus truei Smith, Copeia: 100; Stejneger and Barbour, 1933, Check-list N. Amer. Amph. Rept., p. 25 (part.); ibid., ed. 4, 1939, p. 23 (part.); ibid., ed. 5, 1943, p. 36 (part.); Wright and Wright, 1933, Handbook Frogs and Toads, p. 36 (part.); ibid., ed. 2, 1942, p. 44 (part.); Linsdale, 1933, Copeia: 223; Donaldson, 1934, Copeia: 184; Ricker and Logier, 1935, Copeia: 46; Slater, 1941, Occ. Pap. Coll. Puget Sound, 14: 85; Rogers and Jellison, 1942, Copeia: 10; Slipp and Carl, 1943, Copeia: 127; Carl and Cowan, 1945, Copeia: 52.

Diagnosis: Combined vomerines $8-22$; eye/SV ratio $10.44-13.60 \%$ (12.31-13.60\% in $70 \%$ of specimens); $\mathrm{HW} / \mathrm{SV}$ ratio $33.4-39.4 \%$ (35.6 - $38.6 \%$ in $74 \%$ of specimens).

Range: The Northern Rocky Mountains Province in Idaho, western Montana, probably extreme eastern Oregon and Washington, and adjacent British Columbia.

Holotype: USNM $102505 \hat{\delta}$, tributary of Lincoln Creek, Glacier National Park, Flathead County, Montana; collected by Leonard P. Schultz. Paratypes: See list of specimens studied.

Specimens studied: 122, as follows:

IDAHO

Adams County: $0.5 \mathrm{mi}$. E. of Black Lake, $6000 \mathrm{ft}$. (MVZ 12340-3; 12345).

Benewah County: East Fork of Charley Creek, near Emida (CNHM 43583 ).

Washington County: $1.0 \mathrm{mi}$. NE of Heath, on SW slope of Cuddy Mt., $4000 \mathrm{ft}$. (MVZ 12344, 12336).

\section{MONTANA}

Flathead County: Midvale Creek, near Glacier Nat. Pk. (Univ. Wash., 2 spec.); Tributary to Lincoln Creek, Glacier Nat. Pk. (USNM 102506-7); Hidden Lake, Glacier Nat. Pk. (USNM 102503); Lake Evangeline, Glacier Nat. Pk. (USNM 102508-9); Coal Creek, Glacier Nat. Pk. (USNM 102510-11; 30 spec.); Ole Creek, Glacier Nat. Pk. (USNM 102512; 12 spec.) ; Park Creek, Glacier Nat. Pk. (USNM 102514; 55 spec.); Dutch Creek Nat. Pk. (USNM 102513; 16 spec.); Muir Creek, Glacier Nat. Pk. (USNM 102504).

BRITISH COLUMBIA

Cascade Creek, $5 \mathrm{mi}$. NW of Hatzic (PMBC 634, 692); Cultus 
Lake, Fraser River Valley District (ROMZ 5382-5; 5391-6; $5389-90$; 5497, 4 spec.; 5399-5409; 3459; 7194-8).

Also, three additional specimens from southern British Columbia, to be reported by Dr. G. Clifford Carl.

The following key to the races of Ascaphus truei will correctly identify $85 \%$ of the post-metamorphic specimens seen:

Key to the Races of Ascaphus truei

1. Eye/SV ratio $13.6 \%$ or more; combined vomerine count 7 or less. Del Norte, Humboldt, and Siskiyou counties, California. Ascaphus truei californicus, n. ssp.

Eye/SV ratio $13.5 \%$ or less; combined vomerine count 8 or more. Provenance non-Californian 2

2. Eye/SV ratio $11.85 \%$ or less; $\mathrm{HW} / \mathrm{SV}$ ratio $35.2 \%$ or less. Oregon and Washington, in the Cascade-Sierra and Pacific Border Provinces.

Eye/SV ratio 12.31-13.50\%; HW/SV Rocky Mountains Province in Idaho, western Montana, adjacent British Columbia, and probably extreme Washington and Oregon.

Ascaphus truei montanus, n. ssp.

\section{Acknowledgements}

For the loan of specimens, and for extending the use of various facilities, we are indebted to Drs. Doris M. Cochran and Waldo L. Schmitt, of the U. S. National Museum; Dr. G. Clifford Carl, of the Provincial Museum of British Columbia; Dr. Lauren Donaldson, of the University of Washington; Dr. Robert C. Stebbens, of the Museum of Vertebrate Zoology; Mr. E. B. S. Logier, of the Royal Ontario Museum of Zoology; Mr. Joseph R. Slevin, of the California Academy of Sciences; and Messrs. Clifford H. Pope and Robert F. Inger, of the Chicago Natural History Museum. Miss Ruth Breiger lent aid in the collation of data on certain specimens, for which we express our gratitude.

\section{Literature Cited}

Boulenger, G. A.

1882 Catalogue of the batrachia Salientia s. Ecaudata in the collection of the British Museum. London: printed by order of the Trustees. pp. 503, pls. 1-30.

1910 Les batraciens et principalement ceux d'Europe. Paris. pp. 305. Fitzinger, L. J.

1861 Eine neue Batrachier-Gattung aus Neu-Seeland. Verhandl. k. k. zool.-bot. Gesellsch. Wien, 11: 217-220, pl. 6.

Gaige, H. T.

1920 Observations upon the habits of Ascaphus truei Stejneger. Occ. Pap. Univ. Mich. Mus. Zool., 84: 1-9, pl. 1.

Myers, G. S.

1931 Ascaphus truei in Humboldt County, California, with a note on the habits of the tadpole. Copeia: 56-57. 
1943 Notes on Rhyacotriton olympicus and Ascaphus truei in Hum. boldt County, California. Copeia: 125: 125-126. and Carvalho, A. L. de

1945 Notes on some new or little-known Brazilian amphibians, with an examination of the history of the Plata salamander, $E n$. satina platensis. Bol. Mus. Nac., n. s., zool., 35: 1-24, figs. 1-18. and Maslin, T. Paul

1948 The California plethodont salamander, Aneides flavipunctatus (Strauch), with description of a new subspecies and notes on other western Aneides. Proc. Biol. Soc. Wash., 61: 127-138.

Noble, G. Kingsley

1922 [Editorial note on Ascaphus truei.] Copeia, 102: 6. - and Putnam, G. Phillipps

1931 Observations on the life-history of Ascaphus truei Stejneger. Copeia: 97-101.

1931 The biology of the amphibia. New York: MeGraw-Hill. pp. xiii +577 , figs. 1-174, frontis.

Slevin, J. R.

1928 The amphibians of western North America. Occ. Pap. Calif. Acad. Sci., 16: 5-144, pls. 1-23.

Smith, H. M.

1932 Ascaphus truei Stejneger in Montana. Copeia: 100.

Steindachner, F.

1867 Amphibien. In: Reise der Oesterreichischen fregatte "Novara" um die Erde ... etc. Wissensch. Theil, Zool. Theil, rol. 1, pp. 70,5 pls.

Stejneger, L. H.

1899 Description of a new genus and species of discoglossoid toad from North America. Proc. U. S. Nat. Mus., 21: 899-901, figs. $1-4$, pl. 89 .

1905 Résumé of geographical distribution of the discoglossoid toads. Bull. Am. Geog. Soc., 37: 91-93.

Storer, T. I.

1925 A synopsis of the amphibia of California. Univ. Calif. Publ. Zool., 27: 1-342, 42 figs., pls. 1-18.

Van Denburgh, J.

1912 Notes on Ascaphus, the discoglossoid toad of North America. Proc Calif. Acad. Sci., (4), 3: 259-264.

Villiers, C. G. S. de

1934 Studies of the cranial anatomy of Ascaphus truei Stejneger, the American "leiopelmid." Bull. Mus. Comp. Zool., 13-38.

Wright, A. A. and Wright, A. H.

1933 Handbook of frogs and toads. Ithaca: Comstock Publ. Co., pp. xi +231 , pls. $1-82$.

1942 Ibid., ed. 2, pp. xi +286 , pls. 1-88.

35 John Alden Road, New Rochelle, N. Y., and Natural History Museum, Stanford University, California. 
Mittleman-Geographic Variation in the Ribbed Frog 67 
68 Proceedings of the Biological Society of Washington 
behind middle of total length. Dorsal fin rays II,8. Origin of anal fin distinctly behind a vertical from posterior end of dorsal base. Nine to 11 black transverse bands on body.

DESCRIPTION: In the following description the measurements and counts are taken from all four types with those for the holotype given first, followed by the range of variation for the three para. types in parentheses. The measurements were made with a pair of fine-point dividers to the nearest tenth of a millimeter and divided into standard or head length as indicated. The fleshy skin at the bases of the fins was dissected away to make the counts. The last two elosely applied rays in the dorsal and anal fins are counted as one.

Body elongate, moderately compressed, that of the holotype strongly compressed and deep. Body depth 6.9 (7.0-7.2) in standard length. Caudal peduncle long, slightly tapering in depth, its least depth 2.9 (2.1-2.4) in its length from end of dorsal base. Anus immediately in advance of anal fin.

Head moderately deep and compressed, 7.5 (6.0-7.0) in standard length. Snout steep, rounded before eye, 2.4 (1.9-2.7) in head length. Nostrils on each side close together, situated immediately before the eye. Anterior nostril with a raised tube, its underside pigmented, the opening inclined obliquely forward. Posterior nostril without a raised rim, half-moon shaped or oval. Interorbital strongly convex, its width $5.3(5.0-6.1)$ in head. The two suborbital spines in a slit below eye, their bases inserted slightly before eye. Anterior spine small, its tip extending beyond posterior border of pupil. The larger prong terminates beyond posterior rim of eye. Mouth small, inferior, the maxillary not reaching to a vertical from anterior border of eye. Three pairs of barbels present, well developed: rostral pair close together near the apex of the snout; maxillary pair and mandibular pair near the angle of the gape. In holotype mandibular barbels slightly the longest; in paratypes barbel pairs approximately of equal length. Lips of mandible expanded into two well developed fleshy lobes on each side of symphysis. Eye small, before middle of head length, its diameter $9.0(6.7-8.8)$ in head. Gill opening restricted, its width $3.6(3.4-4.1)$ in head, extending to opposite uppermost rays of pectoral fin.

Scales excessively small, present on body and nape. Absent on head. Lateral line absent.

Dorsal fin II,8 (II,8) on posterior third of body. Distance from tip of snout to dorsal origin 1.4 (1.3-1.5) in standard length. Distance from dorsal origin to pelvic origin $6.7(6.6-8.1)$ in standard length. Distance from posterior end of dorsal base to a vertical from anal fin origin $4.5(10.0-13.4)$ in head. Length of dorsal base $2.3(1.1-2.8)$ in head. Anal fin II,7 (II,6 or 7). Length of anal base $2.7(2.3-2.4$ ) in head. Length of anal fin measured from origin to tip of longest ray $1.3(1.4-1.5)$ in head. Distance from anal fin origin to tip of snout 1.3 (1.2-1.3) in standard length. Distance form pelvic fin origin to anal base $4.7(4.8-5.0)$ in standard length. Pectoral fin $1,9(1,9)$, its longest ray 1.3 (1.6-1.8) in head. Pelvic fin $1,5(1,5)$, its length 2.0 (2.42.9 ) in head. Distance from tip of snout to pelvic fin organ 2.0 (1.6-1.7) in standard length. Caudal fin slightly lunate, 14 principal rays, its length $8.0(6.2-6.8)$ in standard length. 
MEASUREMENTS IN PERCENT OF STANDARD LENGTH: Length of head 13.3 (14.4-16.6); length of snout 5.7 (5.4-7.0); diameter of orbit 1.5 (1.7-2.5); width of interorbital 2.5 (2.7-3.0); width of gill opening 3.7 (3.5-5.0); greatest depth of body 14.6 (13.2-14.4); length of caudal peduncle from end of dorsal base to mid-base of caudal fin 25.3 (21.7-23.3); least depth of caudal peduncle 8.8 (9.8-10.2); distance from snout to dorsal origin 70.8 (71.3-76.7); distance from pelvic origin to a vertical from dorsal origin 14.9 (12.4-15.2); distance from end of dorsal base to a vertical from anal fin 3.0 (1.2-1.5); length from dorsal origin to tip of longest depressed ray 10.3 (10.9-12.5); distance from snout to anal 76.6 (77.1-81.9); distance from pelvic origin to anal $21.4(20.0-20.8)$; length of anal base 4.9 (6.3-7.0); length from anal origin to tip of longest depressed ray 10.1 (10.4-11.2); length of longest pectoral ray 10.0 (8.7-9.5); distance from tip of snout to pelvic fin base 50.6 (56.5-61.3); length of pelvic fin 6.9 (5.6-6.0); length of caudal fin from mid-base of fin to tip of longest rays 12.5 (14.7-16.2).

COLORATION: Color pattern same as that of A. kuhlii in the holo. type and $A$. sumatranus in the paratypes, but significantly differs from both species in fewer body bands and by lacking the lighter coloration at the middle of each band, which is characteristic of the other two species. Broad transverse bands (in life colors black, according to Smith) alternate with narrow light bands (in life colors red, according to Smith). These bands extend well down the side to the belly. Three dark bands are present on the head, 9-11 on the body (in the holotype 11 on the left, 10 on the right side), and one large darker band on the caudal fin. Belly and throat light, yellowish in alcohol specimens.

The dark body bands in the paratypes do not extend as far down the sides as in the holotype and are more irregular in outline, approaching A. semicinctus in this respect. It would appear that the bands become more complete ventrally with age.

DISCOSSION OF RELATIONSHIPS: The Cobitid loaches of the genus Acanthophthalmus related to $A$. kuhlii have been the subject of a recent study by Fraser-Brunner (1940). His review revealed that several forms had been confused as the actually very rare kuhlii. $\mathrm{He}$ recognized four forms: $A$. shelfordi (Popta) from Borneo, semicinctus Fraser-Brunner from the Malay Peninsula, kuhlii kuhlii Cuvier \& Valenciennes from Java, and kuhlii sumatranus from Borneo. The two subspecies are recognized from a single example from each locality. Considering the difficulty of pursuing a problem of subspeciation on the basis of so few examples, I am inclined to accept Fraser-Brunner's subspecies as full species until further investigations show that these forms intergrade. Fraser-Brunner's basic divisions in his key to differentiate shelfordi and semicinctus from kuhlii are apparently invalid. Specific variation in semicinctus alone overlaps in all the characteristics he used. In addition, the head length of 8 for kuhlii and sumatranus does not agree with his illustrations of the species, which show it as approximately 6.5 times in standard length. Neither are the pelvic fins shown in the latter two species as far behind the middle of the total length as would be expected from the key. The color pattern differences are the only characters evident that will sufficiently differentiate the several forms. 


\section{Proceedings of the Biological Society of Washington}

The closest relatives of $A$. myersi appear to be khulii, sumatranus and semicinctus. It is similar to the first two forms in the number of dorsal rays (II, 7 or 8 ), the number of anal rays (II, 6 or 7 ), in the position of the pelvic fin which is somewhat behind the middle of the standard length, in the relation of the anal origin to the dorsal base (anal fin commencing distinctly behind end of dorsal), and in basic color pattern (parallel bands of body in a single series, extending well down the side). It can be differentiated from them by greatest depth (6.9-7.2 in myersi versus $8-9$ in 7 uhlii and sumatranus), in distance from pelvic origin to anal origin (4.7-5.0 versus 4.0-4.3 in standard length), in head length (6.0-7.5 versus $8 \%$ ), by the number of vertical bands on the body exclusive of the head (9-11 versus 12-17) and by the coloration of the bands (Body bands not normally divided in the middle [divided on one band on the holotype only] and never paler in the center than at the edges, versus bands paler in the center than at the edges or are distinctly paired).

A. myersi is separated from semicinctus by the number of dorsal rays (II, 8 versus II, 6 or 7 ), and by differences of coloration (parallel bands extending down the sides, lacking a median light saddle on any of the bands versus tapering patches confined to the upper part of the body and generally a median light saddle on every band).

This species is named Acanthophthalmus myersi in honor of Prof. George Sprague Myers of Stanford University in appreciation of his interest and research on Indo-Malayan fishes.

\section{Literature Cited}

Fraser-Brunner, A.

1940 On some fishes of the genus Acanthophthalmus, with description of a new species. Ann. \& Mag. Nat. Hist. ser. 11, vol. 6, pp. 170-175, figs. $1-4$.

1947 The loaches of the genus Acanthophthalmus. Aquarium (Philadelphia), vol. 16, no. 12, pp. 271-273, figs. 1-3.

Smith, Hugh McCormick

1945 The fresh-water fishes of Siam, or Thailand. Bull. U. S. Nat. II us., vol. 188, pp. i-xi, 1-622, pls. 1-9, text-figs. 1-107. 


\section{Proceedings of the Biological Society of Washington}

12 are synonyms or varieties. Their Linckia multifora from the figures they give appears to be L. laevigata. A new species, Hippasteria philippinensis, is undoubtedly the young of Culcita novaeguineae. They did not include Leiaster speciosus from Port Galera listed by Dr. H. L. Clark, or Bunaster lithodes from Apo reef.

Although the list of Domantay and Roxas includes 38 species, and the present list only 17, Dr. Van Name and Mr. Oesch secured no less than seven species not found by them. These seven species are: Goniodiscus forficulatus, Ophidiaster lioderma, Ophidiaster pustulatus, Asterina coronata coronata, Asterina cephea, Valvaster striatus, and Mithrodia clacigera.

\section{ANNOTATED LIST OF THE SPECIES ARCHASTERIDAE \\ Archaster typicus Müller and Troschel}

Localities.-Padada Beach, Gulf of Dávao, Mindanao; G. R. Oesch, April 5, 12, May 2, 3, 1936 (5+ specimens).

Mouth of the Padada River; G. R. Oesch, June 23, 24, 1936 (2 specimens).

Notes. - The size ranges from $\mathrm{R}=48 \mathrm{~mm}$. to $\mathrm{R}=22 \mathrm{~mm}$. In the largest specimen one arm forks half way to the tip, the two branches diverging in almost a straight line.

\section{GONIASTERIDAE}

Goniodiscaster forficulatus (Perrier)

Locality.-Padada Beach; G. R. Oesch, Juue 20, 1936 (1 specimen). Note.-This specimen is very small, $R=11 \mathrm{~mm} ., \mathrm{r}=4 \mathrm{~mm}$.

\section{OREASTERIDAE \\ Protoreaster nodosus (Linné)}

Localities.-About 1.5 miles from the Paloda River, Gulf of Dávao, near Mangrove Island; Dr. W. G. Van Name (2 specimens).

Stony beach just south of Santa Cruz, Gulf of Dávao; Dr. W. G. Van Name, November 7, 1937 (2 specimens).

Notes.-The specimens from near Mangrove Island in life were light yellow with the tubercles and tips of the rays brown. They measured $R=68 \mathrm{~mm}$. and $R=60 \mathrm{~mm}$. Dr. Van Name said that some individuals are redder, and some brick or rich red.

One of the specimens from near Santa Cruz with $R=90 \mathrm{~mm}$. was yellowish, becoming warm brown on the tubercles and toward the tips of the arms; the oral side was wholly yellowish. The other, with $R=80$ mm., was mostly yellowish gray above, becoming warm brown on the spines and distal part of the arms, and yellowish below.

\section{LINCKIIDAE}

Fromia elegans H. L. Clark

Locality.-Puerto Galera, northern end of Mindoro; Dr. W. G. Van Name, October 1937 (3 specimens). 
Notes.-The specimens measured $\mathrm{R}=48 \mathrm{~mm} ., \mathrm{r}=10 \mathrm{~mm}$.; $\mathrm{R}=46$ mm., $r=10 \mathrm{~mm}$, and $R=45 \mathrm{~mm}$, $r=9 \mathrm{~mm}$. The color in life was bright red.

This species was described by Dr. H. L. Clark from specimens from Mer, Murray Islands, Torres Strait. He gave the size of the type as $\mathrm{R}=36.38 \mathrm{~mm}$., $\mathrm{r}=8.5 \mathrm{~mm}$. (in life nearly $10 \mathrm{~mm}$.).

In 1938 Messrs. Domantay and Roxas recorded it from "Port Galera Bay and other places" and noted that it was the most common species of Fromia found at the station. They gave the color as "body brick red with abactinal plates light brick red. Ambulacral, adambulacral, and furrow spines together with paxillae on oral side uniformly brick red."

In $1946 \mathrm{Dr}$. Clark wrote that "This is an endemic [Australian] species so far as is yet known, and since it has been found at three widely separated points, it is probably pretty well distributed on the tropical coasts of Australia. It has not been found elsewhere, for although Domantay and Roxas (1938) record it from the Philippines, it is evident both from the figures given and from their description of the color in life that their specimens are different from the Australian species."

The specimens at hand are eertainly $F$. elegans. The figures given by Domantay and Roxas are rather vague, but there is nothing in them nor in their description to indicate that their determination was not correct.

Nardoa tuberculata Gray

Localities.-Padada Beach; G. R. Oesch, March 8, May 9, 10, June 20, 21, 1936 (22 specimens).

Santa Cruz, Gulf of Dávao; Dr. W. G. Van Name, November 21, 1937 (5 specimens).

Notes.-The specimens range in size from $R=70 \mathrm{~mm}$. to $R=20 \mathrm{~mm}$. One with $R=37 \mathrm{~mm}$. is six-rayed.

\section{Linckia laevigata (Linné)}

Localities.-Padada Beach; G. R. Oesch, March 8, May 9, 10, June 20, $21,25,26,28$, July 6-19, 1936 (20 specimens).

Reef of Digos, Gulf of Dávao; Dr. W. G. Van Name, November 14, 1937 (4 specimens).

North of Paloda River, Gulf of Dávao; Dr. W. G. Van Name, November 6,1937 ( 1 specimen).

About 1.5 miles from the Paloda River, Gulf of Dávao, near Mangrove Island; Dr. W. G. Van Name (1 specimen).

Puerto Galera, northern end of Mindoro; Dr. W. G. Van Name, October 1937 (2 specimens).

Notes.-Large specimens, $R=90$ to $165 \mathrm{~mm}$., are described as "bright blue" or "blue all over." Two specimens with $R=75 \mathrm{~mm}$. and $62 \mathrm{~mm}$. were purplish in life. One with $R=16-45 \mathrm{~mm}$. was dull red. One specimen from Padada Beach has three rays $33-27 \mathrm{~mm}$. long and three small buds.

Domantay and Roxas' figures of Linckia multifora from Port (or Puerto) Galera appear to me to represent $L$. laevigata. They say that their two specimens of $L$. multifora had only a single madroporite, which would suggest that they were really $L$. laevigata. 


\section{Linckia multifora (Lamarck)}

Locality.-Padada Beach; G. R. Oesch, May 9, 10, 1936 (2 specimens). Notes.-In one of the specimens the rays are $27,17,17,17,15 \mathrm{~mm}$. long; in the other they are $47,37,37,32,27 \mathrm{~mm}$. long.

\section{Ophidiaster lioderma H. L. Clark}

Locality.-Padada Beach; G. R. Oesch, May 9, 10, 1936 (2 specimens). Note.-In one of the specimens $\mathrm{R}=55 \mathrm{~mm}$.

\section{Ophidiaster granifer Lütken}

Localities.-Padada Beach; G. R. Oesch, March 8, June 5, 6, 20, 21, 23, 24, June 28 to July 8, July 6-19, 1936 (20 specimens).

Mouth of the Padada River; G. R. Oesch, June 23, 24, 1936 (94 specimens).

About 1.5 miles from the Paloda River, Gulf of Dávao, near Mangrove Island; Dr. W. G. Van Name (1 specimen).

Reef of Digor, Gulf of Dávao; Dr. W. G. Van Name, November 14, 1937 (1 specimen).

Santa Cruz, Gulf of Dávao; Dr. W. G. Van Name, November 21, 1937 (1 specimen).

Notes.-The specimens range in size from $R=30 \mathrm{~mm}$. to $R=12 \mathrm{~mm}$. When dried this species usually has a characteristic broadly blotched light and dark grayish color.

\section{Ophidiaster pustulatus (von Martens)}

Locality.-Padada Beach; G. R. Oesch, July 6-19, 1936 (1 specimen).

Notes. $-\mathrm{R}=37 \mathrm{~mm}$. Pedicellariae with straight alveolae are rather numerous, occurring sometimes on every supermarginal beyond the first six or eight, and frequently elsewhere.

\section{ASTERINIDAE \\ Asterina coronata coronata von Martens}

Localities.-Padada Beach; G. R. Oesch, March 8, May 9, 10, June 20, 21, 28, June 28 to July 8, 1936 (15 specimens).

Mouth of the Padada River, Gulf of Dávao; G. R. Oesch, June 23, 24, 1936 (1 specimen).

Reef of Digos, Gulf of Dávao; Dr. W. G. Van Name, November 14, 1937 (1 specimen).

About 1.5 miles from the Paloda River, Gulf of Dávao; Dr. W. G. Van Name (6 specimens).

One kilometer north of Santa Cruz, Dávao Gulf; Dr. W. G. Van Name, November 20, 1937 (1 specimen).

\section{Asterina cephea Müller and Troschel}

Localities.-Padada Beach; G. R. Oesch, March 8, Juno 20, 21, 25, 26, 28, June 28 to July 8 , July $6-19,1936$ (12 specimens).

One kilometer north of Santa Cruz, Dárao Gulf; Dr. W. G. Van Name, November 20, 1937 (1 specimen).

Note.-Dr. Van Name's specimen from nortl of Santa Cruz is sixrayed. 


\section{Patiriella exigua (Lamarck)}

Localities.-Padada Beach; G. R. Oech, March 8, May 2, 3, 9, 10, June $20,21,28$, June 28 to July 8, July 6-19, 1936 (92 specimens).

About 1.5 miles from the Paloda River, Gulf of Dávao, near Mangrove Island; Dr. W. G. Van Name (6 specimens).

Note.-One of the specimens from Padada Beach, March 8, 1936, is six-rayed.

\section{ECHINASTERIDAE \\ Othilia luzonica Gray}

Locality.-Padada Beach; G. R. Oesch, June 28 to July 8, 1936 (1 specimen).

Note.-The single specimen is six-rayed.

\section{ACANTHASTERIDAE Acanthaster planci (Linné)}

Locality.-One kilometer north of Santa Cruz, Gulf of Dávao; Dr. W. G. Van Name, November 20, 1937 (1 specimen).

Notes.-This specimen has 13 rays $90 \mathrm{~mm}$. long. In life the upper surface was gray with small purple dots, the spines brown.

\section{VALVASTERIDAE \\ Valvaster striatus Perrier}

Locality.-Puerto Galera, northern end of Mindanao; Dr. W. G. Van Name, October 24, 1937 (1 specimen).

Notes. $-\mathrm{R}=55 \mathrm{~mm} ., \mathrm{r}=17 \mathrm{~mm}$. The color in life was yellowish with brown markings.

\section{MITHRODIIDAE}

Mithrodia clavigera (Lamarck)

Localities.-Padada Beach; G. R. Oesch, July 6-19, 1936 (fragments). Santa Cruz, Gulf of Dávao; Dr. W. G. Van Name, November 21, 1937 (1 specimen).

Note.-Dr. Van Name's specimen from Santa Cruz is small, with $\mathrm{R}=95 \mathrm{~mm}$.

\section{REFERENCES}

1. Fisher, Walter R. Starfishes of the Philippine Islands. U. S. Na. tional Museum Bulletin 100, vol. 3, pp. i-xi, 1-712, pls. 1-156, 1919.

2. ClaArK, Hubert Lyaran. The Echinoderm Fauna of Torres Strait: is Composition and its Origin. Department of Marine Biology of the Carnegie Institution of Washington, vol. 10, Publication No. 214, pp. i-viii, 1-223, pls. 1-38, January 3, 1921.

3. Domantay, Jose S., and Hilario A. Roxas. The littoral Asteroidea of Port Galera Bay and Adjacent Waters. The Philippino Journal of Science, vol. 65, No. 3, pp. 203-237, pls. 1-17, March 1938. 
78 Proceedings of the Biological Society of Washington 
Clark-Sea-Stars from the Philippine Islands 
80 Proceedings of the Biological Society of Washington 


\title{
14.0673
}

Vol. 62 , pp. $81-88$

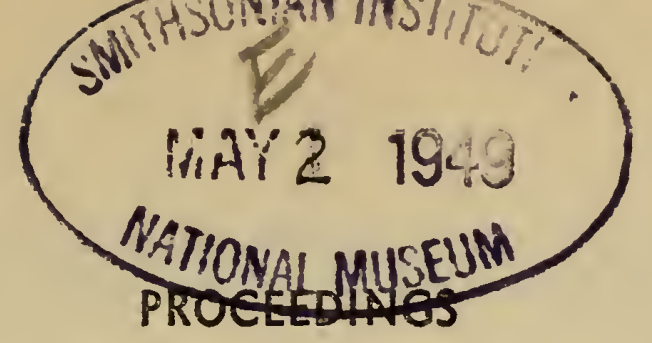

April 27, 1949

OF THE

BIOLOGICAL SOCIETY OF WASHINGTON

\section{THREE NEW SPECIES OF DIPLOPODA FROM VIRGINIA}

\author{
Bt Richard L. HoFfman
}

\section{Miller School of Biology, University of Virginia}

Collections of diplopods made in Virginia during the summers of 1947 and 1948 include several new species, three of which are herein described.

\section{PARAIULIDAE \\ Saiulus montanus, new species}

(Figures 5 \& 6)

Diagnosis.-A small member of the genus, characterized as follows: posterior gonopods of male large, as high as anterior, coxal portion of anterior much reduced; outer valves of female gonopods fused with operculum along lateral edge.

Description of male holotype.-Width approximately $1.5 \mathrm{~mm}$., length undetermined because of breakage; body with 51 segments, ventrolateral portion of each metazonite finely striate; anal valves inflated, large and somewhat protruding; spine of terminal segment large, strongly decurved, sharply pointed.

Color rery dark brown or black (in alcohol) with the eaudal half of each metazonite light tan, producing a sharply ringed appearance; collum and head lighter brown, front of head fading into tan at the labrum, antenuae black; legs yellowish-brown.

Gonopds of the canadensis type, i.e., with the coxal elements of the anterior pair shorter than the femoral. Sternal plate small, its basal margin concave at the center, swept upwards toward the sides, distal margin produced into a triangular, distally rounded projection. Immediately laterad of the sternal plate are two small pyriform pieces, wide at their bases and tapering laterad, their ends bent proximal. Coxal plates broad at base, the outer basal portion set off by a conspicuous oblique groove; the inner, produced portion witl a large mesial shoulder; the plate distally rounded. Femoral plates thin, upright pieces, three times as high as long, distally setose, the rear margin of each produced at about midlength into a small arm which projects caudomesiad and orerlaps the posterior gonopods. Posterior pair of gonopods strongly chitinous, flattened, lamellae, as broad and high as the femora of the anterior pair, and distally crenulate. A single, clavate, structure projects distad in front of the posterior gonopods. See figure 6 for gonopods drawn in cephalic aspect.

Description of female allotype.-Width approximately $1.8 \mathrm{~mm}$., length undetermined due to breakage; body with 52 segments. Color and other features much as in the male. 
Female gonopods of the same type as those figured by Brolemann (1922: fig. 32) for Saiulus immaculatus, differing however, and distinet in the following characters: operculum relatively smaller in comparison with other parts, its caudal portion with a conspicuous, short indentation; outer valve smaller, its distal portion directed mesiad, the lateral edge fused with the operculum at about the same level as the point of fusion of the mesial edge with the inner valve.

Type specimens.-Male holotype, female allotype, and male paratype in the U. S. National Museum, No. 1847, collected on July 1, 1947.

Type locality.-Mount Rogers, Grayson County, Virginia, at an elevation of 5000 feet. The specimens were found beneath a board in a small grassy field, with the surrounding forest chiefly hemlock (Tsuga ssp.), maple (Acer pennsylvanicum), yellow poplar (Liriodendron tulipfera), and redbud (Cercis canadensis). Millipeds associated with the paraiulids were Spirostrephon lactarium (Say) and Pseudopolydesmus serratus (Say).

Distribution.-In addition to the type locality, Saiulus montanus has been found only at Mountain Lake, Giles County, Virginia, where several males and females (R.L.H. no. 108) were obtained at Castle Rock, west of the Biological Station, by members of the Arthropods class on July 20, 1947, and transmitted to me by Dr. Horton H. Hobbs, Jr. This locality is at about 4000 feet elevation, and in the same biotic province (Canadian) as is Mount Rogers.

Remarles.-Apparently Saiulus is a genus with boreal affinities, widespread in northern United States, but confined, in more southern latitudes, to high elevations. Another, rather different, species-S. fumans Chamberlin (1943:10) — has been described from the Great Smoky Mountains in Sevier County, Tennessee.

\section{XYSTODESMIDAE \\ Nannaria shenandoa, new species}

(Figures 1-4)

Diagnosis.-A small member of the genus, characterized by the distally expanded and bifid telopodite of the male gonopod, and by the falcate nature of the lateral process, unusual in being conspicuously bent mesiad across the main branch.

Description of male holotype.-Body small, length, 23.5, width, 4.2 mm.; sides nearly parallel, segments four through fourteen being of almost exactly full width, body thus tapering abruptly cephalad and gently caudad; dorsum but slightly arched, keels small and continuing slope of dorsum.

Head small, vertex with very faint groove, interantennal width, .83 $\mathrm{mm}$; length of antennae, $3.5 \mathrm{~mm}$., sixth article conspicuously longer than the others which are subequal in length.

Collum large, subtrapezoidal in dorsal aspect, the caudal margin almost straight, the cephalolateral corners rounded, the cephalic margin slightly convex. Cephalolateral marginal ridges large and distinct.

Tergites of segments two through four similar, keels produced somewhat forward of rest of dorsum; marginal ridges well developed.

Tergites five through fifteen similar, keels more or less in line with rest of dorsum, marginal thickenings becoming larger; edges of keels slightly oblique, dirceted cephaloventrad, but to a lesser extent than in 
most xystodesmids; anterior corners slightly rounded, posterior corners angular, becoming slightly produced towards the rear of the body; posterior margins of keels slightly sinuate; upper surface of tergites smooth.

Tergites of segments sixteen through nineteen becoming narrower caudad, with keels increasingly produced, those of nineteenth forming short, rounded, lobes, $.45 \mathrm{~mm}$. in length, width of tergite between bases of lobes, $1.12 \mathrm{~mm}$.

Repugnatorial pores small, placed on the lateral margin of the keels, in the posterior third of the length.

Twentieth segment triangular in dorsal aspect, about as long as broad, tip slightly truncate. Anal valves almost flat, minutely wrinkled vertically, setiferous tubercules close to the well developed mesial ridges.

Preanal scale broad, short, triangular, the lateral tubercules obsolete.

Bases of last pair of legs well separated, prefemora ${ }^{1}$ separated at base by approximately $.34 \mathrm{~mm}$; sternites becoming wider cephalad, legs at midbody $.91 \mathrm{~mm}$. apart; the sternites between the last pair of legs on each segment posterior to the 6th produced into conspicuous sharp processes.

Legs at midbody with prefemora and femora small, subequal in size, tibia somewhat longer, tarsi 1 and 2 short, as broad as long, tarsus 3 longer, conical, tarsal claw short, heavy, angularly bent. Lengths of joints of legs, from base distad, .53, .53, .87, .38, .33,.41 mm.

Pleurites finely coriaceous, prozonite with the wrinkles much smaller. Stigma very narrow, upper end drawn out.

Gonopodal aperture broadly oval, the margin uninterrupted in front. Gonopods at rest with the basal portion caudad (facing cephalad when the organs are protruded), the tips of the telopodite blades crossing and directed caudolaterad. Coxa subcylindrical, the caudal portion much elevated, mesial side with a small but prominent rounded knob. Mesial process low, sparingly setiferous, rather broad in cephalic aspect; Jateral process produced into a long, slender, falcate spine, curving mesiad across the femoral portion of the telopodite and distally recurved laterad. Telopodite slender, flattened at the base, becoming subcylindrical distad and curved mesiad and cephalad, the extremity becoming flattened and angularly bent proximad with a small "heel" at the outside edge of the bend. The distal half of this flattened portion is bifid.

Sternites between the fourth pair of legs with a pair of upright, subconical processes, very conspicuous and as high as the cylindrical seminal processes of the second pair of legs which in this form are longer than usual for xystodesmids. Other legs without special processes.

Color in life as follows: tergites blackish with outer portions of keels (both cephalo- and caudolateral corners) pink, head brown with margin of labrum and an interantennal band light tan; underparts pale gray, sternites tan. Antennae gray with distal portion of each article white.

Description of female allotype.-Agreeing in general with the male, differing as follows: length 25, width, $4.7 \mathrm{~mm}$; dorsum more arched; marginal thickenings and angularity of caudolateral corners of keels

IThis term is arbitrarily used in preierence to either coxa or trochanter for the joint between the femur and sternite, pending an investigation to determine which of the prefemoral joints is lost in xystodesmids. 


\section{Proceedings of the Biological Society of Washington}

more pronounced. Femoral spines larger, anterior sternites without paired processes.

Gonopodal aperture large, including second pair of legs and large female organs. Lateral edge of aperture margined with a thin upright flange, also caudal edge with an upright, shallowly indented flange. Gonopods composed of a pair of thick, reniform valves, their surface granular and setose in places, attached by their basal ends to a triangular receptacle, into which they are retractable. When protruded, the free ends are directed caudad and the valves are parallel with the median axis of the body. The left gonopod is illustrated, in lateral or outer view.

Color apparently not fully developed, being chiefly uniform tan with a dark median line on the tergites. Underparts white.

Type specimens.-Male holotype, female allotype, and male paratype in the U. S. National Museum, No. 1848. Four paratypes in my personal collection, RLH no. 160, collected on July 3, 1948.

Type locality.-Shenandoah Mountain, about 15 miles west of Harrisonburg, Rockingham County, Virginia, elevation about 3500 feet. Specimens were found in a rather dry stand of Quercus (Q. alba and related species) with undergrowth mainly scrub oak and laurel (Kalmia latifolia). The humus layer was about two inches deep, overlying loose sandstone fragments. The only invertebrates noted in association were numerous ants and a few small beetles.

Remarks. - The relationships of this species are clearly with the recently described Nannaria morrisoni Hoffman (1948:348), a form known from several localities in the Blue Ridge in Virginia. These two species, with another yet undescribed from Mountain Lake, Virginia, form a distinct section within the genus, differing from $N$. media and related forms in which the telopodite blade is bent laterad and distally unmodified. It is possible that the disjunct forms should be properly included in a separate genus, but it is felt that such a step should be preceded by a study of all the known forms of Nannaria, towards which I am now accumulating material.

\section{Zinaria rubrilata, new species}

Diagnosis.-A small member of the genus, related to butleri, characterized by the size, color of the metazonites, and the relatively short, straight lateral spine of the male gonopod.

Description of male holotype.-Body small, length, 32.5, width, 5.6 $\mathrm{mm}$; ; sides subparallel, segments five through fifteen of approximately full width; dorsum compressed, less arched than in butleri; keels relatively wide, continuing slope of dorsun.

Vertex of head with a very faint shallow groove. Interantennal width, $1.0 \mathrm{~mm}$.; antennae relatively long, slender, $5.5 \mathrm{~mm}$. in length. Labral pores in upper series, 20 , in lower 20 ; labrum with a very deep median notch, teeth subequal in size.

Collum large, subellipsoidal in dorsal aspect, tapering evenly towards the ends, cephalolateral marginal ridge small but sharply defined.

Tergites of segments two through four similar, keels conspicuously bent forward, their posterior mesial margins well forward of caudal margins of tergite at midline; marginal ridges larger than on collum and 
somewhat more tumid, upper surface of keels becoming coriaceous and caudolateral corner with a suggestion of a denticle.

Tergites five through fifteen similar, keels more or less in line with rest of dorsum, marginal thickenings becoming larger; edges of keels slightly oblique, directed cephaloventrad; anterior corners broadly rounded, posterior corners angular and slightly produced caudad, this becoming more pronounced towards the rear of the body; posterior margins of keels slightly sinuate; upper surface of keels distinctly coriaceous, of rest of dorsum finely wrinkled, prozonite smooth.

Tergites of segments sixteen through nineteen becoming narrower caudad, with keels increasingly produced, those of nineteen forming short, bluntly triangular lobes, $.50 \mathrm{~mm}$. in length; width of tergite between bases of lobes, $1.37 \mathrm{~mm}$.

Twentieth segment triangular in dorsal aspect, somewhat elongate in appearance; two pairs of tiny lateral setiferous tubercules; tip slightly truncated. Anal valves slightly inflated, very finely wrinkled vertically, setiferous tubercules almost in contact with the well developed mesial ridges.

Preanal scale large, broadly triangular, lateral tubercules large and well set off from the margin.

Bases of last pair of legs almost in contact, prefemora separated at bases by approximately $.37 \mathrm{~mm}$.; sternites becoming wider cephalad, legs at midbody $1.0 \mathrm{~mm}$, apart; the sternites between last pair of legs on each segment enlarged and slightly produced caudad, but not forming actual lobes or spines.

Legs at midbody with prefemora subtrapezoidal, flattened; femora short, cylindrical, femoral spine short, conical; tibiae elongated, cylindrical, enlarged distally; tarsus 1 much thicker than distal two, tarsus 3 the longest, bearing a slender curved elaw; all joints with numerous slender bristles.

Pleurites finely but distinctly coriaceous. Stigmata cephalodorsad of legs, elongate, the ends pointed.

Gonopodal aperture broadly oval, margin uninterrupted at midline. Gonopods large, generally similar to those illustrated by Chamberlin (1939: fig. 5) for butleri (under the name $Z$. urbana), differing somewhat in having the long spine from the lateral process straight instead of bent mesiad across the face of the telopodite.

Sternites between third pair of legs with a pair of thin, upright, keellike processes; those between fourth pair with two small, conical processes, their ends slightly erenulate. Coxae of second pair of legs with the usual seminal lobes; these short and slightly enlarged distally.

Color in life as follows: majority of tergite orange-red or bright chestnut brown, keels, legs, and pleurites yellowish; middle portion of collum and exposed parts of prozonites black; top of head brownish. black, fading into white along margin of labrum and in antennal sockets; antennae whitish-yellow, becoming slightly darker distally.

Description of female allotype.-Agreeing in general with the male, differing in the following respects: slightly smaller, length, 30, width, $6.1 \mathrm{~mm}$.; dorsum more arched; body widest near posterior end; femoral spines larger; anterior legs without processes.

Gonopodal aperture wide and short, its edges without special rims or flanges as noted above under Nannaria. Exposed portion of gonopod 
appearing tripartite (resembling three appressed fingertips); outer valve of gonopod with distal (free) end conspicuously larger than that of inner.

Color much as in the male, not as intense, black or prozonites slightly encroaching on metazonites.

Type specimens.-Male holotype, female allotype, and a paratype of each sex in the U. S. National Museum, No. 1849, and nine male and two female paratypes in my collection, RLH no. 161 , to be distributed to other museums. All specimens taken together, July 13, 1948.

Type locality.-State Highway 3, one mile north of Kilmarnock, Lancaster County, Virginia. Specimens taken at the mouth of a culvert draining a large pond on the northeast side of the highway. Surrounding area chiefly wooded, a pine-oak association.

Remarles. - The nearest relative seems to be Z. butleri (McNeill), which is considerably different in lacking red on the dorsum (at least in all of the Virginia material referred to butleri) and in having the lateral spine of the male gonopod larger and curved mesiad. Also, all of the Virginia butleri (from five localities) are somewhat larger than rubrilata. Of course, there is the possibility than the Virginia population may be different form that of Indiana, but this has no bearing on the identity of rubrilata. In addition to the type locality, it has been found also near Irvington, in Lancaster County (a single female, RLH no. 162, August 17, 1948).

The red pigment of rubrilata seems to be more extensive than in any other known xystodesmid. At a distance it is difficult to observe the thin black edge of the prozonite and the impression is that of a uniformly red milliped.

\section{REFERENCES}

Brolemann, Henry W., Notes on female paraiulids (Myriapods), with description of a new species. Ann. Ent. Soc. Amer., vol. 15, no. 4, pp. 281-309, pls. XIX-XXIV, figs. 1-57, 1922.

Chamberlin, Ralph V., On some diplopods of the family Fontariidae. Bull. Univ. Utah, vol. 30, no. 2, pp. 1-19, figs. 1-37, 1939.

, On some genera and species of American millipeds. Bull. Univ. Utah, vol. 34, no. 6, pp. 1-20, figs. 1-36, 1943.

Hoffman, Richard L., Three new eastern millipeds of the family Xystodesmidae. Journ. Wash. Acad. Sci., vol. 38 , no. 10, pp. 346-50, figs. 1-6, 1948.

\section{Explanation of Plate}

Figure 1. Nannaria shenandoa, n. sp., left gonopod of male, cephalic view. L-lateral process, M-mesial process; S-solenite.

Figure 2. Nannaria shenandoa, left gonopod of male, mesial aspect.

Figure 3. Nannaria shenandoa, left gonopod of female, lateral view. $\mathrm{R}$-receptacle, OV-outer valve.

Figure 4. Nannaria shenandoa, preanal scale and bases of last two pairs of legs, showing production of sternite.

Figure 5. Saiulus montanus, n. sp., gonopods of female, caudad view.

Figure 6. Saiulus montanus, gonopods of male, cephalic view. 


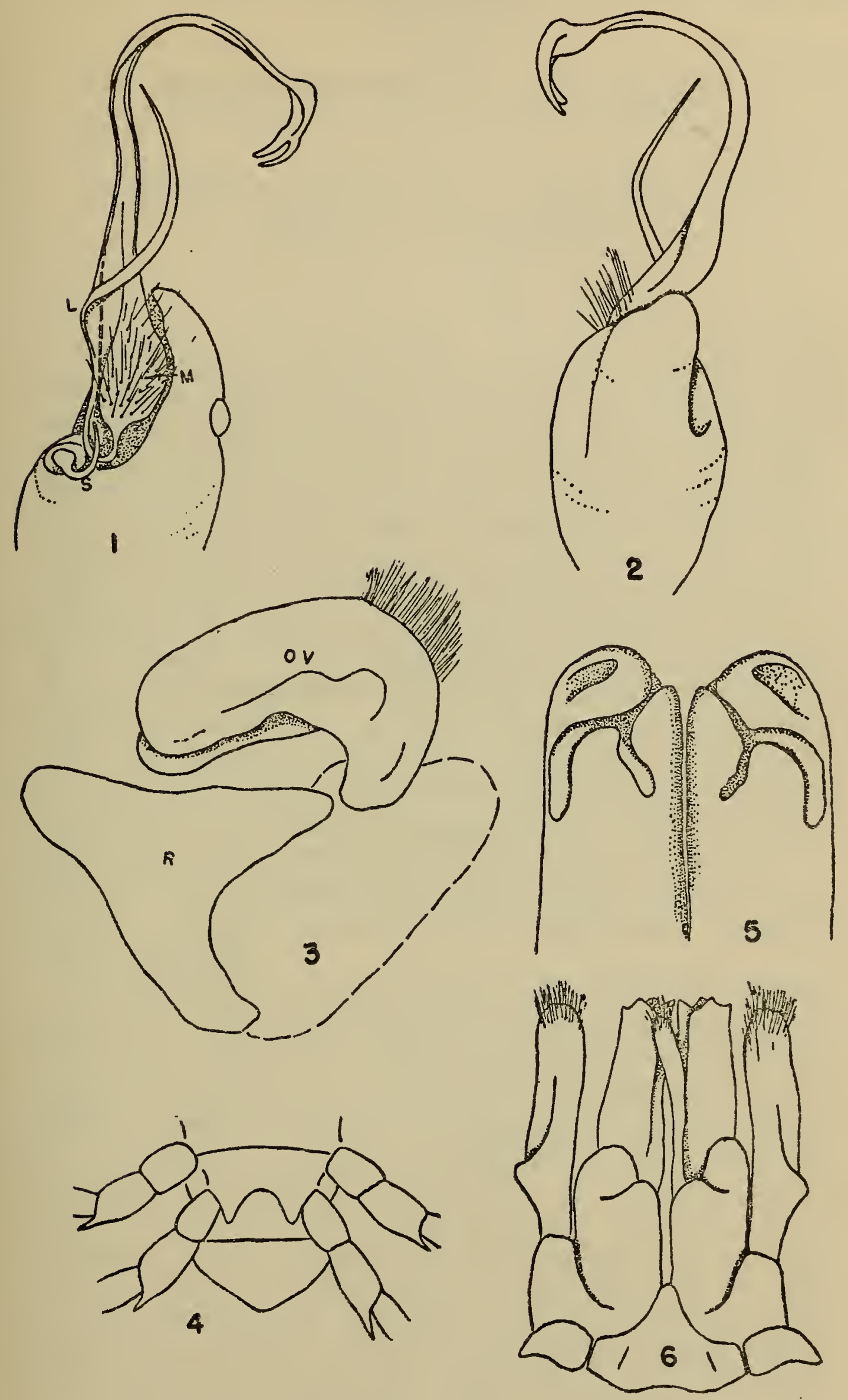


88 Proceedings of the Biological Society of Washington 
gray or brownish, and occasionally there is a series of light spots running parallel to-and immediately below-the dorsolateral dark stripe. There is often a small swelling, or tubercle, at the base of the naso-labial groove on the upper lip, in sexually active males, and occasionally also submental and caudal hedonic swellings.

Salamanders agreeing with this definition are found from eastern Quebec to southern Virginia, and west through the Appalachian uplift almost to the Ohio River in West Virginia. Out of 210 sexually mature specimens of both sexes from this region, 110 (=53\%) have 15 costal grooves, while the remaining 100 specimens have 16 grooves; there is no association between the costal groove count and age, sex, or geographic origin. The combined vomerine counts in this series vary from 8 to 21 , average $12.2 \pm 3.07$, and as in the case of the costal grooves, are not associated with age, sex, or provenance. A maximum total length of $109 \mathrm{~mm}$. is found in this series ( $q$, Harrison, Westchester County, New York, personal collection M. B. Mittleman). The ratio of tail length to total length in metamorphosed specimens is from $46.7 \%$ (in a specimen with a total length of $47 \mathrm{~mm}$.), to $59.5 \%$ (in a specimen with a total length of $96 \mathrm{~mm}$.) ${ }^{1}$.

Although relatively widely distributed and comparatively stable morphologically, the two-lined salamander undergoes several changes in the southern portion of its range, and evolves ultimately into two distinct forms, cirrigera and wilderae. In the Atlantic and Gulf Coastal Plain, and the Piedmont, the two-lined salamander population is characterized by a costal groove count of 13 or 14, a combined vomerine count of $10-24$ (average $15.8 \pm 2.54$ ), a more intense pigmentation with the dorsolateral stripe usually extending to the distal fourth (or even tip) of the tail, a well-developed lateral series of white (or at least light) spots, and prominent cirri in sexually mature males. These are the characteristics of the race cirrigera which extends from southern Virginia through the Coastal Plain to northern Florida and extreme eastern

${ }^{1} \mathrm{My}$ findings concerning the ontogenetic variation in proportionate tail length in bislineata are almost identical with those of Oliver and Bailey (1939: 200), and $I$ agree with them in considering $E$. bislineata major Trapido and Clausen (1938: 119) to be synonymous with $E$. b. bislineata. A count of 17 costal grooves occasionally occurs in major (fide Trapido and Clausen. l.c.); this results from the anoinalous branching of either the first or last costal groove, and is not normal. The type of major (USNM $104239 \sigma^{*}$, Val Jalbert, Ouiachouan River. Lake St. John Co., P. Q.) has 16 costal grooves, a tail/total length ratio of $56.5 \%$, and a combined vomerine count of 14. Two paratypes (USNM 107208-9) from Bonaventure Co., P. Q.. are similar in all respects, and like the type, are indistinguishable from many bislineata. 
Louisiana, and inland through the Piedmont generally to the border of the Blue Ridge Province, in the Carolinas and Georgia.

The montane two-lined salamander of the Blue Ridge Province, wilderae, is similar to cirrigera in normally having 13 or 14 costal grooves (rarely, an anomalous branch of the first or last groove results in a count of 15 ), and prominent cirri in sexually mature males. It differs from cirrigera in having fewer vomerine teeth, the combined vomerine counts ranging from 4 to 17 , average $11.4 \pm 3.33$; wilderae is also distinguished in that the heavy black (rather than brown) dorsolateral stripes stand out sharply (not tending to fuse with the pigments of the sides of the body and tail), and rarely extend beyond the middle of the tail. The range of wilderae is from White Top Mountain, Virginia, south through the Blue Ridge Province to Rabun and Gilmer counties, Georgia, and west to Sevier County, Tennessee.

Two-lined salamanders from Brunswick and Mecklenburg counties, Virginia ( $\mathrm{RLH}^{2}$ 955, 966-8), are characteristic cirrigera; however, specimens from Buckingham, Charlotte, and Prince Edward counties, Virginia (RLH 952-4), have the teeth of bislineata (combined vomerines 7, 12, 12), 14 vostal grooves as in cirrigera, and an intermediate color and pattern. I regard them as intergrades; Dunn (1926: 303) has recorded intergrades of cirrigera $\times$ bislineata from Midway and Gloucester, Virginia.

Specimens from the extreme southern Piedmont in Georgia are difficult to assign racially. Two-lined salamanders from Rabun and Gilmer counties are referable to wilderae, as noted by Dunn (1926 : 313; also WTN 7022-3, betw. Tiger and Wylie, Rabun Co.), although they are somewhat aberrant in having higher combined vomerine counts $(12,20)$ than is usual in this race. Specimens from Tray Mountain, Habersham County (USNM 115622-5) are definitely aberrant; they display the vomerine counts of cirrigera in three out of four specimens $(12,16,18,18)$, and have a more intense pigmentation than is normal for wilderae. Specimens from Duluth, Gwinnette County (USNM 91809-11) are similar, and have a pattern intermediate between wilderae and cirrigera; two of the three specimens have combined vomerine counts of 12 , and one has

\footnotetext{
2Abbreviations used for collections: $R L H=$ private collection of Richard $L$. Hoffman; WTN = private collection of Wilfred T. Neill; CAS = Chicago Academy of Sciences; USNM = United States National MIusenm; OUZ = Department of Zoology, Ohio University.
} 
a count of 19 . On the other hand, specimens taken barely forty miles to the east, in Clarke County (WTN 7543-6, 7565, 7583 ), have patterns which are very similar to those of Coastal Plain cirrigera; two of the six specimens have the characteristically high vomerine count of cirrigera $(17,20)$, while the other four have low to moderate counts $(5,8,10,14)$. The single male in this series has no cirri, although it is large (snout-vent $45 \mathrm{~mm}$.) and has a fairly prominent caudal hedonic swelling. Specimens from Augusta (which is on the Fall Line) display all of the usual characteristics of cirrigera, and I conclude that this city and its surrounding area marks the northernmost limit of "typical" cirrigera in Georgia.

In addition to the differentiation which the two-lined salamander undergoes in the southern part of its range, still other changes occur in the populations lying to the west of the Alleghanian uplift, for these transmontane salamanders differ in several respects from bislineata and its races wilderae and cirrigera. In these specimens the costal groove count is normally 14 ( $81 \%$ of specimens), less often 15 ( $18.2 \%$ of specimens) or 16 ( $0.8 \%$ of specimens), thereby distinguishing them from bislineata. The combined vomerine counts range from 8 to 27 , average $15 \pm 3.73$, which likewise serve to differentiate these specimens from bislineata and wilderae (although not from cirrigera). The color and pattern approximate bislineata, although the common presence of fairly well developed light spots on the sides is strongly reminiscent of cirrigera (as is also the extension of the dorsolateral stripe to the tip, or the distal fourth of the tail, in many specimens). The lack of cirri in sexually mature males suggests bislineata, rather than wilderae or cirrigera, although occasional specimens have pronounced, even slightly elongate, swellings at the base of the naso-labial grooves. In sum, this population is most similar to bislineata in color and pattern and lack of extreme sexual dimorphism; it is closest to cirrigera in dentition and costal groove count. The transmontane population and cirrigera differ considerably in limb length, for the latter is a long-legged form, while the former has rather short legs. In transformed cirrigera of $35+\mathrm{mm}$. snout-vent length, the appressed limbs sometimes just meet, but are more often separated by one or two costal spaces, the usual condition being about one and a half spaces. Transmontane specimens of comparable snout-vent lengths almost invariably have a great- 
er number of costal spaces between the appressed toes; in this population two to four and a half spaces are found between the appressed limbs, usually about three.

It is obvious that the transmontane specimens are not iden. tifiable with any of the earlier-described races of the two-lined salamander, and since they are nameless, I propose to call them

Eurycea bislineata rivicola, n. ssp.

HOLOTYPE.-An adult male in my personal collection (to be deposited in the U. S. National Museum), taken in Echo Canyon, McCormick's Creek State Park, Owen County, Indiana, by Mary E. and M. B. Mittleman, August, 1942.

ALLOTYPE.-An adult female in my personal collection, same data as the holotype, to be deposited in the U. S. National Museum.

PARATYPES.-(I have examined several hundred specimens, and still more are extant from a great many localities; rather than enumerate all of these, I have selected as paratypes only a sufficient number of specimens to illustrate the geographic and morphologic range of this race), WEST VIRGINIA-Wood County: $5 \mathrm{mi}$. S. of Parkersburg (OUZ 924); Mingo County: Varney (OUZ 933). OHIO-Athens County: Canaan Twp., Sec. 11 (OUZ 28-9); Carroll County: no specific locality (OUZ 906); Hamilton County: Cincinnati (USNM 8832); Hocking County: Salt Creek, Benton Twp. (OUZ 1028, 13 spec.); Monroe County: Adams Twp., Sec. 6-36 (OUZ 946, 2 spec.); Preble County: 5 mi. SE of Camden (USNM 76825-6); Washington County: Marietta (USNM 118302-6; OUZ 945, 6 spec.). KENTUCKY-Carter County: Carter Caves (OUZ 1058, 6 spec.), Cascade Cave (OUZ 1029). INDIANABrown County: Brown County State Park (10 spec., MBM coll.), Pike's Peak (5 spec., MBM coll.); Jennings County: Muscatatuck State Park (4 spec., MBM coll.); Marion County: Indianapolis (USNM 17465-8; 10 spec., MBM coll.); Monroe County: Morgan-Monroe State Forest (2 spec., MBM coll.); Owen County: McCormick's Creek State Park (8 spec., MBM coll.); Parke County: Turkey Run State Park (CAS 1436-64); Tippecanoe County: Lafayette (USNM 17972-4). ILLINOIS -LaSalle County: Starved Rock (CAS 1573). TENNESSEE-Cheatham County: $2 \mathrm{mi}$. S. of Shacklett (USNM 85686); Cumberland County: $3 \mathrm{mi}$. E. of Pleasant Hill (USNM 87615); Davidson County: $5 \mathrm{mi}$. NW of Belleview (USNM 85689); Grainger County: Bean Station (USNM 88754); DeKalb County: Dowelltown (USNM 88755).

DIAGNOSIS.-A race of Eurycea bislineata usually having 14 costal groores ( $81 \%$ of specimens), less often 15 or 16 grooves ( $19 \%$ of specimens); costal spaces between appressed toes two to four and a half, usually three; combined vomerine count $8-27$, average $15 \pm 3.73$; no cirri in sexually active males; dorsolateral stripe extending well beyond the middle of the tail in most specimens, often reaching the tip.

DISTRIBUTION.-Extreme western West Virginia at low altitudes, west to central and northern Illinois and southwestern Michigan, Ten. nessee between the Blue Ridge and the rest branch of the Tennessee River. 


\section{Proceedings of the Biological Society of Washington}

REMARKS.-The distributional limits of rivicola are known only imperfectly. Material from West Virginia indicates that this race occurs only in the extreme western part of the state, apparently only below the 1,000 foot contour along the Ohio River Valley; whether rivicola enters Pennsylvania in the extreme western portion of the state is uncertain, two specimens from Meadville, Crawford Co. (USNM 3718,2 spec.) being quite typical bislineata. The westernmost limits of rivicola are Will, LaSalle, and Edgar counties, Illinois; presumably, the Berrien County, Mich., record for bislineata (Maldonado-Koerdell and Firschein, 1947: 140), which I have not examined, is referable to rivicola.

I have not seen any specimens from Coastal Plain Tennessee, i.e., that portion of the state lying to the west of the Tennessee River, but I suspect that this population will show a prominent tendency toward rivicola, if not actual identity with this race. Parker $(1947: 79)$ has reported cirrigera from northwestern DeSoto Co., Mississippi, but the specimens $I$ have examined from this county $(1 \mathrm{mi}$. $\mathrm{E}$. of Walls, CAS 10847, 10 spec.) are actually intergrades between cirrigera and rivicola, and on the whole are closer to the latter race. In pattern and dentition they are intermediate, while in the costal groove count (14 in seven specimens, 15 in three) and number of costal spaces between the appressed limbs (3 or 4 in all specimens) they suggest rivicola, as does also the lack of cirri in the sexually mature male of this series. If these specimens are correctly identified as intergrades, then it is probable that rivicola extends into extreme western Tennessee, and the northernmost parts of Mississippi and Alabama as well.

Eastward in Tennessee, rivicola is found as far as Grainger County (Bean Station, USNM 88754, at an altitude of approximately 2,000 feet. King (1939: 557-9) has described specimens of "Eurycea bislineata $X$ cirrigera" from low altitudes (below 2,500 feet) in the Great Smokies, in Sevier County, Tennessee, which appear to be rivicola; King's descrip. tion fits rivicola in all important respects, except the number of costal spaces between the limbs. Interestingly enough, King reports no instances of intergradation between wilderae and his "Eurycea bislineata $X$ cirrigera" ( = rivicola), which may be due to the fact that the former takes up a semi-terrestrial existence, while the latter, according to King, is restricted to springs, marshy areas, and small streams. Dunn (1926: 303) reports intergradation between wilderae and bislineata at Abingdon, Washington Co., Virginia.

The four races of Eurycea bislineata, as recognized and defined in this paper, may be identified by the following key:

1a. Costal grooves 15 or 16 ; occasional naso-labial swellings or tubercles, but no cirri present in sexually mature males

1b. Costal grooves 13 or 14 ; if cirri are present, costal spaces between the appressed limbs are 2, if cirri are absent there are 3 costal spaces between the appressed limbs

2a. Combined vomerines $8-21$, average 12 ; dorsolateral stripe usually not extending beyond middle of tail. Southern Quebec to southern Virginia, west to the Ohio River valley in West Virginia bislineata 
2b. Combined romerines 8-27, average 15 ; dorsolateral stripe usually extending well beyond middle of tail (to distal fourth or beyond). Ohio River valley in West Virginia, west to central and northern Illinois, and extreme southwestern Michigan, Tennessee between the Blue Ridge and the west branch of the Tennessee River rivicola

3a. Costal spaces between the appressed limbs usually 2; cirri present in males

$3 b$. Costal spaces between the appressed limbs usually 3 ; no cirri present in males. Range $a s$ in $2 \mathrm{~b}$ _______ricola

4a. Combined romerines 10-24, average 15.8; sides dark with prominent white (or light) spots; dorsolateral stripe extending to tip, or at least the distal fourth, of tail. Southern Virginia to extreme Louisiana in the Coastal Plain and Piedmont .. cirrigera

4b. Combined vomerines 4-17, average 11.4; sides light, dorsolateral stripe black (rather than brown) and extending only to the middle of the tail. The Blue Ridge Province, from White Top Mountain, Virginia, to Rabun and Gilmer counties, Georgia wilderas

\section{ACKNOWLEDGMENTS}

For the privilege of examining specimens, and many other courtesies, I am grateful to Dr. Doris M. Cochran, Dr. Herschel T. Gier, Dr. Howard K. Gloyd, Mr. Richard L. Hoffman, and Mr. Wilfred T. Neill. My wife has helped me greatly in recording data and making various tabulations, and for this she has my appreciative thanks.

\section{LITERATURE Cited}

Bishop, Sherman C. 1943. Handbook of salamanders. Ithaca: Comstock Publ. Co., xiv +555 pp., frontis., figs. 1-144, maps 1-56.

Dunn, Emmett R. 1926. The salamanders of the family Plethodontidae. Northampton: Smith College, $x+441$ pp., frontis., 2 pls., figs. 1-86.

King, Willis. 1939. A survey of the herpetology of Great Smoky Mountains National Park. Amer. Midl. Nat., 21(3): 531-582, map, figs. 1-9.

Maldonado-Koerdell, Manuel and Irwin L. Firschein. 1947. Notes on the ranges of some North American salamanders. Copeia: 140.

Oliver, James A. and Joseph R. Bailey. 1939. Amphibians and reptiles of New Hampshire (pp. 195-221, 2 pls.), in, Biological Survey of the Connecticut Watershed. Surv. Rept. 4, New Hampshire Fish and Game Dept.: 1-256, figs. 1-86.

Parker, Malcolm V. 1947. Distribution of three amphibians and a rep. tile in the midsouth. Herpetologica, 4:79-80.

Reynolds, A. E. and E. G. Black. 1936. The salamanders of Putnam County. Proc. Indiana Acad. Sci., 45:287-294.

Stejneger, Leonard and Thomas Barbour. 1943. A check list of North American amphibians and reptiles. Bull. Mus. Comp. Zool., $93(1):$ xix $+1-260$.

Trapido, Harold and Robert T. Clausen. 1938. Amphibians and reptiles of eastern Quebec. Copeia: 117-125.

Plate.-Distribution of the races of Eurycea bislineata (modified after Bishop, 1943: 405). Intergradation between races is not shown, except 


\section{Proceedings of the Biological Society of Washington}

in the case of wilderae $\times$ cirrigera. The inclusion of northern Alabama and extreme northwestern Georgia in the range of rivicola is based on the expected, but as yet hypothetical, extension of this subspecies' distribution. The distributional vacuum in northwestern Alabama, northern Mississippi, and western Tennessee is purely artificial; Eurycea bislineata cap, occurs in this area, but the status of the form is as yet uncertain. Similarly, some race occurs in extreme western Kentucky, but whether it is cirrigera or rivicola, or an intergradant population, is not known. The range boundary of rivicola and bislineata in northeastern Ohio and western Pennsylvania is artificial; whether the two races interdigitate or replace each other abruptly in this region remains to be determined.

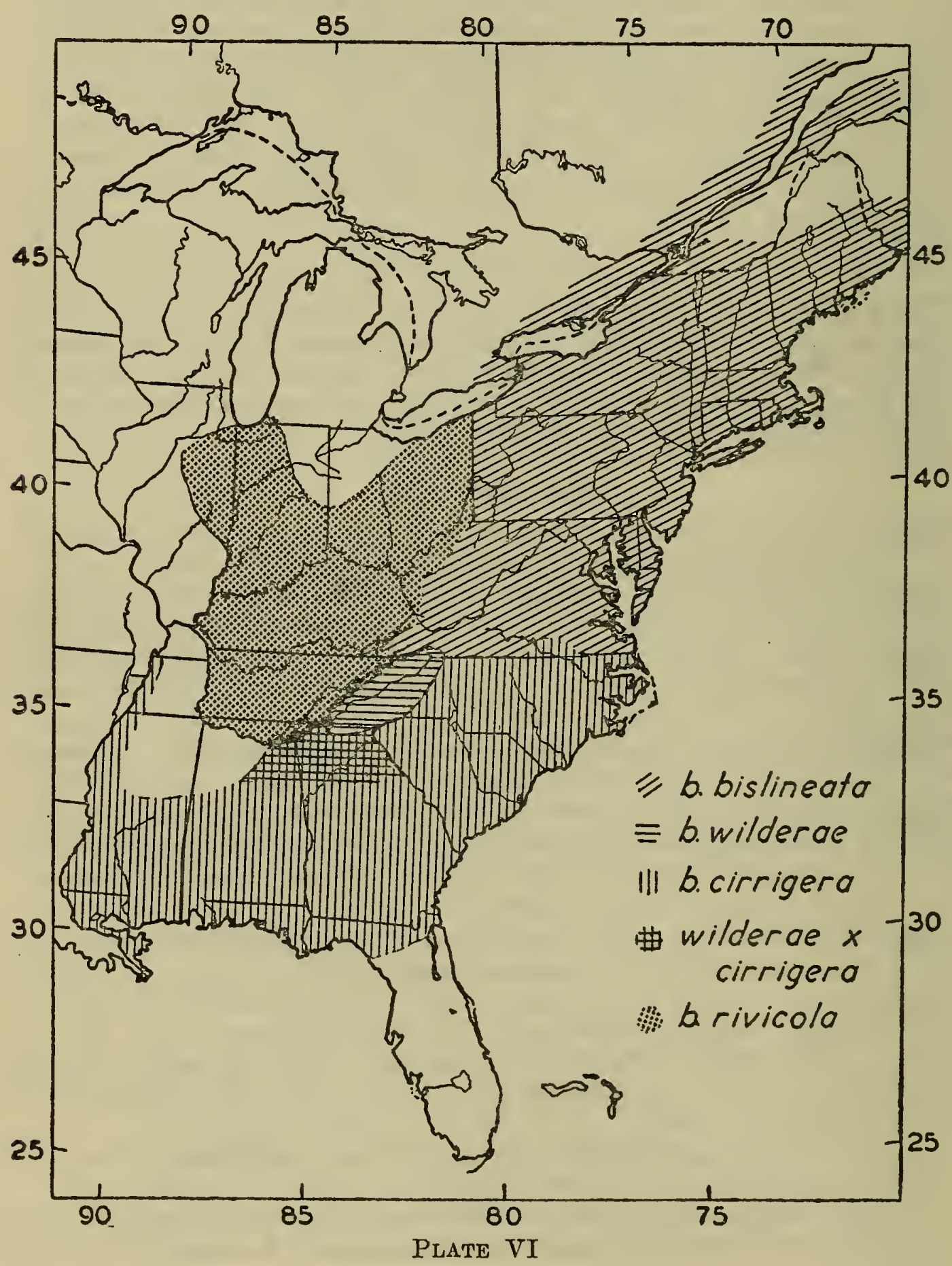




\title{
PROCEEDINCS
}

\author{
OF THE
}

\section{BIOLOGICAL SOCIETY OF WASHINCTON}

\section{REMARKS ON THE GENUS \\ OCHETORHYNCHUS MEYEN}

By Alexander Wetport and James L. Phters

As long ago as 1926, in discussing Upucerthia certhioides Wetmore ${ }^{1}$ remarked "the association of this and allied straight billed forms in the genus Upucerthia with species of the U. dumetaria type is questionable." Recently while engaged in a general revision of the Furnariidae, Peters came to the conclusion that the continued retention of certhioides in Upucerthia was not warranted, and proposed to Wetmore that the question of the generic allocation of this species be reopened.

In connection with the study of this question all the known species currently referred to Upucerthia were examined as well as nearly all of the described races. One of these (excelsior) has already been shown by Bond ${ }^{2}$ to be referable to the genus Cinclodes, a disposition in which we entirely concur. Of the other species currently placed in Upucerthia, there are three, dumetaria, albigula and validirostris, that are similar structurally in that the bill is slender and longer than the head, with the culmen strongly arched. Two others, andaecola and serrana, have somewhat stouter and shorter bills, which, however, are arched as in the dumetaria group.

The three remaining species, ruficauda, harterti and certhioides, differ noticeably from any of the others mentioned, in having the culmen straight, slightly decurved terminally, and not arched. There seem to be no other structural characters, but in our estimation this striking bill difference is sufficient to be of generic value.

The three species listed above may be placed in the Genus Ochetorhynchus Meyen, ${ }^{3}$ the type of which is Ochetorhynchus ruficaudus Meyen.

Examination of a large series of Ochetorhynchus certhioides from widely separated parts of its range reveals the existence

\footnotetext{
1D. S. Nat. Mus. Bull. 133, 1926. p. 251.

Proc. Acad. Nat. Sci. Philadelphis, 97, 1945, p. 23.

${ }^{3}$ Nova Acta Acad. Caes. Leop.-Carol., 16, 1834, suppl. 1, p. 80.
} 
of a hitherto unrecognized race, occupying a larger area than the ranges of either of the two currently recognized forms as restricted below. A brief history of the two currently described forms may be of interest. In 1838 d'Orbigny and Lafresnaye ${ }^{4}$ described Anabates certhioides from Corrientes, Argentina. Following this in 1860 Burmeister $^{5}$ named Ochetorhynchus luscinia, with types from Mendoza. The existence of the name set up by d'Orbigny and Lafresnaye was over-looked by all orinthologists until resurrected by Ménégaux and Hellmayr ${ }^{6}$, and the few specimens that were collected along the Paraguay River were referred to luscinia, which had been transferred to the genus Upucerthia by Sclater and Salvin ${ }^{7}$. Ménégaux and Hellmayr (loc. cit.) pointed out the differences between the eastern and western populations in Argentina, but regarded them as distinct species. Hartert ${ }^{8}$ three years later reduced luscinia to the status of a subspecies of certhioides. While Hartert was correct in his interpretation of relationships, he apparently lacked topotypical material of luscinia, and assumed that the specimens at hand from the Argentine provinces of Salta, Catamarca and Tucumán represented that form. Hellmayr's treatment in the fourth part of the Catalogue of the Birds of the Americas was essentially the same as that of Hartert. Thus it now appears that the bird we propose to describe is in reality Upucerthia certhioides luscinia of authors, not of Burmeister, which appears to be restricted in its distribution to the precordillera in the Argentine provinces of La Rioja and Mendoza, while the population from Salta, Catamarca, Tucumán, Santiago del Estero, western Chaco and the Paraguayan Chaco belongs to an undescribed race that we name.

\section{Ochetorhynchus certhioldes estebani new subspecies}

Type M. C. Z. no. 94198, ad. ô, Leales Bajo, 700 meters elevation, Tucumán, collected 16 May, 1915 by Luis Dinelli.

Characters.-Similar to Ochetorhynchus certhioides certhioides (d'Orbigny and Lafresnaye), but dorsal coloration much paler brown; ventral coloration duller, especially the flanks, which lack any rufus tinge; bill relatively as well as absolutely shorter; wing longer, with tail equal to or slightly longer than wing. Similar also to $O$. c. luscinia Burmeister but more brownish, less grayish above and below; smaller in all dimensions.

\footnotetext{
¿Syn. Av., in Mag. Zool., 8, 1838, cl. 2, p. 15.

sJourn. f. Orn. 8, 1860, p. 249.

Mem. Soc. Hist. Nat. Autun, 19, 1906, p. 56

7 Nomencl. Av. Neotrop., 1873, p. 62.

Nov. Zool., 16, 1909, pp. $207-208$.
} 
This new form is named for Dr. Juan G. Esteban of the Instituto Miguel Lillo in Tucumán, in recognition of his current work in the family Furnariidae.

The races and ranges of Ochetorhynchus certhioides may be summarized thus-

o. o. luscinia Burmeister.

Ochetorhynchus Luscinia Burmeister, Journ. f. Orn., 8, no. 46, July, 1860, p. 249. (Mendoza.)

The largest and palest form, the brown eoloration with a distinct grayish cast; wing longer than tail. 1 of, La Rioja, wing 74.5 ; tail 76.1 ; culmen $24.9 \mathrm{~mm} ., 3$ \%, Mendoza, wing 70.9-75.2 (72.7); tail 73.882.3 (77.9); culmen 22.6-24.5 (23.5) $\mathrm{mm}$.

Range: Precordillera of western Argentina in provinces of Mendoza and La Rioja; presumably also in San Juan.

o. c. estebani Wetmore and Peters.

Browner, less grayish, than $O$. o. luscinia; somewhat smaller.

\begin{tabular}{|c|c|c|c|}
\hline & Wing & Tail & Culmen \\
\hline 1 ô Salta & 70.5 & 70.7 & 20.4 \\
\hline 1 o Catamarca & 68.4 & 69.1 & 22.8 \\
\hline $\begin{array}{l}3 \text { o Tucumán } \\
5 \text { o Santiago }\end{array}$ & $70.6-72.3 \quad(71.5)$ & $72.1-73 \quad(71.6)$ & $20.7-21.8$ (21) \\
\hline $\begin{array}{l}\text { del Estero } \\
\text { Chaco }\end{array}$ & $69 .-72.4(70.6)$ & $68-75.5 \quad(71.6)$ & $20.5-23.1$ (21.6) \\
\hline $\begin{array}{l}\text { (western) } \\
\text { o Paraguay. }\end{array}$ & 68.5 & 69 & 22.1 \\
\hline an Chaco & $65.8 .68 .7(67.3)$ & $65.2-68.5 \quad(66.9)$ & $20.4-21.4 \quad(20.6)$ \\
\hline $\begin{array}{l}3 \text { ㅇ Tucumán } \\
8 \text { q } \text { Santiago }\end{array}$ & $67-70.3(68.6)$ & $67-71.3 \quad(69.6)$ & $18.3-20.7 \quad(19.6)$ \\
\hline $\begin{array}{l}\text { del Estero } \\
\text { ㅇ Chaco }\end{array}$ & $65-72.5(68.8)$ & $66.8-75.7 \quad(71.1)$ & $19.7-22.8 \quad(21.8)$ \\
\hline $\begin{array}{c}\text { (western) } \\
\text { ㅇ Paraguay- }\end{array}$ & 65.4-69.2(67) & $64.6-69.8 \quad(66.9)$ & $19.7-22.9 \quad(20.4)$ \\
\hline an Chaco & 67.4 & 69.5 & 21.7 \\
\hline
\end{tabular}

Range:-Northern and northwestern Argentina in provinces of Salta, Catamarea, Tucumán, C6rdoba, Santiago del Estero, and Gobernación del Chaco (General Pinedo), extending into the Paraguayan Chaco to a point $265 \mathrm{~km}$. west of Puerto Casado. Paraguayan specimens are somewhat intermediate in size and proportions between this race and o. c. certhioides, but are nearer to estebani in shorter bill and paler coloration.

O. c. certhioides (d'Orbigny and Lafresnaye)

Anabates certhioides d'Orbigny and Lafresnaye, Syn. Av., in Mag. Zool., 8, cl. 2, 1838, p. 15. (Corrientes.)

The most deeply eolored race, with the shortest wings and tail, the latter member averaging slightly shorter than wing, whereas in the other two races the tail slightly exceeds the wing; bill longer than in estebani, but shorter than in luscinia. 


\begin{tabular}{|c|c|c|c|}
\hline & Wing & Tail & Culmen \\
\hline 2 \& Formosa & $67.3-68.5(67.9)$ & $64.9-65.3(65.1)$ & $23 .-23.6(23.3)$ \\
\hline ern) & $65.1-66.5 \quad(65.8)$ & $62.9-65.6(64.2)$ & $21.6-22.9 \quad(22.2)$ \\
\hline $\mathrm{Fe}$ & 67.3 & 63.1 & 22.1 \\
\hline Chac & $61.2-68.7(64.9)$ & $62.3-67.6(64.9)$ & $22.8-22.9$ \\
\hline q Santa $\mathrm{Fe}$ & 64.3 & 63.8 & 23.4 \\
\hline
\end{tabular}

Range:-Eastern Formosa, and Chaco (Las Palmas) south to Banta Fe (Mocoví), Corrientes ${ }^{9}$ and Entre Ríos, ${ }^{9}$ Argentina.

The forms included in Ochetorhynchus under the arrangement set up in this paper will stand as follows:

Ochetorhynchus harterti (Berlepsch)

Ochetorhynchus certhioides certhioides (d'Orbigny and Lafresnaye)

Ochetorhynchus certhioides estebani Wetmore and Peters

Ochetorhynchus certhioides luscinia Burmeister

Ochetorhynchus ruficaudus ruficaudus Meyen

Ochetorhynchus ruficaudus montanus (d'Orbigny and Lafresnaye)

\section{MATERIAL EXAMINED}

o. c. luscinia.-MENDOZA: near Mendoza, 3 ${ }^{1}$. LA RIOJA: Chilecito, 1 ô 1.

o. c. estebani.-SALTA: Arenal, 1 đ̊ ${ }^{2}$ CATAMARCA: Catamarca, $1 \hat{o}^{2}$. TUCUMÀN: Vipos, $1 \hat{\delta}^{2}$; Tapia, $1 \hat{\delta^{3}, 3} q^{1,2,3}$; Leales Bajo, $1 \hat{o}$ (type). SANTIAGO DEL ESTERO: Lavalle, $5 q^{2}$; Suncho Corral, $4^{2} \hat{o}, 4{ }^{2}$. CHACO: General Pinedo, $1 \hat{o}^{2}, 3$ $q^{2}$. PARA-

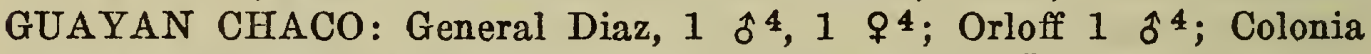
Fernheim $2 \hat{\delta^{4}} ; 265 \mathrm{~km}$. W. of Puerto Casado $1 \hat{\hat{o}^{3}}$.

o. c. certhioides.-FORMOSA : Kil. 182, 2 î 1 . CHACO: Las Palmas,

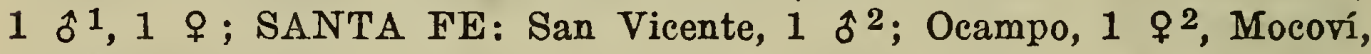
$1 \hat{\delta}^{2}, 1$ q $^{2}$.

We are indebted to the authorities of the American Museum of Natural History, Chicago Natural History Museum and the Museum of Zoology, University of Michigan, for the loan of material, in addition to that contained in the United States National Museum and the $\mathrm{Mu}$ seum of Comparative Zoölogy.

Smithsonian Institution, Washington 25, D. C.

Museum of Comparative Zoölogy, Cambridge 38, Mass.

\footnotetext{
'Specimens from these provinces not seen.

TSpecimens in U. S. National Museum.

2Specimens in American Museum of Natural History.

SSpecimens in Museum of Comparative Zoology.

"Specimens in Chicago Natural History Museum.

oSpecimens in Museum of Zoology, University of Michigan.
} 
OF THE

BIOLOGICAL SOCIETY OF WASHINGTON

\title{
A NEW RACE OF PIPILO FUSCUS FROM MEXICO
}

\author{
BY ROBERT T. MOORE
}

Since the publication of "Notes on Pipilo fuscus of Mexico" (Proc. Biol. Soc. Wash., 55, 45-48, May 12, 1942), more than 100 new specimens of this species have been added to the Moore Collection, coming chiefly from northeastern Mexico and the Central Plateau. It is now indicated that an undescribed race occurs in Hidalgo. It is herewith described:

\section{Pipilo fuscus campoi, subsp. nov. ${ }^{1}$}

Type.-Male adult acquiring fresh winter plumage, number 34212 , collection of Robert T. Moore; Metztitlán, Hidalgo, Mexico; September 27, 1942; collected by Mario del Toro Avilés.

Subspecific characters.-Nearest in coloration to $P$. f. toroi of Oaxaca (both races having a gray pileum concolor with back), it differs in being (1) darker above; (2) slightly darker below with less extensive white on belly; and (3) size apparently smaller, but most of the individuals are either badly worn or acquiring their winter plumage. About the size of P. fuscus fuscus of the State of Mexico, it differs by having (1) the pileum uniform with back, instead of browner; (2) paler buff on throat and (3) whiter on breast. Compared with potosinus of Guanajuato, (1) the pileum is much less brown, and (2) size probably smaller. Compared with the birds of the Valley of Mexico, which, although slightly paler, are nearer to true fuscus, campoi is paler below and darker above (pileum less brown). Compared with the topotypical series of texanus from Kerrvill,e Texas, with which I have made direct comparison, campoi differs markedly in (1) not having the very rusty pileum; (2) in being darker above and below (especially on the flanks), and (3) whiter on the belly. Our 41 specimens from Coahuila, Nuevo Leon, San Luis Potosí and Tamaulipas have pileums dark brown (not rusty as in texanus), much browner than the back. Some authors may differentiate them as a fairly well-marked intermediate race between texanus on the north and potosinus. Here they are treated as intergrades between these forms, but closer to potosinus.

Range-Campoi attains its typical characters in the arid area of Metztitlán, Hdg., from which the Moore Collection possesses sixteen specimens, all quite uniform. Our eleven brown towhees from other lo-

1It is a pleasure to name this interesing form for Dr. Rafael Martín del Campo, Curator of Birds in the Instituto de Biología, Mexico City, in recognition of the assistance he has given to the Compiling Group, in the preparation of the Check List of the Birds of Mexico. 


\section{Proceeding of the Biological Society of Washington}

calities in Hidalgo, (Real del Monte, Portezuelo, Jolotepec and Huichopán) although increasing in darker coloration of the pileum, as they occur farther west, approach potosinus. The birds of El Caracol, Querétaro, are about intermediate but slightly closer to potosinus and those farther west are definitely of this richer colored form. To the south in the Valley of Mexico the birds are nearer to the nominate race, whose type came from Tmascaltepec in the southwestern part of the State of Mexico.

Average Measurements.-The average of 10 adult males ( 5 in fresh plumage) from Metztitlán, Portezuelo, Jolotepec and Real del Monte shows wing 92.7 and tail $93.9 \mathrm{~m} . \mathrm{m}$. The average of 5 adult males of fuscus in good plumage ( 3 from Temascatepee and 2 from Lerma, State of Mexico, shows wing 93.4 and tail 91.4. For comparison with the other larger races, see the Table of Measurements in Proc. Biol. Soc. Wash., 55, p. 47.

Specimens Examined.-In addition to sixteen specimens of campoi from the type locality, eleven of campoi from other localities (Real del Monte, Jolotepec, Huichopán, and Portezuelo) in Hidalgo, as well as the 41 intergrades mentioned above from northeastern Mexico, I have reexamined the large series in the Moore Collection listed in the reference above-mentioned and in addition nearly one hundred new specimens from the Central Plateau; also, the ten topotypical specimens of texanus.

Remarks. - The new race from Hidalgo is a rather pale small race (wing and tail about equal in length) with pileum gray like the back, which is practically surrounded by richer colored, larger birds with brown heads to the north, west and south. Two specimens from a loeality to the East near Huachinango, Puebla, have the uniform back and pileum of campoi, but are conspicuously darker above and below in both the grays and buffs and seem to lie between the intergrades from the northeast and campoi, being the only group of them showing any approach to campoi. Farther east is the Tropical Zone of Veracruz, where this species does not occur. In the far south, separated from campoi by the richer colored, brown-headed birds of the high valley of Mexico, we find on the deserts of eastern Oaxaca the paler race, of toroi, with which it has its closest affinities.

My grateful acknowledgments are made to Mr. J. L. Peters and the Museum of Comparative Zoology and to Mr. E. R. Blake and the Chicago Museum for the loan of the topotypical series of texanus; also to Dr. Alden $\mathrm{H}$. Miller for arranging for the transfer of this material, while it was on loan to him. Mr. John Davis of the University of California, while doing work for his Doctor's degree in the collection of the Orcutt Trust, was very helpful in measuring the nearly 300 Mexican Brown Towhees in our collection. 


\title{
PROCEEDINCS
}

OF THE

\section{BIOLOGICAL SOCIETY OF WASHINGTON}

\section{A NEW HUMMINGBIRD OF THE GENUS LOPHORNIS FROM SOUTHERN MEXICO}

\author{
By ROBERT T. MOORE
}

The receipt of two specimens of the species Lophornis delattrei, taken in the state of Guerrero by Chester C. Lamb in May, 1947, extends the range of the genus nearly twelve hundred miles north from Costa Rica, whence Lophornis delattrei lessoni has been reported by Bangs. The new specimens represent a well-marked race, which is described below.

Lophornis delattrei brachylopha, subsp. nov.

Type--Adult male, number 46,062, collection of Robert T. Moore; San Vicente de Benitez, Guerrero, México; altitude 1,500 feet; May 9, 1947, collected by Chester C. Lamb.

Subspecific characters.-Nearest to Lophornis delattrei lessoni Simon, but differs in having (1) crest much shorter (about one-half as long), with no spangles on the tips of the feathers; (2) blackish shaft-streaks on the lateral crest feathers; (3) greens much darker throughout, particularly on back, hind-neck and wing-coverts; (4) tufts on side of neck longer, with larger streaks of green as compared with the smaller spots of lessoni; (5) tips of rectrices with a wide band of black, especially conspicuous below, instead of practically none, or golden green ones; (6) bill (both maxila and madible) entirely black instead of cinnamon (in dried skins); (7) rump much darker green, the feathers broadly tipped with iridescent Pomegranate Purple ${ }^{1}$; (8) bases of feathers or lower half of belly cinnamon-buff tipped with darker green, instead of uniform pale golden green; (9) size larger. Brachylopha differs from Lophornis delattrei delattrei (Lesson) of Perú and Bolivia in all the characters given above, except size, but to a greater degree.

Range.-Known from two adult males, both taken in May at the same locality; San Vicente de Benites, about thirty-five miles northwest of Acapulco, Guerrero, in the Sierra del Sur, at an altitude of 1,500 feet.

Average Measurements of Males in Millimeters

Wing Tail $\quad \begin{array}{ccc}\text { Exposed } \\ \text { Culmen }\end{array}$

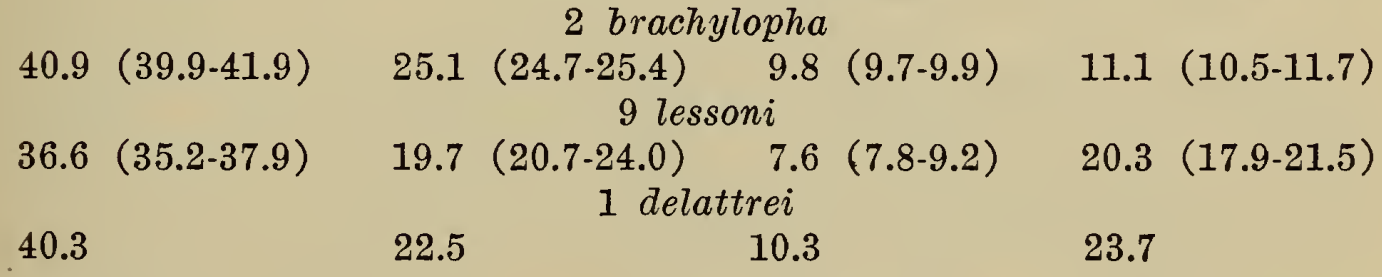

1Names of colors when capitalized are taken from Ridgway's Color Standard and Nomenclature, 1912.

2The length of the crest is measured from the base of the anterior long crest feathers to the tips of the longest ones.

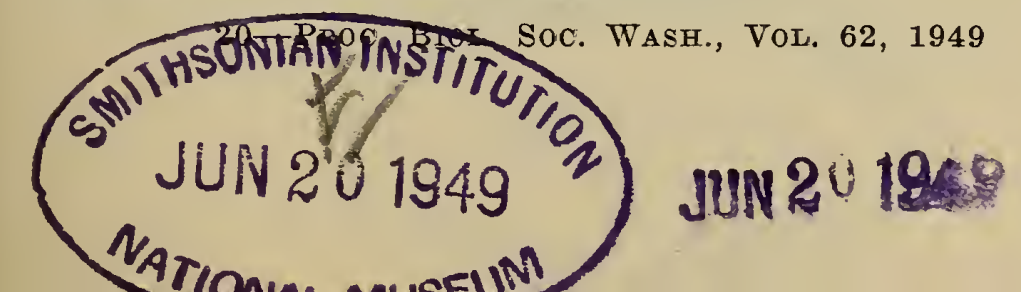




\section{SPEOIMENS EXAMINED}

Brachylopha: 2 adult males from Guerrero in Moore Collection. Lessoni: 1 ad $\hat{o}$, Clitra, Veraguas, Columbia; 5 ad $\hat{s} \mathrm{~s}$, "Bogota", 1 ad $\hat{o}$ "Columbia"; 2 ims. from Columbia; and one of uncertain origin; 2 ad $\hat{s} \mathrm{~s}$ from Panamá; $2 \mathrm{im}$. $\hat{s} \mathrm{~s}$ from San Pedro, Costa Rica. Delattrei: 1 ad $\hat{o}, 1 \mathrm{im}$., Buena Vista, Bolivia.

My acknowledgements are gratefully made to Dr. Herbert Friedmann and the United States National Museum, to Mr. James Peters and the Museum of Comparative Zoology, and to Mr. W. E. Clyde Todd and the Carnegie Museum for their courtesy in providing the comparative material necessary for the completion of this paper. 


\title{
PROCEEDINGS
}

\author{
OF THE
}

BIOLOGICAL SOCIETY OF WASHINGTON

\section{A NEW SPECIES BELONGING TO THE GENUS MYZOCALLIS (APHIDIDAE)}

\author{
F. C. HоTTES
}

The species described herewith and believed to be new to Science has been under rather close observation for two seasons. The opportunity is taken to discuss briefly its affinity to several other very closely allied species one of which has been heretofore considered a synonym.

\section{Myzocallis tonkawa, new species}

Alate viviparous female.

Size and general color.-Average length from vertex to tip of anal plate $2.06 \mathrm{~mm}$. Range in size from $1.71-2.43 \mathrm{~mm}$. Both extremes represented by a single specimen. Most common length about $2.21 \mathrm{~mm}$. Width of head through the eyes $.43 \mathrm{~mm}$. The color of this species is quite variable. Some specimens are pale yellowish-green, others are dusky yellow, while still others may have the head and prothorax a pale pink or orange with the abdomen green. As a rule the margins of the head show more or less dusky and the same may be said for the whole of the mesothorax which may also be light brown. The cornicles are concolorous with the abdomen, but may be slightly lighter in color. The cornicles are never dusky. Cauda and anal plate more or less concolorous with abdomen with the margins light dusky. First and second antennal segments dusky brown, darker on median margins. Third, fourth, fifth and sixth antennal segments light dusky with varying amounts of darker dusky to brown near the apex. The secondary sensoria on the third segment are commonly surrounded by dusky patches. Femora pale dusky-green with dorsal portions darker. Tibiae with a brownish spot near the knee, remaining portion light dusky as a rule but sometimes rather dark. Apex of tibiae not much if any darker than region above.

Stigma dusky. Veins brown surrounded by fuscous and ending in dusky areas before margin of wing. Anal vein as a rule darkest and surrounded by darkest area. Anal cubital and radial sector originating in dusky areas.

Head and appendages.-Comparative length of antennal segments as follows: III .786-.858 ave. .84mm., IV $.51-.60$ ave. .55mm., V $.443-.514$ ave. $.47 \mathrm{~mm}$., VI .20-.228 ave. $22 \mathrm{~mm}$., $+.312-.328 \mathrm{~mm}$. Secondary sensoria confined to the third antennal segment and numbering from seven to fifteen each represented by a single antenna. Ten to twelve sensoria are common. The first two or three sensoria are slightly oval the other sensoria are round. All sensoria have wide rims. The rostum reaches about half way to the coxae of thomesothoracic pair of legs. The anterior

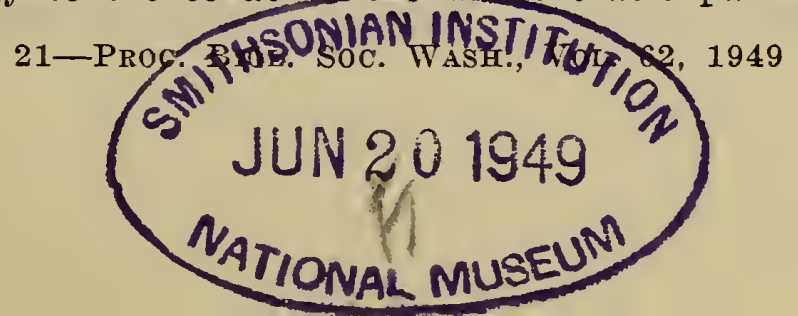




\section{Proceedings of the Biological Society of Washington}

margin of the head has a well developed tubercle. The dorsum of the head has two pair of wart-like tubercles each terminated by a short hair. These structures are difficult to determine unless the specimen is mounted on the side.

Thorax and appendages.-The dorsum of the prothorax has two pair of finger-like tubercles which are subequal in length. The dorsum of the mesothorax has a single pair of tubercles which have a much wider base than those on the prothorax. The radial sector is long and forms an acute angle with the margin of the wing. The second branch of the media is midway between the first branch and the margin of the wing. The outer surface of the wing is scale-like. The hind tibiae are from $1.35-1.44 \mathrm{~mm}$. long. The hair on the tibiae is sparce. The hind tarsi are from $.1-.128 \mathrm{~mm}$. long.

Abdomen.-The segments anterior to the cornicles are provided with well-developed lateral tubercles, these are blunt at the tip and rather wide at the base. The dorsum of the abdomen has six pair of finger-like tubercles. Of these the first two pair are about equal in length and as a rule better developed than the third and fourth pair. The fifth and sixth pair of tubercles on the abdomen are often represented by mere nubbins. The cornicles are typical of the genus and vary in length from $.1-.128 \mathrm{~mm}$. The anal plate is deeply divided and the cauda knobbed. Both the anal plate and the cauda are provided with long rather spine-like hair.

\section{Alate male.}

Size and general color.-Length from vertex to tip of anal plate $1.67 \mathrm{~mm}$., width of head through the eyes $.43 \mathrm{~mm}$. Head dusky with the margins darker. Prothorax dusky green. Mesothorax brown. Abdomen with anterior portion greenish and the portion posterior to the cornicles light yellowish. Cornicles light dusky. Cauda and anal plate dusky brown. Gonapophyses dark brown with a lighter area near the base. Femora uniform dusky. Tibiae brown at the base remainder uniform dusky. Antennal except for segments I and II which are darker light dusky.

Head and appendages.-Antennal segments with the following proportional lengths: III .786mm., IV .457mm., V .429mm., VI .214+ $.347 \mathrm{~mm}$. Secondary sensoria arranged as follows: III 43-48, IV 18-25, V 11-14, VI 1. The sensoria are uniformly distributed. Rostrum short. Dorsal tubercles lacking.

Thorax and abdomen.-Wings as in alate viviparous female. Hind tibiae $1.21 \mathrm{~mm}$. long. Hind tarsi $.128 \mathrm{~mm}$. long. Tubercles apparentTy lacking on both thorax and abdomen. Anal plate entire, cauda knobbed. Gonapophyses large and very well supplied with hair, some of which originate, in light colored areas.

This species may be collected on the under side of the leaves of Quercus gunnisonii a scrub oak. It is never abundant and may best be taken by sweeping with a net. I have often taken it along with Myzocallis alhambra Davidson. However it appears later than alhambra in the spring and remains several weeks in the fall after alhambra has disappeared.

This species is very closely allied to three other species which have much in common. The species are Myzocallis kiowanica which I described from the same general region, Myzocallis californicus Baker and Myzocallis maureri Swain which has I think unjustifiably been considered a synonym of californicus. Myzocallis tonkawa differs from the above 
mentioned species as follows: the greater number of tubercles on the dorsum of the abdomen, the greater number of secondary sensoria on the third antennal segment, although californicus may have as many sensoria at times as are represented by the minimum number in tonkawa. In californicus the first pair of abdominal tubercles is shorter than the second pair, which is not true in tonkawa. The radial sector is longer in tonkawa and forms a differed angle with the margin of the wing than the radial sector of the other three species. The shape of the radial sector and hence the shape of cell $R_{1}$ is also different.

Prof. Palmer and Prof. Essig have kindly supplied me with material of both species for study. This material contained males which may be easily separated into two species on the basis of color marking on the dorsum of the abdomen and secondary sensoria as well as size. These males differed from the male here described, and should furnish a basis for separating californicus from maureri should other factors, such as size, the number of secondary sensoria, the shape of the radial sector and the angle it makes with the margin of the wing, and the relative length of the radial sector to the length of the anal vein fail as valid factors to differentiate the two species.

Holotype slide deposited in the United States National Museum with the following data:

U.S. National Monument Grand Junction, Colorado, Sept. 22, 1947 Quercus gunnisonii Alate viviparous females.

Allotype alate male Oct. 24, 1947 U.S. National Grand Junction, Colo. Thirty paratypes taken on various dates during 1947-48. 
108 Proceedings of the Biological Society of Washington 


\section{PROCEEDINCS}

OF THE

BIOLOGICAL SOCIETY OF WASHINGTON

\section{ELEVEN NEW SUBSPECIES OF BIRDS FROM VENEZUELA}

By William H. Phelps and William H. Phelps, Jr.

The senior author wishes to thank Mr. Rudolph Meyer de Schauensee of the Academy of Natural Sciences of Philadelphia, Dr. John T. Zimmer of the American Museum of Natural History, Mr. W. E. Clyde Todd of the Carnegie Museum, Mr. Emmet R. Blake of the Chicago Natural History Museum and Dr. Herbert Friedmann of the U. S. National Museum for their help in the examination of specimens in their respective institutions.

The junior author likewise is indebted to Mr. N. B. Kinnear, Mr. J. D. Macdonald and Mr. Usher of the British Museum (Natural History) for their kindness and help in the examination of specimens in their museum during the summer of 1948, and to M. J. Berlioz of the Muséum Nationale d'Histoire Naturelle of Paris for his collaboration in the examination of the Hummingbirds in his museum and in the Simon Collection.

The apparently new birds here described are in the Phelps Collection, Caracas, and, unless otherwise specified, the specimens listed as examined are also in that collection.

Names of colors are capitalized when dircet comparison has been made with Ridgway's "Color Standards and Color Nomenclature".

\section{Tinamus tao larensis, new subspecies}

Type: From Cerro El Cogollal, Quebrada Arriba, Lara, Venezuela; altitude 1600 meters. No. 18385, Phelps Collection, Caracas, Venezuela. Adult male collected June 29, 1942, by Ramón Urbano. (Type on deposit at the American Museum of Natural History.)

Diagnosis: Differs from $T$. $t$. septentrionalis, and more so from $T$. $t$. tao, in being lighter above, olive with dusky brown barring and speckling instead of bluish gray with black markings. Below paler, more brownish gray, less bluish gray. Differs additionally from $T$. t. tao in having paler under tail-coverts.

Range: Mountainous region of north-central and northwestern Venezuela from the Federal District west to Lara; Mérida and, in Colombia, native "Bogotá" collections.

Description of Type: Top of head and neck gray with dusky shaft streaks to the feathers, hind neck with fine white speckles; back, rump and upper tail-coverts Dark Olive-Buff, speckled and barred with blackish, 


\section{Proceedings of the Biological Society of Washington}

with scattered small whitish spots on tail-coverts; sides of head dusky, speckled with white. Chin white; throat white, more buffy posteriorly, the feathers tipped or edged with black; breast, abdomen, sides and flanks olivaceous gray with fine dusky speckling; lower abdomen more whitish; thighs more olivaceous with dusky barring instead of speckling; under tail-coverts Pinkish-Cinnamon $X$ Cinnanion. Upper surface of primaries dusky, the inner vanes with bluish sheen; under surface brownish, inner half of inner webs grayish blue; exposed surface of secondaries and tertials, and upper wing-coverts uniform with back; under surfaces grayish finely barred or speckled with buffy-olive; greater under wingcoverts brownish, lesser ones grayish or dusky speckled with whitish or dusky. Tail pale olivaceous finely speckled and barred with dusky.

Maxilla (in life) "black"; mandible "purplish-white"; feet "dark gray"'; iris "dark". Wing, $268 \mathrm{~mm}$; tail, 95; exposed culmen, 35; eulmen from base, 43 ; tarsus, 76 .

Remarks: Sexes alike. Size similar to occidentalis. Range of measurements: two adult males (incl. type)-wing, 255, 268 (261.5); tail, 95, 95 (95); culmen from base, 41,43 (42); three adult females-wing, 273-285 (279.3); tail, 110-123 (114.7); culmen from base, 43-49 (45.3). T. $t$. septentrionalis : two adult males-wing, 272,275 (273.5) ; tail, 115, 122 (118.5); culmen from base, 41,46 (43.5); three adult femaleswing, 280-293 (286); tail, 98-115 (104.3); culmen from base, 41-46 (43.7).

The race septentrionalis is intermediate in coloration between the new sub-species and the typical form.

\section{SPECIMENS ExAMINED}

T. t. tao.-BRAZIL 1 : Rio Tapajoz, $1 \hat{\delta}, 2$ 우 Rio Xingu, $1 \hat{\delta}, 1$ 우 ; Rio Machados, $1 \hat{\delta}, 1$ ㅇ.

T. t. septentrionalis.-VENEZUELA: Cerro Azul, 1 \% Cerro Humo, $2 \hat{o}, 1$ 우 ; Cerro Negro (Monagas), $1 \hat{o}$; "Plain of Cumana", 1 우.

T. t. larensis.-VENEZUELA: Cerro El Cogollal, $1 \hat{o}$ (type), 2 ; Urama, 19 ; Colonia Tovar, $1 \hat{o}$; Lagunita de Aroa, $1 \hat{o}{ }^{2}$; Cumbre de Valencia, 1 juv. (?) ${ }^{2}$; Puerto de la Cruz (Dist. Fed.), 1 $^{2}$; La Azulita, $1 \hat{o}^{3}$; Maracay, 1 우. COLOMBIA1: "Bogotá", 1 (?); no locality, 1 (?).

T.t. kleei.-PERU 1 : Pozuzo, $1 \hat{\jmath}, 2$ 우 ; Chanchamayo, $1 \hat{\jmath}, 1$ 우.

\section{Pyrrhura picta cuchivera, new subspecies}

Type: From Cerro El Negro, Upper Cuchivero River, State of Bolívar, Venezuela; altitude 1300 meters. No. 42330, Phelps Collection, Caracas, Venezuela. Adult male collected November 25, 1947, by Manuel Castro. (Type on deposit at the American Museum of Natural History.)

Diagnosis: Differs from $P$. p. picta, $P . p$. amazonum and $P . p$. lucianii in whiter throat; chin, neck, throat and anterior breast have the black markings of the feathers narrower and more elongated and the white margins correspondingly wider.

Range: Known only from Cerro El Negro, Alto Rịo Cuchivero, in the Lower Subtropical Zone at altitudes from 900 to 1300 meters.

Description of Type: Forehead and anterior crown bluer than Niagara

1Specimens in the American Museum of Natural History.

2Specimens in the Carnegie Museum.

3Specimens in the Chicago Natural History Museum. 
Green; posterior crown and nape Natal Brown X Bone Brown, the feathers very narrowly edged with grayish, the posterior ones with bluish Niagara Green forming a narrow, partially concealed, collar; nape, scapulars and upper tail-coverts Cosse Green $X$ Lettuce Green; back and rump Morrow Red; lores and sides of head Claret Brown; auriculars, except bases, grayish white; feathers of gular region with bluish centers. Chin whitish, throat and sides of neck grayish white the throat feathers with narrow blackish shaft streaks, wider on neck; breast with still wider blackish shaft markings, the edgings posteriorly tinted with yellowish green; anterior abdomen, sides, shanks and under tail-coverts Javel Green. Primaries Light Cerulean Blue; secondaries and tertials green uniform with scapulars; all remiges with very pale edges to inner vanes and dusky tips except the tertials; alula and greater wing-coverts blue uniform with primaries; median and lesser coverts green uniform with secondaries and tertials; bend of wing Scarlet-Red; greater under wingcoverts grayish olive, lesser ones and axillaries green, uniform with sides. Tail Claret Brown, more dusky below, the rectrices edged externally and basally (except the outermost), and tipped narrowly, with green, uniform with seapulars.

Bill (in life) "grayish black", feet "grayish black", iris "brown". Wing, $114 \mathrm{~mm}$; tail, 105; culmen from cere, 14; exposed culmen, 16; culmen from base, 19.5 ; tarsus, 13.5 .

Remarks: Sexes alike. Size similar to picta. Range of measurements: five adult males-wing, 114-118 (115.6) mm; tail, 101-111 (105.2); culmen from cere, 14.5-15 (14.7) ; one adult female-wing, 117; tail, 93; culmen from cere, 14 ; one adult of undertermined sex-wing, 115; tail, 105; culmen from cere, 14 . Measurements of picta: five adult males from La Paragua, Bolívar-wing, 119-120 (119.6); tail, 98-114 (109.4); culmen from cere, 14-16 (14.6).

The locality of this new subspecies lies to the north and west of the known range of picta. The species is not known from the Upper Orinoco River.

SPECIMENS Examined

P. p. cuchivera.-VENEZUELA: Cerro El Negro, 5 ô (incl. type), 1 i , 1 (q).

P. p. picta.-VENEZUELA:Manoa, $2 \hat{o}$; Altiplanicie de Nuria, $2 \hat{o}$, 2 우 Cerro Tomasote, 1 ㅇ ; El Palmar, $1 \hat{o}$; El Dorado, $1 \hat{0}, 1$ 우 ; La

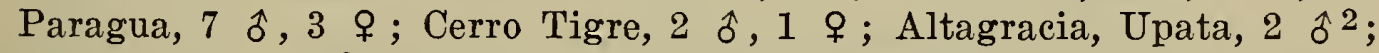
Río Yuruán, 1 올 El Perú Mine, 5 ồ ${ }^{2}$; La Prisión, 4 ồ ${ }^{1}$; La Unión ${ }^{1}$,

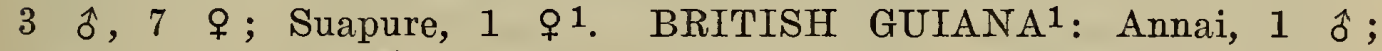
"Demarara", 1 (q); "British Guiana", 1 ô. DUTCH GUIANA ${ }^{1}$ : Paramaribo, 1 q ; "Interior of Surinam", 1 ô, 1 (?); Rivata, $2 \hat{o}$,

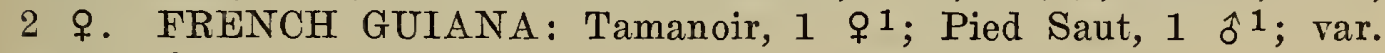
locs., $18^{2}$.

P. p. amazonum.-BRAZIL": Santarem, 2 (?); "Amazon", 1 (?) ; Obidos, 2 ô, 1 우; Calama, Rio Madeira, 3 ô, 3 우; Humaytha, 1 ô; Allianca, $1 \hat{\delta}$; Porto Velho, 1 (?) ; Rio Roosevelt, $1 \hat{\jmath}, 2$ ㅇ․

P. p. lucianii ${ }^{1}$-BRAZIL: Rio Juruá, $1 \hat{o}$. PERU: La Pampa, 1 ô ; "Napo", 1 (?) ; Río Ucayali, 2 ô, 2 ㅇ, 2 (?); Paleaza, 1 ô, 1 (?). ECUADOR: Oroso, 4 ô.

Leucippus fallax occidentalis, new subspecies

Type: From Sabaneta, State of Falcón, Venezuela; altitude 60 meters. 


\section{Proceedings of the Biological Society of Washington}

No. 5579, Phelps Collection, Caracas, Venezuela. Adult male collected March 24, 1940, by William H. Phelps. (Type on deposit at the American Museum of Natural History.)

Diagnosis: Differs from L. $f$. fallax of the Caracas region by paler brown erown, much paler back, more grayish, less bluish green; under parts also paler, more yellowish, less salmon color. Differs from $L$. $f$. richmondi of Margarita Island and of the Caribbean coasts of Sucre and Anzoátegui, by darker under parts.

Range: The northwestern arid coast from the Paraguaná Peninsula through Falcón and Zulia to the Goagira Peninsula; State of Lara (El Tocuyo; Barquisimeto). Northeastern Colombia on the Guajira Peninsula (Río Hacha; Parashi).

Description of Type: Crown, back and uropygium Light Yellowish Olive, the feather's of upper tail-coverts edged with grayish; forehead more pale brownish; a small post-ocular whitish spot; sides of head paler brownish gray. Chin, throat, breast, sides and flanks Light VinaceousCinnamon $X$ Vinaceous-Cinnamon merging into the white of abdomen and under tail-coverts. Wings Benzo Brown, the remiges, greater and median upper wing-coverts very narrowly edged with grayish; lesser coverts Light Yellowish Olive; under wing-coverts and axillaries uniform with breast. Rectrices Light EIm Green, tipped with white except the median ones, more broadly towards the outermost; a dusky area between the green and the white tips.

Maxilla (in life) "black"; mandible "pink, tip black"; feet, "black". Wing, $60 \mathrm{~mm}$; tail, 34; exposed culmen, 21; culmen from base, 27 ; tarsus, 7 .

Remarks: Sexes alike. Wings longer than in fallax. Range of measurements: five adult males-wing, 60-63 (61) mm; tail, 32-34 (32.8); exposed culmen, 20-21 (20.8); five adult females-wing, 52-60 (57); tail, 31-34 (32.4); exposed culmen, 20-22 (21). Measurements of fallax: three adult males-wing, 54-58 (55.8); tail, 33-34 (33.6); exposed culmen (2), 22, 23 (22.5); two adult females-wing, 52, 58 (55); tail, 32, 35 , (33.5) ; exposed culmen (1), 22 ; two adults of undetermined sexwing, 54, 58 (56); tail, 32, 33 (32.5); exposed culmen, 21, 22 (21.5).

Peters ${ }^{5}$ says that fallax inhabits the littoral of Venezuela and he synonimizes richmondi with it. He ealls the birds of the coast of northeastern Colombia cervina and comments that it is "doubtfully distinct from L. f. fallax'".

The type of cervina was examined by the junior author in the British Museum during the summer of 1948 . It has two labels, one reading: "Wilson. Leucippus cervinus. Gould. No. 236"; the other: "Gould Coll. Doleromya fallax. Type of Dolerisca cervina Gould. Mon. Troch. Intr., p. 56. (8 vo. Ed.) d." This specimen is similar to fallax of the Caracas region and dissimilar to richmondi of the northeastern Venezuelan coast and Margarita Island in having the darker, browner head, darker green back and darker under parts of the typical form. It seens unquestionable that this specimen, the type of cervina, of unspecified locality, came from the Caracas region and that the name should not be used to designate the paler form of the northwestern coast and the Colombian Guajira Peninsula.

The specimen in the British Muscum listed as " $b$ " 6 has a label reading: "Doleromya fallax, Venezuela. Probably the type of $T$. fulviventris Gould. PZS, 1846:88. b.', We have listed it provisionally as a synonym 
of fallax pending an opportunity to compare it with a series of topotypicals from the Caracas region which is lacking in the British Museum.

\section{SpeCimens Examined}

L. f. occidentalis. - VENEZUELA: Barquisimeto ${ }^{1}, 3$ ô, 1 ㅇ ; El

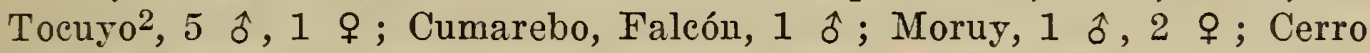
Santa Ana, 1 q ; Sabaneta, 1 ô (type); Urumaco, 1 ô, 2 q; Dabajuro, 1 우 ; Casigua, 1 ô ; Río Aurare, $1 \hat{o}^{3}$; Empalado Sabana, 1 q $^{3}$; Cojoro, Pen. de la Goagira, 1 $\hat{o}, 1$ o, 1 (q). COLOMBIA: Río Hacha ${ }^{2}, 1$ ô, 3 우 ; Parashi, Pen. de la Guajira, 2 (?) 4.

L. f. fallax.-VENEZUELA: Turiamo, 1 ㅇ ; Puerto Cabello, 3 ô,

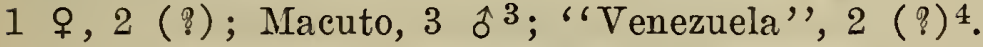

L. f. richmondi.-VENEZUELA: Porlamar, Isla de Margarita, 5 ô, 2 ㅇ, 1 (?), 9 (?) ${ }^{4}$; Isla de Coche, 1 q ; Isla Tortuga, $2 \hat{o}, 2$ 우 Carúpano, 3 ㅇ, $1 \hat{o}^{4}$; San Antonio del Golfo, $1 \hat{o}, 1$ 우 ; Laguna Grande del Obispo, 1 ô, $2(\text { (? })^{4}$; Golfo de Cariaco, 1 (?) ${ }^{4}$; Cumaná, 1 (?) $)^{4}, 2$ 우, 1 (?); Puerto de la Cruz, 1 (?); Barcelona, 7 ô, 4 우 1 (?) ${ }^{4}$; Píritu, $1 \hat{o}$.

\section{Xiphorhynchus guttatus margaritae, new subspecies}

Type: From El Cafetal, Margarita Island, Venezuela, altitude 740 meters. No. 3837, Phelps Collection, Caracas, Venezuela. Adult male collected July 29, 1939, by Alberto Fernández Y. (Type on deposit at the American Museum of Natural History.)

Diagnosis: Differs from $X . g$. jardinei, from the adjacent mainland, and from $X$. g. susurrans from Trinidad and Tobago, in having fewer and larger spots on the throat and breast and in lacking the scale-like appearance of the throat; it differs additionally from jardinei in being paler brown below, more grayish, less ochraceous; differs from $X$. g. demonstratus in having a more spotted, less striped breast as well as a paler breast and abdomen, more grayish, less olivaceous.

Range: Known only from Margarita Island.

Description of Type:Top of head and nape dusky brown with pale buffy spots, larger and more elongated posteriorly; back Cinnamon Brown, more rufous on rump and upper tail coverts; interscapular region more olivaceous, the feathers with large pale buffy elongated shaft stripes with blackish borders; lores dusky; a white superciliary stripe, the feathers bordered with dusky; ear-coverts and sides of neck dusky with buffy shaft streaks. Chin and forethroat buffy white; rest of under parts Tamny-Olive, posterior throat and breast spotted with pale buffy; under tail-coverts and thighs more brownish. Remiges Auburn, the under surface much paler, and the primaries more dusky towards the tips; upper wing-coverts Tawny-Olive; under wing-coverts Cinnamon.

Bill (in life) "gray"; feet "gray"; iris "brown". Wing, $105 \mathrm{~mm}$; tail, 85; exposed culmen, 36 ; culmen from base, 39 ; tarsus, 24.

Remarks: Sexes alike. Size slightly smaller than jardinei and susurrans. Range of measurements: three adult males-wing, 103-106 (104.5) $\mathrm{mm}$; tail, 85-90 (87.5); culmen from base, 37-39 (38); one adult female -wing, 97 ; tail, 80 ; culmen from base, 37 ; one adult of undetermined sex-wing, 104; tail, 81; culmen from base, 37 . Measurements of jardinei (from the Paria Peninsula): five adult males-wing, 106-111

4Specimens in the British Museum.

5Check-List of the Birds of the World. Cambridge. Vol. 5, p. 59, 1945.

6Cat. Birds British Museum. 16, p. 177, 1892 


\section{Proceedings of the Biological Society of Washington}

(108.2); tail, 88-92 (89.8); culmen from base, 40-41 (40.4); five adult females-wing, 106-111 (109.2); tail, 82-90 (86); culmen from base, 37-39 (38). Measurements of susurrans: five adult males-wing, 108-114 (111.6); tail, 79-90 (86); culmen from base, 40-41 (40.4); five adult females-wing, 93-110 (99.3) ; tail, 70-83 (75.5) ; culmen from base, 3739 (38).

Until the five specimens in the Phelps Collection were obtained, only one had been collected in Margarita; this was obtained by Ferry, for the Chicago Natural History Museum and Cory 8 comments: "It differs slightly from specimens from Tobago and the mainland in having the under parts more olive and the shaft stripes on the head and breast feathers more tawny. Whether these differences are constant or not remains for future investigators to determine."

For the reasons for considering susurrans and jardinei as subspecies of guttatus, instead of maintaining susurrans as a species, with jardinei as its subspecies, see Phelps and Phelps, Jr. 1948:192.9

\section{SPeCimens Examined}

X. g. guttatus.-BRAZIL: $12 .^{7}$

X. g. d'orbignyanus ${ }^{7}$.-BOLIVIA: 17. BRAZIL: 7 .

$X$. g. eytoni.-BRAZIL: 60.7

X. g. guttatoides.-BRAZIL: 927. PERU: 627. ECUADOR: $10^{7}$. COLOMBIA: $2^{7}$. VENEZUELA : 777. Terr. Amazonas, 21.

$X$. $g$. polystictus.-BRITISH GUIANA: 77 . DUTCH GUIANA: $2^{7}$. BRAZIL: $9^{7}$. VENEZUELA: $3^{7}$. State of Bolívar, 54 ; Terr. Amazonas, 21.

X. g. susurrans.-TRINIDAD: $40^{1}$. TOBAGO: $13^{1}$. VENEZUELA: Guanoco, 1 ô.

Z. g. margaritae.-VENEZUELA: Margarita Island, 3 ô (incl. type), 1 ㅇ, 1 (?).

X. g. jardinei.-VENEZUELA: Los Altos, 1 ô, 1 우 ; Quebrada Bonita, 3 ô, 1 ㅇ ; Caripe, 1 우 ; Cerro Negro (Caripe), 1 ô, 5 우; Guaraúnos, 1 우 ; Yaguaraparo, $1 \hat{o}, 1$ 우 ; Cerro Humo, $2 \hat{o}, 1$ 오, 2 (?); Cerro Azul, 2 오.

X. g. demonstratus.-VENEZUELA: Miranda, 7 ; Guárico, 3 ; Federal District, 1; Aragua, 8; Carabobo, 12; Yaracuy, 5; Lara, 6; Portuguesa, 2 ; Barinas, 7 ; Mérida, 2; Falcón, 4; Táchira, 1; Zulia, 7.

X. g. nanus.-VENEZUELA: Guasdualito, $1 \hat{o}, 1$ 우; La Fría, 1 ô ; La Sabana, Perijá, 1 ㅇ. COLOMBIA: 101. PANAMA (eastern) : $10^{1}$. X. g. marginatus.-PANAMA: 171 .

$X . g$. rosenbergi.-COLOMBIA: $7^{1}$.

X. g. costaricensis.-COSTA RICA: 291. NICARAGUA: $3^{1}$.

Dendrocincla fuliginosa barinensis, new subspecies

Type: From Santa Bárbara, State of Barinas, Venezuela; altitude 200 meters. No. 12120, Phelps Collection, Caracas, Venezuela, Adult male collected March 22, 1941, by William H. Phelps. (Type on deposit at the American Museum of Natural History.)

Diagnosis: Nearest to $D$. $f$. meruloides of the Caracas and Cumaná regions but breast darker, more dusky, less yellowish, and above darker,

7For localities see Zimmer, Am. Mus. Nov., No. 756, p. 2, 1934

8The Birds of the Leeward Islands, Caribbean Sea. Field Mus. Nat. Hist., Orn. Ser., 1, No. 5, p. 247, Oct. 1909.

9 Notas sobre Aves Venezolanas. Bol. Soc. Ven. Cien. Nat., No. 72. 
more brownish, less yellowish. Differs from phaeochroa by lacking the whitish chin, and by being lighter, more yellowish above.

Range: Known from the upper Apure Valley near the base of the Andes, from Santo Domingo (Táchira) to La Veguita (Barinas) and in Turén (Portuguesa).

Description of types: Top of head and back Brussels Brown; more yellowish on the rump; upper tail-corerts Auburn; sides of head, lores and ear-coverts dusky brown. Chin grayish brown merging into the Snuff Brown of the rest of under parts; under tail-coverts more rufous. Remiges Auburn, paler on under surface, the primaries edged apically, and broadly tipped, with dusky; upper wing-corerts uniform with back; under wingcorerts and axillaries Pinkish Cinnamon. Tail Chestnut, paler on under aspect; sharts of rectrices blackish abore, yellowish brown below.

Maxilla (in life) "dark olive"; mandible "olive"; feet "bluish slate". Wing, $103 \mathrm{~mm}$; tail, 84; exposed culmen, 25; culmen from base, 29 ; tarsus, 24.

Remarks: Sexes alike in color; females slightly smaller. Size sinilar to meruloides. Range of measurements: five adult males-wing, 102-105 (103.2) $\mathrm{mm}$; tail, 78-84 (81.6); culmen from base, 27-30 (28.6); fire adult females-wing, 93-97 (95.2); tail, 67-76 (73.2); culmen from base, 25-28 (26.8). Measurements of meruloides (from the Sucre-Monagas region): fire adult males-wing, 97-103 (100.6); tail, 73-85 (79.6); culmen from base, 29-30 (29.4) ; five adult females-wing, 91-97 (94.6); tail, 70-82 (77.2); culmen from base, 27-29 (27.8).

The specimens were collected in March and April and have breeding gonads.

\section{Specimens Examined}

D. $f$. fuliginosa.-FRENCH GUIANA : $4^{10}$. DUTCH GUIANA : $2^{10}$. BRITISH GUIANA: $4^{10}$; Kamarang Mt., 1 ㅇ. BRAZIL: $8^{10}$; Kutuweik Falls, 1 ㅇ. VENEZUELA: Altiplanicie de Nuria, $2 \hat{o}, 1$ 우 1 (?).

D. f. rufo-olivacea.-BRAZIL: 2210 .

D. f. atrirostris ${ }^{10}$.-BRAZIL: 10 . BOLIVIA: 5 .

D. f. phaeochroa.-VENEZUELA: Cerro Uaipán-tepui, 1 ô; Cerro Auyan-tepui, 1 ô ; Cerro Chimantá-tepui, 1 ô, 1 $\$$; Caño Pácara, 1 (?); La Paragua, 2 ô; Raudal Perro, 1 우 ; Cerro Guaiquinima, $1 \hat{o}, 1$ 우 ; Raudal Capuri, $1 \hat{\delta}$; Cerro Arebuchi, 1 ô, 1 (?); Cerro Paurai-tepui, 2 ㅇ, 1 (?) ; Sabana Kirichú, 1 우 ; Santa Rosalía, 1 ô, 1 ( q) ; El Cambur, 1 ô, 1 $q$; Cerro El Negro, 1 ô; Caño Cataniapo, 2 ô, 5 q, 1 (q); Isla Ratón, $2 \hat{o}, 1$ ㅇ, 1 (?); Caño Cuao, $1 \hat{o}$; San Fernando de Atabapo, 2 ô, 3 ㅇ, 4 (?) ; Cerro Yaví, 1 ô; Las Carmelitas, 1 ô, 1 o ; Puerto Yapacana, 1 ㅇ, 1 (q); San Carlos, Río Negro, $1 \hat{o}$.

D. $f$. barinensis.-VENEZUELA: Santo Domingo, $2 \hat{o}, 3$ q; Santa Bárbara, Barinas, $2 \hat{o}$ (incl. type), 1 $q$; Ciudad Bolivia, $2 \hat{o}, 1$; La Vaguita, 2 ô ; Barinitas, 2 ô, 2 우; Turén, 1 (?).

D. f. meruloides.-VENEZUELA: Cristóbal Colón, 1 ô ; Cerro Humo, 7 ô; Cerro Azul, 1 우 ; El Pilar, 2 아, 1 (?); Tunapuí, 1 (?); Yaguaraparo, 1 ô, 1 우 ; Caripe, 3 우 1 (?); Quebrada Bonita, $4 \hat{o}, 4$ 우 ; Cabo Codera, 1 울 Aricagua, 1 $q, 2$ (q); Cerro Negro, Miranda, $1 \hat{o}$, 1 (q) ; San José de los Caracas, 1 $\hat{o}, 1$ o ; Hda. Altamira, 1 ô; Cerro Golfo Triste, $2 \hat{o}, 1$,+ 3 (?); Tacarigua de Mamporal, $2 \hat{\delta}, 1$ \%; Baruta, 1 ㅇ ; Urama, $2 \hat{o}, 1$ 영 Hda. Santa Clara, $1 \hat{o}$; Hda. Panchito, 
1 우 ; Palma Sola, 1 (?); Curimagua, $6 \hat{\text { o }, 4}$ 우 ; Cerro El Cogollal 1 (?). D. f. lafresnayi.-VENEZUELA: La Sabana, Perijá, 2 ô ; La Sierra, 2 ô, 1 ㅇ, 1 (?); El Vigía, 2 ô; Seboruco, 3 ô; Santa Cruz de Mora, 1 ô.

D. f. ridgwayi ${ }^{10}$.-ECUADOR: 17. COLOMBIA: 4. PANAMA: 12. COSTA RICA : 6 .

\section{Philydor rufus cuchiverus, new subspecies}

Type: From Cerro El Negro, upper Cuchivero River, State of Bolívar, Venezuela; altitude 1000 meters. No. 42400, Phelps Collection, Caracas, Venezuela. Adult male collected November 24, 1947, by Manuel Castro. (Type on deposit at the American Museum of Natural History.)

Diagnosis: Nearest to $P$. r. columbianus and $P . r$. panerythrus but the breast is more ochraceous without any olivaceous shading; forehead, crown and back darker, more dusky, less yellowish.

Range: Known only from Cerro El Negro, in the lower Subtropical Zone at the altitude of 1000 meters.

Description of Type: Top of head Olive-Brown with pale inconspicuous shaft streaks, more Ochraceous-Tawny on forehead; back and uropygium Snuff Brown; lores dusky ochraceous; superciliary stripe and gular region Yellow Ocher uniform with breast; post-ocular streak Olive-Brown. Throat, breast and upper abdomen Yellow Ocher merging into the Dresden Brown of flanks, lower abdomen, thighs and under tail-coverts. Remiges Tawny, paler below, apical portions Fuscous; inner tertials brownish olive; greater upper wing-coverts brownish olive, median ones Tawny, lesser ones more olivaceous; under wing-coverts and axillaries Ochraceous-Tawny. Tail Tawny, paler below, the inner rectrices, and outer vanes of the two following pairs, brownish olive; shafts of rectrices brown above, whitish below.

Bill (in life) "black, base grayish black"; feet "grayish yellow"; iris, "brown"'. Wing, $95 \mathrm{~mm}$; tail, 85; exposed culmen, 18; culmen from base, 23 ; tarsus, 25.

Remarks: Size similar to columbianus. Range of measurements: two adult males (incl. type)-wing, 94, 95 (94.5); tail, 83, 85 (84); culmen from base, 23, 23 (23). Measurements of columbianus: Two adult males (incl. type) -wing, 92, 95 (93.5) ; tail (1), 84; culmen from base, 22, 22 (22); three adult females-wing, 76-89 (83.3); tail, 79-82 (80); culmen from base, 21-22 (21.3). Measurements of panerythrus: two adult males-wing, 99, 100 (99.5) ; tail (1) , 84; culmen from base, 21,21 (21); one adult female-wing, 95 ; tail, 86 ; culmen from base, 21 ; two specimens of undetermined sex-wing, 99, 104 (101.5); tail, 86, 99 (90.2); culmen from base, 22, 22 (22).

The locality of the proposed new subspecies constitutes an extension of the range of the species from the north coast of Venezuela, Colombia and from Brazil, soutl of the Amazon.

\section{Spectmens Examined}

P. r. panerythrus ${ }^{1}$.-COSTA RICA: Navarro, 1 우 ; La Estrella, 1 ô; Navarrito, 1 ô ; Chiriquí, 1 (?) ; Boquete, 1 (?).

P. r. columbianus.-VENEZUELA: Cumbre de Valencia, 1 울 $\mathrm{Hda}$ Santa Clara, 1 ô, 1 $q$; Silla de Caracas, $1 \hat{o} \mathbf{1}$; Hda. Izcaragua, 1 $q$.

P. r. cuchiverus.-VENEZUELA: Cerro El Negro, $2 \hat{o}$ (incl. type). 
P. r. riveti ${ }^{1}$-COLOMBIA: Arenosas, Antioquia, 1 ô. ECUADOR: Mindó, 1 ô ; La Gualea, 1 ô ; Pichincha, 1 ô.

P. r. bolivianus ${ }^{1}$-PERU: Río Seco, 1 î, 1 ㅇ․ BOLIVIA: Vermejo, 3 ô, 1 ㅇ.

P. r. chapadensis ${ }^{1}$.-BRAZIL: Chapada, 9 ô, 6 q.

P. r. rufus ${ }^{1}$-BRAZIL: San Sebastian, 2 ô; Monte Serrat, 2 q ; "Rio", 1 (?) ; Roca Nova, 1 ô, 1 우 ; Faz. Esperança, 1 ô, 1 우 ; Faz. Cayoa, $1 \hat{\delta}, 1$ 우; Ponte Maromba, $1 \hat{\delta}$; Alta de Serra, $1 \hat{o}$. ARGENTINA: Ignazú, $1 \hat{o}, 1$ ㅇ.

\section{Knipolegus poecilurus paraquensis, new subspecies}

Type: From Cerro Paraque, Terr. Amazonas, Venezuela; altitude 1600 meters. No. 33729, Phelps Collection, Caracas, Venezuela. Adult male collected February 15, 1946, by William H. Phelps, Jr. (Type on deposit at the American Museum of Natural History.)

Diagnosis: Differs from all other subspecies of poecilurus by the total absence of any rufous on the rectrices.

Range: Known only from the type specimen from Cerro Paraque in the Subtropical Zone at the altitude of 1600 meters.

Description of Type: Top of head and back Hair Brown X Chaetura Drab, the rump slightly paler and upper tail-coverts with dusky centers; dusky centers to the feathers of crown and forehead giving a spotted appearance; sides of head slightly more brownish. Throat, breast, sides and thighs Deep .Grayish Oiive, merging into the Pale Ochraceous-Buff of abdomen, the throat mixed with pale buffy; under tail-coverts Ochraceous-Buff. Wings Blackish Brown, the outer vanes of remiges very narrowly edged with grayish, except the outermost, most prominently on the tertials; the inner vanes edged with very pale buffy, progressively more extensively towards the innermost; upper wing-coverts broadly edged with grayish giving a mottled rather than banded appearance; axillaries and under wing-coverts Light Ochraceous-Salmon $X$ OchraceousSalmon. Upper surface of tail Blackish Brown, narrowly and faintly barred with blackish, the outer rectrices very narrowly edged outwardly and apically with whitish and all the rectrices, except the central ones, inwardly and narrowly edged with whitish; lower aspect of tail paler.

Bill (in life) "brownish black" ; feet "brownish black"; iris "red". Wing, $75 \mathrm{~mm}$; tail, 63; exposed culmen, 11; culmen from base, 15; tarsus, 17.

Remarks: Size similar to $K$. p. salvini. Range of measurements: one adult male (type)—wing, $75 \mathrm{~mm}$; tail, 63 ; culmen from base, 15 . $K . p$. salvini: four adult males-wing, 75-81 (77.7); tail, 62-70 (66.5); culmen from base, 15-17 (16); four adult females-wing, 70-73 (71.2); tail, $58-62(60.1)$; culmen from base, $15-17(16.2)$. $K$. p. venezuelanus: one adult male-wing, 74 ; tail, 63 ; culmen from base, 16 ; one adult femalewing, 72 ; tail, 61 ; culmen from base, 15 .

The type is in fresh plumage comparable with two specimens from Mt. Duida in the American Museum of Natural History and with two from Mts. Chimantá-tepui and Yapacana in the Phelps Collection; paraquensis is less whitish on the throat and breast.

\section{SPECIMENS EXAMINED}

K. p. poecilurus.-COLOMBIA ${ }^{1}$ : La Palma, Huila, 1 ô, 1 i ; La Candela, 1 ô ; San Augustín, 1 ô; San Antonio, W. Col., $1 \hat{o}$; Santa Elena, Antioquia, 1 ㅇ. 


\section{Proceedings of the Biological Society of Washington}

K. $p$. venezuelanus.-VENEZUELA: Queniquea, Táchira, 1 ô, 1 ㅇ․

K. p. salvini.-VENEZUELA: Cerro Roraima ${ }^{1}, 5$ ô, 2 i ; Cerro Ueitepui, 2 ô; Cerro Sororopán-tepui, 1 ô, 2 우 ; Cerro Chimantá-tepui, 3 ô, 1 우 ; Cerro Murú, 1 (?); Cerro Acopán-tepui, 1 ô, 1 (?); Cerro Sarisariñama, 2 (?) ; Cerro Yapacana, 1 o, 1 (?); Cerro Duida 1 , $2 \hat{o}$.

K. p. paraquensis.-VENEZUELA: Cerro Paraque, 1 ô (type).

K. p. peruanus ${ }^{1}$-PERU: Lomo Santo, 1 ô, 1 우 ; Nuevo Loreto, $1 \hat{\text { of }}$ 1 (?); Chaupé, $5 \hat{o}, 1$ ㅇ ; Utcuyacu, $2 \hat{o}, 2$ ㅇ. ECUADOR: Zamora, 2 ô, 1 우 ; Guayaba, 1 ô, 1 우 ; Sabanilla, 1 ㅇ.

\section{Troglodytes rufulus yavii, new subspecies}

Type: From Cerro Yaví, La Cumbre, Terr. Amazonas, Venezuela; altitude 2250 meters. No. 37787, Phelps Collection, Caracas, Venezuela. Adult male collected March 3, 1947, by Ramón Urbano. (Type on deposit at the American Museum of Natural History.)

Diagnosis: Nearest to T. r. duidae from Mts. Duida and Paraque but under tail-coverts paler, more yellowish.

Range: Known only from Mts. Yaví and Sarisariñama in the Subtropical Zone at altitudes between 1800 and 2250 meters.

Description of Type: Top of head, back and uropygium Hazel X Auburn; lores dusky, tipped with grayish; prominent supereiliary stripe extending from eye to neck pale buffy; wide post-ocular streak uniform with crown; ear-coverts buffy brown. Chin, throat and breast Pale Smoke Gray, whiter on abdomen; sides washed with olive brown; flanks Argus Brown, thighs more dusky; under tail-coverts Ochraceous-Tawny, narrowly barred with dusky. Wings Fuscous; outer vanes of two outer remiges narrowly edged with whitish; rest of remiges more broadly banded with pale brown on outer edges, basally; upper wing-coverts broadly edged with Hazel; bend of wing and axillaries whitish; under wing-coverts white mixed with dusky. Rectrices buffy, narrowly barred with dusky, the outer ones paler.

Bill (in life) "black, base flesh"; feet "brownish black"; iris "brown". Wing, $53 \mathrm{~mm}$; tail, 37 ; exposed culmen, 13 ; culmen from base, 18 ; tarsus, 23.

Remarks: Sexes alike. Wings shorter than T. $r$. duidae. Range of measurements: five adult males-wing, 53-53 (53) $\mathrm{mm}$; tail, 37-38 (37.6) ; culmen from base, 16-18 (16.8) ; five adult females-wing, 5053 (51); tail, 34-36 (35.4); culmen from base, 16-17 (16.2). T. r. duidae:11 five males-wing, 55-59; tail, 37-41; culmen, 17-17.5; five females-wing, 54-47; tail, 37-38; culmen, 16-17.

Description of juvenile (No. 19732): upper parts Auburn, the crown, wings and tail barred with dusky; superciliary stripe as in adult; sides of head mottled buffy and dusky. Chin, throat, breast and abdomen whitish, barred or scalloped with dusky; sides tinged with pale brownish; vent buffy; under tail-coverts Argus Brown; axillaries and under wing-coverts mixed grayish and dusky.

\section{SPECIMENS Examined}

T. r. rufulus.-VENEZUELA: Cerro Roraima, 5 ô, 5 ㅇ ; Cerro Ueitepui, 5 ô, 3 o, 2 (?) ; Cerro Aprada-tepui, 2 ô, 2 우; Cerro Chimantátepui, 3 ô, 3 ㅇ, 1 (?).

11Chapman, Am. Mus. Nov., No. 380, p. 22, 1929. 
T. $r$ duidae.-VENEZUELA: Cerro Duida, $1 \hat{\jmath}, 1$ 우 $37^{1}$; Cerro Paraque, 14 ô, 6 ㅇ, 6 (?).

T. $r$ yavii.-VENEZUELA: Cerro Sarisariñama, 1 ô, 1 (?) juv.; Cerro Yaví, 8 ô (incl. type), 4 우, 3 (?).

T. r. fulvigularis.-VENEZUELA: Cerro Auyan-tepui, $2 \hat{o}$; Cerro Ptari-tepui, 4 ô, 7 ㅇ, 1 (?); Cerro Sororopán-tepui, $2 \hat{o}, 2$ 우 1 (?).

\section{Conirostrum speciosum guaricola, new subspecies}

Type: From El Socorro, State of Guárico, Venezuela; altitude 80 meters. No. 40231, Phelps Collection, Caracas, Venezuela. Adult male collected June 25, 1947, by Ramón Urbano. (Type on deposit at the American Museum of Natural History.)

Diagnosis: The male differs from $C . s$. amazonum in being paler above, light instead of dark blue, in this being similar to $C$. s. speciosum. Differs from speciosum in being darker below, more bluish gray. The female differs from amazonum in having the under tail-coverts pale yellowish instead of salmon or dark buffy; differs from speciosum in having a darker blue crown and more greenish, less yellowish, back; the under tail-coverts are pale yellowish instead of whitish.

Range: Known only from the Llanos in east central Guárico and central Anzoátegui near the Guárico border.

Description of Type: Top and sides of head and back near to Delft Blue, merging into the Parula Blue of rump and upper tail-coverts. Chin, throat, breast and sides Pale Medici Blue X Glaucous Gray, merging into the whitish abdomen; under tail-coverts Amber Brown. Wings Fuscous; remiges narrowly edged, outwardly, with Parula Blue, more broadly on tertials; primary coverts Fuscous; rest of upper wing-coverts edged with Parula Blue; a prominent white speculum exposed for $5 \mathrm{~mm}$; under wing-coverts whitish and dusky; axillaries white. Tail Fuscous, paler below, the rectrices edged with Parula Blue.

Bill (in life) "black, base grayish blue"'; feet "grayish blue"; iris "dark". Wing, $56 \mathrm{~mm}$; tail, 37; exposed culmen, 10; culmen from base, 12 ; tarsus, 14 .

Remarks: Sexes different in color. Range of measurements: four adult males-wing, 56-60 (57.5) mm; tail, 37-42 (39.6); culmen from base, $12-13$ (12.2). Measurements of one adult male amazonum (from Puerto Páez, Venezuela)—wing, 58; tail, 40; culmen from base, 12.

Description of female: Top of head Parula Blue, slightly mixed with dusky; back, rump and upper tail-coverts Oil Yellow X Yellowish Oil Green; lores and sides of head pale buffy. Chin, throat and breast pale buffy; sides more greenish; abdomen whitish; thighs dusky; under tailcoverts pale buffy. Wings Fuscous; remiges edged externally uniformly with the back and internally with whitish; under wing-coverts whitish and dusky; axillaries whitish. Tail Fuscous, paler on under surface, the rectrices broadly edged externally uniformly with the back.

The speculum in the male varies in exposure. On the type it is exposed only on one wing; on two specimens it is not exposed at all and on another only on one wing.

A specimen from Puerto Páez, in the Phelps Collection, and those from Frechal and "Bogotá" in the American Museum of Natural History are intermediates and should be referred at present to amazonum.

12Am. Mus. Nov., No. 1193, p. 11, Oct. 7, 1942. 


\section{Proceedings of the Biological Society of Washington}

Regarding the Frechal and "Bogotá" specimens Dr. Zimmer12 says: "It appears probable that there may be a separable form on the Surumú and in the Guianas (whence I have no material) -. I hesitate, therefore to propose a formal separation until a good series from the critical region is available for study. The allocation of east-Colombian birds will then be open for further examination.',

\section{SPECIMENS ExaMined}

C. s. speciosum.1-PARAGUAY: Sapucay, 1 ô, 1 우; Trinidad, 1 우 ; Fort Wheeler, 1 우 ; Candamo, 1 ô. BOLIVIA: Río Cachimayo, $1 \hat{o}$. BRAZIL: Urueum, Matto Grosso, 5 ô, 1 우 ; Chapada, $5 \hat{\delta}, 1$ $q$; Rio San Lorenzo, 2 ô; Corumba, 2 ô ; "Para", 1 ô; "Bahia", $1 \hat{o}$; "Brazil", 2 ô.

C. s. amazonum.-PERU: Upper Río Ucayale, 1 ơ 1. ECUADOR: Río Suno Abajo, 1 ô 1 . BRAZIL ${ }^{1}$ : Rosarinho, Rio Madeira, $1 \hat{o}$; Faro, $3 \hat{o}$; Villa Bella Imperatriz, 1 우 ; Frechal, Rio Surumú, 3 ô, 1 ô juv., 1 ㅇ. COLOMBIA1: "Bogotá", 2 (?). VENEZUELA: Puerto Páez, Apure, 1 ô.

C. s. guaricola. - VENEZUELA: El Socorro, $1 \hat{\delta}$ (type); Santa María de Ipire, 1 ô, 1 \&, 1 ( ใ); Pariaguán, $1 \hat{o}$.

Atlapetes brunnei-nucha allinornatus, new subspecies

Type: From San Luis, State of Falcón, Venezuela; altitude 1360 meters. No. 5948, Phelps Collection, Caracas, Venezuela. Adult male collected March 29, 1940, by Ventura Barnés, Jr. (Type on deposit at the American Museum of Natural History.)

Diagnosis: Nearest to $A$. $b$. inornatus of western Ecuador from which it differs in size only, the wings and tail being longer; differs from xanthogenys of the Caracas region and from brunnei-nucha of the Mérida region, and México to Perú, by lacking the pectoral band.

Range: The San Luis mountains of Falcón and Bucaral, Yaracuy, in the Subtropical Zone at altitudes from 1300-1360 meters.

Description of Type: Forehead and sides of head biack, the former with three prominent white spots; crown darker than Amber Brown; back and uropygium Pyrite Yellow X Warbler Green; below white, the hidden basal part of the feathers, except the throat, dusky; sides and forebreast grayish and dusky; rest of sides, flanks and thighs uniform with back; under tail-coverts olivaceous with buffy bars. Wings Benzo Brown, remiges and upper wing-coverts edged with green uniform with back; bend of wing Amber Yellow; under wing-corerts olivaceous and dusky. Tail Benzo Brown with very faint narrow dusky bands, paler below; outer vanes tinted with olivaceous, especially basally.

Bill (in life) "black"; feet "blackish"; iris "brown"; Wing, $82 \mathrm{~mm}$; tail, 80 ; exposed culmen, 16 ; culmen from base, 18; tarsus, 30.

Remarks: Sexes alike. Range of measurements: two adult males (incl. type)-wing, 81,82 (81.5) ; tail, 80,82 (81); culmen from base, 18, 20 (19); one adult female-wing, 80 ; tail, 81 ; culmen from base, 19. $A$. b. inornatus (from western Ecuador): one adult male-wing, 75; tail, 70 ; culmen from base, 19 ; two adult females-wing, 75, 77 (76); tail, 65, 65 (65); culmen from base, 18, 18.5 (18.2). Allinornatus has a $7 \%$ longer wing and $11 \%$ longer tail than inornatus.

13Mutation among Birds in the Genus Buarremon. Bull. Am. Mus. Nat. Hist. 48, Art. 9, pp. 244, 1923. 
It is interesting that the two subspecies without pectoral bands are found so far apart (western Ecuador and northern Venezuela), their ranges being separated by the pectoral banded brunnei-nucha and xanthogenys. Chapman 13 studies the causes of the presence or absence of the black pectoral band in this species and says: "It is this black collar which is the principal mutant character and which, as I shall attempt to show, appears or disappears purely as an individual variation and without relation to external influences. Its perpetuation or establishment as a specific mark does, however, depend upon enviroment expressed in what is doubtless the most important external agent in promoting evolutionthat is, isolation."

There is a specimen in the American Museum of Natural History labelled: "A. b. brunneinucha, 520453. Pet Grove (Petit Goare), 32 miles west of Port au Prince, Hayti, July, 1885. C. F. Navell. ô'". We can find no published records for the species from the West Indies, so the abore label may be in error. Regarding this specimen, James Bond, of the Academy of Natural Sciences of Philadelphia, examined the specimen and writes: "In our opinion there can be no doubt that the individual was a cage-bird, possibly one that had escaped confinement. $I$ have numerous records of this sort from various West Indian islands, ....'.

\section{SPECIMENS ExaMined}

A. b. inornatus.-ECUADOR ${ }^{1}$ : Los Llanos, 1 ô ; Coco, Río Chimbo (2800 ft.), 2 ㅇ ; Pallatanga ( $5000 \mathrm{ft}$.), 1 우 juv.

A. b. brunnei-nucha.-MEXICO ${ }^{1}:$ 7. GUATEMALA ${ }^{1}:$ 14. NICARAGUA $^{1}$ : 22 ; COSTA RICA ${ }^{1}$ : 19. PANAMA ${ }^{1}$ : 38. COLOMBIA ${ }^{1}: 64$. ECUADOR ${ }^{1}$ : 46. VENEZUELA: Villa Páez, Páramo de Tamá, 1 (?); Páramo Zumbador, $1 \hat{o}, 1$ 우 Queniquea, $1 \hat{o}, 1$ 울 Boca de Monte, 3 ô, 1 q , 4 (?) ; El Valle, Mérida, 1 ô, 1 o ; Páramo de Misisí, 2 ô; Cerro Niquitaz, $1 \hat{\delta}, 1$ ㅇ.

A. b. xanthogenys.-VENEZUELA: Cubiro, 2 ô, 1 ㅇ, 1 우 juv., 1 (?) ; Cumbre de Valencia, 1 ô; Colonia Tovar, $6 \hat{o}, 2$ $q$; El Junquito, 6 ô, 2 ㅇ, 3 (?); Cerro El Avila, 1 ô, 2 우; No León, $1 \hat{o}, 1$ (?); Hda. Santa Clara, $2 \hat{o}$; Izearagua, 1 ô, 2 o ; Cerro Negro, Miranda, 1 ㅇ.

A. b. allinornatus.-VENEZUELA: San Luis, $1 \hat{o}$ (type), $1 \hat{o}$ juv., 1 우 Bucaral, Yaracuy, $1 \hat{\delta}$.

\section{Atlapetes torquatus larensis, new subspecies}

Type: From Cerro El Cogollal, Quebrada Arriba, State of Lara, Venezuela; altitude 1400 -meters. No. 18792, Phelps Collection, Caracas, Venezuela. Adult male collected June 24, 1942, by Fulvio Benedetti. (Type on deposit at the American Museum of Natural History.)

Diagnosis: Nearest to $A$. $t$. perijanus, from the Perijá Mountains, Zulia, from which it differs in having darker flanks and under tail-coverts, brownish olive instead of yellowish olive. Differs from phaeopleurus of the Caracas region in having gray superciliary stripes instead of white.

Range: Known from the mountains in the northeastern corner of Lara and eastern Táchira, in the Subtropical Zone at altitudes between 1300 and 1800 meters.

Description of Type: Head, except throat, black with wide gray crown and superciliary stripes, the latter narrower and whiter anteriorly; back 
and uropygium Old Gold X Orange-Citrine; sides of neck gray. Chin, throat and center of breast and abdomen white; prominent black pectoral band; sides gray merging into olivaceous flanks and thighs, the under tail-coverts browner. Wings Benzo Brown, very indistinct dusky bars on tertials; outer vanes of remiges heavily edged with yellowish green, uniform with back; bend of wing Lemon Chrome; under wing-coverts and axillaries grayish and olivaceous. Tail Benzo Brown with indistinct dusky bars on median rectrices; outer vanes heavily tinted with olivaceous, darker than the back; under aspect of tail paler.

-.Bill (in life) "black"; feet "brown"; iris "brown". Wing, $80 \mathrm{~mm}$; tail, 77; exposed culmen, 18; culmen from base, 21 ; tarsus, 29.

Remarks: Sexes alike. Size similar to $A$. t. perijanus. Range of measurements : six adult males-wing, 79-85 (81.3) mm; tail, 77-82 (79); culmen from base, 19-21 (20.1) ; one adult female-wing, 83 ; tail, 83 ; culmen from base, 21 . A. $t$. perijanus: two adult males-wing, 84,84 (84); tail, 79, 81 (80); culmen from base, 21, 22 (21.5) ; four adult females-wing, 74-85 (80) ; tail, 70-81 (77); culmen from base, 20-22 (21) ; two adults of undetermined sex-wing, 75,85 (80); tail, 73,79 (76) ; culmen from base, 21, 22 (21.5).

The range of larensis (Lara and Táchira) is interrupted by assimilis which is known in Venezuela only by two specimens from the State of Mérida (Páramo de La Culata) according to Hellmayr ${ }^{14}$. Neither is the range of assimilis continuous since it jumps from Colombia over our Táchira specimens of larensis to the Páramo de La Culata. This distribution is similar to that of the species $A$. brunnei-nucha in which the subspecies inornatus from western Ecuador, without pectoral band, jumps over the intervening range of brunnei-nucha to the State of Falcón, in northwestern Venezuela where it changes to allinornatus, a race differing from it only in size.

\section{SPECIMENS ExaMined}

A. t. assimilis.-COLOMBIA: El Piñon, $1 \hat{o}^{1}$; Santa Isabel, 1 우 ${ }^{3}$; Laguneta, Cauca, $1 \hat{o} \mathbf{1}$.

A. t. basilicus.-COLOMBIA ${ }^{1}$ : Valparaíso, Santa Marta, 1 ô; El Líbano, 1 \&.

A. t. perijanus.-VENEZUELA: La Sabana, Zulia, 2 ô, 4 $q, 2$ (?).

A. t. larensis.-VENEZUELA: Cerro El Cogollal, Lara, $2 \hat{\delta}$ (incl. type); Cerro El Cerrón, 3 ô; Queniquea, Táchira, 1 đิ; Seboruco, 1 q. A. t. phaeopleurus.-VENEZUELA: Silla de Caracas, 1 ô ${ }^{1}$; Curupao, $1 \hat{o}$; Cerro Golfo Triste, $1 \hat{o}, 1$ \&, 1 (?).

A. t. phygas.-VENEZUELA: Quebrada Bonita, 1 (?); Cerro El Peonía, 1 ô ; Los Palmales 1,1 ô, 1 $q$; Cerro Negro (Monagas), $5 \hat{o}$, 4 ९, 2 (2) juv.; Caripe, 1 ô ; Cerro Humo, 10 ô, 4 ९, 1 (?), 1 (?) juv.

14Bds. Americas, etc., Pt. XI, p. 418 (footnote). 


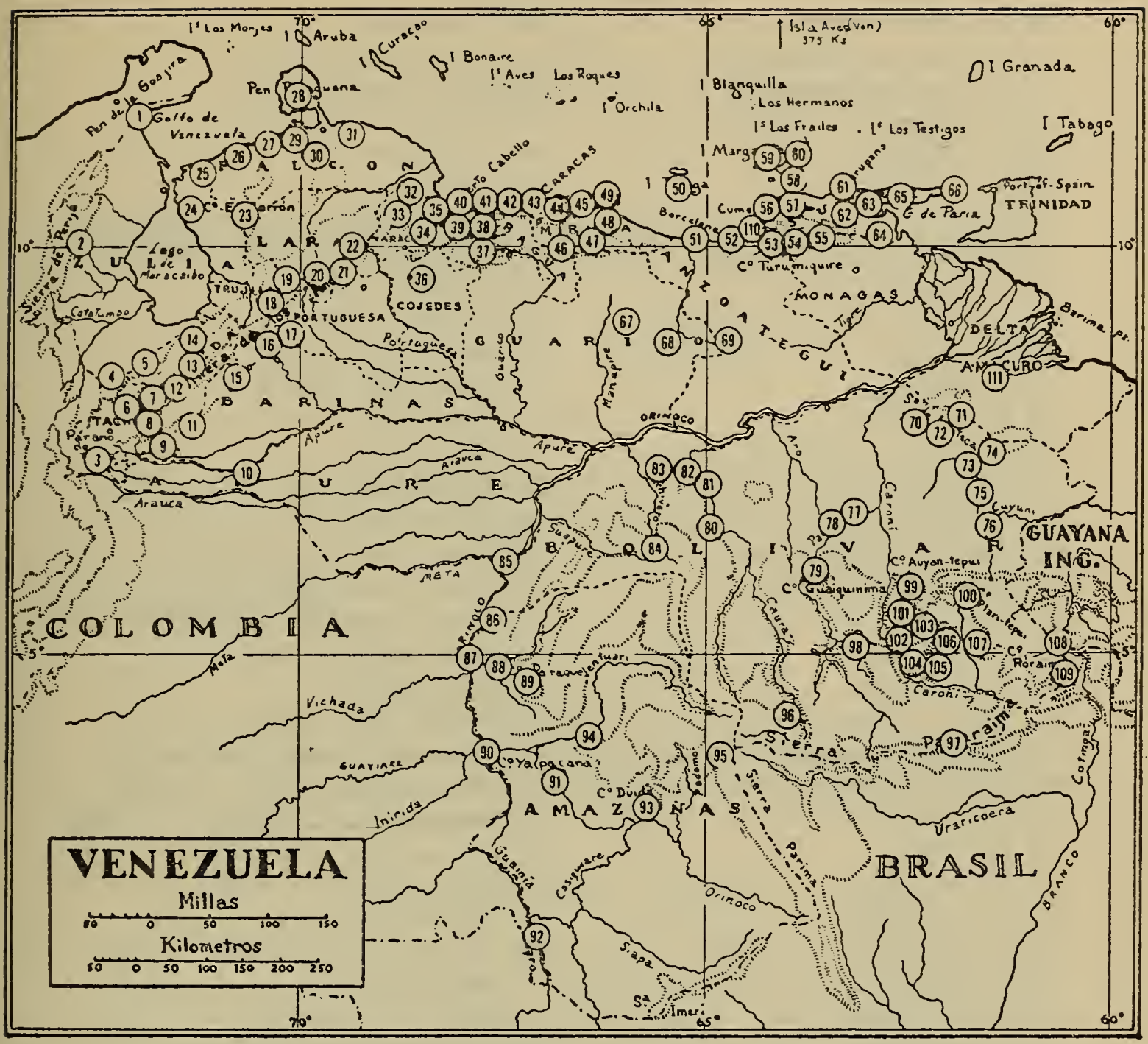

Explanation of Plate

106 Acopán-tepui, Cerro

70 Altagracia (Upata)

37 Altamira, Hda. (Carabobo)

74 Altiplanicie de Nuria

103 Aprada-tepui, Cerro

105 Arebuchi, Cerro

49 Aricagua

24 Aurare, Río

99 Auyan-tepui, Cerro

66 Azul, Cerro

52 Barcelona

16 Barinitas

22 Barquisimeto

44 Baruta

7 Boca de Monte

33 Bucaral

82 Cambur (El Cambur)

49 Codera, Cabo

98 Capuri, Raudal

57 Cariaco, Golfo de
55 Caripe

61 Carúpano

25 Casigua

86 Cataniapo, Caño

104 Chimantá-tepui, Cerro

15 Ciudad Bolivia

58 Coche, Isla de

1 Cojoro

42 Colonia Tovar

66 Cristóbal Colón

88 Cuao, Caño

21 Cubiro

14 Culata, Páramo de la

56 Cumaná

31 Cumarebo

39 Cumbre de Valencia

30 Curimagua

45 Curupao

26 Dabajuro

93 Duida, Cerro 


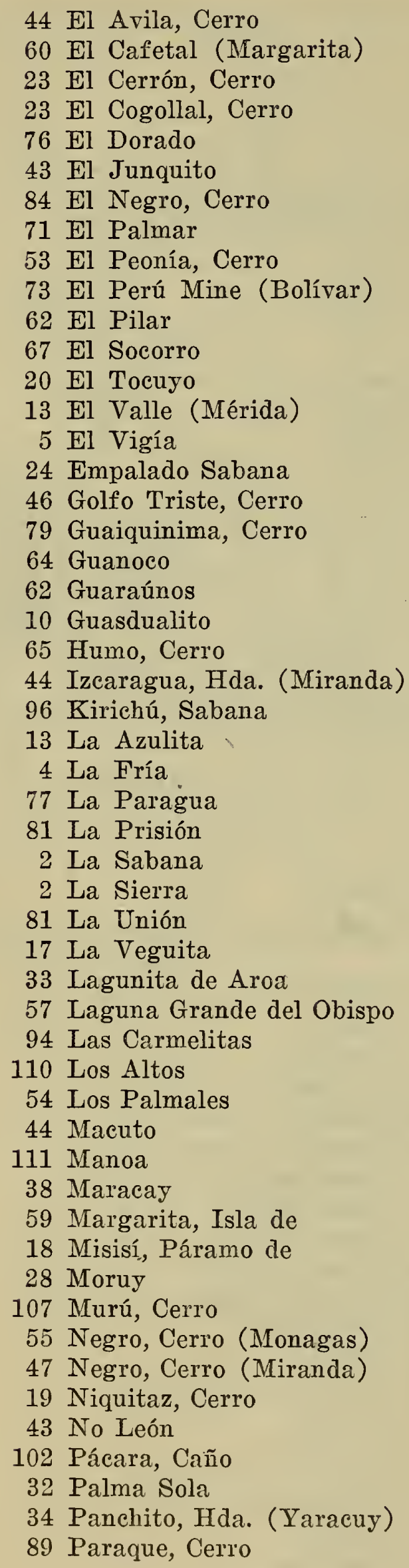

69 Pariaguan

97 Paurai-tepui, Cerro

78 Perro, Raudal

51 Píritu

100 Ptari-tepui

60 Porlamar

52 Puerto de la Cruz (Anzoátegui

42 Puerto de la Cruz (Dist. Fed.)

40 Puerto Cabello

85 Puerto Páez

23 Quebrada Arriba

53 Quebrada Bonita

8 Queniquea

87 Ratón, Isla

108 Roraima, Cerro

29 Sabaneta

57 San Antonio del Golfo

92 San Carlos (Río Negro)

90 San Fernando de Atabapo

45 San José de Los Caracas

30 San Luis

28 Santa Ana, Cerro

11 Santa Bárbara (Barinas)

41 Santa Clara, Hda. (Aragua)

12 Santa Cruz de Mora

68 Santa María de Ipire

83 Santa Rosalía (Bolívar)

9 Santo Domingo

95 Sarisariñama, Cerro

6 Seboruco

44 Silla de Caracas

100 Sororopán-tepui, Cerro

80 Suapure

48 Tacarigua de Mamporal

3 Tamá, Páramo de

77 Tigre, Cerro

72 Tomasote, Cerro

50 Tortuga, Isla

62 Tunapuí

36 Turén

41 Turiamo

101 Uaipán-tepui, Cerro

109 Uei-tepui, Cerro

35 Urama

27 Urumaco

3 Villa Páez

63 Yaguaraparo

75 Yuruán, Río

91 Yapacana, Cerro

91 Yapacana, Puerto

Yavi, Cerro. $75 \mathrm{ks}$. soutl of 84

8 Zumbador, Páramo 
Vol. $6 \frac{2}{3}$, pp. $125-132$

August 23, 1949

PROCEEDINGS

OF THE

BIOLOGICAL SOCIETY OF WASHINCTON

\title{
SOME WESTERN MILLIPEDS OF THE FAMILY CHELODESMIDAE
}

\author{
By Ralph V. Chamberlin
}

The notes and diagnoses recorded in the present paper are based upon material in the author's collection at the University of Utah where the types of the new forms are for the present retained.

\section{Genus CHONAPHE Cook, 1904}

\section{Orthotype: Chonaphe armata (Harger)}

The type species has been the only one heretofore known for Chonaphe as here restricted by removal of Chonaphe elrodi Chamberlin to a new genus. Three new species are here added.

\section{Chonaphe armata (Harger)}

Polydesmus armatus Harger, 1872, Amer. Jour. Sci. and Arts, 4:120.

Chonaphe armata Cook, 1904. Harriman Alaska Exped., 8(1):56;

*2a-2c ?-Polydesmus erucs Wood, 1865, Trans. Amer. Phil. Soc., 13:27

? Chonaphe eruca Cook, 1904, Harriman Alaska Exped., 8(1):57.

Type locality: Oregon.

The form illustrated by Cook may be accepted as the true armata. Since eruca Wood was based upon a female only, it is doubtful whether it can ever be identified with certainty even as to its genus in the $a b$ sence of any type specimen.

\section{Chonaphe cygneia new Species}

Fig. 1

Dorsum approximately chestnut in color, with the keels yellow. Legs light brown, the distal articles darkest. Antennae brown.

From remissa differening in the general outline of the anterior lamina of the gonopods, in the details of the distal end of that lamina, and in the much larger lamina or fold on the anterior face. See further fig. 1.

Width, $4.7 \mathrm{~mm}$.

Type locality: Washington: White Swan. One male taken May 7, 1933, by Wm. W. Baker.

This is a notably smaller form than C. patriotica.

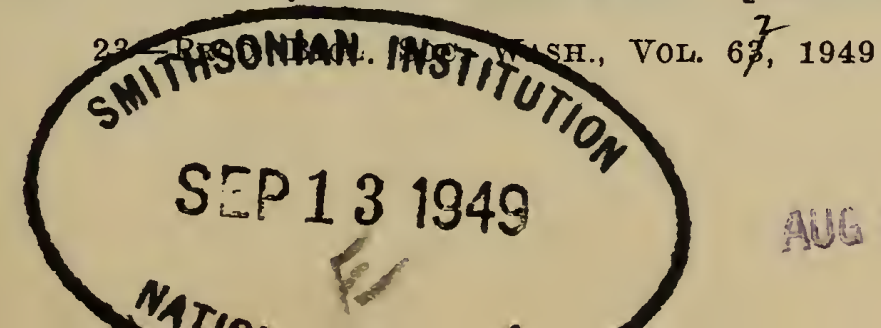


126 Proceedings of the Biological Society of Washington
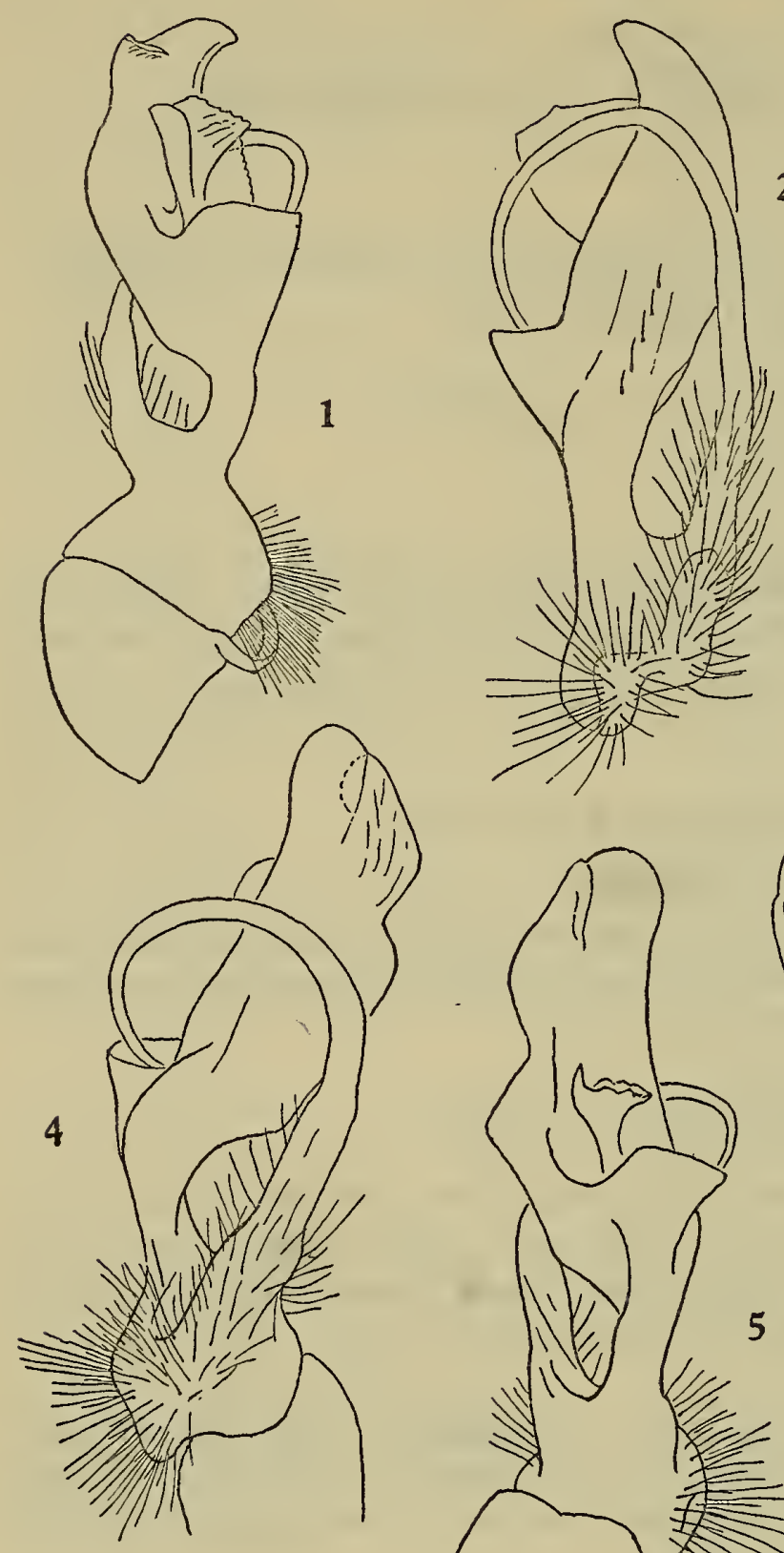

2
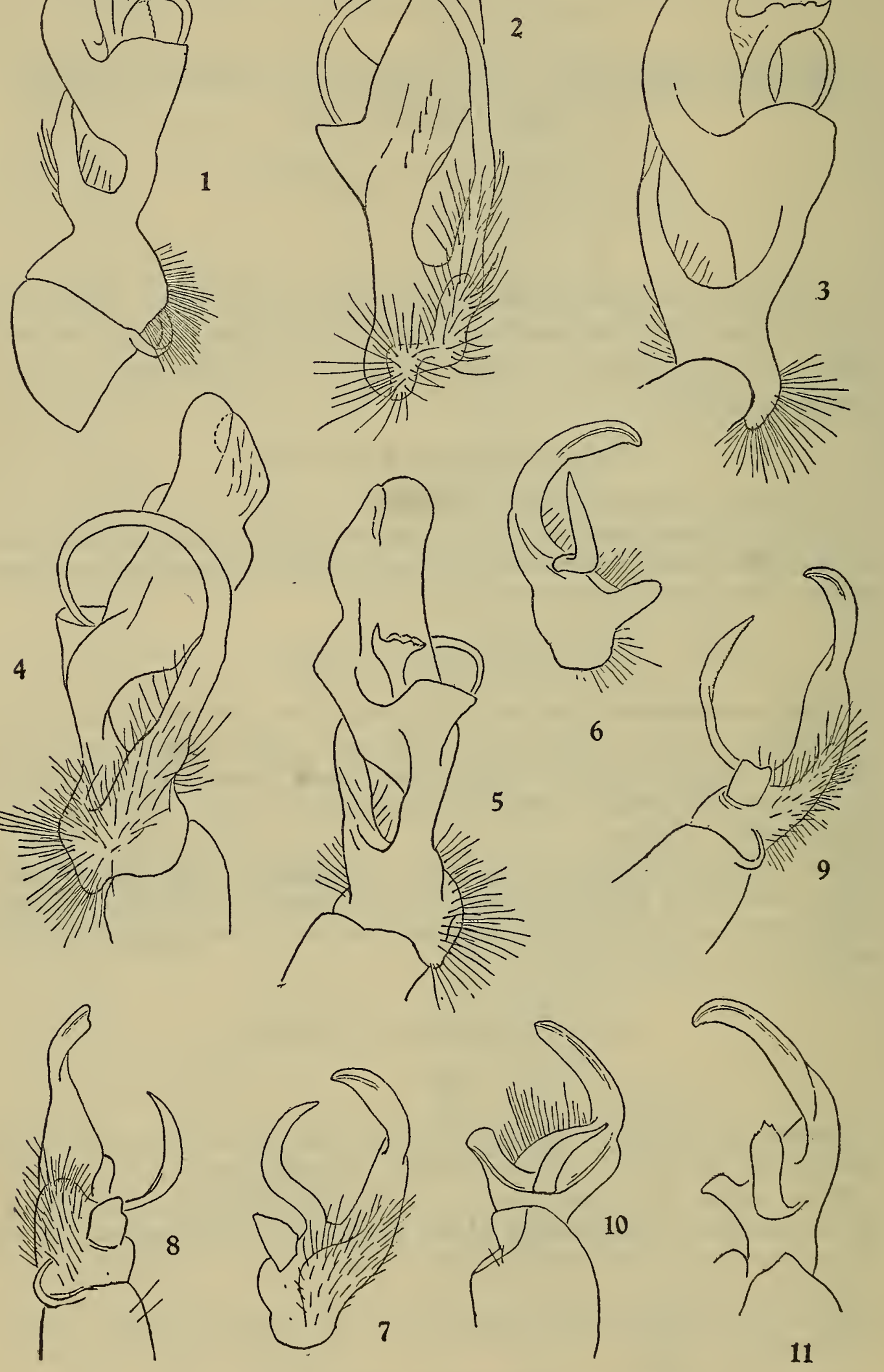

11

Plate VIII 
Chonaphe patriotica new species

Figs. 2 and 3

Prozonites chestnut above; metazonites chestnut to black, the keels in preserved specimens yellow. Legs and antennae dark brown to chestnut.

The gonopods are of the same general structure as in armata but differ in details, especially those of the terminal portion of the anterior lamina as shown in figs. 2 and 3.

Length, about $32 \mathrm{~mm}$; width, up to $6.5 \mathrm{~mm}$.

Type locality: Idaho: Fourth of July Canyon. Males and females taken Aug. 12, 1929, by Edith S. and R. V. Chamberlin.

\section{Chonaphe remissa new species}

Figs. 4 and 5

Dorsum dark chestnut, in part blackish; keels yellow, probably faded from orange, excepting the anterior and posterior borders which are dark, the dark band of posterior border narrow. Legs lighter chestnut, the antennae somewhat darker.

A smaller form than $C$. patriotica from which it differs also in the details of the gonopods, especially those of the anterior lamella, as, e.g., form and small size of the lobe on its anteriar face. The general outline of the anterior branch is also obviously different from that of patriotica and armata. See further figs. 4 and 5.

Width, $5.3 \mathrm{~mm}$.

Type locality: Washington: Puyallup. Male holotype taken by Wm. W. Baker.

\section{Genus MONTAPHE new}

Related to Chonaphe in having the gonopods much longer and more exposed than in Harpaphe. Differing from Chonaphe in having the anterior branch of the gonopods slender and bearing short, uncate processes distally, instead of being conspicuously laminate-cristate.

Orthotype: Montaphe elrodi (Chamberlin).

Montaphe elrodi (Chamberlin)

Leptodesmus (Chonaphe) elrodi Chamberlin, 1913, Canad. Entomologist, p. $24 ; * 17$.

Type locality: Montana: Flathead Lake.

\section{Genus HARPAPHE Cook, 1904}

Orthotype: Harpaphe haydeniana (Wood).

Harpaphe haydeniana (Wood)

Leptodesmus haydenianus Wood, 1864, Proc. Acad. Sci. Phil., p. 10; 1865, Trans. Amer. Phil. Soc., 13:226.

Harpaphe haydenianus Cook, 1904, Harriman Alaska Exped., 8(1):59; * $3: 4 \mathrm{a}-4 \mathrm{c}$.

Type locality: Oregon.

Other records: Oregon: North fork of Alcea River; Laturell Falls, 
Aug. 4, 1929 (Chamberlin coll.) ; Boyer, Sept. 23, 1937 (J. A. Macnab coll.) ; Rosy Creek, Pistol River, Aug. 3, 1945 (Ned Chapman coll.). Washington: Quinalt Lake; Issaquah, Aug., 1929 (Chamberlin). British Columbia: Cameron, Sept. 13, 1935 (Chamberlin coll.); Steelhead, 1933 (H. Leach); White Cliff; Metlakatla.

\section{Harpaphe clara new species}

Figs. 6,7

Dorsum at present dark brown or chocolate colored, with the keels yellow. Legs light brown.

The posterior blade of the gonopods more strongly curved beyond its middle than in the closely related $H$. intaminata, with the upper, or inner, margin more concave; anterior hook relatively narrower, with the apical portion more slenderly prolonged; median process with distal margin nearly straight instead of convex. See further figs. 6 and 7 .

Width, $6.2 \mathrm{~mm}$.

Type locality: California: Santa Clara Co., Stevens Creek. Male holotype taken Apr. 23, 1921, in a rotten log.

Other record: California: Santa Cruz Co., Santa Cruz.

\section{Harpaphe inlignea new species}

Fig. 8

The color of the type has faded from long preservation. At present the keels are the usual yellowish color and the dorsum elsewhere a light, in part somewhat pinkish, brown.

The posterior blade of the gonopods moderately short, not distally acuminate, the end being blunt or notched as shown in fig. 8. The middle process with distal margin highest at anterior end as shown in the figure.

Width, $6 \mathrm{~mm}$.

Type locality: California: Inwood. One male.

\section{Harpaphe penulta new species}

Fig. 9

When in full color the dorsum is black, with the keels orange color, but these colors fade in alcohol. Legs and antennae dark brown or chocolate colored.

In contrast with the distal margin of the median hook of the gonopods in, e.g., haydeniana, that of the present species, instead of being convex, is truncate or, more commonly, concave as shown in the figure, which see for the other features. (Fig. 9.)

Length, about $32 \mathrm{~mm}$; width, $5.8 \mathrm{~mm}$.

Type locality: Oregon: 9 miles south of Belnap Springs. Males and females taken July 14, 1946, by S. and D. Mulaik.

Other records: Oregon: McKenzie Bridge, males and females, July 14, 1946 (S. and D. Mulaik); two miles west of Blue River, July 13, 
1946 (S. and D. Mulaik), males and females; Lane County, near Vida, June 28, 1941.

\section{Harpaphe pottera new species}

Fig. 10

General coloration similar to that of related species. The dorsum chocolate brown or mahogany colored, with the keels lemon yellow and the prozonites often contrasting in being lighter colored than the metazonites. Legs brown, and the antennae more chestnut.

Most readily distinguished by the peculiarities of the gonopods, in particular by those of the principal blade which is shorter and less curved than usual and has the distal margin evenly convex. See further fig. 10.

Length, about $45 \mathrm{~mm}$; Width, $7 \mathrm{~mm}$.

Type locality: California: Potter Creek. Males, females and young individuals taken July 15, 1937, by R. V. Chamberlin.

\section{Harpaphe telodonta Chamberlin}

Fig. 11

Paimokia telodonta Chamberlin, 1945, Bull. Univ. Utah, Biol ser., $8(2): 17^{*} 33$.

Type locality: California: Humboldt County: Arcata.

Other records: California: 4 miles south of Requa, on the Crescent City road; Prairie Creek Park, Red Wood Fork.

\section{EXPLANATION OF FiguRES}

1. Chonaphe cygneia n. sp. Left gonopod, anterior view.

2. Chonaphe patriotica $\mathrm{n}$. sp. Right gonopod, ectocaudal view.

3. Chonaphe patriotica $\mathrm{n}$. sp. Right gonopod, submedian view.

4. Chonaphe remissa, n. sp. Right gonopod, subposterior view.

5. Chonaphe remissa n. sp. Right gonopod, subanterior view.

6. Harpaphe clara $\mathrm{n}$. sp. Telopodite of left gonopod, anterior view.

7. Harpaphe clara n. sp. Telopodite of left gonopod, submesal view.

8. Harpaphe inlignea n. sp. Right gonopod, mesal view.

9. Harpaphe penulta $\mathrm{n}$. sp. Left gonopod, mesal view.

10. Harpaphe pottera $\mathrm{n}$. sp. Right gonopod, anterior view.

11. Hurpaphe telodonta (Chamberlin). Right gonopod, anterior view. 
130 Proceedings of the Biological Society of Washington 
132 Proceedings of the Biological Society of Washington 
Vol. 6\%, pp. 133-134

August 23, 1949

\title{
PROCEEDINCS
}

OF THE

BIOLOGICAL SOCIETY OF WASHINGTON

\section{CAVIES OF SOUTHERN PERU}

\author{
By Colin Campbell Sanborn
}

The first Peruvian cavy to be named was Cavia tschudii Fitzinger 1867 based on Cavia cutleri Tschudi 1845 from Ica, Department Ica, Peru. The Peruvian Zoological Expedition 1941-42, of the Chicago Natural History Museum, collected a series of five topotypes of $C$. $t$. tschudii. These are brown above, heavily mixed with black; below light gray or buffy gray; collar on throat like sides but lighter; face and nose lighter than back; hind feet dark gray or brownish.

A series of twelve specimens from Arequipa and Yura (northwest of Arequipa) differ from the Ica series in having the under parts a darker gray with darker collars and with a prominent white spot below the collar. Above, some agree exactly with Ica specimens while others are grayer with a greater admixture of black hairs.

Two specimens from near Cuzco are darker still, both above and below but lack the white spot below the collar.

When Thomas described $C$. $t$. pallidior he compared it with Cuzco specimens and with one from Tambo on the coast near Maldonado. As he described it as paler than tschudii he must have had dark individuals. A paratype of pallidior matches closely a topotype of tschudii.

Cavia tschudii pallidior Thomas, renamed Cavia tschudii arequipae Osgood should be considered a synonym of Cavia tschudii tschudii Fitzinger.

It is possible that the Cuzco specimens represent an unnamed race that intergrades with tschudii in the Arequipa region, one being a coastal and the other a mountain race, but lack of material from intervening areas does not warrant its recognition at this time.

East of the Andes in southern Peru is found a dark cavy that is here described as:

\section{Cavia tschudii osgoodi subsp. nov.}

Type.-No. 52472 Chicago Natural History Museum. Limbani, 12,000 feet, District Limbani, Province Sandia, Department Puno, Peru. Adult female. Skin and skull. Collected 1 October 1941 by C. C. Sanborn. Original number 2906.

Color.-Very dark, almost reddish brown heavily mixed with black. Under parts dark buffy gray on center of belly, collar dark brown. Quite similar to $C$. $t$. atahualpae from Cajamarca.

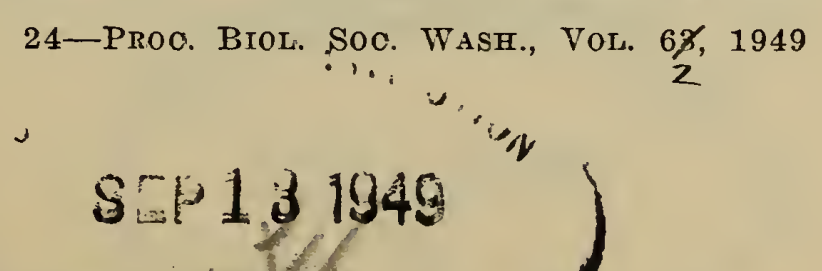


Skull.-Differs from atahualpae by the low, not arched, braincase and in having a much wider nasopharyngeal fossa.

Measurement of type.-Head and body $270 \mathrm{~mm}$. ; hind foot 49 . Skull: greatest length $60.4 \mathrm{~mm}$; condylo-basal length 56.0 ; zygomatic breadth 31.7 ; interorbital breadth 11.7 ; mastoid breadth 25.-; length of bulla 13.1; nasals $20.5 \times 7.7$; upper tooth row 14.9 .

Specimens examined.-Type and three paratypes, all females.

Remarks.-Limbani lies on the east side just over the crest of the Andes, in a region of clouds and heavy rain. It is the type locality of numerous dark colored races. This form is named for the late Dr. Wilfred $\mathrm{H}$. Osgood in recognition of his early important work on the genera of the Caviidae. 


\title{
PROCEEDINCS
}

\author{
OF THE
}

BIOLOGICAL SOCIETY OF WASHINGTON

\section{SOME RECENT COLLECTIONS OF PLETHODON FROM VIRGINIA WITH THE DESCRIPTION OF A NEW FORM}

\author{
BY ARNOLD B. GROBMAN \\ Department of Biology, University of Florida
}

Recent collections by a number of herpetologists necessitate an extension of the arrangement of certain of the plethodons in Virginia as given in the most recent of the general reviews (Bishop, 1943; Grobman, 1944). The ranges of Plethodon richmondi and $P$. wehrlei are extended in Virginia and a new form of the flecked plethodons (Welleri Group) is described.

Messrs. Clifford H. Pope, Harry G. M. Jopson, Hubert I. Kleinpeter, and Richard L. Hoffman have made separate and successful efforts to collect additional pertinent specimens, and have thereby contributed materially to these notes. I am also indebted to Dr. Doris M. Cochran, Mr. M. Graham Netting, and Mr. James A. Fotwler for loaning me comparative material from the collections under their care.

\section{Plethodon richmondi Netting and Mittleman}

Bishop (1943: 239) maps the distribution of richmondi as exclusive of Virginia, and Grobman (1944: 312) shows a single locality in Virginia based upon a specimen in the Carnegie Museum (No. 18499) collected at Blacksburg in Montgomery County. The following material extends the range eastward well into the Valley and Ridge Province in Virginia and thereby confirms the Blacksburg record. A series of specimens (R.L.H.1 10, 11, 48, 99, 155, 469-72, 594-96, 759, 972-73, 990, 992, and 1086) was collected by Richard L. Hoffman in the vicinity of Clifton Forge, Allegheny County. Additional new records include Porters Cave, State Rte. 42, 12 miles northeast of Clifton Forge, Bath Co. (R.L.H. 901); Sizer's Cave, about 4 miles south of Newcastle, State Rte. 42, Craig Co. (R.L.H. 946); Natural Bridge near Buck Hill Care entrance, Rockbridge Co. (J.A.F. 1051) ; and vicinity of Warm Springs, Bath Co. (J.A.F. 159). This Virginia material has not been compared with typical richmondi in order to evaluate racial variation.

\footnotetext{
IAbbreviations used in this paper designate the collections of the following institutions or persons as follows: A.M.N.H., American Museum of Natural History; A.N.S.P., Academy of Natural Sciences of Philadelphia; C.A.S., Chicago Academy of Sciences; C.M., Carnegie Museum; C.N.H.M., Chicago Natural History Museum; D.B.U.F., Department of Biology, University of Florida; J.A.F., James A. Fowler; M.C.Z., Mu seum of Comparative Zoology; R.L.H., Richard L. Hoffman; S.C.B., Sherman C. Bishop; U.M.M.Z., University of Michigan Museum of Zoology; and U.S.N.M., United States National Museum.
}

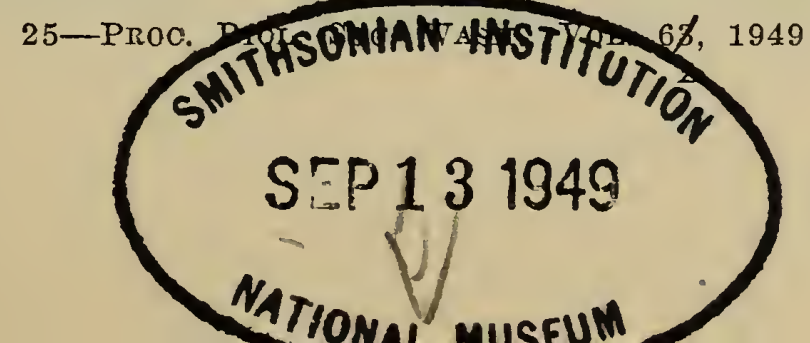




\section{Proceedings of the Biological Society of Washington}

\section{Plethodon wehrlei Fowler and Dunn}

In a recent paper (Netting, Green, and Richmond, 1946) records of wehrlei in Virginia are discussed. An immature specimen (C.N.H.M. 57029), presumably of this species, was subsequently collected near the side of the road elose to the junction of State Rte. 56 and the Blue Ridge Parkway in Nelson County during September, 1946, by Hulda and Arnold Grobman. The records of Netting, Green, and Richmond (1946: 157-60), for Montgomery, Roanoke, and Highland Counties extend the range of wehrlei eastward into the Valley and Ridge Province although these contributors are careful to point out that the habitat seems to be continuous from the Appalachian Plateous into the Valley and Ridge Province. The Nelson County record, if the salamander in question is correctly identified, extends the range eastward into still another physiographic province, the Blue Ridge. I am not able to state, however, whether or not it is possible to trace the habitat continuously between the Nelson County station and the nearest known localities to the west, though I doubt that there is such continuity.

On a trip from Rochester, New York, to Gainesville, Florida, in September of 1946, my wife and I drove along the Skyline Drive in the Shenandoah National Park in Virginia. While along the Drive we stopped to observe casually the salamander fauna with no particular thought of collecting and preserving specimens. At our first stop, however, we came upon a specimen which we thought to be of interest in representing either a considerable range extension of nettingi or welleri or in being an example of a new form of this group of Plethodon. This and additional specimens were saved and subsequent examination suggested that the latter assumption was correct. Additional trips were made to obtain more material; the personnel consisted of: Aug., 1947, Hoffman, Kleinpeter, and myself; Sept., 1947, my wife and myself; Sept., 1947, Kleinpeter and S. A. Peabody; July, 1948, Jopson; and Aug., 1948, Pope and family. A total of thirty specimens of the new form was in this way accumulated. As far as I am aware, the first known specimen of this form was taken by my wife and so it is with great pleasure that I suggest the new form be called:

\section{Plethodon huldae, sp. nov.}

Diagnosis-A small flecked Plethodon morphologically similar to Plethodon nettingi from which it most conspicuously differs in having one more costal groove and a lighter venter.

Holotype-U.S.N.M. 127955, collected along the foot trail to Hawksbill Mountain about 100 yards from the Skyline Drive at an elevation of approximately 3500 feet in Madison County, Virginia in the late morning of September 5, 1947, by Hulda and Arnold Grobman.

Paratypes-All from Virginia. M.C.Z. 26588, Madison Co., 2 miles north of Hawksbill Mt. at spring nearly opposite juncture of foot trail and Skyline Drive, 3350 feet, Sept., 1946, H. and A. Grobman; A.M.N.H. A53996-97, Page Co., near Skyland campsite about 1/2 mile southwest of Stony Man Mt. and about $1 / 4$ mile west of Skyline Drive, 3650 feet, September, 1946, H. and A. Grobman; U.S.N.M. 127956-58, type locality, Aug., 1947, H. I. Kleinpeter and S. A. Peabody; U.M.M.Z. 98748-51,

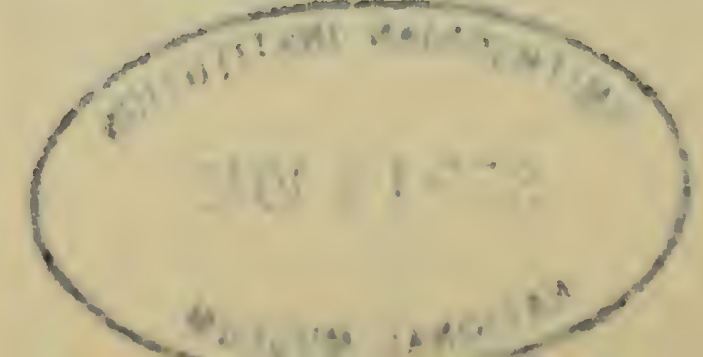


Madison-Page Co. line, trail to Stony Man Peak from Skyland campsite, 3750 feet, July 18, 1948, H. G. M. Jopson; C.N.H.M. 56501-08, extreme northeast Rockbridge Co., 11.4 miles north of intersection of U. S. Rte. 60 and Blue Ridge Parkway, just above point where Parkway crosses a branch of Nettle Creek, 3150-3300 feet, Aug. 9, 1948, C. H. Pope and family; C.N.H.M. 56509, Roanoke Co., on Poor Mt., a few miles south of Salem, 3400-3600 feet, Aug. 19, 1948, Hallowell Pope; A.N.S.P. 26054 and C.A.S. 14682, Nelson Co., side of road near juncture of State Rte. 56 and Blue Ridge Parkway, 3000 feet, Sept., 1946, H. and A. Grobman; C. M. 28897-99, S.C.B. (3 specimens), and D.B.U.F. 2208-09, type locality, Aug. 7, 1947, Richard Hoffman, H. I. Kleinpeter, and A. Grobman.

Description of the species-Plethodon huldae belongs to that group of Plethodon that includes richmondi, welleri and nettingi. These are all relatively small salamanders with a dark dorsum flecked in life with green, bronze, gold, silver or brassy, as described by different investigators. (The diversity of these markings may be in their recording rather than in their actual color.) These flecks tend to disappear in preserved specimens within a very short time. Of the three previously described forms, richmondi is characterized by a rather elongate body and, associated with it, a high number of costal grooves (20 to 23 as counted by Netting and Mittleman, 1938). At the other extreme of the series is welleri with, usually, 16 costals. P. nettingi generally has 18 , and huldae, 19 costals. P. c. cinereus, which I do not believe is as closely related to these forms as they are to each other, has a number of costals similar to that of huldae. In the accompanying table (Table I) there are listed costal groove counts made by myself within a short period of time and as uniformly as possible.

\section{TABLE I}

Costal Groove Counts of Certain Forms of Plethodon AS DESCRIBED IN THE TEXT

\begin{tabular}{|c|c|c|c|c|c|c|}
\hline Costal Grooros & 15 & 16 & 17 & 18 & 19 & 20 \\
\hline P. huldae ... & $-\ldots$ & -..- & $\ldots$ & 5 & 20 & 5 \\
\hline P. nettingi & --- & --- & 4 & 20 & 2 & $\ldots$ \\
\hline P. welleri & 2 & 18 & 4 & --- & --- & $\ldots$ \\
\hline$P$. c. cinereus & --- & --- & --- & 15 & 26 & 1 \\
\hline
\end{tabular}

The maximum count obtainable was recorded by including a groove over the axilla, whether or not it was well defined so long as there was room for it, and by including all grooves in the region of the groin regardless of any ventral anastomoses or lack of them. Counts were made on both sides of a specimen and recorded separately; occasionally a difference of one groove between the right and left sides of an individual was observed. No attempt was made to force agreement for it was thought that less bias would obtain by permitting occasional errors to be randomized than by subjecting selected individuals to a more detailed study that other specimens received. The cinereus studied were specimens taken with the collections of huldae. The nettingi and welleri counts were made on specimens from the Carnegie and U. S. National 


\section{Proceedings of the Biological Society of Washington}

Museums. The species of the Welleri Group, arranged in descending order of their costal groove counts, are: richmondi, huldae, nettingi and welleri.

$P$. richmondi, nettingi and huldae are alike in that the dorsal flecks are relatively discrete; in welleri they are frequently coalesced.

The number of vomerine teeth in each series seems to be about the same for each form with an average number of approximately 6 .

It is, of course, almost impossible to form a reliable impression of maximum size without an abundance of material. With the information I have available at the present time, it might be said that the size order follows that of the number of costal grooves, but the only fair statements are that richmondi is the longest, and welleri the shortest, of the four. I do not have figures sufficient to establish that huldae is larger than nettingi although I suspect that that is the case.

On the specimens I have studied, I find that the number of costal grooves between the toes of adpressed limbs in adults average 5 in welleri, 6 in nettingi and 7 in huldae. ( $\mathrm{I}$ have chosen to use grooves rather than folds because the former are more discrete and do not require the juggling of fractions the usual method does.) I have restricted these comparisons to adults because of the ontogenetic change that has been demonstrated in this character by Netting and Mittleman (1938: 292), Grobman (1943: 9-11), and others.

Three of the characters discussed above (grooves between adpressed toes, maximum size, and number of costal grooves) are obviously associated and probably do not indicate as much genetic disimilarity as their listings might suggest. If other recognizable forms within the series are to be expected, the most likely place would be between huldae and richmondi.

The venter of huldae is progressively darker posteriorly. The throat is speckled, the abdomen mottled, and the tail dark. There is a similar, but much less pronounced anterior-posterior pattern gradient in nettingi. The throat and anterior abdomen of huldae are not matched by nettingi but the darker parts are. $P$. huldae, then, has a lighter venter than nettingi.

I am indebted to Mr. Pope for the following color deseription of one of the paratypes (C.N.H.M. 56509) taken in life: "Dorsum: Ground color uniform dark brown, almost black. Moderately profuse silvery flecks over head and back; similar flecks somewhat more profuse on tail except near its tip where they are scarcely visible or lacking. Flecks about as profuse on limbs as on back. Ventrum: Purplish black with profuse irregularly arranged and shaped light areas. Anterior to gular fold, light areas become progressively more profuse until they predominate and finally all but replace the purplish black ones. Lower jaw narrowly bordered with purplish black anteriorly. Soles light colored except for the purplish black webbing. Limbs purplish black except for light creases and a very few light areas like those of the belly. Pattern of ventrum tends to invade lower sides. Eye: Iris black, narrowly bordered with gold above."

Habitat-The great majority of specimens were collected from under rocks, occasionally from under, or in, a log. The sites of collection were high and well forested, usually with a mixed stand of conifers and hardwoods. There was usually plenty of ground cover. Plethodon c. cinereus 
was found in the same specific areas and seemed to outnumber huldae about 3 or 4 to 1 .

Physiographic and altitudinal restrictions-All known localities are in the Blue Ridge Province at altitudes between 3000 feet and 3750 feet. The range may therefore be given as above 3000 feet in the Blue Ridge Province in suitable habitats between Poor Mt., Roanoke Co., and Stony Man Mt., Page-Madison Cos.

Identification of cinereus and huldae-In the general area under discussion cinereus, as far as is known, exists exclusively in the red-backed phase. Since huldae comes to resemble lead-backed cinereus after being in preservative, it may be that there are other specimens of huldae in collections that have been identified as cinereus. A similar situation existed at the time of the description of $P$. richmondi (Netting and Mittleman, 1938: 287). In the present instance the number of costal grooves will be of no help in segregating the confused specimens.

Relationships in the Welleri Group-The Welleri Group consists of four species as presently outlined. Geographically, richmondi is related sympatrically to nettingi and perhaps to huldae. It is also the largest form with the highest costal groove count and it is suggested (which suggestion is in agreement with that of Green, 1938: 298-99) that a richmondi-like animal was ancestral to the other forms in the group. $P$. huldae, nettingi and welleri, are montane dwarf derivatives with the degree of differentiation being in that order.

Use of the binomial-The most closely related form, morphologically, to huldae is nettingi; these forms seem to be distinct and could either be considered separate species or "insular" races. The most closely related form, geographically, is richmondi; there is, at this writing, no evidence for intergradation between the two. On the basis of present information and current systematic procedure, it seems more reasonable to refer to huldae with a binomial than with a trinomial.

Related distributional problems-Further desirable distributional information regarding $P$. huldae includes range extensions to the north; intermediate stations between Poor Mt. and Nelson Co.; and altitudinal range of the form. Collectors in the northern part of the Southern Section of the Blue Ridge between Poor Mt., the southernmost record for huldae, and Mt. Rogers, the northernmost record for welleri (Hoffman and Kleinpeter, 1948: 107), should search for a flecked Plethodon. Intergrades, or an intermediate form, between welleri and huldae may be anticipated. Pt. Lookout, rising to above 4600 feet, might well be a locality involved.

\section{Literature Cited}

Bishop, Sherman C. 1943. Handbook of Salamanders. Comstock Publ. Co., Ithaca, N. Y. Pp. i-xiv, 1-555. Figs. 1-144. Maps 1-56.

GREEN, N. BAYARD. 1938. A new salamander, Plethodon nettingi, from West Virginia. Ann. Carnegie Mus., XXVII:295-99.

Grobman, ARnold B. 1943. Notes on salamanders with the description of a new species of Cryptobranchus. Occ. Pap. Mus. Zool. Univ. Mich. No. 40:1-12. Pl. 1. Fig. 1. 
1944. The distribution of the salamanders of the genus Plethodon in eastern United States and Canada. Ann. N. Y. Acad. Sci., XLV, Art. $7: 261-316$. Figs. 1-11.

HOFFMAN, RiCHARD L. and HUBERT I. KLETNPETER, 1948. A collection of salamanders from Mount Rogers, Virginia. Journ. Wash. Acad. Sci., 38(3):106-108.

Netting, M. Graham, N. Bayard Green, and Neil D. Richmond. 1946. The occurrence of Wehrle's salamander, Plethodon wehrlei Fowler and Dunn, in Virginia. Proc. Biol. Soc. Wash., 59:157-160.

Netiting, M. Grahai and M. B. Mitutleman. 1938. Description of Plethodon richmondi, a new salamander from West Virginia and Ohio. Ann Carnegie Mus. XXVII:287-293. Pl. XXX. 
142 Proceedings of the Biological Society of Washington 


\section{PROCEEDINCS}

OF THE

\section{BIOLOGICAL SOCIETY OF WASHINGTON}

\section{A NEW POCKET GOPHER FROM SOUTHEASTERN UTAH}

BY KEITH R. KELSON

In the comprehensive taxonomic work on the pocket gophers of Utah, Durrant (The Pocket Gophers (Genus Thomomys) of Utah, Univ. Kansas Publ., Mus. Nat. Hist., 1(1) :1-82, Aug. $15,1946)$ referred the animals from the mountains east of the Green and Colorado rivers in Utah to the subspecies Thomomys talpoides fossor, but mentioned (p. 22) that they were not typical. Furthermore, he remarked that, when more material became available, they might prove to be sufficiently different from $T$.' $t$. fossor to merit separation and naming. Subsequently, additional specimens were collected by field parties sponsored by the University of Utah Research Council. Comparison of these animals with near topotypes of $T$. $t$. fossor indicates that they do constitute an heretofore undescribed subspecies. It seems appropriate to name the new animal in honor of Professor Stephen D. Durrant who has contributed so materially to the understanding of the taxonomy of this group of mammals in Utah. The name and description of the new form are as follows:

\section{Thomomys talpoides durranti new subspecies}

Type.-Female, adult, skin and skull, No. 5603, Museum of Zoology, University of Utah, Johnson Creek, $14 \mathrm{mi}$. N Blanding, 7,500 ft., San Juan County, Utah; May 23, 1947 ; collected by Keith R. Kelson, original number 201.

Range.-The mountains east of the Green and Colorado rivers in Utah, bounded by the southern flank of the East Tavaputs Plateau on the north and the Abajo [Blue] Mountains on the south.

Diagnosis.-Size medium (see measurements); hind foot average for the species. Color: Upper parts Cinnamon-Brown grading to CinnamonBuff on flanks and inguinal region (capitalized color terms according to Ridgway, Color Standards and Color Nomenclature, 1912); underparts Avellaneous with deep Mouse Gray undertone; chin and openings to the check pouches white; ears medium in size with rounded or pointed pinnae, pinnae with moderate pigmentation; postauricular patches re-

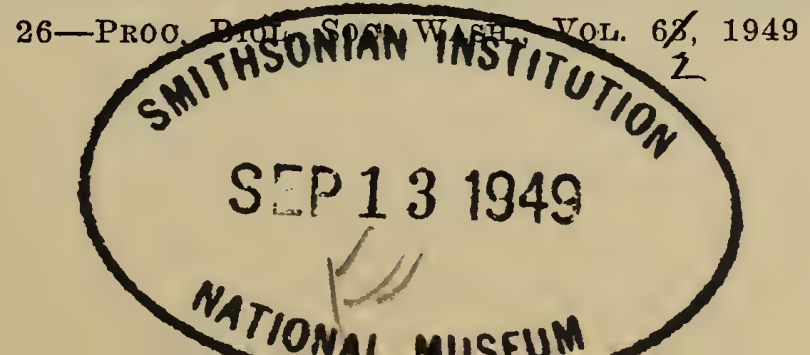




\section{Proceedings of the Biological Society of Washington}

duced, between Dusky Neutral Gray and black; proximal half dorsal surface hind feet same color as upper parts of body, distal half with short whitish hairs; tail white below, Cinnamon-Brown above in the proximal half, grading to white distally. Skull: Size medium, angular and narrow; frontonasal region flat or nearly so; nasals rounded proximally; premaxillae extending posterior to nasals; rostrum long; interparietal boardly triangular; tympanic bullae large and well inflated ventrally; basioccipital narrow; supraoccipital markedly lengthened, developed as a distinct shelf rather than as a crest; upper incisors long and moderately recurved; molariform dentition light.

Measurements.-Average and extreme measurements in millimeters of 6 males and 8 females from the type locality are, respectively, as follows: Total length, 208 (224-201), 208 (220-195); length of tail, 61 (66-54), 59 (63-55); length of hind foot, 28 (32-26), 28 (31-26); basilar length, 31.6 (35.0-31.0), 30.3 (31.2-28.8); length of nasals, 13.7 (14.9-13.1), 13.0 (14.1-11.9); zygomatic breadth, 20.2 (20.8-19.7, available from only 3 males), 20.7 (21.5-19.8); mastoid breadth, 17.1 (17.916.8), 17.7 (18.5-16.3); interorbital breadth, 6.3 (6.5-6.1), 6.3 (6.5-5.8); alveolar length of upper molariform series, 7.1 (7.6-6.8), 7.2 (7.7-6.8); extension of premaxillae posterior to nasals, 0.6 (0.8-0.1), $0.5(0.9-0.0)$; length of rostrum, as measured from the dorsal point of union of the lacrimal, frontal, and maxilla to the tip of the nasal, 15.6 (17.1-15.0), 15.4 (16.2-14.8); breadth of rostrum, 7.3 (7.8-7.0), 7.2 (7.5-6.8).

Comparisons.-From Thomomys talpoides ocius, $T$. $t$. durranti can be distinguished as follows: Size larger throughout. Color: Darker, brownish as opposed to grayish. Skull: More angular and massive; frontonasal region more nearly flat as opposed to gently arched; nasals and rostrum longer; supraoccipital shelf more pronounced, extended farther posteriorly; incisors markedly longer and less recurved; tympanic bullae smaller; interorbital breadth actually as well as proportionately narrower; anterior palatine foramina larger; interpterygoid space more narrowly V-shaped; interparietal triangular rather than suborbicular.

From Thomomys talpoides uinta, $T$. $t$. durranti differs as follows: Skull: Longer and narrower; rostrum and nasals longer; interparietal triangular rather than pentagonal; tympanic bullae larger and more inflated ventrally; basioccipital narrower; supraoccipital a shelf rather than a crest; frontonasal region more nearly flat.

From 6 males, near topotypes, of Thomomys talpoides fossor, which it most nearly resembles, from La Plata City, 9,200 feet, La Plata County, Colorado, T. t. durranti differs as follows: Tail shorter $(61 \mathrm{~mm}$. as opposed to $65 \mathrm{~mm}$.). Color: Slightly lighter dorsally in specimens of comparable molt; postauricular patches smaller. Skull: More angular; more nearly flat in the frontonasal region as opposed to gently arched; basilar length averages slightly greater (31.6 mm. as opposed to $30.6 \mathrm{~mm}$.) ; extension of the premaxillae posterior to the nasals greater $(0.6 \mathrm{~mm}$. as opposed to $0.05 \mathrm{~mm}$.) ; rostrum broader $(7.3 \mathrm{~mm}$. as opposed to $6.9 \mathrm{~mm}$.) ; supraocipital shelf extended farther posteriorly; interparietal averages broader in proportion to the length; upper incisors not as procumbent; cranial root of the zygomatic arch heavier.

Remarks.-In his original description of Thomomys fossor, Allen 
(Bull. Amer. Mus. Nat. Hist., 5:51, April 28, 1893) placed particular emphasis on the fact that the premaxillae terminated posteriorly on the same line as the nasals. The near topotypes from La Plata City, La Plata County, Colorado, available to me, agree in this character with Allen's description. Other specimens of $T$. $t$. fossor from Colorado which I have examined do not agree with the description in this particular, nor do those of the near topotypical series studied by Durrant (p. 26-27). Since the La Plata series also agrees with the description in other characters, I consider it to be fairly typical. Indeed, the variability is so great in animals from Colorado, assigned to $T$. $t$. fossor that I have studied that it seems apparent that when the species Thomomys talpoides of that state has been thoroughly re-studied, many of the animals now understood to belong to the subspecies $T$. $t$. fossor will be found to comprise several unnamed kinds.

Twelve specimens from the La Sal Mountains in Grand and San Juan counties, Utah, are intergrades between $T$. $t$. fossor and $T$. $t$. durranti. The degree of intergradation appears to be proportional to the relative distance that the La Sal Mountains are removed from the two type localities. They resemble $T$. $t$. durranti in the extent of the supraoccipital shelf, length and curvature of the upper incisors, heavy anterior root of the zygomatic arch, length of the tail and overall coloration; they are like T. $t$. fossor in the length of the hind foot; they are intermediate between the two in the shape of the frontonasal region, and the posterior extension of the premaxillae; they exceed both $T$. $t$. durranti and T. $t$. fossor in total length, basilar length, and the breadth of the rostrum. These specimens more nearly resemble $T$. $t$. durranti to which they are here referred.

Specimens from Oak Spring, Middle Fork Willow Creek, 14 miles north Thompson, Grand County, Utah, were considered by Durrant ( $p$. 22) to be intergrades between $T$. $t$. ocius and $T$. $t$. fossor, and referable to the latter. These animals are here referred to $T$. $t$. durranti primarily on distributional concepts. A series of 5 specimens from PR Springs, 43 miles south of Ouray, 7,950 feet, Uintah-Grand County line, Utah, and 3 specimens from Brown's Corral, 20 miles south of Ouray, 6,250 feet, Uintah County, Utah, are intergrades between T. $t$. durranti and $T$. $t$. ocius the range of which occurs to the north of these localities. In general the skulls are more like those of T. $t$. ocius, but show features of T. $t$. durranti in the shape of the interparietal and the size of the tympanic bullae. The color of the specimens from PR Springs is like that of T.t. durranti, while that of the specimens from Brown's Corral is like that of $T$. $t$. ocius. Both are closer to $T$. $t$. ocius to which they are here referred. Gradual intergradation is thus demonstrated between $T$. $t$. durranti and T. $t$. ocius in a series of specimens taken along a northsouth transect. The ranges of the two subspecies may be regarded as meeting between the PR Springs and Oak Creek localities or, roughly, along the southern crest of the East Tavaputs Plateau. Specinens from the vicinity of Vernal, Uintah County, Utah, north of the above localities, were regarded by Durrant (p. 18) as intergrades between $T$. $t$. ocius and $T$. $t$. uinta. Durrant also commented on intergradation between $T$. t. uinta and T. t. ravus (p. 16) and suggested slight intergradation between $T$. $t$. uinta and T. t. pygmaeus (p. 15). Intergradation is, then, 


\section{Proceedings of the Biological Society of Washington}

demonstrable in the several subspecies of the Thomomys talpoides group from the eastern half of Utah.

In view of the foregoing, Thomomys talpoides fossor is no longer considered to be a part of the fauna of Utah.

Specimens examined.-Total, 50, from the Museum of Zoology, University of Utah, distributed as follows: Grand County: Warner R. S., La Sal Mountains, 9,750 ft., 3; San Juan County: 1 mi. SE Mesa R. S., La Sal Mountains, 9,200 ft., 4; $3 \mathrm{mi}$. W Geyser Pass, La Sal Mountains, $10,000 \mathrm{ft.,} \mathrm{5}$; Dalton Spring, $5 \mathrm{mi}$. W Monticello, Abajo [Blue] Mountains, 8,300 ft., 14; Gooseberry R. S., Elk Ridge, 8,300 ft., 5; Duck Lake, $1 \mathrm{mi}$. S Gooseberry R. S., Elk Ridge, 8,400 ft., 5; Johnson Creek, $14 \mathrm{mi}$. $\mathrm{N}$ Blanding, 7,500 ft., 14.

Contribution from the Division of Biology, Department of Vertebrate Zoology, University of Utah, Salt Lake City, Utah. 


\section{Proceedings of the Biological Society of Washington}

zone, pine slope, Sept. 11, 1936, H. S. Gentry 2669 (type sheet in U. S. National Herbarium, duplicates seen in U. S. National Arboretum, Missouri Botanical Garden). Other duplicates of this collection may probably be found elsewhere filed with Drymaria tenella, under which name they were originally distributed and eited by Gentry, Carn. Inst. Wash. Pub. $527: 114,1942$.

This peculiar species seems more or less intermediate between the group of small annuals centering around $D$. leptophylla and the group containing $D$. tenuis and $D$. anomala. It approaches the latter group, particularly $D$. tenuis, in its tendency for one lateral branch to be suppressed, the strong mid-nerve of the sepals, and its lanceolate leaves. The latter, however, are similar also to those of $D$. depressa, of the other group. The multiflorous eymes, long petals, 5 stamens, and general appearance influence me to keep it for the present in the group with $D$. leptophylla, in which it is possibly closest to D. effusa. To this, however, it cannot be regarded as very elose, as it differs in the broad leaves, acute sepals, puberulence and other features. 


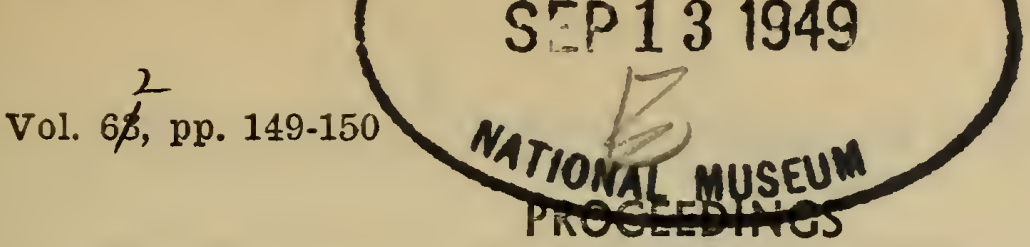

\title{
OF THE
}

\section{BIOLOGICAL SOCIETY OF WASHINGTON}

\section{A NEW SUBSPECIES OF COTTON RAT, SIGMODON HISPIDUS, FROM MICHOACÁN, MÉXICO}

\author{
By E. RAYMOND HALL
}

Among mammals collected in the vicinity of Zamora, Michoacán, in 1943, only one individual of the genus Sigmodon was included. That cotton rat differed so much from any named kind that a manuscript description, including a new name, was drawn up for the animal, but being reluctant to propose a new name on the basis of only one specimen, I laid the description aside. In December past, on a visit to the Biological Surveys Collection in the United States National Museum a second specimen, from Zamora, was found. In as much as the second specimen agrees with the first and since each of the two differs from any previously described kind the following account is offered as contributing to our knowledge of this group of rodents of Austral and Tropical distribution.

Sigmodon hispiduas atratus new subspecies

Type.-Male, subadult, skin and skull; no. 100628, Mus. Vert. Zool.; 61/2 mi. W Zamora, 5950 ft., Michoacán, México; March 27, 1943; obtained by E. R. Hall, original no. 6009 .

Range.-Known only from Zamora and the type locality.

Diagnosis.-Size medium (see measurements); hind foot short; color blackish yellow on upper parts and sides; whitish on underparts, feet, and under side of tail; tail blackish above and haired densely enough to obscure the annulations; skull (see figs. 1-3) deep; anterior projection of maxillary arm of zygoma short and straight; anterior palatine foramina constricted posteriorly.

Comparisons.-From Sigmodon hispidus mascotensis Allen as known by specimens of equal age from Pátzcuaro and Tacámbaro, S. $h$. atratus differs in hind foot shorter; upper parts darker (more nearly black); tail more densely haired; skull shorter and more convex in dorsal longitudinal outline; anterior palatine formanina posteriorly constricted rather than parallel-sided; anterior process of maxillary arm of zygoma shorter and less decurved (less of a hook). The same differences are apparent in comparisons with other specimens of $S . h$. mascotensis from the state of Jalisco, more exactly from Tuxpan, Las Canoas and Artenkiki.

Remarks.-The short hind foot, the relatively hairy tail with resultant concealment of the annulations on the tail, and the high degree of convexity of the skull dorsally in the longitudinal axis are points of re- 


\section{0

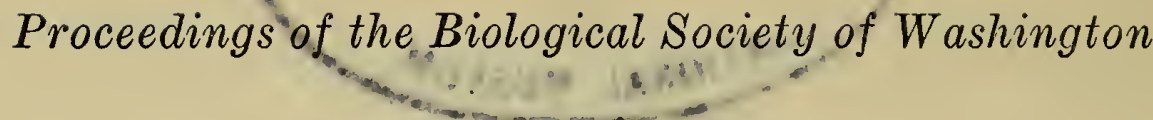

semblance to the $S$. melanotis group of cotton rats. Nevertheless, the differences between $S$. $h$. atratus on the one hand and Sigmodon melanotis Bailey and Sigmodon alleni Bailey on the other hand, are of such a nature that I judge the newly named animal to bear no close relationship to $S$. melanotis and $S$. alleni. From them, $S$. $h$. atratus differs in more grayish and less reddish upper parts, and longer (but no more decurved) anterior process of the maxillary arm of the zygoma. In these two respects the newly named animal shows greater resemblance to Sigmodon hispidus. Furthermore, some specimens of Sigmodon hispidus mascotensis from other localities in Michoacán (Queréndaro, 1 specimen; Huacana, 8; Los Reyes, 3 ; La Salada, 2), like S. h. atratus, have a short and straight anterior process on the maxillary arm of the zygoma, and the specimens from Los Reyes are almost as dark as $S$. $h$. atratus. The above evidence is the basis for regarding the newly named kind of Sigmodon first as more closely allied to Sigmodon hispidus than to Sigmodon melanotis and second as only a subspecies of Sigmodon hispidus.

The constriction of the posterior part of the anterior palatine foramina, so well shown in the holotype of $S$. $h$. atratus and present in lesser degree in the referred specimen from Zamora, appears rarely as an individual variation (unrelated to age or sex), at least in northern populations of Sigmodon hispidus. In S. h. atratus our knowledge of the constancy of this feature and its taxonomio worth, therefore will remain uncertain until more specimens of $S$. $h$. atratus are available.

The specimen of $S$. $h$. atratus from Zamora ( $q$ no. $120268 \mathrm{U}$. S. B. S.) is slightly the older of the two but unfortunately has a broken skull. The younger specimen is selected as the holotype because its skull is intact.

Acknowledgment is made to Dr. H. H. T. Jackson and Mr. Stanley P. Young for their courtesy in allowing use of materials in their charge and to Miss Annie M. Alexander and the John Simon Guggenheim Memorial Foundation for assistance with the field work in Michoacán.

Measurements (first the type and second no. 120268).-Total length, 228,245 ; length of tail, 112, 113; length of hind foot, 30,33 ; length of ear from notch, 18, —; weight, 53.2, —— grams; basal length, 25.7 , — ; length of nasals, 11.2, 11.4; zygomatic breadth, 18.0, mastoid breadth, 12.8, 13.5; alveolar length of upper molar series, 6.1, 6.1 .

Specimens examined.-Two, the type and one from Zamora.

Museum of Natural History, University of Kansas, Lawrence, Kansas. Transmitted January 2,1918 .
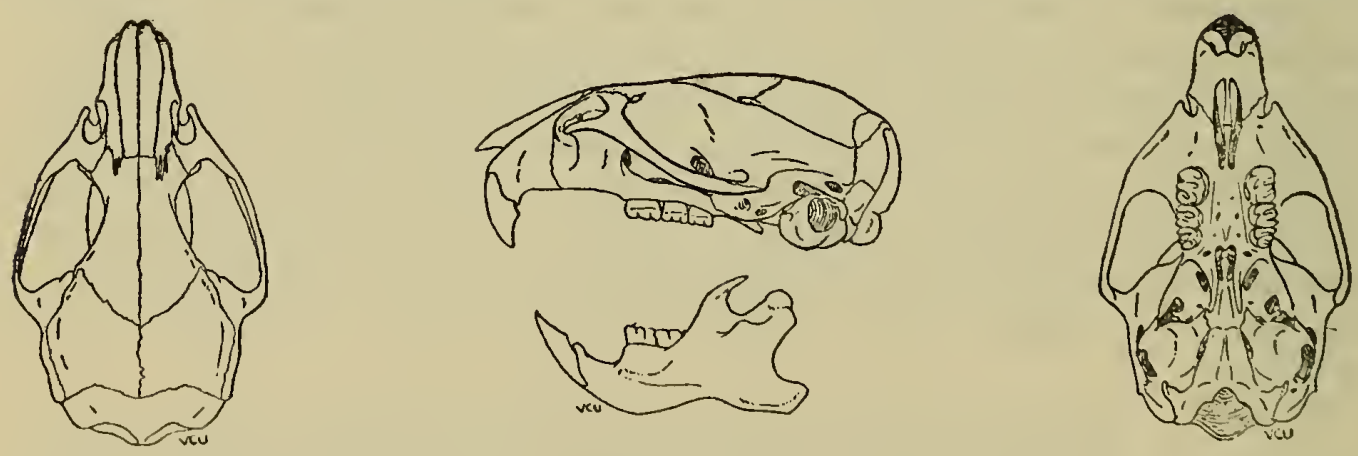

PLATE IX

Figs. 1-3. Three views of the skull of the type specimen of Sigmodon hispidus atratus. $\mathrm{X} 1$. 


\title{
BIOLOCICAL SOCIETY OF WASHINCTON
}

\section{A NEW BRUNFELSIA FROM BRAZIL}

\author{
BI C. V. MORTON
}

Investigations of the genus Brunfelsia (Solanaceae) have uncovered the following new species, previously misidentified.

\section{Brunfelsia amazonica Morton, sp. nov.}

Lamina foliorum oblongo-elliptica, apice abrupte acuminata, basi cuneata, subcoriacea, nitida, fere glabra; flores solitarii vel bini, pedicellis elongatis, curvatis, apice incrassatis; calyx campanulatus, irregulariter 5-lobatus, glaber; corolla hypocrateriformis, tubo crasso, limbo amplo, patente.

Shrub, branchlets subterete, about $3 \mathrm{~mm}$. in diameter, glabrous, shining, the cortex exfoliating, the internodes normally $1-2 \mathrm{~cm}$. long; petioles short, $3-5-\mathrm{mm}$. long, $1.5 \mathrm{~mm}$. thick, glabrous, transversely corrugate; leaf blades oblong-elliptic, 6-11 $\mathrm{cm}$. long, $2.5-4.5 \mathrm{~cm}$. broad, abruptly acuminate at apex, the apex itself rounded, entire, subcoriaceous, deep green, shining and glabrous above, beneath paler and glabrous except for scattered microscopic hairs, the lateral veins about 5 pairs, strongly arcuate and anastomosing well within the margin; inflorescence terminal, 1 or rarely 2 -flowered, the peduncle very short or none, the pedicels elongate, 15-19 $\mathrm{mm}$. long, stout, conspicuously thickened toward apex, glabrous; calyx green, campanulate, $9-12 \mathrm{~mm}$. long, glabrous, shining, irregularly 5-lobate, the lobes ovate, strongly unequal, 2.5-6 mm. long, acute; corolla whitish, hypocrateriform, about $3 \mathrm{~cm}$. long, the tube cylindric, $2-2.3 \mathrm{~cm}$. long, $2.5-3 \mathrm{~mm}$. thick, lacking an annulus within, glabrous, the limb spreading, $2.5 \mathrm{~cm}$. wide or more, the lobes subequal, ovate-orbicular, about $1 \mathrm{~cm}$. long, filaments adnate to corolla for most of their length, the shorter ones free for $3 \mathrm{~mm}$., the longer for $5 \mathrm{~mm}$., glabrous; anthers included, orbicular, the cells completely confluent; style glabrous, included; stigma bilobed; ovary conic, $2 \mathrm{~mm}$. long, glabrous.

Type in the U. S. National Herbarium, no. 1,693,434, collected at Estrada da Raiz, Manáos, State of Amazonas, Brazil, in secondary forest, March 24, 1937, by A. Ducke (no. 430). A second specimen with the same data but collected March 18, 1943, is also in the National Herbarium.

The type specimen was identified by Dr. Ducke as Brunfelsia guianensis Benth. ${ }^{1}$, a little-known species described from two specimens from French Guiana and Surinan, collected by Perrottet and Hostman (no. 1278) respectively. Certain details of the description suggested that Dr. Ducke's plant was misidentified and consequently Dr. Cotton was asked to supply

$$
\text { 29-Pro. BIOL. SOC. WAsH., VoL. } \frac{6 \%}{2} 1949
$$


a photograph of these two collections. He replied that he was unable to locate a Perrottet specimen at Kew, but that there were two sheets of the Hostman plant, one from the Bentham Herbarium. This sheet, which must be considered as the type of the species, Dr. Cotton very kindly lent for study. The specimen consists of a single branch, bearing 6 leaves, one complete flower and two old flowers represented by calyces only. The label reads, "1278 Brunfelsia guianensis Benth, in DC. Prod. 10:200, Arbor, fl. candidus, Surinam, Hostmann 1843.", Bentham's description of the fruit was doubtless taken from the Perrottet specimen, which is probably in the Paris Museum.

Brunfelsia amazonica is surely distinct from $B$. guianensis, the principal characters being shown in the following key:

Corolla tube very slender, about $0.8 \mathrm{~mm}$. thick; corolla limb about 1.5 $\mathrm{cm}$. wide; calyx about $6 \mathrm{~mm}$. long; pedicels straight, very short, 3-4 mm. long; leaf blades obovate, strongly attenuate at base, the lower surface bearing numerous miscroscopic hairs ... B. guianensis.

Corolla tube stouter, $2.5-3 \mathrm{~mm}$. thick; corolla limb $2.5 \mathrm{~cm}$. wide or more; ealyx about $9 \mathrm{~mm}$. long; pedicels curving, 15-19 mm. long; leaf blades oblong-elliptic, cuneate at base, nearly glabrous beneath.

B. amazonica.

IIn DC. Prodr. $10: 200.1846$. 


\section{Proceedings of the Biological Society of Washington}

(14 j) Amber Brown to between Burnt Sienna and Chestnut instead of Cinnamon Buff to between Yellow Ocher and Cadmium Yellow; in "gray" phase near (h) Clay Color instead of grayish to Avellaneous.

Remarks.-Natalus mexicanus has been recorded from Central America but by us no specimens have been examined from areas south of Mexico. Consequently we do not know the southern extent of the geographic range of the subspecies here newly named; we suppose that $N . m$. saturatus is the name applicable to Natalus mexicanus of Central America although the possibility is recognized that an unnamed subspecies occurs there.

Among specimens from the type locality of $N . m$. saturatus, the palest individual in the red phase is darker than the darkest individual in that phase from Baja California and Sonora. The one topotype of $N . m$. saturatus in the gray phase likewise is darker than any animals in the corresponding color phase from Baja California and Sonora. Intergradation is indicated by the intermediacy in color of a specimen in the United States National Museum from Mojaráchie, Chihuahua. In other features this specimen agrees with $N . m$. mexicanus. Seven specimens in the U. S. National Museum from Rosario, Sinaloa, and one from Itzatlan, Jalisco, are like $N$. m. mexicanus in length of tooth-row, length of skull, and contour of posterior part of roof of braincase. Only in color do they show some, but slight, approach to the darker $N . m$. saturatus. Finally, the specimen from eight kilometers northeast of Antiguo Morelos is slightly lighter than topotypes of $N . m$. saturatus and therein could be thought of as showing some approach to $N . m$. mexicanus. In other features, however, this specimen agrees with $N . m$. saturatus.

Natalus mexicanus saturatus, here newly named, is a strongly marked geographic race especially as regards color. It is noteworthy that of the 59 skins examined from the state of Veracruz (see below) only one (K. U. no. 17845) is in the gray phase; all the others are in the red phase.

Acknowledgment is made of assistance from the Kansas University Endowment Association with the field work which yielded the series of specimens from Sonora and from Veracruz. We are grateful to those persons in charge of the collections of the United States National Museum, the Biological Surveys Collection, and the Museum of Vertebrate Zoology for lending us comparative materials.

Measurements.-Average and extreme measurements, in millimeters, of ten adult females from the type locality, are as follows: Total length, 99 (96-105); length of tail, 49.6(47-52); ear from notch, 15.1(13-16); greatest length of skull, 16.2(16.0-16.6); zygomatic breadth, $8.3(8.1$ $8.4)$; interorbital constriction, $3.2(3.1-3.2)$; breadth of braincase, 7.7(7.6-7.9); maxillary tooth-row (including canine, 6.9(6.7-7.0); breadth across last upper molars, 5.3(5.1-5.3).

Specimens examined (Unless otherwise indicated in the Univ. Kansas Mus. Nat. Hist.).-Total number, 93, distributed by localities as follows: San Luis Potosí: $8 \mathrm{~km}$. NE Antiguo Morelos, $500 \mathrm{ft}$., 1. Veracruz: San Andreas Tuxtla, 1(U. S. Nat. Mus.) ; 3 km. E San Andreas Tuxtla, 88(including 10 skeletons and 20 alcoholics). Campeche: Apazote, 1 (U. S. Nat. Mus.); La Tuxpena, 2(U. S. Nat. Mus.).

Museum of Natural History, University of Kansas, Lawrence, Kansas. December 9, 1948 . 


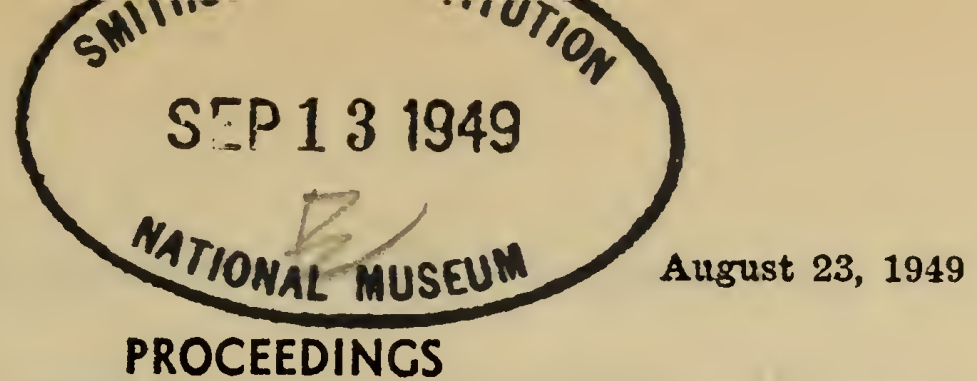

OF THE

BIOLOGICAL SOCIETY OF WASHINCTON

\title{
TWO NEW ORIOLES FROM THE PHILIPPINES
}

\author{
BY E. T. GILLIARD
}

During current studies of Philippine birds based on large comparative collections recently obtained by a joint expedition of the American Museum of Natural History and the National Museum of the Philippines to the peninsula of Bataan, two new races of Oriolus chinensis were found and the validity of a third form substantiated.

I am greatly indebted to Dr. Ernst Mayr who has read the manuscript for many valuable suggestions.

An examination of 130 Black-naped Orioles from the islands of Fuga, Luzon, Mindoro, Samar, Negros, Mindanao, Basilan and the Sulus reveals the existence of five well-marked races, two of which remain to be named. Racial characters are predicated on depth of yellow forehead, degree of yellow on primary coverts and inner secondary tips, and, to a minor degree, on size. Generally speaking, the yellow forehead becomes narrower (with consequent increase in width of black nape band), and the yellow tips of the primary coverts and inner secondaries decrease to the point of obsoletion from north to south (N. Luzon to Basilan Island). In dimensions the species tends to become larger than average in Northern Luzon, extreme Southern Luzou and in the Sulu Islands. Distinct racial populations inhabiting north-central Luzon in the north and the Mindanao-Basilan area in the south are about equal in size.

Adult males and females are bright yellow. Meinertzhagen's observation (Ibis, 1923:72) that adult females have "back green, not yellow, central rectrices green, not black," applies to subadult females and immature males. Sexual dimorphism, as noted for this species in the Philippines, is restricted to a slight mean difference in size, the females being smaller.

\section{Oriolus c. chinensis Linnaeus. Black-naped Oriole}

Oriolus chinensis Linn. Syst. Nat. 12th ed. i. 1766, p. 160: China (error), Cochinchina (ex. Brisson) = Manila, Meinertzhagen, (Ibis, 1923 , p. 72).

In assigning a precise type locality to this race Meinertzhagen (1923: 72) writes: ". . . the name chinensis is clearly applicable to one member of this group, which induces me to accept it for the Philippine bird, to which the deseription and plate most closely agree. In the days of Brisson, type-localities were very vague and the Philippines might easily 


\section{Proceedings of the Biological Society of Washington}

be held to be covered by the general term China. As the type locality of chinensis, I cite Manila."

Adult examples in the American Museum of Natural History from the vicinity of Manila ( $1 \hat{\delta}$, San Mateo; $1 \hat{\delta}$ San Juan, Laguna de Bai; 5 to $\hat{o}, 4$ $q$ $q$, Lamao, Bataan) agree well together. However, they are quite different from a long series of specimens from Sorsogon, extreme southern Luzon, and from a single specimen from Fuga island off the northern tip of Luzon, both of which are described below. In fact, the characters distinguishing each of the three races are sufficiently vivid to permit accurate field identification.

\section{Oriolus chinensis fugaensis new subspecies}

Type: No. 670475. American Museum of Natural History (Rothschild Collection). $q$ ad. Fuga Island, off the coast of northern Luzon, Philippine Islands, April 15, 1895. Whitehead Collection.

Diagnosis: Nearest to chinensis but differing by reason of much more extensive yellow forehead patch and longer wings (see table of measurements). In chinensis the forelead patch is never more than $23 \mathrm{~mm}$. in depth, terminating on the center-line of the crown just behind the eyes. In fugaensis the patch is $30 \mathrm{~mm}$. deep terminating on the occiput.

Measurements of type: Wing $159 \mathrm{~mm}$; tail 104; bill from anterior edge of nostril 25 ; tarsus 29.

Range: Known only from the type locality.

\section{MEASUREMENTS}

fugaensis

1 \& Fuga Island

chinensis

3 우 Lamao, Bataan

5 f of Lamao, Bataan

1 s San Mateo, N. of Manila

1 ô San Juan, E. of Manila

sorsogonensis

7 ô ô Sorsogon

6 \& $q$ Sorsogon

5 ô $\delta$ Tayabas

2 \& $q$ Tayabas

4 ô $\hat{o}$ Mindoro Island

yamamurae

1 ô Samar Island

1 \& Negros Island

5 ô $\delta$ Mindanao Island

2 of $\hat{\delta}$ Basilan Island suluensis

3 ô $\hat{o}$ Sulu Islands

\begin{tabular}{lll}
\multicolumn{1}{r}{ Wing } & \multicolumn{1}{c}{ Tail } & \multicolumn{1}{c}{ Bill } \\
159 & 104 & 25 \\
& & \\
$148-154$ & $96.5-100$ & $24-25$ \\
$151.5-155$ & $98.5-105$ & $24-26$ \\
154 & 101 & \\
156 & 102.5 & 25 \\
& & \\
$156-164$ & $102-111$ & $24.5-26.5$ \\
$149-157.5$ & $98-104$ & $24.5-26$ \\
$154.5-159$ & $103.5-106.5$ & $24.5-26$ \\
154 & $103-105$ & $24.3-27$ \\
$155-160$ & $103-105$ & $25-27$
\end{tabular}

$158 \quad 102 \quad 26.5$

$\begin{array}{lll}157 & 108 & 25\end{array}$

153-156.5 $\quad 100-106 \quad 25-28$

$154-155 \quad 101-105 \quad 25-27$

14\$-156.5 111-118 25-26

It is remarkahle that the population of chincnsis inhabiting the southernmost portion of Luzon should differ from birds living about Manila. Perhaps an explanation is to be found in the fact that the species chinensis thrives in the semi-open lowlands and is restricted both by 
forested hills of moderate height and by belts of original tropical jungle. In this connection it is pertinent to note that a series from Infanta, on the eastern coast of Luzon at approximately the same latitude as that of Manila, which lies on the western coast, is closely similar to the southern Luzon race, now to be described:

\section{Oriolus chinensis sorsogonensis, new subspecies}

Type: No. 94316. American Museum of Natural History. $\hat{o}$ ad. Sorsogon, southern Luzon, Philippine Islands. March 22, 1903. Collected by Dr. E. H. Porter.

Diagnosis: Similar to chinensis but with a much narrower yellow forehead and perceptibly larger wings and tail (see table of measurements). The yellow forchead patch is never more than $16 \mathrm{~mm}$. deep with a maximal terminal point on the mid-crown between the eyes.

Measurements of the Type: Wing $159.5 \mathrm{~mm}$; tail 106; bill from anterior edge of nostril 26; tarsus 29.5.

Range: Southern Camarines province, Luzon. A series from northern Camarines (Tayabas) contains a few intermediates but in general is more closely related to sorsogonensis. This is true of 4 Mindoro $\hat{\delta} \hat{\delta}$ which agree in size with Sorsogon $\hat{\delta} \delta$ but hare somewhat larger yellow forehead patches; as observed in the series of $\delta \hat{\delta}$ from Tayabas. This race probably ranges to the islands of the Sibuyan Sea. One Samar island $\hat{\delta}$ before me is intermediate between sorsogonensis and yamamurae but closer to the latter. It agrees with Sorsogon birds in size and depth of vellow forehead but retains the distinct black wings of the southern form.

\section{Oriolus chinensis yamamurae Kuroda}

Oriolus chinensis yamamurae Kuroda, 1927. Tori, vol. 5, no. 23, p. 257, (Basilan Island).

Five $\hat{o} \hat{o}$ form Mindanao and 2 ô $\hat{o}$ from Basilan Island are similar. Together they differ considerably from all other Philippine races by having wings black without yellow tipping on primary coverts and inner secondaries. Although described as differing from the nominate form mainly by smaller size, there is no appreciable difference, as pointed out by Mayr in Delacour and Mayr, 1945: Zoologica, Vol. 30, pt. 3, Nov. 15, 1945 , p. 117).

In coloration yamamurae is similar to suluensis from which it differs by reason of a much shorter tail. It differs from the nominate form by having a much narrower forehead patch (not exceeding $12.5 \mathrm{~mm}$. in depth) and, in this respect, is but slightly smaller than sorsogonensis which has the forehead patch not exceeding $16 \mathrm{~mm}$.

Range: Mindanao and Basilan Islands. Also Samar? and Negros?

Remarks: A single Negros Island $o$ before me is slightly larger (wing and tail) than any in the Mindanao-Basilan series, but otherwise it is similar. 
158 Proceedings of the Biological Society of Washington 
rini describes his species as " $\mathrm{E}$ di un color rosso carico di sangue 0 pavonazzo." The species described by Walker is a homonym of the species described by Contarini and if not a synonym the next available name is that of Macrosiphoniella staticis Theobald.

In his 1887 work Oestlund names a "pale red or pinkish" aphid taken on the roots of Trifolium repens, Aphis trifolii. There is no formal description of the species nor are specimens in the Oestlund collection of the University of Minnesota, of this date under this name. One would be inclined to consider this species a nomen nudum where it not for the fact that Davis, 1908 in a discussion of Aphis bakeri Cowen inentions sending specimens determined as trifolii to Oestlund and of his reply as follows: He believed the specimens to be the same species described by him some twenty years ago and named Aphis trifolii; though he had never seen the adult form before, either spuriæ or migrants and his original description was based only on the larvæ. The Davis slides remain in the Oestlund collection and it is from these that a new lectotype for the species should be selected.

It is true that Oestlund described trifolii as a subterranean species and one feeding on the roots which is not true of $A$ phis bakeri. It is obvious however that Oestlund was not the original collector and thus relied on the uncritical observations of another, who may have taken the shedlike structures often constructed by ants over the basal parts of the stems and erown of the plant for the surface of the soil.

Despite the fact that there is almost no possibility of supporting the contention that Aphis bakeri Cowen is a synonym of Aphis trifolii Oestlund on the presence of preserved specimens, on the basis of the entire agreement as to color and on Oestlunds statement to Davis that he believed specimens sent him by Davis to be the species described by him as trifolii Aphis bakeri Cowen is declared a synonym of Aphis trifolii Oestlund.

\section{BIBLIOGRAPHY}

Contarini, Nicola Bertuccr.

1847. Venezia E Le Sue Lagune. Volume Secondo p. 190. Copy CURTIS, JOHN. in Library of Congress.

1835. British Entomology Vol. XII part 577.

Davis, J. J.

1909. Studies of Aphididæ I. Annals of the Entomological Society of America Vol. II, no. I,p. 259.

LAMBers, D. Hille Ris.

1939. Contributions to a Monograph of the Aphididæ of Europe. Temminckia Vol. IV, p. 69.

MENKE, KARL THEODOR.

1818. Pyrmont und seine Amgebungen mit besonderer Rücksicht auf seine Mineralquellen, historish, geographish und medicinish dargestellt . p. 152. Copy in John Crerar Library Chicago.

Oestuund, O. W.

1887. Synopsis of the Aphididæ of Minnesota. Bulletin No. 4 Geographical and Natural History Survey of Minnesota. p. 55 .

RAFINESQUE, C. S.

1814. Précis Des Découvertes Somiologiques ou Zoologiques et Botaniques. Palerme. p. 28. Copy in Library United States Department of Agriculture.

SCHUMACHER, F.

1918. Deutung der von Contarini als neu beschriebenen HemipteremArten. Entomologische Mitteilungen. Band VII, Nr. I/3

WALKER, F. pp. 32-34.

1852. List of Specimens of Homopterous Insects in the collection of the British Museum, part IV, p. 957. 
2

Vol. 6\%, pp. 161-162

August 23, 1949

PROCEEDINGS

OF THE

BIOLOGICAL SOCIETY OF WASHINGTON

\section{AN ADDITIONAL FORM OF THE SOUTH AMERICAN GRASSHOPPER SPARROW}

BY ALEXANDER WETMORE

A recent check on the forms of the South American Grasshopper Sparrow, Myospiza humeralis has brought to attention a very distinct subspecies, hitherto unrecognized, in collections made in the arid Guajira Peninsula of northeastern Colombia and northwestern Venezuela. The new form may be known as

Myospiza humeralis pallidula, subsp. nov.

Characters: Similar to IIyospiza humeralis humeralis (Bose) 1 but decidedly paler above, with the dark streaking much reduced both on back and crown, the brown edgings more extensive and lighter in color, and the gray tones lighter; sides and flanks paler; definitely lighter colored than any of the other known races.

Description: Type, U. S. Nat. Mus. No. 370,276, male adult, from Maicao, Guajira, Colombia, taken April 14, 1941, by A. Wetmore and M. A. Carriker, Jr. (orig. no. 11,385). Center of crown pale smoke gray, bordered on either side by broad darker bands where the feather centers are dull black bordered narrowly with pale smoke gray anteriorly, the paler border replaced posteriorly by edgings of sayal brown that become progressively broader, until at the level of the center of the crown they largely replace the black; superciliary line from base of bill to about center of eye wax yellow, changing then to pale smoke gray; hindneck, back and rump sayal brown, with edgings of pale smoke gray; middle of back with restricted median dull black streaks; rump and upper tailcoverts wood brown, with slightly paler edgings and concealed darker shaft streaks; bend of wing empire yellow, changing to pale lemon yellow beneath the alula; primaries and secondaries fuscous; wing-coverts vinaceous-buff changing externally to tilleul-buff, with concealed portions dull black; primary coverts fuscous, edged lightly with vinaceous-buff; primaries edged narrowly with tilleul-buff; secondaries bordered broadly with sayal brown, this edging changing distally to tilleul-buff; rectrices fuscous, edged narrowly with tilleul-buff, and tipped indistinctly with dull vinaceous-buff; lores and space around eye dull grayish white; cheeks light grayish olive, with a narrow post-ocular streak of sayal brown; throat, lower breast and abdomen dull white; upper breast and sides dull light buff; flanks and under tail-coverts dull pinkish buff; under wing-coverts white; inner webs of primaries toward base vinaceous-buff as seen from underneath. Maxilla fuscous-black, mandible light drab; tarsus and toes wood brown (from dried skin).

Measurements: Male, type, wing 58.2, tail 48.0 , culmen from base 11.4, tarsus $19.2 \mathrm{~mm}$.

Females (2 specimens), wing 56.0-56.7, tail 44.1-44.4, culmen from base 11.7-11.9, tarsus 19.3-19.8 mm.

Range: The Guajira Peninsula, where recorded at Maicao, Puerto

1 Tanagra humeralis Bosc, Journ. Hist. Nat. (Choix des Mém.), vol. 2, no. 17, September 1, 1792, p. 179, pl. 34, fig. 4. (Cayenne.).

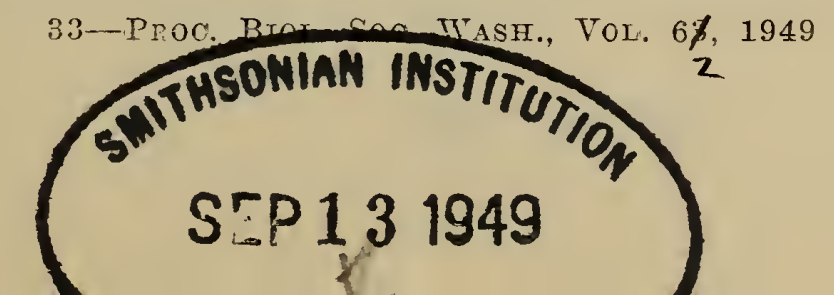


López and Puerto Estrella, Colombia, and at Paraguaipoa, Zulia, Venezuela.

Remarks: In the vast range of Myospiza humeralis, from Colombia and Venezueia south to northern Patagonia, there is considerable individual variation within comparatively narrow limits, but except for the new form here described, relatively slight differences that can be correlated with geographic distribution as a basis to separate subspecies. One of the principal individual variants, found mainly in $M . h$. humeralis, is an occasional example of a slightly rufescent phase. The more northwestern birds in northern Colombia are darker, and are recognized as the subspecies columbiana. The more southern ones are grayer and are separable as xanthornus. The race tarijensis, which is not available to me at the moment, as said to resemble xanthornus but to differ in slightly larger size. Other names that have been proposed fall as synonyms.

It has been a matter of note therefor to find that the Guajira birds are set apart from all others, completely and definitely, by their decidedly paler coloration. This is especially remarkable when it is recalled that many regions in the far south inhabited by these birds are equally arid. While Carriker and I prepared only three specimens, these differ so radically from all others seen that $I$ have no hesitance in describing them as a new form. In fact I find that I noted in my journals their pale color when seen in life. The three that we secured come from Maicao and Puerto López where the birds were fairly common. Others were seen at Puerto Estrella to the north of the point last mentioned.

W. H. Phelps, Jr., has kindly compared for me two males in the Phelps Collection from Paraguaipoa in the Venezuelan section of the Guajira Peninsula, his observations demonstrating that these two birds are pallidula as indicated by their paler color. This point is probably near the southern limit of the race. 


\subsection{3}

Vol. $6 \beta^{2}$, pp. $163-164$

BIOLOGICAL SOCIETY OF WASHINGTON

\section{A NEW HARVEST MOUSE FROM MICHOACAN, MEXICO}

By E. Raymond Hall and Bernardo Villa R.

In preparing a check-list of the mammals of the state of Michoacan we have had occasion to identify some harvest mice of the species Reithrodontomys chrysopsis, which species lives mostly on the upper slopes of the higher volcanoes of the southern edge of the table land of Mexico. In 1914 when Howell (N. Amer. Fauna No. 36) revised the genus Reithrodontomys, he had a total of only 27 specimens of the species $R$. chrysopsis. Twenty-five of these, including 7 from Mount Tancítaro, in Michoacán, he referred to the subspecies $R$. $c$. chrysopsis. From this westernmost record station of occurrence, J. S. Candy in 1940, and F. C. Wonder in 1941, obtained in all 22 specimens at elevations of 6000 to 11000 feet. This series shows well the variation with age and reveals, in comparison with topotypes of Reithrodontomys chrysopsis chrysopsis Merriam, from Mount Popocatepetl, that the animals on Mount Tancitaro pertain to an heretofore unnamed subspecies which may be characterized and named as follows:

Reithrodontomys chrysopsis seclusus, new subspecies

Type--Male, adult, skin and skull; no. 52114 Chicago Nat. Hist. Mus. (4th Hoogstrool Mexican Biol. Expedition); Mount Tancítaro, $7800 \mathrm{ft.}$ Michoacán, Mexico; June 30,1941; obtained by F. C. Wonder, original no. 1036.

Range.-Mount Tancítaro, Michoácan, 6000 to 11000 feet or higher.

Diagnosis.-Size small (see measurements); color near $\left(14^{\prime} j\right)$ Cinnamon-Brown (color terms after Ridgway, Color Standards and Color Nomenclature, Washington, D. C., 1912) on upper parts and sides; overlaid with blackish on back; in some specimens suggestion of OchraceousTarny lateral line; braincase globular; upper molars with accessory cusps between main cusps.

Comparison.-From three January-taken topotypes of $R$. c. chrysopsis, seclusus differs as follows: Body, hind foot and ear shorter; color everywhere darker red, that is to say, nearer Cinnamon-Brown than Ochraceous-Tawny; skull averaging larger in every measurement taken except least interorbital constriction which is more; consistently smaller in hasilar length, mastoid breadth, alveolar length of upper molar tooth- 


\section{Proceeding of the Biological Society of Washington}

row and postpalatal length. Specimens of equal age, as judged by amount of wear on the first upper molar, were used in comparisons; the differences, therefore, are not ascribable to age.

Remarks.-Our topotypes of $R$. c. chrysopsis are in full winter (January) pelage whereas all the specimens of $R$. c. seclusus were taken in June and July. Therefore, the differences in color mentioned above may be of seasonal rather than geographic significance. The pelage of seclusus is the shorter and its tail is less heavily haired. The ears of R. c. chrysopsis are blackish whereas those of seclusus are reddish, and we doubt that this difference is seasonal. However this may be, the lesser size and cranial differences serve fully to permit of differentiating seclusus from $R$. c. chrysopsis. We have no specimens available of $R$. $c$. tolucae, $R$. c. perotensis or $R$. c. orizabe but of these subspecies, tolucae and perotensis are lighter-colored (instead of markedly darker) than chrysopsis, and orizabe was said in the original description to be of the same color as chrysopsis, but by Davis (Journ. Mamm., 25:394, 1944) to be a synonym of $R$. c. perotensis. $R$. c. seclusus, therefore, is the darkest of the four geographic races which now are recognized.

We thank Messrs. Karl P. Schmidt and Colin C. Sanborn of the Chicago Natural History Museum for the opportunity to study the specimens from Tancítaro, are grateful to the University of Kansas Endowment Association for funds supporting the field work which was productive of the topotypes of $R$. c. chrysopsis, and to the Comision Impulsora y Coordinadora de la Investigación Cientifica for assistance with the investigation of Mexican mammals.

Measurements, in millimeters, of topotypes of two subspecies of Reithrodontomys chrysopsis

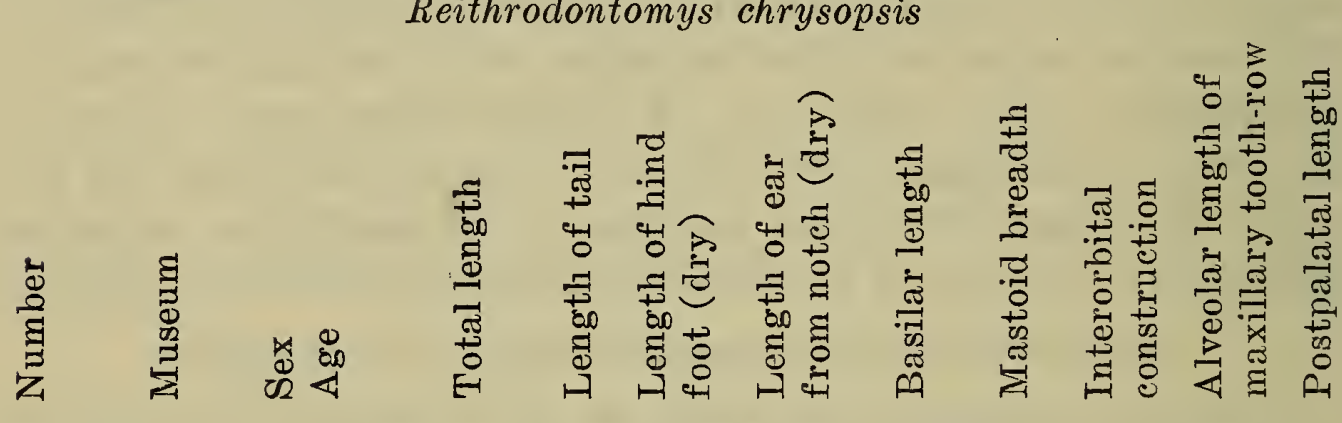

51411 Chi.M. ô ad.

R. c. seclusus, Mt. Tancítaro, $7800 \mathrm{ft}$.

$\begin{array}{lllllllll}173 & 98 & 19.5 & 15.9 & 17.3 & 10.4 & 3.3 & 3.5 & 7.5\end{array}$

$\begin{array}{lllllllllll}52114 & \text { Chi.M. } \hat{o} \text { ad. } & 173 & 100 & 19.1 & 14.1 & 17.0 & 10.5 & 3.3 & 3.6 & 7.3\end{array}$

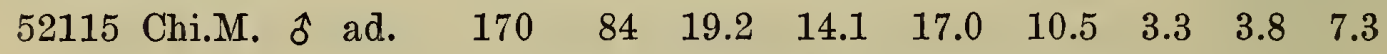

R. c. chrysopsis, Popocatepetl, $3450 \mathrm{mts}$.

$\begin{array}{llllllllllll}1681 & \text { B.V.R. } \hat{o} & \text { ad. } & 173 & 95 & 19.9 & 17.5 & 17.8 & 10.8 & 3.1 & 3.9 & 7.9\end{array}$

$\begin{array}{llllllllllll}1688 & \text { B.V.R. } \text { \& } & \text { ad. } & 182 & 94 & 20.0 & 17.5 & 17.8 & 10.9 & 3.1 & 4.0 & 7.9\end{array}$

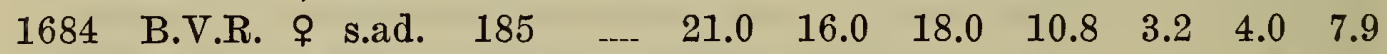

$\begin{array}{llllllllllll}17980 & \text { K.u. } & \text { q ad. } & 189 & 107 & 20.0 & 19.0 & 18.0 & 10.7 & 3.2 & 3.9 & 8.2\end{array}$

Specimens examined.-Twenty-two, all from Mount Taneítaro, Michoacán, distributed by altitude as follows: $6000 \mathrm{ft} ., 5 ; 7800 \mathrm{ft} ., 10 ; 10500$ ft., 1; $11000 \mathrm{ft.}$, ; no altitude recorded on label, 5 .

Contribution from the Institute de Biologia de la Universidad de Mexico and the Museum of Natural History of the University of Kansas.

Transmitted August 9, 1949. 


\title{
PROCEEDINGS
}

\section{OF THE \\ BIOLOGICAL SOCIETY OF WASHINCTON}

\section{A NEW TRIMETOPON (OPHIDIA) FROM GUATEMALA}

\author{
By L. C. STUART
}

Laboratory of Vertebrate Biology, University of Michigan

During the course of investigating the herpetofauna of the southwestern highlands of Guatemala in 1947, the writer had the opportunity to spend some ten days at a coffee finca on the Pacific slopes. While raking in the mulch that accumulates in the coffee groves, I encountered, along with Rhadinaea lachrymans, Ninia s. sebae, Geophis nasalis, and Adelphicos q. sargii, a small snake which appears to be new to science, and may be assigned tentatively to the genus Trimetopon Cope.

As investigations into the nature and composition of the Middle American ophidian groups allied to the genus Rhadinaea Cope have progressed, the genus Trimetopon has become increasingly difficult of definition. Originally diagnosed as possessing a single prefrontal and a reduced number of dorsal scale rows (15), the genus has been redefined to include species with two prefrontals and 17 scale rows. Dunn ${ }^{1}$ essayed a redescription of the group on the basis of the four species known to him at the time. Since then two Trimetopons have been named and in this paper I add another two. As the genus now stands, therefore, it cannot be differentiated from Rhadinaea, though it is possible that a reexamination of all material may reveal some hemipenial or tooth character by which the genus may be defined. In the opinion of the writer, however, the genus represents an unnatural group of species which appear to have had independent origins, in part at least, from several Rhadinaean ancestors, or, rather, Rhadinaean-like prototypes.

Not withstanding, the writer believes that, on the basis of our present knowledge, the genus is of value. In assembling under it a group of forms which in morphological characters and habits show some similarity and which would, for the present, confuse rather than clarify the nature of some other genus into which they might be forced, Trimetopon is worthy of recognition if its possible shorteomings are kept in mind. For my good friend and hospitable host, Señor don Walter Hannstein of Finca La Paz and Panajachel, I am, therefore, pleased to name

\section{Trimetopon hannsteini new species}

Holotype.-University of Michigan, Museum of Zoology No. 98756. An adult male collected at Finca La Paz (18 kilometers [straight line]

IDunn, E. R., "Newormamed Snakes from Costa Rica." Copeia, 4, 1937: 214-15. Tisolilat IHSTIT

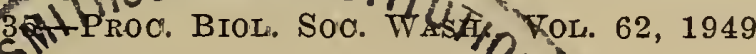


due north of Coatepeque), Department of San Marcos, Guatemala, May 14, 1947. Elevation, 1,450 meters.

Paratypes.-University of Michigan, Museum of Zoology Nos. 9875355, 98757. Collected with the holotype.

Diagnosis.-A small snake differing from all other species currently included in Trimetopon in possessing two prefrontals (eliminates gracile and simile), 17 dorsal scale rows (eliminates barbouri), eight supralabials (eliminates posadasi, slevini, and viquezi), and a single postocular (eliminates veraepacis, discussed below).

Description of holotype.-A full colubrine complement of normal head scutes. Rostral broader than high; visible from above. Two internasals; broader than long and only about one-half as long as the paired prefrontals. Frontal pentagonal; longer than its distance from the tip of the snout. Supraoculars long and narrow; equal in length to the prefrontals. Nostril between two nasals. Loreal slightly longer than high. One pre- and one postocular. Temporals $1+2$. Eight supralabials, the fourth and fifth entering the eye. Eight infralabials, four in contact with the anterior chin shields which are longer than the posterior ones. Eleven slender teeth on the maxilla; increasing in size posteriorly. These followed by a diastema (?) behind which lie two stout, slightly enlarged teeth. Dorsal scales without apical pits, in 17 longitudinal rows throughout the body length. Abdominals 147; pre-anal divided; subcaudals 70 . Supra-anal scales with low, but definite keels. Body length, $232 \mathrm{~mm}$.; tail length, $92 \mathrm{~mm}$.

The hemipenis of the species is short, extending only to the sixth subcaudal in the inverted position. In contrast to Cope's figure ${ }^{2}$ of that of T. pliolepis ( = gracile) which is colubrine in structure, the hemipenis of $T$. hannsteini is typically xenodontine with a divided sulcus spermaticus, slightly bifurcate distally, and capitate or at least moderately so. The sulcus lies on the medial side of the organ and originates occasionally as two groves which join as the calyculate portion of the hemipenis takes form, and bifurcates about halfway up the length of the organ. The medial side of the hemipenis, except for one or two large spines flanking the sulcus at its base, is entirely calyculate. The lateral side, except at the very tip, is spinous. On this latter side there are two large basal hooks concealing two smaller ones. Above these basal hooks are two patches of small spines separated by a naked area. Proximally these spines are scattered or arranged into three irregular rows which merge into a single row distally where the spines become shorter and more slender. Each spinous patch is comprised of about 25 individual spines.

Inasmuch as the color of the holotype is somewhat darker than that of the paratypes, its pattern is difficult to discern. The top and sides of the head are dark brown minutely flecked with lighter shades; each supralabial with an irregular white spot. The lower jaw is cream-color heavily dusted with brown on the infralabials. There is a trace of a white collar on the nape which is definitely apparent only ventro-laterally and is merely indicated dorsally by light spots. Ground color of the dorsum dark brown flecked with lighter shades. There are nine longitudinal stripes on the dorsum which are produced by a darkening of certain portions of the various scale rows, and which are disposed as follows:

"Cope, E. D., "The Classification of the Ophidia," Trans. Amer. Philos. Soc., 18, 1895: Pl. 20, Fig. 1. 
lateral edges of the abdominals and the ventral one-quarter of scale row one; dorsal one-half of scale row one and ventral one-half of scale row two; dorsal one-half of scale row three and ventral one-half of scale row four; dorsal one-half of scale row five, all of scale row six (except for light flecks on its center) and the ventral one-half of scale row seven; center one-half of the vertebral scale row. Undersurfaces of tail and body, except for the edges of the abdominals, immaculate creamcolor.

Variation.-The paratypes are like the holotype in all essential features. Ventral scutellation varies as follows:

$\begin{array}{cccc}\text { Number } & \text { Sex } & \text { Abdominals } & \text { Subcaudals } \\ 98755 & \hat{\circ} & 144 & \text { broken } \\ 98753 & \hat{o} & 141 & 72 \\ 98754 & \text { ᄋ } & 150 & 63 \\ 98757 & \text { ㅇ Juv. } & 153 & 66\end{array}$

Of the nature of the maxillary dentition of this species I cannot be certain. In Nos. 98754 and 98756 there appears to be a diastema, though this may be a space left by a shed tooth. In Nos. 98753 and 98755 there is no indication of a diastema. In all the specimens the last two or three teeth are stouter than the others. The total tooth count varies 10-13.

The only other variability in the type series worthy of note is the color. The holotype is by far the darkest of the lot. The pattern of the paratypes is, therefore, more apparent than in the holotype, especially the white collar.

Comments. - I have previously noted that a species described by Stuart and Bailey ${ }^{3}$ under the name of Rhadinaea veraepacis might better be allocated to the genus Trimetopon. I take this step at the moment because in its general features the species is very similar to others assigned to this same genus. It was noted in the original description that veraepacis was something of a waif in the Rhadinaea picture. It is, however, not very different from hannsteini and may well be related to it. Dunn ${ }^{4}$ has already suggested a barbouri-viquezi-slevini chain. Thus three very definite groups might be sorted out in the genus as now constituted. Based upon a very little material personally examined and upon the literature ${ }^{5}$ relating to the genus, it may be summed up as follows :

A. A single prefrontal

B. Ventrals 151-154 B

BB. Ventrals 122
A. Two prefrontals

gracile simile

C. Dorsal scales in 15 longitudinal rows barbouri

CC. Dorsal scales in 17 longitudinal rows $\mathrm{D}$

3Stuart, L. C., and Joseph R. Bailey, "Three New Species of the Genus Rhadincea from Guatemala." Occ. Papers Mus. Zool. Univ. Michigan, 442, 1941: 9 .

"Dunn, E. R., "New and Noteworthy Herpetological Material from Panama." Proc. Acad. Nat. Sci. Phila., 92, 1940: 118.

DDunn, E. R., "New Snakes from Costa Rica and Panama." Occ. Papers

Boston Soc. Nat. Hist., 5. 1930: 330-32.

Dunn, op. cit., 1937 "and 1940. . 23 (4), 1936: 79-81.

Stuart and Bailey, op. cit. 
168 Proceedings of the Biological Society of Washington

D. Seven supralabials

E. A single postocular $\mathrm{E}$

EE. Two postoculars posadasi

F. Paired light spots on nape; no dark stripe on scale row 4 slevini FF. No light nape spots; a dark stripe on scale row 4 viquezi

DD. Eight supralabials

G. A single postocular

hannsteini

GG. Two postoculars veraepacis

Acknowledgements.-For their courtesy in submitting their opinions on the species described herein, I wish to thank Dr. Joseph R. Bailey of Duke University and Dr. E. R. Dunn of Haverford College. 
PROCEEDINGS

OF THE

BIOLOGICAL SOCIETY OF WASHINGTON

\section{A NEW SUBSPECIES OF HARVEST MOUSE (REITHRODONTOMYS) FROM CENTRAL AMERICA}

BY EMMET T. HOOPER

University of Michigan Museum of Zoology

The excellent series of specimens of harvest mice obtained in El Salvador by R. A. Stirton and associates at the University of California makes possible clear appraisal of variation in the species Reithrodontomys mexicanus in that part of Central America. To judge from those specimens, several populations of $R$. mexicanus in El Salvador differ from one another in external and cranial features. Each is partly or completely isolated by inhospitable terrain. As now sampled, however, none alone appears to be sufficiently unique to warrant recognition by name, for reasons that will be given in a detailed treatment of the genus now in preparation. Instead, by reason of morphological features common to all, in contrast to those of other populations of $R$. mexicanus, they may be considered conveniently as comprising one geographic race, which may be known as

\section{Reithrodontomys mexicanus orinus, new subspecies}

Type.-Adult male, skin and skull, No. 98459, Univ. Calif. Mus. Vert. Zool.; El Salvador, Dept. Sonsonate, about 12 miles southeast of Sonsonate, near summit of Balsam Range, Hacienda Chilata, elevation 2,000 feet; collected 12 May 1942 by M. Hildebrand; original No. 1465.

Distribution.-Mountain slopes of El Salvador and of southeastern Guatemala. Known range from San Rafael and Lago de Amatitlan, Guatemala, southeast in the coastal chain of volcanoes to the Balsam Range, El Salvador, and southeast on the southern flanks of the interior highlands of El Salvador as far as Cerro Cacaguatique. Vertical range from 2,000 feet at Hacienda Chilata to 6,400 feet on Los Esesmiles, El Salvador.

Characters and Comparisons.-Upper parts Ochraceous-Tawny or Tawny (Ridgway, Color Standards and Color Nomenclature, 1912), the tawny bands of the underfur but slightly obscured by the black bands of the comparatively few guard hairs. Underparts white or creamy white, the hairs Dark Plumbeous basally, except on throat where they are white throughout. A blackish eye ring. Ears Cinnamon-Drab to Fuscous. A longitudinal, Fuscous stripe of varying width and length on the upper surface of ewch forefoot and hind foot, the remainder of the

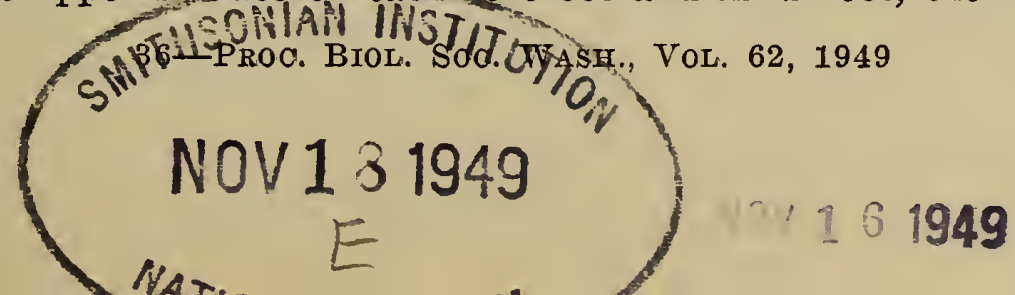




\section{Proceedings of the Biological Society of Washington}

upper surface white. Tail Fuscous, and monocolor or slightly paler ventrally. Skull of moderate size (for the species) with shallow brain case, long rostrum and incisive foramina, small molar teeth, and small auditory bullae.

$R . m$. orinus resembles $R . m$. lucifrons in body size, and both races are characterized by bright tawny coloration, which in full adult pelage compares favorably with that of Peromyscus nuttalli aureolus. The upper parts of the race orinus, however, average paler and the underparts are usually white, rather than Light Pinkish Cinnamon as in lucifrons. Cranially, orinus differs from lucifrons as follows: shallower brain case; relatively ${ }^{1}$ longer rostrum (averages 91 . per cent of brain ease depth in orinus and 87 per cent in lucifrons); shorter palate; longer incisive foramina (average 50 per cent of brain case depth, compared with 47 per cent in lucifrons); and smaller auditory bullae.

From howelli, orinus differs in larger size, paler upper parts (the orange bands similar in hue but the black bands more abundant), relatively broader zygomata, narrower and longer rostrum, longer palate, and smaller auditory bullae.

Compared with orinus, ocotepequensis is smaller and much darker dorsally; it has a shorter tail and smaller skull, with relatively smaller brain case, narrower zygomata and larger auditory bullae.

Measurements.-Averages and extremes, in millimeters, of six adult topotypes: total length, 181 (175-187); tail vertebrae, 108 (100-126); hind foot, 19 (18-21). Greatest length of skull, 23.1 (22.6-23.4); zygomatic breadth, 12.0 (11.5-12.6); breadth of brain case, 11.0 (10.7-11.4); depth of brain ease, 8.6 (8.2-8.9); interorbital breadth, 3.6 (3.4-3.7); breadth of rostrum, 4.2 (3.9-4.3); length of rostrum (from notch, near lacrimal, on anterior inner border of zygomatic arch anteriorly to tip of nasal), 8.3 (8.0-8.8); length of hard palate, 3.4 (3.2-3.5); length of incisive foramen, 4.3 (4.1-4.6); alveolar length of molar row, 3.2 (3.2-3.3); least transverse breadth of zygomatic plate, 1.6 (1.4-1.7); breadth of mesopterygoid fossa, 1.5 (1.4-1.8)

Remarks. $-R$. $m$. orinus lives in comparatively arid parts of El Salvador and southeastern Guatemala. The diagnostic characters of the race apparently are best developed in southwestern El Salvador, as indicated by specimens from Hacienda Chilata and Volcán de Santa Ana. Those from Chilata are the palest and have the most distinctive crania: relatively broad zygomata; shallow, posteriorly depressed brain case; long rostrum and incisive foramina; slight molar teeth, and small auditory bullae. The examples from Volcán de Santa Ana have larger molars and average slightly darker dorsally, but are otherwise similar. Away from those two localities, to the north (Los Esesmiles), east (Cerro Cacaguatique) and northwest (San Rafael and Lago de Amatitlan), the pelage color averages slightly darker, the eranium deeper, and the rostrum shorter.

Specimens examined.-A total of 50 from the following localities:

EL SALVADOR: Dept. Chalatenango: Los Esesmiles, 6,400 ft., 12. Depts. Morazan and San Miguel: Cerro Cacaquatique, 3,500-4,800 ft., 22. Dept. Sonsonate: Hacienda Chilata, 2,000-2,600 ft., 7; Volcán de Santa Ana, 4,500-5,000 ft., 4.

\footnotetext{
IIn these comparisons the term "relatively" implies: with respect to depth of brain case.
} 
GUATEMALA: Dept. Guatemala: Lago de Amatitlan, 4,200 ft., 4; San Rafael, 5,000 ft., 1.

(The above-listed specimens are from collections as follows: all from El Salvador, Museum of Vertebrate Zoology, University of California; from Amatitlan, Fish and Wildlife Service Collections of the U. S. National Museum; from San Rafael, Chicago Natural History Museum.) 
172 Proceedings of the Biological Society of Washington 


\title{
PROCEEDINCS
}

OF THE

\section{N 4 - 1950 BIOLOCICAL SOCIETY OF WASHINGTON \\ NAL MUSEUII}

A NEW RACE OF RALLUS NIGRICANS FROM COLOMBIA

\author{
BY BOARDMAN CONOVER
}

For some time I have been aware that specimens of Rallus nigricans from Colombia in my collection differed from a series from Paraguay and Brazil. However, press of other work has kept me before this from making more than a superficial examination of the series. A more thorough investigation has now convinced me that the Colombian birds deserve to be named.

I wish to thank the American Museum of Natural History and the Philadelphia Academy of Natural Sciences for the loan of specimens.

\section{Rallus nigricans caucae subsp. nov.}

Type.-From Munchique, El Tambo, Cauca, Colombia, El. 5700'; No. 12471, adult female in the Conover Collection, Chicago Natural History Museum; collected May 29, 1937, by Kjell von Sneidern.

Characters.-Differs from typical nigricans from Paraguay and Brazil by having the undersides much lighter more bluish gray. This is especially noticeable about the crissum and vent, which are inclined to be blackish in the typical race. Also the light throat patch is generally whiter and more extensive.

Description of type.-Forehead and fore part of crown dull gray; rest of upperparts, except tail, uniform olive brown; upper tail coverts and tail black; primaries and underwing coverts dark brown; throat white; sides of face, neck, chest, breast and flanks bluish gray (nearest to Deep Mouse Gray of Ridgway); crissum and vent dull gray; undertail coverts black; bill "green yellow" with darker tip; legs light brick red. Wing 125 , culmen 52 , tarsus 46 , middle toe with claw $57 \mathrm{~mm}$.

Range.-The Cauca Valley of Colombia.

Remarks.-Among the specimens examined an occasional Colombian bird approaches in the darkness of its underparts the series from Brazil and Paraguay, but some of this would seem to be due to wear. Also, one specimen from Horqueta, Paraguay is as light gray on the breast as the average Colombian example. Nevertheless, the Colombian series when compared to the Brazilian and Paraguayan specimens, is undoubtedly much lighter gray underneath.

No specimens from eastern Peru (humilis) were to be had for comparison. However, in the original description no mention is made of the type having lighter underparts than the typical race. Also, Dr. C. E. Hellmayr (Field Mus. Nat. Hist., Zool. Ser., 13 part 1, no. 1, p. 322, 
1942) who had the opportunity of examining the type, synonymized humilis with typical nigricans, while at the same time stating that specimens from Colombia averaged slightly paler gray underneath.

Specimens examined:

Rallus nigricans nigricans.-17: Brazil (Rio Paranapanema, Sao Paulo, 1; Rolante, Rio grande do Sul, 1; Joinville, Santa Catharina, 1); Paraguay (Villa Rica, 7; Horqueta, 7).

Rallus nigricans caucae.-22: Colombia, Cauca (Timba Valle, 1; Munchique, El Tambo, 16; Popayan, 2; Rio Frio, 2); Antioquia (Medellin, (L. l. muriei). 


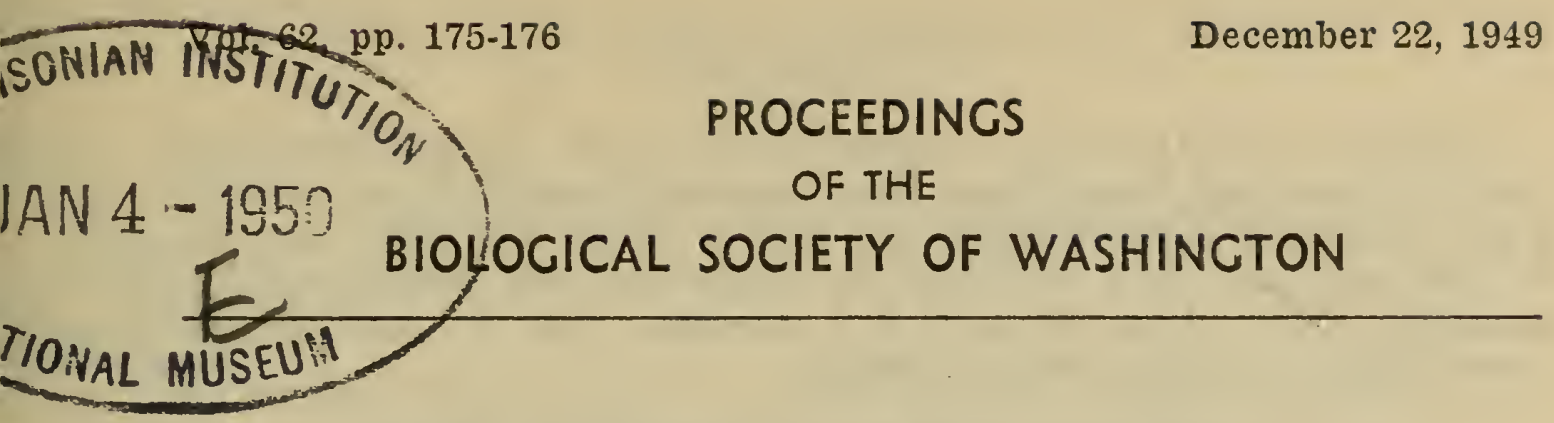

\section{A NEW RACE OF PTARMIGAN IN ALASKA}

By Ira N. Gabrielison and Frederick C. Lincoln

While working on Alaskan Willow Ptarmigan, considerable difficulty was encountered in properly assigning skins from Kodiak westward. This difficulty was intensified when six skins from the Aleutians (two from Atka and four from Unalaska) were examined. Additional skins were secured from the Museum of Vertebrate Zoology, California Academy of Science, and the Chicago Academy of Science to supplement those in the U. S. National Museum, the Fish and Wildlife Service collection, and the Gabrielson collection. These skins, where comparable in plumage, were examined and revealed an undescribed race of ptarmigan which is hereby named:

Lagopus lagopus muriei subsp. nov.

Type--adult male (Fish and Wildlife Service coll. U.S.Nat. Mus. 366615) taken on Nagai Island in the Shumagin Islands, May 15, 1936, by 0 . J. Murie. This race is named for $O$. J. Murie in recognition of his contribution to Alaskan ornithology.

This form is distinguished from $L$. $l$. alexandrae which it most closely resembles by being redder and paler in the brown parts of the plumage. Birds from the Aleutians were both the reddest and palest of the group while those from Kodiak aproached more closely Prince William Sound skins in comparable plumage. Howerer, Kodiak skins both freshly collected and old specimens were more nearly like this new race. All birds used in this study were adults in breeding and post-breeding plumages.

As compared with $L$. $l$. alascensis, this race is much redder and darker when skins in comparable plumages are compared. $L . l$. alascensis is buffy; the new race, muriei, more reddish and darker, near walnut brown, while alexandrae is dark brown to bister.

There is no significant difference in measurements although $L$. l. muriei tends to have a more slender bill than the other races.

Only one adult female of this new race was available and no determination could therefore be made of female plumages.

Somewhat to our surprise, all birds from the Alaska peninsula were much closer to L. $l$. alascensis. Birds from Morzhovi Bay, only a few miles from False Pass, certainly belonged to $L$. $l$. alascensis also, while those from Unimak Island just as definitely belonged to the island group (L. l. muriei). 


\section{Proceedings of the Biological Society of Washington}

Twenty-five adult males from Atka, Unalaska, and Unimak Islands in the Aleutians, and from Unga, Nagai, Little Konaiiji, Simeonof, and Popof Islands in the Shumagins and Kodiak Island, the range ascribed to this new race, were available for comparison with seventeen $L$. $l$. alexandrae, and a large series of $L$. $l$. alascensis from the mainland included eight from the Alaska peninsula. 


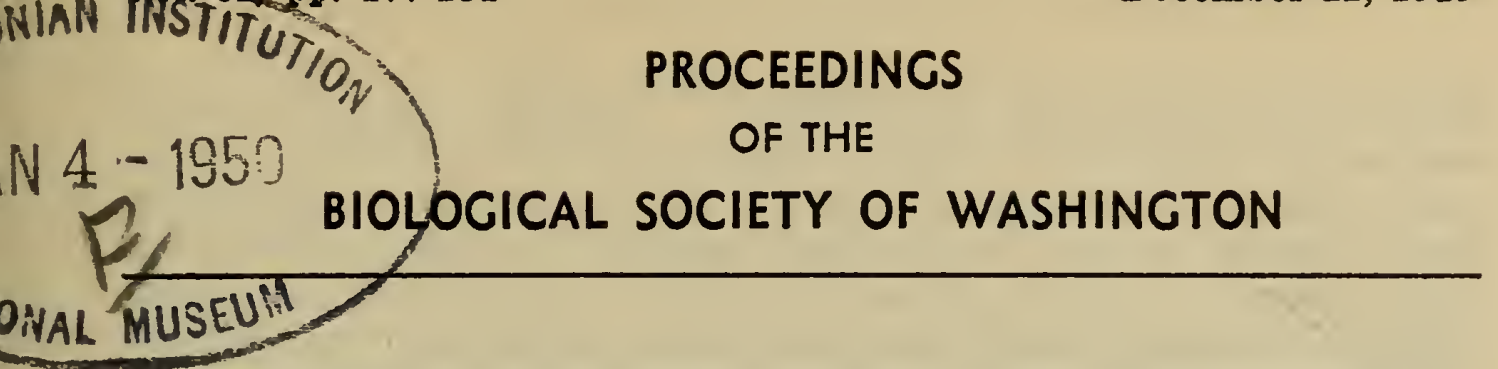

TWO NEW SPECIES OF SALDIDAE (HEMIPTERA) FROM WESTERN UNITED STATES

\author{
By C. J. Drake and F. C. Hottes
}

The present paper contains the descriptions of two new species and notes on allied species of shore bugs from western United States. The types are in collection of C. J. Drake. Paratypes are in the collections of U. S. National Museum, Museum of Comparative Zoology (Harvard) and authors. The drawings of the right parameres were made by F. C. Hottes. Saldula ourayi, n. sp., is named in memory of the famous Indian Chief Ouray, who was a sincere friend of the pioneers and early settlers of the Rocky Mountain region.

\title{
Saldula andrei Drake
}

Saldula andrei Drake, Ark. Zool., 42B(3). 1949.

The type specimens of $S$. andrei were collected in New Mexico and Arizona. During August and September, 1937, specimens were taken by the authors in Colorado (Gateway; Telluride, Trout Lake; Palisades; Skyway; Georgetown; Delta; and Grand Junction), Utah (Green River and Logan), Idaho (Lewiston and Twin Falls), Washington (Spokane), and Wyoming (Jackson Lake), and Canada (Cranbrook, Br. Col.). The right paramere of a male from Grand Junction, Colo., is figured.

S. andrei is about the same size and shape as $S$. azteca, n. sp., but the two species may be easily separated by color as pointed out under the description of the latter. Both are largely stone- or rock-resting species and are taken only sparingly on muddy or sandy beaches near stony areas of streams and lakes. Specimens have also been collected while resting on drift wood near the edge of the water.

In markings and color pattern, andrei more closely resembles $S$. conAuenta Say of the eastern and central states, but it is readily separated from the latter by its smaller size, slenderer form, much narrower basal portion of the hemelytra and dull corium. S. confluenta has a longer, paler and slenderer antennae, the second segment being longer than the next two taken together. The frontal callosities are much less swollen and tend to be brown or blackish in color. Also, the entire hemelytra tend to be shining. Both species have a vesture of long hairs.

\section{Saldula azteca, n. sp.}

Moderately large, elongate-ovate, black, clothed with nearly erect, short golden pubescence and very long, fine, erect or slightly reclining posteriorly, black hairs, the hairs larger and more conspicuous along outer 


\section{Proceedings of the Biological Society of Washington}

margins of pronotum and basal portion of hemelytra. Head, pronotum and scutellum deep black, shining, highly polished. Hemelytra black, velvety-like, not shining, lighter in color than pronotum; embolium deep black, shining, as dark and as highly polished as pronotum, wide, becoming wider and a little reflexed anteriorly; clavus and corium rather dull, much lighter in color than scutellum, the clavus with or without subapical pale spot; corium usually with two to four small, rounded yellowish white spots, occasionally without any spots; outer corium usually with a large subapical yellow-white spot and inner corium often with two smaller pale spots (spots variable in size); membrane fumose, subhyaline, clouded with dark brown within at base, with four cells, each cell with a brown or fuscous streak; veins dark brown, prominent.

Head with a few bristly hairs in front, the clypeus, juga and transverse ridge beneath eyes yellowish white, sometimes brownish or even black; a small pale spot between each eye and ocellus. Rostrum dark ferrugineous, shining, with terminal segment paler, extending to middle of hind coxae. Antennae dark brown, moderately pilose, with a few long scattered bristly hairs on last two segments; segment I yellowish white, with a large elongate black spot, sometimes almost entirely black; proportions-I, 16; II, 36; III, 21; IV, 20. Body beneath black, densely clothed with silvery gray pile. Legs black, with variable degrees of brownish markings sometimes almost entirely black, clothed with long grayish hairs, beneath much darker, shining and with longer hairs; femora with long brownish stripe in front, much widened at apices; tibiae often brownish beneath, sometimes quite brownish apically, with usual brownish spines; tarsi with second and often most of third segments brownish or testaceous. Pronotum nearly three times as wide at base as median length, strongly convergent anteriorly, narrower in front than head and eyes taken together, the lateral margins moderately explanate, slightly refexed, nearly straight; callus with large discal impression, moderately swollen, not extending on explanate margins of pronotum; transverse furrow sinuate, deep, pitted at the bottom, the hind lobe deeply, broadly excavated behind, about one-half as long as the front lobe and two-thirds as long as callus; scutellum about as long as wide, the impression placed just in front of the middle. Pubescence not as dense on hemelytra as on pronotum and scutellum.

Length, 4.00 to $5.10 \mathrm{~mm}$; width, 1.90 to $2.25 \mathrm{~mm}$.

Type (male), allotype (female) and 6 paratypes, Aztec, New Mexico, Aug. 26, 1934, taken on stones, C. J. Drake and Floyd Andre. Paratypes, 60 specimens, taken by the authors during August to October, 1949 in Colorado (Delta, Gateway, Skyway, Grand Junction, Georgetown, Ridgeway, Grand Masa and Telluride), Utah (Green River, Salt Lake City and Logan), Idaho (Twin Falls and Lewiston), Washington (Spokane), Wyoming (Jackson Lake and Rocksprings) and Canada (Coleman, Alberta).

S. azteca, n. sp., is primarily saxicolous, and most frequently taken resting on rocks and stones in very stony situations near the edge of water of streams and lakes. It is rarely taken on sand or wet mud, even near stony places. Some specimens were also collected on drift wood near the later.

Other shore bugs taken on stones in the same habitats were Saldula nigrita (Parshley), S. explanata (Uhler), S. andrei Drake. Azteca seems 
to be more closely associated with the stony habitats than the other species. It was also dominant in numbers.

S. comatula (Parshley) is a larger, broader species and rather dull; the hemelytra are very variable in color and its legs are pale. S. andrei Drake is quite similar in size and form, but also has pale legs, and large prominent yellowish or yellowish orange markings on the hemelytra. The color and markings also seperate it from comatula. S. illinoiensis Drake is a smaller species, with rather sparse vesture of long hairs; the hemelytra have a moderately large, pale, subapical, marginal spot in the corium.

\section{Saldula ourayi, n. sp.}

Small, obovate, black, with or without small, luteous or whitish markings or small rounded spots, the pubescence short, dense, dark golden; without vesture of long hairs. Head with a small pale spot between each eye and ocellus, the transverse callosities beneath eyes, clypeus and often juga yellowish white, swollen; rostrum ferrugineous, shining, reaching end of hind coxae. Antennae brownish black, shortly pilose, the first segment yellowish white, usually with a large elongate black spot, the second brownish apically, the two terminal segments with a few scattered bristly hairs; proportions-I, 12 ; II, 25; III, 14; IV, 15. Pronotum deep black, slightly shining, indistinctly pitted, deeply excavated behind, three times as wide at base as median length, not strongly narrowed anteriorly, the side margins slightly rounded and slightly reflexed; callus moderately swollen, not extending on explanate margins, with large, deep impression at middle; lobes separated by rather shallow arcuate furrow, finely pitted at bottom, the hind lobe about three-fourths as long as callus. Scutellum about as wide as long, deep black, slightly shining, indistinctly pitted, the pubescence of pronotum and scutellum slightly longer than on hemelytra.

Hemelytra black, rather dull; clavus usually without subapical pale spot; corium usually with two or four small, whitish or yellowish, rounded, small spots, often with a narrow, marginal, luteous stripe, the stripe often longly interrupted at middle; sometimes entire corium black and with only two small pale spots; membrane densely clouded with fuscous, non-transparent, with four cells, the veins a little darker; usually without dark spots in cells. Legs black, generally with some brown or fuscous markings, sometimes entirely black. Body beneath black, with dense grayish pile. Hemelytra slightly variable in length.

Length, $3.50 \mathrm{~mm}$.; width, $1.62 \mathrm{~mm}$.

Type (male), allotype (female) and 70 paratypes, Soap Lake, Washington, and series of lakes to the north to Deep Lake, Washington, Aug. 29, 1949, C. J. Drake and F. C. Hottes. Paratypes also from Colorado (Georgetown, Gateway and Delta), Idaho (Lewiston), Wyoming (Jackson Lake and Yellowstone National Park), Utah (Green River), California (San Francisco, Aug. 26, 1934, Drake and Andre), and Canada (Cranbrook, Brit. Col.).

Allied to S. bassingeri Drake, but easily separated by its larger size, darker color and different markings on hemelytra and dark legs. It was taken on the muddy and sandy shores of lakes and reservoirs of rivers. Soap Lake and the series of lakes north to Deep Lake are the only places where it was taken in large numbers. S. pallipes (Fabr.), S. saltatoria (Fabr.), and $S$. comatula (Parsh.) were often found in the same habi- 


\section{Proceedings of the Biological Society of Washington}

tats. At Deep Lake, 8 specimens of Micracanthia pusilla Van Duzee were taken at one small point in company with ourayi and pallipes. A few specimens of $S$. ourayi are conspicuously marked with two large flavous areas on each hemelytron, and might represent a distinct variety. The right paramere of a paratype from Soap Lake is figured. The parameres of $S$. ourayi differ distinctly in shape from those of $S$. bassingeri Drake. The hair on the hump of the parameres of bassingeri are much longer than those on the hump of the parameres of ourayi and from a distinct tuft. 

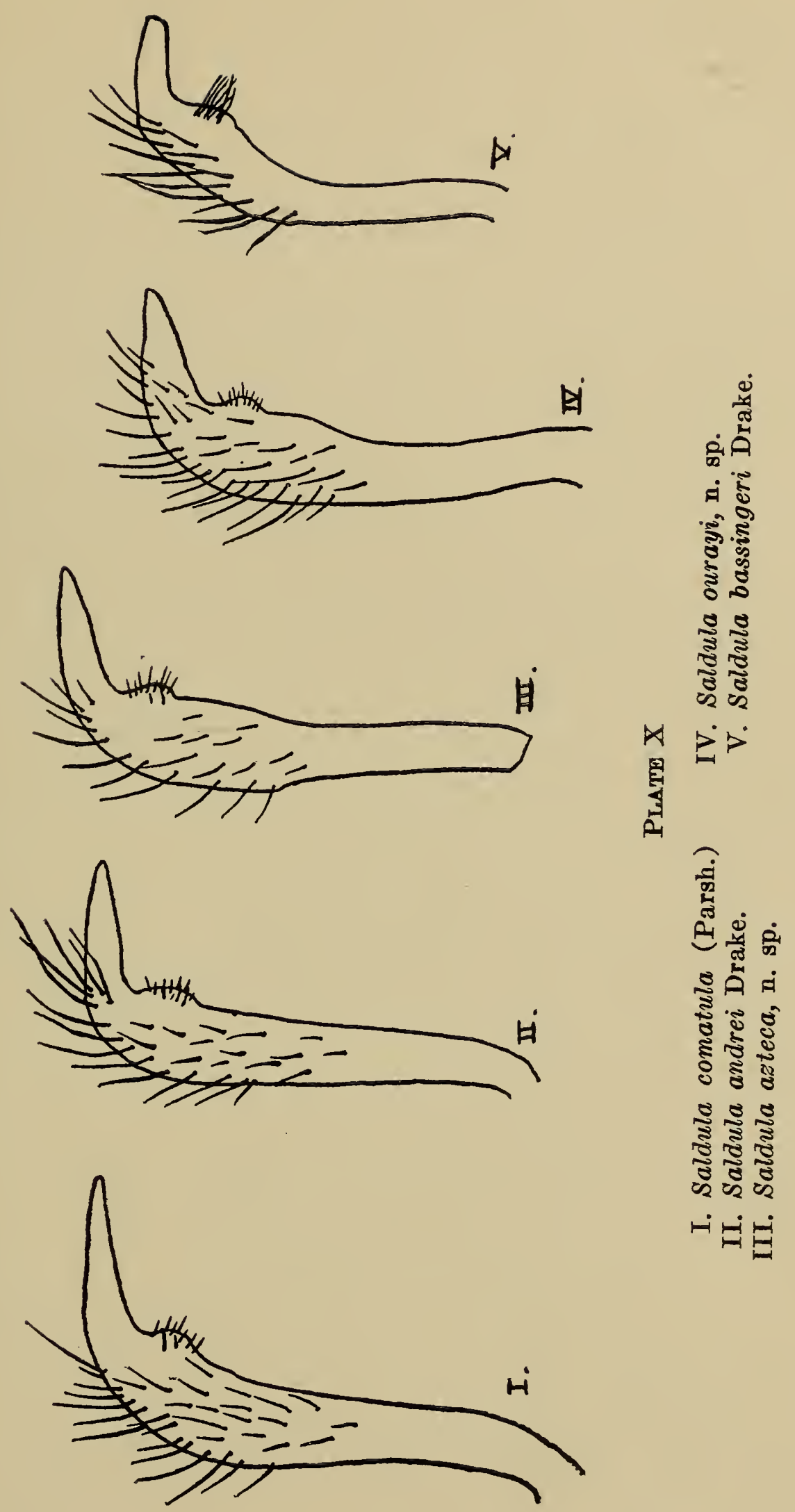
182 Proceedings of the Biological Society of Washington 
Drake and Hottes-Two New Species of Saldidae 183 
184 Proceedings of the Biological Society of Washington 


\section{Oiv \\ PROCEEDINCS \\ OF THE \\ BIOLOGICAL SOCIETY OF WASHINGTON}

\section{ONAL MUSEUS'E VENEZUELA}

By Wriliam H. Phelps and William H. Phelps, JR.

The senior author wishes to thank Dr. John T. Zimmer of the American Museum of Natural History, Dr. Herbert Friedmann of the U. S. National Museum, Mr. W. E. Clyde Tood of the Carnegie Museum and Mr. Emmet R. Blake of the Chicago Natural History Museum for their help in the examination of specimens in their respective institutions.

The specimens listed as examined are in the Phelps Collection, Caracas, unless otherwise specified.

Names of colors are capitalized when direct comparison has been made with Ridgway's "Color Standards and Color Nomenclature."

\section{Chaetocercus jourdanii andinus, new subspecies}

Type.-From Cubiro, Lara, Venezuela; altitude 1650 meters. No. 8799, Phelps Collection, Caracas. Adult male collected October 23, 1940, by William H. Phelps. (Type on deposit at the American Museum of Natural History.)

Diagnosis.-Closest to $C . j$. rosae of the Caracas region but the iridescent throat has a more rose colored, less purplish, tint.

Range.-The Subtropical Zone of the Venezuelan Andes from Lara to Táchira and of the Dept. Santander in Colombia.

Description of Type.-Upper parts nearest to Cosse Green; an ill defined whitish post-orbital stripe; lores slightly rufous. Chin and throat Tyrian Rose; a white band from side of neck across anterior breast; anterior breast, abdomen, sides and flanks Cosse Green; vent and patches on flanks white; under tail-coverts pale greenish edged with whitish. Wings Warm Blackish Brown; lesser coverts, under wing-coverts and axillaries Cosse Green. Tail Warm Blackish Brown, median rectrices with inner webs basally pale rufous.

Bill (in life) "black"; feet "brown." Wing, $34 \mathrm{~mm}$; tail, 21 ; exposed culmen, 11 ; culmen from base, 16 ; tarsus, 11.

Remarks.-Sexes different. Size similar to rosae. Range of measurements: five adult males-wing, 33-35 (34) mm.; tail, 21-24 (22.2); exposed culmen, 11-12 (11.8); five adult females-wing, 33-38 (36.2); tail, 16-17 (16.4); exposed culmen, 12-13 (12.8). Measurements of rosae: three adult males-wing, 32-33 (32.3); tail, 22-24 (22.7); exposed culmen, 11-14 (13.7); two adult females-wing, 37-39 (38); tail, $15-16$ (15.5); exposed culmen, 13-14 (13.5).

Females are similar in coloration to jourdanii. The Bucaral male has the throat intermediate between andinus and rosae, as would be expected 


\section{Proceedings of the Biological Society of Washington}

from its intermediate range. Those from Queniquea do not have the typical throats of andinus. Measurements of exposed culmen are given because of uncertainty in measuring from base.

\section{Specimens Examined}

C. j. jourdanii.-VENEZUELA: Caripe, 1 ô, 1 $q$; Cerro Negro, $3 \hat{o}$, 3 ; Cerro Turumiquire, $4 \hat{\delta}^{1}$; Rincón de San Antonio, $1 \hat{\delta}^{3}$; Los Palmales, $1 q^{2}$; Cerro Humo, 1 ô juv., 1 ㅇ. TRINIDAD: $1 \hat{\delta^{1}, 3} \hat{\delta}^{2}$, 2 ㅇ․ $^{2}$.

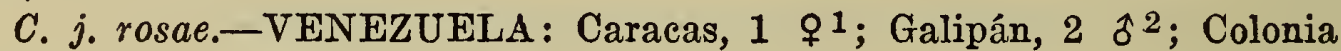
Tovar, $1 \hat{\delta}^{2}$; Hda. Santa Clara, Carabobo, 1 ô; Cumbre de Valencia, $1 \hat{o}{ }^{1}$; Bucaral, Yaracuy, $1 \hat{o}$; Curimagua, Falcón, $1 \hat{o}, 2$ ô juv.; San Luis, 1 \& ; "Venezuela," 4 के 2 .

C. $j$. andinus.-VENEZUELA: Cubiro, Lara, 2 ô (incl. type), 2 o ; Guarico ${ }^{4}, 1$ ô, 1 우 ; Páramo de Cendé, Trujillo, 1 우 ; Tabay, Mérida, 1 우 ; Páramo Conejos, 1 ớ2, 2 우; Páramo de los Pinos, 3 ố2; El Valle, 2 ㅇ, 1 $^{3}$; Páramo de la Culata, $1 q^{2}$; Páramo Tambór, $1 \hat{o}^{2}$,

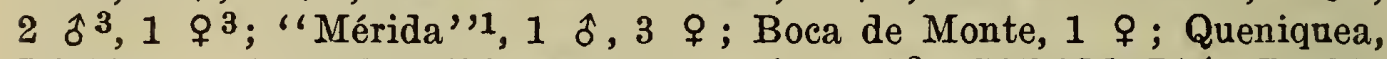
Táchira, $2 \hat{\delta}, 1$ 우 ; "Venezuela," $1 \hat{\delta}, 1 \hat{\delta^{2}}$. COLOMBIA ${ }^{4}$ : Pueblo Nuevo, Santander, 1 o, 3 우 La Palmita, 3 ㅇ․

\section{Bucco tamatia cuyunii, new subspecies}

Type.-From Carabobo, Alto Río Cuyuni, Bolívar; Venezuela; altitude 240 meters. No. 46006, Phelps Collection, Caracas. Adult male collected September 16, 1948, by Manuel Castro. (Type on deposit at the American Museum of Natural History.)

Diagnosis.-Similar to $B$. $t$. tamatia except that the back is darker brown than in any other subspecies.

Range.-Known only from Carabobo on the upper Cuyuni River.

Description of Type.-Back and uropygium paler that Bone Brown, lighter on crown; feathers on forehead, pre-ocular region and upper tailcoverts heavily, and those of lower back and rump slightly, edged with buffy; a whitish nuchal collar; ear-coverts dusky, slightly edged with whitish; a white gular streak; sides of throat and neck black; throat and fore breast Tawny, paler on ehin; rest of under parts whitish with a buffy tinge on abdomen and under tail-coverts, heavily spotted with dusky; under tail-coverts lightly spotted. Wings Natal Brown; remiges partially and lightly edged externally, heavily internally, with buffy; upper wing-coverts and tertials lightly edged and tipped with buffy giving a scaled appearance; greater under wing-coverts grayish, the lesser ones pale buffy. Tail Natal Brown, paler below, the rectrices lightly edged with buffy and lightly tipped with whitish.

Bill "black"; feet "gray"; iris "brown." Wing, $75 \mathrm{~mm}$; tail, 62 ; exposed culmen, 23 ; culmen from base, 30 ; tarsus, 16 .

Remarks. - Sexes alike. Size similar to tamatia. Range of measurements: four adult males-wing, 74-75 (74.7); tail (3), 59-62 (60.3); culmen from base (3), 28-30 (29); three adult females-wing, 76-78 (77.3) ; tail, 63-65 (63.7) ; culmen from base, 29-29 (29). Measurements of tamatia: five adult males from Cayenne and Surinam-wing, 74-80 (77.2) ; tail, 60-66 (63.4); culmen from base (4), 26-28 (27); fire adult

\footnotetext{
1Specimens in Chicago Natural History Museum.

2Specimens in American Museum of Natural History.

${ }^{3}$ Specimens in U. S. National Museum.

Specimens in Carnegie Museum.
} 
females from Surinam and British Guiana-wing, 75-81 (78.6); tail, 61.66 (63.4); culmen from base, 28-29 (28.2).

\section{Specimens Examined}

B. $t$. cuyunii.-VENEZUELA: Carabobo, 4 ô (incl. type), 3 $q$.

B. t. tamatia.-FRENCH GUIANA": "Cayenne," 1 ô. DUTCH GUIANA ${ }^{2}$ : Kroata, 1 q ; Javaweg, 1 ô ; Paramaribo, 1 of ; "interior," 3 ô, 3 q. BRITISH GUIANA: Annai ${ }^{2}, 1$; Rupurumi River ${ }^{2}, 1$ oे ; Kamacusa 2 , 1 ; Mutusi Hole ${ }^{2}, 1$ \& ; "British Guiana," 3 (q) $)^{2}$; Upper Mazaruni River, 1 ô ; Mambaro Creek, 1 $q, 1$ (q). BRAZIL: Isla Macará, Rio Negro, 1 q. COLOMBIA ${ }^{2}$ : Maipures, 1 ô, 1 q. VENE-

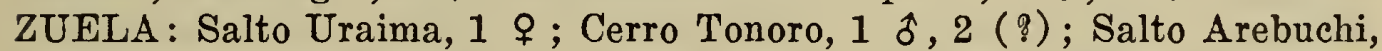
3 ㅇ ; Cerro Tabarerupá, 1 \% ; Sanariapo, 1 o, 1 웅 San Fernando de Atabapo, 2 ô; El Platanal, 1 o ; Puerto Yapacana, 1 ô, 1 q.

B. t. hypnaleus.-BRAZIL2 : Santarem, 1 \%, 2 (2); Marajó Is., 1 (\&).

B. t. interior.-BRAZIL2 : Campos Novas, Matto Grosso, 1 \& ; Tapirapoan, 1 ㅇ.

B. $t$. pulmentum 2 -ECUADOR: Boca Rio Curaray, 1 ô, 1 ‥ BRAZIL: Rio Humytha, Rio Madeira, 1 \&; "Napo," 1 (q) ; "Upper Amazonia," 1 ( $($ ) .

\section{Piprites chloris perijanus, new subspecies}

Type.-From La Sabana, Río Negro, Perijá, Zulia, Venezuela; altitude 1300 meters. No. 6779, Phelps Collection, Caracas. Adult male collected March 5, 1940, by Alberto Fernández Y. (Type on deposit at the American Museum of Natural History.)

Diagnosis.-Nearest to $P$. c. tschudii from which it differs by a more extensive and prominent yellowish forehead, less buffy or chestnut.

Range.-Known only from the type locality.

Description of Type.-Crown, back and uropygium yellower than Warbler Green; forehead Primuline Yellow; pre-ocular region and lores pale yellowish; eye-ring yellowish white; ear-coverts and sides of neck grayish, tinted with olivaceous. Chin yellow, more greenish on throat and still more greenish on breast; abdomen and under tail-coverts Citron Yellow; sides, flanks and axillaries yellowish green. Wings Fuscous; remiges narrowly edged with greenish; inner vanes and tips of innermost tertials broadly whitish; greater wing-coverts broadly tipped with yellowish white and median coverts more narrowly, forming two wing bands; band of wing Citron Yellow; under wing-coverts mixed yellowish, white and dusky; inner vanes of remiges edged basally with yellowish white. Tail Fuscous, paler below; rectrices faintly edged with greenish and prominently tipped with whitish.

Bill (in life) "gray"; feet "gray"; iris "brown." Wing, $68 \mathrm{~mm}$; tail, 50 ; exposed culmen, 8 ; culmen from base, 12 ; tarsus, 16.

Remarlis - Size similar to tschudii. Range of measurements: two adult males-wing, $68,69 \mathrm{~mm}$; tail, 50,50 ; culmen from base, 12, 12 . Measurement of tschudii from Ecuador: five adult males-wing, 66-69 (67.4); tail, 43-47 (44.8); culmen from base, 12-13 (12.6); five adult femaleswing, 67-72 (68.6); tail, 42-49 (45.6); culmen from base, 12-13 (12.6).

The range of the new subspecies is very distant from the nearest record for the species which is antioquiae from Dept. Antioquia, Colombia. There is a specimen of chlorion in the Phelps Collection from the State of Carabobo, the only known occurrence in northern Venezuela. 


\section{Proceedings of the Biological Society of Washington}

\section{Specimens Examined}

P. chloris antioquiae.-COLOMBIA: La Frijolera, Antioquia, 1 $\delta^{2}$ (type).

$P$. chloris perijanus.-VENEZUELA: La Sabana, Sierra de Perijá, 2 oे (incl. type).

$P$. chloris chlorion.-VENEZUELA: Hda. Santa Clara, Carabobo, 1 \&; Caño Cuao, Terr. Amazonas, 2 ô, 1 (q); pica Yavita-Pimichín, 4 ô, 1 ㅇ ; Santa Elena, Bolívar, 1 ; Hato Santa Teresa, 1 우 ; Raudal Guaiquinima, $1 \hat{\delta}$; Erebenequén, $1 \hat{\delta}$; Salto María Espuma, $1 \hat{\delta}$; Cerro Ptari-tepui, $7 \hat{\delta}, 2$ $q, 2$ (q); Cerro Paurai-tepui, 1 ô, 1 $q, 1$ (q); Altiplanicie de Nuria, $3 \hat{\delta}, 2$; foot of Cerro Duida, $2 q^{2}$; Playa del Río Base, $1 \hat{\delta}^{2}$; El Merey, $1 \hat{\delta}^{2}$; Cerro Auyan-tepui, 1 일. BRITISH GUIANA $^{2}: 1$ (q). BRAZIL ${ }^{2}$ Faro, 5 ô, 2 q ; Villa Bella Imperatríz, $1 \hat{o}$; Cussary, 1 우.

P. c. bolivianus.-BRAZIL: Igarapé Amorim, Rio Tapajoz, $1 \hat{\delta}^{2}$.

$P$. c. tschudii.-VENEZUELA ${ }^{2}$ : Río Guainía, junction with Caño Casiquiare, $2 \hat{\delta}, 2$ q ; opposite El Merey, 1 ㅇ. COLUMBIA: Macacuni, $1 \hat{\jmath}$. BRAZIL ${ }^{2}$ : Rio Curycuryari, $1 \hat{\jmath}$. ECUADOR ${ }^{2}$ : Lagarto, $1 \hat{\delta}$, 1 q; Zamora, 1 q, 1 (q); below San José de Sumarco, 1 \% ; Boca Río Curaray, 1 ô, 2 \%; Río Suno Abajo, 1 웅 Río Suno, above Avila, 1 ô, 1 ․

\section{Pachyramphus castaneus parui, new subspecies}

Type.-From Cerro Parú, Terr. Amazonas, Venezuela; altitude 1600 meters. No. 46817, Phelps Collection, Caracas. Adult male collected February 20, 1949, by Kathleen D. Phelps. (Type on deposit at the American Museum of Natural History.)

Diagnosis.-Nearest to $P$. c. saturatus but differs from all other subspecies by darker crown, back and lower parts.

Range.-Known only from the Subtropical and upper Tropical Zone of Cerro Parú between 940 and 1600 meters.

Description of Type.-Top of head Chestnut, base of feathers dusky giving a mottled appearance; rump paler, merging into the Tawny of upper tail-coverts; post-ocular stripe and narrow nuchal collar dark grayish; lores dusky, ear-coverts dusky tawny. Under parts Ochraceous Tawny, darkest on side of throat, breast and sides, merging into the whitish chin and Cinnamon-Buff under tail-coverts. Wing Blackish Brown, the feathers edged with Tawny, except tips of primaries and secondaries; under wing-coverts and axillaries Ochraceous-Tawny. Tail Tawny above, under surface pale Cinnamon-Brown; inner webs of reetrices paler, outer webs and middle rectrices more dusky, all very narrowly tipped with whitish.

Bill (in life) "maxilla black, mandible slate"; feet "cinder"; iris "brown." Wing, $80 \mathrm{~mm}$; tail, 58; exposed culmen, 12; culmen from base, 15 ; tarsus, 20.

Remarks.-Size similar to saturatus. Range of measurements: three adult males-wing, 75-80 (77) $\mathrm{mm}$; tail, 58-60 (58.7) ; culmen from base, 15-15 (15). Two adult males of saturatus-wing, 73-77 (75); tail, 51-55 (53); culmen from base, 14-15 (14.5); three adult females-wing, 70-74 (72); tail, 49-57 (53); one adult female from Hato Santa Teresawing, 72 ; tail, 53 ; culmen from base, 16 . Five adult males of intermedius-wing, 73-77 (75.2) ; tail, 54-58 (55.6); culmen from base, 15-15 (15) ; five adult females-wing, 69-74 (71.2); tail, 50-57 (54.6); culmen from base, 14-16 (15.2). 
It is noteworthy that this new form is the only one whose range extends into the Subtropical Zone. All the others inhabit the Tropical Zone.

The species was only known from southern Venezuela by one specimen of saturatus in our collection from Hato Santa Teresa, Río Uairen, near the Brazilian boundary west of Mt. Roraima.

\section{Speciments Examined}

P. c. castaneus ${ }^{2}$.-BRAZIL: $17^{5}$. PARAGUAY: $3^{5}$.

P. c. amazonus.-BRAZIL $: 21^{5}$.

P. c. saturatus.-BRAZIL ${ }^{2}: 2^{5}$. PERU ${ }^{2}: 3^{5}$. VENEZUEL9: Hato Santa Teresa, 1 ㅇ.

Pr. c. parui.-VENEZUELA: Cerro Parú, 3 ô (including type).

P. c. intermedius.-VENEZUELA: $14^{2,5}$; San Luis, $1 \hat{\delta}, 1 q$; Curimagua, $1 \hat{o}, 2$; Urama, 1 (q) ; Colonia Tovar, 1 (q); Sierra de Carabobo, 1 (q); San José de Los Caracas, 1 ô ; Cerro Golfo Triste, 2 ô., 1 우 ; Cerro Negro (Miranda), 1 $\hat{\jmath}, 1$ 우, 1 (q); Los Altos, 2 ( $(q)$; Quebrada Bonita, 2 ô, 1 (q); Caripe, 1 ô, 1 q, 2 (q); El Pilar, 1 q ; Cerro Azul, 1 ㅇ.

\section{Leptopogon superciliaris pariae, new subspecies}

Type--From Cerro Azul, Paria Peninsula, Sucre, Venezuela; altitude 900 meters. No. 44096, Phelps Collection, Caracas. Adult of undetermined sex collected May 27, 1948, by Ramón Urbano. (Type on deposit at the American Museum of Natural History.)

Diagnosis.-Differs from $L$. s. venezuelenis of northern Venezuela by a darker, more grayish, less yellowish, breast, a paler yellow abdomen and a darker green, less yellowish, back. Differs from poliocephalus of Colombia by more extensive white on forehead and superciliaries and whiter, less buffy, wing bands.

Range.-Known from the tip of the Paria Peninsula in the Tropical and lower Subtropical Zones to an altitude of 900 meters and from the nearby island of Trinidad.

Description of Type.-Back and uropygium darker than Yellowish Oil Green; crown and nape Chaetura Drab; center of forehead dusky uniform with crown but feathers with some whitish tips; rest of forehead and pre-ocular region extensively whitish; wide post-ocular grayish white streak; ear-coverts dusky, mixed with gray. Breast and sides Deep Grape Green merging into the whitish throat and chin and into the Martius Yellow abdomen; under tail-coverts and axilliaries whitish; wings Fuscous; remiges, except three outermost pairs, edged with yellowish green, more widely on the tertials; wing-coverts tipped with whitish forming two prominent bands; under wing-coverts mixed brownish and whitish. Tail Benzo Brown, paler below, the rectrices edged externally with greenish.

Bill (in life) "black"; feet "gray"; iris "brown." Wing, $59 \mathrm{~mm}$; tail, 48; exposed culmen, 13 ; culmen from base, 15 ; tarsus, 15.

Remarks.- Sexes alike. Size similar to venezuelensis. Range of measurements: three adult males from Cristóbal Colón-wing, 63-66 (64.7) mm; tail, 50-57 (52.7); culmen from base, 14-15 (14.7); three adult females from Cristóbal Colón and Cerro Azul-wing, 60-62 (61) ; tail, 50-55 (52);

FFor localities see Zimmer, Studies of Peruvian Birds, Am. Mus. Nov., No. 894, pp. $8 \cdot 9,1936$. 
culmen from the base 14-14 (14); one adult of undertermined sex from Cerro Azul (see the type). Measurements of venezuelensis: five adult males from the Caracas region-wing, 63-68 (66); tail, 53-62 (56.2); culmen from base, 15-15 (15); five adult females-wing, 58-62 (60.4); tail 47-62 (54.2); culmen from base, 14-15 (14.6).

\section{Specimens Examined}

L. s. albidiventer ${ }^{2}$-CBOLIVIA: ${ }^{6}$. PERU: $9^{6}$.

L. s. superciliaris ${ }^{2}-\mathrm{PERU}: 22^{6}$. Ecuador: $6^{6}$. 76 .

L. s. transandinus ${ }^{2}$-ECUADOR: $1^{6}$. COLOMBIA: $3^{6}$. PANAMA:

L. s. hellmayri ${ }^{2}$-PANAMA: $4^{6}$.

L. s. poliocephalus.-COLOMBIA 2 : "Bogotá," 5 (q); Villavicencio, $2 \delta$; Buena Vista, $1 \hat{\delta}, 1$ 울 east of Palmira, $1 \hat{\delta}, 1$; ; Peque, $1 \hat{\delta}$. VENEZUELA : La Sabana, Perijá, 1 ô, $1(q)$.

L. s. venezuelensis.-VENEZUELA: Bramón, 1 \&, 1 ( ( ) ; Queniquea, $1 \delta, 1$ q ; Cerro El Cerrón, 2 o ; Cerro El Cogollal, 1 ( $q)$; Cubiro, $1(q)$; Altamira (Barinas), $1 \hat{\delta, 1} q, 2(q)$; San Luis, 1 (q); Curimagua, 1 ( $q)$; Bucaral, 1 q ; Cumbre de Valencia, 1 o 2 ; Sierra de Carabobo, 1 \&, 1 (q); Hda. Altamira (Carabobo), 1 (q); Colonia To-

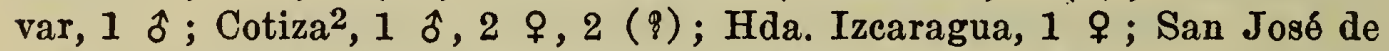
Los Caracas, 1 (q); Cerro Golfo Triste, $1 \hat{\delta}, \cdot(q)$; Cerro Negro (Miranda), 5 of, 4 \&, 7 ( $($ ) ; Quebrada Bonita, 3 ô, 3 q, 3 (q); Que-

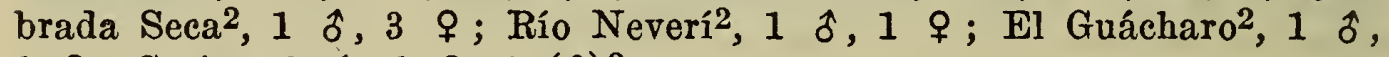
1 울 Caripe, 3 ô, 1 \%, 1 (q) 2 .

L. s. pariae.-VENEZUELA: Cerro Azul, 1 q, 1 (q) (type); Crist6bal Colón ${ }^{2}, 3 \hat{\delta}, 2$ ㅇ. TRINIDAD ${ }^{2}$ : Carenage, $1 \hat{\delta}$; Heights of Aripo, $1 \hat{\delta}$.

pp. 5, 1941.

\section{Compsocoma flavinucha virididorsalis, new subspecies}

Type.-From Cerro Golfo Triste, Aragua, Venezuela; altitude 1200 meters. No. 19415, Phelps Collection, Caracas. Adult male collected August 29, 1942, by Ramón Urbano. (Type on deposit at the American Museum of Natural History.)

Diagnosis.-Similar to $C$. $f$. venezuelana except that green cast extends over the back instead of being confined to rump.

Range.-Known only from Cerro Golfo Triste in the lower Subtropical Zone at altitudes from 1000 to 1300 meters.

Description of Type.-Head black, the crown, from between the eyes back to the nape and $8 \mathrm{~cm}$. in width, darker than Lemon Chrome; back and uropygium dark greenish, the feathers terminally dusky thus giving a mottled appearance, slightly more greenish on rump. Underparts and axillaries darker than Lemon Chrome. Wings Fuscous; remiges, except the outermost pair, edged externally, except terminally, with Turquoise Green; inner vanes edged basally with whitish; innermost tertials and greater wing-coverts black; lesser wings-coverts Light Violet Blue; under wing-coverts mixed dusky and yellowish white. Tall blackish, paler below, the rectrices broadly edged externally with Turquoise Green except the outermost pair.

Bill (in life) "black, base blue"; feet "black"; iris "reddish

${ }^{6}$ For localities see Zimmer, Studies of Peruvian Birds, Am. Mus. Nov., No. 1126, 
brown." Wing, $90 \mathrm{~mm}$; tail, 68, exposed culmen, 17 ; culmen from base, 19 ; tarsus, 24.

Remarks.-Sexes alike. Size similar to venezuelana. Range of measurements: three adult males-wing, 88-90 (89) mm; tail, 66-68 (67.3); culmen from base, 19-19 (19); two adult females-wing, 85-87 (86); tail (1), 64; culmen from base, 19-19 (19); one of undetermined sex-wing, 85 ; tail, 63 ; culmen from base, 19 . Measurements of venezuelana from the Caracas region: five adult males-wing, 86-91 (87.4); tail, 62-67 (63.8) ; culmen from base, 17-19 (18.4) ; five adult females-wing, 88-93; tail, 65-70 (68.2); culmen from base, 19-20 (19.4).

\section{Specimens Examined}

C. f. somptuosa ${ }^{2}$-PERU: $21^{7}$. ECUADOR: $7^{\top}$.

C. f. flavinucha ${ }^{2}$.-PERU: 187. BOLIVIA: $21^{7}$.

C. f. baezae ${ }^{2}$-ECUADOR: $9^{7}$.

C. f. cyanoptera ${ }^{2}$.-Ecuador: $18^{7}$. COLOMBIA: $41^{7}$.

C. f. victorini.-COLOMBIA ${ }^{2}: 28^{7}$.

C. $f$. venezuelana.-VENEZUELA: var. locs. ${ }^{7}, 16^{2}$; Bucaral, 1 \&; Las Quiguas, $1 \hat{\delta}$; Colonial Tovar, 7 $\hat{\delta}, 1$ \& No León, $1 \hat{\delta}, 2$; El Junquito, 3 ô, 2 क , 1 (q); Hda. Izcaragua, 1 ㅇ.

C. f. virididorsalis.-Cerro Golfo Triste, 3 o (incl. type); 2 \&, 1 ( $($ ).

Rhodinocichla rosea beebei, new subspecies

Type.-From La Sabana, Río Negro, Perijá, Zulia, Venezuela; altitude 1300 meters. No. 7015, Phelps Collection, Caracas. Adult male collected February 27, 1940, by William H. Phelps, Jr. (Type on deposit at the American Museum of Natural History.)

Diagnosis.-The male differs from all other subspecies of $R$. rosea by the superciliary stripe which in this new form is entirely lacking or very indistinct, instead of prominent.

Range.-The Sierra Perija in the lower Subtropical Zone.

Description of Type.-Crown dark Citrine, mixed with dusky; forehead, except in the center, paler than Rose Red; back and uropygium grayish olive; a barely perceptible superciliary streak, rose colored above the eye and grayish post-orbitally; lores and sides of head black. Chin and throat paler than Rose Red, darker on breast and merging into Geranium Pink on abdomen and under tail-coverts; sides of neck, sides, flanks, thighs and axillaries grayish olive, the latter mixed with dark crimson. Wings Fuscous, the under surface paler with exposed edges of remiges grayish basally; remiges except the outermost, edged externally with olive gray; wing-coverts heavily edged with gray; a prominent patch on bend of wing, and edge of wing, paler than Rose Red; under wing-coverts mixed whitish and grayish. Tail Fuscous, paler below.

Maxilla (in life) "black"; mandible "horn color"; feet "brownish pearl"; iris "brown". Wing, $81 \mathrm{~mm}$; tail, 80; exposed culmen, 19; culmen from base, 24 ; tarsus, 27.

Remarks.-Size similar to rosea. Range of measurements: five adult males-wing, 80-83 (80.8) $\mathrm{mm}$; tail, 76-82 (78.6); culmen from base, 22-24 (23.2); one adult female-wing, 78; tail, 76; culmen from base, 22. Measurements of rosea: three adult males-wing, $81-82$ (81.6); tail (3), 80-83 (81.5) ; culmen from base, 23-24 (23.3); two adult females-

${ }^{7}$ For localities see Zimmer, Studies of Perurian Birds, Am. Mus. Nov., No. 1262, pp. $8-9,1944$. 
wing, 77-79 (78); tail, 76-80 (78); tail, 76-80 (78); culmen from base, $23-24$ (23.5).

Description of female. Crown dark Citrine, mixed with dusky; back and uropygium near Brownish Olive; forehead, except in center, and superciliary stripe, anteriorly, Ochraceous-Orange; the prominent supereiliary streak white posteriorly; lores and sides of head black. Chin, throat, breast and abdomen Ochraceous-Orange, darkest on breast; lower abdomen whitish; sides, flanks, thighs and axillaries grayish olive; under tail-coverts Xanthine Orange. Wings Fuscous, the under surface paler with exposed edges of remiges grayish basally. Remiges edged externally with olive gray except outermost; wing-coverts edged with gray; a prominent patch on bend of wing, and bend of wing, Ochraceous-Orange; under wing-coverts mixed ochraceous and gray. Tail Benzo Brown, paler on under surface.

Every one of the specimens examined of the other subspecies, both males and females, have very prominent superciliary streaks.

It gives us great pleasure to name this beautiful bird in honor of Dr. William Beebe who, during a half century of intense scientific reesarch, has made so many valuable contributions to Venezuelan ornithology.

\section{Specimens Examined}

R. r. rosea.-VENEZUELA: Caracas ${ }^{1}, 4$ ô, 4 $q$; Galipán, 1 q2 ; San Julián, Macuto, 1 ổ; San José de los Caracas, 1 ô; Pie del Cerro, Aragua, $1 \hat{\delta}^{4}$; Puerto La Cruz, $1 \hat{o}^{4}, 2$ $\overbrace{}^{4}, 1 \hat{o}^{3}$; Sierra de Carabobo, $1 \hat{\delta}^{4}$; San Esteban, $2 \hat{o}^{4}, 1 \overbrace{}^{4}, 1 \hat{\delta}^{2}, 1$ o $^{2}$; Cerro Negro, Miranda,

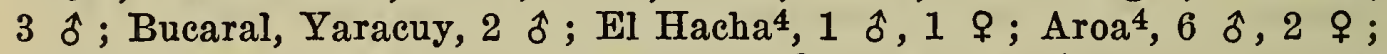
Guarico, Lara, $1 \hat{\delta}^{4}$; Cerro Bucarito, $1 \hat{\delta}^{2}$; Anzoategui ${ }^{4}, 1 \hat{o}$; San Luis, Falcón, 2 ô, 3 $q$.

R. r. zeebei.-VENEZUELA: La Sabana, 1 ô, 1 o, 2 ôं; Ayapa, Perijá, 2 ồ 9.

R. $r$. harteri.-COLOMBIA: San Antonio ${ }^{2}, 2 \hat{\delta}, 1$ 우 Anolaima, 1 울 "Colombia", 1 우 ${ }^{2}$; "Bogotá",2, 1 ô, 2 ㅇ.

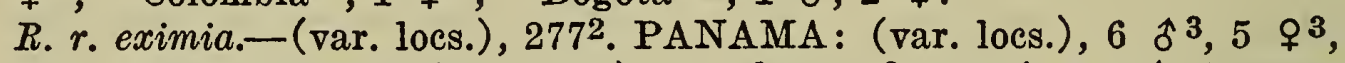

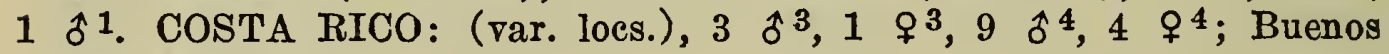
Aires 1,5 o, 4 우.

R. r. schistacea.-(var. locs.), $13^{2}$. MEXICO: Colima ${ }^{1}, 3$ ô, 4 ㅇ.

${ }^{8}$ Specimens in Pons Collection, Maracaibo.

9Specimens in Museo de Ciencias Naturales "La Salle," Caracas. 


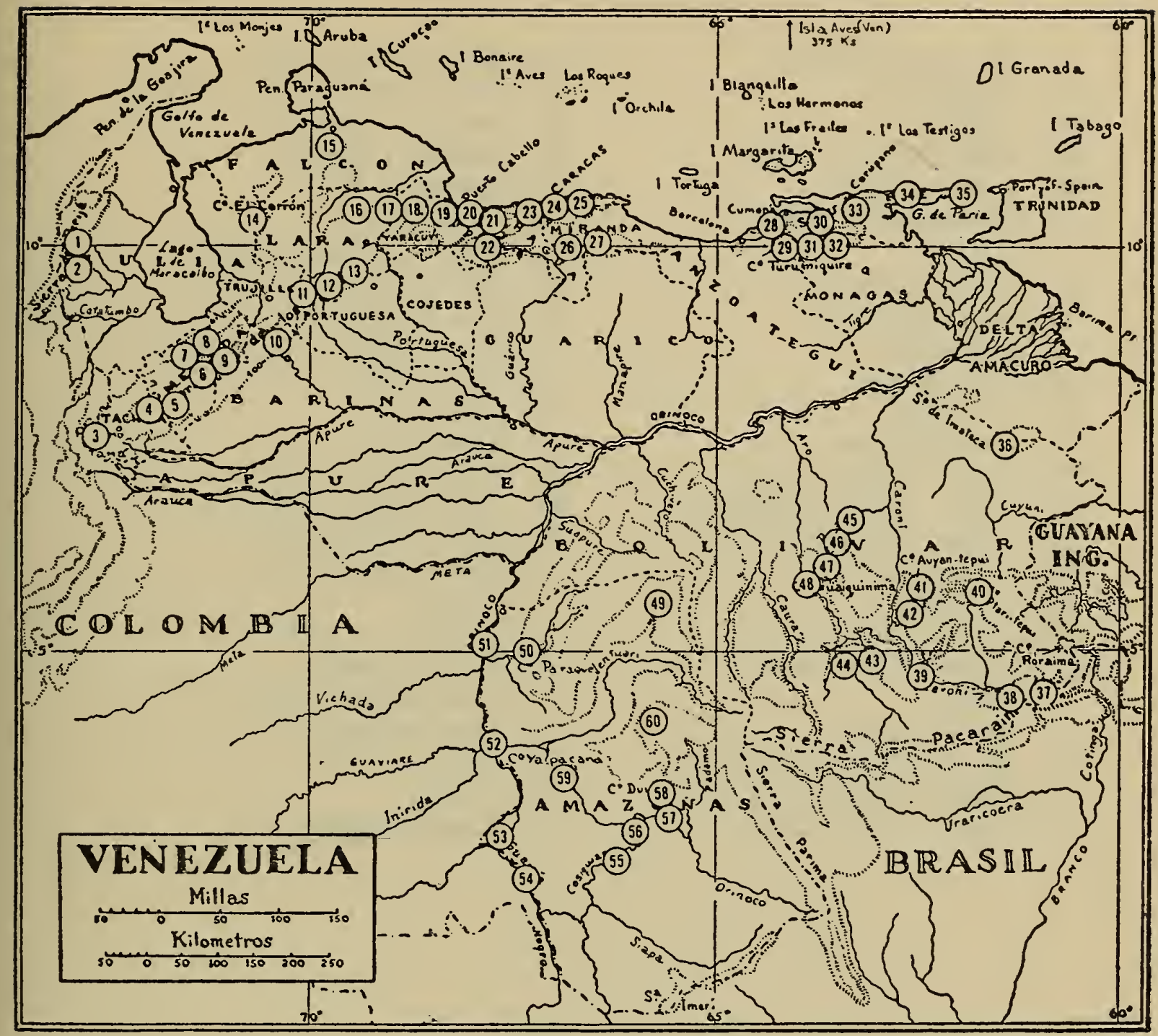

Plate XI.

List of LOCALITIES

10 Altamira (Barinas)

22 Altamira, Hda.

36 Altiplanicie de Nuria

12 Anzoátegui

39 Arebuchi, Salto

17 Aroa

41 Auyan-tepui, Cerro

2 Ayapa, Cerro

35 Azul, Cerro

5 Boca de Monte

3 Bramón

18 Bucaral

12 Bucarito, Cerro

32 Caripe

22 Carabobo, Sierra

24 Caracas

55 Casiquiare, Caño

11 Cendé, Páramo de
23 Colonia Tovar

7 Conejas, Páramo de

35 Cristóbal Colón

50 Cuao, Caño

13 Cubiro

8 Culata, Páramo de la

20 Cumbre de Valencia

15 Curimagua

58 Duida, Cerro

6 Egido

14 El Cerrón, Cerro

14 El Cogollal, Cerro

32 El Guácharo

18 El Hacha

24 El Junquito

56 El Merey

33 El Pilar

49 El Platanal 
194 Proceedings of the Biological Society of Washington

8 El Valle (Mérida)

43 Erebenequén

24 Galipán

26 Golfo Triste, Cerro

54 Guainía, Río

48 Guaiquinima, Raudal

12 Guarico

34 Humo, Cerro

25 Izcaragua, Hda.

1 La Sabana

20 Las Quiguas

28 Los Altos

30 Los Palmales

44 María Espuma, Salto

27 Negro, Cerro (Miranda)

32 Negro, Cerro (Monagas)

28 Neverí, Río

23 No León

60 Parú, Cerro

38 Paurai-tepui, Cerro

1 Perijá

45 Perro, Cerro

23 Pie del Cerro (Aragua)

7 Pinos, Páramo de los

57 Playa del Riú Base
40 Ptari-tepui, Cerro

23 Puerto La Cruz (Dto. Federal)

59 Puerto Yapacana

29 Quebrada Bonita

30 Quebrada Seca

4 Queniquea

31 Rincón de San Antonio

25 San José de los Caracas

20 San Esteban

52 San Fernando de Atabapo

24 San Julián

15 San Luis

51 Sanariapo

21 Santa Clara, Hda.

37 Santa Elena (Bolívar)

37 Santa Teresa, Hda.

48 Tabarerupá, Cerro

9 Tabay

7 Tambor, Páramo

47 Tonoro, Cerro

31 Turumiquire, Cerro

42 Uaipán-tepui, Cerro

46 Uraima, Salto

19 Urama

53 Yavita-Pimichín, pica 
196 Proceedings of the Biological Society of Washington 


\section{INDEX}

New names are printed in heavy type.

A

Acanthaster planci Acan thoph thalmus kuhlii

kuhlii
myersi

semicinctus
shelfordi sumatranus

Acer pennsylvanicum

Adactynus

Adelphicos q. sargii

alascensis, Lagopus lagopus. alba, Quercus

Albatross

albescens, Zorilla mapurito... albidiventer, Leptopogon superciliaris

albigula, Upucerthia

Aldrich, John W.

A New House Fincl from the Palouse Country of the Nor thwestern United States

Note on the nesting of the barn owl in the Smithsonian Tower alexandrae, Lagopus lagopus alhambra, Myzocallis

Allen, A. A.

Voices of the Night alleni, Sigmodon

allinornatus, Atlapetes brun-

nei-nucha

alnifolia, Amelanchier altissima, Vitex

alveolatus, Pentaceraster

amazonica, Brunfelsia

Mephitis

amazonum, Conirostrum speciosum

Pyrrhura picta

amazonus, Pachyramphus

castaneus

Amelanchier alnifolia …......

americana, Walchia

ampla, Rudheckia

Anabates certhioides

andaecola, Upucerthia

andinus, Chaetocercus jour.

danil
andrei, Saldula $\ldots 177,178$,
179,186

Aneides flavipunctatus .... 64,66

anomala, Drynaria -.

antioquiae, Piprites chloris

Aphis

bakeri
costata
limoni
montana
striata
trifolii
versicolor

versicolor

Archaster typicus

archeyi, Leiopelma

$69,71,72$

69,71

$(9,71$

七9, 72

71,72

82

165

14

190

ix

$\mathbf{x}$
150

120, 121

73

151, 152

119,120

110,111

189

47

47

98,99

97

187,188

159

160

159

159

74 arequipae, Cavia tschudii

armata, Chonaphe _.

armatus, Polydesmus

69 Arnett, Ross H., elected

71,72

175,176

84

member

Ascaphus

$57,58,59,61$

- $57,58,59,61,62,63,64,65,66$ californicus $\mathbf{6 3}, 65$ montanus _._._._._._. 64,65

truei ......... 62, 65

assimilis, Pyrrhomyias cin-

namomea

Astacus

Asterina cephea

coronata coronata

atalmalpae, Cavia tschudil _._ 133, 134

Atlapetes brunnei=nucha

allinornatus

brunneinucha

brunnei-nucha

inornatus xanthogenys

torquatus assimilis

basilicus

larensis

perijanus

phaeopleurus

phygas

atratus, Sigmodon hispidus

atrirostris, Dendrocincla

fuliginosa

auora, Rana ...........

aureolus, Peromyscus nuttalli auricularis, Basileuterus

tristriatus

azteca, Saldula

62,65

40
23

120,121

121

120,121

120,121

122

121, 122

121,122

121,122

149, 150

115

64

170

42

47

159

159

160

159
33 baeza, Basileuterus tristri-

atus …. 42

Compsocoma flavinucha... $\quad 191$

bakeri, Aphis …................... 160

barbouri, Trimetopon …..... 166, 167

barinensis, Dendrocincla $\quad 114,115$

Basileuterus tristriatus au-

ricularis
ricus au-

baeza - 42

bessereri 41,42

daedalus __...____ 42

melanotis _............... 42

meridanus ............. 41,42

parlae _._._._._......... 41,42

punctipectus _..._._. 42

tacarunae 42

bassingeri, Saldula ___ 179, 180, 181

$\begin{array}{lr}\text { Batrachoseps } & 64 \\ \text { beebei, Rhodinocichla rosea } & 191\end{array}$

Bendict, J. E., Jr., elected
Vice President

bessereri, Basileuterus 41,42

tristriatus -.......... 41,42

bislineata, Eurycea $89,92,93,94,95,96$
bislineata $89,90,91,92$
bislineata
$93,94,95,96$

(20)

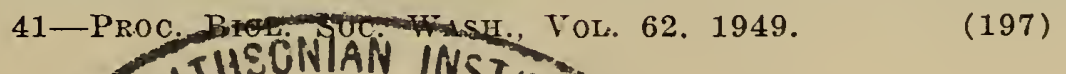

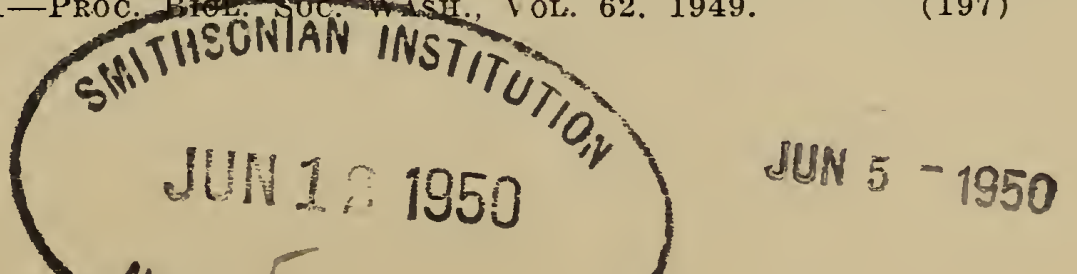




\section{Proceedings of the Biological Society of Washington}

bislineata, Salamandra.... Black, Robert F.

Geology of Alaska and its biological significance

Blacke, S. F., elected Recording Secretary

bolivianus, Philydor rufus

Piprites chloris

boreas, Bufo

Bortwick, Harry A., Member of Council

brachylopha

Lephurnis delattrei

Brunfelsia

amazonica

guianensis

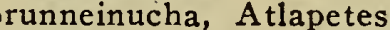

brunnei-nucha Atlapetes

brunnei-nucha,
brunnei-nucha

brunniceps, Myioborus brun. niceps

Bucco tamatia cuyuni hypnaleus interior pulmentum ___ tamatia

Bufo borea

Bunaster lithodes ...............

butleri, Zinaria

\section{C}

californicus, Ascaphus truel. Myzocallis

Caluromys

Cambarus

compressus

validus

campol, Pipilo fuscus

canadensis,

Saiulus

Canis latrans

incolatus

latrans

lestes

ochropus

thamnos

umpquensis _.........

Carpodacus mexicanus grinnelli

solitudinis _-_ _ sordidus

castanea, Fontaria

Mimularia

Nannaria

castaneocapillus, Myioborus

brunniceps

castaneus, Polydesmus -.....

caucae, Rallus nigricans

Cavia cutleri

tschudii

arequipae

a tahualpae

osgoodi

pallidior

tschudii

cayopollin, Philander -

cephea, Asterina

Cercis canadensis

certhioides, Anabates -.............

Ochetorhynchus

certhioides

Upucerthia

cervina, Dolerisca

cervinus, Leucippus
89

ix

$\mathbf{x}$

117

188

64

103,104

103, 104

151

151,152

151,152

121

121

41

186, 187

187

187

186,187

64

73,74

$84,85,86$

63,65

106

12

23

23

23
102

101, 102

82

81
31

31

31

32

32

31

29

29, 30

30
4
4

4

40,41

4
173

133

133

133

133,134

133

133

133

4,5

74, 76

82

98,99

98,100

97,98

112

112
Chaetocercus jourdanil andinus

jourdanii rosae

Chamberlin, Ralph V.

A New Genus and Four New Species in the Diplopod Family Xys. todesmidae

A New family in the Diplopod Order Chordeumida

Some Western Millipeds of the Family Chelodesmidae

chapadensis, Philydor rufus. Cherokla georgiana

chinensis, Oriolus

chinensis

Chironectes minimus _.__ 12

chlorigaster, Treron phoeni-

coptera

chlorion, Piprites chloris

Chonaphe

armata

cygneia

patriotica

remissa

chrysopis, Reithrodontomys chrysopis

Churchill, Ethan D., elected member

Cinara symphiti

Cinclodes

185,186

185,186

185,186

$125-132$

125,129

125

$25,127,129$

163,164

163,164

ix

159

97

cinereus, Plethodon cinereus 137, 138, 139

cinnamomea, Pyrrhomyias

cinnamomea

cirrigera, Eurycea bislinea-

ta - $89,90,91,92,93,95$

cirrigera $\times$ bislineata $91,94,96$

clacigera, Mithrodia _____ 74

clara, Harpaphe

Clark, Austin $\mathrm{H}$

On a Collection of Sea-

stars from the Philip. pine Islands

128,129

Columba subvinacea peninsularis columbiana, Myospiza humeralis

columbianus, Philydor rufus comatula, Saldula

compressus, Cambarus _-_

$$
\text { Orconectes }
$$

Compsocoma flavinucha

baezae

cyanoptera
flavinucha
somptuosa
venezuelana
victorini
virididorsalis

virididorsalis

conepatl, Viverra

Coneptaus semistriatus -

confluenta, Saldula

Conirostrum speciosum amazonus

guaricola

speciosum

Conover Boardman

A New Race of Rallus nigricans from Colom. bia

73-78

33

162

116

179,181

$17,18,19$

191

19

191

191

190, 191

190, 191

15,16

177

119,120

119,120

119,120

coronata, Asterina coronata. costaricensis, Xiphorhynchus guttatus

74,76

114 
costata, Aphis

Cottam, Clarence

Conservation in New

Zealand

Note on damage done by squirrels to lead pipe used to protect telephone wire

Cryptobranchus

cuchivera, Pyrrhura picta

cuchiverus, Philydor rufus...

Cuica

murina

Culcita novaeguinae

cumanensis, Grallaricula

nana

cutleri, Cavia

cuyunli, Bucco tamatia -.......

cyanoptera, Compsocoma

flavinucha

Cyclorhamphus

cygneia, Chonaphe

$\mathrm{D}$

daedalus, Basileuterus tris triatus

Dalquest, W. W. and Hall, E. Raymond

A New subspecies of Funnel-eared Bat (Natalus Mexicanus) from Eastern Mexico

Davis, Malcolm, Member of

Council

Note on the observation of a European ruff

Note on a turkey buzzard snatching a frank. furter from a small boy at the $\mathrm{Zoo}$ and eating it

Dayton, W. A.

elected Vice President

Deignan, H. G. elected Vice President

Deason, H. J., elected Mem. ber of Council

delattrei, Lophornis delattrei

demonstratus, Xiphorhny-

chus guttatus

Dendrocincla fuliginosa atrirostris

barinensis
fuliginosa
lafresnayi
meruloides
phaeochroa
ridgwayi
rufo-olivacea

Didelphis lanata laniger

opossum

philander

Didelphys

disparunguis, Walchia .................

Dolerisca cervina

Doleromya fallax

d'orbignyanus, Xiphorhynchus guttatus

Drake, C. J. and

Hottes, F. C.

Two New Species of Saldidae (Hemiptera) from Western United States

Drymaria
159

$\mathrm{xi}$

$\mathrm{xi}$

139

110,111

116

12

74

36,37

133

186, 187

191

5, 129

42

153-154

$\mathbf{x}$

ix

xi

$\mathrm{x}$

$x$

103
103

113,114

114,115

115

116

114,115

115

116

115

148

12

12

11,12

12

11
1

112

112

114

$177 \cdot 184$

147 anomala

depressa

effusa

gentryi

leptophylla

tenella

tenuis
duidae, Myioborus brunniceps

Troglodytes rufulus

dumetaria, Upucerthia

durranti, Thomomys tal-

poides

Duvall, A. J., elected Treas-

Dynoria medialis icana

$\mathbf{3}, \begin{array}{r}\mathbf{x} \\ 3\end{array}$

$\mathrm{E}$

effusa, Drynaria

148

elegans, Fromia

elgonis, Zorilla mapurito -...

elrodi, Chonaphe

Leptodesmus (Chonaphe)

Montaphe

enode, Walchia

Ensatina platensis

equalis, Nannaria

Ergethidae

Ergethus

perditus

erus, Polydesmus

erythreae, Zorilla mapurito....

estebani, Ochetorhynchus

certhioides

74,75

14
125

127

127

1

4,5

4, $\frac{5}{7}$

7

125

14

98,100

Eurycea bislineata $89,92,93,94,95,96$ bislineata

$89,90,91,92,93,94,95,96$ cirrigera $89,90,91,92,93,94$ cirrigera $\times$ bislineata $91,94,96$ major

rivicola $93,94,95$ wilderae $\quad 89,90,91,92,95,96$

ewing $i$, Trombidium _

Walchia

excelsior, Upucerthia _-__ 97

exigua, Patiriella _._. 77

eximia, Rhodinocichla rosea. 178

extoni, Xiphorhynchus gut.

tatus

\section{F}

fallax, Doleromya Leucippus fallax

flavinucha, Compsocoma flavincula

flavipunctatus, Aneides _-

Fontaria georgiana

tuobita

forficulatus, Goniodiscaster..

formosa, Pipreola formosa

Fosberg, F. R.

A New Drymaria (Caryophyllaceae) from Mexico

fossor, Thomomys

Thomomys talpoides

$143,144,145,146$

Fromia elegans

74,75
73 japonica

fugensis, Oriolus chinensis _

fuliginosa, Dendrocincla

fuliginosa

156

91

66
3

4

74
39

$147-148$

144,145

115 
Fuiler, Henry S.

A New Name for the Genotype of Walchia Ewing (Acarina: Trom. biculidae)

fulvigularis, Troglodytes rufulus

fulviventris, Trochilus -....................... fumans, Saiulus

fuscus, Ophidiaster

Pipilo fuscus

G

Gabrielson, Ira N. and Lincoln, Frederick C A New Race of Ptarmigan in Alaska

Gamba palmata

gentryi, Drymaria

Geophis nasalis

georgiana, Cherokia

Fontaria

Gilliard, E. Thomas, elected member

Two New Orioles from the Philippines

glabrum, Trombidium

Goniodiscaster forficulatus gracile, Trimetopon

Grallaria haplonota haplonata pariae

Grallaricula nana cumanensis kukenamensis nana pariae

granifer, Ophidiaster

granulosus, Triturus

Griffith, Richard E.

Conservation of Alaska's wildlife resources

grinnelli, Carpodacus mexicanus

Grobman, Arnold B.

Some Recent Collections of Plethodon from Vir. ginia with the Descrip. tion of a New Form

guaricola, Conirostrum

speciosum

guianensis, Brunfelsia _..........

Gulo quitensis

gumillae, Mephitis _..--..--_-

gunnisonii, Quercus

guttatoides, Xiphorhynchus

guttatus

$\mathrm{H}$

Hall, E. Raymond

A New Subspecies of Cotton Rat, Sigmodon hispidus, from Michoacán, México

Hall, E. Raymond and Dalquest, W. W.

A New Subspecies of Funnel-eared Bat ( $\mathrm{Na}$ talus Mexicanus) from Eastern Mexico

Hall, E. Raymond and Villa

$R$, Bernardo

A New Harvest Mouse from Michoacan, Mexico

hamiltoni, Leiopelma hamnsternii, Trimetopon

$165,166,167,168$ llaria
1-2

119

112

82

73

101

$175-176$

12

165

3,5

ix

155-158

1

166, 167

37

37

37, 38

36,37

36,37

36, 37

$135-142$

119,120

151,152

15

15
106

114

149-150

$153 \cdot 154$
127

128, 129

127,128

127

128, 129

128, 128

129

129

pottera

telodonta

Harry, Robert $R$

A new Loach of the $\mathrm{Ge}$ nus Acanthophthalmus from Siam

harterti, Ochetorhynchus

Rhodocichla rosea ...........

Upucerthia

haydeniana, Harpaphe ----

haydenianus, Harpaphe

Leptodesmus .............

hellma y ri, Leptopogon superciliaris

Hershkovitz, Philip

Generic Names of the Four-eyed Pouch Opossum and the Woolly Opossum (Didelphidae)

Technical Names of the African Muishond (Genus Zorilla) and the Colombian Hog-nosed skunk (Genus Conepatus)

Hippasteria philippiensis .... Hobbs, Horton H., Jr.

A New Crayfish of the Genus Orconectes from the Nashville Basin in Tennessee, with notes on the Range of Or conectes compressus

(Faxon) (Decapoda, Astacidae)

hochstetteri, Leiopelma -.---

Hoffman, Richard L.

Three New Species of Diplopoda from Virginia

Holothylax

Hooper, Emmet T.

A New Subspecies of Har vest Mouse (Reithrodontomys) from Central America

Hottes, F. C.

Descriptions of Some Un described Forms $\mathrm{Be}$ longing to Two LittleKnown Species of the Family Aphididae ...

Descriptions of the Sexual Forms of Some Species of Aphididae

69-72

A New Species Belonging to the Genus Myzocallis (Aphididae)

Some Obscure Aphid Spe. cies F. C., and

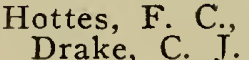

Two New Species of Sal. didae (Hemiptera) from Western United States. howelli, Reithrodontomys

huld 
humeralis, Myospiza humeralis humilis, Rallus nigricans hypnaleus, Bucco tamatia

I

icana, Drynoria medialis

Ictonyx striatus

Illinoia striatus

illinoiensis, Saldula

immaculatus, Saiulus

incolatus, Canis latrans

inlignea, Harpaphe

inornatus, Atlapetes brunneinucha

insignis, Retaster

intaminata Harpaphe

interior, Bucco tamatia

intermedius, Pachyramphus castaneus

Zorilla mapurito

\section{$\mathrm{J}$}

Jackson, Hartley H. T.

Two New Coyotes from the United States japonica, Fromia

jardinei, Xiphorhynchus gut-

tatus Johnson, D. H., elected Corresponding Secretary

jourdanii. Chaetocercus jourdanii

\section{$\mathrm{K}$}

Kakimia tutigula wahinkae

Kalmia latifolia

Kelson, Keith R.

A New Pocket Gopher From Southeastern Utah kickapoo, Macrosiphum kiowanica, Myzocalis

kleei, Tinamus tao

Knipolegus pcecilurus

paraquensis peruanus poecilurus salvini venezuelanus

kuhlii, Acanthophthalmus kuhlii

kukenamensis, Grallaricula nana

\section{L}

lachrymans, Rhadinaea

lactarium, Spirostrephon -..laevigata, Linckia Macrosiphum

lafresnayi, Dendrocincla

fuliginosa

Lagopus lagopus alascensis. alexandrae muriei

lanata, Didelphis

lancasteri, Zorilla

laniger, Didelphis

larensis, Tinamus tao

latifolia, Kalmia
161,162

161,162

173

187

latrans, Canis
latrans
Leiaster speciosus

Leiaster speciosus$$
\text { archeyi }
$$

hamiltoni

hochstetteri

Leptodesmus (Chonaphe)

elrodi

haydenianus -

leptophylla, Drymaria _-

Leptopogon superciliaris albidiventer

hellmayr

pariae

poliocephalus

superciliaris

transandinus

venezuelenis

lessoni, Lophornis delattrei

lestes, Canis 1.

Leucippus cervinus .............

fallax fallax occidentalis richmondi

lewthawaitei, Walchia

limoni, Aphis

limpopoensis, Zorilla mapurito

Linckia laevigata

113,114

multiflora
Lincoln, F. C. elected President

The homing instinct in birds

Lincoln, Frederick C., and Gabrielson, Ira $\mathrm{N}$

185,186

A New Race of Ptarmigan in Alaska

lioderma, Ophidiaster ...

I,iriodendron tulipfera ........

lithodes, Bunaster

Lophornis delattrei

$$
\text { brachylopha }
$$

delattrei

lessoni

lucianii, Pvrhura picta .....

lucifrons, Reithrodontomys

mexicanus

117, 118

118

117

117,118

117
72

$69,71,72$

69,71

36,37

luscinia, Ochetorhynchus Upucerthia certhioides....

M

Macrosiphoniella staticis Macrosiphum kickapoo laevigatae

macrosiphum rudbeckiarum y agasogae

major Eurycea bislineata

Mallodelphys .......... mapurito, Mephitis

Viverra

165

82
4,75

50,51

116

175,176

175,176

175

12

14

109,110

margaritae, Xiphorhnychus guttatus marginatus ..........

murina

mascotensis, Sigmodon

hispidus

maureri, Myzocallis

maximus, Zorilla mapurito

media. Nannaria

medialis, Drynoria

melanotis, Sigmodon .........

Basileuterus tristriatus.
31

73,74

57

57

57

127

127

147,148

190

190

189,190

189,190

190

190

189,190

103, 104

32

112,113

111, 113

112, 113

1
159

$\begin{array}{r}14 \\ 74,75 \\ \hline\end{array}$

$74,75,76$

$\mathrm{x}$

$x$

$175-176$

74,76

73,74

73,74
103

103, 104

103

103,104

110,111

170

98,99

$98,99,100$
160

55

50,51

47,51

55

90

12

15

$13,14,15$

113, 114

114

11

149,150

160

14

38

3,5
150

42 


\section{Proceedings of the Biological Society of Washington}

Mephitis amazonica

gumillae

mapurito

zorilla

meridanus, Basileuterus

tristriatus

meruloides, Dendrocincla

fuliginosa

Metachirops

mexicanus, Natalus mexicanus

Reithrodontomys

Micoureus

Micracanthia pusilla

Mimularia castanea

minimus, Chironectes

Mithrodia clacigera

Mittleman, M. B.

American Caudata. VI. The Races of Eurycea bislineata

Mittleman, M. B., and

Myers, George S.

Geographic Variation in the Ribbed Frog, As. caphus truei

Monodelphis

montana, Aphis

Rudebeckia

montanus, Ascaphus truel

Ochetorhynchus ruficaudus

Saiulus

Montaphe

elrodi

Moore, Robert T.

A New Race of Pipilo fuscus from Mexico....

A New Hummingbird of the Genus Lophornis from Southern Mexico.. Moreno, Abelardo, elected member

morobensis, Walchia

morrisoni, Nannaria

Morton, C. V.

A New Brunfelsia from Brazil Brunfelsia from

multiflora, Linckia …_-

muriel, Lagopus lagopus

murina, Cuica

Marmosa

Mustela zorilla

Myers, George S., and

Mittleman, M. B.

Geographic Variation in the Ribbed Frog, As caphus truei

myersi, Acanthophthalmus ... Myioborus brunniceps brun. niceps

castaneocapillus duidae pariae

Myospiza humeralis columbiana humeralis

pallidula

tarijensis

xanthornus

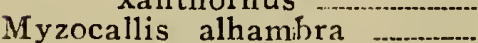

californicus

kiowanica

maureri

tonkawa
15

15

15

15

41,42

114,115

12

153,154

153,154

169

12

180

74,77

89-96

57-68

50,51

64,65

100

$81,82,86$

127

127

$101-102$

103-104

151-152

$74,75,76$

175

57.68

69,72

41

40, 41

40, 41

161, 162

162

161,162

161, 162

162

162

106

106

106

106

\section{$\mathrm{N}$}

nana, Grallaricula nana

Nannaria

castanea

cayugae

equalis

media

morrisoni

ohionis

shenandoa _..._._.

tuobita

ursa

nanus, Xiphorhynchus gut-

tatus

Nardoa novaecaledoniae -

pauciforis

squamulosa

tuberculata

nasalis, Geophis

Natalus mexicanus mexicanus

saturatus

Nectarophora rudbeckiarum nettingi, Plethodon ___. 136, 137 nigricans, Rallus nigricans

nigrita, Saldula

Ninia sebae sebae

nodosus, Protoreaster

novaecaledoniae, Nardoa

novaeguinae, Culcita

37

84,85

4,5

4,5

84
84

82,86

4

114

73

73

$\begin{array}{r}73 \\ 7,75 \\ \hline\end{array}$

165

153,154

153,154

153,154

47

138,139

173,174

174

178

165
73

73

74

\section{O}

obscuratus, Zorilla mapurito occidentalis, Leucippus tallax

Ochetorhynchus

certhioides certhioides estebani

harterti

luscinia

ruficaudus

montanus

ruficaudus

ochopus, Canis latrans

ocius, Thomomys talpoides... ocotepequensis, Reithrodon-

tomys ocotepequensis

ohionis, Nannaria

olympicus, Rhyacotriton -...

O'Neill, Hugh, elected Vice President. Vegetation of Alaska .

Ophidiaster fuscus

granifer

lioderma

pustulatus

opossum, Didelphis

Orconectes compressus

rhoadesi

validus

Oreopeleia linearis pariae-...-...

Oriolus chinensis ..................

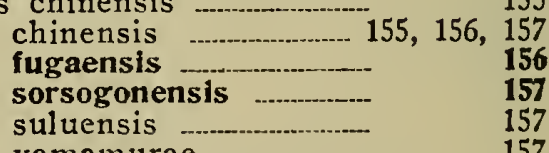

suluensis yamamurae

orinus, Reithrodontomys

mexicanus

169, 170

$\begin{array}{lr}\text { osgoodi, Cavia tschudil } & \mathbf{1 3 3} \\ \text { Othilia luzonica } & \end{array}$

ourayi, Saldula …............... 177, 179, 180, 181 
$\mathbf{P}$

Pachyramphus castaneus amazonus parui saturatus

pallidior, Cavia tschudii pallidula, Myospiza humeralis pallipes, Saldula palmata, Gamba panerythrus, Philydor rufus. paraquensis, Knipolegus

poecilurus

pariae, Basileuterus tristriatus

Grallaria haplonota _ _... nana

Myioborus brunniceps Oreopeleia linearis

Pipreala formosa Premnoplex tatei Pyrrhomyias cinnamomea Synallaxis cinnamomea

Parks, Kenneth C., elected member

parui, Pachyramphus castanx eus

Patiriella exigua _________ patriotica, Chonaphe

pauciforis, Nardoa -........

peninsularis, Columba subvinacea

pennsylvanicum, Acer _-

Pentaceraster alveolatus

penulta, Harpaphe

perditus, Ergethus

perijanus, Piprites chloris

Peromyscus nuttalli aureolus perotensis, Reithrodon-

tomys chrysopis

peruanus, Knipolegus

poecilurus

Peters, James L., and

Wetmore, Alexander

Remarks on the Genus Ochetorhynchus Meyen

phaeochra, Dendrocincla

fulignosa

Phelps, William H., and

Phelps, William H., Jr.

Eight New Birds from the Subtropical Zone of the Paria Peninsula, Venezuela

Eleven New Subspecies of Birds from Venezuela Seven New Subspecies of Birds from Venezuela.

Philander

cayopollin

virginianus

philander, Didelphis

philippinensis, Hippasteria

phillipsi, Treron-phoenicop=

tera

Philydor rufus bolivianus... chapadensis

columbianus

cuchiverus

panerythrus _...........

riveti

rufus

picta, Pyrrhura

pingue, Walchia

Pipilo fuscus

campol

fuscus
189

188,189

188,189

188,189

133

161,162

179

12

116

117, 118

41, 42

37, 38

36, 37

40,41

33

38,39

39,40

39, 40

$\mathbf{x}$

188,189

77

127, 129

129
73

33

82

128,129

7

187, 188

170

164

118

$97-100$

$33-44$

109-124

185-196

11,12

11,12

11,12

74

9
117

117
117

116

116

116

117

117

110,111

101

101, 102

101 potosinus

texanus

- 101,102

Pipreola formosa formosa__
pariae

rubidior

Piprites chloris antioquiae bolivianus _- 188 chlorion - 187, 188 perijanus — 187, 188 tschudii _-_ 187, 188

planci, Acanthaster —_ $\quad 77$

platensis, Ensatina - 136, 137, 140

cinereus cinereus _-_ 136, 138, 139 huldae _-136, 137, 138, 139 nettingi ___ $136,137,138,139$

richmondi - _ - 136, 135, 139, 140

wehrlei ___ 136,140 welleri — $136,138,139$

pliolepis, Trimetopon _____ 166

peocilurus, Knipolegus

poecilurus

poliocephalus, Leptopogon

superciliaris

carmatus

castaneus

erucs 125

polystictus, Xiphorhynchus

guttatus

pondoensis, Zorilla mapurito.

posadasi, Trimetopon

Pipilo fuscus__.

ottera, Harpaphe

Premnoplex tatel parlae tatei

pretiosa, Rana

Protoreaster nodosus

Pruitt, William O., elected member

Pseudopolydesmus serratus . pulmentum, Bucco tamatia punctipectus, Basileuterus

tristriatus

pusilla, Micracanthia -

pustulatus, Ophidiaster _._.

putorius, Viverra
pygmaeus, Thomomys tal-

poides
Pyrrhomyias cinnamomea

assimilis

cinnamomea ________

\section{pariae}

pyrrhoptera

spadix

vieillotioides _-_.._

pyrrhoptera, Pyrrhomyias

cinnamomea

Pyrrhura picta amazonum cuchivera

lucianii

picta

\section{$Q$}

Quercus

alba

quitensis, Gulo

\section{R}

Rallus nigricans

nigricans
caucae
humilis
nigricans

Rana aurora pretiosa
117

4
25

114

166,168

101
129

35

35

64

73

82

187

42

74,76

14,15

145

40

40

39, 40

39,40

40

40

110,111

110, 111

110,111

110,111

173,174

173

173

174

64 


\section{Proceedings of the Biological Society of Washington}

Rausch, Robert, elected member

ravus, Thomomys talpoides.

Reithrodontomys

chrysopis

chrysopis

perotensis seclusus

mexicanus

howelli

lucifrons

ocotepequensis

orinus

remissa, Chonaphe

repens, Trifolium

Retaster insignis

Rhadinaea lachrymans -n

rhoadesi, Orconectes

Rhodinocichla rosea

beebei
rosea
eximia
harterti
schistacea

Rhyacotriton

richmondi, Leucippus fallax

Plethodon

ridgwayi, Dendrocincla

fuliginosa

Ripley, S. Dillon

A New Race of the

Southern Indian Green Pigeon

riveti, Philydor rufus

rivicola, Eurycea bislineata

rivularis, Triturus

Romanoff, Mrs. Anastasia J.

elected member

rosae, Chaetocerus jourdani

rosea, Rhodinocichla rosea

rosenbergi, Xiphorhynchus

guttatus

rubidior, Pipreola formosa

rubrilata, Zinaria

Rubus

Rudebeckia

ampla

montana

rudbeckiarum, Macrosiphum

Nectarophora

ruficauda, Upucerthia

ruficaudus, Ochetorhynchus ruficaudus

rufo-olivacea, Dendrocincla

fuliginosa

rufulus, Troglodytes rufulus rufus, Philydor rufus.

rustica, Walchia

\section{S}

Sailer, Reese I.

The bloodsucking insects of Alaska

Saiulus canadensis -...-

fumans

immaculatus

montanus

Salamandra bislineata

salatoria, Saldula

Saldula andrei azteca $178,179,189$ comatula ……nconfluenta explanata

177

$93,94,95$ illinoiensis - - - 179

nigrita ourayi … $177,179,180,181$ pallipes __________ 179 saltatoria ….......

163, 164 Salix 50,51

salvini, Knipolegus

poecilurus 117, 118

Sanborn, Colin Campbell

Cavies of Southern Peru.. 133-134

sargii, Adelphicos q. - 165

saturatus, Natalus mexicanus

Pachyramphus castaneus 188,189

Scaphiopus $\quad 64$

schistacea, Rhodinocichla

rosea

sebae, Ninia sebae

seclusus, Reithrodontomys

chrysopis

semicinctus, Acanthophthal-

mus

emistriata, Viverra

semistriatus, Coneptaus ....

senegalensis, Zorilla mapu-

rito

septentrionalis, Tinamus tao serrana, Upucerthia

serratus, Pseudopolydesmus. shelfordi, Acanthophthalmus. shenandoa, Nannaria

shoae, Zorilla mapurito

shortridgei, Zorilla mapurito Sigmodon

alleni

hispiduas atratus mascotensis

melanotis

Sigmoria zyga

simile, Trimetopon

slevini, Trimetopon

solitudinis, Carpodacus

somptuosa, Compsocoma

flavincula

sordidus, Carpodacus

mexicanus

sorsogonensis, Oriolus

chinensis

spadix, Pyrrhomyias cinna.

momea

speciosum, Conirostrum speciosum

speciosus, Leiaster ….................

Spilogale ...

Spirostrephon lactarium .......

squamulosa, Nardoa

Stage, H. H.

Observations of an entomologist in Africa and Mauritius; $\mathrm{Nag}$ an a, African sleeping sick. ness of animals (sound film)

ix Stager, Kenneth E., elected member staticis, Macrosiplioniella ...... Staticobium

Stickel, William, Member of Council

striata, Aphis

striatipectus, Synallaxis cin-

namomea

striatus, Ictonyx striatus

Valvaster

71,72

15

15,16

14

109,110

97

82

82,86

14

14

149, 150

150

149,150

149,150

150

3,5

166,167

166, 168

29, 30

157

39,40

119,120

73,74

13,15 
Stuart, L. C.

A New Trimetopon (Ophidia) from Guatemala

sudanicus, Zorilla mapurito suluensis, Oriolus chinensis sumatranus, Acanthothphalmus kuhlii _________

superciliaris, Leptopogon superciliaris susurrans, Xiphorhynchus guttatus

Swift, Lloyd W., Member of Council

symphiti, Cinara

Syra!laxis cinnamomea

pariae striatipectus _.....

\section{$\mathrm{T}$}

tacarunae, Basileuterus

tristriatus

talpoides, Thomomys ......... tamatia, Bucco tamatia

tao, Tinamus tao

tarijensis, Myospiza humeralis

tatei, Premnoplex tatei -

Telmatobius

telodonta, Harpaphe -.

tenella, Drymaria

tenius, Drymaria

texanus, Pipilo fuscus

thamnos, Canis latranis

Thomomys fossor

talpoides

durrant
fossor
ocius
pygmaeus
ravus
uinta

Thone, Frank

Exhibition of new books on biological subjects.

Timetopon veraepacis _-_

Tinamus tao kleei

larensis
septentrionalis

tenkawa, Myzocalis septentrionalis

toroi, Pipilo fuscus

-

transandinus, Leotopogon

Treron phoenicoptera chlorigaster

if phillipsi

Trifolium repens ___

Trimetopon

barbouri

gracile

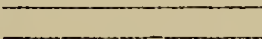

hannstenii

pliolepis

posadasi

simile

slevini

viquez

tristriatus, Basileuterus

tristriatus

Triturus granulosus rivularis

Trochilus fulviventris

Troglodytes rufulus duidae... fulvigularis rufulus vavii

Trombicula

118,119

$165 \cdot 168$

71,72

69,71

190

113,114

42

145,146

186,187

109,110

\section{2}

35

144,145

145,146

$143,144,145$

146

145

145

144,145

166,168

110

109,110

109,110

109,110

$105,106,107$

101,102

190

\section{9}

160

160

165,167

166,167

166,167

167,168

166,166

166,168

166,168

166,168

42
64

64

112

118, 119

119

Trombidium ewingi

glabrum
truei, Ascaphus A_ truei

$62,63,64,65,66$

tschudii, Cavia —__

tschudii 133

Piprites chloris ____ 178, 188

Tsuga

tuberculata, Nardoa ___

tulipifera, Liriodendron

tuobita, Fontaria

Nannaria

turmalis, Walchia

tutigula, Kakimia

typicus, Archaster

73,75

73,75

82

4
1
56

$\mathrm{U}$

uinta, Thomomys talpoides umpquensis, Canis latrans Upucerthia

albigula

rthioides

dumetaria

dumetaria

harterti

ruficauda

serrana

validirostris

urban, Zinaria

ursa, Nannaria

$\mathrm{V}$

validirostris, Upucerthia validus, Orconectes

Valvaster striatus
valvidus, Cambarus

renezuelana, Compsocoma

flavincula

poecilurus

venezuelensis, Leptopogon

superciliaris

veraepacis, Trimetopon - -

versicolor, Aphis _..._._.

victorini, Composocoma

flavinucha

vieillotioides, Pyrrhomyias

cinnamomea

Villa R.. Bernardo and

Hall, E. Raymond

A New Harvest Mouse

from Michoacan, Mex.

viquezi. Trimetopon

virginianus, Philander

virididorsalis, Compsocoma

flavinucha

Vitex altissima

Viverra conepatl

mapurito

putorius

semistriata

zoralla

ronFritsch, Karl

144,145

97,98

98

97,98

$98,99,100$

97
97

97

97

97

85

97

17,23

74,77

19

190, 191

117

189,190

166,168

159

191

40

$163-164$

166,168

11,12

190, 191

10

$13,14,15$

14,15

13,14

W

The language of bees

wahinkae, Kakimia

Walchia americana

disparunguis

enrode 


\section{Proceedings of the Biological Society of Washington}

ewingi

lewthawaitei

morobensis

pingue

rustica

turmalis

Walford, Lionel A.

Sardines; It's the Maine sardine (color film)

wehrlei, Plethodon

welleri, Plethodon

Wendt, Lorina

Note on the observation of crossbills at Lebanon, Virginia

Wetmore, Alexander

An Additional Form of the South American

Grasshopper Sparrow..

Wetmore, Alexander and

Peters, James L.

Remarks on the Genus

Ochetorhynchus Meyen

wilderae, Eurycea bislineata $89,90,91,92,95,96$

\section{$\mathrm{X}$}

xanthogenys, Atlapetes

brunnei-nucha

xanthornis, Myospiza

humeralis

Xiphorhynchus guttatus

costaricensis

demonstratus

d'orbignyanus

eytoni

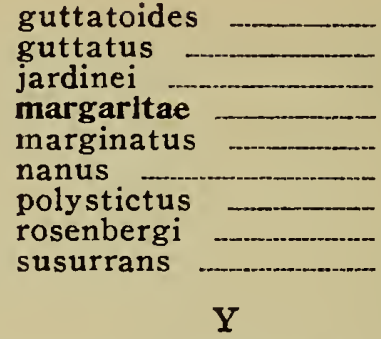

yairi, Troglodytes rufulus yagasogae, Macrosiphum

yamamura, Oriolus chinensis

\section{Z}

$161-162$

Zinaria butleri

rubrilata

urbana

zoralla, Viverra

Zorilla lancasteri

mapurito albescens elgonis

erythreae

intermedius

limpopoensis

maximus

obscuratus

senegalensis

shoae

shortridgei

sudanicus

zorilla, Mephitis

Mustela

zyga, Sigmoria
114

114

113,114

113,114

114

114

114

114

113,114

118, 119

55
157

157

$84,85,86$

$84,85,86$

13,14

14

14

14

14

14

14

14

14

14

14
14
14

14

15

3. 5 
208 Proceedings of the Biological Society of Washington 


\section{PROCEEDINGS}

OF THE

\section{Biological Society of Washington}

VOLUME 63

1950

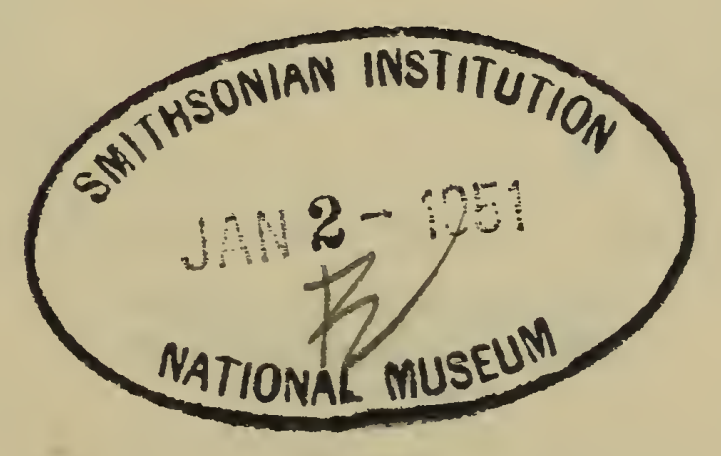

WASHINGTON

PRINTED FOR THE SOCLETY 


\title{
COMMITTEE ON PUBLICATIONS
}

\author{
HERBERT FRIEDMANN, Chairman \\ REMINGTON KELLOGG $\quad$ E. P. KILLIP J. S. WADE
}

\section{PUBLICATION NOTE}

By a change in the By-Laws of the Biological Society of Washington, effective March 27, 1926, the fiscal year now begins in May, and the officers will henceforth hold office from May to May. This, however, will make no change in the volumes of the Proceedings, which will continue to coincide with the calendar year. In order to furnish desired information, the title page of the current volume and the list of newly elected officers and committees will hereafter be published soon after the annual election in May.

All correspondence should be addressed to the Biological Society of Washington, c/o U. S. National Museum, Washington, D. C. 


\section{OFFICERS AND COUNCIL \\ OF THE \\ BIOLOGICAL SOCIETY OF WASHNGTON \\ (FOR 1950-1951)}

(ELECTED MAY 13, 1950)

\section{OFFICERS}

President

FREDERICK C. LINCOLN

$\nabla$ ice-Presidents

(In the order of election)

W. A. DAYTON

H. G. DEIGNAN

HUGH T. O'NEIL

MALCOLM DAVIS

Recording Secretary

S. F. BLAKE

Corresponding Secretary

HARALD A. REHDER

Treasurer

ALLEN J. DUVALL

Custodian of Publications

DAVID H. JOHNSON

\section{COUNCIL}

Elected Members

H. A. BORTHWICK

H. J. DEASON

DAVID H. JOHNSON

L. W. SWIFT

W. H. STICKEL

Ex-Presidents

J. W. ALDRICH

PAUL BARTSCH

C. E. CHAMBLISS

A. D. HOPKINS

H. B. HUMPHREY

H. H. T. JACKSON

H. C. OBERHOLSER

T. S. PALMER

S. A. ROHWER

J. S. WADE

E. P. WALKER

A. WETMORE

\section{STANDING COMMITTEES-1950-1951}

Committee on Communications

HUGH T. O'NEIL

R. M. GILMORE, Chairman

Committee on Zoological Nomenclature
A. WETMORE, Chairman

PAUl Bartsch

$$
\text { C. F. W. Muesebeck }
$$

H. H. T. JACKSON

Committee on Publications

H. G. Deignan, Acting Chairman

Remington KedLogg

E. P. KILLIP

J. S. WADE

Trustees of Permanent Funds

J. E. GraF, Chairman

H. B. HUMPHREY

S. F. BLAKD 
EX-PRESIDENTS

OF THE

\section{BIOLOGICAL SOCIETY OF WASHINGTON}

-THEODORE N. GiLL, 1881, 1882

-Charles A. White, 1883, 1884

-G. Brown Goode, 1885, 1886

"William H. DahL, 1887, 1888

-Lester F. Ward, 1889, 1890

*C. Hart Merriam, 1891, 1892

C. V. Rilex, 1893, 1894

"Geo. M. Sternberg, 1895, 1896

"L. O. How ARD, 1897, 1898

- Frederick V. Coville, 1899, 1900

*F. A. LuCas, 1901, 1902

B. W. EvermanN, 1903, 1904

*F. H. KNowlton, 1905, 1906

*L. SteJNeger, 1907, 1908

T. S. PALMER, 1909, 1910

* David White, 1911

E. W. Nelison, 1912, 1913

Paul Bartsch, 1914, 1915

*W. P. HAY, 1916, 1917

*J. N. Rose, 1918

"Hugh M. Sмith, 1919

A. D. Hopkins, 1920

N. Hollister, 1921

-Vernon Bailey, 1922

*A. S. Hrtchcock, 1923

"J. W. Gidley, 1924

S. A. ROHWER, 1925

H. C. OBERHOLSER, 1926-1927

*E. A. Goldman, 1927-1929

AleXANDER WeTMORE, 1929-1931

H. H. T. JACKSON, 1931-1933

C. E. Chambliss, $1933-1936$

H. C. Fuller, 1936-1938

-W. B. BeLl, 1938-1940

E. P. WALKER, 1940-1942

H. B. HuMpHREY, 1942-1944

*F. THONe, 1944-1946

J. S. W $\triangle D E$, 1946-1947

J. W. ALDRICH, 1947-1949

^Deceased. 


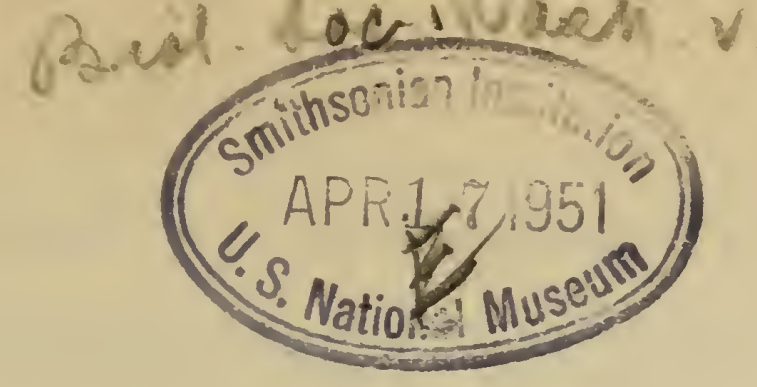

TABLE OF CONTENTS

Officers and Committees for 1950 .

Proceedings for 1950

A New Jumping Mouse (Genus Zapus) from Kansas, by E. Lendell Cockrum and Rollin H. Baker

iii

Critical Notes on the Cotingas, by W. E. Clyde Todd.

A New Cave Spider from North Carolina, by Sherman C. Bishop

A New Tree Squirrel from Central Utah, by Ross Hardy

Descriptions of Western Colorado Aphididae, by F. C. Hottes

Hirstionyssus obsoletus, A New Mesostigmatic Mite from Small Mammals of the Western United States (Acarina), by E. W. Jameśon, Jr.

Descriptions of Some Aphididae from Carex, by F. C. Hottes

Three New Subspecies of Birds from Venezuela, by William H. Phelps and William H. Phelps, Jr.

Another Neotenic Eurycea from the Edwards Plateau, by W. Leslie Burger, Hobart M. Smith and Floyd E. Potter, $\mathrm{Jr}$.

A New Race of the Species, Amazilia beryllina, from Southern Mexico, by Robert T. Moore

An Additional Form of Pepper-shrike from Western Panamá, by Alexander Wetmore

A New Subspecies of Snowshoe Rabbit from Wyoming, by Rollin $\mathrm{H}$. Baker and Robert M. Hankins

A List of Maryland Mammals (Part I. Marsupials and Insectivores), by Marshall C. Gardner-

Systematic Notes on Some Central American Millipeds, by Richard L. Hoffman

Two New Gobies from the Philippines With Notes on a Third Rare Goby, by Albert W. C. T. Herre

New Species of Solitary Vespidae from North America (Hymenoptera, Vespidae), by Richard M. Bohart

Two Apparently New Oven-Birds from Colombia, by W.

E. Clyde Todd 
A New Crayfish of the Genus Cambarellus from Texas (Decapoda, Astacidae), by Horton H. Hobbs, Jr.

New Species of Aphididae, by F. C. Hottes $97-100$

New Birds from Nepal and the Indian Region, by S. Dillon Ripley 101-108

A New Race of Melanerpes chrysogenys from Central México, by Robert T. Moore.

A List of Maryland Mammals (Part II. Bats), by Marshall C. Gardner $111-114$

Seven New Subspecies of Venezuelan Birds, by William H. Phelps and William H. Phelps, Jr. $115-126$

A New Agamid Lizard (Agama kirkii fitzsimonsi) from Southern Rhodesia, by Arthur Loveridge. $127-130$

New Frogs of the Genera Cyclorana and Hyla from Southeastern Australia, by Arthur Loveridge.

A New Hoplothrips from Cuba, by J. Douglas Hood $139-146$

Some Diplopods from Puerto Rico, by Ralph V. Chamberlin

Some Chilopods from Puerto Rico, by Ralph V. Chamberlin

New Records of Neotropical Gentianaceae, by Joseph Ewan 163-166

Descriptions of Two Subspecies of Harvest Mice (Genus Reithrodontomys) from Mexico, by Emmet T. Hooper.- 167-170

Additional Forms of Birds from the Republics of Panama and Colombia, by Alexander Wetmore

A New Varicorhinus from Lake Tanganyika, by J. T. Nichols and F. R. LeMonte

Three New Species of Saldidae (Hamiptera), by C. J. Drake and F. C. Hottes $177-184$

The Status of the Milliped Chelodesmus marxi Cook, and of the Family Name Chelodesmidae, by Richard L. Hoffman

New Philippine Fruit Bats, by Colin Campbell Sanbord_.-. 189-190

A New Race of Swainson's Warbler from the Appalachian Mountains, by Brooke Meanley and Gorman M. Bond_.. 191-194

North American Additions to the Genus Pterocheilus ( $\mathrm{Hy}-$ menoptera, Vespidae), by Richard M. Bohart

A New Cacomistle from Southeastern California, by Kenneth E. Stager 203-204

A New Tyroglyphid Mite from Puerto Rico, by Irving Fox 205-208 
The Committee on Publications declares that each paper of this rolume was distributed on the date indicated on its initial page. The contents, minutes of meetings, and index for 1950 ( $p p$. v-xi, 209-218) were issued on April 13, 1951. The title page and lists of officers and committees for 1949-1950 (pp. i-iv) were issued on December 29, 1950.

\section{PLATES}

Plate I, page 2. Skull of Zapus hudsonius pallidus.

Plate II, page 11. New Cave Spider from North Carolina.

Plate III, page 34. Hirstionyssus obsoletus.

Plate IV, page 48. Map of Venezuela.

Plate V, page 55. Posterior basibranchials of Eurycea.

Plate VI, page 56. Presacral ribs of Eurycea.

Plate VII, page 57. Hyobranchium of Eurycea pterophila.

Plate VIII, page 94. Cambarellus ninae.

Plate IX, page 125. Map of Venezuelan localities.

Plate X, page 144. Holothrips bradleyi.

Plate XI, page 153. Diplopods from Puerto Rico.

Plate XII, page 181. Three New Species of Saldidae.

Plate XIII, page 188. Eurydesmus marxi.

Plate XIV, page 208. Suidasia insetcorum. 
viii Proceedings of the Biological Society of Washington 
PROCEEDINCS

OF THE

BIOLOGICAL SOCIETY OF WASHINGTON

\section{PROCEEDINGS}

The Society meets from October to May on the second Saturday of each month at 8 P.M. All meetings in 1950 were held in Room 43 of the U. S. National Museum.

\section{7th Meeting-January 14, 1950}

President Lincoln in the chair; 40 persons present.

New members elected: Thomas W. Donnelly, Frederic R. Scott.

Informal Communications: S. F. Blake, Report of finding three clumps of Solidago juncea in flower in Arlington Va., that day; Lorina Wendt, Report on observation of Snowy Owl near the Interior Department building.

Formal Communication: Thaddeus E. Jones, Antarctic travelogue.

\section{8th Meeting-February 11, 1950}

Informal Communications: F. C. Lincoln, Exhibition of newspaper picture of a "sea monster," probably a whale, that had come ashore in Egypt; S. F. Blake, Report of observation of about 50 Red-winged Blackbirds in Alexandria that day, including one female.

Formal Communications: Merle A. Gee, Big game management on the North Kaibab; U. S. Forest Service, Every man's empire (moving picture).

\section{9th Meeting-March 11, 1950}

Ex-president Aldrich in the chair; 60 persons present.

New member elected: Arthur B. Mickey.

Formal Communications: Malcolm Davis and John McCabe, Exhibition of a live Snowy Owl; C. R. Eklund, Wildlife of the Ungava Peninsula. 
990th Meeting-April 8, 1950

President Lincoln in the chair; 41 persons present.

The President announced that S. F. Blake had been appointed delegate of the Society to the Seventh International Botanical Congress to be held at Stockholm in July.

The President announced that the Society had accepted Dr. Paul Bartsch's invitation to hold a field meeting at his estate Lebanon, on Gunston Cove, on April 30.

New members elected: Philip A. Klein, Edward A. Simmons.

Informal Communication: S. F. Blake, Report of the voice of the Snowy Owl as described by various observers.

Formal Communication: Albert C. Smith, A botanist in Fiji.

\section{1st Meeting-May 13, 1950}

\section{IST ANNUAL MEETING}

President Lincoln in the chair; 40 persons present.

New member elected: R. C. Ballard.

The reports of the Recording Secretary, Corresponding Secretary, and Treasurer were presented.

The deaths of Oakes Ames, G. L. Eadie, L. O. Howard, Henry Pittier, and Frank Thone were reported.

The following officers and members of council were elected: President, F. C. Lincoln; Vice Presidents, W. A. Dayton, H. G. Deignan, Hugh O'Neill, Malcolm Davis; Recording Secretary, S. F. Blake; Corresponding Secretary, H. A. Rehder; Treasurer, A. J. Duvall; Members of Council, H. A. Borthwick, H. J. Deason, L. W. Swift, W. H. Stickel and D. H. Johnson.

The business meeting was followed by an open meeting, at which two colored motion picture films on "Alaska wildlife," prepared by the Fish and Wildlife Service, were shown.

\section{2d Meeting-October 14, 1950}

President Lincoln in the chair; 45 persons present.

New members elected: Earl L. Atwood, Stillman Wright. The death of H. S. Barber was noted.

Informal Communication: F. C. Lincoln, Report of attendance at Tenth International Ornithological Congress.

Formal Communication: Raymond M. Gilmore, Whaling on the west coast. 


\section{3d Meeting-November 11, 1950}

President Lincoln in the chair; 39 persons present.

New members elected: Wm. E. Benyon, Faxon W. Cook, Albert M. Day, Tobías Lasser, Alden H. Miller, Javier Oritz de la Puente, Ralph Russell, Robert J. Russell, Jr.

Informal Communication: F. C. Lincoln, Report on conference on Alaska recently held in Washington.

Formal Communication: R. Tucker Abbott, Giant African snails.

\section{4th Meeting-December 9, 1950}

President Lincoln in the chair; 40 persons present.

Informal Communication: S. F. Blake, Exhibition of specimens of Wolffia papulifera from Texas, and Wolffiella floridana and Lemna minor from Kenilworth Aquatic Gardens.

Formal Communication: Clarence Cottam, The National Wildlife Refuges. 
xii Proceedings of the Biological Society of Washington 
less distinct; zygomatic arch heavier; lateral margins of incisive foramina broadly concave as opposed to moderately concave; dorsal process of maxillary arm of zygoma less expanded laterally; arch formed by maxillary arm of zygoma and molariform tooth-row more expanded (broader); cranium at junction with squamosal arm of zygoma more inflated; interparietal bone narrower (anteroposteriorly), and not extending laterally to junction of parietal, squamosal and supraoccipital; post parietal region of cranium more rounded, less flattened, posteriorly.
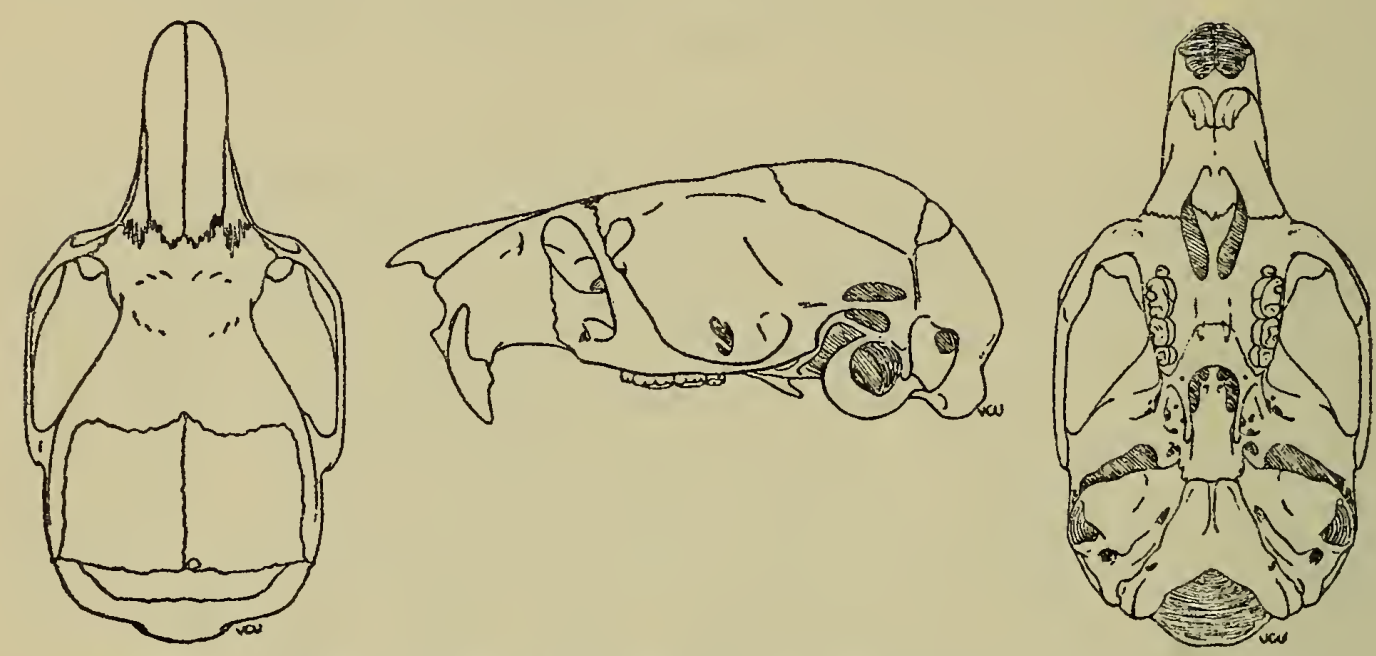

Figure I. Three views of the skull of the type specimen of Zapus hudsonius pallidus. UKMNH no. 22953 , ․ $\times 2$.

From specimens of $Z$. $h$. hudsonius (Zimmerman) from Sherburne County, Minnesota, $Z$. $h$. pallidus differs as follows: Averaging smaller in measurements of total length, length of tail, length of hind foot and length of upper molariform tooth-row and larger in zygomatic breadth, interorbital constriction and length of nasals; color lighter (but less so than as in comparion with $Z$. h. campestris); zygomatic arch lighter; posterior margin of hard palate even with or posterior (instead of anterior) to line connecting posterior margins of third upper molars; lateral margins of nasals not markedly constricted posteriorly; lateral margins of incisive foramina broadly concave as opposed to moderately concave; arch formed by maxillary arm of zygoma and molariform toothrow more expanded (broader).

From specimens of $Z$. $h$. rafinesquei from Posey County, Indiana, $Z$. $h$. pallidus differs as follows: Averaging larger in measurements of greatest length of skull, least interorbital constriction, length of palatal bridge, length of nasals and height of skull; color lighter, with distinct middorsal stripe which is lacking in specimens of $Z$. $h$. rafinesquei examined; zygomatic arch relatively lighter; posterior margin of hard palate even with or posterior (as opposed to slightly anterior) to line connecting posterior margins of third upper molars; basioccipital longer and narrower; lateral margins of nasals not markedly constricted posteriorly.

Remarks.-Zapus hudsonius pallidus, on the basis of eight specimens from the type locality, agrees most closely in size with $Z$. $h$. rafinesquei and in color with $Z$. $h$. campestris; there is less resemblance between 
Z. h. pallidus and Z. h. hudsonius. Z. h. pallidus is definitely smaller both in external and cranial measurements than either $Z$. $h$. campestris or $Z$. $h$. hudsonius, and closely approximates $Z$. $h$. rafinesquei in these respects except as noted in the comparisons. As regards color, apparently a gradation exists from the darker $Z$. $h$. hudsonius through the lighter $Z$. $h$. campestris to the lightest $Z$. $h$. pallidus.

Three specimens available from Nebraska are typically $Z$. $h$. pallidus. One specimen from southwestern South Dakota (Bennett County) is referred to $Z$. $h$. pallidus but shows evidence of intergradation with $Z$. h. campestris in the shape of the nasals and the incisive foramina. Two specimens from northeastern South Dakota (Day County) show evidence of intergradation between $Z$. $h$. campestris, $Z$. h. hudsonius and $Z$. h. pallidus in the structure of the nasals, interparietal, posterior margin of the hard palate, in the shape of the incisive foramina and in external measurements. These specimens are here referred to $Z$. $h$. hudsonius. Specimens from North Dakota show no relationship to $Z$. h. pallidus; our examination indicates that these are referable to $Z$. $h$. hudsonius but show some characteristies of $Z$. $h$. campestris. In so far as South Dakota is concerned, $Z$. $h$. campestris apparently is restricted to the Black Hills and adjacent areas. Specimens examined from northwestern Iowa are referred to $Z$. $h$. hudsonius but show evidence of intergradation with $Z$. $h$. pallidus in the shape of the incisive foramina and the nasal bones, in the breadth of the least interorbital constriction and in the length of the upper molariform toothrow. Two specimens examined from Cole County, in central Missouri, are referable to $Z$. $h$. pallidus, and show no characters of intergradation with the more eastern $Z$. $h$. rafinesquei. Two specimens from southern Illinois (Perry County) are referred to $Z$. $h$. rafinesquei but show evidence of intergradation with $Z$. $h$. pallidus in the color of the pelage and the breadth of the least interorbital constriction. In other respects they resemble specimens of $Z$. $k$. rafinesquei.

In Zapus, wear on the upper molariform tooth-row begins on the third molar and proceeds forward with the first molar receiving wear last. Specimens were judged to be adults when the third molar showed definite wear, that is, when the cusps were mostly or totally worn down. This degree of tooth wear was found to be correlated with adult pelage. In our specimens at least, wear on the third molar was correlated also with sexual maturity in females of $Z . h$. campestris; those in late preg. nancy show wear on the third molars, and some of these pregnant females show wear on no other teeth. All of these females, however, had adult pelage and all were obtained in Crook County, Wyoming, in July, 1947.

Prior to 1948, fewer than ten specimens of Zapus hudsonius were known from Kansas, although considerable collecting had been done in the state in the past 70 years by personnel of the University of Kansas Museum of Natural History as well as by personnel of the Bureau of Biological Survey (U. S. Fish and Wildlife Service) and other institutions. Although of apparent widespread distribution within the state, Zapus hudsonius may be one of the rarest of small mammals in Kansas and, certainly, is one of the least known. Probably it is found principally in relatively undisturbed marginal situations between grasslands and woodlands, especially in the more humid parts of eastern Kansas. Blair (Amer. Midl. Nat., 22, no. 1, 1939, p. 127) suggests that the 
distribution of this species in northeastern Oklahoma follows the stream systems. Swenk (Nebr. Acad. Sci., 8, no. 3, 1907, p. 111) reports that the animal occurs in wooded areas in Nebraska. Eight specimens taken in April and May, 1948, in Douglas County, Kansas, from which the type of $Z$. $h$. pallidus has been selected, were obtained on a grassy slope along the side of a brushy drainage course. The grassy area, approximately $2 \frac{1}{2}$ acres in size, was covered with a thick stand of undisturbed blue stem grass and was surrounded on three sides by grazed woodlands. Now included in the University of Kansas Natural History Reservation, this area will be preserved as a natural area for ecologic study.

Measurements.-Average and extreme measurements of four adult males and four adult females of $Z$. $h$. pallidus from the type locality are, respectively, as follows: Total length, 199.2 (193-204), 189.5 (178197); length of tail, 114.5 (107-121), 113.2 (106-119); length of hind foot, 28 (28-28), 27.2 (26-29); length of ear, 12.5 (11-14), 13.8 (13$15)$; weight, 17.0 (15.2-20.0), 14.4 (11.7-16.2); greatest length of skull, 22.4 (22.1-22.7), 21.6 (21.0-22.6); zygomatic breadth, 11.5 (10.9-11.8), 10.9 (10.5-11.1); mastoid breadth, 9.7 (9.5-10.0), 9.5 (9.1-9.7); least interorbital constriction, $4.3(4.1-4.6), 4.4$ (3.9-4.8); length of palatal bridge, 3.4 (3.3-3.5), 3.3 (3.2-3.4); alveolar length of upper molariform tooth-row, $3.4(3.2-3.5), 3.2(3.0-3.6)$; greatest height of skull, 9.2 (9.0-9.8), 8.6 (8.4-8.7); length of nasals, 8.5 (8.2-8.7), 8.2 (7.9-8.4). All of the measurements listed above are available for each of the eight specimens included except that the weight for one male and one female was not taken.

Specimens examined.-Total, 20 distributed by localities of capture as follows and unless otherwise stated in the University of Kansas Museum of Natural History:

South Dakota:-Bennett County: Batesland, 1 (Chicago Natural History Museum).

Nebraska:-[Buffalo County] : Platte Meadows, Kearney, 1 (Hastings Museum, Hastings, Neb.) ; Thomas-Blaine Counties line: Dismal River, 1 (Nebraska Game, Forestation and Parks Commission); Richardson County: 5 mi. SE Rulo, 1 (Nebraska Game, Forestation and Parks Commission).

Kransas:-Brown County: Horton, 1; Douglas County: NW corner sect. 4, T12S, R20E, $51 / 2 \mathrm{mi}$. N, 13/4 mi. E Lawrence, 8 ; sect. 8, T12S, R20E, 4 mi. N, 18/4 mi. E Lawrence, 1; Lakeview, 2; $71 / 2$ mi. SW Lawrence, 2.

Missouri:-Cole County: Jefferson City, 2 (Univ. of Missouri Museum of Zoology).

Other records of occurrence (probably representative of $Z . h$. pallidus): -Oklahoma:-Tulsa County: Mohawk Park, 2 (Blair, Amer. Midl. Nat., 22 , no. 1,1939, p. 127).

The authors are indebted to the authorities of the following institutions for making available material used in this study: United States National Museum and Biological Surveys Collection; Chicago Natural History Museum; Chicago Academy of Sciences; Cleveland Museum of Natural History; Iowa State College; Ohio State University; Hastings Museum, Hastings, Nebraska; Nebraska Game, Forestation and Parks Commission, Lincoln, Nebraska ; University of Missouri, Museum of Zoology. 
Remarks.-Nine adult males in our collection from Cumbre de Valencia and Lagunita de Aroa differ constantly from four adult males from El Limon and Santa Lucia in the reduced orange area on the breast. Presumably the latter represent typical formosa, since they come from points respectively west and south of the type-locality (Caracas). When Hellmayr discussed this species (Arch. f. Naturg., 78 , A, pt. 5, 1912, 93) he had only birds from Cumbre de Valencia, which prove upon comparison to be appreciably different from the nominate race. Females of the two races, however, are indistinguishable, although both are easily different from rubidior.

Iodopleura isabellae paraensis, subsp. nov.

Type, No. 69,740, Collection Carnegie Museum, adult male; Benevides, Pará, Brazil, October 14, 1918; Samuel M. Klages.

Subspecific characters. - Similar to Iodopleura isabellae isabellae Parzudaki of western Brazil, eastern Peru to eastern Colombia, etc., but underparts with less mesial white, and the sides and flanks with more brownish white barring and mottling, giving a decidedly duller effect.

Range.-Lower Amazon Valley of Brazil.

Remarks.-Five specimens from Benevides (near Pará) differ from seven specimens from Arimã (Rio Purús) and Tonantins as aforesaid. Parzudaki's bird came from the Rio Negro, "Venezuela." Dr. Zimmer has sent me a pair of this species from opposite Tahuapunto, Rio Uapés, Colombia, which comes as near the type-locality as we can get, and it is fair to presume that these correctly represent isabellae. They agree well with our skins from the Rio Purús and the upper Amazon. The white mesial streak on the underparts is comparatively broad; the sides and flanks are decidedly blackish, with little brownish mottling. In the Benevides specimens, on the other hand, the white mesial streak is much less distinct, and wholly or partly interrupted on the breast by the encroachment of dark color; the sides and flanks are distinctly mottled or barred with brownish white.

\section{Pseudattila phoenicurus (von Pelzeln)}

A female specimen of this generically distinct form was taken by Mr. Samuel M. Klages at Arimã, Rio Purús, on September 30, 1922.

\section{Rhytipterna simplex frederici (Bangs and Penard)}

Considerable variation in color is in evidence in our series of seventythree specimens from Bolivia, Brazil, and French Guiana. Some examples are darker, more grayish; others are paler, with a yellowish cast. Immaturity is indicated by rusty edgings on the wings and tail.

The distinctions claimed by Dr. Zimmer (Am. Mus. Nov. 893, 1936, 11) for his proposed race intermedia from south of the Amazon I am unable to verify in this series, although I have not seen true simplex. I can discover no constant differences between specimens from opposite banks of the river. Messrs. Griscom and Greenway (Bull. Mus. Comp. Zoöl., $88,1941,258)$ also disagree with Dr. Zimmer's conclusions, but they go on to point out that " 12 specimens before us from the Rio Purus and Rio Solimoës appear instantly separable from Lower Amazon birds in being darker below.' But the difference is actually very slight, and far from constant, and $I$ agree that no formal separation is advisable. 


\section{Lipaugus cineraceus dispar, subsp. nov.}

Type, No. 50,887, Collection Carnegie Museum, adult male; Buena Vista, Bolivia, September 23, 1914, José Steinbach.

Subspecific characters.-Similar to Lipaugus cineraceus cineraceus (Vieillot) of the Guianas, southern Venezuela, Brazil, etc., but decidedly larger. Wing (three males), 136, 136, $141 \mathrm{~mm}$; tail, 115, 118, $115 \mathrm{~mm}$. Range.-Bolivia.

Remarls.-This new race is based solely upon relative size, as compared with a large series from other parts of the species' range. Hellmayr (Field Mus. Zool. Ser., 13, pt. 6, 1929, 159) argues that a southern race cannot be recognized, while at the same time he admits that a series from the Yungas of Cochabamba in Bolivia probably represents a different race. Count Gyldenstolpe (K. Svenska Vet. Akad. Handl., 22 , No. 3, 1945, 210-211) gives measurements of the series at his command; they fully confirm Hellmayr's conclusions. His birds from the lower Rio Beni in Bolivia, however, are no larger than Brazilian birds.

\section{Pachyramphus polychopterus tristis (Kaup)}

To this race I would refer our series of 118 specimens from various localities in Venezuela, Trinidad, French Guiana, and Brazil. These I have re-examined after a study of Dr. Zimmer's (Am. Mus. Nov. 894, 1936, 12-15) and Count Gyldenstolpe's (K. Svenska Vet. Akad. Handl., 22 , No. 3, 1945, 211-214) remarks. Our series does not justify the contention of these authors that the Rio Tapajóz bird is true polychopterus, and I thus agree with Hellmayr's original identification. There is reason to believe that light-colored males are younger birds; they probably grow blacker with age.

\section{Pachyramphus polychopterus similis Cherrie}

Mr. J. L. Peters (Bull. Mus. Comp. Zoöl., 69, 1929, 454) considers this race identical with cinereiventris of northern Colombia. Males are not noticeably different, but females of similis (ten) from Costa Rica are certainly darker-colored than Colombian females (ten); the wingand tail-edgings tend to be rusty rather than buffy. On this ground I think that similis should be reinstated. The case has been discussed also by Messrs. Aldrich and Bole (Sci. Pub. Cleveland Mus., 7, 1937, 91), but inconclusively. 
8 Proceedings of the Biological Society of Washington 
and from the lateral by about the diameter; all eyes nocturnal and, except anterior median, elongate oval in outline; endites of the palpi widely separated at base, the distal margins with a sharp ridge and the disto-mesal margins truncated and bearing dense scopulae; labium about twice as wide as long and with scarcely an indication of a groove separating it from the sternum; sternum smooth and shining, strongly convex, broadly heart-shaped and produced behind, between the coxae of the fourth legs, into a squarely truncated lobe, sternum armed with seattered long, brown hairs; legs damaged in capture but generally long and slender; coxae globose; trochanters short; femora cylindrical, slightly tapering distally; patellae short, arched above; tibiae slender; metatarsi siender, about as long as tibiae; tarsi about half as long as metatarsi; paired claws long, curved and armed at base below with series of about 11 slender teeth increasing in size distally; third claw smooth, about half as long as others and bent ventrally at the middle of its length; all legs armed sparsely with short, light brown hairs and many longer, stronger spinelike bristles which increase in size, number and length on the distal segments. Femur of palpus moderately long, cylindrical; patella short, arched above and bearing dorsally one very long and several shorter spines, ratio of length of patella to that of tibia as 4 to 15; tibia one and one half as long as patella, strongly swollen and armed ventro-laterally with two very long, curved spines and numerous smaller ones at the distal margin and distributed around the segment; cymbium long and narrow and provided with a basal, lateral apophysis which is very large, trough-shaped and armed, on either side of trough, with a strong pointed tooth; distally the apophysis is produced into three prongs, the dorsal one long, sinuous and serrated along the distal margin; the middle piece thin and broad and squarely truncated, the ventral part more slender, somewhat twisted and strongly serrated distally. Bulb of palpus large with the long, slender, curved embolus arising from the ventro-lateral side at base and curving forward around the mesal side.

Color. Cephalothorax and its appendages bright yellow; abdomen above dirty white with a suggestion of paired gray spots on dorsum; sternum with the margins dusky; venter of abdomen with grayish blotches in front of epigastric furrow and spinnerets.

Female. Length $3.5 \mathrm{~mm}$. Similar to the male in general appearance and armature but with the thorax and basal segments of the legs lighter yellow; margins of thorax dusky and with faint tinges of dusky behind the eyes and in a triangular patch in front of median depression of thorax; abdomen globose, marked above, on a dirty white ground color, with five or six pairs of large, faint grey spots; epigynum protuberant and consisting of three lobes, the center one with paired openings at the margin behind.

Holotype male, allotype female, only known specimens; found clinging to wall of cave a short distance from the entrance.

Type locality. Linville Cave, near Linville Falls, N. C., April 6, 1947.

Types in author's collection.

Invesia carolinensis is obviously closely related to $I$. tennesseensis Pet. (Figs. 5-8) from which it may be distinguished by the form of the apophysis of the cymbium of the male and the epigynum of the female.

The drawings were made by Miss Carolyn Fallon, staff artist, Department of Zoology, University of Rochester. 
12 Proceedings of the Biological Society of Washington 


\section{A NEW TREE SQUIRREL FROM CENTRAL UTAH}

By Ross HaRdY

Los Angeles, Orange Co. State College

A sufficient number of specimens of the tree squirrel (Tamiasciurus) has been collected to reveal the presence of a new variety from the southern Wasatch Mountains of Utah. This form is annectant between two forms heretofore considered species (T. fremonti and T. hudsonicus) but it has sufficient characters of its own - enough to make it desirable to recognize a new race. Since the name hudsonicus has priority, this race, like all others of the fremonti group, should be listed as subspecies of hudsonicus. It is proposed that this race be known as

\section{Tamiasciurus hudsonicus wasatchensis, new subspecies WASATCH CHICKAREE}

Type.-Male, adult, skin with skull; United States National Museum, Fish and Wildlife Service Collection, no. 276,398; from about 10,000 feet, in spruce-fir area along Skyline Drive east of Mt. Nebo, Juab County near Juab - Utah County line, Utah; August 19, 1942; collected by Ross Hardy; original no 2431 (33443X).

Distribution.-Known from the fir and spruce belts of the southern Wasatch Plateau of Central Utah, including San Pete and Emery Counties as well as the Mt. Nebo area of Utah and Juab Counties. Intergrades northward into $T$. $h$. ventorum of the northern Wasatch Mountains.

Diagnostic characters.-Dark tail usually with Pinkish-Cinnamon to Ochraceous-Buff tips to hairs; overall color of pelage, especially top of head, with much black; body and cranial measurements medium for western races of the species.

Measurements (in $\mathrm{mm}$.): Type: male, total length, 337 ; tail vertebrae, 134; hind foot, 51; ear from notch, 26. Skull: basal length, 41.9; palatilar length 22.0 ; zygomatic breadth, 27.5 ; cranial breadth 21.5 ; interorbital breadth, 14.9 ; breadth at postorbital constriction, 14.7 ; nasal length, 16.4; maxillary tooth row, 8.2 ; diastema, 10.9 ; width of palate between second and third molars, 7.0.

The average and extreme measurements of 11 males and 8 females are, respectively : total length, 328.1 (303-345), 328.1 (324-335); tail, 128.4 (93-141), 131.9 (126-140) ; foot, 51.1 (49-53), 51.4 (48-54); ear from notch, 27.5 (26-29), 27.1 (25-29). Skull: basal length, 41.4 (40.0$42.0), 41.2$ (40.5-42.5); palatilar length, 21.3 (20.0-22.0), 22.2 (21.523.2); zygomatic breadth, 27.4 (25.5-29.1), 26.8 (26.0-27.4); cranial breadth, 20.9 (20.2-21.8), $21.1(20.5-22.0)$; interorbital breadth, 15.1 
(14.4-16.1), 15.2 (14.2-15.7) ; postorbital constriction, 15.3 (14.6-16.5), 15.1 (14.4-15.7); length of nasals, 15.8 (15.0-16.4), 15.1 (13.4-15.7); length of maxillary tooth row, 8.4 (8.0-8.7), 8.6 (8.0-9.2); diastema, 11.5 (10.9-12.1), $11.4(10.2-12.0)$; width of palate between second and third molars, 7.0 (6.3-7.7), $7.0(6.6-7.8)$.

Compared with paratypes of dixiensis and with fremonti from Colorado, the skull of this race averages slightly shorter but has about the same zygomatic breadth.

The width of the palate between the second and third molars averages greater than in any of the races examined.

Compared with dixiensis, this race has shorter nasals, but they are not as short as in ventorum. The rostrum is shorter than in dixiensis or ventorum as shown by a shorter diastema. The interorbital width is only slightly wider than in ventorum.

Comparisons of pelages: From Colorado and Southern Wyoming specimens of $T$. hudsonicus fremonti in comparable summer pelage, this form differs principally in the tail color, having the hairs tipped with Pinkish-Cinnamon or Ochraceous-Buff (Ridgway 1912). In five of the 19 specimens, many of the hairs are white-tipped but in none is this white "frosting" as extensive as in dixiensis or in fremonti. The central terminal portion of the tail is black, usually with few if any light tips on the hairs. The tail viewed from the ventral surface is darker than in fremonti, having more black and fewer gray hairs. The overall appearance is slightly darker than in fremonti because of more black barring on the hairs. The top of the head has more black hairs.

From paratypes of $T$. $h$. dixiensis from Pine Valley Mts., Utah, this form differs in its darker tail and the "rustier" appearance of the tail and hind feet even in those with white in the tail.

From T. hudsonicus ventorum from Rich and Weber Counties, Utah, this form differs in being much darker in overall appearance, with less "rusty" in pelage, including the tail. The terminal portion of the tail is black being more like $T$. $h$. richardsoni of Oregon whereas the amount of black in the tail of ventorum is reduced. The top of the head is darker than in any of the material examined except possibly dixiensis.

The greater amount of cinnamon and the reduction of black in the tail of some specimens from 11 miles east of Fairview, which is in San Pete Valley, show that they are closer to ventorum than is material from the type locality near Mt. Nebo west of San Pete Valley.

Remarks. - My thanks are given to Paul Newey and Richard D. Porter, students of Weber College, for their help in the collection of material used in this study.

Specimens examined.-UTAH. Total number 19, as follows: Juab County east of Mt. Nebo on Scenic Loop Road near Juab - Utah County line at 10,000 feet, 13. San Pete County near Skyline Drive 17 miles northeast of Ephraim at 10,300 feet, 3; 11 miles east of Fairview on summit of Wasatch Mts. pass at 8,500 feet, 3 . 
Vol. 63 , pp. $15-30$

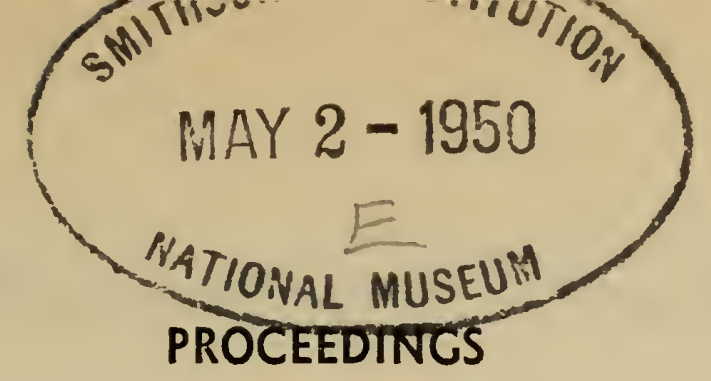

April 26, 1950

OF THE

BIOLOGICAL SOCIETY OF WASHINGTON

\section{DESCRIPTIONS OF WESTERN COLORADO APHIDIDAE}

Bу F. C. HотTES

The specimens described here were collected during the summer of 1948, in a region known as Unaweep Canyon through which highway 141 has been built.

\section{Macrosiphum bonitum, new species}

Apterous viviparous female. Size and general color.-Average length from vertex to tip of anal plate $1.95 \mathrm{~mm}$, range from 1.71-2.18 mm. Width of head across eyes $.371-.40 \mathrm{~mm}$. Head thorax and abdomen bright radiant red in forms taken in the summer changing to brownish red for forms taken late in the fall. Antennae dark brown to almost black, except for I and II and the extreme base of III and most of VI. These segments and regions are somewhat lighter in color. Femora with basal halves yellowish to dusky yellow quickly shading to dark brown. Tibiae and tarsi almost uniform dark brown, sometimes with basal and apical portions almost black, and the region between very dark brown. Cornicles black and very uniform in color. Cauda, except for lighter basal portion brown with setulose surface darker.

Head and appendages.-Comparative lengths of antennal segments as follows: III .50-.629, average $.571 \mathrm{~mm}$, IV $.35-48$, average $.41 \mathrm{~mm}$, V .314-.316, average .379 mm, VI .114-.143+ .46-.53 $\mathrm{mm}$. Secondary sensoria confined to the third antennal segment and numbering from 10 to 25 with the average number 15. However, seven specimens taken at random out of twelve had fifteen or more sensoria. The sensoria are, as a rule, confined to the basal three fourths of the segment; they vary greatly in size, the smaller ones being tuberculate, the larger ones not. Some of the smaller sensoria are no larger than the base of the antennal hairs which are quite similar to the sensoria, being lighter than the antennal surface in color. The sensoria are without rims. Antennal hair is sparse, that on III slightly knobbed and shorter than the segment is wide. The third antennal segment is smooth, the remaining segments are imbricated, segments five and six being more imbricated than the fourth. Antennal tubercles only moderately well developed and diverging. First antennal segment only slightly gibbous. Rostrum reaching to or almost to the coxae of the metathoracic pair of legs. Segments four and five of the rostrum rather long, about equal to the second segment of the hind tarsus in length, rather narrow but by no means acute. All segments of the rostrum beyond the basal half of the szcond dark brown.

Thorax.-The thorax is without lateral tubercles. The hair on the legs is pale and arises from clear colored elevations. The hair on the outer surface of the tibiae is longer than that on the inner surface and gets 


\section{Proceedings of the Biological Society of Washington}

progressively longer towards the apex. The hair near the base of the tibiae is much shorter than the width of the tibiae at this point. The hair on the outer surface of the tibaie near the apex is longer than the width of the segment while that on the inner surface is less than half the tibiae in width. The tibial hairs are sparse but the hair on the apical region is more abundant. The hind tibiae measure from $1.07-1.35 \mathrm{~mm}$ in length. As a rule the tibiae are longer than $1.20 \mathrm{~mm}$ but much shorter than $1.35 \mathrm{~mm}$. The hind tarsi measure from $.128-.143 \mathrm{~mm}$ in length.

Abdomen.-The abdomen is without lateral tubercles. The cornicles measure from $.614-.745 \mathrm{~mm}$ in length. As a rule, the cornicles range between $.64 \mathrm{~mm}$ and $.71 \mathrm{~mm}$. The cornicles taper slightly from a rather wide base to a weakly developed rim. They are coarsely imbricated so that the basal half appears rather rough. About $.1 \mathrm{~mm}$ of the cornicle near the apex is reticulated. The reticulations are weak and on some specimens rather difficult to determine. The cauda is from .214-.257 $\mathrm{mm}$ long, with the most common length $.243 \mathrm{~mm}$. The cauda is slightly constricted or constricted on one side only. Its tip is rather blunt. On its sides one may find from three to four hairs. It is common for the cauda to have three hairs on one side and four on the other. A hair on the dorsum near the apex may or may not be present. The entire surface of the cauda is coarsely setulose.

Alate viviparous female.-Size and general color.-Length from vertex to tip of anal plate 1.21-1.87, average length $1.51 \mathrm{~mm}$. Width of head across eyes $.343-.386 \mathrm{~mm}$. Color of head thorax and abdomen quite similar to that of the apterous viviparous female. Color of appendages similar to those of apterous viviparous female.

Head and appendages.-Comparative lengths of antennal segments are as follows: III .50-.58, average $.53 \mathrm{~mm}$; IV .314-.40, average .365 $\mathrm{mm} ; \mathrm{V} .328-.40$, average $.349 \mathrm{~mm}$; VI .114-.20, average $.15 \mathrm{~mm}+.543$ $.614 \mathrm{~mm}$. The secondary sensoria are confined to the third antennal segment. They vary considerably in size and all have wide rims, the smaller ones being slightly tuberculate. The sensoria are irregularly arranged but are few to lacking on the dorsal surface. The hair on segment III are sparse, spine-like, pale in color and sharp pointed. In length they are about equal to half the width of the segment. All antennal hair arise from clear-colored slightly raised tubercles which at times suggest small sensoria. Antennal segment III is smooth, the remaining segments are progressively more and more imbricated. The anterior margin of the head is provided with a median tubercle. The antennal tubercles are moderately well developed. The rostrum attains the middle of the coxae of the metethoracic pair of legs, segments four and five are about equal in length to the second segment of the tarsi, and are narrow but not acute.

Thorax.-Thoracic and abdominal tubercles lacking. Stigma narrow and pale dusky in color. Second branch of media about midway between first branch and margin of wing. Veins pale dusky with a pale border. Median portion of wing pale, outer portion light dusky and rather rough. Hind tibiae varying in length from 1.14-1.28 $\mathrm{mm}$, as a rule more than $1.20 \mathrm{~mm}$ long. Hind tarsi $.143 \mathrm{~mm}$ in length. Hair on hind tibiae very sparse, that near the base very short, in other respects similar to that found in the apterous viviparous female.

Abdomen.-Cornicles varying in length from $.57-.686 \mathrm{~mm}$. Other 
features of cornicles similar to those of apterous viviparous female. Cauda .185-.228 mm, similar to that of apterous viviparous female.

Apterous oviparous female. Size and general color.-Average length from vertex to tip of anal plate $1.79 \mathrm{~mm}$, range from 1.28-2.04 mm. Width of head across eyes, .347-.371 mm. Color of head thorax and abdomen variable. Specimens taken October first were a rich dark brown with the head and antennal tubercles shading to darker dusky brown. Specimens taken October nineteenth, after several frosts, in part were similar to those taken October first, others had the head dark brown with some indications of green. These specimens had the thorax and abdomen dark brown with a greenish-metallic sheen. The antennae, legs, cornicle, and cauda are similar to corresponding structures in the viviparous females.

Head and appendages.-The anterior margin of the head is slightly convex but there is no median tubercle. Comparative lengths of antennal segments are as follows: III .46-.59, average .53 $\mathrm{mm}$; IV .314-.40, average $.33 \mathrm{~mm} ; \mathrm{V} .30-.40$, average $.35 \mathrm{~mm}$ (in only one case was V shorter than IV); VI .10-.128 + .457-.543, average .48 mm. Secondary sensoria are limited to third antennal segment and number from three to twelve, each number represented by only one specimen. Average number of sensoria is seven, most common number of sensoria, four to six. The sensoria, as a rule, extend only a short distance beyond the basal half of the segment. They vary considerably in size, are irregularly arranged but confined largely to one side of the antenna. The larger sensoria have wide rims which are lacking in the smaller ones. The rostrum extends to or slightly beyond the metathoracic pair of coxae. It may be much darker than that of the viviparous females.

Thorax.-The hind tibiae vary in length from 1.00-1.94 $\mathrm{mm}$, and average $1.26 \mathrm{~mm}$. This average is made much larger than it should be by the tibiae of a single specimen. $1.10 \mathrm{~mm}$ would appear to be about the correct average length. The hind tarsi are from $.128-.143 \mathrm{~mm}$ in length. The basal half of the hind tibia is very slightly swollen and it is in this region that a moderate number of irregularly sized sensoria are located. The sensoria on the tibiae are less abundant near the median portion of the swollen area than elsewhere.

$A b$ domen. - The cornicles vary in length from $.50-.61 \mathrm{~mm}$. The surface of the cornicle not reticulated is roughly imbricated. Anal plate very shallow, apical surface with a few hair. Cauda .171-.251 mm, each represented by a single specimen. The most common length of the cauda is $.214 \mathrm{~mm}$. The setulose surface of the cauda is very dark. The lateral surfaces of the cauda have from four to six hair. The cauda is not constricted.

Apterous male. Size and general color.-Average length from vertex to tip of anal plate is $1.14 \mathrm{~mm}$, the range from $.929-1.25 \mathrm{~mm}$, the most common length, $1.22 \mathrm{~mm}$. Width of head across eyes $.314 \mathrm{~mm}$. The male of this species is described only from the collection made October nineteenth although males may have been present on October first but overlooked on this date because of their small size. Head, thorax and abdomen are dark green shading to dusky brown. Antennae, cornicles, tibiae, and tarsi are blackish brown, less dark than corresponding structures in the female. Basal half of the femora is greenish.

Head and appendages.-Antennal segments with the following com. parative lengths: III $.386-.443 \mathrm{~mm}$, IV $.314 \mathrm{~mm}, \mathrm{~V} .286-.316 \mathrm{~mm}, \mathrm{VI} .10$ - 
$.143 \mathrm{~mm}+.50-.543 \mathrm{~mm}$. Secondary senoria distributed as follows: III 21-42, average 30 ; IV 10-15; V 8-11. On III the sensoria are irregularly arranged, have wide rims and vary considerably in size. On IV the sensoria are confined more or less to one side of the segment. They are irregularly arranged. On this segment the sensoria are more uniform in size and there is a strong tendency for them to be more abundant on the apical half. On $V$ the sensoria are in an irregular row. The rostrum extends slightly beyond the coxae of the metathoracic pair of legs.

Thorax.-The hind tibiae vary around $1.00 \mathrm{~mm}$ long. The hair on the tibiae is very sparse and that on the inner side may be very short. The hair near the apex of the tibiae is no longer than that near the middle, that near the base is very short. The hind tarsi are about $.128 \mathrm{~mm}$ long.

Abdomen.-The cornicles are from .314-.343 mm long, their surface is roughly imbricated. The apex of the cornicles is so feebly reticulated that in most specimens the imbrications appear to reach the apex of the cornicle. The cauda is from $.10-.11 \mathrm{~mm}$ long and almost triangular in shape, being but little longer than wide at the base. There are about five lateral hairs on the cauda. The gonapophyses are dark brown and well supplied with hair.

Holotype apertous viviparous female August 14, 1948, Morphotype alate viviparous female August 27, 1948, Morphotype apterous oviparous female October 1, 1948, Allotype apterous male October 19, 1948. All types deposited in United States National Museum. The host upon which this species was taken was Stephanomeria pauciflora. On this host it lives on the flower stems. Type locality about twenty-five miles north of Gateway, Colorado, near highway 141.

This species is closely allied to Macrosiphum atripes G\&P from which it differs in the following respects: the males are apterous, the cornicles are much longer and show fewer and more feeble reticulations, the cauda is shorter, thicker, and much darker, neither do the hair on the abdomen arise from dark spots.

\section{Braggia uncompahgrensis, new species}

Apterous viviparous female. Size and general color.-Length from vertex to tip of abdomen (the anal plate rarely reaching as far as the tip of the abdomen) varying from .858-1.43, average length $1.27 \mathrm{~mm}$. Specimens taken during the hot dry period of the summer will average smaller than the average given here, while specimens taken after the fall rains, and perhaps those taken in the spring, will average longer. Width of head across eyes .286-.314 mm. Head thorax and abdomen grey-green with a very slight but very uniform frost-like pulverulence, in part due to long hair and in part due to scant pulverulent matter. Antennae pale yellowish-green except for apical three-fourths of segment which is light dusky. Rostrum yellowish-green except for apical segments which are dusky and the extreme tip which is black. Femora yellowish green. Tibiae similar except for a portion near the apex about equal in length to the tarsi which is dusky. Tarsi dusky. Cornicles concolorous with abdomen or slightly dusky at the apex. A few specimens may have the cornicles dusky throughout. Cauda seldom seen but concolorous with abdomen. Anal plate seldom seen but concolorous with abdomen except for the outer margin which is dusky.

Head and appendages.-Comparative lengths of antennal segments as 
follows: III .128-.176, most common length $.157 \mathrm{~mm}$; IV .085-.128, most common length $.128 \mathrm{~mm} ; \mathrm{V} .071-.128$, as a rule $.085 \mathrm{~mm}$ or more; VI $.075-.085$, most common length $.071 \mathrm{~mm}+.057-.071$, as a rule just equal to base of six. Secondary sensoria distributed as follows: III 1-4, most common number 3 ; IV $0-2$, distributed almost equally $0-1-2 ; \mathrm{V} 0$. All sensoria very difficult to determine, being but little differentiated from the rest of the segment as regards to color. All antennal segments lightly imbricated. Antennal hair almost absent, if present on III very sparse, fine, and very short. Anterior margin of head well rounded and commonly with two long pointed hair. The rostrum reaches slightly beyond the coxae of the mesothoracic pair of legs, but never reaching the coxae of the metathoracic pair. Apical portion of the rostrum thin but not acute, segment four and five longer than the hind tarsi.

Thorax.-Prothorax with a pair of long tubercles. The hand tibiae are from .429-.529 mm long. As a rule they are longer than $.471 \mathrm{~mm}$. The hind tarsi are $.086-1.00 \mathrm{~mm}$ long. The hair on the tibiae is very sparse and shorter than one half the width of the tibiae on the basal half. The tarsal claws are very well developed with the apex of the claw very sharp and clear in color.

Abdomen.-The cornicles very from $.057-.085 \mathrm{~mm}$ in length, with the most common length $.0715 \mathrm{~mm}$. The cornicles are distinctly constricted just before the apex, which has a well developed rim. The surface of the cornicle is imbricated. The dorsal surface of the thorax and abdomen is reticulated. The thorax and abdomen are provided with long .057 . $.071 \mathrm{~mm}$ sharp to dull pointed hair. These body hair are set on excep. tionally well developed tubercles, the height of which was not measured in determining the length of the hair. No body hair are enlarged at the tip, none knobbed, and none have a square apical surface. The cauda is very short and, strange as it may seem, hardly ever extends to the tip of the abdomen. It is about $.071 \mathrm{~mm}$ long and about twice as wide at the base. The surface of the cauda is setulose and the sides have about three hair. The anal plate is also peculiar, being wider than the cauda at the base and very short. Its apical margin is provided with long fine hair which are not situated on tubercles. In most mounted specimens the abdomen extends well beyond the cauda and anal plate hair similar to that found on the rest of the abdomen forming a sort of posterior margin.

Alate viviparous female. Size and general color.-Average length from vertex to tip of abdomen $.924 \mathrm{~mm}$, range in size from .829-1.00 $\mathrm{mm}$. Head pale dusky to rather dark dusky brown. Thoras with similar variations. Abdomen grey green with slight frosty pulverulence which in this case is not due to hair. Antenna uniform pale to pale with apical portion of segments light dusky. Femora pale with apical portions dusky. Tibiae pale with distal portions dusky. Femora pale with apical portions dusky. Tarsi dusky. Cornicles concolorus with abdomen or pale dusky.

Head and appendages.-Comparative lengths of antennal segments as follows: III .214-.228 mm, IV $.10-.143 \mathrm{~mm}, \mathrm{~V} .08-.128 \mathrm{~mm}$, VI $.05-.07$ + 0.4-.1 mm. Secondary sensoria arranged as follows: III 5-9, most common number nine arranged in more or less of a row; IV 1-3, $\mathrm{V}$ 0-1. The sensoria are comparatively large. All antennal segments are imbricated and segments III, IV, and V lack hair. The median portion of the vertex has a well developed tubercle. The rostrum extends well 
beyond the metathoracic pair of coxae.

Thorax.-Femora rather short and wide, considerably flattened laterally. Hind tibiae $.57 .68 \mathrm{~mm}$ long. Hind tarsi $.08 \mathrm{~mm}$ long. Hair on hind tibiae very short and scant on inner surface and almost lacking on the outer surface. Stigma light dusky with a scale-like surface. Radial sector narrow and weakly bowed. Second branch of media about midway between first branch and the margin of the wing. All veins are light dusky with a pale border and end in a dusky patch before reaching the wing margin. The outer portion of the wing is rougher than the more median portion. Prothorax with well developed lateral tubercles. The cubitus of the hind wings may or may not be present.

Abdomen.-Cornicles .05-.07 mm long, shaped as in apterous viviparous female. Hair on body unlike that on apterous female, comparatively sparse, fine, and sharp-pointed. Cauda and anal plate as in apterous female.

Apterous oviparous female. Size and general color.-Average length from vertex to tip of abdomen $1.23 \mathrm{~mm}$. Range in length from 1.07$1.38 \mathrm{~mm}$. Width of head across eyes $.257 \mathrm{~mm}$. Color of head, thorax and abdomen as in apterous viviparous female, or with the head, thorax and abdomen bronze-green.

Head and appendages.-Comparative length of antennal segments as follows: III .157-.171 mm, IV .114-.128 mm, V .071-.100 mm, VI .057$.071+.071 \mathrm{~mm}$, or as a rule equal to base of VI. Secondary sensoria on III, $2-4$, most common number 2 , IV $0-2, \mathrm{~V} 0$. The rostrum which has the last two segments long and thin reaches to the metathoracic pair of coxae.

Thorax.-Prothorax with small lateral tubercles. Hind tibiae .40-.42 $\mathrm{mm}$. long, not swollen, but rather wide throughout all but the extreme apex. Sensoria on tibiae numerous, round, of uniform size, and reaching almost to the apex of segment.

Abdomen.-First abdominal segment with lateral tubercles. Cornicles, cauda, and anal plate as in apterous viviparous female. Abdomen posterior to cornicles slightly constricted.

Alate male. Not observed in life. Length $1.21 \mathrm{~mm}$. Proportional length of antennal segments as follows: III .228 mm, IV .20, V .157 mm, VI .1 $+.1 \mathrm{~mm}$. Secondary sensoria distributed as follows: III 24-27, IV 13-18, V 11-14, VI 0-2. The sensoria are irregularly arranged, are round and rather uniform in size. The head has a median tubercle. The head and thorax are dusky brown, the abdomen is light green. The cornicles are light dusky.

This species is very closely allied with Braggia echidna G\&P from which it differs most conspicuously by the character of the body hair in the apterous viviparous female. In the species here described, the hair are sharp-pointed for the most part but some of the hair are slightly blunt, not blunt, or squarely cut off at the apex and distinctly not capitate as described for echidna. The body hairs are also longer than those of echidna. The color of the males and eviparous females also differs.

Professor Palmer has kindly sent me several slides from the type series of Braggia echidna for study. None of these slides shows capitate hairs as described in the original description but the character of the hair differs much from the character of the hair found in Braggia uncompahgrensis. 
Holotype slide Apterous viviparous female October 19, 1948.

Morphotype Alate viviparous female August 27, 1948.

Morphotype apterous oviparous female October 19, 1948.

Allotype alate male October 19, 1948.

All types deposited in United States National Museum. Specimens of this species are extremely difficult to collect. In only one case were specimens taken in a colony on the flower stems of the host Eriogonium corymbosom. Other collections were made on the flower stems and the under sides of the leaves of the host species, the specimens being taken individually. The sparse distribution of this species makes the collection of it extremely tedious and time consuming.

\section{Aphis agathona, new species}

Alate viviparous female. Size and general color.-Length from vertex to tip of anal plate $.94 \mathrm{~mm}$. Head and thorax dark dusky brown with the anterior margin of head and lateral portions of thorax more dusky than brown. Abdomen dark brown with lateral dusky patches. Cormicles dusky. Femora shading from light dusky to dark dusky. Hind femora darkest. Tibiae light dusky at the base shading to pale dusky and again shading to dusky at the apex. The apical portion of the tibiae of the metathoracic pair of legs, shaded dusky, is much darker than that of the other legs and very considerably longer. Tarsi concolorus with apical portion of tibiae. First and second antennal segments concolorus with head, remaining segments light but dusky with the apical portions darker.

Head and appendages.-Antennal segments with the following proportional lengths: III $.271 \mathrm{~mm}$, IV $.171 \mathrm{~mm}, \mathrm{~V} .157 \mathrm{~mm}$, VI $.085 \mathrm{~mm}$ $+.114 \mathrm{~mm}$. All antennal segments imbricated and provided with but few fine hair, which are short. Sensoria on III irregularly arranged, varying considerably in size from extra large to minute and all with wide rims, the smaller ones tuberculate. On segment III the sensoria number 15 on one antenna and II on the other. Sensoria on IV in an irregular row and numbering 5. Segment $V$ has 2 sensoria. Anterior margin of head well rounded with a median tubercle.

Thorax.-Prothorax with a pair of lateral tubercles. Stigma pale dusky. Radial sector long and narrow, little bowed. Second branch of media closer to margin of wing than to the first branch. Margin of wing very considerably rougher than median portion. Hind tibiae .715 $\mathrm{mm}$ long. Hind tarsi .1 mm long. Hair on outer portion of tibiae exceedingly sparse, hair on remaining outer portion of tibiae fewer and finer in texture than that on inner portion.

$A b d o m e n .-F i r s t$ abdominal segment and also the seventh provided with lateral tubercles. Cornicles $.057 \mathrm{~mm}$ in length, asymetrical, with the surface almost smooth, distinctly constricted near the apex. The cornicles of this form are not nearly as juglike as those of the apterous viviparous female. Cauda $.042 \mathrm{~mm}$ long, wider at base than long. The sides of the cauda are almost parallel and the apex is very broadly rounded. The hair on the cauda cannot be seen on the single specimen here described. The anal plate is longer than the cauda. It has a setulose surface and its outer margin is provided with a few long, slightly eurved hair.

Apterous viviparous female.-Size and general color.-Average length from vertex to tip of anal plate $1.54 \mathrm{~mm}$. Range in length 1.43-1.78 mm. 
The smaller specimens were collected in August, the larger ones in October. Head thorax and abdomen clothed with a white pulverulence which at times becomes rather dense. The pulverulent matter is not uniform in distribution, being either naturally lacking or rubbed off in a rather uniform pattern which takes the form of an irregular longitudinal line with frequent deviations to the sides and lateral areas. The denuded areas are a pinkish-brown. The antennae are considerably lighter in color than those of the alate viviparous female. The legs are similar to those of the alate female but the middle portion of the tibiae is much paler. The cornicles are black or almost so. Cauda, with a crescent-shaped area at the base, pale. Remaining portion dusky with apical margin darkest.

Head and appendages.-Comparative length of antennal segments as follows: III .272 mm, range from .243-.300 mm; IV .155 mm, range $.143-.185 \mathrm{~mm} ; \mathrm{V} .132 \mathrm{~mm}$, range $.114-.143 \mathrm{~mm}$, most common length $.128 \mathrm{~mm}$; VI most common length $.1 \mathrm{~mm}$, range $.08-.128+.011-.12$, most eommon length $.11 \mathrm{~mm}$. Sensoria very difficult to determine being but little differentiated from the rest of the antenna in color, arranged in a straight or irregular row showing considerable range in size but on the whole small. Sensoria on III, 2-7, each number represented by but one case, most common number 3 ; IV, $1-5$, each represented by one case, most common number $2 ; \mathrm{V}, 0-3$, commonly none. Rostrum reaching to the coxae of the mesothoracic pair of legs. Last two segments of rostrum semi-acute but not needle-like, and as long as or longer than the terminal process of the sixth antennal segment.

Thorax and Abdomen.-Prothorax with well developed lateral tubercles. Hind tibiae .74-.85 mm long. Hind tarsi .085-.1 mm long. Hair on outer surface of apical portion of tibiae longest. Hair on outer portion of tibiae much sparser than that on inner surface. First and seventh abdominal segments with lateral tubercles. Spiracles surrounded by darker patches. Dorsum of mounted specimens shows several isolated irregular spots which are darker in color than surrounding areas. Thorax and abdomen reticulated. Hair on abdomen about $.057 \mathrm{~mm}$ long, arising from small elevations. Cornicles $.085-1.00 \mathrm{~mm}$ in length, very wide at the base with a distinct neck near the apex making them look like small jugs. The cornicles are very poorly imbricated. Cauda never as long as wide at the base ranging in length from $.042 .085 \mathrm{~mm}$, with the longer length the more common. Apex of Cauda very dull and broadly rounded, distinctly without nipple-like apex. Surface of cauda setulose, margins with from 2-4 hair.

Oviparus female. Size and general color.-Range in size from 1.43-1.79 $\mathrm{mm}$, most common length $1.5 \mathrm{~mm}$. Width of head across eyes $.341 \mathrm{~mm}$. Color suggestive of apterous viviparous female and with similar pulverulence. Mounted specimens appear darker than those of apterous viviparous females.

Head and appendages.-Comparative length of antennal segments as follows: III .243-.314 mm, IV .140-.185 mm, V .143-.157 mm, VI .07$.08 \mathrm{~mm}+.7-.1 \mathrm{~mm}$. Secondary sensoria distributed as follows: III $1-4$, each represented by one case, as a rule $2-3$; IV 1-5, each represented by one case, most common number, $2-3 ; V 0-3$, as a rule none. Anterior margin of head arched. Rostrum reaching to or beyoud mesothoracic pair of coxae.

Thorax and abdomen.-Prothorax with lateral tubercles. Hind tibiae 
almost uniform dark dusky brown, uniformly swollen throughout most of length except extreme base and apex. Swollen portion with numerous round and irregular sensoria, some of which may be slightly tuberculate. The length of the tibiae varies from $.686-.715 \mathrm{~mm}$. First and seventh abdominal segments with lateral tubercles. Cornicles $.071 \mathrm{~mm}$ in length and less constricted near apex than those of apterous viviparous female. Abdomen beyond cornicles little constricted. Anal plate very broad and shallow.

Alate male. Size and general color.-Length from vertex to tip of anal plate 1.02-1.08 mm. Color not observed in life but from mounted specimens appears to be as follows: Head and thorax varying from dark dusky brown to rick dark brown. Abdomen varying from yellowishbrown with lateral dusky spots to brown with similar markings. Antennae dusky. Femora almost uniform dusky, tibiae light dusky with basal and apical portions darker. Cornicles dusky. Gonapophyses dark brown. Cauda and anal plate dusky.

Head and appendages.-Secondary sensoria distributed as follows: III 40-43, IV 17-18, $\nabla$ 7-8. Sensoria arranged irregularly but confined mostly to one side of segment. Comparative lengths of antennal segments as follows: III .343-.347 mm, IV .228-.257 mm, V .157-.214 mm, VI .1-1.12 + .114-.171 mm. The vertex has a median tubercle. The rostrum reaches to or slightly beyond the mesothoracic coxae.

Thorax.-The prothorax has a pair of lateral tubercles. The veins of the wings are dúsky. The second branch of the media is closer to the margin of the wing than it is to the first branch, in all but one wing. The radial sector is but little bowed and rather close to the margin of the wing.

Abdomen.-The first and seventh abdominal segments have lateral tubercles. The cornicles, which measure $.057 \mathrm{~mm}$ in length, are more like those of the alate viviparous female than they are like those of the apterous viviparous female. Cauda $.028-.057 \mathrm{~mm}$ in length. Gonapophyses very broad and flat at the apex with the corners somewhat drawn out suggestive of a well worn scoop shovel.

Holotype alate viviparous female August 27, 1948. Morphotype apterous viviparous female October 1, 1948. Morophotype apterous oviparous female October 19, 1948. Allotype alate male October 19, 1948. All deposited in the United States National Museum. The host on which this species was taken was Eriogonium corymbosum, on which it lives on the undersides of the leaves. Type locality east side of highway 141 a few miles north of Gateway, Colorado. This species keys to Aphis erigoni Cowen in Gillette and Palmer's Key to the genus Aphis, part II, Aphididae of Colorado, but not satisfactorily so. But there is no question that this species and the species described by Cowen are closely allied. Professor Palmer has seen specimens of the species here described and agrees that they are close to erigoni but believes they should be regarded as distinct. She has also supplied me with specimens determined as Aphis erigoni. Aphis agathona differs from Aphis erigoni in the following respects: The shorter unguis or terminal process, the fewer and, in the apterous female, much harder-to-see secondary sensoria which are also smaller, the color under the pulverulent matter, the shorter cornicles, a more rounded cauda, and the broken spots on the dorsum of the abdomen (not seen in living specimens). 


\section{Proceedings of the Biological Society of Washington}

\section{Aphis urovaneta, new species}

Alate viviparous female.

Size and general color.-Length from vertex to tip of anal plate varying from .858-1.07, average length $.943 \mathrm{~mm}$. Head thorax and abdomen black. Antennae almost uniform dusky. Femora dusky. Tibiae dusky at base and apically with region between light yellowish. Tarsi dusky. Cornicles dusky to black, cauda the same.

Head and appendages.-Comparative length of antennal segments as follows: III .185-.243, average length .213 mm; IV .10-.143, average length .113 mm; V .1-.128, average length .110 mm; VI .071-.10, average length, $.83 \mathrm{~mm}+.1-.143$, average length $.133 \mathrm{~mm}$. Secondary sensoria confined to third antennal segment numbering from 3-7 with 5 by far the most common number followed by 6 . It is not unusual for the number of sensoria on the two antennae to differ. The sensoria are large and have wide rims. All antennal segments are coarsely imbricated. The antennal segments are without hair except for the tip of VI. The width of the head varies from $.30-.314 \mathrm{~mm}$. The ocular tubercles are well developed. The rostrum reaches to or just beyond the metathoracic pair of coxae. Segments IV and $V$ of the rostrum are long and narrow but not acute. Segments IV and $V$ of the rostrum as a rule are longer than the base of VI and may be as long as the terminal process.

Thorax.-There is a large tooth-like tubercle on each side of the prothorax. The stigma is rather narrow and short. The radial sector is long and but little bowed. The second branch of the media is closer to the margin of the wing than it is to the first branch. All veins are lightly bordered with dusky. The entire surface of the wing is very rough, only the anal vein reaches the margin of the wing. The hind tibiae measure $.529 \cdot .60 \mathrm{~mm}$ in length. The hind tarsi are $.1 \mathrm{~mm}$ long. The hair on the tibiae is sparse and less than one half the width of the tibiae in length. That near the apical portion of the tibiae is even shorter.

Abdomen.-The first segment of the abdomen has a pair of lateral tubercles and a similar pair of tubereles is located on the seventh segment. A few specimens in which the abdomen appears light green show the spiracles surrounded by small dusky areas; this condition is, perhaps, common. The cornicles vary in length from .071-.085 mm. The surface of the cornicles is weakly imbricated and the rim at the apex is poorly developed. The apex of the cornicles is very slightly wider than the base but the sides are straight. The cauda is almost triangular, its apex is acute. There are from three to four hair on the sides of the cauda. The most common length of the cauda is $.042 \mathrm{~mm}$ but in one case a length of $.085 \mathrm{~mm}$ was measured. Hair on the abdomen is sparse and short except for the hair on the cauda which is moderately abundant and considerably longer than that found elsewhere.

Apterous viviparous female.-Size and general color.-Length from vertex to tip of anal plate varying from .943-1.43, each length represented by a single specimen. Average length $1.17 \mathrm{~mm}$. Specimens taken during the hot dry spell when the host plants were in need of water were much shorter than the average given here. Width of head across eyes $.28 \mathrm{~mm}$. Head thorax and abdomen distinctly grey due to the presence of powder-like pulverulent matter except where the powder has been rubbed off, as it usually is in a more or less regular pattern, 
being lacking at the sides of the abdomen and along a more or less irregular elongated area on the mid dorsum. These powder-free areas expose the black color of the abdomen. Antennal segments I and II black, segments III, IV, and the base of V, pale to light dusky. Apical portion of $\mathrm{V}$ and all of VI dusky to light black. Femora almost uniform dark brown. Tibiae with extreme basal portion dusky, apical portion the same, intermediate portion pale yellowish. Tarsi brownish. Cauda and cornicles black.

Head and appendages.-Antennal segments with the following proportional lengths: III .143-.214. Specimens taken in August have segment averaging $.171 \mathrm{~mm}$, while III of specimens taken in October average $.214 \mathrm{~mm}$. IV $.08-.17 \mathrm{~mm}, \mathrm{~V} .1-.128 \mathrm{~mm}$, VI .071-.114 mm + .128$.143 \mathrm{~mm}$. There are no secondary sensoria. All antennal segments are imbricated, V and VI more so than the others. The anterior margin of the head is distinctly dome-shaped. The rostrum, shaped as in the alate female, reaches to the metathoracic coxae. The ocular tubercles are well developed.

Thorax.-The thorax has a pair of large tooth-like tubercles. The hind tibiae are from $.45-.643 \mathrm{~mm}$ long.

Abdomen.-The dorsum of the abdomen is reticulated. There are few hair on the abdomen and these are short. The cornicles are $.143 \mathrm{~mm}$ long and show almost no variation in length. They are feebly imbrieated and the rim at the apex is very poorly developed. Cauda $.071 \mathrm{~mm}$ long showing almost no variation in length, it is almost as wide at the base as long. The tip of the cauda is pointed, the sides are provided with from 3-4 inwardly curving hairs. The upper surface of the cauda is setulose and rather rough.

Apterous oviparous female.-Described from two measured specimens. Length, $1.35 \mathrm{~mm}$. Width of head across eyes, $.343 \mathrm{~mm}$. Color as in apterous viviparous female. Comparative length of antennal segments as follows: III .214-.243 mm, IV .143 mm, V .128-.143 mm, VI .1-.128 $\mathrm{mm}$. There are no secondary sensoria. Rostrum hardly reaching coxae of metathoracic pair of legs. Segments 4 and 5 of rostrum almost as long as cornicles. Prothorax with lateral tubercles. Hind tibiae .527 $\mathrm{mm}$ long, rather thick except for a distance at the apex about equal to two times the tarsi. Thickened portion of hind tibiae provided with slightly tuberculate round and uniform sensoria. Hair on hind tibiae minute and very sparse even near the apex of the tibiae where hair as a rule is more abundant.

Abdomen.-First abdominal segment with lateral tubercles. A similar pair is located on the seventh segment. Cornicles .114 mm long. Cauda $.071 \mathrm{~mm}$ long, no longer than wide at the base and provided with 3 hair at the sides. The abdomen is but little constricted posterior to the cornicles.

Alate Male.-Average length from vertex to tip of anal plate 1.05 $\mathrm{mm}$, range from .92-1.28 mm. Width of head across eyes $.343 \mathrm{~mm}$. Color of head, thorax, and abdomen black. Head similar to that of alate female in shape. Comparative lengths of antennal segments as follows: III .214-.314 mm, IV .171-.214 mm, V .157 mm, VI .085-.1 + .128-.171 $\mathrm{mm}$. Secondary sensoria distributed as follows: III $30-46$, as a rule more than 37 ; IV $21-31$, as a rule more than $24 ; \mathrm{V} 9-17$, as a rule fewer than 12. The sensoria are irregularly arranged on all segments. On III and 
to a lesser extent on IV, two or three and even four sensoria are crowded together so that they touch one another. Such groups are followed by areas which are free from sensoria. The sensoria are round, of uniform size, and are very slightly tuberculate. Antennal hair is very sparse and short, being hardly two times the height of the imbrications in length. The thorax and abdomen are provided with lateral tubereles similar to those of the females. Wings as in the alate female. Hind tibiae .643-.686 mm. Hind tarsi .1-.114 mm. Gonapophyses black, short, and very hairy.

This species is, as a rule, very abundant, often encrusting the flower stems and upper portions of its host Eriogonium $s p$. (one of the herbaceous members of the genus). From the forms here described, one would appear justified in saying that the species does not migrate. It may not be keyed in any key known to me. From Aphis eriogoni Cowen, it differs in color, cornicles and secondary sensoria, as well as in the anterior margin of the head.

Holotype alate viviparous female August 24, 1948.

Morphotype apterous viviparous female October 1, 1948.

Morphotype oviparous female October 1, 1948.

Allotype alate male October 1, 1948. All deposited in the United States National Museum. Type locality about twenty miles north of Gateway, Colorado, or just south of old stone house on highway 141.

\section{Macrosiphum glabrum, G. \& P.}

Apterous male. Described from only two specimens. Size and general color.-Length of vertex to tip of anal plate $1.38-1.35 \mathrm{~mm}$. Head dusky brown with traces of dark green. Antennae, with the exception of $I$ and II and the base of III, brownish-black. Femora greenish at the base shading to dark dusky brown. Tibiae, brown shading to black. Tarsi dark dusky. Dorsum of thorax dusky, remaining portion green. Abdomen green with narrow, more or less broken bands which extend laterally. Cornicles and cauda dark dusky.

Head and appendages.-Comparative lengths of antennal segments as follows: III .60-.65 mm, IV $.54-.60 \mathrm{~mm}, \mathrm{~V} .45-.48 \mathrm{~mm}$, VI $.143-.157 \mathrm{~mm}$ $+.60 \mathrm{~mm}$. The secondary sensoria are distributed as follows: III 48-51, IV 31-39, V 13-16. The sensoria are uniform in size, very slightly tuberculate and irregularly arranged. On 4 and 5, the dorsal side is more or less free from sensoria. The rostrum reaches the metathoracic coxae, the last two segments are obtuse.

Thorax and abdomen.-The hind tibiae are from 1.40-1.43 $\mathrm{mm}$ long. The hind tarsi measure from .143-.157 $\mathrm{mm}$ in length. The tibial hair, except for those near the apex which are fine and short, are spine-like and about equal to the width of the tibiae in length. The cornicles measure from .228-.243 in length; a little more than one third of their length is reticulated. The portion of the cornicle not reticulated is coarsely imbricated. The cauda varies from .143-.176 mm. The cauda has three hair on a side and its surface is coarsely setulose. The gonapophyses have their apical surface rather flat and square.

Allotype: apterous male taken near Gateway, Colorado, October 19, 1948. Host Artemisia dracunculoides L. Deposited in the United States National Museum. The males here described were taken together with 
apterous viviparous and apterous oviparous females. As the females differed from the original description for the most part as made by Gillette and Palmer in respect to portion of cornicle reticulated, length of rostrum, and size, specimens were sent to Professor Palmer for checking. Professor Palmer sent me a paratypic slide and wrote that the species shows considerable variation within the limits of which my specimens fall.

\section{Macrosiphum atripes, Gillette \& Palmer}

Oviparous female. Size and general color.-Average length from verter to tip of anal plate $2.21 \mathrm{~mm}$. Color in all respects similar to that of apterous viviparous female.

Head and appendages.-Antennal segments with the following proportional lengths: III .715-.772 mm., IV .486-.50 mm., V .347-443 mm., VI $.10-.14 \mathrm{~mm}$. + .715-786 mm. Width of head across eyes $.429 \mathrm{~mm}$. Antennal segment III with from 18-25 round to oval secondary sensoria The sensoria are slightly tubereulate, and are irregularly arranged but are confined more or less to one side of the segment. The hair on the third antennal segment is almost as long as the width of the segment slightly enlarged at the tip and very upright. The rostrum almost reaches the coxae of the mesothoracic legs.

Thorax and appendages.-The metathoracic tibiae are very uniformly swollen except for the apical fourth the swollen portion has numerous sensoria. The hair on the inner portion of the hind tibiae is much shorter than that on the outer portion. The hair in the middle outer portion of the hind tibiae is almost at right angles to the tibiae. The hair at the apex of the tibiae is sparse. The hind tibiae measure $1.57 \mathrm{~mm}$. in length.

Abdomen.-The cornicles vary in length from $.622-.815 \mathrm{~mm}$. the last $.228 \mathrm{~mm}$ is reticulated. The hair on the abdomen arises from small brown spots. The cauda is about $.443 \mathrm{~mm}$. long, with from 6-7 exceptionally long lateral hair. In shape the cauda is similar to that of the viviparous females.

Alate male.-Described from two specimens not observed in life. Length from vertex to tip of anal plate $1.85 \mathrm{~mm}$. Color indicated from mounted specimens to be quite similar to that of females.

Head and appendages.-Length of antennal segments as follows: III $.805-.81 \mathrm{~mm}$., IV $.60 \mathrm{~mm} ., \mathrm{V} .429-.50 \mathrm{~mm}$., VI .112-.114 + .643-.715 mm. Secondary sensoria arranged as follows: III 66, IV 22, V 15. The sensoria are irregularly arranged but are confined more or less to one side of the segment. The sensoria have wide rims and are slightly tuberculate. The rostrum reaches just beyond the coxae of the mesothoracic pair of legs.

Thorax.-The second branch of the media has its origin about midway between the first branch and the margin of the wing. The veins are dusky and are lightly bordered. The surface of the wing is rough.

Abdomen.-The cornicles vary in length from $.347-.42 \mathrm{~mm}$. the surface not reticulated is slightly imbricated. The cauda is $.185 \mathrm{~mm}$. long, much shorter and wider than expected, the sides of the cauda carry five long and rather drooping hair. The gonapophyses are long finger-like and provided with many hair. 


\title{
28 Proceedings of the Biological Society of Washington
}

\begin{abstract}
Allotype, alate male, Morphotype, apterous oviparous female taken about five miles North of Gateway, Colorado October 12, 1948. Both the allotype and the morphotype deposited in the United States National Museum.

This species was observed from August 16 to October 20, 1948. It was taken during this time on Kuhnia leptophylla which represents a new host plant for the species. It feeds on this host on the stems of the new growth and on the flower stems.
\end{abstract}


Hottes-Descriptions of Western Colorado Aphididae 29 
30 Proceedings of the Biological Society of Washington 
OF THE

\section{BIOLOGICAL SOCIETY OF WASHINGTON}

\section{HIRSTIONYSSUS OBSOLETUS, A NEW MESOSTIG- MATIC MITE FROM SMALL MAMMALS OF THE WESTERN UNITED STATES (ACARINA)}

By E. W. Jameson, JR.

Division of Zoology, University of California, Davis

In this paper is described a new species of Hirstionyssus Fonseca from western United States. Ichoronyssus hubbardi Jameson and Liponyssus occidentalis Ewing are allocated to Hirstionyssus, and a key to the females of the Nearctic species is given. The relationship of Neoichoronyssus Fonseea, 1941 and Hirtionyssus Fonseca, 1948 is discussed.

Fonseca specified (1948: 266) that the males of Hirstionyssus possess an undirided holoventral plate. Although the male of Ichoronyssus hubbardi has a separate anal plate, the coxal spurs, the genito-ventral plate with a single pair of setae, and the general facies indicate that hubbardi is closely allied to the species of Hirstionyssus. A cotype of Liponyssus occidentalis Ewing likewise has the above characters, and it also belongs to Hirstionyssus; occidentalis is closely related to the genotype of Hirstionyssus, Dermanyssus arcuatus Koch, 1839.

Key to the females of Nearctic species of Hirstionyssus

A. Some of the coxal spurs bifid and some setigerous

Coxal spurs acutely pointed, rounded, or truncate, but not bifid

and none setigerous

B. Peritreme extending to coxa I; coxa I with two spurs; genitoventral plate narrowed posteriorly

dentipes (Strandtmann \& Eads)

Peritreme not extending forward of coxa III; coxa I with one spur; genito-ventral plate broadly rounded posteriorly

hubbardi (Jameson)

C. Coxa II with a conspicuous caudo-dorsal spur or knob geomydis (Keegan)

Coxa II rounded on the caudo-dorsal margin

D. Tarsus II with two stout ventral spines or setae; genito-ventral plate separated from the anal plate by a distance equal to at least half the length of the latter

Tarsus II without modified setae; genito-ventral plate separated from the anal plate by a distance not greater than the length of the anus (except in engorged specimens); ventral coxal spurs much reduced and rounded obsoletus, n. sp. 
E. Length of the sternal plate (along the median line) about onethird the distance between the first pair of sternal setae occidentalis (Ewing)

Length of the sternal plate (along the median line) one-half to two-thirds the distance between the first pair of sternal setae

F. Ventral spurs on coxae II and III blunt in outline

occidentalis (Ewing)

Ventral spurs on coxae II and III acutely pointed _- carnifex (Koch)

\section{Hirstionyssus obsoletus, n. sp.}

Dorsum (fig. 1, D): Dorsal plate in one piece, almost completely covering the dorsum, with slightly undulating anterior margin, rounded posteriorly; armed with about 29 pairs of slender setae, tending to be heavier anteriorly. A pair of slit-like pores near the anterior margin, and 13 pairs of circular pores placed as illustrated.

Peritreme extending from coxa IV to coxa I; peritremalia extending posteriorly about twice the diameter of the stigma, and apparently connected to coxa IV.

Venter (fig. 1, A): Sternal plate about four times as wide as long, concave caudally, bearing three pairs of slender setae, each setae slightly longer than the length of the sternal plate. Genito-ventral plate long, rounded caudally, bearing a single pair of setae. Genito-ventral plate separated from the anal plate by a distance not greater than the length of the anus in unengorged specimens. Anal plate ovoid; adanal setae slightly smaller than the postanal seta. Soft parts of venter with about 19 pairs of slender setae.

Legs: Coxa I with a ventral and a marginal seta. Coxa II with two slender setae on the margin, an acute cephalo-dorsal spur, and a small, blunt ventral spur. Coxa III with a marginal and a submarginal seta, and two small, ventral spurs, the more mesal being rounded. Coxa IV with a submarginal seta, and no ventral marginal spur; margin fimbriated (fig. 1, C). Tarsus II without modified setae.

Gnathosoma (fig. 1, B): Chelicerae shear-like, fixed arm slightly longer than the movable arm. Four pairs of hypostomal setae, relative size and position as illustrated. Hypostomal teeth alternately and in two rows at the base, converging to one row distally; about 15 teeth in all. Epistome narrow distally, apex with $2-4$ teeth.

Types: Holotype female and 22 paratype females; holotype and 10 paratypes deposited with the U. S. National Museum.

Collection data: California: Plumas County, 4 miles east of Quincy; 10 March 1949; from a long-tailed shrew, Sorex trowbridgii Baird.

The "true host" appears to be Sorex trowbridgii, but this mite occurs on the shrew-mole (Neurotrichus gibbsii (Baird), the deer mouse (Peromyscus maniculatus (Wagner)), and the red-backed vole (Clethrionomys californicus (Merriam)). The records from rodents suggest a poorly developed host specificity for $H$. obsoletus. However, these mice are parasitized by other species of Hirstionyssus, and specimens of obsoletus on rodents may be strays from insectivores.

The relationship of Neoichoronyssus Fonseca, 1941 and Hirstionyssus Fonseca, 1948.

The genus Neoichoronyssus was erected for Liponyssus wernecki Fonseca, 1935, a parasite of opossums (Didelphiidae). Neoichoronyssus 
was characterized (Fonseca, op. cit.: 269) as possessing two pairs of setae on the sternal plate, the genital plate of the female pointed posteriorly and bearing a single pair of setae, and a ventral spine on coxa I. Specimens of $N$. wernecki taken from Didelphis virginiana (Greenwood County, Kansas) agree quite well with the description except with regard to the sternal setae. In one specimen (cleared in potassium hydroxide) the projections of the sternal plate which normally bear the thord pair of setae are barely perceptible; and in other specimens of the same series (cleared in polyvinyl alcohol) the sternal plate bears three pairs of setae. There appears to be individual variation, or a difference due to the method of preparation. In other respects $N$. wernecki possesses the generic characters of Hirstionyssus. The synonymy of Hirstionyssus under $N^{\top}$ eoichoronyssus is not urged here in view of the likelihood of a still earlier generic name for this group of species.

\section{ACKNOWLEDGMENTS}

I wish to thank Dr. E. W. Baker for the loan of a cotype of Liponyssus occidentalis Ewing; Dr. R. W. Strandtmann for checking the key; Dr C. D. Radford for the loan of a paratype of Hirstionyssus cynomys (Radford); and Dr. Claude W. Hibbard for specimens of Neoichoronyssus wernecki (Fonseca).

\section{Literature Cited}

Fonseca, Flavio da 1948. A monograph of the genera and species of Macronyssidae Oudemans, 1936 (synom.: Liponyssidae Vitzthum, 1931) (Acari). Proc. Zool. Soc. London 118. 249-334. 


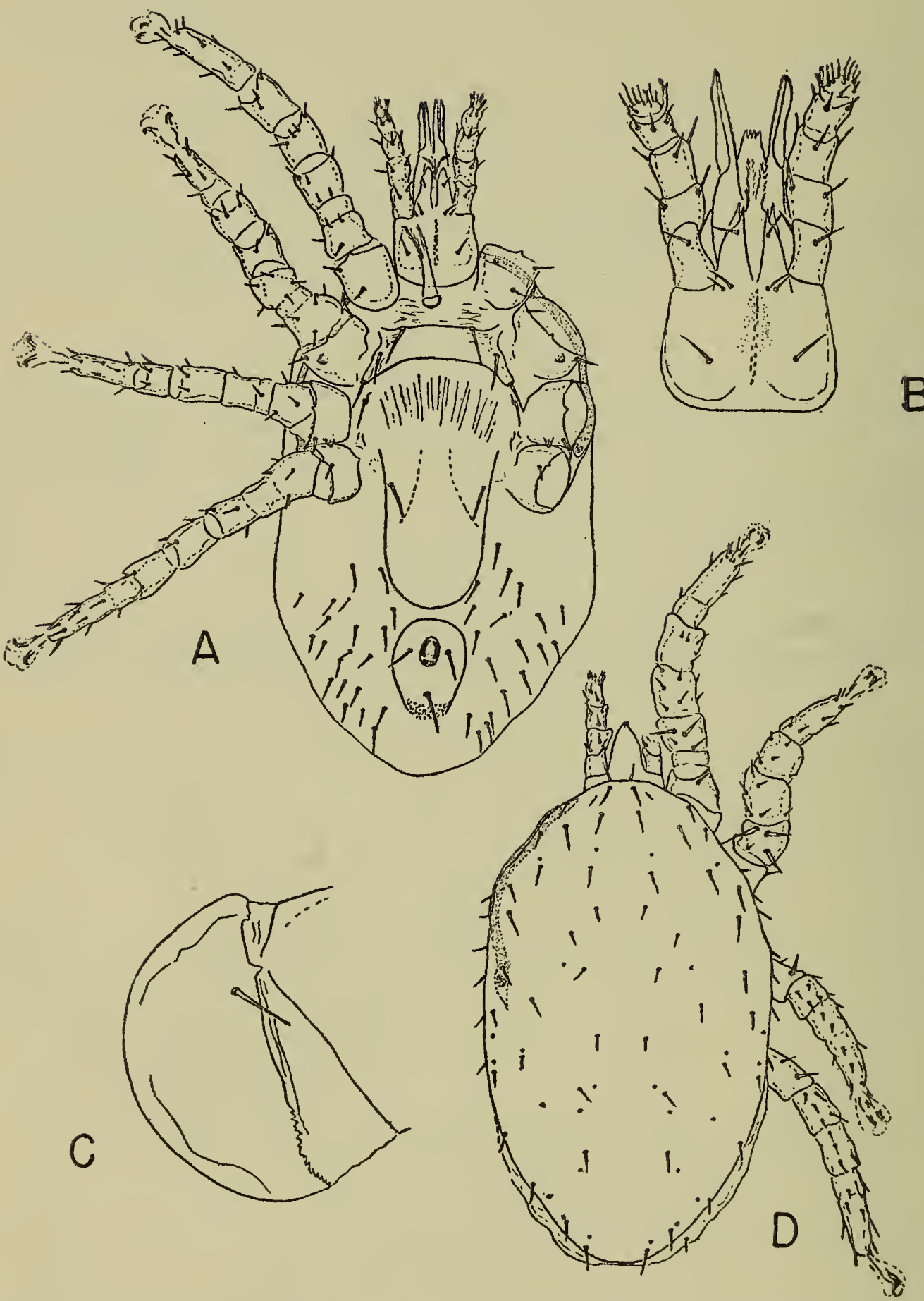

Plate III. Female of Hirstionyssus obsoletus, n. sp. A, ventral; B, gnathosoma; C, coxa IV (ventral); D, dorsal. 
Vol. 63, pp. $35-42$

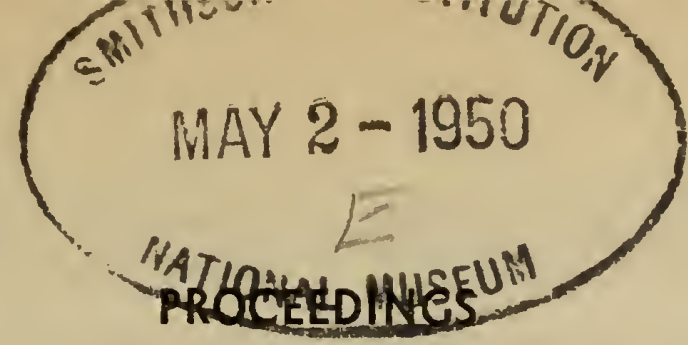

April 26, 1950

OF THE

BIOLOGICAL SOCIETY OF WASHINGTON

DESCRIPTIONS OF SOME APHIDIDAE FROM CAREX.

BY F. C. HOTTES

The species described here were collected while sweeping Carex in several regions of Colorado.

\section{Aphis tahasa, new species}

Alate viviparons female.

Size and general color.-Average length from vertex to tip of anal plate $1.56 \mathrm{~mm}$. Range in length from 1.50-1.71 mm. Head and thorax brown, thoracic lobes with dusky margins. Abdomen pale green with small lateral dusky spots. Region just posterior to origin of cornicles dusky as is the region just anterior to cauda. Cornicles, cauda and anal plate dusky. Base of third antennal segment pale remainder of antenna dusky. Proximal region of femora pale remaining portion dusky. Tibiae pale dusky with region near apex darker and concolorous with tarsi.

Head and appendages.-Proportional lengths of antennal segments as follows: III .31-.39 mm, IV .15-.27 mm, each length represented by one case, most common length $.19 \mathrm{~mm}$. , V. .18-.24 mm., VI .08-.1 + .34-.50 $\mathrm{mm}$, as a rule the terminal process is not more than $.40 \mathrm{~mm}$. Secondary sensoria distributed as follows: III 10-15 most common number 10-12. On this segment the sensoria are arranged in a straight row, but it is common for one or two sensoria not to be so arranged. Frequently two sensoria are more or less united. The sensoria vary in size, have wide rims and may be irregular in shape. Segment four as a rule has no sensoria but may have as many as two. All antennal segments are imbricated. Antennal hair is very spruce and very short and fine. The rostrum in most cases fails to reach the mesothoracic pair of coxae by a considerable distance, the terminal segment is rather short and thick. The antennal tubercles are unusually well developed for an Aphis and are as a rule provided with a fine short hair. The anterior margin of the head has a well developed tubercle, accessory tubercles characteristic of apterous viviparous females absent.

Thorax and appendages.-The prothorax is provided with a pair of small lateral tubercles. The stigma is rather narrow, and its surface is scale-like, its ventral border is much darker. The radial sector is rather narrow and only moderately bowed. The second branch of the media is very close to the margin of the wing, in fact it may be so close to the margin that it sometimes is lacking in one wing, or only represented by a shadow. None of the reins reach the margin of the wing.

The hair on the tibia are shorter than the width of the tibia.

Abdomen.- The cornicles vary in length form .14-.21 mm. They are somewhat suggestive at times of the cornicles of Rhopalosiphun prunifoliae (Fitch) for the most part they are less curved and the neck is not as well developed. The surface of the cornicles is poorly imbricated, and the rim is weakly developed. The hair on the abdomen is rery sparse. 
The entire surface of the abdomen is finely setulose, this condition is best seen on the dusky areas and on well cleared specimens. The setulae are arranged in short irregular rows which form a sort of net over the surface of the body. The anal plate is rounded and not very deep. The cauda is slightly constricted if at all and carries two to three hair on a side, its surface like that of the anal plate is setulose.

Apterous viviparous female.

Size and general color.-Length from vertex to tip of anal plate 1.70$2.02 \mathrm{~mm}$. As a rule considerably longer than the minimum length given here. Head thorax and abdomen apple green with the anterior and lateral margins of head more or less dusky. First antennal segment much darker inwardly, remaining segments of the antennae dusky. Legs cornicles and cauda similar to those of Alate viviparous female.

Head and appendages.-Comparative length of antennal segments as follows: III .31-.39 mm., IV $.15-.27 \mathrm{~mm}$, as a rule about .20 mm., V .18$.24 \mathrm{~mm}$., as a rule as long or slightly longer than IV, VI .08-.1 +.34-.50 $\mathrm{mm}$., as a rule less than .40. There are no secondary sensoria. The rostrum is short and fails to reach the mesothoracic pair of coxae. The first antennal segment is rather rough on the median portion and is provided with a few short fine hair. The anterior margin of the head is broadly rounded, the raised portion with two short and fine hair. Arising from the ventral portion of the head in the region of the antennal tubercles there are two small accessory tubercles. These are as a rule directed inwardly. These tubercles carry one short hair each. The accessory tubercles are apt to be overlooked, but are constant and very characteristic.

Thorax and abdomen.-The hair on the tibiae is short, that at the base of the tibia being from one third to one half the width of the tibia at that point, the hair at or near the apex being no longer than the width of the tibia and most often considerably less than the width of the tibia in length. The cornicles measure from $.17-.22 \mathrm{~mm}$. in length, they are apt to have a slight neck near the apex and to be very slightly swollen just anterior to this. The cauda is about $.14 \mathrm{~mm}$. in length. It is slightly constricted and earries two inwardly bent hairs on a side. The surface of the abdomen is finely setulose.

Despite the fact that this species is being placed in a different genus than the species described by Gillette and Palmer as Toxoptera viridirubra I think the two species have much in common, the accessory tubercles are much alike, they have a common host, although $I$ have never collected the two species together. The cornicles of tahasa are not as long or dark as those of viridi-rubua the cauda is less constricted. The alate of tahasa has fewer sensoria on IV and none on V. However the most conspicious difference to me lies in the character of the hair found on the tibiae. The hair in viridi-rubra being long and almost suggestive of that found in the genus Cinara.

This species was collected by sweeping Carex sp. It was taken at Gateway, Colo., Skyway, Colo., Creede, Colo., and Pagosa Springs, Colo. Only at Pagosa Springs was the population of the species large enough to locate without sweeping. At Skyway and also at Gateway this species was associated with another species suggestive of $R$. prunifoliae (Fitch) which has not been recorded from Carex. For this reason and becanse of other structural differences the species has not been definitely determineil as prunifoliac. 
Holotype: apterous vivipatrous female Creede, Colo. Aug. 14, 1949. Morphotype alate viviparous female Creede, Colo. Aug. 14, 1949. Both types deposited in United States National Museum.

\section{Macrosiphum oljatae, new species}

Alate viviparous female.

Size and general color.-Length from vertex to tip of anal plate 2.47 $\mathrm{mm}$. Head dusky brown. Prothorax light dusky green, with lateral portions more dusky. Meso and metathorax green with lobes and lateral portions dusky brown. Abdomen pale green with dusky lateral spots, dorsum of abdomen with dusky spots of variable size arranged in transverse rows, the median spots being smallest. Cornicles dusky black with a dusky patch just anterior to point of origin on abdomen. Anal plate dusky. Cauda greenish with the proximal portion darkest, and rather dusky. Femora with basal portion greenish remaining portion brown. Tibiae except for apical portion light dusky yellow. Stigma dusky, veins light dusky very lightly bordered.

Head and appendages.--Length of antennal segments as follows: III $.715 \mathrm{~mm}$., IV $.54 \mathrm{nmm}$, V $.40 \mathrm{~mm}$., VI $.12 \mathrm{~mm}$. Secondary sensoria confined to third antennal segment, arranged in a row numbering seven on one and ten on the other antenna. Antennal segment III smooth except for apex, segments IV, V and VI moderately imbricated. Antennal hair very sparse, that on III very short and dull tipped, hair on remaining segments somewhat longer and sharp pointed. Rostrum short, not reaching midway between pro and mesothoracic coxae. Anterior margin of head rounded. Antennal tubercles only moderately well developed.

Thorax and abdomen.-Hair an tibiae spine-like. Hair an inside tibiae more spine-like than that on outside. Hair at apex of tibiae quite recumbent, and no more abundant or longer than elsewhere. Surface of stigma very scale-like. Radial sector much bowed. Second branch of media about midway between first branch and margin of wing. No veins reach the margin of the wing. Much of the surface of the wing is rough and scale-like. This is particularly true of the area near the margin.

The hair on the abdomen is exceedingly sparse, short and somewhat spine-like. Segment anterior to cornicles with a small lateral tubercle, posterior to the cornicles there is a similar tubercle. Dusky areas of abdomen very finely setulose. Anal plate rather narrow but deep extending to constricted portioon of cauda. Cauda $.23 \mathrm{~mm}$. long, setulose with four long inwardly eurved hair laterally. Cornicles $.43 \mathrm{~mm}$. long with apical third reticulated, remainder of cornicle much imbricated. The sides of the cornicles are almost straight being only slightly reduced in width about the origin of the reticulated area. The rim of the cornicles is poorly developed.

Apterous viviparous female.

Size and general color.- Length from vertex to tip of anal plate 1.72$2.86 \mathrm{~mm}$. Average length $2.30 \mathrm{~mm}$. Head thorax and abdomen light green. Anterior margin of head and antennal tubercles light dusky. Dorsum of thorax with three light dusky stripes. Region just anterior to cornicles with two pale dusky spots, region posterior to cornicles more or less dusky. Dusky spots on the dorsum of the abdomen are rare. Antenna pale brown to dusky the segments being darker at apex. Legs cornicles and cauda as in the alate viviparous female. 
Head and appendages-Comparative lengths of antennal segments as follows: III .643-.715 mm., IV .39-.49 mm., V .31-.35 mm., VI .11-.12 + $.59-.70 \mathrm{~mm}$. Secondary sensoria either one or absent near base of III, always small when present. Third segment very smooth, remaining segments moderately imbricated. Anterior margin of head moderately convex, with two hair. Antennal tubercles low. Rostrum short failing to reach coxae of mesothoracic pair of legs.

Abdomen.-Cornicles .47-.64 mm. long. Reticulated portion of cornicles varying in length from .11-.14 mm. Anal plate and cauda as in alate viviparous female. Surface of abdomen very finely setulose. This condition is difficult to determine except in very clear specimens. The setulae are arranged in irregular rows. The cauda varies from $.33-49$ $\mathrm{mm}$. in length.

I have not seen specimens of Macrosiphum caricis described by Glendening in 1926. Macrosiphum oljatae differs from the description of caricis in the following respects: In the alate the sensoria are not confined to the basal $3 / 4$ of segment, cornicles distinctly shorter than third antennal segment, more than one eighth of cornicle reticulated.

Holotype taken by sweeping Carex sp. near Skyway, Colorado, Sept. 19, 1949. Morphotype taken by sweeping Carex sp. near Creede, Colorado, Aug. 14, 1949. Paratypes taken at Skyway, Colorado, Aug. 2, Sept. 19, 1949. Type slides deposited in the United States National Museum. Specimens of this species are so sparce in population that they have not been observed on the host mentioned. The very short rostrum indicated strongly that the aphid and plant are correctly associated.

\section{Utamphorophora timpanogos Knowlton.}

Apterous viviparous female.

Size and general color.-Described from two specimens. Length from vertex to tip of anal plate 1.72-1.92 $\mathrm{mm}$. Width of head through the eyes $.386-.471 \mathrm{~mm}$. Head light green with anterior margin and tubercles slightly dusky. Thorax and abdomen light apple-green. First antennal segment light dusky, with median portion darkest. Second antennal segment pale dusky. Third antennal segment shading from pale dusky at the base to light brown at the apex. Remaining antennal segments uni. form dusky brown. Last two segments of rostum dusky brown, remaining segments pale green. Femora pale greenish near base shading to light dusky at the apex, darkest on the dorsum. Tibiae pale dusky except for apical portion which is brown to dusky brown. Tarsi dusky brown. Cornicles pale dusky, cauda the same.

Head and appendages.-Comparative length of antennal segments as follows: III .47-.67 mm., IV .29-.40 mm., V .26-.33 mm., VI .10-.14 + $.57 \mathrm{~mm}$. First antennal segment with median portion rather rough. Third, fourth, fifth and sixth antennal segments imbricated. Third an. tennal segment with two to three small eircular sensoria near the base. Hair on antennae very sparce, fine and exceedingly short. Antennal tubercles characteristic of genus, strongly bent inwardly and provided with two short fine hair. Anterior portion of head convex, the convex portion provided with two fine short hair. Rostrum short, just reaching coxae of mesothoracic pair of legs.

Thorax and abdomen.-Tibiae with hair on outer portion very short, hair on inner portion langer and thicker. Hair at apex of tibiae very little longer than elsewhere and not more abundant. Tarsi short. Corni- 
cles $.429 \mathrm{~mm}$. long, Outer margin of cornicles almost straight, inner margin of cornicles considerably curved. Surface of cornicles weakly imbricated. Anal plate rounded very little wider than base of cauda, provided with a few marginal hair. Cauda weakly constricted $.214 \mathrm{~mm}$. in length provided with two lateral hair and one near the apex on the dorsum. The surface of the cauda is setulose.

The specimens here described were collected by sweeping Carex sp. Skyway, Colorado, on July 26, and August 9, 1949, one specimen being taken on each date. Dr. Knowlton in his original description of Utamphorophora timpanogos records the host as Monarda (q). I have no proof that the host questioned by Dr. Knowlton is not correct for I did not see them on Carex. That Carex is the true host is strongly indicated by the very short rostrum and the rather dull terminal segment of the same.

Morphotype apterous viviparous female Skyway, Colorado July 26, 1949, deposited in the United States National Museum. 
40 Proceedings of the Biological Society of Washington 
42 Proceedings of the Biological Society of Washington 
OF THE

\section{BIOLOGICAL SOCIETY OF WASHINGTON}

\section{THREE NEW SUBSPECIES OF BIRDS FROM VENEZUELA}

By Willian H. Phelps and William H. Phelps, JR.

Study of new material in our collection shows the following forms to be worthy of recognition.

The specimens listed are in the Phelps Collection, Caracas, unless otherwise specified.

Names of colors are capitalized when direct comparison has been made with Ridgway's "Color Standards and Color Nomenclature."

\section{Lepidocolaptes souleyetii uaireni, new subspecies}

Type: From Hato Santa Teresa, Río Uairén, Bolívar; altitude 940 meters. No. 44583 , Phelps Collection, Caracas, Venezuela. Adult female collected June 19; 1948, by Manuel Castro. (Type on deposit at the American Museum of Natural History.)

Diagnosis: Differs from littoralis by being darker below; the stripes are blacker, less brownish; the brown edges of the feathers are more olivaceous, less yellowish; the center stripes are whitish instead of buffy. The back is darker, browner, less yellowish and the crown stripes are narrower and whiter. Differs from lineaticeps by being darker both above and below and by a whitish throat instead of buffy, and from all other races of souleyetii by longer and narrower crown stripes.

Range: Known only from the type locality.

Description of Type: Top of head Raw Umber X Prout's Brown; feathers with long, narrow whitish streaks; back Antique Brown $\mathrm{X}$ Argus Brown, the feathers of nape with long, narrow, faint whitish streaks; uropygium Hazel; sides of head with wide whitish stripes and narrower dusky ones; chin and fore-throat whitish with a tinge of buffy; feathers of posterior throat edged with brownish; breast and rest of under parts Buffy Brown X Snuff Brown, the feathers broadly striped with buffy whitish and narrowly with blackish, these stripes being most prominent in breast, gradually becoming narrower and more indistinct posteriorly; remiges Hazel $X$ Auburn, very narrowly and faintly edged externally with grayish; inner vanes of primaries and secondaries tipped with dusky, progressively and more extensively outwardly; upper wing-coverts Snuff Brown X Saccardo's Umber; bend of wing whitish; under wing-coverts Cinnamon; tail paler than Auburn, lighter on under surface.

Bill (in life) "black, base orange"; feet "gray"; iris "brown." Wing, $85 \mathrm{~mm}$; tail, 72 ; exposed culmen, 26; culmen from base, 29 ; tarsus, 16.

Remarks: Sexes alike in coloration but the females have shorter wings and tails. Size similar to littoralis. Range of measurements: Three 
adult males-wing, 92-93 (92.7) $\mathrm{mm}$; tail, 77-83 (79.7); culmen from base, 29.30 (29.3); five adult females-wing, $82-87$ (84.4); tail, 60-72 (69.6); culmen from base, 29-30 (29.8). Measurements of littoralis (from the northeast coast of Venevuela) ; five adult males-wing, 83-90 (86.8); tail, 74-83 (78.8); culmen from base, 28-30 (29); five adult females-wing, 81-85 (82.6); tail, 69-77 (73); culmen from base, 28-31 (31.6).

We have no intermediates. Our large series of littoralis from south of the Orinoco shows no approach to the new form. Even our series of 10 specimens from La Paragua and Cerro Tigre, only 215 miles to the northwest of Hato Santa Teresa, are similar to nearly topotypical littoralis from the northeast coast. The specimens in the American Museum from Frechal and Limao on the Cotinga River in Brazil are intermediates but closer to littoralis.

\section{Specimens Examined}

I. s. souleyetii.-PERU: 271. ECUADOR: $9^{1}$.

L. s. esmeraldae.-ECUADOR: 231. WESTERN COLOMBIA ${ }^{1}$; Tumaco, 1 \&, 1 (q); Barbacoas, 2 o, 1 \&, 1 juv.

L. 8. lineaticeps.-COLOMBIA ${ }^{1}$ : Honda, 1 q, 1 juv.; Cali, 1 (1); Puerto Valdivia, 1 ô ; Río Frío, 1 ô ; Caquetá, 1 ô ; Buena Vista, 1 $q$; Villavicencio, 1 ô, 1 $q, 1$ (१); "Bogotá", 6 (q). EASTERN PANAMA1: El Real, 1 o, 1 $\uparrow$; Tapaliza, 1 ; “Panama”, 1 o, 1 ㅇ. VENEZUELA: Bramón, 2 ô, 2 $q$; La Fría, $1 \hat{\delta}, 1$ ( $q)$; Seboruco, 1 ; ; Santa Cruz de Mora, 1 o, 1 q ; Santo Domingo, 1 o, 3 q ; Santa Bárbara, Barinas, 3 ô, 1 \% .

L. s. littoralis.-VENEZUELA: La Sabana, 1 q; La Sierra, 2 $\delta$, 1 q : Machiques, 1 ô; Santa Rosalía, Perijá, 1 ô, 1 q ; Los Cañitos, 1 o ; Cerro El Cogollal, 1 (q); Cerro El Cerrón, 1 ( $\uparrow)$; Bucaral, 1 (१); Nirgua, $2 \hat{o}, 2$, 1 ( () ; Urama, $4 \hat{o}, 1$ \% Colonia Chirgua, 1 ( $९$ ) ; Ocumare del Tuy, 1 $q$; Cerro Negro, Miranda, 1 of ; Hda. Santa Clara, Carabobo, 1 ; San José de Los Caracas, 1 ô, 1 ; ; Aricagua, 1 \%; Carenero, 2 q; Río Chico, 1 \%; Barcelona, 3 ô, 1 q, 1 ( $($ ); Los Altos, 3 ô, 2 $q$; Caripe, 1 ( $q$ ); San Antonio del Golfo, 1 ( $\uparrow$; Yaguaraparo, 1 of; Bergantín, 1 q; Quebrada Bonita, $3 \hat{\delta}, 2$; Cristóbal Colón, $1 \hat{\delta}, 1$ ( $q)$; Barinitas, $1 \hat{\delta}, 1$ q ; Altamira, Barinas, 2 ô, 1 q; Guanare, 1 (q); La Veguita, 1 ô, 1 q; El Baúl, 1 \%; Acarigua, 1 $q, 3$ (q); Turén, 1 q ; Palenque, 2 ô; El Socorro, 1 ô; San Mateo, 1 $q$; Altagracia de Orituco, $4 \hat{\delta}, 3 q, 3(q)$; Santa María de Ipire, 1 $\hat{\delta}, 2$ $q, 2$ ( () ; Pariaguán, 1 ô; Quiribana de Caicara 1 , $2 \hat{\delta}, 2$; Caicara, 1 ô, $3 \hat{o}{ }^{1}$; Raudal Alto, Río Cuchivero, 1 ô; Caño Guaniamo, 1 ô ; Cerro El Negro, 1 $q$; Cascabel, $1 \hat{\delta} \mathbf{1}$; El Cambur, $1 \hat{\delta}$, 1 (q); Ciudad Bolívar, 1 o 1 ; La Paragua, 3 ô, 3 \&, 2 ( () ; Cerro Tigre, $1 \hat{\delta}, 1$ q ; Cerro Tomastote, 2 $q$. BRAZIL 1 : Limao, Rio Cotinga, 1 ô, 1 ; Frechal, Rio Surumú, 4 $\hat{\delta}, 1$.

L. s. uaireni.-VENEZUELA: Hato Santa Teresa, Río Uairén, 3 ô, 9 ㅇ.

L. s. compressus ${ }^{1}$.-COSTA RICA: 25. W. PANAMA: 7. NICARAGUA: 11.

L. s. insignis 1,-GUATEMALA: 35. NICARAGUA: 2.

ISpecimens in the American Museum of Natural History. 


\section{Diglossa duidae parui, new subspecies}

Type: Fron Cerro Parú, Terr. Amazonas, Venezuela; altitude 1650 meters. No. 46933, Phelps Collection, Caracas, Venezuela. Adult male collected February 16, 1949, by William H. Phelps, Jr. (Type on deposit at the American Museum of Natural History.)

Diagnosis: Differs from $D$. $d$. duidae by less prominent spotting on under parts; from $D$. $d$. hitchcocki by a paler throat, more bluish, less blackish, and by lacking the whitish edges on the under tail-coverts.

Range: Known only from Cerro Parú in the Subtropical Zone at altitudes from 1600 to 1700 meters.

Description of Type: Back black with bluish sheen, top of head darker, merging into the Deep Neutral Gray of upper tail-coverts; sides of head dusky; chin dusky merging into the Dark Neutral Gray of breast which in turn merges into the Neutral Gray of sides, flanks, thighs and under tail-coverts; posterior breast and anterior abdomen mottled with grayish; abdomen and edges of under tail-coverts more whitish; wings Fuscous-Black; primaries and secondaries very narrowly edged with pale bluish, the tertials more broadly; inner webs of remiges basally more grayish; upper wing-coverts tipped and edged terminally with pale blue; under wing-coverts and axillaries grayish; tail FuscousBlack, the rectrices, except outermost pair, edged externally with pale bluish.

Bill (in life) "black"; base of maxilla "gray"; feet "dark brown"; iris "brown." Wing, $70 \mathrm{~mm}$; tail, 53 ; exposed culmen, 12 ; culmen from base, 16 ; tarsus, 22.

Remarks: Sexes alike in coloration, but females have shorter wings. Size similar to duidae. Range of measurements : five adult males-wing, 70-72 (70.6) mm; tail, 52-57 (55); culmen from base, 15-16 (15.6); five females ( 4 with white tips on greater wing-coverts)-wing, 64-66 (65); tail, 51-55 (52); culmen from base, 16-17 (16.4). Measurements of $D . d$. duidae: three adult males-wing, $71-72$ (71.7); tail, 55-58 (56.6); culmen from base, 16-16 (15.6); two adult females-wing, 67, 71 (69); tail (1), 55; culmen from base (1), 16.

The immature specimens have the tips of the greater upper wing. coverts, and occasionally indications on the tips of the median coverts, whitish; the whitish mottling on the under parts is less prominent and the color, both above and below, is more dusky, less bluish.

Twenty of our 35 specimens have no white tips on the greater npper wing-coverts as against 34 of the 64 in the series of duidae in the American Museum of Natural History, 12 of the 30 hitchcocki in our collection from Cerro Yavi and only 2 of the 16 from Cerro Paraque. Thus the percentages collected of presumably adults are: Cerro Parú, 57\%; Cerro Duida, 53\%; Cerro Yaví, $40 \%$; Cerro Paraque, $12 \%$.

Many of the specimens of the new form have not completed the moult, while others have done so, and a few seem not to have commenced it. The duidae specimens in our collection have worn plumage; they were collected at the beginning of January. Our hitchcocki from Mts. Yavi and Paraque were collected at the end of February and the first days of March and during the middle of February, respectively.

The new form was collected during the middle of February. We had 
presumed ${ }^{2}$ that the white wing-coverts markings were a sign of immaturity. Now we consider it a fact as ten specimens of the new race which have the wing spots also have a recognizably different color. The pattern of the under parts is also differaent. Why, out of 16 specimens collected on Cerro Paraque, only 2 were adults, is puzzling.

\section{Specimens Examined}

D. a. duidae.-VENEZUELA: Cerro Duida, 3 ô, 2, 1 imm.; Cerro Duida $1,64$.

D. d. parui.-VENEZUELA: Cerro Parú, 14 ô, 10 q, 4 ô imm., 3 ( ) inm.

\section{Atlapetes personátus pani, new subspecies}

Type: From Cerro Parú, Terr. Annazonas, Venezuela; altitude 1200 meters. No. 47015, Phelps Collection, Caracas, Venezuela. Adult male collected February 18, 1949, by Manuel Castro. (Type on deposit at the American Museum of Natural History.)

Diagnosis: Differs from $A . p$. duidae, from Mts. Duida and Guaiquinima, by darker chestunt head and breast; from the other subspecies of personatus it differs greatly by the greater extension of chestnut on the throat and breast.

Range: Known only from Cerro Parú in the Subtropical Zone at altitudes from 1200 to 1650 meters.

Description of Type: Top of head and nape of Chestnut X Bay; back and uropygium black, a few feathers of lower rump fringed with yellowish green; sides of head uniform with crown, the color merging into the slightly paler throat and breast; ehin, throat and breast Auburn $\mathrm{X}$ Chestnut; lower breast and abdomen Lemon Chrome, merging into the dusky olivaceous sides, flanks and axillaries; thighs dusky; under tail-coverts dusky olivaceous, edged with greenish yellow; wings Fuscous-Black; outer vanes of primaries faintly edged with grayish and the outermost narrowly edged with white except towards the tip; bend of wing yellowish white; edge of inner vanes of remiges pale grayish basally; under wing-coverts grayish, edged with whitish; tail black.

Bill (in life) "black"'; feet "gray"; iris "brown". Wing, $79 \mathrm{~mm}$; tail, 79; exposed culmen, 14 ; culmen from base, 18; tarsus, 27.

Remarls: Sexes alike. Size similar to duidae. Range of measurements: five adult males-wing, 76-80 (78.6) $\mathrm{mm}$; tail, 77-83 (79.4); culmen from base, 17-18 (17.4); five adult females-wing, 72-75 (73.4); tail, 75-77 (75.6); culmen from base, 16-18 (17). Measurements of dudae from Mt. Duida ${ }^{1}$ : five adult males-wing, 77-80 (79.2); tail, 79 88 (81.8); culmen from base, 16-17 (16.8); three adult females-wing, 74-83 (76.2); tail, 70-79 (75.2); cumen from base, 17-17 (17).

Two immature specimens have a trace of yellowish on the chin, the back, and wing-coverts are washed with brownish and the crown and nape are dark olivaceous with indications of ehestnut.

The yellowish fringe at the base of the rump on the type is a variable character and is entirely absent on many specimens. The gonads of the adults in the series from Cerro Parú are in breeding condition.

2Phelps y Phelps, Jr. "Descripción de Seis Aves Nuevas de Venezuela y Notas sobre Veintncuatro Adiciones a la Avifauna del Brasil." Bol. Soc. Ben. Cien. Nat., No. 71, p. 70, 1947. 
Specimens Examined

A. p. personatus.-VENEZUELA: Cerro Roraima, $6 \hat{\delta}, 2$ $q, 2$ ( $q)$; Cerro Ptari-tepui, 8 o, 9 \&, 5 ( () ; Cerro Sororopán-tepui, 2 \&; Cerro Chimantá-tepui, 13 o, 13 $\uparrow, 2$ ( $(\uparrow)$; Cerro Aprada-tepui, $6 \hat{\delta}, 4 \uparrow$, 1 ( 8 ); Cerro Acopán-tepui, 4 ô, 1 \&, 1 ( $($ ).

A. $p$. collaris.-VENEZUELA:Cerro Auyán-tepui, 1 ㅇ.

A. p. duidae.-VENEZUELA: Cerro Duida, $1 \hat{\delta}, 7$ $\delta^{1}, 1$ \&, 3 ${ }^{1}$, $1(?)^{1}$; Cerro Guiaquinima, $9 \hat{\delta}, 10 \%, 5(q)$.

A. p. parui.-VENEZUELA: Cerro Parú, 11 ô (incl. type), 11 , 1 \& juv., 1 juv. ( $\$$ ).

A. p. paraquensis.-VENEZUELA: Cerro Paraque, 9 o (incl. type), 4 \&, $3(q)$. 


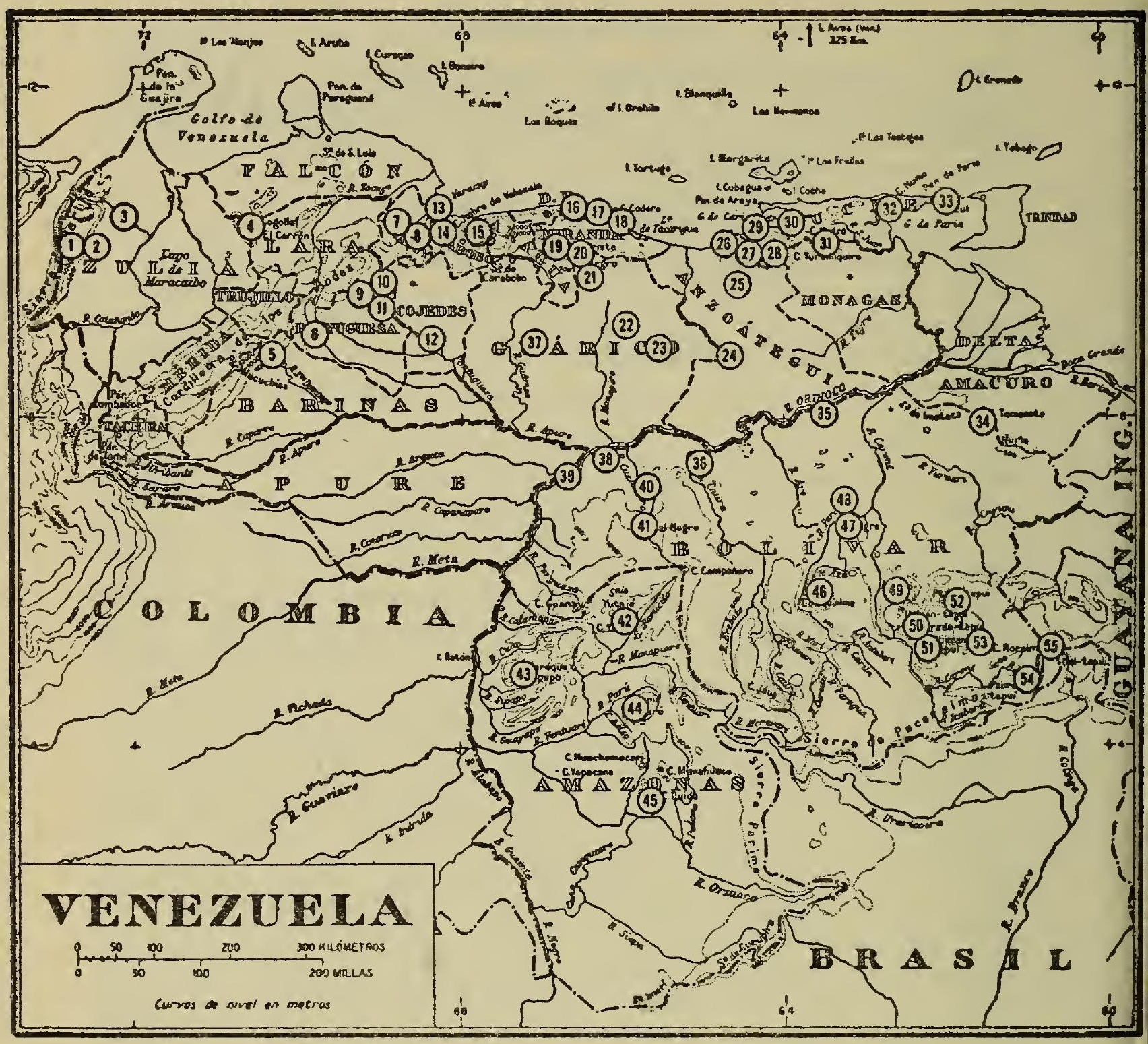

PLATE IV.

List of LOCALITIES

10 Acarigua

53 Acopán-tepui, Cerro

21 Altagracia de Orituco

5 Altamira (Barinas)

50 Aprada-tepui, Cerro

17 Aricagua

49 Auyán-tepui, Cerro

26 Barcelona

5 Barinitas

27 Bergantín

7 Bucaral

38 Caicara

18 Carenero

31 Caripe

39 Cascabel, Isla
29 Los Altos

2 Los Cañitos

2 Machiques

20 Negro, Cerro (Miranda)

8 Nirgua

19 Ocumare del Tuy

37 Palenque

43 Paraque, Cerro (= C. Sipapo)

24 Pariaguán

44 Parú, Cerro

52 Ptari-tepui, Cerro

28 Quebrada Bonita

38 Quiribana de Caicara

41 Raudal Alto (Río Cuchivero)

55 Roraima, Cerro 
51 Chimantá-tepui, Cerro

35 Ciudad Bolívar

14 Colonia Chirgua

33 Cristóbal Colón

45 Duida, Cerro

12 El Baúl

36 El Cambur

4 El Cerrón, Cerro

4 El Cogollal, Cerro

41 El Negro, Cerro

22 El Socorro

46 Guaiquinima, Cerro

9 Guanare

40 Guaniamo, Caño

$48 \mathrm{La}$ Paragua

1 La Sabana

2 La Sierra

6 La Veguita
30 San Antonio del Golfo

16 San José de Los Caracas

25 San Mateo (Anzoátegui)

15 Santa Clara, Hacienda (Carabobo)

23 Santa María de Opire

3 Santa Rosalía (Perija)

54 Santa Teresa, Hato (Río Uairén)

43 Sipapo, Cerro

52 Sororopán-tepui, Cerro

47 Tigre, Cerro

34 Tomasote, Cerro

11 Turén

13 Urama

32 Yaguaraparo

42 Yaví, Cerro 
50 Proceedings of the Biological Society of Washington 
Wimberley on the Blanco River road, Hays County, Texas, by Floyd E. Potter, Jr. on May 22, 1946. Paratypes. Ten (Floyd Potter Nos. A989A992, A994-A999), all taken at the type locality at the same time as the holotype. Hypoparatypes. Six specimens (H. M. Smith Nos. G1, G3G7), also from the same series, stained with alizarine red and cleared in glycerine.

Diagnosis. Indistinguishable from Eurycea neotenes in external morphology. This form is distinctive in several features of the skeleton: the irregularly $\mathrm{Y}$-shaped posterior basibranchial; the single articulation of the last rib; tuberculum of penultimate rib approximately twice as long as capitulum but less than length of shaft of rib; phalanges irregularly reduced in number.

Description of holotype. Head definitely flattened with only a very slight elevation in the interorbital region; eyes lidless, diameter .80 of the interorbital distance and .63 of the snout length; nostrils near the upper lip at the angle of the rather truncate jaw, separated from each other by a distance about equal to the snout length; conspicuous creases from the eye to the corner of the mouth and from the corner of the mouth posterodorsal over the base of the gills.

Three gills, fairly well developed, the largest reaching almost to the eye when adpressed anteriorly and to the elbow when both leg and gills are adpressed posteriorly; gills heavily pigmented, with 1-3 rows of dark brown chromatophores extending down the center of each of the filaments $3 / 4$ or more of the total distance to the tip; gular fold curving slightly posteriorly on each side from the middle of the throat.

Forelegs short, well-developed; fingers $1-2-4-3$, in order of increasing length; hind legs longer and stouter; toes $1-5-2-4-3$, in order of increasing length.

Costal grooves 16 (counting not more than one groove in either axilla or groin); 7 grooves between adpressed limbs; narrow yellowish strip of glandular tissue extending posteriorly along the midventral line from the anus $4 / 5$ the length of the tail.

Coloration in preservative finely mottled brown and yellow above, darkening somewhat laterally; top of head darkly mottled, the color fading posteriorly in the middle of the back except in a narrow, middorsal area and along the costal grooves, which are darker; dorsal fin, which originates at a point above the base of the hind legs, bordered by a dull orange stripe extending $4 / 5$ the length of the tail; mottled brown color extending down sides of tail and lightening only slightly before reaching the yellow glandular stripe; chin, ventrum of body, and lower half of sides yellow.

Variation. The shape of the posterior basibranchium and that of the penultimate rib do not vary greatly from the condition given in the diagnosis. The total number of phalanges is reduced in this form from 16 (phalangeal formula $2 \cdot 3 \cdot 4-4-3$ ), the basic number in related forms, to 11-16 (average 12.1) on the hind limb, and from 12 (phalangeal formula 2-3-4-3) to 10-12 (average 11.4) on the forelimb. The rariation of other skeletal features in the hypoparatypic series is giren in Table I. Table II gives the variation of some of the important external morphological characters in the holotype and paratypic series.

Comparisons. As previously stated Eurycea pterophila is indistin. guishable from $E$. neotenes in external morphological features, and thus obviously differs from $E$. nana and $E$. latitans in the same way that 
Table I. Variation in the hypoparatypic series

\begin{tabular}{|c|c|c|c|c|c|c|c|c|}
\hline \multirow[b]{2}{*}{ 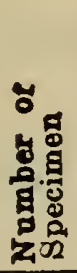 } & \multicolumn{2}{|c|}{$\begin{array}{c}\text { No. of Phalanges Per } \\
\text { Digit Ant. P Post. }\end{array}$} & \multirow[b]{2}{*}{ 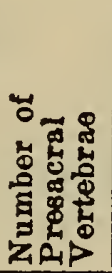 } & \multicolumn{5}{|c|}{ Teeth } \\
\hline & 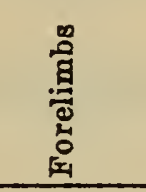 & 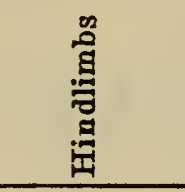 & & 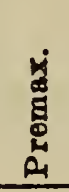 & 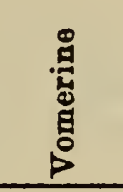 & 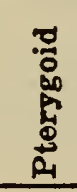 & $\begin{array}{l}5 \\
\text { 吾 } \\
\text { 口 }\end{array}$ & 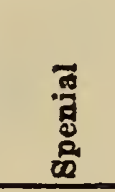 \\
\hline \multirow[t]{2}{*}{ G1 } & $2-3-4-3$ & $2-3-4-4-3$ & \multirow[t]{2}{*}{18} & \multirow[t]{2}{*}{15} & \multirow[t]{2}{*}{$10-10$} & \multirow[t]{2}{*}{$7 \cdot 8$} & \multirow[t]{2}{*}{$20-20$} & \multirow[t]{2}{*}{$5-6$} \\
\hline & $2-3 \cdot 4-3$ & $2-3-4-4-3$ & & & & & & \\
\hline \multirow[t]{2}{*}{ G3 } & $2-3-4-3$ & $1-2-3-3-2$ & \multirow[t]{2}{*}{18} & \multirow[t]{2}{*}{12} & \multirow[t]{2}{*}{$8-8$} & \multirow[t]{2}{*}{$7 \cdot 6$} & \multirow[t]{2}{*}{19.20} & \multirow[t]{2}{*}{7.9} \\
\hline & $2-3-4-3$ & $1-2-3-3-2$ & & & & & & \\
\hline \multirow[t]{2}{*}{ G4 } & $2-3-4-2$ & $2-3-3-3-2$ & \multirow[t]{2}{*}{18} & \multirow[t]{2}{*}{12} & \multirow[t]{2}{*}{9.10} & \multirow[t]{2}{*}{$6-8$} & \multirow[t]{2}{*}{$18-21$} & \multirow[t]{2}{*}{8.7} \\
\hline & $2-3-4-2$ & $1-3 \cdot 3 \cdot 3 \cdot 2$ & & & & & & \\
\hline \multirow[t]{2}{*}{ G5 } & $2 \cdot 3 \cdot 4-3$ & $1-3-4-2-2$ & \multirow[t]{2}{*}{18} & \multirow[t]{2}{*}{15} & \multirow[t]{2}{*}{$11-11$} & \multirow[t]{2}{*}{9.9} & \multirow[t]{2}{*}{21.22} & \multirow[t]{2}{*}{8.9} \\
\hline & $2-3-4-3$ & $1-2 \cdot 3-2 \cdot 2$ & & & & & & \\
\hline \multirow[t]{2}{*}{ G6 } & 2-3-3-2 & $1-3-3-3 \cdot 0$ & \multirow[t]{2}{*}{19} & \multirow[t]{2}{*}{13} & \multirow[t]{2}{*}{$10-10$} & \multirow[t]{2}{*}{$7-7$} & \multirow[t]{2}{*}{22.20} & $10-13$ \\
\hline & $1-3-3-2$ & $1-3-3-3-0$ & & & & & & \\
\hline G7 & $2-3-4-3$ & $2-3-4-3-1$ & 18 & 11 & $9 \cdot 9$ & $7 \cdot 7$ & 20.20 & $11-12$ \\
\hline & - & $2-3-4-2-1$ & & & & & & \\
\hline
\end{tabular}

Table II. Variation of the holotype and paratypic series.

\begin{tabular}{|c|c|c|c|c|c|c|c|c|}
\hline 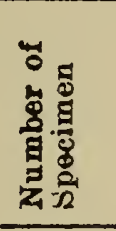 & 今 & 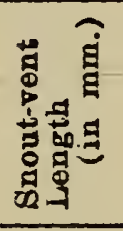 & 高 & 商 & 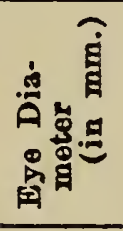 & 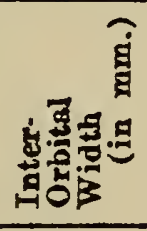 & 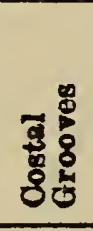 & 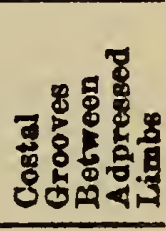 \\
\hline A989 & $\hat{o}$ & 31 & $301 / 2$ & $611 / 2$ & 1.2 & 1.6 & 16 & 7 \\
\hline A990 & $\hat{o}$ & $341 / 2$ & 31 & $651 / 2$ & 1.2 & 1.8 & 17 & 7 \\
\hline A991 & $\hat{o}$ & 30 & 29 & 59 & 1.1 & 1.9 & 16 & 6 \\
\hline A992 & $\hat{o}$ & 33 & $19+$ & $521 / 2+$ & 1.2 & 2.0 & 16 & 7 \\
\hline A993 & q & 31 & 28 & 59 & 1.1 & 1.5 & 16 & 7 \\
\hline A994 & q & 31 & $281 / 2$ & $591 / 2$ & 1.2 & 1.6 & 16 & 7 \\
\hline A995 & 우 & 29 & - & - & 1.1 & 1.4 & 15 & 6 \\
\hline A996 & q & $281 / 2$ & $161 / 2$ & $45+$ & 1.1 & 1.3 & 15 & 6 \\
\hline A997 & 우 & $291 / 2$ & 26 & $551 / 2$ & 1.2 & 1.5 & 15 & 6 \\
\hline A998 & 우 & $301 / 2$ & $10+$ & $401 / 2+$ & 1.2 & 1.5 & 15 & 6 \\
\hline A999 & q & $251 / 2$ & $211 / 2$ & 47 & .9 & 1.2 & 16 & 6 \\
\hline
\end{tabular}

E. neotenes (see Bishop, 1943, and Smith and Potter, 1946) does. The $Y$-shaped posterior basibranchium of this form is in marked contrast to the irregularly circular structure in $E$. nana and the T-shaped affair in $E$. latitans. In topotypic $E$. neotenes this structure is absent. The articulation of the last rib of $E$. pterophila is simple, while in $E$. neotenes, $E$. latitans and $E$. nana this articulation is differentiated into a capitulum and a tuberculum. In $E$. pterophila the tuberculum of the penultimate rib is approximately $1 / 2$ the length of the capitulum while in the related forms the two processes of the penultimate rib are approximately equal in length. 
54 Proceedings of the Biological Society of Washington

Bishop, Sherman C.

Literature Cited

1943. Handbook of salamanders. Ithaca (New York): Comstock Publishing Co., pp. 439-444.

Smith, Hobart M. and Floyd E. Potter, Jr.

1946. A third neotenic salamander of the genus Eurycea from Texas. Herpetologica, Vol. 3, Part 4, pp. 105-109. 


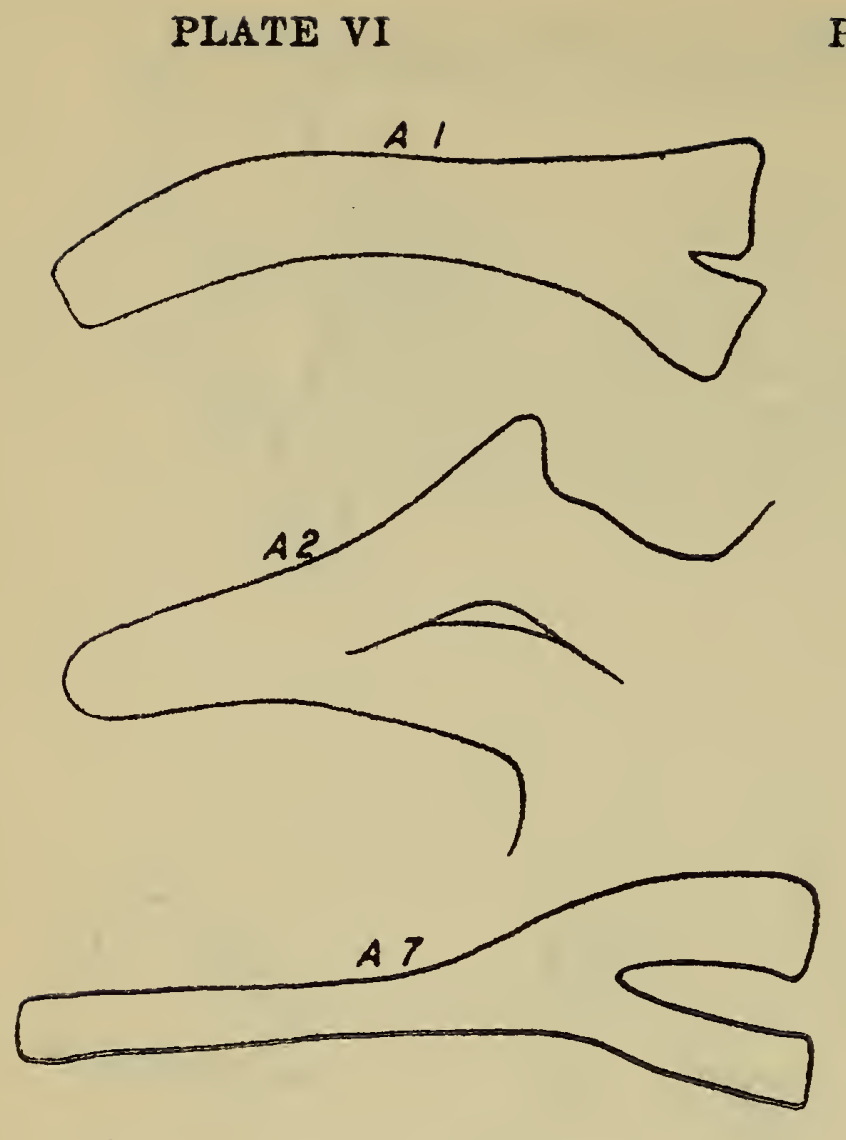

PROC. BIOL. SOC. WASH., VOL.63
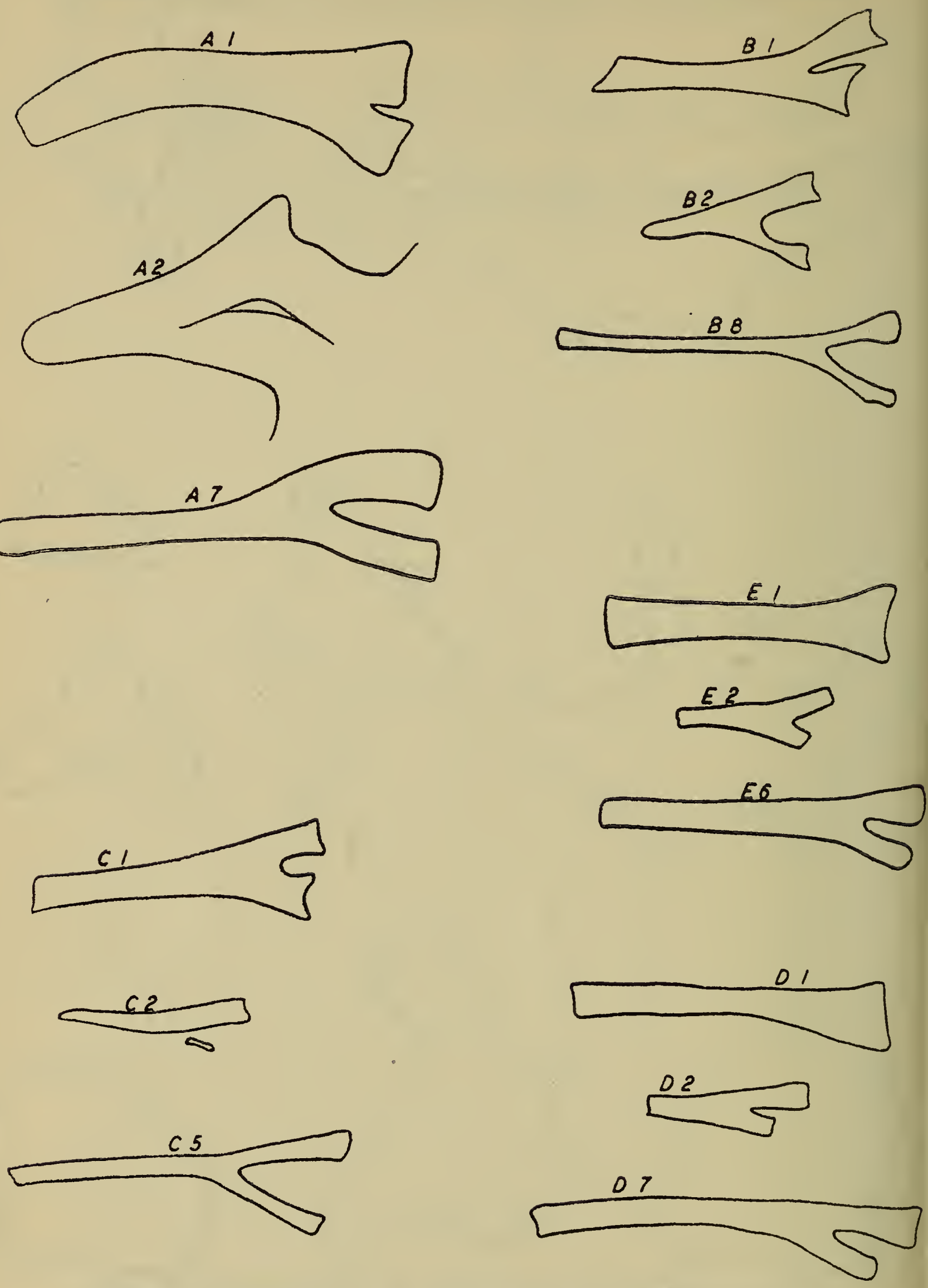

Plate VI.-Presacral ribs of various species of Eurycea, all $\times 43$. The number indicates the position of the rib counting forward from the sacrum. A, $\mathbb{E}$. latitans; $\mathrm{B}$, and $\mathrm{C}, \boldsymbol{E}$. bislineata; $\mathrm{D}$ and $\mathrm{E}, \boldsymbol{E}$. pterophila. 


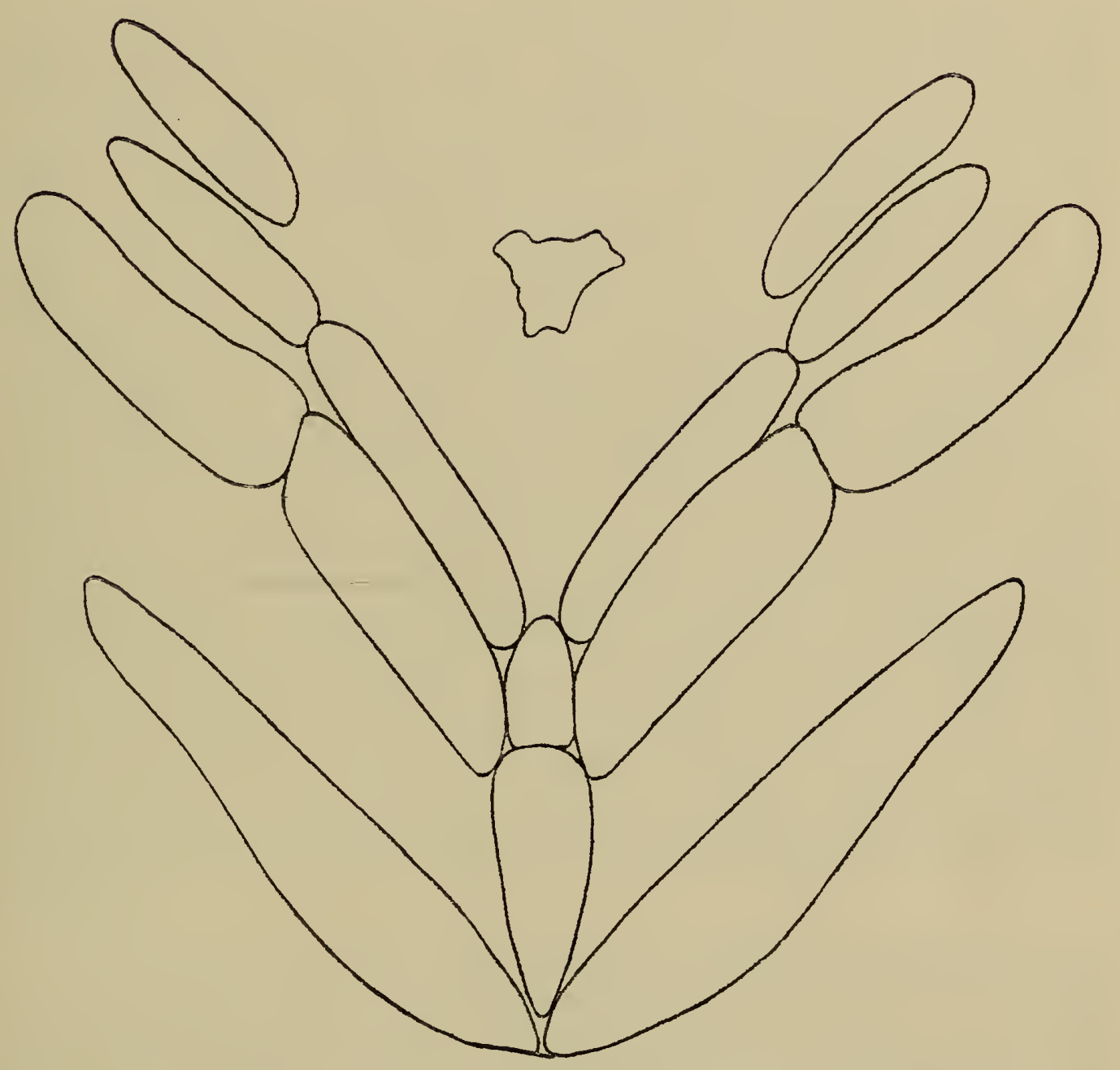

Plate VII.-Hyobranchium of $E$. pterophila (G1), $6.5 \mathrm{~mm}$ in width. 
58 Proceedings of the Biological Society of Washington 


\section{SA TPROAEETPINOSI \\ OPITIE}

BIOLOGICAL INSTITUTE OF WASHINGTON society

\section{A NEW RACE OF THE SPECIES, AMAZILIA BERYL- LINA, FROM SOUTHERN MEXICO}

\section{BY ROBERT T. MOORE}

A large series of the species Amazilia beryllina has been accumulated, due to the activity of Chester C. Lamb and Señor Mario Del Toro Avilés. The latter collected 114 of these in Chiapas. There is also a considerable number from Oaxaca and a very large aggregation of $A . b$. beryllina and $A . b$. viola from central and northwestern México making a total for the entire species in the Moore Collection from México of 284. In addition, I am greatly indebted to the Museum of Comparative Zoology and to the Museum of Zoology of the University of Michigan for the loan of critical specimens of devillei from the Pacific coastal District of Soconusco. The courtesy of Mr. James Bond of the Academy of Natural Sciences of Philadelphia, in loaning the valuable type and three other specimens of Amazilia beryllina motaguae deSchauensee is deeply appreciated. When Lichtenstein described the nominate race in the Preiz-Verzeichniss, based upon specimens collected by Deppe, he did not give any type locality. Deppe collected at Temascaltepec a number of other species. It is therefore, reasonable to restrict the type locality of Trochilus beryllinus Lichtenstein, to Temascaltepec, State of México, which I herewith do.

The assembling of this series, makes clear that the northwestern race of the species, viola, extends from southeastern Sonora south to Guerrero and east to Michoacán; that the nominate race, $b$. beryllina, ranges from the western part of the State of México east to Veracruz and thence south to Oaxaca; that in extreme southeastern Oaxaca, the nominate race intergrades in the lower mountains and Pacific lowlands with devillei which extends in a narrow strip along the entire Pacific coast of Chiapas through to western Guatemala; that a well-marked undeseribed form is found in the higher mountain and upland areas of central Chiapas, intergrading with devillei in the extreme southern part of the state.

It is interesting that the characters, as we proceed from northwestern México to Guatemala, do not all develop normally as one might expect. It is true that the development of the color of the abdomen is orderly, the posterior half of the underparts in viola being gray, becoming buffier in true beryllina of western México and the Valley of México, and even rusty in central eastern Oaxaca, while the green of the anterior underparts, gradually encroaches upon it. Finally in devillei and the new race, iridescent green occupies all of the underparts, with the exception of the under tail-coverts. On the other hand, violet or purple on the 
rectrices reach the highest intensity only in the end-races at the northwest and the extreme south, whereas in the in-between races, these parts in true beryllina are duller reddish-brick color and in the new race of Oaxaca become brilliant iridescent copper, with hardly a trace of violet.

$I$ herewith describe the new race:

Amazilia beryllina lichtensteini, ${ }^{1}$ subsp. nov.

Type--Adult male, number 27,335, collection of Robert T. Moore; Gerro Brujo, Ocozocuautla, Chiapas, México; July 2, 1940, collected by Mario del Toro Avilés.

Subspecific characters.-Not an intermediate in all characters between $A$. $b$. beryllina of central México and $A . b$. devillei of western Guatemala and coastal Chiapas, because it lacks the purple in the upper tail coverts characteristic of both these forms and has less violet or purple than either in the rectrices, it differs in the male from true beryllina in having, (1) the entire abdomen uniformly iridescent green like the rest of the anterior underparts; (2) median rectrices much less purplish approaching a color approximating iridescent Orange Chrome ${ }^{2}$ of Ridgeway, the other rectrices showing this color only on their tips the remainder of each feather being duller; (3) outer remiges darker with less chestnut at their bases; (4) the chestnut on the bases of the secondaries, not nearly so extensive. The females are more nearly like the males than in true beryllina, even in the extension of the green over the abdomen, showing only in a few specimens, slight traces of gray. Lichtensteini differs from devillei in having (1) much less purple in both the median and other rectrices; (2) anterior upper parts much brighter (more golden); (3) underparts much more golden (less bluish-green); (4) bases of secondaries brighter and lighter chestnut.

It is more difficult to compare lichtensteini with motaguae of eastern Guatemala, because the original and apparently the only series of the latter (which is before me), contains only one adult bird, a male. However, lichtensteini clearly differs from motaguae of eastern Guatemala in having, (1) the abdomen much greener (less gray); (2) undertailcoverts entirely cinnamon, lacking the heavy increment of white, characteristic of montaguae; (3) the upper anterior parts much brighter (more iridescent golden green). The females differ from the three females in the type series of motaguae in the same characters as the males.

Range.-Although attaining its best-marked characters, in the Cerro Brujo area of the mountains of west-central Chiapas it extends northeast to Petalcingo and east and south to Socoltenango, where only one out of six specimens show a slight approach to devillei, but only in having slightly more purplish median rectrices.

Specimens examined.- In addition to the 114 specimens of the new form, the majority of which eome from the Cerro Brujo region, there are several from Petalcingo and Tuxtla Gutierres and ten from Socoltenango. There is a huge representation of the nominate race, ranging from Temascaltepec to Rancho Santa Ephigenia in extreme southern Oaxaca. In addition, I have before me, the entire type series of four specimens of $A . b$. motaguae from eastern Guatemala, five specimens of devillei from the Pacifie coastal area of Chiapas and six individuals in the Moore Collection from Honduras.

\footnotetext{
Named in honor of the Great German ornithologist, who described many forms of Mexican birds, including the nominate race of this species.
} 


\title{
PROCEEDINCS
}

\author{
OF THE
}

\section{BIOLOGICAL SOCIETY OF WASHINGTON}

\section{AN ADDITIONAL FORM OF PEPPER-SHRIKE FROM WESTERN PANAMÁ}

\section{By Alexander WetMore}

During study of specimens of Cyclarhis gujanensis from northern Colombia and Panamá there has come to attention an interesting, handsomely colored race, found along the base of the eastern side of the Azuero Peninsula in western Panamá, that is new to science. It may be known as

\section{Cyclarhis gujanensis perrygoi subsp. novi.}

Characters.-Similar to C. g. nicaraguae, 1 but with yellow of under surface brighter, especially on sides and flanks; upper surface brighter green; crown with the ffown wash deeper in color.

Description.-Type, U. S. Nat. Mus. no. 400,660, male, from Ciénaga Macana, near El Rincón, Province of Herrera, Panamá, taken March 17, 1948, by A. Wetmore and W. M. Perrygo (orig. no. 13,896). Forehead and a broad band extending back on either side of the pileum, with a narrow line on the lower eyelid, russet; lores (extending to the eye to break the russet on the lower eyelid), sides of head and upper neck light neutral gray; crown and nape deep olive, with the feathers tipped very narrowly with russet, producing a brownish wash; back and wingcoverts between warbler green and olive-green; rump and upper tailcoverts warbler green; exposed surface of secondaries and remiges olivegreen; secondaries and primaries with inner webs dark mouse gray, and outer webs between warbler green and olive-green; rectrices olive-green; chin, extreme upper throat, and center of abdomen white; under tailcoverts eitron yellow; rest of under surface strontian yellow, becoming lemon yellow on the lower breast and flanks; under wing-coverts and edge of wing lemon yellow; inner webs of primaries edged with strontian yellow. Maxilla bister, becoming grayish olive on the sides near the tip, a color that extends down on the tip of the mandible; rest of mandible plumbeous black; tarsus, toes and claws dull army brown.

Measurements.-Males (7 specimens), wing 69.6-74.9 (72.6), tail 50.055.5 (53.1), culmen from base 17.3-19.7 (18.6), tarsus 22.2-23.0 (22.5) $\mathrm{mm}$.

Females (3 specimens), wing 70.5-76.0 (72.3), tail 51.4-54.9 (53.3), eulmen from base 17.8-18.7 (18.2), tarsus 22.8-23.4 (23.1) $\mathrm{mm}$.

Type, male, wing 73.1, tail 54.2, culmen from base 18.1, tarsus $22.6 \mathrm{~mm}$.

Range.-In western Panamá from southern Coclé (Aguadulce) south through the Province of Herrera (El Rincón, Parita), and west in the drainage of the Río Santa María into extreme east central Veraguas (El Villano, 15 miles southeast of Santiago). Sight records assumed to be

${ }^{1}$ Cyclarhis faviventris nicaraguae Miller and Griscom, Amer. Mus. Nov. no. 183, July 18, 1925, p. 6. (Matagalpa, 2,200 feet elevation, Nicaragua.) 
this race from Santa María, Quebrada Tejel and Quebrada Chitrabé to the south and west of Pesé, and El Barrero, Province of Herrera.

Remarks.- In the lowland, dry area of the eastern side of the Azuero Peninsula in western Panamá these birds are local in distribution, though not uncommon within the range outlined above. It is probable that they extend through tracts of scattered forest in hilly areas south through the Province of Los Santos, though there are no records at hand at present to substantiate this. The bright coloration of this new form is strikingly ditierent from that of Cyclarhis gujanensis subfavescens Cabanis, found in the Provinces of Veraguas and Chiriquí to the west, the transition between these two forms in the lowlands east of Santiago, Veraguas, apparentiy being along the low watershed between the Río Santa María of Coclé, Herrera and extreme eastern Veraguas, which flows into the Gulf of Panamá, and the Río Martín Grande, with its tributaries, which empties into the Gulf of Montijo. A specimen from El Villano, in the drainage of the Santa Maria, is easily recognized as C. g. perrygoi, while another from La Colorada on a tributary of the Martín Grande, while somewhat intermediate, is to be placed with subflvescens.

This new form is named for Watson M. Perrygo of the U. S. National Museum, my friend and companion on many days afield in Panamá and elsewhere, who shot the first of our specimens of it.

While pepper-shrikes seem to be common in suitable places in Veraguas and Chiriquí there are few reports of them through the area of the isthmus to the eastward. On March 9 and 10, $1949 \mathrm{I}$ found one singing on Barro Colorado Island in the Canal Zone, and in April I noted a few in the brush-covered hills near the east bank of the Río Mamoni at Chepo in the Province of Panamá. But in neither of these localities was I able to obtain specimens so that there is no certainty as to race. Bond and de Schauensee ${ }^{2}$ record a specimen taken at Garachiné, Darién, April 25,1941 , but state that the specimen was in too bad condition to deternine accurately. This bird can not be located at the present moment for new examination, but, as in the original notes it is reported to be unlike subflavescens and more on the order of flaviventris and nicaraguae, it seems possible that it is like the new form here described. I did not find Pepper-shrikes on the Pacific side of eastern Darién in 1946 and 1947.

The two specimens known of Cyclarhis gujanensis coibae Hartert, from Coiba Island off the Pacific coast of western Panamá, now in the American Museum of Natural History, are decidedly darker above than either subflavescens or perrygoi, the green having an olive cast, the crown being deeper brown, and the foreneck, breast, sides and flanks definitely greenish yellow, paler only on the lower breast and upper abdomen. The under tail-coverts are white. The type specimen of coibae, while fully grown and in full post-juvenal plumage, is a bird of the year, as is shown by the uniformly colored bill. The second specimen, the only other known at present, is a fully adult male, as is indicated by the lower mandible which is blackish except at the tip. The color of the plumage is similar to that of the type. A specimen in the American Museum (No. 505,408 ) collected on Jicarón Island, immediately to the south of Coiba, cannot be distinguished from subflavescens of Chiriquí, which is a strange circumstance since Coiba Island, from which $C . g$. coibae is described, lies between Jicarón and the mainland where subflavescens is found.

${ }^{2}$ Acad. Nat. Sci. Philadelphia, Mon. no. 6, 1944, p. 40. 


\title{
PROCEEDINGS
}

\author{
OF THE
}

\section{BIOLOCICAL SOCIETY OF WASHINGTON}

\section{A NEW SUBSPECIES OF SNOWSHOM RABBIY FROM WYOMING}

BY ROLLIN H. BAKeR AND ROBERT M. HANKINS

-In preparing a map of the geographic distribution of the snowshoe rabbit we were impressed with an unusual feature of the range currently assigned to the subspecies Lepus americanus americanus Erxleben. This unusual feature was the alleged presence of a population of this subspecies in the Bighorn Mountains of north-central Wyoming, far removed from other populations of $L$. a. americanus and geographically near the range of Lepus americanus bairdii Hayden. Reference to specimens in the University of Kansas Museum of Natural History revealed that snowshoe rabbits from the Bighorn Mountains did.resemble $L$. $a$. americanus more than $L$. $a$. bairdii but disclosed also that there were some characteristics in which the animals from the Bighorn Mountains differed from both $L$. a. bairdii and L. a. americanus. Accordingly we appealed to those in charge of the U. S. Biological Surveys Collection for specimens to supplement our not wholly adequate material. With the combined material it was ascertained that the snowshoe rabbit of the Bighorn Mountains is an hitherto unrecognized subspecies which may be named and described as follows :

\section{Lepus americanus seclusus new subspecies}

Type.-Male, adult, skin and skull; no. 20897, Univ. Kansas Mus. Nat. Hist.; $12 \mathrm{mi}$. E and $2 \mathrm{mi}$. N Shell, $7900 \mathrm{ft}$., Bighorn Mts., Big Horn County, Wyoming ; 8 July 1947 ; obtained by Gilbert Winemiller, original no. 22 of João Moojen.

Range.-Bighorn Mountains of north-central Wyoming.

Diagnosis.-Size medium (see measurements); top and sides of head Cinnamon Brown (capitalized color terms after Ridgway, Color Standards and Color Nomenclature, Washington, D. C., 1912); upper parts of body grayish; tympanic bullae moderately inflated; nasals, in anterior third, convex dorsally in longitudinal axis; interpterygoid space slightly wider anteriorly than posteriorly.

Comparison.-From L. a. americanus (specimens from Fort Chippewyan, Alberta, and Oscar, Ontario), $L$. a. seclusus differs as follows: Top and sides of head Cinnamon Brown instead of near (14) Brussels Brown; hair on basal half of anteromedial part of pinna of ear lightercolored (short hair more buffy, and white marginal hairs longer giving 
greater expanse of white); upper parts of body more grayish and less reddish; interpterygoid space broader anteriorly than posteriorly instead of parallel-sided; tympanic bullae larger. From L. a. bairdii (topotype and Albany Co., Wyo.), L. a. seclusus differs as follows: Top and sides of head Cinnamon Brown instead of near (a) Cinnamon Buff; hair on basal half of anteromedial part of pinna of ear darker (short hair darker buff, and white marginal hairs shorter giving smaller expanse of white); upper parts of body more grayish; nasals more convex in longitudinal axis; interpterygoid space less expaned anteriorly; tympanic bullae smaller.

Remarks. - L. a. seclusus appears to be restricted to the Bighorn Mountains. Nelson (N. Amer. Fauna, no. 9, p. 89, 1909) was correct in judging the rabbits from there to be more closely related to the subspecies Lepus americanus americanus than to the geographically adjacent Lepus americanus bairdii, which occurs in the several mountain ranges to the westward of the Bighorn Mountains. Immediately eastward of the Bighorns, there are no snowshoe rabbits; at least none has been reported from any of the higher areas where they might be expected to occur, as for example, the Black Hills. Although $L$. a. seclusus is distinguishable from either $L$. a. americanus or $L$. $A$. bairdii by each of five or more characters, $L$. a. seclusus is apparently structurally intermediate between $L$. $a$. bairdii and $L$. a. americanus rather than distinguished by any unique structural feature. For example, the width of the interpterygoid space, measured on a line between the last upper molars, averages 6.1 (5.5-6.5) $\mathrm{mm}$. in L. a. americanus, $6.7(6.3-7.2)$ in $L$. a. seclusus, and $7.2(6.9-7.7)$ in L. a. bairdii.

Measurements.-Three adult males (first the type, and two others from $8400 \mathrm{ft}$. in the Bighorn Mountains, nos. 56005 and 56006, U.S.B.S.) measure as follows: Total length, 420, 450, 440; length of tail, 38, 47, 41; length of hind foot, 132, 136, 125; ear from notch (dry), 72, 73, 66; weight of the type, 1115 grams; basilar length of Hensel, 58.0, 59.5, 55.4; zygomatic breadth, $37.5,38.8,37.8$; postorbital constriction, 12.0, 12.4, 11.8; length of nasals, 29.7, 31.2, -; alveolar length of maxillary tooth-row, 13.3, 14.3, 14.0.

Spocimens examined.-Total number, 6, all from Wyoming, as follows: $12 \mathrm{mi}$. E and 2 mi. N Shell, 7500 and $5900 \mathrm{ft}$., Big Horn County, 2 (U.K.M.N.H.) ; Bighorn Mountains, 8400 ft., 4 (U.S.B.S.).

Museum of Natural History, University of Kansas, Lawrence, Kansas. Transmitted March 22, 1949. 


\section{PROCEEDINCS}

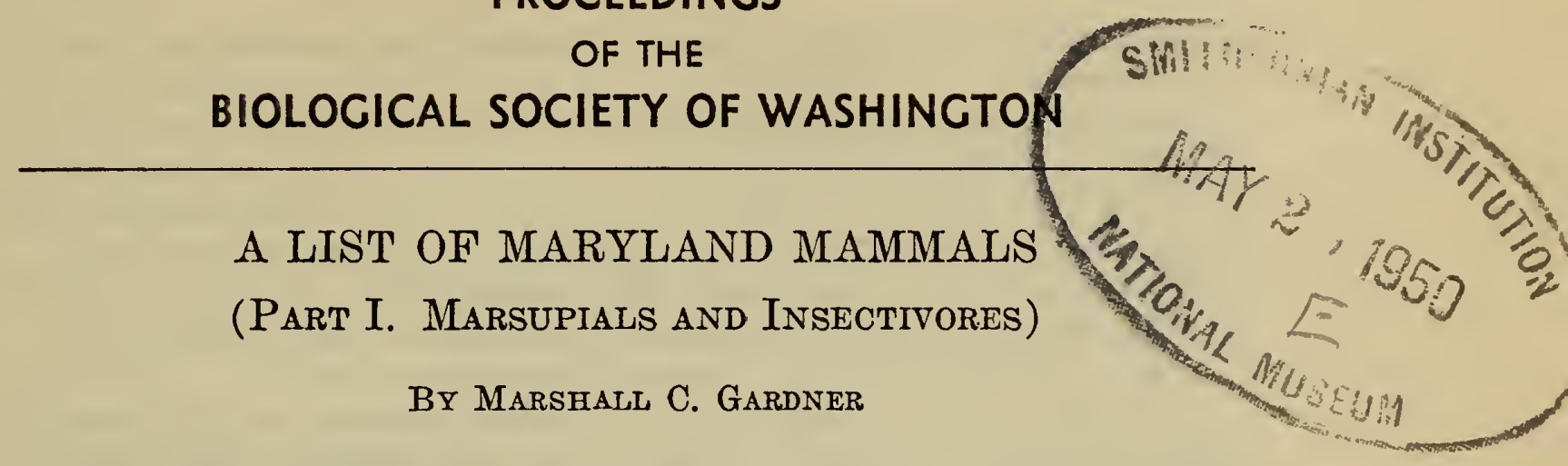

This list is based upon a survey of the mammal literature and the specimens contained in the collections of the U. S. National Museum and the U. S. Fish and Wildlife Service. The latter includes the collections of the Biological Surveys and the Patuxent Research Refuge. The list will be published in sections by orders or families as completed. The one marsupial genus and the insectivores are included in this first part. District of Columbia records are listed with those of the State because of their close relationship.

The limited number of locality records emphasizes the gaps in our knowledge of Maryland mammal ranges. It is hoped that naturalists will be stimulated to collect in unrepresented areas.

\section{Order Marsupialia \\ Family Didelphiidae}

Didelphis virginiana virginiana Kerr. Virginia Opossum.

1792. Didelphis virginiana Kerr, Anim. Kingd., p. 193.

Type locality.-Virginia.

Maryland records.--Since LeCompte (1942: 4) says that opossums were killed in every county in 1941, other literature records are not listed. U. S. National Museum specimens follow: Howard County: Long Corner; Montgomery County: Bethesda, Cabin John, Plummer Island, Boyds; Prince Georges County: Beltsville, Bladensburg, Branchville, Laurel, Patuxent Research Refuge, T.B.; District of Columbia.

Remarks.-Maryland specimens are indistinguishable from typical Virginia specimens.

\section{Order Insectivora \\ Family Talpidae-Moles}

Scalopus aquaticus aquaticus (Linnaeus). Eastern Mole. 1758 (Sorex) aquaticus Linnaeus, Syst. Nat., ed. 10, 1: 53.

Type locality.-Philadelphia, Pennsylvania.

Maryland records. - Anne Arundel County: Baltimore City; Baltimore County: Lake Roland (Bures, 1948: 61-62), Patapsco State Park (Hampe, 1939: 5) ; Calvert County: Chesapeake Beach ; Howard County: Cabin John, Capitol View, Chevy Chase, Plummer Island, Rockville, Seven Locks, Silver Spring, Woodside; Prince Georges County : Berwyn, Branch- 
ville, Landover, Laurel, Mt. Rainier, Patuxent Research Refuge. District of Columbia.

Remartes.-According to Jackson (1915: 35) "toward the south S. a. aquaticus gradually decreases in size ... A large series from the District of Columbia averages smaller than specimens from the type region, but in all essential characters except size they are typical of aquaticus."

Parascalops breweri (Bachman). Hairy-tailed Mole.

1842. Scalops breweri Bachman, Boston Journ. Nat. Hist. 4: 32.

Type locality.-Martha's Vineyard, Massachusetts.

Maryland records.-This species is not represented in the State by either literature or museum records. There are, however, the two following letter references in the Biological Surveys files of the U. S. Fish and Wildlife Service: Allegany County: Warrior Mountain, note by C. Hart Merriam dated 1908; Garrett County: Letter to C. Hart Merriam from S. N. Rhoads dated 1902.

Remarks.-Jackson (1915: 81) states that "the hairy-tailed mole shows remarkably little geographic variation ...' consequently Mary. land specimens when taken will probably not differ markedly from typical specimens.

Condylura cristata cristata (Linnaeus). Star-nosed Mole.

1758. Sorex cristatus Linnaeus, Syst. Nat., ed. 10, 1: 53.

Type locality.-Eastern Pennsylvania.

Maryland records.-Charles County: Marshall Hall; Howard County: Ellicott City ; Montgomery County: Brookeville, Burnt Mills, Cabin John, Chevy Chase, Plummer Island, Woodside; Prince Georges County: Beltsville, College Park, Glendale, Lanham, Laurel, Patuxent Research Refuge; Washington County: Williamsport. District of Columbia.

Remarks.-Maryland specimens are similar to those from eastern Pennsylrania.

\section{Family Soricidae-Shrews}

Sorex cinereus cinereus Kerr. Cinereous Shrew.

1792. Sorex arcticus cinereus Kerr, Animal Kingdom, p. 206.

Type locality.-Fort Severn, Ontario, Canada.

Maryland records.-Garrett County: Bittinger.

Sorex cinereus fontinalis Hollister. Maryland Shrew.

1911. Sorex fontinalis Hollister, Proc. U. S. Nat. Mus. 40: 378.

Type locality.-Cold Spring Swamp, near Beltsville, Prince Georges County, Maryland.

Maryland records.-Baltimore County: Lake Roland, Loch Raven, Patapsco State Park (Hampe, 1936: 17-18); Dorchester County: Cambridge; Montgomery County: Ashton, Cabin John, Glen Echo Heights, Rockville, Sandy Springs; Prince Georges County: Beltsville (Cold Spring Swamp, near) (type locality), Bowie, Hollywood, Hyattsville, Landover, Laurel, Patuxent Research Refuge, Tuxedo.

Sorex fumeus fumeus Miller. Smoky Shrew.

1895. Sorex fumeus Miller, North Amer. Fauna No. 10, p. 50.

Type locality.-Peterboro, Madison County, New York.

Maryland records.-Garrett County: Bittinger, Finzel.

Sorex dispar Batchelder. Gray Long-tailed Shrew.

1911. Sorex dispar Batchelder, Proc. Biol. Soc. Washington 24: 97.

Type locality.-Beedes, Essex County, New York. 
Maryland records. - Not known from Maryland but may occur in the highest portions of the western part of the State.

Sorex palustris punctulatus Hooper. Allegheny Water Shrew.

1942. Sorex palustris punctulatus Hooper. Occas. Papers, Mus. Zool., No. 463 , pp. 1.4 .

Type locality.-Shavers Fork of the Cheat River, 6 miles northwest of Durbin, Randolph County, West Virginia.

Maryland records.-Not recorded but considered by Hooper (1942: 2) as probably occurring in Western Maryland.

Sorex longirostris longirostris Bachman. Bachman's Shrew.

1837. Sorex longirostris Bachman, Journ. Acad. Nat. Sci. Philadelphia $7(2): 370$.

Type locality.-Hume Plantation, swamps of the Santee River (Cat Island, mouth of Santee River), South Carolina.

Maryland records.-Calvert County: Camp Roosevelt, Chesapeake Beach ; Prince Georges County: Hall. District of Columbia.

Microsorex hoyi winnemana Preble. Winnemana Pigmy Shrew.

1910. Microsorex winnemana Preble, Proc. Biol. Soc. Washington 23: 101.

Type locality.-Bank of the Potomac River near Stubblefield Falls, 4 miles below Great Falls of the Potomac, Fairfax County, Virginia.

Maryland records.-Prince Georges County: Berwyn.

Cryptotis parva parva (Say). Small Short-tailed Shrew.

1823. Sorex parvus Say, Long's Exped. Rocky Mts. 1: 63.

Type locality.-West bank of the Missouri River, near Blair, Washington County, Nebraska.

Maryland records.-Baltimore County: Loch Raven, Parsons Island; Montgomery County: Bethesda, Sandy Spring; Prince Georges County: Laurel (Merriam, 1895: 18), Patuxent Research Refuge; Worcester County: Chincoteague Bay. District of Columbia (Merriam, ibid.).

Remarks.-Although Cryptotis parva harlani and Cryptotis parva elasson have been named from Indiana and Ohio respectively, the status of the eastern races has not been sufficiently determined to justify the use of either of these names.

Blarina brevicauda carolinensis (Bachman). Carolina Short-tailed Shrew.

1837. Sorex carolinensis Bachman, Journ. Acad. Nat. Sci. Philadelphia

$7(2): 366$.

Type locality.-Eastern South Carolina.

Maryland records.-Dorchester County: Cambridge.

Blarina brevicauda kirtlandi Bole and Moulthrop. Kirtland's Short-tailed Shrew.

1942. Blarina brevicauda Kirtlandi Bole and Moulthrop, Sci. Publ. Cleveland Mus. Nat. Hist. 5 (6): 99.

Type locality.--Holden Arboretum, Lake and Geauga Counties, Ohio. Maryland records.-Baltimore City; Baltimore County: Patapsco State Park (Hampe, 1944: 73) ; Lake Roland (Bures, 1948: 62-63) ; Frederick County: Locust Grove (Merriam, 1895: 13) ; Garrett County: Bittinger, Finzel, Grantsville, Mountain Lake Park, Swanton; Montgomery County: Cabin John, Cropley, Poolesville, Plummer's Island, Rockville, Sandy Spring (Merriam, 1895: 13) ; Prince Georges County: Hyattsville, Lanham, Laurel, Northwest Branch Anacostia River, Oxon Hill, Paturent Research Refuge, Silver Spring. 
Remarks.-Although Maryland specimens average slightly paler in pelage color, and slightly longer in tail length than typical kirtlandi, they are best referred to this form until a more critical study of the eastern Blarinae is made.

\section{Literature Cited}

BURES, J. A. 1948. Mammals of a limited area in Maryland. Maryland Nat. 18 (4) : 59-68, 4 pls., 3 figs.

HAMPE, I. E. 1936. The occurrence and breeding of the Maryland shrew (Sorex fontinalis) in the Patapseo State Park. Bull. Nat. Hist. Soc. Maryland 7 (4): 17-18, 2 figs.

- 1939. Notes on the mammals of the Patapseo State Park.

Bull. Nat. Hist. Soc. Maryland 10 (1): 4-7.

. 1944. An unusual color phase of the short-tailed shrew. Maryland 14 (3): 73 .

HoOPER, E. T. 1942. The water shrew (Sorex palustris) of the southern Allegheny Mountains. Occas. Papers, Mus. Zool., No. 463: 1-4.

JACKson, H. H. T. 1915. A review of the American moles. North Amer. Fauna No. 38, 100 pp., 6 pls., 27 figs.

LE CoMpte, E. L. 1942. Analysis of game kill statistics for season of 1941. Maryland Conserv. 19 (3) : 4-5, 8.

MERRIAM, C. H. 1895. Revision of the shrews of the American genera Blarina and Notiosorex. North Amer. Fauna No. 10, 34 pp., 3 pls. 2 figs.

U. S. Fish and Wildlife Service. 


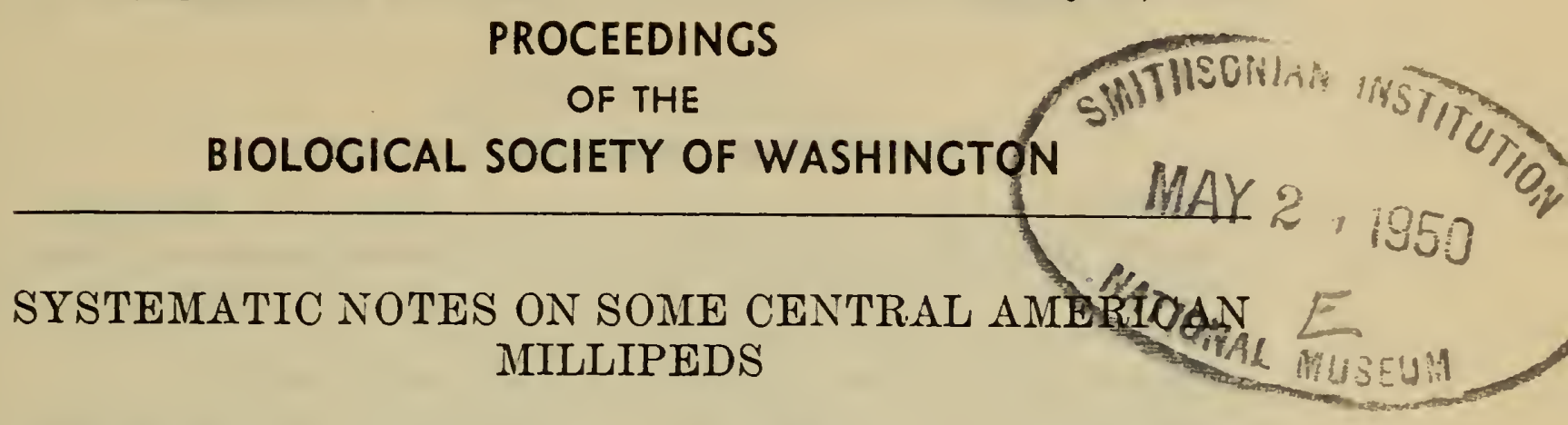

\author{
By Richard L. HofFMaN \\ Miller School of Biology, University of Virginia, Charlottesville
}

During the accumulation of material for a projected checklist of the millipeds of tropical North America, a number of taxonomic errors have been noted, and this occasion is taken to present notes and corrections, as well as to propose a few new names.

\title{
RHINOCRICIDAE
}

\section{Rhinocricus approximans, new name}

Rhinocricus simulans Chamberlin, Proc. Acad. Nat. Sci. Phila., vol. 99, pp. 39, 41, figs. 33-35, 1947; preoccupied by Rhinocricus simulans Chamberlin, Proc. U. S. Nat. Mus., vol. 60 , art. 8, p. 22 , pl. 10, figs. 7-10, 1922.

Type locality.-Nicaragua, without further data.

Type specimen.-Male, Acad. Nat. Sci. Phila., type no. 9963.

\section{CLEIDOGONIDAE}

\section{Cleidogona}

Cleidogona Cook and Collins, Ann. N. Y. Acad. Sci., vol. 9, p. 41, 1895. Mexiceuma Verhoeff, Zool. Anz., vol. 68, no. 3/4, p. 112, 1926.

Verhoeff proposed a family Mexiceumidae for the reception of a new genus and species, Mexiceuma maculata, which he described from specimens taken at Desierto de los Leones, Distrito Federal, Mexico. Comparison was made with two other chordeumoid families, and there is no evidence that he even considered the long established American group Cleidogonidae. Actually his drawings of the gonopods of M. maculata are quite typical of Cleidogona, and since there is nothing in the description to preclude such an association, I suggest that the species be henceforth known as Cleidogona maculata (Verhoeff). Another species, C. leona Chamberlin (Bull. Unir. Utah, vol. 34, no. 7, p. 34, 1943) has been described from Desierto de los Leones, but is distinctive in larger size and other particulars.

Verhoeff's predilection for erecting numerous diplopod families, while not to be entirely condemned, was frequently based on minor characters and insufficient knowledge of exotic faunas. This, with a noticeable tendency to disregard the work of others, led to the proposal of several families of American diplopods (e. $g$. Mexiceumidae, Onychelidae) for which other names have long been established. 


\section{CHELODESMIDAE}

Chondrodesmus chamberlini, new name

Chondrodesmus panamenus Chamberlin, Proc. Biol. Soc. Washington, vol. 38, p. 42 , 1925; preoccupied by Chondrodesmus panamenus Chamberlin, Proc. U. S. Nat. Mus., vol. 60, art. 8, pp. 46, 47, 1922. Type locality.-Barro Colorado Island, Panama.

Type specimen.-Female, Museum of Comparative Zoology.

Curiously enough, the 1925 name was proposed as new on the same page as a reference to the older panamenus! I am not completely assured that the two names actually apply to different species, but until such a time as the males become known, they are retained as separate entities.

\section{Cyclorhabdus}

Comparison of the drawings and descriptions of the species referred to this genus indicates that two generic types are involved. Cyclorhabdus in the strict sense is well characterized by the articulation between the femur and tibiotarsus of the male gonopods, and includes two species: decoratus (Peters) and annulus Brolemann, both Venezuelan. In this genus the tibiotarsus of the gonopods is slender and tapering, without modification. The character of the jointed gonopod is strongly reminiscent of the condition found in the North American xystodesmid genus Brachoria, and the gonopod of $C$. annulus is strigingly similar to that of B. glendalea (Chamberlin). A Guatemalan species, contortus Brolemann, has been generally referred to Cyclorhabdus despite a very different sort of gonopod, which lacks an articulation and has a prominent tibiotarsal solenomerite. In view of these differences, as well as others which obtain in certain non-sexual characters, it seems necessary to propose a new genus for the Guatemalan form.

\section{Solaenorhabdus, new genus}

A chelodesmid genus, characterized as follows: body with 20 segments, pore formula normal, keels rather small, pores more or less lateral; sternites without processes; prefemora and femora without spines, a tibial pad present. Male gonopod with femur elongated and continuous with tibiotarsus, a rudimentary femoral process; end of tibiotarsus with a rather large solenomerite; the entire appendage bent, not forming a complete circle. For complete description of the type species, see one of the references cited below.

Generotype.-

\section{Solaenorhabdus contortus (Brolemann)}

Cyclorhabdus contortus Brolemann, Mem. Soc. Zool. France, vol. 13, p. 98, pl. 6, figs. 21-25, 1900; Pocock, Biol. Centr. Amer., Diplop., p. 168, 1909 ; Attems, Das Tierreich, lief. 69, pp. 172-73, fig. 189, 1938.

Leptodesmus contortus Carl, Rev. Suisse Zool., vol. 10, p. 607, pl. 10, figs. 28-31, 1902.

Type locality.-Guatemala, without further locality.

Type specimen.-Present location uncertain, presumably in the Paris Museum. 


\section{PERIDONTODESMIDAE}

\section{Hexodontia}

Hexodontia Verhoeff, Zool. Jahrb., Syst., vol. 62, p. 516, 1932.

Trachyphloeus (nec Germar, 1817) Attems, Ann. Mus. Wien, vol. 46, p. 264, 1933.

Rhexiphloeus Attems, Das Tierreich, lief. 70, p. 460, 1940.

This genus has had a somewhat interesting history. Described as a group in the Cryptodesmidae, its actual identity was overlooked by Attems on two occasions, first when he proposed Trachyphloeus in 1933 for Peridontodesmus electus Chamberlin, and again when he proposed Rhexiphloeus as a substitute name in the third of his great volumes on polydesmoids.

Actually, comparison of the drawings and descriptions of the two genera in Lieferung 70 of Das Tierreich (Hexodontia, p. 231; Rhexiphloeus, p. 461) shows that a single group is involved, with Verhoeff's name taking priority. It must be transferred from the Cryptodesmidae to the Peridontodesmidae, however.

A list of the species now referable to Hexodontia follows:

1. H. cordobanus Verhoeff, Zool. Jahrb., Syst., vol. 62, p. 518, figs. 45-47, 1932. Cordova, Vera Cruz, Mexico.

2. H. morelus (Chamberlin), Bull. Univ. Utah, vol. 34, no. 7, p. 59, pl. XIV, figs. 140-43, 1943. Chapultepec, near Cuernavaca, Morelos, Mexico.

3. H. electus (Chamberlin), Trans. Amer. Ent. Soc., vol. 40, pp. 188-89, pl. 2, fig. 3, 1914. Laguna, Juan Vinas, Costa Rica; also reported from Carpintera, C. $R$.

It will be seen that the genus occupies a fairly large range, and that numerous additional species are to be expected. 
72 Proceedings of the Biological Society of Washington 


\section{PROCEEDINCS}

OF THE

\section{BIOLCGICAL SOCIETY OF WASHINGTON}

\section{TWO NEW GOBIES FROM THE PHILIPPINES WITH NOTES ON A THIRD RARE GOBY}

By Albert W. C. T. Herre

School of Fisheries, University of Washington

The Checklist of Philippine Fishes completed by me in May, 1948, contained approximately 2,145 species known from Philippine waters. It was thought that this number would stand for some time to come. However, field work during June and July, 1948, showed that one could make additions to the fish fauna of the Islands by careful collecting almost anywhere. Manila Bay gave a surprising number not hitherto recorded from the Philippines, especially of Scorpaenidae. Rare and little known species were obtained from both salt and fresh water.

Few of the additions were new, but extensive additions were made to our knowledge of geographical distribution. No effort was made to collect gobies, as the time available for field work was very limited. Attention was chiefly directed toward getting commercial fishes of importance. In spite of this some gobies were necessarily collected, and among them several proved to be new. Two of them are herewith presented, together with a re-description of a third little known species. The other new gobies may appear in a later paper.

The specimens here mentioned are in the collection of the School of Fisheries, University of Washington. When dimensions are given the standard length is always understood.

\section{Intonsagobius Van Clevei Herre, new species}

Dorsal VI-1.9; anal I-6; scales in longitudinal series 30 , plus 2 on the caudal base, in tranverse series 9 ; predorsal scales 7 , extending forward to eyes.

The body is plump anteriorly, but compressed posteriorly, very little elevated, its breadth nearly equal to the depth, which is four and a third times in length. The breadth of the head is greater than its depth and three-fourths of its length. The head and long pointed caudal are equal, 3.25 in the length. The large dorso-lateral eyes are high up, 2.66 times, the snout 3.15 in the head; the interorbital is very narrow, 4.5 in the eye. The mouth is strongly oblique, the maxillary scarcely reaching a vertical from the front margin of the eye; teeth typical, the large vomerine teeth 
more or less concealed. Three vertical and 2 transverse ridges of sensory papillae on the cheek, a vertical and 2 transverse opercular ridges, with other ridges on the snout, nape, and under side of head, but none on the median row of scales along the sides of the body. Conspicuous pores in the interorbital and about the eye.

All the dorsal spines have elongate filiform tips, the first one longest, reaching beyond the middle of the second dorsal when depressed, and equal to the head. The second dorsal is high, the last ray longest, 1.5 times in the head and reaching the caudal base; the anal is very high, the last ray elongate, nearly as long as the head, and extending upon the caudal base when depressed. The long pointed pectoral extends upon the anal when depressed, and is longer than the head, 2.6 times in the total length. The long and pointed ventral extends upon the genital papilla, 3.9 in the length; the least depth of the caudal peduncle is 1.66 times in its own length. The female genital papilla is rather broad, with a slightly notehed tip.

The color in life was deep brown to black, darkest on the head, the under side much paler, all the fins black. In preservative most of the dusky epidermis on the head has been rubbed off, and many of the scales lost, so that the specimen has lost its original swarthiness.

Here described from the type and only specimen, a female $39 \mathrm{~mm}$. long, collected at Dumaguete, Negros Oriental Province, Philippine Republic.

I take pleasure in naming this in honor of Dr. Richard Van Cleve, Acting Director of the University of Washington School of Fisheries.

\section{Vaimosa zebrinus Herre, new species}

Dorsal VI-1-7; anal I-6; scales in longitudinal series 30 , plus 2 on the caudal base, and 10 in transverse series; predorsal scales 13 in males, 14 to 16 in females, the anterior scale much larger than the others and extending between the posterior margins of the eyes; opercular scales imbedded and difficult to observe, apparently 6 to 8 .

The body is low, somewhat elongate; the dorsal and ventral profiles nearly horizontal and parallel; the trunk laterally compressed but the head is broad with budging cheeks, its breadth 1.4 in its own length, the depth is 5.55 times in the length; the broadly rounded caudal equals the head, which is 3.57 , the pectoral 5 , the ventral 6.25 times in the length.

The large dorso-lateral eyes are in the anterior half of the head, 4.1 times in the head, the snout slightly longer than an eye diameter in a male specimen; females have larger eyes in proportion, 3.2 in the head, the snout shorter than the eye. Onterorbital broad on males, 1.2 in eye or 5 in head, but much narrower in females, 2.22 in eye or 7 in head. The oblique mouth is terminal in males, the angle of the mouth beneath the front margin of the eye, but the angle of the maxillary beneath the middle of the eye; in females the mouth is slightly inferior and somewhat smaller; the very small teeth are in 3 rows in both jaws, those of the outer row larger than the others.

The dorsals are separated by 2 scales; males have the second spine of the first dorsal elongate and thread-like, equal to the head in length and reaching nearly to the middle of the second dorsal; the first dorsal is not elongate in females, its height about half the length of the head; the height of the second dorsal and anal are each about half the length of 
the head, the last ray of each falling much short of the caudal when depressed. The pectorals are rather broad, extending to a vertical from the genital papilla; the ventrals extend little more than half way there. Genital papilla very slender and pointed in a young male, plump and subcylindrical with rounded tip in females.

The color in alcohol is whitish gray, masked except on the under side by rounded or angulate brown bars along the hind margin of each scale, and by minute dark dots sprinkled over the upper half of the body; a large irregular blackish brown spot under the pectoral, followed by 5 or 6 smaller spots along the middle of the side, the one at the caudal base usually double; from these spots dark brown bars may descend obliquely forward. On the side of the head are 6 conspicuous dark brown stripes, 2 from the eye to the maxillary, 1 from the eye behind the maxillary angle, and 3 curved more or less downward across the cheek; opercle and under side of the head with numerous circular black dots which extend upon the pectoral base and may cover the preventral area. First dorsal with 3 or 4 transverse rows of black spots on the spines, the second dorsal with 4 rows of similar spots; caudal with 8 to 10 transverse rows of black spots, which on some specimens cross only the upper threefourths of the fin, but others have the whole fin barred. The other fins are clear, or the ventrals may be brown.

Here described from the type, an immature male $25 \mathrm{~mm}$. long, and 3 females 23 to $24 \mathrm{~mm}$. in length. I caught them in a brackish estero at Layia, Batangas Province, Luzon.

This little fish is related to Vaimosa fusca Herre, but differs markedly in the predorsal and opercular scalation.

Zebrinus, in allusion to the conspicuously brindled cheeks.

\section{Tamanka talavera Herre}

A single specimen of this rare goby was taken at Dumaguete. It is considerably larger than the type and paratypes obtained by me in 1940 from a nipa swamp near Capiz, Capiz Prov., Panay. The new find is $43 \mathrm{~mm}$. long, as opposed to $33 \mathrm{~mm}$. for the type and 20 to $31 \mathrm{~mm}$. for the paratypes. There are enough differences to warrant a re-description, as it seemed at first to be specifically different from $T$. talavera.

Dorsal VI-1-9; anal I-8; scales in longitudinal series $48,+3$ on the caudal base, 20 in transverse series, and 20 predorsal; opercular scales apparently 32 .

The body is low, laterally compressed, the dorsal and ventral outlines nearly parallel and horizontal; the head nearly flat and noticeably broad with bulging cheeks, its width six-sevenths of its own length, which is 3.44 times in the standard length. The depth is 5.37 in the length; the broad rounded caudal equals the pointed pectoral, 4.3, the ventral 4.77 times in the length. The eye is in the front half of the head, lateral but very high up, level with and equal to the wide flat interorbital and also equal to the broad convex snout, 4.16 in the head. The wide inferior mouth is oblique, the posterior angle of the maxillary extending beyond the eye; teeth typical of the genus, the tip of the tongue slightly emarginate. The vertical fins are low, the tips of the dorsal spines attentuate and filiform, the third, fourth, and fifth equal to the last anal ray, 1.78 in the head or 6.14 in the length. The second dorsal spine is 3.125 in the head, the rays successively longer, the last ray twice as long and 
extending on the caudal when depressed, 1.56 in the head or 5.375 in the length. The pectoral and ventral origins opposite, the pectoral extending beyond the ventral but not reaching the anus. Least depth of caudal peduncle six-serenths of its own length. The body is covered with ctenoid scales, which extend forward of the dorsal to above the middle of the preopercle; beyond this is naked, including the interorbital, snout, and preopercle, as well as the under side of the head; anal papilla of male is rather large and pointed.

The color of body and fins is dark brown with blackish brown vertical or diagonal stripes, spots, and lines on the upper half; a diagonal stripe from the eye above the preopercle to beneath the pectoral; another short predorsal stripe across the nape; two stripes beneath the first dorsal, three beneath the second dorsal, two across the caudal peduncle, and one on the caudal base; top of the head with irregular dusky lines, and one running from the eye back across the middle of the preopercle and opercle; first dorsal with a wide median transverse black band, a narrow clear band above it, and the tips of the fin black. The membrane of the second dorsal has a vertical black bar between each two rays, with a submarginal clear band and the tips of the rays black; anal with more or less black on its outer portion; caudal with five cross bars of dusky brown spots.

Tamanka talavera Herre, Copeia, No. 1, p. 4, March 31, 1945; near Capiz, Panay. 


\section{PROCEEDINGS}

\section{OF THE}

\section{BIOLOGICAL SOCIETY OF WASHINGTON}

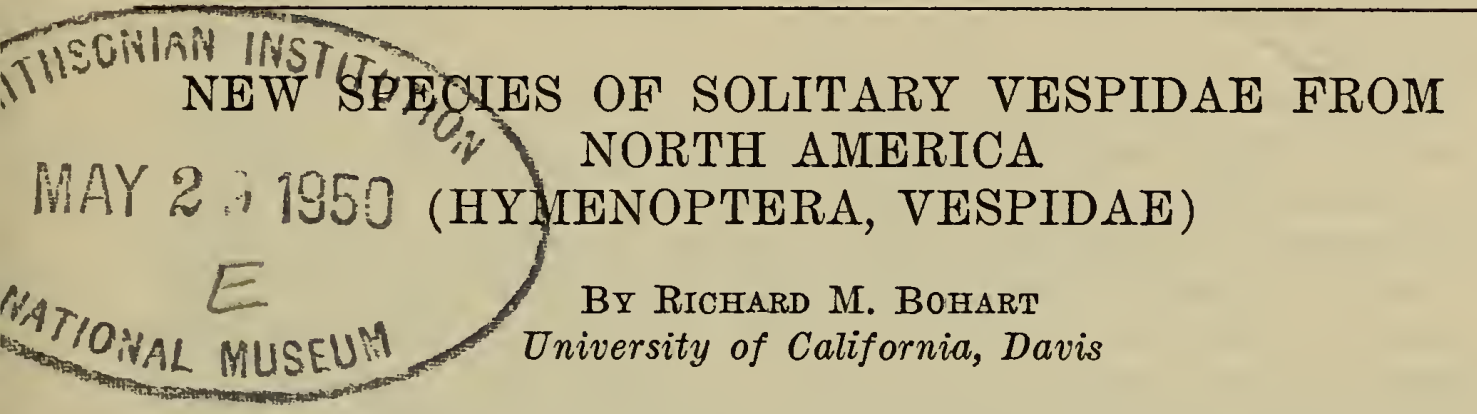

The following species and subspecies are described at this time so that the names can be included in the proposed catalogue of Hymenoptera sponsored by workers at the U. S. National Museum.

\section{Zethus (Zethusculus) arizonensis, new species}

Male.-Black, marked with deep yellow. Yellow are: small spot on frons at base of antenna, ocular dot, humeral margin, mesopleural and 2 scutellar spots, parategula apically, 2 spots on tegula, broad apical margin of tergite I, narrow one on II, median apical one on III, apical dot at side of sternite II. Wings brown-stained with purplish reflections, heaviest toward leading edge. Legs partly brownish. Puncturation coarse and close, reduced toward base of abdominal segment II and on terminal abdominal segments, tegula shining. Pubescence minute, pale, well distributed, silvery on propodeum and sides of face in some lights. Antenna with segment III less than one-half as long as I, segment XII small and largely concealing the minute XIII. Clypeus about twice as broad as long, ending in 2 blunt teeth separated by interantennal distance; mandible with teeth rather regularly spaced; antennal bases joined by an irregular transverse carina, interocellar area with a pair of prominent polished tubercles, not bridged in front; head in lateral view divided about in half by hind ocular margin. Humeral margin with a forwardprojecting carina about as great as an ocellus diameter, humeral angles small but sharp; postscutellum traversed by a sharp, prominent, wshaped carina; hind face of propodeum roughened with a deep median groove, a small submedian projection behind postscutellum and an irregular ridge on lateral angles; tarsi broad and flattened, fore tarsus almost as broad as fore tibia. Tergite I swelling abruptly before middle, widest just beyond, where it is about 1.7 times apical breadth and 0.4 times length of segment; segment II with a short stalk, wider than high; tergite I with a clear apical membrane projecting about 3 ocellus diameters; tergite III with a similar membrane laterally but abruptly notched and narrowed over strongly convex middle portion; apices of sternites II and III broadly membranous. Length to apex of second tergite $13.0 \mathrm{~mm}$.

Female.-Markings and structure about as in male. Length to apex of second tergite $13.5 \mathrm{~mm}$.

Holotype, male, California Academy of Sciences, Ent. no. 6141, Phoenix, Arizona, July 15, 1932 (H. S. Gentry). Paratypes, 10 males 
and 1 female from the following Arizona localities: Phoenix (H. S. Gentry, H. A. Scullen), Coolidge Dam (H. A. Scullen), Tucson (J. O. Martin), Oracle and San Simon. Three male paratypes from Steins, Grant Co., New Mexico, July 14, 1917. All type material taken in July or August.

The elypeal shape and arrangement of membranes on the abdomen place this species close to clypearis Saussure but the points of difference are many. The clypeus has weaker teeth and is less humped, the mandibular teeth are more regular, the antennae are shorter and the hook in the male is minute, instead of prominent, there is no longitudinal interantennal carina, the interocellar tubercles are polished, there is no carina from the humeral angle to the tegula, the postscutellar carina is better developed, the tarsi are broader, the first abdominal segment is stouter.

This is the first species of the genus to be described from the western United States and makes the third species for the entire country.

Pseudomasaris zonalis albopictus, new subspecies

Structure and markings exactly as in zonalis Cresson (description in Bradley, J. C., 1922, Calif. Univ. Pub. Ent. 1:426-428) except that markings are whitish instead of yellow.

Holotype male, California Academy of Sciences, Ent. no. 6142, Jenny Lake, Grand Teton National Park, Wyoming, June 20, 1940 (G. E. Bohart). Paratypes, 3 males and 11 females from the following localities: Grand Teton National Park (E. C. Van Dyke, G. E. Bohart); Butte Pass Creek, Butte Co., Idaho (R. Bohart); Craters of the Moon, Idaho (R. Bohart); Giveout, Idaho; Wallowa Lake, Oregon (I. McCracken); Colfax, Washington (C. L. Fox). Collections were made in June and July.

The only other species with similar markings is marginalis Cresson which, however, has abundant erect black hair on tergite $I$ and in the male the middle femur and tibia are less abruptly swollen. Also in marginalis males the sixth antennal segment is less than 3 times its greatest breadth whereas in albopictus and the parent species it is nearly 4 times.

\section{Eumenes sculleni, new species}

Male.-Black and yellow. Yellow markings are: mandible partly, clypeus, interantennal mark reaching clypeus, scape in front, postocular line, humeral band, posterior pronotal angle, 2 mesopleural spots, lateral mesonotal spot in front of tegula, parategula, tegula partly, small scutellar spots, line across postscutellum, propodeal angle, legs partly including all of tibiae, large ovoid spots separated by less than their diameter at apical two-fifths of tergite $I$ and narrow apical margin, transverse band on tergite II before middle and connected laterally with broad apical band, latter greatly expanded toward middle where it is slightly notched in front, apical margins of tergites III to $\mathrm{V}$ and sternites II to VI, dot near apex of sternite I. Antennal apex reddish; wings lightly stained. Pubescence abundant, thick and fulvous. That of tergite I mostly 4 ocellus diameters long, that of II about 2 ocellus diameters, that on apical one-half of tergite II curved toward head contrary to that on basal one-half of tergite. Puncturation of head and thorax moderately close, that of clypens more coarse toward base. Abdominal tergites very 
finely and sparsely punctured, polished; puncturation at middle of tergite II minute; about the same as that at middle of II. Clypeus longer than broad, emargination a rounded $\mathrm{v}$; last antennal segment slender, flattened, and minutely pubescent beneath; first abdominal segment stout, about two-fifths as broad as long, second tergite subglobose, swelling abruptly and roundly from base. Length to apex of second tergite $12.0 \mathrm{~mm}$.

Female.-Markings and structure about as in male. Clypeus sometimes with a small median black mark, mandible mostly black, transverse band on tergite II sometimes narrowly broken (likewise in some male paratypes). Length to apex of second tergite about $12.5 \mathrm{~mm}$.

Holotype male, California Academy of Sciences, Ent. no. 6143, Charleston Mts., Clark Co., Nevada, 7500 feet, July 25, 1942 (H. A. Scullen). Paratypes, 5 males and 2 females, same data as type; 1 male, Charleston Mts, Nevada, 9000 feet, June 21, 1940 (R. M. Bohart). I have also seen a male specimen from Dry Canyon, Iron Co., Utah, August 3, 1919.

This species is very close to $E$. verticalis tricinctus Isely and might be a localized race of it. However, all of the type specimens differ clearly in the pubescence and more globular shape of the second tergite. The markings of sculleni are similar in the 2 sexes, whereas in tricinctus the female is usually much yellower. Also, the second tergite in sculleni is black basally although the yellow bands are broad. This gives it a broadly striped appearance rather than the more patchy or spotted aspect of tricinctus. Furthermore, the barely punctate condition of the tergites is not often found in tricinctus where at least tergite II has small distinct punctures.

\section{Eumenes crucifera flavitinctus, new subspecies}

Male.-Yellow with reddish markings and a small amount of black. Reddish are: antennal flagellum, tip of mandible, frons partly, occiput and vertex mostly, stains along thoracic sutures, posterior spot on pronotum, mesonotum except for triangular lateral spot, mesopleural spot, legs partly, especially on femora, first tergite largely, base of second and transverse spot across summit, basal marks on other tergites and sternites (seen when these are extended). Black are: spot around ocelli, basal one-fifth of first tergite. Wings lightly brown stained, reddish toward base. Pubescence golden, inconspicuous. Puncturation of head and thorax moderate and close. Tergite I well punctured but punctures separated by about 1 to 2 puncture diameters at middle of tergite. Those at middle of second tergite finer but closer, becoming farther apart toward sides and base of tergite. Length to apex of second tergite $11.0 \mathrm{~mm}$.

Female.-Markings about as in male. Mesonotum sometimes with a median anterior yellow line and small posterolateral spot. Reddish band across second tergite usually broken medially. Length to apex of second tergite about $12.0 \mathrm{~mm}$.

Holotype male, Cornell University, Lot 542, sub 327, Blythe, California, August 20, 1927. Paratypes, 1 male and 6 females from the following California localities: Blythe (J. MacSwain, C. M. Dammers); Coachella (E. C. Van Dyke); Laguna Dam, Imperial Co. (C. M. Dammers); Palm Springs. Collecting dates are May 25 to November 25.

This subspecies differs from all other known Eumenes of North Amer- 
ica by its predominantly yellow markings and great reduction of the black. It represents the extreme desert type of crucifera Prov. Occasional specimens of the typical subspecies from more northern points in California tend toward yellow and red but all of these that $I$ have seen have the thorax mostly black. The abdominal puncturation is finer than in typical crucifera and much finer than in subspecies bolliformis Viereck.

\section{Dolichodynerus vandykei, new species}

Male.-Black with the following yellow markings: inverted $\mathrm{w}$-shaped mark on upper half of clypeus, interantennal dot, scape in front, humeral margin, anterior spot on tegula, mesopleural spot, stripe across scutellum posteriorly, outer stripes on tibiae, membrane on propodeum below, bands on apical margins of tergites I to IV and sternites II and IV, exposed portions of sternites V to VII mostly. Brownish are: most of terminal 3 antennal segments, wing veins, leg joints and tarsi. Pubescence pale and inconspicuous. Punctures moderate on head and thorax, coarse and close on most of abdomen, sparse on humps of vertex, well-spaced on pronotum, well-spaced but distinct on tergite V. Emargination of clypeus shallow, sides not produced into sharp points; antennal hook small reaching base of $\mathrm{XI}$; head slightly longer than broad, swollen behind eyes and between ocelli so that vertex has 3 pairs of swellings, ocular emargination depressed about an ocellus diameter below eye level. Humeral margin carinate; mesonotum with a longitudinal median ridge; scutellum and postscutellum not raised, propodeum rough, continued on a level with postscutellum for about 5 ocellus diameters, then sharply nearly vertical. First abdominal segment longer both above and below than second, also longer than broad above; tergites III and IV with subbasal transverse ridges which prevent telescoping of their segments beneath II. Length to apex of second tergite $7.0 \mathrm{~mm}$.

Female.-Markings and structure much as in male. Clypeus and scape black, antenna reddish beneath toward apex, faint reddish postocular spots, tibiae black, sternites III and IV with lateral spots, V and VI black. Head swellings a little less prominent, covered with scattered punctures. Length to apex of second tergite about $9.5 \mathrm{~mm}$.

Holotype male, California Academy of Sciences, Ent. no. 6144, Maricopa Mts., Arizona, April 14, 1947 (H. and M. Townes). Paratypes, 7 males and 3 females from the following localities in Arizona: Maricopa Mts. (H. and M. Townes), Tempe, Santa Rita Mts. (W. Benedict), Nogales (E. C. Van Dyke), Santa Catalina Mts. (H. A. Scullen), 5 mi. N. Wickenburg (L. K. Gloyd). Collecting dates were in every month from April through August.

Structurally this species is very elose to turgiceps $\mathrm{R}$. Bohart, differing mainly in details of the clypeus. There appear to be several constant pattern differences, however. The following is a key to the 3 known species.

\section{KEY TO THE SPECIES OF DOLICHODYNERUS}

1. Tergites III and IV without a subbasal ridge; eye emarginations level with eyes; markings black, orange-red and yellow

Tergites III and IV with a subbasal ridge which prevents their 
telescoping under II; eye emarginations sharply depressed be-

neath eye level; markings essentially black and yellow.

2. Clypeal emargination ending in spiniform teeth; puncturation at apical middle of tergite $\mathrm{V}$ indistinct; tergite $\mathrm{I}$ with a large subbasal crescentic yellow spot; male with clypeus edged in black and interantennal spot linear. turgiceps R. Bohart

Clypeal emargination not ending in spiniform teeth; puncturation at apical middle of tergite $\mathrm{V}$ distinct; tergite $\mathrm{I}$ black except for apical band; male clypeus with apical two-thirds black, basal one-third yellow; male interantennal spot dot-like

vandykei R. Bohart

\section{Symmorphus projectus, new species}

Male.-Black with yellow markings as follows: mandible mostly, elypeus, scape in front, interantennal and postocular spots, spot on humeral angle, tegular and mesopleural spots, 2 spots on scutellum, legs partly, apical margins of tergites I, II, IV and sternite II (all except that on tergite $I$ incomplete). Apices of antenna and tarsi reddish brown; wings brown-tinted. Pubescence obscure. Clypeus and tergites II to VII finely punctured. Head about as broad as long in front view, clypeus weakly incised, interantennal carina absent or very faint, humeral angle sharply projecting, last antennal segment more than three-quarters as long as XII, postcarinal area of tergite I half as long as its apical breadth. Length to apex of second tergite $6.0 \mathrm{~mm}$.

Female.-Markings and structure about as in male except as follows: antenna black, elypeus with a basal yellow spot, tergite IV black. Head swollen between eyes, vertex pits subequal in circumference to posterior ocelli. Length to apex of second tergite $7.5 \mathrm{~mm}$.

Holotype male, Calif. Acad. Sci. Ent. no. 6145, Fallen Leaf Lake, Eldorado Co., Calif., July 1931 (O. H. Swezy). Paratypes, 40 males and 39 females from the following California localities: Mineral King, Gold Lake, Berkeley, Davis, Fallen Leaf Lake, Tokopah Valley, Quincy, Tahoe, Angora Peak, San Bernardino Mts., Sequoia National Park, Coffee Creek, S. Sonoma Co., Snowline Camp, Carl Inn, Danville, Fort Seward, Alta, Santa Cruz Mts., Mendocino Co., Ventura Co., Calaveras Co., Martinez, Mt. Diablo, West Los Angeles, and Santa Monica. Also, 17 males and 13 females from Oak Creek Canyon and Workman Creek, Arizona; Wallowa National Forest, Klamath Lake, and Forest Grove, Oregon. Other specimens have been studied from Washington, British Columbia, Idaho, Wyoming and Montana. As indicated by the paratype localities, the species is widespread in California, occurring from sea lerel to over 10,000 ft. in the Sierras.

There is considerable rariation in markings (some specimens have complete yellow bands on several abdominal segments) and degree of prominence of the humeral angles. The suppression of the interantennal carina, the large last antennal segment in the male, and the short broad first tergite differentiate it from other known species. 
82 Proceedings of the Biological Society of Washington 
84 Proceedings of the Biological Society of Washington 


\title{
PROCEEDINGS
}

\author{
OF THE
}

EGIIAN IISTITUBIOLOCICAL SOCIETY OF WASHINGTON

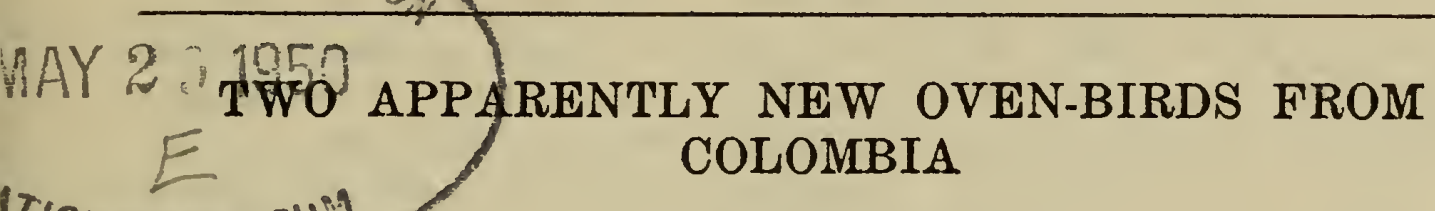

By W. E. Clyde TOdD

In working over the Furnariidae or Oven-birds in the collection of the Carnegie Museum not long since I came across two specimens, one of an Asthenes and one of a Philydor, which proved to be not readily determinable. Since they required further investigation, they were omitted from the brief paper summarizing the results of my study of this group (Annals Carnegie Museum, 31, 1948, 33-43). One of these appears to represent a form new to science; the other, if now correctly identified, involves and necessitates the description of a new form from an outlying region. Although naturally reluctant to describe such new forms on the basis of single specimens, I propose to waive my reservations in these particular cases, in the hope that future investigations will confirm my findings.

I take advantage of this opportunity to correct the number of the typespecimen of my Sclerurus rufigularis furfurosus, wrongly cited in the paper (l.c.) as 83,826 . It should be 82,826 . Also, my Certhiaxis cinnamomea albescentior (p. 38) is undoubtedly the same as the Certhiaxis cinnamomea valenciana Zimmer and Phelps (Am. Mus. Nov. No. 1270, $1944,7)$, the description of which was inadvertently overlooked.

Asthenes wyatti sanctae-martae, subsp. nov.

Type, No. 45,261, Collection Carnegie Museum, adult male; Macotama, Sierra Nevada de Santa Marta, Colombia, April 6, 1914; M. A. Carriker, Jr.

Subspecific characters. - Similar to Asthenes wyatti wyatti (Sclater) of the Eastern Andes of Colombia and the Andes of Merida, but smaller, and upperparts not so coarsely streaked, the streaks inclining to brown rather than to black.

Measurements.-

C. M. No. 45261 ô Wing, 58 ; tail, 61 ; bill, 13

$\begin{array}{lllll}45270 & \hat{o} & 58 & 63 & 11.5\end{array}$

$\begin{array}{lllll}45282 & \text { के } & 59 & 66 & 12\end{array}$

$\begin{array}{lllll}45325 & \text { กิ } & 57 & 60 & 14\end{array}$

45366 oे $\quad 60 \quad 66 \quad 14$

$\begin{array}{lllll}45408 & \text { o } & 57 & 54 & 12.5\end{array}$

$\begin{array}{lllll}45411 & \text { oे } & 61 & 64 & 13.5\end{array}$

$\begin{array}{llll}\text { Average } & 58.5 & 62.5 & 13\end{array}$

17-Proa. Biol. Soc. Wash., Vor. 63, 1950 
Range.-Paramo Zone, Sierra Nevada de Santa Marta, northern Colombia.

Remarks.-Some years ago Messrs. Phelps and Gilliard (Am. Mus. Nov. No. $1153,1941,8)$ discriminated a supposed new race of this species, Asthenes wyatti mucuchiesi, from the Andes of Merida. Their comparisons were made with our Santa Marta series of (supposed) wyatti, which (presumably on Chapman's authority-Am. Mus. Nov. No. $18,1921,4)$ were considered "essentially identical" with the type of the species from the Paramo de Pamplona in the Eastern Andes of Colombia. Hellmayr had called attention to certain divergencies between the two, but these were dismissed (I think rightly) as due to individual variations. Now it is the exception, in the case of alticoline species, to find a given form common to the Eastern Andes and the Sierra Nevada of Colombia, but represented by a different form in the Andes of Merida (cf. Todd and Carriker, Ann. Carnegie Mus., 14, 1922, 88). The only exception I now recall is in the case of Cinclodes fuscus (cf. Ann. Carnegie Mus., 31, 1948, 34). Judging by analogy, one would sooner expect to find the birds of the Eastern Andes and of the Andes of Merida (respectively) the same and that of the Sierra Nevada different.

Accordingly, I sent our single specimen (a male in good condition) from Teta de Niquitao, Venezuela, and which had been handled by Phelps and Gilliard in connection with their own, to the British Museum (Natural History) for comparison with the type-specimen of wyatti. The report, made for the Curator of Birds, says, "Your specimen of Asthenes agrees in appearance and measurements with our type of Asthenes wyatti wyatti (Synallaxis wyatti Sclater and Salvin, P.Z.S., ' 1870 ,' p. 840,1871 ). Any slight differences can, I think, be attributed to individual variation." Our specimen measures: wing, 64; tail, 74; bill, 16. In the original description of mucuchiesi the measurements average a little smaller.

In the original description of wyatti the measurements of the wing and tail, converted into millimeters, are 50.8 and 71.1. (The type is a male.) I am unable to reconcile the figure for the wing-length with the positive statement that our specimen "agrees in appearance and measurements" with the type. The Santa Marta male having the shortest wing in our series has this member $57 \mathrm{~mm}$. long. Feeling as I did that the original wing-measurement, as given (and repeated) by Sclater was untrustworthy, I wrote again to Mr. J. D. McDonald of the Bird Section of the British Museum, asking him to make new measurements of the type, using the same methods as I had done in making my own. He now reports that these measurements are as follows: wing, $63 \mathrm{~mm}$.; tail, 71 ; exposed culmen, 15 .

The upshot of all this discussion is to suggest that the population of the Andes of Merida is in fact identical with that of the Eastern Andes, and that it is the Sierra Nevada bird which deserves to be named. However, I am unable to verify most of the color-differences claimed to exist between the Merida and the Sierra Nevada bird, insofar as my material goes. The size-difference is the best character.

Philydor fulvescens, sp. nov.

Type, No. 59,009, Collection Carnegie Museum, adult male; El Tambor, Santander, Colombia, December 9, 1916; M. A. Carriker, Jr. 
Description.-Pileum medal bronze; hindneck and sides of the neck (bohind the auriculars) Sudan brown, forming an ill-defined halfcollar); back bright Dresden brown, passing into Sudan brown on the ramp and upper tail-coverts; wings hair brown, the primary-coverts darker (chætura drab), the greater coverts more or less edged and tipped with the color of the back; tail uniform auburn; superciliaries buff; postorbital line and (indefinite) subauricular line dull Sudan brown, the auricular area buffy-tinged; throat colonial buff, becoming duller on the rest of the underparts, the sides of the breast shaded with chamois-color; under wing-coverts chamois-color; remiges below margined with pale buffy; "iris brown; bill black above, flesh-color below; feet yellowish olive." Wing, 91 ; tail, 72 ; bill, 19 ; tarsus, 18.5.

Range.-Known only from the type-locality, in the Rio Lebrija region of Colombia.

Remarles.-The above specimen was submitted to Dr. John T. Zimmer of the American Museum of Natural History for examination. He reported as follows: "I have examined the specimen of Philydor which you sent with a great deal of interest. I agree with you that it appears to be intermediate between subfulvus and erythronotus, but it does not exactly match anything that we have in the collection. Possibly it represents an undescribed race.

"I see no reason why the type of erythronotus could not have been a Bogotá skin. Additional material apparently was found in Remedios in the Antioquia region, and certainly some of the Bogota skins may easily have been collected in the Antioquia area.... There is no certainty that the examples from the west which have been identified as erythronotus are exactly like the types. Nevertheless, the description of erythronotus indicates a bird with considerably more rufescent coloration on the underparts than is shown by your specimen, and I doubt if your bird represents true erythronotus."

Our specimen was later compared with the type of Philydor erythronotus (Sclater and Salvin) in the British Museum, with the following result: "Your specimen of Philydor does not agree with our type of $\boldsymbol{P}$. erythronotus.

"The upper parts of the type are chestnut rufous, and not olivaceous brown as in your bird.

"The underparts of the type are again rufous and not olive brown. In other words, imagine your specimen with its olivaceous brown replaced by chestnut rufous and you get a picture of the colour of the type. There is however a certain amount of basic brown in the crown.

"The tail feathers are identical in colour, as are the primary and secondary wing feathers, although the inner secondaries of the type are all slightly tipped with rufous."

For the time being, and provisionally, I am describing this form as a full species, pending final determination of its affinities. It hails from a point so relatively close to the Antioquian region as to suggest that such a ranking would not be improbable. 
88 Proceedings of the Biological Society of Washington 


\section{PROCEEDINGS}

\section{ESUNAA IWSTIT OF THE \\ MAY B BOLOCICAL SOCIETY OF WASHINGTON \\ A NEW CRAY NISH OF THE GENUS CAMBARELLUS

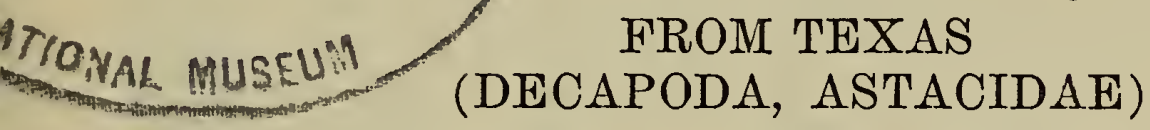

HoRTON H. HoBBS, JR. ${ }^{1}$

For many years the genus Cambarellus in the United States has been almost totally neglected, and subsequent to 1884, except for the repetition of "Louisiana" locality records and two new state records ${ }^{2}$ for Cambarellus shufeldtii (Faxon $1884: 134)$, practically nothing appeared in the literature until 1942. Penn (1942:644-647) published notes on the biology of C. shufeldtii, and in commenting on its range in Louisiana stated that it "has been found only east of the Mississippi and Atchafalaya Rivers." Hobbs and Marchand (1943:18) added three Tennessee records, all of which were in the vicinity of Reelfoot Lake, Obion County. In 1942 I described Cambarellus schmitti (Hobbs 1942:149), which extended the known range of the genus from Louisiana eastward to Alachua Co., Florida. In 1945 two additional species were described: C. diminutus (Hobbs 1945:467) from Liberty Co., Texas, and C. puer (Hobbs 1945:469) from Mobile Co., Alabama.

Prior to the discovery of schmitti, puer and diminutus, it was generally considered that the genus Cambarellus was principally a Mexican one and largely confined to the Mexican Plateau. With the discovery of the aforementioned species it became evident that the genus was much more widely dispersed than was originally supposed. Actual locality records are still few, and these are widely scattered, thus indicating that additional collecting is badly needed from the Mexican Plateau eastward to Florida and in the interior in Texas, southern Oklahoma, Arkansas, Mississippi, Louisiana, Alabama, and perhaps Georgia.

My first specimens of the species described below were sent to me by Mr. Joel W. Hedgpeth from the Aransas Refuge, Aransas County, Texas. Later Mr. Robert P. Allen kindly made several additional collections. I wish to express my appreciation to both of them for sending me the specimens on which the following description is based.

\section{Cambarellus ninae, sp. nov. ${ }^{3}$}

Diagnosis.-Areola broad, never more than three times as long as wide, with five or six punctations in narrowest part; first form male with hooks on second and third pereiopods strong and recurved, those on

${ }^{1}$ Miller School of Biology, University of Virginia.

IIlinois (Faxon 1914:371) and Mississippi (Lyle 1938:76).

3I name this species in honor of my daughter, Nina Thompson Hobbs. 
third bituberculate; palm of chela smooth; postorbital ridges terminating cephalad in spines; lateral surface of carapace devoid of spines. First pleopod of first form male extending to coxopodite of third pereiopod and terminating in three distinct parts all of which are bent caudad at angles less than, equal to, or greater than a right angle, and central projection exceeding the other terminal elements in length. First pleopod of second form male with terminal elements directed at about a 45-50 degree angle to the main shaft of the appendage and with the central projection markedly longer than either of the other terminal elements. Annulus ventralis semiovate with sinus only slightly to the left (or to the right) of middle.

Holotypic Male, Form I.-Body in cross section subovate, compressed laterally. Width of abdomen less than that of carapace. Width of carapace in region of caudodorsal margin of cervical groove slightly less than depth. Greatest width of carapace caudad to caudodorsal margin of cervical groove.

Areola about three times as long as wide and approximately $33.7 \%$ of entire length of carapace; five or six punctations in narrowest part.

Rostrum broad at base with margins converging to base of acumen; lateral spines acute and setting off an acute acumen which reaches almost to distal end of penultimate segment of peduncle of antennule. Surface of rostrum with setiferous punctations. Postorbital ridges terminate cephalad in small acute tubercles. Subrostral ridges visible in dorsal aspect along most of length of rostrum.

Surface of carapace punctate. No spine present on lateral surface. Suborbital angle acute and prominent. Branchiostegal spine absent.

Abdomen longer than thorax. Cephalic section of telson with two spines in the left and one in the right caudolateral corner.

Epistome as seen in fig. 2.

Antennules of the usual form. A moderate spine present on the ventromesial margin of basal segment.

Antennae extending caudad to telson. Antennal scale broad; broadest portion near midlength; spine on outer margin moderately strong, extending cephalad to middle of distal segment of peduncle of antennule.

First pereiopod with propus subovate, long, slightly inflated, with setiferous punctations. Opposable margins of both fingers with minute denticles and hairs. Neither finger bearing ridges.

Carpus longer than broad with setiferous punctations. A single large acute tubercle present on lower distolateral margin.

Upper surface of merus with a small tubercle on distal third and an additional one on distolateral margin, otherwise with setiferous punctations.

Ischiopodites of second and third pereiopods with hooks; both hooks strongly recurved and that on third bituberculate.

Coxopodite of fourth pereiopod with a conspicuous ventrally projecting prominence; that of fifth pereiopod with a much smaller, more com. pressed one.

First pleopod reaching coxopodite of third pereiopod. Tip terminating in three distinct parts. Mesial process slender, non-corneous, and directed caudad with the tip decidedly recurved. Cephalic process absent. Central projection corneous, longer than the other two terminals, directed caudad, and lying subparallel to the mesial process. Caudal process, 
the slenderest of the three terminals, arises from the caudolateral margin, is non-corneous, more acute than mesial process, and while directed subparallel to the other two terminals does not extend so far caudad.

Allotypic Female.-The allotypic female differs from the holotype in only a few minor points; however, in addition to the usual dimorphic condition of the chelae of the two sexes, in the allotype they are distinctly more setose; both fingers with submedian longitudinal ridge above; opposable margin of immovable finger with a single tubercle and two on opposable margin of dactyl (see fig. 12); spine on upper distal surface of merus strong. Annulus ventralis movable; compressed in the longitudinal axis of the body, subtriangular in caudal aspect with the sinuate sinus to the right of the apex of the triangle. Sternal plate immediately eaudad to annulus acute.

Morphotypic Male, Form II.-Differs only slightly from the holotype: chela more setiform than those in holotype; hooks on ischiopodites of second and third pereiopods much reduced. The three terminal elements of first pleopod all present; however, none is corneous; central projection markedly larger and longer than either of the other terminals.

Measurements. - In millimeters.

\begin{tabular}{|c|c|c|c|c|}
\hline \multirow{2}{*}{\multicolumn{5}{|c|}{ Carapace - }} \\
\hline & & & & \\
\hline & height & 4.4 & 5.9 & 4.0 \\
\hline & width & 4.1 & 5.7 & 4.3 \\
\hline & length & 8.3 & 11.9 & 7.9 \\
\hline \multicolumn{5}{|l|}{ Areola - } \\
\hline & length & 2.8 & 3.8 & 2.6 \\
\hline & width & 1.1 & 1.6 & 0.9 \\
\hline \multicolumn{5}{|l|}{ Rostrum - } \\
\hline & length & 2.0 & 3.5 & 2.1 \\
\hline & width & 1.4 & 1.9 & 1.1 \\
\hline \multicolumn{5}{|c|}{ Right Chela - } \\
\hline & $\begin{array}{l}\text { length, inner margin } \\
\text { of palm }\end{array}$ & 2.4 & 3.3 & 2.5 \\
\hline & width of palm & 1.6 & 2.2 & 1.7 \\
\hline & $\begin{array}{l}\text { length, outer margin } \\
\text { of hand }\end{array}$ & 5.6 & 6.4 & 5.8 \\
\hline & length of dactyl & 2.8 & 3.3 & 2.7 \\
\hline
\end{tabular}

Type Locality.-Borrow ditches in the Aransas Refuge (along East Shore Road), Aransas Co., Texas.

Disposition of Types.-The holotypic first form male, the morphotypic male, form II, and the allotypic female are deposited in the United States National Museum, Nos. 89768, 89769, and 89770. From the paratypic series, one male, form I, one male, form II, and a female are deposited in the Museum of Comparative Zoology, and similar series are at the University of Michigan Museum of Zoology and in the collection of George H. Penn, Jr. at Tulane University (No. 1351). Five first form males, seven second form males, and eleven females are retained in my personal collection at the University of Virginia.

Specimens Examined.-The following specimens were collected in the Aransas Refuge, Aransas County, Texas by Messrs. Joel W. Hedgpeth and Robert P. Allen: April 24, 1946-1 $\hat{o}$ I, 1 ô II, I + (J.W.H.); 


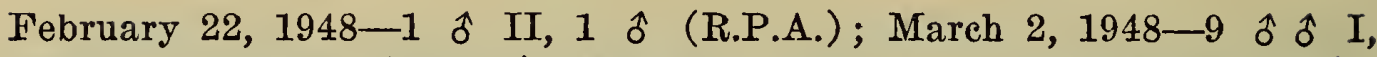
11 ô $\hat{o}$ II, 15 ㅇ ㅇ (R.P.A.); March 2, 1948-1 우 with eggs (R.P.A.); March 30, 1948-1 ô II, 1 o with eggs (R.P.A.); March 30, 1948-

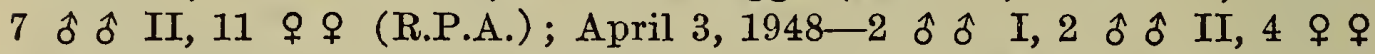
2 ô $\hat{o}$ imm., 3 우 + imm. (R.P.A.) ; January 8, 1949-1 수 I, 4 우 우 (R.P.A.).

Relationships.-With little doubt this species has its closest affinities with Cambarellus puer Hobbs, and may prove to be a subspecies of the latter. Since there is some indication that there may be intergradation between puer and schmitti, until a thorough study of this complex is made it seems advisable to accord all three of these specific status. Dr. George H. Penn, Jr. is now engaged in conducting a survey of this genus in the United States.

Variations.-The most significant variations are illustrated in the figures; however, there are marked differences in the development of the postorbital ridges-in some specimens they terminate cephalad in long spines which extend cephalad to the cephalolateral margins of carapace. Recently molted specimens are distinctly more setose.

Key to the species of the genus Cambarellus occurring in the United States (Based on the First Form Male)

1 Terminal elements of first pleopod straight

C. shufeldtii (Faxon 1884: 134)

$1^{\prime}$ Terminal elements of first pleopod directed caudad or caudodistad

$2\left(1^{\prime}\right)$ Central projection of first pleopod extending farther caudad than other terminal elements C. ninae (supra)

$2^{\prime} \quad$ Central projection of first pleopod never extending farther caudad than other terminals.

$3\left(2^{\prime}\right)$ Lateral spines on carapace small or absent. Areola five to six times longer than broad. Mesial process of first pleopod bent at approximately an $80^{\circ}$ angle to the main shaft of the appendage

C. puer (Hobbs 1945: 469)

3' Lateral spines present on sides of carapace. Areola two to four times longer than broad. Mesial process of first pleopod of first form male bent at less than an $80^{\circ}$ angle to the main shaft of the appendage

$4\left(3^{\prime}\right)$ First form male with bituberculate hooks on ischiopodites of second and third pereiopods; caudal process of first pleopod subspiculiform; central projection scythe-like. Areola about three times as long as broad C. schmitti Hobbs (1942: 149)

$4^{\prime} \quad$ First form male with bituberculate hooks on ischiopodites of third pereiopods only, those on second simple; caudal process of first pleopod acute but definitely not spiculiform; central projection subtriangular. Areola about twice as long as broad. Annulus ventralis subequal in breadth and depth C. diminutus Hobbs (1945: 467) 


\section{Literature Cited}

FaxoN, WaLter 1884. Descriptions of new species of Cambarus; to which is added a synonymical list of the known species of Cambarus and Astacus. Proc. Amer. Acad. Arts and Sci., 20: 107-158.

1914. Notes on the crayfishes in the United States National Museum and the Museum of Comparative Zoology with descriptions of new species and subspecies to which is appended a catalogue of the known species and subspecies. Mem. Mus. Comp. Zool., Harvard Coll., 40 (8) : 347-427, 11 pls.

HosBs, Horton H., JR. 1942. The erayfishes of Florida. Univ. of Florida Pub., Biol. Sci. Series, 3 (2): 1-179, 3 text figs., 11 maps, 24 pls.

1945. Two new species of erayfishes of the genus Cambarellus from the Gulf Coastal States, with a key to the species of the genus (Decapoda, Astacidae). Amer. Midl. Nat., 34 (2): 466-474, 26 figs.

AND L. J. MARCHAND 1943. A contribution toward a knowledge of the crayfishes of the Reelfoot Lake Area. Journ. Tenn. Acad. Sci., 18 (1): 6-35, 3 pls., 1 map.

Lyle, Clay 1938. The crawfishes of Mississippi, with special reference to the biology and control of destructive species. (Abstract) Iowa St. Coll. Journ. Sci., 13 (1): 75-77.

PENN, GEorge H., JR. 1942. Observations on the biology of the dwarf crawfish, Cambarellus shufeldtii (Faxon). Amer. Midl. Nat., 28 (3): 644-647, 1 fig., 1 table.

\section{Explanation of Plate VIII}

Cambarellus ninae

Fig. 1. Mesial view of first pleopod of holotype.

Fig. 2. Epistome.

Fig. 3. Lateral view of first pleopod of holotype.

Fig. 4. Mesial view of first pleopod of paratypic male, form II.

Fig. 5. Annulus ventralis of allotype.

Fig. 6. Lateral view of first pleopod of paratypic male, form II.

Fig. 7. Mesial view of first pleopod of male, form II.

Fig. 8. Mesial view of first pleopod of male, form $I$.

Fig. 9. Lateral view of carapace.

Fig. 10. Lateral view of first pleopod of male, form I.

Fig. 11. Lateral view of first pleopod of male, form II.

Fig. 12. Upper view of chela of allotype.

Fig. 13. Dorsal view of earapace.

Fig. 14. Ischiopodite of second pereiopod of male, form $I$.

Fig. 15. Ischiopodite of third pereiopod of male, form I.

Fig. 16. Antennal scale.

Fig. 17. Upper view of chela of holotype. 


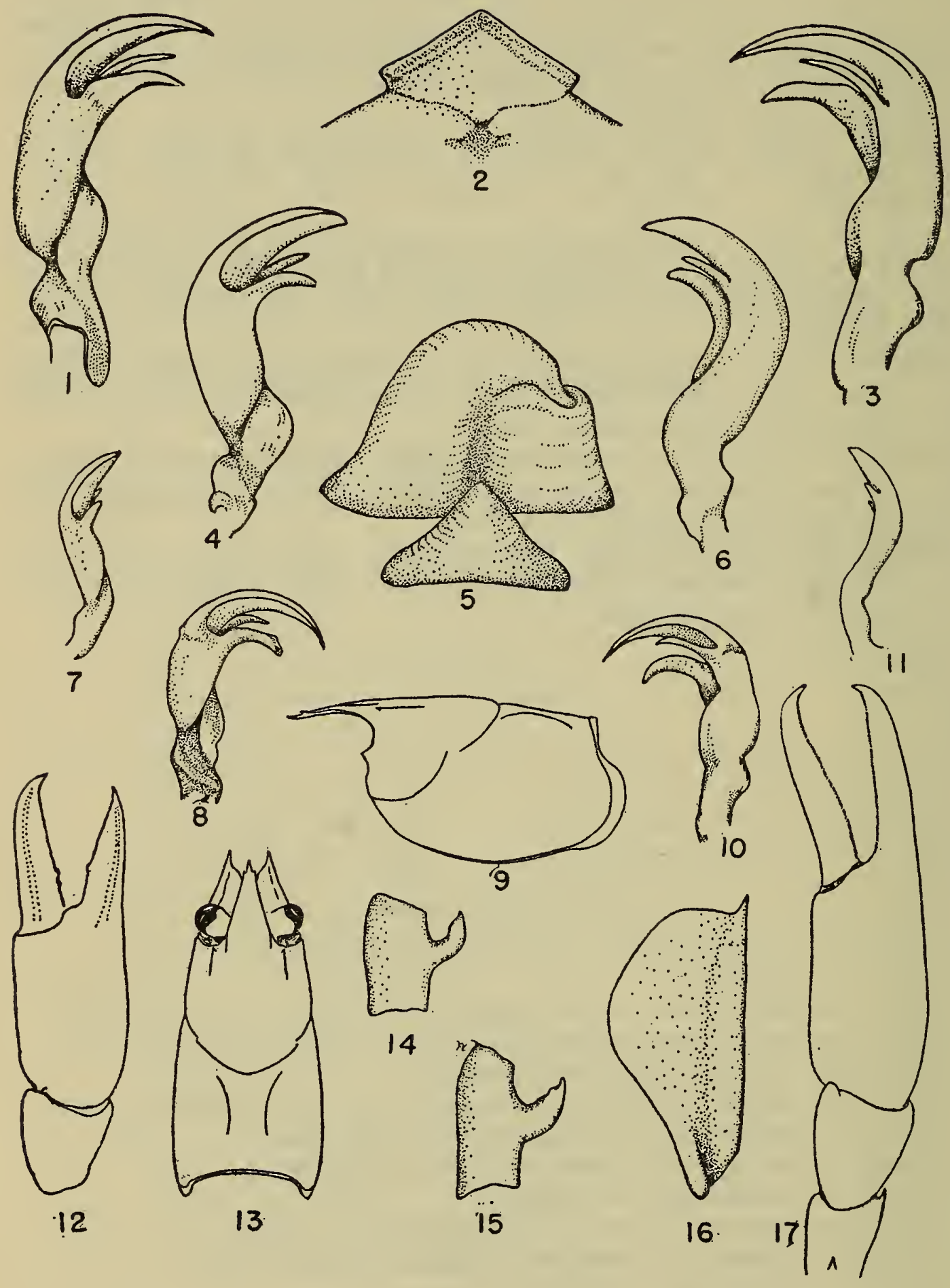


96 Proceedings of the Biological Society of Washington 


\section{OF THE}

PROCEEDINCS

MAY 21950 BIOLOGICAL SOCIETY OF WASHINGTON

NEW SPECIES OF APHIDIDAE

F. C. HотTES

The new species described herewith were collected near Skyway, Colorado, a locality which has proved rather fruitful from the standpoint of new forms. The new names proposed are made necessary either because of mistaken identification or because of rules of nomenclature.

Amphorophora kesocqua, new species

Apterous viviparous female.

Size and general color.-Length from vertex to tip of anal plate 2.78 $\mathrm{mm}$. Width of head through the eyes $.47 \mathrm{~mm}$. Length of hind tibiae $2.17 \mathrm{~mm}$. Head thorax and abdomen bluish-green. First and second antennal segments pale dusky, the second segment with some green. Antennal segments III, IV, and V pale dusky with apical portions brown. Antennal segment VI brown with apical portion lighter. Femora green with basal portion quite pale. Tibiae pale dusky green with apical portions brown. Tarsi brown. Basal half of cornicles pale green remaining portion pale dusky with region just anterior to flange darkest. Cauda pale dusky setulose surface brown.

Head thorax and appendages.-Antennal tubercles well developed, with the inner margins of the tubercles free from hair. Hair lacking on anterior margin of head. Third antennal segment with four small non tuberculate sensoria arranged in a straight row. Third antennal segment smooth, hair sparce dull at the tip but not knobbed. All hair on antennae shorter than width of segment, some hair less than one half the width of the segment in length. Segments IV, V, and VI imbricated. On IV and $\mathrm{V}$ the imbrications are far apart. Comparative length of antennal segments as follows: III .815 mm., IV .50 mm., V .386 mm., VI .171 + .443 $\mathrm{mm}$. The rostrum reaches beyond the mesothoracic coxae but fails to reach those of the metathorax. The prothorax is provided with a pair of poorly developed lateral tubercles. The hair on the hind tibiae is shorter than the width of the tibiae, none of the hairs are knobbed and some are much longer than others. The hair on the inner surface of the tibiae is much more abundant than that on the outer side; this is especially true of the hair near the apex.

The abdomen.- There are no lateral tubercles on the abdomen. The hair on the abdomen is sparse very short and fine in quality. The cornicles are $.715 \mathrm{~mm}$. long. The cornicles are very moderately swollen beyond the middle and the entire surface is weakly imbricated. The flange at the apex of the cornicles is well developed. The cauda is .328 $\mathrm{mm}$. long. The cauda has a very pronounced setulose surface, it is somewhat constricted at its point of origin with the abdomen but not otherwise, it is much flattened and very broad throughout, with the apex dull. 
The anal plate is very broad and shallow, its surface is conspicuously steulose, it is very peculiar and distinguished by the almost total lack of long hair on its surface and margins.

This species described from a single specimen, although three or four others were observed in nature, is unique in a number of respects. The lack of hair on the inner margins of the antennal tubercles and from the anterior margin of the vertex, the conspicuously short terminal process, the few long hair on the anal plate and the shape of the cauda, serve to separate at once from Amphorophora rubi Kalt. and the green form of Amphorophora tigwatensa Hottes.

Holotype deposited in the United States National Museum. Host Rubus sp. Skyway, Colorado, July 21, 1949.

\section{Amphorophora agathonica, new species}

Alate viviparous female.

Size and general color.-Average length from vertex to tip of anal plate $2.91 \mathrm{~mm}$. range in length from 2.29-3.58 $\mathrm{mm}$. Width of head through the eyes $.50-.54 \mathrm{~mm}$. Head light dusky brown with darker brown along margins of antennal tubercles, margin median to the eyes and laterally. First and second antennal segments concolorous with head with median margins darker, remaining segments of antennae with the exception of the extreme base of the third, which is light in color dark brown to dusky black. Rostrum dusky with terminal segments brown. Prothorax light dusky with more or less green remainder of thorax dusky green with thoracic lobes darkest. Abdomen green. Cornicles pale greenish at the base shading to dusky at the beginning of the swollen area, remainder of cornicle dusky with the constricted portion just before the flange darkest. Anal plate more or less dusky brown underlayed with green. Cauda light dusky due to setulose surface, underlayed with green. Tibiae greenish dusky near base shading to dusky brown at apex. Tarsi dark brown. Veins of wings dusky very lightly bordered.

Head and appendages.-Antennal tubercles very well developed. Antennal segments with the following comparative lengths: III 1.15-1.36 ave. $1.21 \mathrm{~mm}$., IV $.79-1.07$ ave. $.99 \mathrm{~mm}$., V .71-.92 ave. $.81 \mathrm{~mm}$., VI .15$.17+1.11-1.43$ ave. $1.29 \mathrm{~mm}$. Secondary sensoria limited to the third antennal segment. The sensoria vary in size, have wide rims, are slightly tuberculate are irregularly arranged and extend throughout the length of the segment. In number the sensoria vary from 53-72 and average 57, however 54 is the more common number. Hair on the third antennal segment is sparse somewhat variable in length but always shorter than one half the width of the segment. The longer hair is slightly knobbed at the apex. Antennal segments four five and six are slightly imbricated. The rostrum just fails to reach the coxae of the mesothoracic pair of legs.

Thorax and appendages.-The prothorax is provided with a pair of small lateral tubercles. These as a rule are very difficult to determine. Second branch of media variable in position in reference to first, most often eloser to margin of wing than to first branch.

The hind tibiae vary in length from $3.00-3.21 \mathrm{~mm}$. The hair on the hind tibiae is subequal to the width of the tibiae in length, it is sharp pointed, rather sparse and coarse on the basal half, much finer more abundant and very much inclined near the apex. 
Abdomen.-There appear to be no lateral tubercles on the abdomen. The cornicles vary in length from .78-1.14 and average $.92 \mathrm{~mm}$. In about half the specimens the cornicles are longer than the fourth antennal segment, of the remainder nost have the cornicles subequal to segment IV but a few specimens have segment IV very much longer than the cornicles. The cornicles are distinctly not smooth, but the imbrications are very fine and for the most part difficult to determine. The cornicles are evenly and moderately swollen distal to middle. Near the apex, in the region of the flange there is just an indication of more pronounced imbrications. The cauda varies in length from $.35-.46 \mathrm{~mm}$. As a rule it is $.40 \mathrm{~mm}$. or more in length. It is coarsely setulose and carries from four to six lateral hair, the apical hair being strongly incurved. The dorsal surface of the cauda as a rule carries from two to three hair. The sides of the cauda are straight, or one side of the cauda is slightly indented. The anal plate is normal.

Apterous viviparous female.

Size and general color.-Length from vertex to tip of anal plate 3.435.21 average length $4.10 \mathrm{~mm}$. Head thorax and abdomen of a uniform pale green, or with the head slightly lighter in color with a trace of light dusky at the nlargins and extending outwards on antennal segments one and two. Width of head across eyes $.57-.60 \mathrm{~mm}$. Antennal segments I and II pale dusky, III and IV pale dusky brown except for the base of III which is concolorous with II, segments V and VI dark dusky. Femora pale green with apical halves light dusky. Tibiae dusky with apical region much darker. Tarsi concolorous with tibiae. Cornicles and cauda similar to those of alate viriparous female.

Head and appendages.-Antennal segments with the following proportional lengths: III 1.28-1.40 ave. length $1.32 \mathrm{~mm}$., IV .88-1.14 are. 1.00 mm., V .71-.91 ave. $.83 \mathrm{~mm}$., VI .14-.18 most common length $.17 \mathrm{~mm}$. + 1.14-1.43 are. $1.28 \mathrm{~mm}$. The secondary sensoria are confined to the third antennal segnent, they are irregularly arranged and cover about three sides of the basal half of the segment. The sensoria are irregular in size, have wide rims and are only slightly tuberculate. The sensoria vary in number from 22; in only one case to 36 and average 32 . The antennal tubercles are very well developed and carry four hair on the inner margins. The anterior margin of the head is provided with two hair which are shorter than those on the antennal tubercles. The rostrum extends to or slightly beyond the mesothoracic pair of legs.

Thorax and appendages.-The prothorax is provided with a pair of poorly developed lateral tubercles. These are always difficult to determine. The hind tibiae are from $3.28-3.93 \mathrm{~mm}$. in length and average 3.76 $\mathrm{mm}$.

Abdomen.-The cornicles vary in length from 1.00-1.20 and average $1.09 \mathrm{~mm}$. The most common length of the cornicles is 1.07 ; they are almost without exception longer than the fourth antennal segment. The average length of the cauda is $.55 \mathrm{~mm}$. and the range in length is from $.50-.64 \mathrm{~mm}$. The sides of the cauda are for the most part straight but a slight indentation may occur in the region of the end of the anal plate. Five to six curved hair are located on the lateral surface of the cauda; these are shorter than the width of the cauda. The anal plate is normal in shape, it has a setulose surface and its margin is provided with long hair. 
This species is perhaps most closely allied to Amphorophora rubi (Kaltenbach) from which it differs in the following respects: The dark color of the cornicles or at least the dark apical halves of them, the cornicles not being smooth but very feebly imbricated, the larger number of secondary sensoria on antennal segment III, the difference being large in the case of the apterous viviparous females. Alate specimens of this species can not be keyed to rubi in Mason's key, either because the cornicles are longer than antennal segment IV or because the sensoria number more than 50. Apterous females can not be keyed to rubi in Mason's key, either because of the color of the cornicles or because the sensoria number more than 30. From Amphorophora tigwatensa $\mathrm{H}$. this species differs in the lighter color of the cornicles, the less well developed imbrications on the cornicles, the larger cauda and more numerous secondary sensoria. This species was collected on the young and tender stems and on the under sides of the leaves of Rubus sp. (Wild red raspberry). It is a pleasure to acknowledge the assistance of Dr. Lambers who confirmed my opinion that the species is not the Amphorophora rubi of Kaltenbach or one of the European varieties of that species.

Holotype alate viviparous female Skyway, Colorado Aug. 6, 1933.

Morphotype apterous viviparous female Skyway, Colorado July 21, 1949.

Holotype and Morphotype together with slides seen by Dr. Lambers deposited in United States National Museum. Paratypes and paramorphotypes taken at Skyway, Colorado during the summers of 1947, 48 and 49.

\section{Macrosiphum cockerelli, new species}

On pages 47-51 of the 1949 volume of the Proceedings of the Biological Society of Washington I described all forms of a species which I had determined as Macrosiphum rudbeckiarum (Cockerell). Prof. Palmer has suggested that I give the species thus described a new name because of the larger number of sensoria on the third antennal segment of the alate viviparous female. I do this in deference to her suggestion and call the species Macrosiphum cockerelli after Prof. T. D. A. Cockerell who in the early years of our century showed an interest in the family Aphididae. Holotype alate viviparous female Skyway, Colorado July, 1936 taken on Rudbeckia montana. Deposited in the United States National Museum.

Capitophorus patonkus H.\&F. var. coloradensis, new variety

Capitophorus patonkus H.\&F. is recorded from Colorado for the first time. Along with the typical forms there was taken during the summer of 1949 a form identical morphologically to the form described, this form however was a pale chocolate-brown covered over with a very light pulverulence suggesting a hoar frost, and the variety name coloradensis is suggested for it. Holotype and morphotype mounted on the same slide, with the following data: Skyway, Colorado July 1, 1949. Host Achillea millefolium. Deposited in the United States National Museum.

\section{Aphis tonahasa, new name}

Aphis ribis Sanborn, a homonym of a species described by Linnaeus has apparently not been redescribed under another name, or renamed. Being a homonym of a well known species a new name is in order and Aphis tonahasa is suggested. 


\section{PROCEEDINCS}

\section{SGIVIAN INSTIT OF THE}

IISULOCICAL SOCIETY OF WASHINCTON MAY $\overline{201950}$ ATIOANAR E

NEW BIRDS FROM NEPAL AND THE INDIAN REGION

By S. Dillon Ripley

During 1947 and again in 1948-49 I was privileged to be able to collect birds and mammals in Nepal as a guest of the Government of that Country and with the special permission of the Ruling Prime Ministers, their Highnesses Maharajah Sir Padma Shamsher Jang Bahadur Rana, who resigned in 1948, and his successor, Maharajah Sir Mohun Shamsher Jang Bahadur Rana. The first trip was sponsored by the Smithsonian Institution and Yale University, the second by the National Georgraphic Society, Yale and the Smithsonian. The following new forms are described as a preliminary report on the collections of birds made in Nepal. A comprehensive report on the birds encountered will be published at a later date in the Journal of the Bombay Natural History Society. I should like to express my gratitude at this time to the authorities of the three Societies and Institutions which supported this field work, and also my very warm thanks to the Prime Ministers of Nepal and their Government for permission to work in areas hitherto closed to all foreigners.

Hemiprocne longipennis dryas, subsp. nov.

Type:- $\hat{o}$ ad. (U.S.N.M. No. 389369), collected March 25, 1946, by Salim Ali at Juna, Rajpipla, south Gujerat.

Diagnosis:-from coronata this race differs by being conspicuously paler gray above and paler on the lower throat and abdomen. In the male the chestnut patch on the sides of the face and chin is paler than in birds from the rest of India, Ceylon and eastwards to Siam.

In size, the two specimens available of this race measure: wing $\hat{\delta} 148$, o 154 ; tail $\hat{o} 110$, +121 . A series from eastern and southern India measure: wing $\hat{o} \hat{o}$ and 우 $q$ 146.5-160.

Range:- -southern Gujerat, possibly into the Dangs.

Remarks:- this species is uncommon in the western less well-wooded parts of India and has not been recorded from Rajputana or from west of Indore. I am most grateful to the authorities of the U. S. National Museum for allowing me to utilize this material, and to Mr. H. G. Deignan for attracting my attention to this form.

Megalaima zeylanica rana, subsp. nov.

Type:- $\hat{o}$ ad. (U.S.N.M. No. 408263), collected January 2, 1949, by S. Dillon Ripley at Bajora, Dailekh District, western Nepal. 


\section{Proceedings of the Biological Society of Washington}

Diagnosis:-from hodgsoni this race differs by being larger and darker, more brownish, particularly on the breast. The type and one other male measure:

Bajora, 2 ô $\hat{o}$

Nepal, Sikkim, Assam

19 ô $\hat{o}$ and $q$ ? wing

$140.5,141$

120-137 (129.9) tail

$87,87.5$

$78-83.5$ culmen

34,37

$30-36(33.2)$

Range:-Terai and foothills of extreme western Nepal.

Remarks:-as the type locality of Megalaima hodgsoni Bonaparte (Consp. Gen. Avium, I, 1850, p. 144), is simply Nepal, I hereby restrict it to Simra in the Terai of central Nepal which is on the route from India to Katmandu, and which consequently forms a likely spot for the original type to have been collected. This new subspecies as well as hodgsoni belongs to the lineata subgroup within the species zeylanica, a subgroup characterized by having the space between the eye and bill feathered.

In the Terai less than twenty miles to the south of Bajora which is in the "duns," the inner valley behind the first range of hills, we found caniceps occurring, a race of the zeylanica subgroup of the species, a subgroup in which the skin between the eye and bill is bare. Formerly of course these forms were listed as separate species on this character alone, but $I$ believe combining them into one species is justifiable as the forms replace each other and are presumably interfertile.

Like so many Himalayan species, the populations tend to move down and reside at lower altitudes from west to east. In the western Himalayas $M$. zeylanica caniceps is found. I cannot recognize the size race Kangrae Whistler which belongs to the naked-faced zeylanica subgroup according to Mr. Usher of the British Museum staff who has kindly examined the type for me. This form extends as far east in the hills as Kumaon. It may breed up to 4,000 feet and descends from there uniformly to the Plains. East of Kumaon it is found only in the Terai, gradually straggling southwards, so that finally in the eastern Nepal Terai it occurs only on the southern border of the Country, more properly in Bihar Province of India. The race rana of the lineatus subgroup then replaces caniceps in the western Nepal foothills. Then ranging farther east, hodgsoni descends finally from the foothills of central Nepal and is found in the Terai areas of eastern Nepal, Sikkim and Assam.

It gives me great pleasure to dedicate this new subspecies to the Rana family, the family of the Prime Ministers of Nepal, who have made and shaped the destiny of that Country for over one hundred years.

\section{Dinopium shorii anguste, subsp nov.}

Type.- $\hat{o}$ ad. (U. S. Nat. Mus. Coll. No. 377546), collected March 12, 1945 by K. E. Stager six miles north of Myitkina, N. Burma.

Diagnosis.-from shorii from the United Provinces, Nepal and Sikkim, this race differs in the male by the considerable reduction of the scarlet wash found over the golden back. In Burma specimens this reddish wash is confined to the lower back and rump. In the female this race differs by much smaller narrower white shafts on the crown and nape. While difficult to measure, in Burma females this white streak is not much over 1 millimeter in width, while in Indian examples it is in the 
neighborhood of $2 \mathrm{~mm}$. In these rather narrowish lanceolate feathers which tend to be about $31 / 2 \mathrm{~mm}$. wide, such a difference is at once clearly apparent. There is no difference in size between these populations.

Range.-Burma from the Chin, Kachin Hills and Arakan Hills south to Thayetmyo. I have not examined northern Assam specimens. Presumably those west of the Brahmaputra fit in with shorii. If this species occurs in the Mishmi and Patkoi Hills it is probably the Burma form.

Mulleripicus pulverulentus mohun, subsp. nov.

Type.- $\hat{o}$ ad. (U. S. Nat. Mus. Coll. No. 408175), collected December 24, 1948 by S. Dillon Ripley at Jamu Ghat on the Bheri River, western Nepal.

Diagnosis.-from harteri of Assam, Burma, Siam and Indochina, this subspecies differs by darker grey coloration both above and particularly on the lower parts. Also the malar stripe is duller and deeper, more vermilion than scarlet. There is no difference in size.

Range.-The Terai and the foothills from the United Provinces through Nepal to Assam. Birds from North Cachar in Assam are harterti. No specimens have been examined from north and west of the Brahmaputra.

Remarks.-This magnificent Woodpecker is rare in collections from India and Nepal. The National Geographic Society-Yale UniversitySmithsonian Institution Expedition found it only in the heavily forested "'duns," the valleys behind the first range of hills spreading north from the Terai. In western Nepal the forest in this region was primary and untouched, composed of tremendous "sal" trees (Shorea robusta) for the most part.

It gives me great pleasure to name this subspecies in honor of the Prime Minister-Ruler of Nepal who did so much to make our Expedition a success, His Highness Maharajah Mohun Shamsher Jang Bahadur Rana, G.C.I.E., G.B.E.

Garrulax striatus vibex, subsp. nov.

Type:- o ad. (U.S.N.M. No. 391175), collected April 29, 1947, by S. Dillon Ripley at Godavari, Central Valley, Nepal.

Diagnosis:-from striatus this race differs by smaller size and generally darker more olive-tinted upper surface and flanks. The dark edging to the median white streak, particularly on the back feathers, is darker than the similar streak in striatus. From sikkimensis, this race differs by being distinctly lighter, less red-brown, particularly on the back and lower parts, the dark edging to the median streaks noticeably darker.

Measurements:-Central Nepal birds measure: wing 138-150.5, tail 130.5-138, culmen 25.5-27, west Himalayan striatus measures: wing 153165, tail 139-148, culmen 26.5-28, while Sikkim and east Nepal sikkimensis measures: wing 140-146, tail 129-137, culmen 26-27.

Remarks:- Sharpe (Cat. Bds. Brit. Mus. 7, 1883, p. 451) quotes Scully as saying that the Nepal specimens of this species are darker than examples from the Himalayas further to the west. Ticehurst (B.B.C.C. 44, 1924, p. 104) in describing sikkimensis from Sikkim notes that Nepal birds are intermediate between his race and striata from the Punjab and U. P. Himalayas. The collection of specimens from east Nepal which 


\section{Proceedings of the Biological Society of Washington}

can be placed with sikkimensis, and yet are distinctly darker than birds from the central valley, prompts me to describe this new race which unhappily does not fit into the adjacent populations to the west or east. feet.

Range:-central and western Nepal in the hills from 3,500 to 9,000

Garrulax rufogularis grosvenori, subsp. nov.

Type:- $\hat{o}$ ad. (U.S.N.M. No. 408533), collected December 28, 1948, by S. Dillon Ripley at Rekcha, Dailekh District, western Nepal.

Diagnosis:-from rufogularis of Sikkim and central Nepal, this race differs by having narrower, less prominent terminal bars on the upper surface, and by being much lighter, less rufous in color. The ear coverts are rusty and only bordered with black and white. On the lower surface the black and white moustachial streaks are more prominent, while the terminal spots on the breast and abdomen are reduced.

From occidentalis of the western Himalayas this race differs by being somewhat more olivaceous on the upper surface with larger terminal spots both above and below. In the type and one other specimen of occidentalis examined, the black mixed with whitish feathers of the moustachial area come close together at the base of the throat in the form of a shield separating the chestnut and white of the throat from the pale grayish of the upper breast. In grosvenori, the moustachial streaks are only streaks, although they are more prominent than in rufogularis. Occidentalis is probably slightly larger than grosvenori. The two specimens examined have wing measurements of 93 and 96 , tail 107, culmen 22.5, in contrast to grosvenori which measures: wing 84-94, tail 99-106, culmen 20-22.5.

Range:-hills of western Nepal.

Remarks:- the type locality of rufogularis Gould is listed by Baker (Fauna British India: Birds, I, 1922, p. 158.) as Sikkim. I hereby fix the type of Cinclosoma rufimenta Hodgson (Asiatic Researches, 19, 1836, p. 148) as Katmandu, as in this paper (1.c. p. 145) he mentions that these species occur in the Minister's garden there. Birds from the Central Valley appear to agree with Sikkim rufogularis, so that rufimenta is a synonym of that form.

The type of this striking Laughing Thrush is illustrated on p. 40 of the National Geographic Magazine (vol. 97, Jan., 1950), and it gives me great pleasure to name it in honor of Dr. Gilbert Grosvenor, President of the National Geographic Society, whose personal interest was so largely responsible for making possible the recent National Geographic Society-Yale University-Smithsonian Institution Expedition to Nepal.

Actinodura nipalensis vinctura, subsp. nov.

Type:- - ad. (U.S.N.M. No. 408570), collected February 1, 1949 by S. Dillon Ripley at Mangalbaré, Dhankuta District, east Nepal.

Diagnosis:-from nipalensis Hodgson (which I hereby restrict to slopes of Katmandu Valley, central Nepal) this race differs by having a deeper black band on the terminal upper surface of the tail, and noticeably heavier black barring on wings and tail. On the central rectrices of vinctura the terminal band measures from $28.32 \mathrm{~mm}$., while in birds from the central valley the black band is absent or reduced to a narrow shading extending to about $15 \mathrm{~mm}$. in depth. The black band 
on wings and tail measures 2 or more millimeters in width, while in nipalensis these bands are of the order of 1 millimeter or less.

From daflaensis, waldeni and poliotis this race differs in having the chin, throat and breast unstreaked as does nipalensis.

Range:- -eastern Nepal, probably east of the Arun Kosi River, Sikkim and Bhutan.

Phylloscopus subaffinis arcanus, subsp. nov.

Type:- $q$ ad. (U.S.N.M. No. 408868), collected January 7, 1949, by S. Dillon Ripley at Tikapur, Kailali District, western Nepal.

Diagnosis:-from subaffinis (Ogilvie-Grant) this race may be distinguished by having the upper parts more olive, less olive-brown, by having the supercilium and the center of the underparts more straw yellow, not mustard or amber yellow, and by having the flanks wax yellow, approaching clay color, rather than fulvous. In all respects this is a paler, more washed-out bird than true subaffinis. In addition arcanus differs from the typical form in having a longer bill, and, apparently, a longer tail, actually and proportionally.

Measurements:- Sixteen specimens of subaffinis from Szechuan, Hupeh and northern Thailand when compared with three females of arcanus taken in Nepal, measure as follows:

\section{wing}

subaffinis $\hat{\delta} \hat{\delta}$ and 우 우 arcanus 우 우
48.5-55 $43.5-50$

$52-55 \quad 51.5-54$

$$
\begin{array}{lc}
\begin{array}{c}
\text { tail-wing } \\
\text { index }
\end{array} & \text { bill } \\
80-96 \% & 9-11 \quad \text { (ave. } 9.2) \\
93-103 \% & 12-13 \mathrm{~mm} .
\end{array}
$$

Range:-My three wintering specimens were secured at Tikapur in January and on Naggerjung, a hill in the Central Valley of Katmandu in April, 1947. As a wintering bird this extends the previously known range of the species seven hundred fifty miles to the west from Myitkina district in north Burma, the westernmost locality for subaffinis, fide Ticehurst (A Systematic Review of the Genus Phylloscopus, London 1938, p. 76). The breeding range of arcanus is a mystery. The species was not encountered in South-eastern Tibet by Ludlow (Ibis, 1944, p. 197-198). In the same author's article on the Birds of Lhasa (Ibis, 1950, p. 39), he mentions a very dark Willow Warbler as passing through the city in the autumn. This is a possibility, if arcanus should prove to be a breeding bird in northern Sikang or western Kansu.

Remarks:-The discovery of a race of Phylloscopus subaffinis wintering in Nepal further complicates the arrangement of this species which is so close to $P$. affinis, the more western breeding species. It becomes more than ever interesting to attempt to solve the breding biology of these two species which apparently meet on the same ground, but may be ecologically separated, in northern Yunnan and southwestern Szechuan. Unfortunately this area, which is such a biological "heartland" seems to continue to be inaccessible to all but non-regimented winter and breeding migrants.

I am most grateful to Mr. H. G. Deignan for his cordial cooperation and assistance in the discovery and diagnosis of this new form, and for the loan of material from the National Museum. 
Phylloscopus maculipennis centralis, subsp. nov.

Type:- o ad. (U.S.N.M. No. 408864), collected December 28, 1948 by S. Dillon Ripley at Rekcha, Dailekh District, western Nepal.

Diagnosis:-from maculipennis Blyth (restricted as to type locality by me to Ilam District, eastern Nepal) this form differs by being lighter, more yellowish-olive on the upper parts and the crown a lighter shade of iron-gray, and paler yellow below. From virens Ticehurst of the Punjab Himalayas, this race differs by being darker, more olive on the back, less yellowish-olive, and by being darker, more fuscous on the erown.

Range:-western and central Nepal. Specimens have been examined from Dailekh District and the central valley of Katmandu.

Certhia himalayana infima, subsp. nov.

Type.-ô ad. (U.S.N.M. No. 408480), collected January 6, 1949, by S. Dillon Ripley at Tikapur, Kailali District, western Nepal.

Diagnosis:-from himalayana this race differs by being conspicuously darker, more blackish on the upper surface. This race has sharply defined narrow streaks of buffy white on the head, nape and upper back, more distinct and in greater contrast to the background color than in the nominate form. The rufous color on the tips of the feathers of the lower back is stronger and darker than in himalayana. On the tail also the barring is more blackish as well as stronger and more distinct. There is no size difference.

Range:-western Nepal in the Karnali River drainage. Winters in the adjacent Terai.

Remarks:-as with other eastern populations of west Himalayan species, this form apparently descends lower than its western relatives. Stuart Baker (Fauna Brit. India: Birds, $I, 1922$, p. 430), speaks of this species in the Simla area as descending to 4,000 feet in winter and breeding at 10,000 feet. In western Nepal this form was encountered wintering in the Terai at less than 1,000 feet altitude.

Kinnear (Ibis, 1937, p. 251) states that himalayana is not found in Nepal. Actually it is of course a western Himalayan species, and if the two specimens listed from Nepal in the Hodgson collection (Cat. Birds Brit. Mus. VIII, 1883, p. 328) are in fact an error, then these specimens constitute the first record for this species in Nepal. 
Ripley-New Birds from Nepal and the India Region 107 
108 Proceedings of the Biological Society of Washington 
PROCEEDINCS

OF THE

BIOLOGICAL SOCIETY OF WASHINGTON

\section{A NEW RACE OF MELANERPES CHRYSOGENYS FROM CENTRAL MÉXICO ${ }^{1}$ \\ By ROBERT T. MOORE}

For several years I have had reason to believe that an undescribed race of Melanerpes chrysogenys existed in Morelos and Michoacán, but waited for an adequate representation of fresh specimens of the nominate race from Sinaloa, and of flavinuchus from Guerrero, to make a satisfactory comparison. We now have 118 specimens of this species, which confirm the validity of the new form. It is herewith described:

\section{Melanerpes chrysogenys morelensis, subsp. nov.}

Type.-Adult male, number 44,726, collection of Robert T. Moore; collected three miles south of Cuernavaca, Morelos, México, altitude 4,700 feet, on October 30,1946 , by Chester C. Lamb.

Subspecific Cháracters.-Nearest to Centurus chrysogenys flavinuchus Ridgway, of Acapulco, Guerrero, but differs in both males and females in having (1) much less yellow about nostrils, malar stripe and chin (in most specimens reduced to a mere trace); (2) much less yellow on abdomen; (3) grayer (less brownish) underparts. Differs from $M$. c. chrysogenys (Vigors), which ranges from southern Sinaloa to the San Blas region of Nayarit, in all of these characters, except that the differences are more marked; in addition, as in flavinuchus, the nape is bright orange-yellow, strongly contrasted with the red of the occiput and crown, instead of bright chrome suffused with orange and not contrasted with the color of crown and occiput.

Range.-Apparently confined to the Aztec and Tarascan faunal districts of the Transverse Volcanic Biotic Province of central México; extending from Cuernavaca of north-central Morelos and Tehuixtla of southwestern Morelos west through Tafetán of central-east Michoacán to Apatzingán of west-central Michoacán.

Remarks.-Our large series from Guerrero makes it possible to delimit more accurately the range of flavinuchus. It extends at least from Atoyac de Alvárez (forty miles northwest of Acapulco) through Acapulco along the coast to Cuajinicuilapa on the boundary of Guerrero with Oaxaca; thence to Putla in western Oaxaca and Iguala in northeastern Guerrero; thence west to Ajuchitán in north-central Guerrero; thence west and northwest at least as far as Lajuela, Colima. I have not examined specimens from Iguala, Guerrero, reported by Ridgway to be flavinuchus.

In extreme northern Guerrero, along the Río Balsas, there is an area of intergradation between flavinuchus and the new race, Birgatiof 
Zirándaro, on the boundary with Michoacán, are browner on the underparts, like flavinuchus, but in all other respects are nearer to morelensis. The birds of Ajuchitán, whence we have nine specimens, are distinctly browner on the underparts, but otherwise are like the birds from Zirándaro. Probably they are nearer to morelensis, as the depth of the brown tone on the underparts may be due to moulting in June and July. True chrysogenys extends at least as far south as Chacala on the southwestern coast of Nayarit.

Specimens examined.-M. c. morelensis: MORELOS: three miles south of Cuernavaca, $1 \hat{\delta}$; Tehuixtla, $5 \hat{o} \hat{\delta}, 1$ 울 Lago de Tequesquitengo, 1 ô. MICHOACAN : five miles northeast of Apatzingán, $3 \hat{o} \hat{o}, 4$ 우 우; Tafetán, $2 \hat{\delta} \hat{\delta}, 2$ 우 우; El Rancho Portrero de Los Indios, $1 \hat{\delta}$. GUERRERO: Zirándaro, on the Río Balesas boundary with Michoacán, $4 \hat{\delta} \hat{\delta}, 2$ 우 $ᄋ$ (breeding). Intergrades (morelensis $X$ flavinuchus) in GUERRERO: Ajuchitán, $6 \hat{o} \hat{o}, 3$ 우 9 .

M. C. flavinuchus: GUERRERO: Cuajinicuilapa, $6 \hat{o}$ ô. 4 오 우; seven miles south of Mexcala, $2 \hat{\delta} \hat{\delta}, 6$ 우 욱 Atoyac de Alvárez, $3 \hat{\delta} \hat{o}, 3$ 우 ㅇ․ COLIMA: Lajuela, $2 \hat{\delta} \hat{\delta}, 4$ 우.

M. c. chrysogenys: SINALOA: Rosario, $5 \hat{o} \hat{o}, 5$ 우 우 Rancho El Fielo, 1 ô; Río Las Camas, 1 ô; Sierra Palos Dulces, $2 \hat{o} \hat{o}, 1 \hat{q}$ (breeding, May 13); San Ignacio, $2 \hat{o} \hat{o}, 1$ 우; Quelite, $2 \hat{o} \hat{o}$; Cacalotán, 1 우 ; Rancho Picacho, $2 \hat{o} \hat{\delta}, 1$, 2 juvs.; 2 miles east of Matatán, 3 우 우 (breeding, April 22); Rancho Santa Barbara, 3 우 우. NAYARIT: San Blas, $2 \hat{o} \hat{o}, 3$ 우 ; Sauta, $4 \hat{o} \hat{o}, 4$ 우 (breeding); Rancho Moloti, 1 ô, 1 우; Chacala, 3 우 .

${ }^{1}$ Contribution from the Moore Laboratory of Zoology, Occidental College, Eagle Rock, California. 


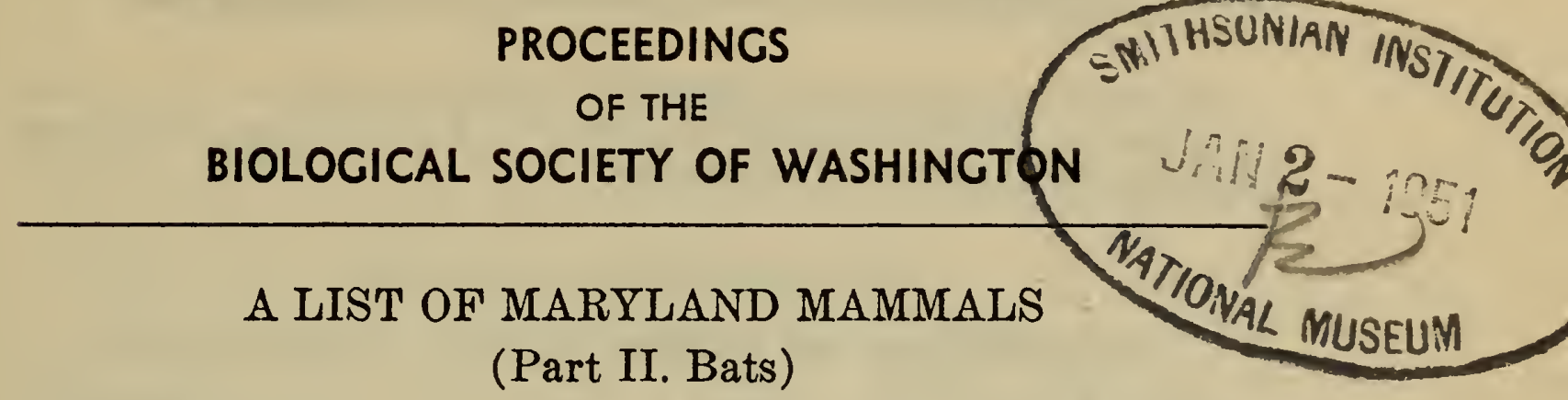

By Marshall C. Gardner, U. S. Fish and Wildlife Service Order CHIROPTERA Family VESPERTILIONIDAE Genus MYOTIS Kaup

Myotis lucifugus lucifugus (Le Conte). Little Brown Bat. 1831. Vespertilio lucifugus Le Conte, McMurtrie's Cuvier, Animal Kingdom, I, Append., p. 431.

Type locality.-Georgia; probably near Riceboro, Liberty County. Maryland records.-BALTIMORE COUNTY: Patapsco State Park (Hampe, 1939: 5). CECIL COUNTY: Seneca Point. MONTGOMERY COUNTY: Plummer Island. DISTRICT OF COLUMBIA.

Myotis keenii septentrionalis (Trouessart). Eastern Long-eared Brown Bat.

1897. Vespertilio gryphus var. septentrionalis Trouessart, Catal. Mamm. viv. foss., p. 131.

Type locality.-Halifax, Nova Scotia.

Maryland records.-BALTIMORE COUNTY: Baltimore, Bare Hills. MONTGOMERY COUNTY: Cabin John Bridge, Forest Glen (Bailey, 1923: 137), Plummer Island. PRINCE GEORGES COUNTY: Muirkirk. DISTRICT OF COLUMBIA.

Myotis sodalis Miller and Allen. Indiana Bat.

1928. Myotis sodalis Miller and Allen, Bull. U. S. Nat. Mus. no. 144, p. 130.

Type locality.-Wyandotte Cave, Crawford County, Indiana.

Maryland records.-Not recorded, but may occur in the western part of the State.

Myotis subulatus leibii (Aubudon and Bachman). Least Brown Bat.

1842. Vespertilio leibii Audubon and Bachman, Journ. Acad. Nat. Sci. Philadelphia, ser. 1, 8: 284.

Type locality.-Erie County, Ohio.

Maryland records.-MONTGOMERY COUNTY: Plummer Island.

\section{GENUS LASIONYCTERIS PETERS}

Lasionycteris noctivagans (Le Conte). Silver-haired Bat.

1831. $V$ [espertilio], noctivagans Le Conte, McMurtrie's Cuvier, Animal Kingdom, 1: 431 .

Type locality.-Eastern United States. 
Maryland records.-MONTGOMERY COUNTY: Great Falls, Plummer Island. PRINCE GEORGES COUNTY: Laurel, Paturent Research Refuge. DISTRICT OF COLUMBIA.

\section{GENUS PIPISTRELLOS KAUP}

Pipistrellus subflavus subflavus (F. Cuvier). Georgian Bat.

1832. V [espertilio], subflavus F. Cuvier, Nouv. ann. mus. hist. nat. Paris, 1: 17.

Type locality.-Eastern United States, probably Georgia.

Maryland records.-BALTIMORE COUNTY: Bare Hills (Bures, 1948: 65), Orange Grove (Hampe, 1939: 5). CHARLES COUNTY: Marshall Hall. MONTGOMERY COUNTY: Glen Echo, Great Falls, Plummer Island. PRINCE GEORGES COUNTY: Hyattsville, Laurel, Patuxent Research Refuge. SAINT MARYS COUNTY: St. George Island. WASHINGTON COUNTY: Keedysville (Muma, 1939: 30). DISTRICT OF COLUMBIA.

Pipistrellus subflavus obscurus Miller. Dusky Georgian Bat.

1897. Pipistrellus subfavus obscurus Miller, North Amer. Fauna, No. 13, p. 93.

Type locality.-Lake George, Warren County, New York.

Maryland records.-MONTGOMERY COUNTY: Capitol View, Plummer Island, near (Bailey, 1923 : 136). PRINCE GEORGES COUNTY: Hyattsville.

\section{GENUS EPTESICUS RAFINESQUE}

Eptesicus fuscus fuscus (Beauvois). Big Brown Bat.

1796. Vespertilio fuscus Beauvois, Catal. Raisonné Mus. Peale, Philadelphia, p. 18. (P. 14 of English edition by Peale and Beauvois.)

Type locality.-Philadelphia, Pennsylvania.

Maryland records.-ANNE ARUNDEL COUNTY: Jessup (Silver, 1928: 149). BALTIMORE COUNTY: Baltimore, Bare Hills (Cohen, 1942: 96), Patapsco State Park (Hampe, 1939: 5). MONTGOMERY COUNTY: Kensington, Plummer Island, Silver Spring, Takoma Park. PRINCE GEORGES COUNTY: Laurel, Patuxent Research Refuge. DISTRICT OF COLUMBIA.

\section{GENUS LASIURUS GRAY}

Iasiurus borealis borealis (Müller). Red Bat.

1776. Vespertilio borealis Müller, Natursyst. Suppl., p. 21.

Type locality.-New York.

Maryland records.-ANNE ARUNDEL COUNTY: Annapolis. BALTIMORE COUNTY: Baltimore, Patapsco State Park (Hampe, 1939: 5). MONTGOMERY COUNTY: Capitol View, Forest Glen, Glen Echo, Plummer Island. PRINCE GEORGES COUNTY: College Park, Laurel, Patuxent Research Refuge. WASHINGTON COUNTY: Hagerstown, Sandy Hook. 
Lasiurus cinereus (Beauvois). Hoary Bat.

1796. Vespertilio cinereus (misspelled linereus) Beauvois, Catal. Raisonné Mus. Peale, Philadelphia, p. 18. (P. 15 of English edition by Peale and Beaurois.)

Type locality.-Philadelphia, Pennsylvania.

Maryland records.-BALTIMORE COUNTY: Baltimore (Merriam, 1887: 86). PRINCE GEORGES COUNTY: Laurel. DISTRICT OF COLUMBIA.

\section{GENUS NYCTICEIUS RAFINESQUE}

Nycticeius humeralis humeralis (Rafinesque). Evening Bat.

1818. Vespertilio humeralis Rafinesque, American Monthly Magazine, $3: 445$.

Type locality.-Kentucky.

Maryland records.-MONTGOMERY COUNTY: Linden, Plummer Island, Silver Spring. PRINCE GEORGES COUNTY: Glendale, Oxon Hill. DISTRICT OF COLUMBIA.

\section{GENUS CORYNORHINUS H. ALLEN}

Corynorhinus rafinesquii rafinesquii (Lesson). Rafinesque's Big-eared Bat.

1827. Plecotus rafinesquii Lesson, Man. de Mamm., p. 96.

Type locality.-Lower Ohio River Valley.

Maryland records. - Not recorded, but may occur in the western part of the State.

\section{LITERATURE CITED}

Bailey, $\mathrm{V}$.

1923. Mammals of the District of Columbia. Proc. Biol. Soc. Washington $36: 103-138$.

Bures, J. A.

1948. Mammals of a limited area in Maryland. Maryland Nat. 18

Cohen, E. (4) : 59-68, 4 pls., 3 figs.

1942. Myotis keenii septentrionalis (Trouessart) in Maryland. Jour. Mammal. 23: 96.

Hampe, I. E.

1939. Notes on the mammals of the Patapsco State Park. Bull.

Merriam, C. H. Nat. Hist. Soc. Maryland 10 (1): 4-7.

Mnma, M. H.

1887. Do any Canadian bats migrate Evidence in the affirmative. Trans. Roy. Soc. Canada. Sec. 4, pp. 85-87.

Silver, J.

1939. Notes on several Maryland caves. Maryland 16: 27-32.

1928. Pilot black snake feeding on the big brown bat. Jour. Mammal. $9: 149$. 
114 Proceedings of the Biological Society of Washington 


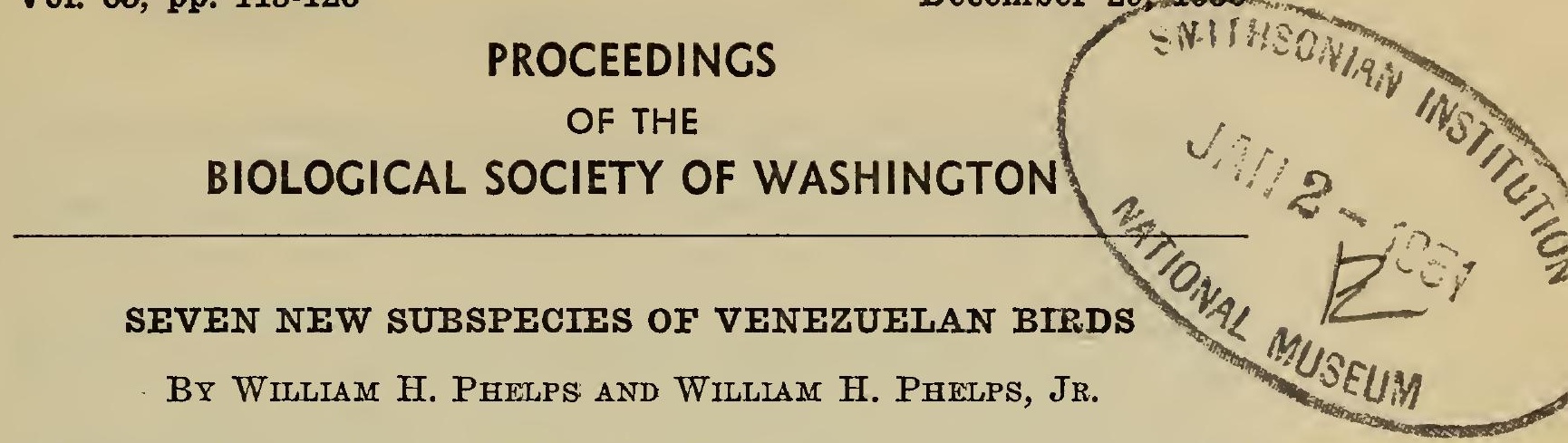

The authors wish to thank Mr. J. D. Macdonald, Curator of Birds in the British Museum, for his kindness in making pertinent measurements of specimens, and Mr. H. B. Usher, Keeper of Birds, for his aid in the examination of specimens in that Museum during the summer of 1950. Their thanks also go to Monsieur J. Berlioz, of the Paris Museum, for his help in several lines of research and for facilities given for study of the Simon Collection of Humming Birds, and to Monsieur C. Jouanin, Assistant Curator of Birds in the same institution, for his aid in the examination of specimens.

Study of the material in our collection has revealed these apparently new forms which we consider worthy of description. Specimens listed are in the Phelps, Collection, Caracas, unless otherwise specified.

Names of colors are capitalized when direct comparison has been made with Ridgway's "Color Standards and Color Nomenclature," 1912.

\section{Celeus elegans deltanus, new subspecies}

Type: From Jobure, Río Jobure, Territorio Delta Amacuro; sea level. No. 49,671, Phelps Collection, Caracas, Venezuela. Adult male collected February 22, 1950, by Ramón Urbano. (Type on deposit at the American Museum of Natural History.)

Diagnosis: Closest to $C$. e. hellmayri, from which it differs by having the top of head dark brown instead of light brown or cinnamon; from leotaudi it differs similarly and, besides, has a longer wing; from jumana, from Venezuelan localities, it differs in having a lighter erown, longer crest, a darker, more brownish, less reddish, body, and in having the rump, flanks, and under wing coverts paler, more whitish sulphur yellow, less ochraceous yellow.

Range: The Delta of the Orinoco River.

Description of Type: Top of head Chestnut, paler on crest; back Chestnut; uropygium Maize Yellow, upper tail coverts tipped or edged with brownish; sides of head Chestnut; wide malar streak Carmine. Chin and throat paler than Chestnut, merging into the Bay of breast, which merges into the Chestnut of abdomen and under tail coverts; flanks partly yellowish white with wide dusky bars; axillaries yellowish white. Primaries Fuscous; outer webs, except those of the external primaries, chestnut; inner webs barred basally with whitish and buffy chestnut; secondaries chestnut, barred on inner vanes basally with whitish buff and dusky; upper wing coverts chestnut, with indistinet dusky bands and very small inconspicuous buffy spots on shafts; bend

23-Proo. BIoL. Soo. WASH., Vou. 63, 1950 


\section{Proceedings of the Biological Society of Washington}

of wing brownish, dusky, and whitish; under wing coverts creamy white, primary ones with large dusky spots. Tail brownish black.

Bill (in life) "lemon yellow"; feet "grayish green"; iris "red". Wing, $161 \mathrm{~mm}$; tail, 106; exposed culmen, 28; culmen from base, 34 ; tarsus, 24.

Remarks: The sexes are similar in coloration, except that the female lacks the Carmine malar streak. Size similar to that of hellmayri. Range of measurements: five adult males from Jobure-wing, 156-165 (161.4) mm.; tail, 93-108 (101.8) ; culmen from base, 32-36 (34.6); five adult females from Jobure-wing, 152-162 (155) ; tail, 94-108 (100.4); culmen from base, 30-35 (32.8). Measurements of hellmayri: five males from British and Dutch Guiana-wing, 147-166 (158.6); tail, 89-105 (97.8); culmen from base, 31-34 (32.6); four adult females from British Guiana (1) and the State of Bolívar (3)-wing, 162-167 (164.5); tail, 94-100 (97.5); culmen from base, 32-34 (33).

Friedmann ${ }^{1}$, after studying 150 specimens of both $C$. elegans and $C$. jumana, comments on the possibility of their being conspecific, as follows: "These color variations are not peculiar to $C . j$. jumana but occur also in $C . j$. citreopygius and in the forms of $C$. elegans. With regard to the latter group, it seems best to continue to consider it as a specifically distinct entity with its markedly pale crest easily setting it off from the jumana group."

The discovery of this new subspecies from the Orinoco Delta, with the erest intermediate in color between $C$. elegans hellmayri and $C$. j. jumana, bridges the only apparent difference that up to now separated the two former "species". We have been unable to find specimens or records which might indicate that $C$. jumana and $C$. elegans occur together.

\section{Specimens Examined}

C. elegans approximans.-BRAZIL: Serra da Lua, 4 웅 Obidos, 1 $\hat{\delta}^{3}, 7^{4}$.

C. elegans elegans.-FRENCH GUIANA: Pied Saute $3,1 \hat{o}, 1$; Approuage, $2 \hat{o}^{3}$ Ipousin River, 1 क ${ }^{3}$; "Cayenne", 2 (?) ${ }^{3}$; "French Guiana", 114; Upper Cirucana, 14 .

C. elegans hellmayri.-DUTCH GUIANA ${ }^{3}$ : Paramaribo, $3 \hat{o}$; Interior of Surinam, $3 \hat{o}$. BRITISH GUIANA: Potaro River, $1 \hat{o} \mathbf{3}$; Tumatumari River, $1 \hat{o}^{3}$; Kamarang River, $1 \hat{o}^{3}$; “Demarara", 1 ô ${ }^{5}, 1$ (?) $)^{3}$;

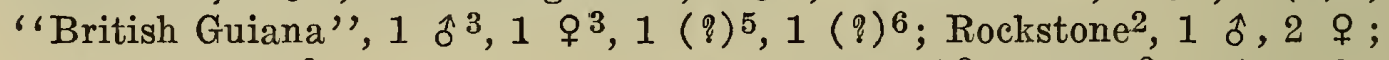
Mazaruni River2 ${ }^{2}, 1 \hat{\delta}, 2$; Demarara River, $1 \hat{o}{ }^{2}$; Mawra ${ }^{2}, 1 \hat{o}, 1$ 우 Oko Mts., 1 ô 2 ; Itabu Creek, 1 우 ${ }^{2}$. VENEZUELA: Río Alto Arabupú, 1 ô ; La Unión, 1 우 “Orinoco", 1 ô6; Río Yuruán, 1 ô 4 La Paragua, 1 우; Cerro Tomasote, 1 ô, 1 o ; Los Altos, 1 우; Bergantín, 1 ô; Cerro El Peonía, 1 우 ; Quebrada Bonita, 1 ㅇ ; Guanoco, 1 ô 3,1 우 Cristóbal Colón ${ }^{3}, 2$ ô, 2 우 ; Cerro Azul, 1 ô.

C. elegans deltanus.-VENEZUELA: Misión Araguaimujo, 1 ô, 1 ;

${ }^{1}$ Birds collected by the National Geographic Society's Expedition to Northern Brazil and Southern Venezuela. Proc. U. S. Nat. Mus., Vol. 97, 1948, p. 442.

2Specimens in Chicago Natural History Museum.

3Specimens in American Museum of Natural History.

${ }^{4}$ Specimens in Carnegie Museum.

${ }^{5}$ Specimens in Philadelphia Academy of Natural Sciences.

${ }^{6}$ Specimens in U. S. National Museum. 
Mision San Francisco de Guayo, $4 \hat{\jmath}, 4$ $\uparrow$; Jobure, $10 \hat{\jmath}$ (incl. type), 8 \% ; Río Guanipa, 1 \%5.

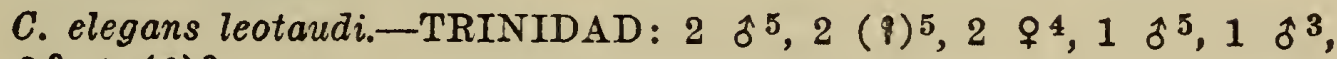
$5 q^{3}, 1(q)^{3}$.

C. elegans jumana.-BRAZIL: Igarapé-Assu, Paráa 1 ô, 3 \&; $12^{3}$ (diamantina, Rio Madeira, Santarem, Santa Isabel, Rio Preio, Pará, Teffe, Matto Grosso); Sao Gabriel ${ }^{6}, 1$ ô ; Maranhao, $1 q^{2}$; Santarem, $1 \hat{\delta}^{2}$; Aramassa I., 1 (q) ${ }^{2}$; Boca Rio Castanho, 1 ô, 1 q ; Utinga, 2 ô 3. COLOMBIA: Maipures ${ }^{3}, 1$ ô, 1 $\uparrow$; Macacuní, 1 $\uparrow$. VENEZUELA: Nacientes Río Siapa, 1 q; El Carmen, 2 ᄋ, 1 (१); Boca Sina ${ }^{3}, 2$, 1 ; Foot of Duida ${ }^{3}, 1$ ô; Sabana, Alto Río Asisa, 1 ô, 1 $q$; Cerro Yapacana, $1 \delta^{6}$; Puerto Yapacana, $2 \hat{\delta}, 3$, 2 ( 8 ); Las Carmelitas, 2 ô, 2 $\uparrow$; Pica Yavita-Pimichín, 1 $q$; San Fernando de Atabapo, 1 ô, 1 \% : Munduapo ${ }^{3}, 1$ $\delta, 2$ \%; Caño Cuao, 1 q; Sanariapo, $1 \hat{\delta}$; Caño Cataniapo, 3 ô, 6 o, 1 (q); Salto Pará, 1 ô, 1 q; El Cambur, 1 ô ;

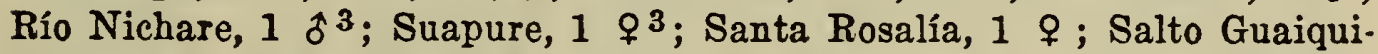
nima, 1 $\hat{\delta}$; Salto María Espuma, 1 ô; Salto Maisa, 2 q Salto Arebuchí, 1 $\hat{\sigma}, 2$ (q); Cerro Paurai-tepui, 1 ô ; Cerro Chimantá-tepui, 1 ( 8$)$; Cerro Auyan-tepui, 3 \$ 3,2 .

C. e. citreopygius ${ }^{3}$.-PERU: Boca Río Curaray, 1 s, 1 \&. ECUADOR: 1 ô, 1 \&; E. Ecuador, 6.

\section{Celeus undatus amacurensis, new subspecies}

Type: From Misión San Francisco de Guayo, Territorio Delta Amacuro; sea level. No. 48,035, Phelps Collection, Caracas, Venezuela. Adult male collected February 11, 1949, by Ramón Urbano. (Type on deposit at the American Museum of Natural History.)

Diagnosis: Nearest to C. u. undatus, from which it differs by darker, more brownish rufous, less yellowish, abdomen, under tail coverts and edges of breast feathers; back and upper tail coverts also darker.

Range: Delta of the Orinoco River. Known from Jobure and the type locality.

Description of Type: Top of head Orange Cinnamon, feathers of crest lightly barred with dusky; back Amber Brown, heavily barred with black; uropygium Sudan Brown prominently barred with blackish; sides of head uniform with crown, feathers of neck speckled with blackish; malar region Spectrum Red. Chin and throat Orange Cinnamon, speckled with blackish; breast blackish, feathers narrowly edged with Amber Brown, merging into the Amber Brown of abdomen and under tail coverts, both of which are heavily barred with blackish; axillaries cream color. Primaries Natal Brown, paler below, barred on inner vanes with a color near Ochraceous Salmon, more distally towards the outer ones; outer vanes heavily barred with Amber Brown; secondaries Amber Brown, paler below, prominently barred with blackish, uniform with back; upper wing coverts Amber Brown, prominently barred with blackish, uniform with back and remiges. Tail Amber Brown, paler below, heavily barred and extensively tipped with blackish.

Bill (in life) "lemon"; feet "greenish gray"; iris "reddish brown". Wing, $112 \mathrm{~mm}$; tail, $68 \mathrm{~mm}$; exposed culmen, $20 \mathrm{~mm}$; culmen from base, $24 \mathrm{~mm}$; ; tarsus, $19 \mathrm{~mm}$.

Remarks: The sexes are similar in coloration, except that the female 
lacks the red malar area. Size similar to that of undatus. Range of measurements: three adult males-wing, 112-115 (114) mm.; tail, 64-73 (68.3) ; culmen from base, 23-24 (23.3); four adult females-wing, 107 115 (111.7) ; tail, 65-70 (66.9) ; culmen from base, 22-25 (23.7). Measurements of five adult males ${ }^{3}$ of undatus from the Guianas-wing, 108115 (112.8); tail, 63-72 (68.2); culmen from base, 23-24 (23.6); five adult females-wing, $112-118$ (115); tail, $63-72$ (68); culmen from base, 23-25 (24.4).

There is great individual variation in the color of top of head and in the absence, presence, or amount of speckling. The species has not previously been recorded from Venezuela.

\section{Specimens Examined}

C. u. multifasciatus.-BRAZIL: Utinga, Pará, 3 \%3.

C. $u$. undatus.-VENEZUELA: Altiplanicie de Nuria, 1 of Carabobo, Alto Río Cuyuni, 2 $q, 1$ (q) ; Camborere, Caño Uey, 2 . BRITISH GUIANA: Membaro Creek, $1 \hat{\delta}$; Kamarang River, $1 \hat{\delta}^{3}$; Potaro Landing, $1 q^{3}$; Kamakusa, $1 q^{3}$; "British Guiana,"3 1 o, $1 \uparrow$; Tumatumari $^{3}, 1$ ô, 1 o. DUTCH GUIANA (interior) ${ }^{3}: 1$ ô, 1 ( FRENCH GUIANA ${ }^{3}$ : Pied Saute, 1 ; Tamanoir, $1 \hat{\delta}$.

C. $u$. amacurensis.-VENEZUELA: San Francisco de Guayo, $2 \hat{o}$ (incl. type), 3 ㅇ, 1 (q); Jobure, 1 ô, 1 ㅇ․

\section{Dendrocincla fuliginosa deltana, new subspecies}

Type: From Misíon Araguaimujo, Territorio Delta Amacuro, Venezuela; sea level. No. 49,714, Phelps Collection, Caracas, Venezuela. Adult male collected February 16, 1949, by Ramón Urbano. (Type on deposit at the American Museum of Natural History.)

Diagnosis: Nearest to $D$. $f$. phaeochroa, from which it differs by a less whitish chin, more nearly uniform with the under parts. Differs from $D$. $f$. barinensis by being more olivaceous, less yellowish brown, both below and above.

Range: Delta of the Orinoco River.

Description of Type: Top of head, back, and rump Argus Brown; sides of head more dusky; upper tail coverts darker than Hay's Russet. Chin slightly grayish, merging into the Cinnamon Brown of under parts; under tail coverts darker than Hay's Russet. Remiges Chestnut, primaries broadly tipped, and outermost externally edged, with dusky; upper wing coverts with an olivaceous tint. Tail chestnut, paler below.

Maxilla (in life) "black"; mandible "bluish gray"; iris "dark". Wing, $102 \mathrm{~mm}$; tail, 87; exposed culmen, 27; culmen from base, 30 ; tarsus, 25.

Remarks: Sexes similar in color, but female smaller. Size similar to that of phaeochroa. Range of measurements: five adult males-wing, 102-107 (104.2) mm.; tail, 85-91 (87.6); culmen from base, 30-31 (30.2) ; five adult females-wing, 91-99 (94.8); tail, 70-83 (78); culmen from base, 27-29 (28). Measurements of phaeochroa (from Caño Cata. niapo to San Fernando de Atabapo on the upper Orinoco): five adult males-wing, 106-112 (107.8); tail, 87-95 (89.8); culmen from base, $30-32(30.6)$; five adult females - wing, $97-101$ (98.8); tail, $77-83$ (80.2); culmen from base, 28-30 (29.2). 


\section{Specimens Examined}

D. $f$. fuliginosa.-FRENCH GUIANA: $4^{7}$. DUTCH GUIANA: $4^{7}$. BRAZIL: 87. VENEZUELA: Altiplanicie de Nuria, 2 ô, 1 $\uparrow, 1$ ( $?$ ).

D. f. rufo-olivacea. ${ }^{7}$-BRAZIL: 22.

D. $f$. atrirostris. ${ }^{7}$-BRAZIL: 10 . BOLIVIA: 5 .

D. $f$. phaeochroa.-VENEZUELA: Cerro Uaipán-tepui, 1 ô ; Cerro

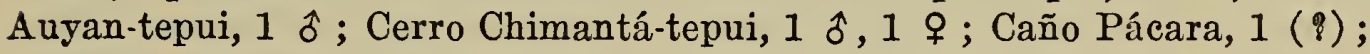
La Paragua, $2 \hat{\delta}$; Raudal Perro, 1 $q$; Cerro Guaiquinima, $1 \hat{\delta}, 1$; ; Raudal Capuri, 1 ô ; Cerro Arebuchi, 1 ô, 1 ( () ; Cerro Paurai-tepui, 2 우 1 (q)); Sabana Kirichú, 1 우; Santa Rosalía, 1 ô, 1 (q); El

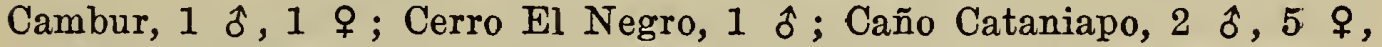
1 (q); Isla Ratón, 2 ô, 1 q, 1 (q) ; Caño Cuao, 1 ô ; San Fernando de Atabapo, $2 \hat{\delta}, 3$ ㅇ, 4 (q) ; Cerro Yaví, 1 ô; Las Carmelitas, 1 ô, 1 우 ; Puerto Yapacana, 1 q, 1 (q); San Carlos, Río Negro, $1 \hat{\text { ô. }}$

D. $f$. deltana.-VENEZUELA: Misión Araguaimujo, $6 \hat{o}$ (incl. type), 6 q, 1 (q); Misión San Francisco de Guayo, 1 ㅇ, 2 (?); Jobure, 2 ô, 2 ㅇ.

D. f. barinensis.-VENEZUELA: Santo Domingo, $2 \hat{\delta}, 3 q$; Santa Bárbara, Barinas, 1 ô, 1 욱 Ciudad Bolivia, $2 \hat{o}, 1$ 우 ; La Veguita, $2 \hat{o}$; Barinitas, 2 ô, 2 우 ; Turén, 1 (?).

D. $f$. meruloides.-TRINIDAD ${ }^{3}: 17$ ô, 12 q, 3 (१). VENEZUELA ${ }^{3}$ : Cristóbal Colón, 3 ô, 6 q; Yacua, 1 (?) ; Río Neverí, 1 ô; Quebrada Seca, Sucre, 2 ô ; Montaña del Guácharo (Guácharo), 1 우; Los Palmales, 1 $q$; Puerto de la Cruz, 2 o ; Las Quiguas, 2 ô; Tucacas, $2 \hat{o}$; Las Trincheras, 2 \%, 1 (?). VENEZUELA ${ }^{8}$ : Estados Sucre, 15; Monagas, 12; Miranda, 15; Distrito Federal, 2; Carabobo, 5; Yaracuy, 2; Falcón, 10; Lara, 1.

D. f. lafresnayei.-VENEZUELA: La Sabana, 2 ô; La Sierra, 2 ô, 1 , 1 ( $)$; El Vigía, $2 \hat{o}$; Seboruco, 3 ô; Santa Cruz de Mora, $1 \hat{\delta}$. COLOMBIA $^{3}$ : Río Frío, 2 우 ; Puerto Valdivia, 2 우; Morritos, 1 우 Río Lima, $1 \hat{\jmath}, 1$ q ; Botero, 1 ( () ; Honda, 1 ô; Las Nubes, Santa Marta, 1 ô, 1 (q) ; Valparaíso, 1 (q); Minca, 1 (q); "Bogotá", 2 (q).

D. f. ridgwayi.7-ECUADOR: 17. COLOMBIA: 4. PANAMA: 12. COSTA RICA: 6 .

\section{Ochthoeca diadema meridana, new subspecies}

Type: From Cerro Mesa de Lino, Santo Domingo, Mérida; altitude 2,600 meters. No. 48,845, Phelps Collection, Caracas, Venezuela. Adult male collected November 25, 1949, by Ramón Urbano. (Type on deposit at the American Museum of Natural History.)

Diagnosis: Differs from 0 . d. diadema, of Páramo de Tamá and Colombia, by brighter, deeper yellow, underparts; and from tovarensis, of the Caracas region, by darker, more dusky, less olivaceous crown.

Range: The Andes of Táchira (except Páramo de Tamá), Mérida and Trujillo, in the Subtropical and Temperate Zones at altitudes between 2,000 and 3,050 meters.

Description of Type: Crown dusky olivaceous, more blackish than Dark Olive; forehead and anterior part of superciliary streak widely

TFor localities see Zimmer, Am. Mus. Nov., No. 728, 1934, p. 19.

sFor list of specimens and localities see: Phelps and Phelps, Jr., Proc. Biol. Soc. Wash., Vol. 62,1949 , p. 115. 
Lemon Chrome; posterior part of superciliary streak prominently Picric Yellow; back and uropygium yellower than Saccardo's Olive, more olivaceous on nape; lores prominently black; ear coverts dusky; cheeks olivaceous. Chin and throat whitish mixed with pale olivaceous and yellowish, merging into the pale olivaceous breast, which merges into the paler than Strontian-Yellow abdomen; sides, flanks, and axillaries olivaceous, more dusky on thighs; under tail-coverts yellowish olive. Wings fuscous; secondaries lightly, tertials heavily, edged with brownish; remiges lightly bordered basally on inner vanes with whitish; wing coverts lightly edged with olivaceous; outer under wing coverts dusky olivaceous, the inner long ones yellowish white. Tail fuscous.

Bill (in life) "'black"; feet "black"; iris "'brown"'. Wing, $63 \mathrm{~mm}$.; tail, 57 ; exposed culmen, 9 ; culmen from base, 13 ; tarsus, 19.

Remarks: Sexes alike. Size similar to that of diadema. Range of measurements: three adult males-wing, 62.63 (62.3) mm.; tail, 53.57 (54.3) ; culmen from base, 13-14 (13.7) ; five adult females-wing, 56-62 (60); tail, 47-55 (50); culmen from base (4), 13-14 (13.5). Measurements of diadema: three adult males from Páramo de Tamá-wing, 6365 (64); tail, 53-56 (54.3) ; culmen from base, 13-14 (13.3).

An immature specimen differs from the adults in having the yellow of the forehead much restricted; the superciliary stripe paler yellow; the back more rufous; the throat whitish, not yellow; and the abdomen pale yellowish white.

\section{Specimens Examined}

o. d. tovarensis.-VENEZUELA: Colonia Tovar ${ }^{3}, 1$ ô (type), $2 \hat{o}$ juv.; No León, 1 (?).

o. d. meridana.-VENEZUELA: El Rincón, Cerro Niquitáz, 2 ; ; Páramo Misisí, 1 9 ; Mesa de Lino, Sto. Domingo, $2 \hat{o}$ (incl. type); El Escorial $^{3}, 2$ ô, 2 $q, 1$ (q); El Muerto, Páramo Aricagua, $1 \hat{o}, 1$ (q) juv.; Boca de Monte, Pregonero, 1 (q).

o. d. diadema.-VENEZUELA: Villa Páez, Páramo de Tamá, 2 ô, 1 q; Párama de Tamá, 1 ô. COLOMBIA ${ }^{3}$ : Choachi, Bogotá, 1 (q); "Bogotá", 5 (q).

o. d. jesupi.-COLOMBIA ${ }^{3}$ : El Líbano, Santa Marta, 1 (q); San Lorenzo, 1 \% ; Valparaíso, 1 ( $($ ).

o. d. gratiosa ${ }^{3}$-COLOMBIA: $7^{9}$. ECUADOR: $3^{9}$.

Euscarthmornis granadensis federalis, new subspecies

Type: From No León, Distrito Federal, Venezuela; altitude 2,000 meters. No. 13,183, Phelps Collection, Caracas, Venezuela. Adult female collected May 7, 1941, by Enrique Riera. (Type on deposit at the American Museum of Natural History.)

Diagnosis: Differs from $E$. g. granadensis, of Páramo de Tamá and Colombia by whiter, less grayish, breast and by having the buffy eye ring darker, less whitish; from lehmanni, of Santa Marta, by lacking the brownish breast; and from pyrrhops, of Perú and Ecuador, by less extensive buffy on the ocular, loral, and frontal regions.

Range: Known only from the type locality in the Subtropical Zone. Description of Type: Top of head, sides of neck, ear coverts, back,

9For localities see Gilliard, Am. Mus. Nov., No. 1871, 1940, p. 8. 
and uropygium yellower than Warbler Green; eye ring and lores Pale Ochraceous-Buff. A blackish area covers chin, anterior throat, and maxillary region; the rest of the throat is whitish, this color merging into the more grayish of the breast, which in turn merges into the white of the abdomen; sides of breast slightly olivaceous; under tail coverts and axillaries yellowish white; thighs dusky. Wings fuscous; remiges narrowly edged outwardly with yellowish green; bend of wing Amber Yellow; under wing coverts yellowish white. Tail Benzo Brown, paler below, the rectrices edged externally with yellowish green.

Bill (in life) "mandible black; maxilla brown with flesh colored tip" ; feet "light brown"; iris "light brown". Wing, $43 \mathrm{~mm}$.; tail, 40; exposed culmen, 11 ; culmen from base, 14 ; tarsus, 16.

Remartes: Size similar to that of granadensis. Range of measurements: three adult females of granadensis (Almaguer ${ }^{3}$ and Cocal ${ }^{3}$, Colombia; Páramo de Tamá, Venezuela)-wing, 44, 45, 45; tail, 38, 43, 39 ; culmen from base, 15, 14, 13.

\section{Specimens Examined}

E. g. federalis.-VENEZUELA: No León, 1 ㅇ (type).

E. g. granadensis.-VENEZUELA: Páramo de Tamá (camp), 3 ô, 1 \&. COLOMBIA ${ }^{3}$ : Sabana Larga, 1 (q); Santa Elena, Antioquia, 1 of ; Cocal, Cauca, 1 ; Silencio, 1 o ; Laguneta, 1 ô, 2 (q); Almaguer, 1 \&, 1 (q) ; Coast Range, west of Popayán, 1 \&.

E. g. lehmanni.-COLOMBIA: Santa Marta, 1 (q) ${ }^{3}$.

E. g. pyrrhops ${ }^{3}$.-ECUADOR: Loja, 1 of, 1 q, 1 (q). PERU: Loma Santa, $1 \hat{o}$; La Legía, $2 \hat{o}, 1$ (q); Chachapoyas, 1 ô, 1 (q); Levanto, $1 \hat{~} \hat{\text {; }}$ : San Pedro, 2 ô; Limabomba, 1 ô.

This conspicuously marked form appears to be extremely rare, for it has escaped the intensive collecting that has taken place in the Mérida and Caracas regions through a century.

\section{Mecocerculus leucophrys parui, new subspecies}

Type: From Cerro Parú, Territorio Amazonas; altitude 1,600 meters. No. 46,853, Phelps Collection, Caracas, Venezuela. Adult male collected February 16, 1949, by William H. Phelps, Jr. (Type on deposit at the American Museum of Natural History.)

Diagnosis: Differs from all other subspecies of $M$. leucophrys by having a darker back. Closest to $M$. $l$. roraimae, from which it differs by having the back more brownish olive, less grayish olive.

Range: Known only from Cerro Parú in the Subtropical Zone, at altitudes from 1,600 to 1,700 meters.

Description of Type: Top of head duskier than Bone Brown; back and uropygium Olive Brown; lores dusky, feathers tipped with whitish; eyelids whitish; a faint whitish superciliary streak; postorbital region dusky; ear coverts and sides of throat whitish. Chin and throat whitish, becoming more grayish on anterior breast, merging into the yellowish olivaceous of rest of breast, sides, flanks, and thighs; abdomen yellowish white; under tail coverts paler; axillaries whitish. Wings Bone Brown; inner vanes of remiges narrowly edged with whitish, inwardly more extensviely; secondaries edged on outer vanes with buff; tertials edged broadly with white; two broad buffy wing bands, becoming more whitish inwardly; lesser upper wing coverts uniform with back; under wing 
coverts mixed dusky, yellowish, and whitish. Tail darker than Benzo Brown, paler on under surface, faintly tipped with grayish; outer rectrices paler.

Bill (in life) "blackish brown"; feet "blackish brown"; iris "brown". Wing, $64 \mathrm{~mm}$.; tail, 61 ; exposed culmen, 10; culmen from base, 14 ; tarsus, 20.

Remarks: Sexes alike in coloration, but female smaller. Size similar to that of roraimae. Range of measurements: five adult males-wing, 6164 (62.4) mm.; tail, 59-61 (60.2); culmen from base, 13-14 (13.4); one adult female-wing, 56 ; tail, 55 ; culmen from base, 13 . Measurements of topotypical roraimae: five adult males-wing, 62-63 (62.4); tail, 6063 (61.6); culmen from base, 13-14 (13.4); five adult females-wing, 57-58 (57.4); tail, 55-58 (56.2); culmen from base, 12-13 (12.8).

\section{Specimens Examined}

M. l. leucophrys ${ }^{3}$--ARGENTINA: 19. BOLIVIA: 9. PERU: 4.

M. l. brunneomarginatus ${ }^{3}$-PERU: 4. ECUADOR: 32 .

M. l. notatus ${ }^{3}$-COLOMBIA: 37 .

M. l. setophagoides ${ }^{3}$-COLOMBIA: 37 .

M. l. gularis.-VENEZUELA ${ }^{10}$ : Estado Táchira, 33; Edo. Mérida, 20, $8^{3}$; Edo. Trujillo, 38 ; Edo. Lara, 3.

M. l. palliditergum.-VENEZUELA ${ }^{10}$ : Edo. Yaracuy, 1; Edo. Carabobo, 2; Edo. Aragua, 6; Distrito Federal, 27, 113; Edo. Miranda, 3.

M. l. nigriceps.-VENEZUELA: Edo. Sucre, $6^{3}$; Edo. Monagas, $16^{10}$.

M. l. roraimae.-VENEZUELA: Cerro Roraima, $8 \hat{\circ}{ }^{3}, 6 \hat{o}, 24{ }^{3}$, $15 q, 2$ (q) ; Cerro Uei-tepui, 2 ô ; Cerro Ptari-tepui, 9 ô, 13 $q, 4$ (q); Cerro Sororopán-tepui, $2 q, 1$ (q); Cerro Chimantá-tepui, 4 ô, 4 \%, 5 (q); Cerro Uaipán-tepui, 1 \&, 2 (q); Cerro Aprada-tepui, 5 ô, 5 \&, 2 (q); Cerro Auyan-tepui, 1 ô, 1 q ; Cerro Yaví, 5 ô, 5 q, 1 (q); Cerro Duida ${ }^{3}, 15$ ô, 12 ㅇ, 4 (?). BRAZIL: Cerro Uei-tepui, 1 \% .

M. l. parui.-VENEZUELA: Cerro Parú, 9 ô (incl. type), 1 우.

\section{Oryzoborus crassirostris magnirostris, new subspecies}

Type: From Misión San Francisco de Guayo, Territorio Delta Amacuro; sea level. No. 48301, Phelps Collection, Caracas, Venezuela. Adult male collected January 30, 1949, by Ramón Urbano. (Type on deposit at the American Museum of Natural History.)

Diagnosis: Differs from $O$. c. crassirostris in having a much larger bill and longer wing and tail; from $O$. c. nuttingi, in having a white speculum.

Range: Known from Trinidad, the Delta of the Orinoco, the Lower Caura River, and Caicara on the Orinoco River.

Description of Type: Body lustrous black with bluish reflections on the upper parts; axillaries white. Wings brownish black, with a prominent, large, exposed, white speculum on the primaries; bend of wing and under wing coverts white, mixed with dusky. Upper surface of tail Blackish Brown, under surface browner.

Bill (in life) "horn color"; feet "black"; iris "dark". Wing, 74 mm.; tail, $64 \mathrm{~mm}$; exposed culmen, $16 \mathrm{~mm}$; ; culmen from base, $20 \mathrm{~mm}$.; tarsus, $19 \mathrm{~mm}$.

${ }^{10}$ For localities see Phelps and Phelps, Jr., Ten New Subspecies of Birds from Venezuela. Proc. Biol. Soc. Wash., Vol. 60, 1947, p. 158. 
Remarks: Sexes different in color. Size larger than that of crassirostris. Range of measurements: eight adult males (2 Delta, 3 Trini$\mathrm{dad}^{3}, 3$ Caicara ${ }^{3}$ )-wing, $73-74$ (73.4) mm.; tail (2 only), 64, 65; culmen from base 18-20 (18.6); one adult female-wing, 71 ; tail, 63 ; culmen from base, 18 . Measurements of crassirostris: twenty adult males ${ }^{3}$-wing, 66-73 (68.7); tail (8 only), 55-61 (57.6); culmen from base, 15-16 (15.4); six adult males-wing, 66-70.5 (67.5); tail, 53-62 (58); culmen from base, 16-16.5 (16.1); four adult females-wing, 65.5-67 (66.4); tail, 54-57 (55); culmen from base, 15-16 (15.7).

From the measurements given above, it is seen that the males of the new form have the bill $20 \%$ longer, the wing $8 \%$ longer, and the tail $12 \%$ longer; the depth and width of the bill are also much greater.

The female (No. 50,030, Phelps Collection) is similar in coloration to that of crassirostris, but larger, with wing, $71 \mathrm{~mm}$; tail, 63 ; culmen from base, 18, against the mean measurements of the four + crassirostris; viz. wing, 66.4 tail, 55 ; culmen from base, 15.7.

One of two immature males in the Phelps Collection is black, with just a few brown feathers showing their tips on breast, abdomen, back and upper wing coverts; the other is in the juvenile plumage, similar to that of the female.

Hellmayr ${ }^{11}$ called attention to the large bills of the Trinidad and Orinoco Valley birds, but remarked that he had "not been able to correlate certain variations in dimensions and in size of bill with geographic areas."

Among the 26 adult male crassirostris and the 8 adult males of the new form there is only one overlap in wing length (the Bogotá specimen), but none in length of bill. There is no overlap in length of tail among the 6 male crassirostris and the 2 males of the new form measured by us.

Mr. J. B. Macdonald, Curator of Birds in the British Museum, kindly measured the three specimens from Trinidad in that institution, with this result: $1 \hat{o}$, wing unflattened, $73 \mathrm{~mm}$., culmen from base, $19 ; 1 \hat{o}$ wing, 72, culmen, $18 ; 1$, wing, 71, culmen, 15. All of these measurements, except that of the bill of the $q$, are typical of the new form.

The known ranges of the new form and of $O$. c. crassirostris approach each other closely in the Caicara region and in the Delta. At the time the Delta specimens of $O$. c. crassirostris were collected, large flocks were feeding on the rice fields. Outside of the breeding season, the birds band together and evidently wander far in search of rice and other ripe grains; they may then approach or even temporarily invade the territory occupied by a neighboring form. In this case the two forms have not been recorded from the same locality.

\section{Specimens Examined}

o. c. maximiliani.-BRAZIL ${ }^{3}$ : Chapada, Matto Grosso, $2 \hat{\delta}, 1$; Esperanza, Goyaz, 1 우 "Brazil", 1 ㅇ.

O. c. crassirostris.-VENEZUELA: Escuque, 1 ổ ${ }^{3}$; Las Guacas, Río

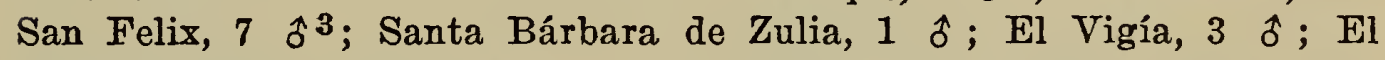
Platanal, Terr. Amazonas, 1 우 ; El Palmar, 1 우 ; Río Jobure, Terr. Delta Amacuro, 2 ô, 4 ô juv., 2 \$, 1 (q). COLOMBIA : "Bogotá",

${ }^{1}$ Catalogue of Birds of the Americas. Part XI, p. 242, 1938. 
1 ( 9$)$; Medellín, 1 s ; Villavicencio, 1 tิ, 1 ㅇ. BRITISH GUIANA: Essequibo River ${ }^{3}, 1$ to, 1 \% ; Annai ${ }^{3}, 5$ to 1 \% juv., 1 [\%]; "Demarara" 6, 1 (q). DUTCH GUIANA ${ }^{3}$ : Paramaribo, 2 s, 1 t juv., 3 q. BRAZIL : Monte Cussary, $1 \hat{\jmath}$.

O. c. magnirostris.-VENEZUELA: Misión San Francisco de Guayo, $2 \hat{\delta}$ (incl. type), $2 \hat{\delta}$ juv., 1 $q$; Maripa, $1 \delta^{3}$; Caicara, $1 \delta^{3}$; Quiribana de Caircara, $1 \delta^{3}$. TRINIDAD: 3 क 3 .

o. c. nuttingi.-NICARAGUA: Nicaragua ${ }^{3}, 5$ t, 1 f juv., 2 ; ; Greytown $^{6}, 3$ $\hat{\delta}, 2$ jo juv. 


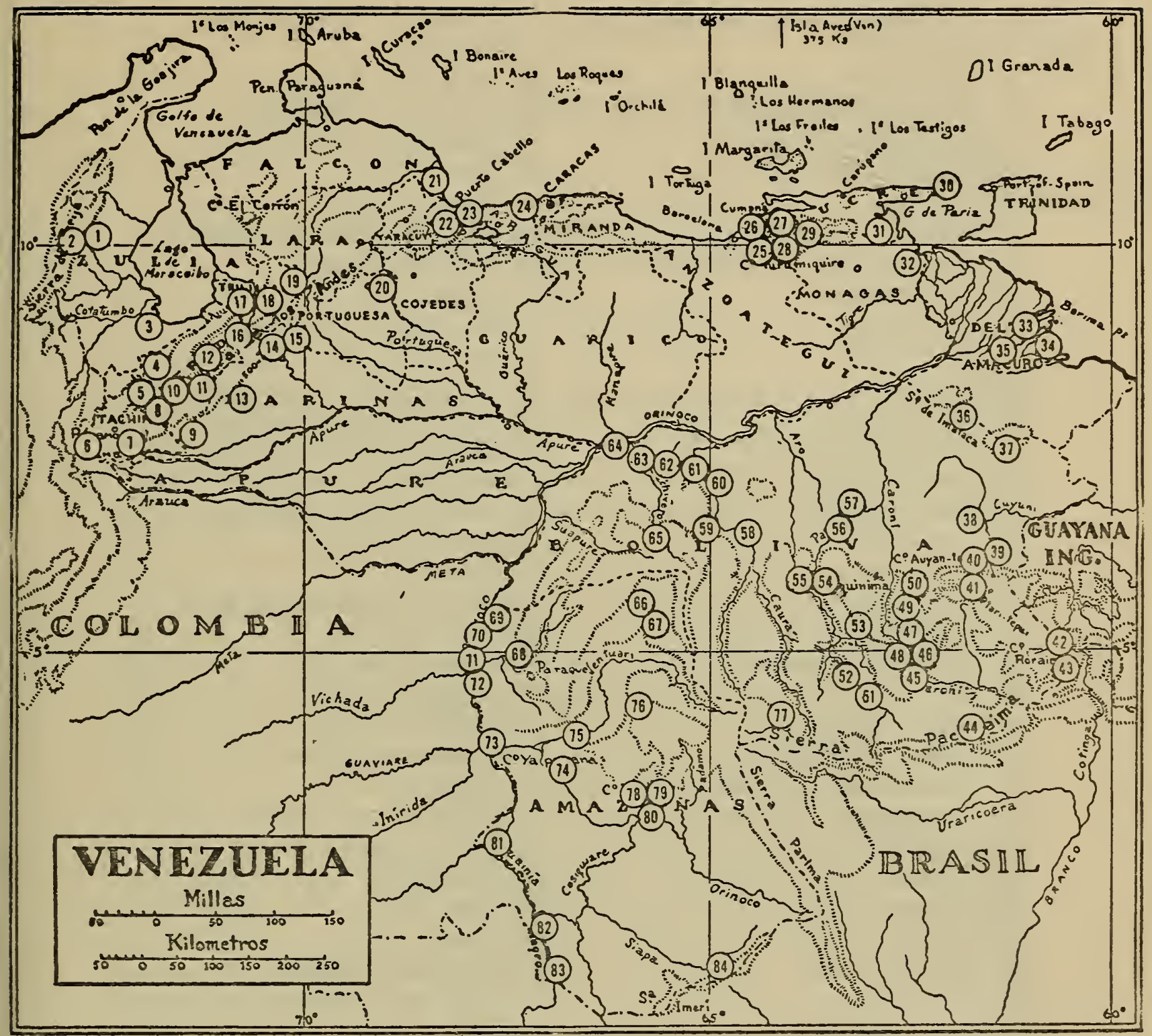

PLATE IX

LIST OF LOCALITIES

37 Altiplanicie de Nuria

47 Aprada-tepui, Cerro

35 Araguaimujo, Misión

45 Arebuchi, Cerro

45 Arebuchi, Salto

50 Auyan-tepui, Cerro

30 Azul, Cerro

14 Barinitas

25 Bergantín

8 Boca de Monte

64 Caicara

40 Camborere

53 Capuri, Raudal

39 Carabobo

69 Cataniapo, Caño
46 Chimantá-tepui, Cerro

13 Ciudad Bolivia

24 Colonia Tovar

68 Cuao, Caño

30 Cristóbal Colón

79 Duida, Cerro

80 Duida, Foot of

61 El Cambur

83 El Carmen

12 El Escorial

11 El Muerto

65 El Negro, Cerro

36 El Palmar

28 El Peonía

67 El Platanal 
19 El Rincón, Cerro Niquitáz

4 El Vigía

17 Escuque

54 Guaiquinima, Cerro

55 Guaiquinima, Salto

32 Guanipa, Río

31 Guanoco

34 Jobure

34 Jobure, Río

57 La Paragua

2 La Sabana

1 La Sierra

60 La Unión

15 La Veguita

75 Las Carmelitas

63 Las Guacas

23 Las Quiguas

22 Las Trincheras

26 Los Altos

29 Los Palmales

51 Maisa, Salto

52 María Espuma, Salto

61 Maripa

16 Mesa de Lino

18 Misisí, Páramo de

29 Montaña del Guácharo

(Guácharo)

72 Munduapo

27 Neverí

59 Nichare, Río

24 No León

48 Pácara, Caño

58 Pará, Salto

76 Parú, Cerro

44 Paurai-tepui, Cerro

56 Perro, Raudal

41 Ptari-tepui, Cerro
24 Puerto de La Cruz, Dto. Federal

28 Quebrada Bonita

27 Quebrada Seca, Sucre

64 Quiribana de Caicara

71 Ratón, Isla

42 Roraima, Cerro

76 Sabana, Alto Río Asisa

77 Sabana Kirichú

70 Sanariapo

82 San Carlos, Amazonas

73 San Fernando de Atabapo

33 San Francisco de Guayo

9 Santa Bárbara, Barinas

3 Santa Bárbara del Zulia

10 Santa Cruz de Mora

62 Santa Rosalía, Bolívar

7 Santo Domingo

5 Seboruco

84 Siapa, Nacientes del Río

78 Sina, Boca de

41 Sororopán-tepui

61 Suapure

6 Tamá, Páramo de

36 Tomasote, Cerro

21 Tucacas

20 Turén

49 Uaipán-tepui

43 Uei-tepui

6 Villa Páez

30 Yacua

74 Yapacana, Cerro

74 Yapacana, Puerto

66 Yaví, Cerro

81 Yavita-Pimichín, Pica

38 Yuruán, Río 
Vol. 63, pp. $127-130$

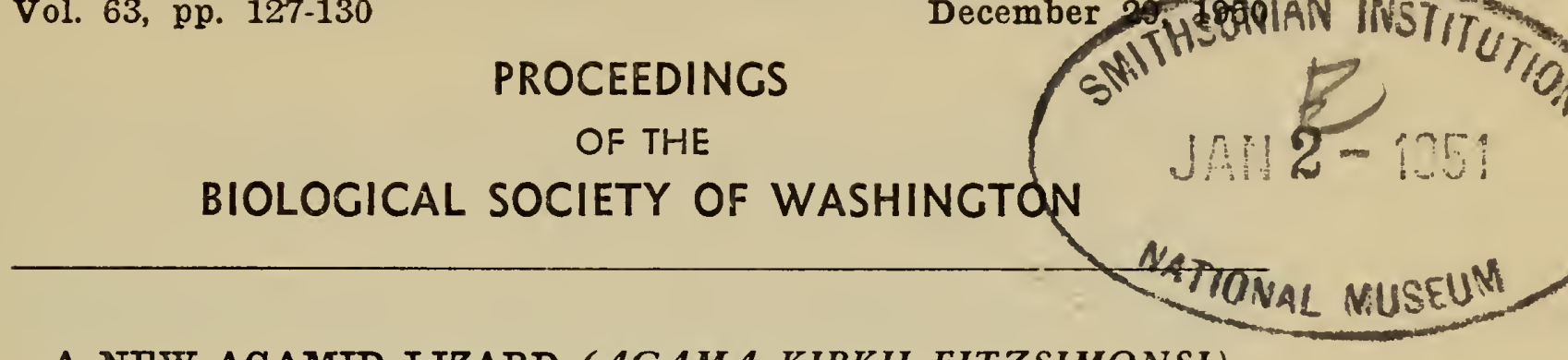

\section{A NEW AGAMID LIZARD ( $A G A M A$ KIRKII FITZSIMONSI) FROM SOUTHERN RHODESI}

\section{By Arthur LOVERIDGE}

In studying an extensive series of agamas from Nyasaland, I was struck by the way in which they differed from their representatives in the southern half of Southern Rhodesia. Our material from the northern portion of Southern Rhodesia conforms more nearly with Nyasaland specimens.

Unfortunately the type of Agama kirkii Boulenger (1885, Cat. Lizards Brit. Mus., 1, p. 354, pl. xxviii, fig. 2) is without precise locality, being merely labelled "Zambesi Expedition." It is common knowledge that in the course of the expedition Livingstone and Kirk ascended the Zambezi River, and from it traced the Shire River to its source in Lake Nyasa (which they reached on September 16, 1859), subsequently visiting the Victoria Falls which lie betwen the two Rhodesias.

Thus it would seem that the name kirkii is unquestionably applicable to the northern form, but in the hope of being able to designate a still more definite type locality I applied for further information to Dr. H. W. Parker. To him I am indebted for the following data regarding the $\delta$ holotype of kirkii, originally labelled " \& Agama mossambica, Zambesi Expedition, Brit. Mus. reg. no. 64.6.28.4.'" but subsequently labelled Quelimane.

But two other agamas were receired from the Zambesi Expedition; an earlier one, registered as 64.5.13.2, is a halfgrown +9 from Quelimane, originally labelled "? Agama mossambica." The identification is confirmed by Boulenger (1885, p. 354). Dr. Parker adds that all the specimens in this earlier consignment registered on May 13 are from coastal localities or places Kirk would have touched at on his way.

The third agama, registered as 64.6 .28 .3 , is an adult $q$ originally labelled "Agama occipitalis, Zambesi Expedition." This, like all material in the June 28 shipment, lacks precise locality data and was presumably collected after the Expedition started up country. Boulenger (1885, p. 354) reidentified this $q$ (which supplied him with the measurements he gives) as mossambica and attributes it to Quelimane in error, having switched the locality data with that of the halfgrown $q$ mentioned above.

The original labels were presumably those of Günther who (1864b, p. 307) lists "Agama occipitalis, Gray" and "? Agama mossambica, Peters. Quelimane" without any indication as to how many specimens he had of each.

I take pleasure in naming this undescribed form after its collector, 


\section{Proceedings of the Biological Society of Washington}

Dr. V. F. FitzSimons, in whose writings (vide infra) will be found much additional information regarding its color and other matters.

Agama kirkii fitzsimonsi subsp. nov.

Agama kirkii FitzSimons (not of Boulenger), 1935b, Ann. Transvaal Mus., 16, p. 347 (near Zimbabwe); 1939b, Ann. Transvaal Mus., 20, p. 29 (Changadzi River; Birchenough Bridge).

Type.-Museum of Comparative Zoölogy No. 44,542, an adult $\hat{o}$ from Changadzi River, an affluent of the Sabi River in southeastern Southern Rhodesia. Collected by V. FitzSimons, January 4-6, 1938.

Paratypes.-Museum of Comparative Zoölogy Nos. 44,540-1, a gravid $q$ and adult $\hat{o}$, also Transvaal Museum No. 18,653, with the same data as the type; T.M. 18,677 from Birchenough Bridge, January 12, 1938; M.C.Z. 33,480-1, two of of from Zimbabwe, collected by the VernayLang Kalahari Expedition in September, 1930; M.C.Z. 33,446, an immature $\hat{o}$ from Gokomeri, north of Fort Victoria, Rev. K. Tasman coll. 1927.

In addition, the undermentioned material, some of it immature, has been examined by Dr. V. FitzSimons, who finds it conforms with my definition of the southern form. Transvaal Museum No. 664 from Khami River near Bulawayo; No. 2,803 from Matopos, Bulawayo; Nos. 14,595-8 from Zimbabwe; No. 14,603 from Changadzi River; besides the Birchenough Bridge specimens listed in the preceding paragraph.

Diagnosis.-Agamas from the southern half of Southern Rhodesia are characterized by having nuchal and vertebral erests, besides the keels and mucrones of the dorsal scales, less well developed than in the typical Nyasaland form; the preanal pores are also slightly smaller. The gular pattern of young males consists of white spots on a dark ground (instead of the alternating light and dark lines of typical kirkii), while adult males of the new form lack the conspicuous dark-blue, basal, gular spot characteristic of Nyasaland kirkii males (85 to $105 \mathrm{~mm}$. from snout to anus).

Description.-Midbody scale-rows 106 (100-113. in five M.C.Z. paratypes); ventrals smooth (very obtusely keeled in two of the paratypes); preanal pores 13 (12-14 in four male paratypes, absent in the female). For further particulars see eitations and diagnosis above.

Size.-Total length of type $\hat{o}$ (M.C.Z. 44,542), $240(98+142) \mathrm{mm}$.; of paratype ? (M.C.Z. 44,540), $209(80+129) \mathrm{mm}$.

Remarks.-Dr. FitzSimons informs me that a basal gular spot is lacking or but very faintly indicated in the Southern Rhodesian material of this species in the Transvaal Museum. As might be expected, it is absent in a subadult $\hat{o}$ (M.C.Z. 33,445) from Cnilimanzi, an intermediate locality from which adult material is desirable before final assignment is made.

A basal gular spot is present in males from Kutamas (M.C.Z. 33,444), Mazoe (M.C.Z. 18,275), and Monte Cassino (M.C.Z. 33,447), all northern localities in Southern Rhodesia.

It is true that no basal gular spot is present in the type of kirkii Boulenger, the underside of which displays the coloring of a female. 
However, Dr. Parker writes that the holotype has pores and is a male. It is obviously subadult, for it measures $79 \mathrm{~mm}$. from snout to anus, while the color pattern on its undersurfaces agrees with that of our halfgrown Nyasaland males measuring 57 to $65 \mathrm{~mm}$. from snout to anus. In our Nyasaland material the spot is present only in adults measuring 85 to $105 \mathrm{~mm}$. from snout to anus. A full account of these Nyasaland agamas will be furnished in a forthcoming report. 
130 Proceedings of the Biological Society of Washington. 


\section{PROCEEDINCS \\ OF THE \\ BIOLOGICAL SOCIETY OF WASHINCTON NATIONAL MUSEUM}

\section{NEW FROGS OF THE GENERA CYCLORANA AND HYLA FROM SOUTHEASTERN AUSTRALIA}

\section{By Arthur LOVERIDge}

The three frogs described below are part of an extensive collection of amphibia made by Mr. J. R. Slevin during 1947 1948. The holotypes, though here bearing the registration numbers of the California Academy of Sciences, are being presented to the Australian Museum ${ }^{1}$ in compliance with Australian law, which requires all visiting zoologists to surrender any types they may have collected in that Commonwealth.

With regard to the type localities, Mr. Slevin has kindly furnished me with the following supplementary data: Noondoo, a siding for the Noondoo Sheep Station, is about ten miles east of Dirranbandi, terminus of a railway line from Brisbane, consequently elose to the border between Queensland and New South Wales. Ulong, a small lumber mill village, is about ten miles west of Coramba, which, in turn, lies west of Goffs Harbour on the northeastern coast of New South Wales.

I am indebted to Mr. J. R. Slevin for allowing me to describe these interesting frogs, with the first of which I take pleasure in associating his name.

\section{Cyclorana slevini sp. nov.}

Type.-California Academy of Sciences No. 82,052, apparently an immature o, from Noondoo, southeastern Queensland near the QueenslandNew South Wales border. Collected by J. R. Slevin, September 16, 1947.

Paratype.-California Academy of Sciences No. 82,053, a $\hat{\delta}$ with same data as the type, except that it was collected on September 17, 1947.

Diagnosis.-A heavily built, toad-like frog with shovel-shaped inner metatarsal tubercle, distinguished from its nearest relative as follows:

Interorbital space almost twice as broad as an upper eyelid; tympanum nearly equal to the diameter of the eye; toes two-thirds webbed, the web between the third and fourth toes extending to the distal tubercle of the fourth toe; range: known only from Noondoo, southeast Queñ sland slevini sp. nov.

Interorbital space at most equals the width of an upper eyelid; tympanum half to two-thirds the diameter of the eye; toes one-third webbed, the web between the third and fourth toes never extending as far as the

\footnotetext{
1The Australian Museum has renumbered these specimens as follows:

R. 13,816 for the Paratype of Cyclorana slevini

R. 13,818 for the Type of Hyla kinghorni

R. 13,817 for the Type of Hyla a. ulongae

25-Proc. Biol. Soc. WAsh., VOL. 63, 1950 
second tubercle of the fourth toe; range: north

Western Australia; Northern Territory; northern

Queensland (as far south as Rockhampton) australis

(Gray)

Description.-Build stout. Head much broader than long (in both these specimens as broad as the distance from end of snout to axilla); snout depressed, twice as long as the eye; nostril equidistant between end of snout and eye; canthus rostralis rounded and very oblique; loreal region slightly concave; interorbital space almost twice as broad as an upper eyelid; tympanum distinct, nearly equal to the diameter of the eye; fingers moderate, first opposed to, and longer than, second; subarticular tubercles distinct; palm with small round tubercles; two metacarpal tubercles (swollen, and therefore more prominent in male paratype); toes two-thirds webbed, the notch in the web between third and fourth toes well in advance of the distal tubercle of the third and level with the basal tubercle of the fourth; subarticular tubereles indistinct; inner metatarsal tubercle large, shovel-shaped; no outer tubercle; tarsus with a slight dermal fold along its inner edge; tibiotarsal articulation of the adpressed hind limb reaches the tympanum only (in both type and paratype).

Skin of dorsum shagreened with some inconspicuous, seattered warts towards the flanks; no median occipital-nuchal groove; a more or less distinguishable curved supratympanic fold; dorso-lateral fold absent. Below, throat and breast smooth (in both); belly and hinder side of thighs granular (only slightly so in the male).

Color.-Above olive-gray (plumbeus in male), edge of upper lip white; back, flanks, and limbs finely spotted or vermiculated with brown. Below, creamy white, slightly yellowish on thighs; palms and soles yellowish, minutely vermiculated with brown.

Size.-Total length from snout to anus of holotype ㅇ, $48 \mathrm{~mm}$; of paratype $\hat{o}, 40 \mathrm{~mm}$.

Remarks.-My sexing of the male has been confirmed by Drs. Ernest Williams and Paulo Vanzolini. These frogs have been compared with nine specimens of australis in the Museum of Comparative Zoölogy, at Cambridge, Massachusetts, besides sundry specimens of alboguttatus, including the Alexandra example (M.C.Z. 11.647) that Parker (1940, Novit. Zool., 42, p. 18) listed in the synonymy of australis, on the mistaken assumption it was that species.

Hyla kinghorni sp. nov.

Type-California Academy of Sciences No. 83,234, an adult fo from Ulong, northeastern New South Wales. Collected by J. R. Slevin, January $28,1948$.

Diagnosis. - Apparently most nearly related to Hyla latopalmata from which it may be distinguished as follows:

Canthus rostralis sharply angular; interorbital space two-thirds the width of an upper eyelid; vomerine teeth in two juxtaposed groups; first finger as long as second; toes from first to fifth have $1 / 2,1,1,1 \frac{1}{2}$, and 0 terminal joints respectively free of web

kinghorni sp. nov. 
Canthus rostralis obtusely rounded; interorbital space $11 / 2-11 / 2$ times the width of an upper eyelid; vomerine teeth well-separated; first finger longer than second; toes from first to fifth have $0,0,0,1 \frac{1}{2}$, and 0 terminal joints respectively free of web.-_latopalmata Günther

Description.-Head as long as broad; snout subacuminate, its length (to anterior corner of eye) equal to the distance separating the anterior corners of the eyes; nostril considerably nearer the end of the snout than it is to the anterior corner of the eye; canthus rostralis sharply angular; loreal region oblique, slightly concave; interorbital space twothirds the width of an upper eyelid; diameter of tympanum rather more than half that of the eye; tongue large, subcordiform, distinctly emarginate behind, slightly free; vomerine teeth strongly developed in two juxtaposed, slightly oblique groups between the choanae.

Fingers free of web, first as long as second, which is shorter than fourth, which is shorter than the third, disk of third only half diameter of tympanum; toes well webbed, the web extending almost to the disk on the first, to the distal subarticular tubercle on the second and third, as a narrow margin to the distal tubercle on the fourth, and to the disk on the fifth; in other words the terminal joints free of web from first to fifth are, $1 / 2,1,1,1 \frac{1}{2}$, and 0 ; subarticular tubercles prominent; an oval inner, but no outer, metatarsal tubercle; tibio-tarsal articulation of the adpressed lind limb reaches beyond end of snout.

Skin above smooth; an indistinct curved supratympanic fold; forearm smooth, without dermal ridge or series of tubercles; being a male there is a partly pigmented nuptial swelling at base of first finger; neither lappet on heel nor dermal ridge along outer edge of foot. Below, throat smooth; breast, belly, and thighs granular.

Color.-Above, pale gray variegated with light-edged black patches that coalesce erratically; from nostril through eye to above forearm an ill-defined dark streak; flanks with a few black spots; thighs with slight marbling on distal half of hinder side only. Below, white, a faint trace of dusky pigmentation around lower jaws; otherwise uniform, becoming yellowish cream on belly and buttocks.

Size.-Total length from snout to anus of holotype $\delta, 45 \mathrm{~mm}$.; hind $\operatorname{limb} 80 \mathrm{~mm}$.

Remarks.-Named for J. Roy Kinghorn, Esq., of the Australian Museum, whose ever-ready helpfulness is known to all visiting herpetologists. This new hylid has been compared with all related form of the twentythree species of Australian Hyla in the collections of the Museum of Comparative Zoölogy, as listed by me (1935, Bull. Mus. Comp. Zoöl., 78, pp. 37-54).

Hyla aurea ulongae subsp. nov.

Type-California Academy of Sciences No. 83,235, a $\hat{o}$ from Ulong, northeastern New South Wales. Collected by J. R. Slevin, January 28, 1948.

Diagnosis.-This frog, uniformly plumbeus above, immaculate white below, is characterized by a single series of vomerine teeth between, and level with, the anterior borders of the choanae. Undoubtedly closely related to aurea from which it may be distinguished as follows: 


\section{Proceedings of the Biological Society of Washington}

1. Length of inner metatarsal tubercle contained 3 to $3 \frac{1}{2}$ times in its distance from the tip of the inner toe

Length of inner metatarsal tubercle contained 2 to $2 \frac{1}{2}$ times in its distance from the tip of the inner toe; dorsolateral fold indistinct or discontinuous; vertebral and dorsolateral light lines usually absent though sometimes indicated in the young

2. Dorsum with more or less strongly developed warts, rarely smooth; dorsolateral fold broken up into a chain of warts and not extending to the groin; a vertebral light line usually indicated; dorsolateral light lines frequently broad and discontinuous, being less sharply defined than in typical aurea; range: Northern Territory; Western Australia; Victoria; Tasmania

a. raniformis (Keferstein)

Dorsum almost or quite smooth; dorsolateral fold continuous from eye to groin; no light vertebral line; a light line along the dorsolateral fold and another from beneath the eye to the shoulder; range: New South Wales (introduced into New Caledonia \& New Hebrides) a. aurea (Lesson)

3. Dorsum smooth; entire underside, including axillae, groins, concealed surfaces of femora, tibia and tarsi, uniformly white; range: New South Wales a. ulongensis subsp. nov.

Dorsum warty; axillae, groins, concealed surfaces of femora, tibiae and tarsi, black with conspicuous, round, yellow spots; range: south Western Australia a. cyclorhynchus (Boulenger)

Description.-Head slightly longer than broad; snout subacuminate, its length (to anterior corner of eye) slightly less than the distance separating the anterior corners of the eyes; nostril considerably nearer the end of the snout than it is to the anterior corner of the eye; canthus rostralis not very distinct; loreal region oblique, concave; interorbital space the width of an upper eyelid; diameter of tympanum two-thirds that of the eye; tongue large, not or but slightly emarginate behind, slightly free; vomerine teeth strongly developed in a single, slightly curved series between, or anteriorly on a level with, the front of the choanae.

Fingers free of web, first shorter than second, which is shorter than fourth, which is shorter than the third, disk of the third rather more than half the diameter of tympanum; toes well webbed, the web extending halfway between the distal tubercle and disk on the first, to the disk on the second, third, and fifth, to just beyond the second tubercle on the fourth toe, in other words the terminal joints free of web from first to fifth are, $1 / 2,0,0,2$, and 0 ; subarticular tubercles well developed; an oval inner, but no outer, metatarsal tubercle; tibio-tarsal articulation of the adpressed hind limb reaches the nostril.

Skin above smooth; a curved supratympanic fold; forearm smooth, without dermal ridge or series of tubercles; being a male there is a partly pigmented nuptial swelling at base of first finger; no lappet on heel; a rather inconspicuous dermal ridge along outer edge of foot. Below, throat and breast smooth; belly and thighs granular.

Color.-Above, uniformly plumbeus. Below, immaculate white. 
Size.-Total length from snout to anus of holotype $\hat{o}, 49 \mathrm{~mm}$. , hind $\operatorname{limb} 82 \mathrm{~mm}$.

Remarks.-The foregoing key is based principally on the findings of Parker (1938, Ann. Mag. Nat. Hist. [11], 2, pp. 302-305), who untangled the involved status of aurea and was correct in thinking that my aurea (1935, Bull. Mus. Comp. Zoöl. 78, p. 49) consisted of more than one form. In fact, all our material there listed from sixteen localities was $H$. a. raniformis, except for the one Sydney frog, which was $H$. $a$. aurea, and the Merredin series that, as indicated, is intermediate between aurea and cyclorhynchus, the inner metatarsal of most of them being contained 2 to $2 \frac{1}{2}$ times in its distance from the tip of the inner toe, but very definitely 3 times in one adult. For this reason I am treating cyclorhynchus as a race, instead of a full species as Parker has done and as its distribution may yet require. 
136 Proceedings of the Biological Society of Washington 
138 Proceedings of the Biological Society of Washington 


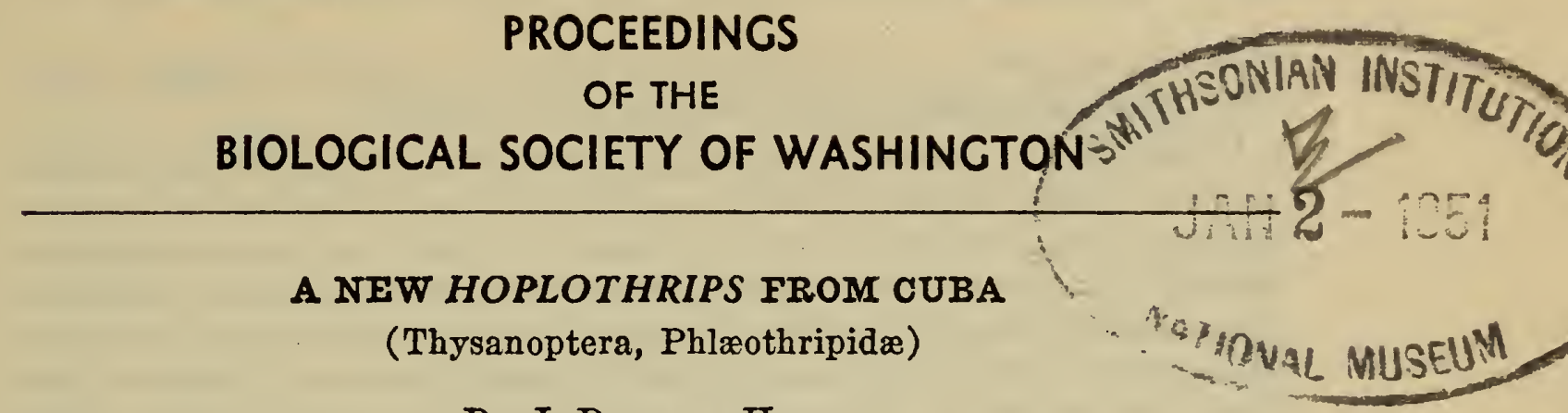

\section{By J. DOUGLas HoOD}

In the Thysanoptera, as in many other insects, the production of a winged form of the species often involves many changes beyond the mere addition of wings. Frequently the coloration and degree of sclerotization are different; always the wing-bearing thoracic segments have a different arrangement of sclerites; almost invariably the prothorax is smaller in long-winged forms; usually the ocelli and eyes are enlarged, and fully formed, though the former may have been wholly wanting in the wingless parents; and often, in thrips, the antennal sense-cones are very different in shape or number, those of the long-winged form tending to be longer, more curved, or more numerous. And this list of differences is far from complete.

When such "variations" are accompanied by deälation, by a progres. sive modification in color as the insect ages, by heterogony or disharmonic growth, and by other effects directly attributable to the action of the environment, we become faced with taxonomic problems whose satisfactory solution depends upon careful field work, difficult rearing experiments, and laborious study of long series of specimens collected under a variety of geographical, ecological, and seasonal conditions. This is the case with most tubuliferous Thysanoptera, including the species described below. From the safe distance lent perhaps by ignorance, the entomologist views with envy the apparently simpler taxonomic problems of other zoologists.

Hoplothrips bradleyi sp. nov.

Figs. 1 and 2

Female, forma macroptera.-Length about $1.1 \mathrm{~mm}$. (distended, about $1.3 \mathrm{~mm}$.). Color nearly uniform brown, with bright, crimson-red internal pigmentation, the tube abruptly bright yellow and narrowly tipped with gray; legs about concolorous with body, with trochanters nearly yellow, femora (especially the fore pair) narrowly yellow at apex, tibiæ (especially the fore pair) yellow or at least paler at base, tarsi perceptibly paler; fore wings pale grayish brown in about apical three-fifths, darkest marginally at tip and in basal portion of anal area, and with a short, narrow, dark vein before middle; antennæ with segment I yellow across base and apex, light brown between, II dull yellow, III dull yellow in about basal third, revuainder of antennæ concolorous with body; major 


\section{Proceedings of the Biological Society of Washington}

setæ light brown, or yellowish brown, most of them with pale, dilated tips, those on segment IX of abdomen nearly yellow.

Head (Fig. 1) about as long as greatest width across cheeks, broadest near middle of latter, where the width is about 1.7 times the distance from eyes to posterior margin of head, the width across eyes approximately equal to the least width just in front of the slightly projecting basal collar; cheeks abruptly but roundly converging to eyes, subparallel or slightly convex in front of middle, slightly concave behind it; head not elevated along median line posteriorly, its dorsal surface nearly smooth, but with a few, faint, dark, anastomosing striæ at base (especially at sides), and with the cheeks very faintly serrate because of short, ventro-lateral striæ extending just onto dorsal surface, the vertex in front of posterior ocelli lightly reticulo-striate; vertex subconical, descending vertically beneath the overhanging median ocellus, with the usual pair of pores and the usual two pairs of minute setæ; postocular setæ dilated at tip, about $46 \mu$ long, $109 \mu$ apart, and $9 \mu$ from eyes; other cephalic setæo minute, slender, pointed, and pale, disposed as shown in Fig. 1. Eyes moderately large for the group, scarcely one-third the length of head, with a few enlarged facets posteriorly, in holotype with dorsal length $50 \mu$, dorsal width $43 \mu$, dorsal interval $46 \mu$, ventral length $55 \mu$, ventral width $44 \mu$, and ventral interval $44 \mu$. Ocelli $16-19 \mu$ in diameter, the median one (when head is horizontal) with its front margin nearly on a line with that of eyes, the posterior ones about $22 \mu$ apart and $16 \mu$ from median ocellus. Antennce typical of the genus, segment VIII pedicellate and lanceolate; sense-cones rather large, that on inner surface of III about $23 \mu$ long, their disposition on inner (and outer) surfaces of segments as follows: III 1 (2), IV 2 (2), V 1 (1), VI 1 (1), VII 1 dorsally. Mouth-cone subconical, rounded at tip, extending about $86 \mu$ beyond posterior dorsal margin of head.

Prothorax with median line of pronotum about 0.56 that of head and contained in the trans-coxal width about 2.9 times, its dorsal sclerites not fused; pronotum smooth, excepting for a few striæ paralleling its sides between the antero-angular and midlateral setæ, and about two along the transverse posterior margin; median apodeme wanting; all usual major setæ present, all of them decidedly knobbed at tip, those of holotype measuring as follows in $\mu$ : antero-marginals 24 , antero-angulars 32 , midlaterals 30, epimerals 45, postero-marginals 45, coxals 37. Pterothorax somewhat broader than prothorax. Wings distinctly tapered apically, the fore pair without accessory fringing hairs on posterior margin, with the two (only) subbasal setæ knobbed at tip and respectively 31 and $40 \mu$ long. Legs normal to the species-group, the fore femora not enlarged, the fore tarsi not toothed.

Abdomen nearly 1.2 times as broad as prothorax across coxæ, its surface smooth excepting for the usual subbasal lines across terga II-VIII and the reticulo-striations on I and IX; I-IX with the usual pair of pores, those on II-VII with accompanying, minute, slender setre behind them, those on VIII and IX with the setæ between. Tube nearly onehalf the length of head, about 1.35 times as long as greatest subbasal width, and about twice as wide near base as at apex, its sides nearly straight, save for a slight concavity just behind the subbasal pores. Major abdominal setae (excepting the wing-retaining ones, the lateral 
pair on segment VIII, those on IX, and the terminal setæ) decidedly dilated at apex; setæ I and II on IX slightly enlarged apically and respectively 67 and $71 \mu$ long, all others mentioned parenthetically above, pointed, seta III on IX about $100 \mu$, terminal setæ about $70 \mu$. ,

Measurements of female (holotypo) in mm.: Length about 1.12 (fully distended, 1.25); head, total length 0.144 , width across eyes 0.132 , greatest width across cheeks (near middle) 0.144 , least width near base (in front of basal collar) 0.128, width across basal collar 0.129 ; prothorax, median length of pronotum 0.080 , width (inclusive of cox») 0.231 ; pterothorax, width across anterior angles 0.238 ; abdomen, greatest width (at segment III) 0.274 ; tube ( $X$, only), length 0.070 , greatest subbasal width 0.052 , least apical width 0.027 .

$\begin{array}{crrrrrrrr}\text { Antennal segments: } & 1 & 2 & 3 & 4 & 5 & 6 & 7 & 8 \\ \text { Length (microns) : } & 30 & 40 & 37 & 40 & 35 & 34 & 31 & 34 \\ \text { Width (microns): } & 27 & 26 & 27 & 28 & 24 & 21 & 20 & 14\end{array}$

Total length of antenna, $0.281 \mathrm{~mm}$.

Female, forma aptera.-Size and color much as in the long-winged form described above. Head longer and more slender; eyes much smaller, especially ventrally; ocelli wanting; antennal segments III-VI each with one sense-cone on inner surface and one on outer; prothorax and $a b$ domen broader, pronotum longer.

Measurements of female (morphotype), in mm.: Length about 1.06 (fully distended, 1.39); head, total length 0.150 , width across eyes 0.111 , greatest width across cheeks 0.136 , least width near base 0.126 , width across basal collar 0.127 ; eyes, dorsal length 0.040 , dorsal width 0.025 , dorsal interval 0.060 , ventral length 0.017 , ventral width 0.022 , ventral interval 0.066 ; postocular setæ, length 0.049 , interval 0.095 , distance from eyes 0.016 ; mouth-cone, length beyond posterior dorsal margin of head 0.080 ; prothorax, median length of pronotum 0.102 , width (inclusive of coxæ) 0.265 ; prothoracic setæ: length of antero-marginals 0.025 , antero-angulars 0.029 , midlaterals 0.027 , epimerals 0.047 , postero-marginals 0.048 , coxals 0.035 ; pterothorax, width across anterior angles 0.249 ; abdomen, greatest width (at segment III) 0.318 ; tube ( $X$, only), length 0.073 , greatest subbasal width 0.057 , least apical width 0.027 ; seta I on IX 0.067 , II $0.067,1110.091$; terminal setæ 0.070 .

$\begin{array}{lrrrrrrrr}\text { Antennal segments: } & 1 & 2 & 3 & 4 & 5 & 6 & 7 & 8 \\ \text { Length (microns) : } & 30 & 40 & 36 & 34 & 36 & 36 & 33 & 36 \\ \text { Width (microns): } & 31 & 27 & 26 & 29 & 26 & 22 & 20 & 15\end{array}$

Total length of antenna, $0.281 \mathrm{~mm}$.

Male, forma aptera.-Length 0.8-1.0 mm. (fully distended, 1.0-1.26 $\mathrm{mm}$.). Color nearly as described for long-winged form of female, differing principally in that segments I and II of antennæ are both dull yellow, with I lightly washed with brownish, and segment IX of the abdomen is much paler than VIII and yellow, or nearly so, apically; in large individuals the head is distinctly paler and more yellowish between and in front of the eyes.

Head variable in form, sculpture, and in the degree of development of the tooth-like projection shown at the anterior end of the cheeks in Fig. 2 ; in small individuals this tooth is wholly wanting, the head is 


\section{Proceedings of the Biological Society of Washington}

about 1.2 times as long as its greatest width near middle of cheeks, and the cheeks themselves are very sparsely and minutely tuberculate, while in large individuals, like the one figured, the tooth is large, the head as much as 1.6 times as long as its greatest width near middle of cheeks, and the cheeks quite closely and roughly tuberculate; sense-cones as in apterous females; ocelli wanting. Prothorax equally variable in form; median apodeme short and weak in small specimens, long and heavy in large ones; major setæ about as in females, excepting that the anteromarginals are minute (about $3 \mu$ ) and pointed; fore legs with femora and tarsal tooth greatly enlarged in large individuals, the femora and tbiæ not toothed in even the largest known specimens.

Measurements of a large male (the allotype), in comparison with those of a small paratype, those of latter in parentheses: Length about 1.00 (0.81), fully distended $1.26(1.00)$; head, total length $0.176(0.134)$, width across eyes $0.107(0.097)$, greatest width across cheeks near middle $0.110(0.109)$, least width near base $0.107(0.100)$, width across basal collar $0.109(0.102)$; eyes, dorsal length $0.036(0.035)$, dorsal width $0.029(0.022)$, dorsal interval 0.050 (0.053), ventral length 0.037 $(0.018)$, ventral width $0.027(0.020)$, ventral interval $0.053(0.057)$; postosular setæ, length $0.048(0.033)$, interval $0.081(0.084)$, distance from eyes $0.020(0.010)$; mouth-cone, length beyond posterior dorsal margin of head $0.087(0.060)$; prothorax, median length of pronotum 0.180 (0.102), greatest width (inclusive of coxæ) 0.297 (0.214); anteromarginal setæ, length $0.003(0.003)$, antero-angulars $0.031(0.026)$, midlaterals $0.024(0.022)$, epimerals $0.033(0.030)$, postero-marginals 0.044 (0.044), coxals $0.039(0.031)$; pterothorax, width across anterior angles, 0.262 (0.200); abdomen, greatest width (at segment II) 0.260 (0.209); tube ( $X$, only), length 0.067 , greatest subbasal width 0.052 , least apical width 0.026 ; seta I on segment IX 0.056 , II 0.037 , III 0.098 ; terminal setæ 0.083 .

$\begin{array}{crrrrrrrl}\text { Antennal segments: } & 1 & 2 & 3 & 4 & 5 & 6 & 7 & 8 \\ \text { Length (microns) : } & 35 & 41 & 40 & 40 & 40 & 37 & 33 & 37 \text {-allotype } \\ & 28 & 36 & 32 & 31 & 31 & 31 & 28 & 34 \text {-paratype } \\ \text { Width (microns) : } & 33 & 27 & 27 & 27 & 25 & 21 & 20 & 14 \text {-allotype } \\ & 27 & 24 & 24 & 24 & 23 & 21 & 19 & 13 \text {-paratype }\end{array}$

Total length of antenna, $0.303(0.251) \mathrm{mm}$.

CUBA: San Miguel de los Baños, Matanzas, July 18, 1940, Dr. J. Chester Bradley, 2 macropterous $q$ 's, 6 apterous females, 14 apterous $\delta$ 's, from dead branches.

PANAMA: Porto Bello, July 9, 1933, J. D. Hood, 1 s, from dead branches [986].

The affinities of this little species, which I have named after my good friend Dr. Bradley, are with tyrannus, aciculatus, flavicauda, and possibly fungosus. The first two of these differ conspicuously in that the submedian pair of pores on abdominal terga II-VII have been replaced by a pair of minute setæ; and the last one, fungosus, described from Formosa, though it agrees with bradleyi in the character of the pores just mentioned, differs sharply in having the antennæ bright yellow in at least the basal portions of segments I-V. The remaining species, flavicauda, widely distributed in Southern and Eastern United States, is 
without doubt the closest relative of bradleyi; but the two are readily separable in both forms of the female sex by the smaller and pointed (instead of knobbed) antero-marginal setæ of flavicauda and, in addition, in macropterous females, by the ratio between the greatest width of the head to the distance of the eyes from the base of the head, the figure being 1.5 for flavicauda and 1.7 for bradleyi.

The males of the two species are very much alike and exhibit a heterogonic range greater than $I$ have seen in any other species. But large males of flavicauda-those with elongated, toothed heads and greatly enlarged fore legs-always have two or three triangular teeth on tho inner surface of the fore femora, near their tip, and a similar fore tibial tooth, while bradleyi has no trace of such structures in any of the material studied. (Compare the figure given by me in Insecutor Inscitiae Menstruus, 2(2):19, Pl. 1, fig. 4, 1914, with Fig. 2 of the present paper.)

[Explanation of figures.]

Hoplothrips bradleyi sp. nov.

Fig. 1. Head and prothorax of macropterous female, holotype; sculpture not shown; all setæ omitted from antennæ and legs.

Fig. 2. Head and prothorax of apterous male, allotype; all setæ and sculpture omitted from antennæ and legs.

[J.D.H., camera lucida.] 

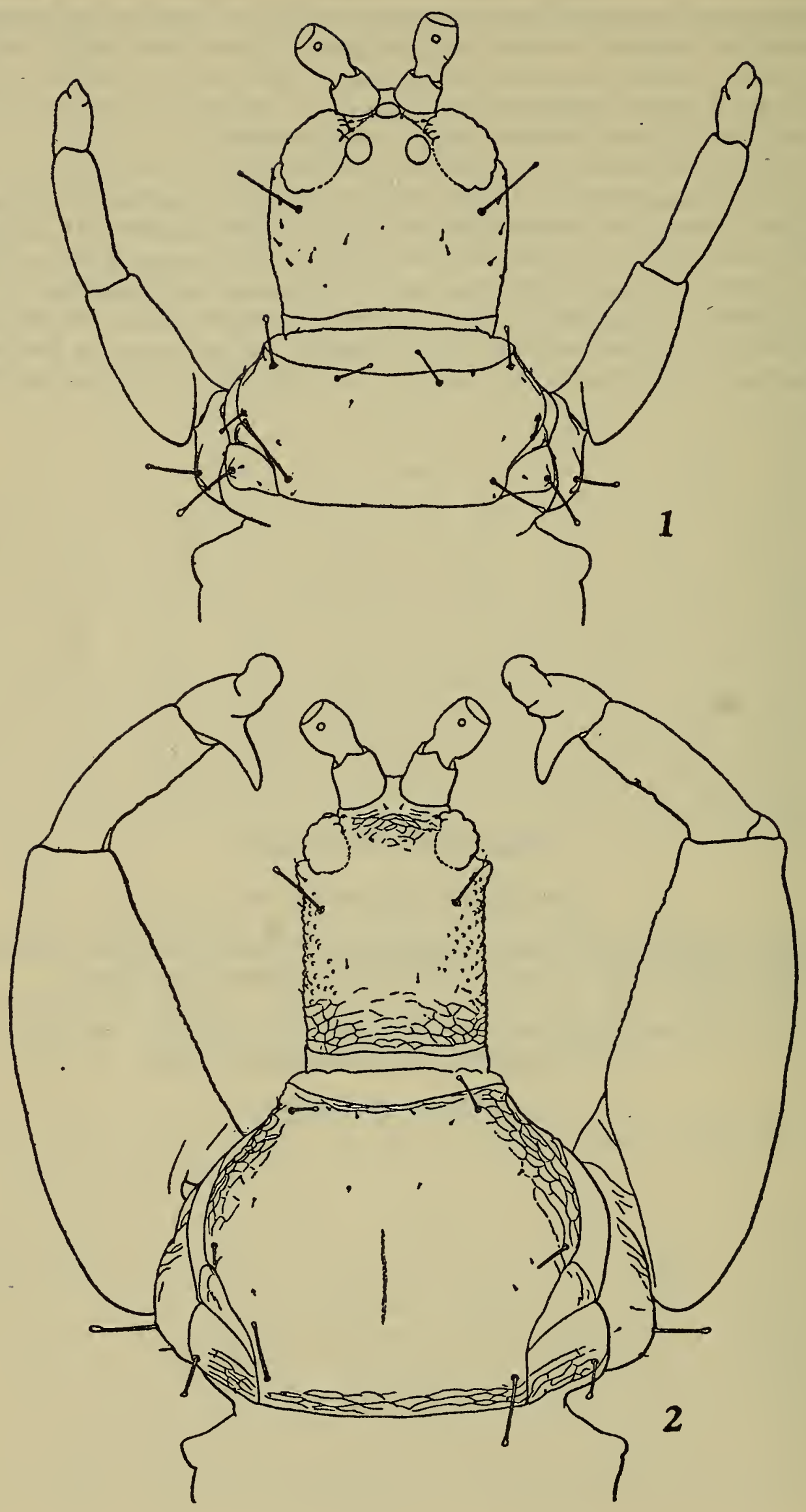
146 Proceedings of the Biological Society of Washington 


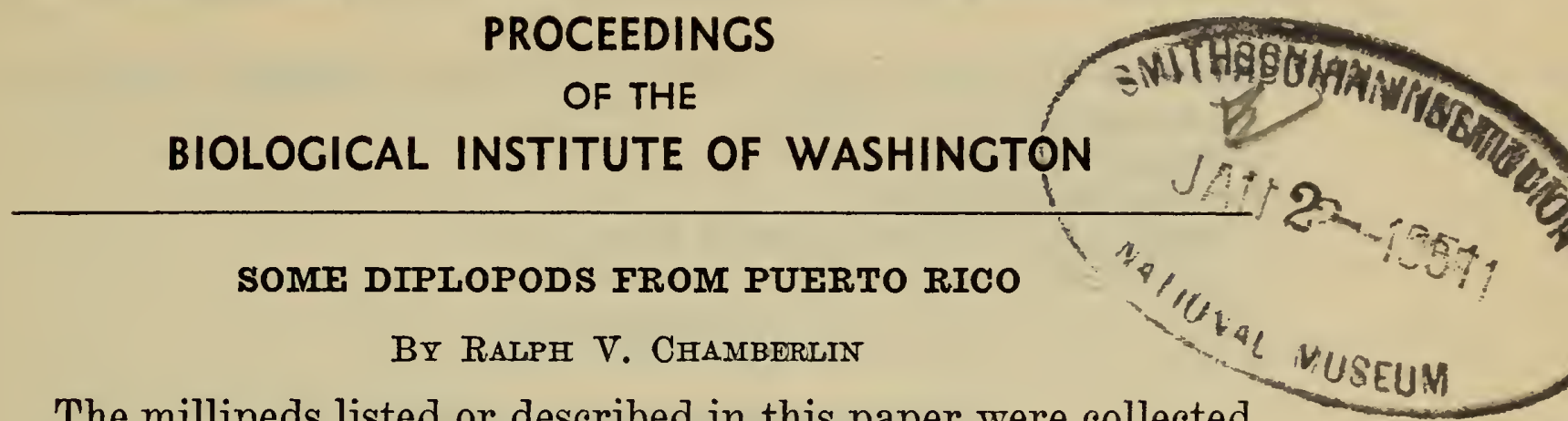

The millipeds listed or described in this paper were collected by J. A. Rivero, of the University of Puerto Rico, aided in some cases by J. B. Ramos and Sr. Maldonado. The collection was turned over to me for identification by Sr. Rivero, who gave me permission to retain types of the new forms in my collection at the University of Utah.

\section{POLYXENIDAE}

\section{Lophoproctus sp.}

\section{Locality.-Villa de Guilarte.}

One specimen $3.5 \mathrm{~mm}$. long (exclusive of setae), too badly rubbed to permit of accurate specific determination, was taken October 9,1949 , by J. A. Rivero and Sr. Maldonado.

\section{GLOMERIDESMIDAE}

\section{Glomeridesmus riveroi, new species}

Description.-A smaller species than any previously reported from the West Indies, the length being mostly near $7.5 \mathrm{~mm}$.

The dorsum is black, with a series of geminate white spots along the middorsal line, and on each side ectad of this a series of single spots and also a submarginal series of spots. Caudal tergite mostly white. Differing from the notably larger $G$. trinidadensis Loomis in having the head blackish over the median area, and whitish or yellowish along the caudal border and lateral and clypeal areas. Antennae dusky over whitish. Legs and ventral surface whitish.

The posterior corners of most of the tergites subrectangular but on the posterior tergites produced into an acute tooth. Differing from $G$. pectinatus, described from El Yunque, P. R., in having the caudal margin of the pleurites smooth, not at all pectinate or setiferous.

Penes of the male of the usual form, extending caudad to the seventh or eighth pair of legs.

Locality.-Toro Negro, Villalba.

Types.-Many specimens taken on October 11, 1946.

Glomeridesmus adjuntus, new species

Description.-Differing in coloration from the preceding species in having the antennae entirely without dusky pigment, and especially in having the lower lateral series of light dots replaced by a continuous, broader, submarginal light stripe.

Posterior margins of pleurites not setose or pectinate. Posterior tergites with inferocaudal corners, produced into a slight acute tooth, 
mesad of which the margin shows a rather narrow concavity, the tooth much smaller than in riveroi.

Length, $7 \mathrm{~mm}$.

Locality.-Adjuntas.

Types.-Four specimens taken in July, 1947.

\section{POLYESMIDAE}

\section{Cryptogonodesmus clarus, new species}

Description.-A much larger form than $C$. rubellus, known from Haiti and Dominica, and $C$. darlingtoni, known from Dominica.

It is brown in color. with head and ventral surface lighter. It differs from $C$. darlingtoni in having the lateral margins of the keels conspicuously dentate, and in having the eaudal corners apparently more acutely and strongly produced.

Tergites with tubercles of middle and posterior rows conspicuously and separately elevated, those of the anterior row less strongly developed. The lateral margins of the non-poriferous keels with three stout setiferous teeth, the poriferous keels with four, in each case counting the acutely produced one at posterior corner. Pores large and definitely dorsal in position, opening at the base of the penult marginal tooth. On caudal margin of keels a conspicuous tooth at proximal end.

Length, $8 \mathrm{~mm}$.

Locality.-Toro Negro, Villalba.

Types.-Three females taken by Rivero and Ramos, October 11, 1946.

\section{CRYPTODESMIDAE}

\section{Tridesmus guilarteus, new species}

Description.-The adult female type has the dorsum essentially black, with antennae and legs yellowish. The dorsum of a young specimen is brown, with keels more yellowish and legs and antennae light yellow to somewhat whitish.

The collum with the typical twelve radiating border areas, with the margin correspondingly weakly scalloped.

The earinae of the following tergites, poriferous as well as nonporiferous, having the lateral border divided into three areas, excepting the fifteenth to nineteenth inclusive in which the border is divided into four areas. On the median dorsal area are four tubercles which cannot properly be called transverse as described by Silvestri for his species portoricensis, nor are those of the anterior pair noticeably larger than the others. In line with the two tubercles on each side the corresponding scallops on the posterior border tend also to be somewhat elevated and tubercle-like, giving thus a series of three tubercles each side of the median line. Laterad from these tubercles on each side are two tubercles of which the anterior is farther laterad than the posterior one. On some of the tergites there is found another tubercle antero-laterad from the two last mentioned.

Length of female holotype, about $8.5 \mathrm{~mm}$.; length of an immature specimen of eighteen segments, $6.7 \mathrm{~mm}$.

Locality.-Villa de Guilarte. 
Types.-One adult female and one immature specimen taken October 9,1948 , by Maldonado and Rivero.

Remartcs.-This species differs from portoricensis in having the keels of the fifth segment three- instead of two-lobed, and seemingly in the form and development of the dorsal tubercles. It also appears from Silvestri's statement that portoricensis has keels sixteen to nineteen fourlobed, with the fifteenth not four-lobed as in the present species. Cook's note on sectilis, the generotype, is too brief and general in character to permit significant comparison.

\section{Iomus recentus, new species}

Description.-The collum differing from that of $I$. incisus Cook, the generotype, in being distinctly, though only slightly, scalloped, not with a single notch near each lateral corner as indicated for incisus. In this respect recentus agrees with the much larger I. platanus, but differs from the latter in having the four dorsal rows of tubercles equidistant, in. stead of having the two more median rows distinctly nearer to each other than to the lateral rows.

A peculiarity in the color pattern, not mentioned in the published descriptions of the other species, is that the basal portion of the under surface of the keels, with adjacent portion of the sides, remain light or colorless, leaving a longitudinal black stripe ectad of the bases of the legs. The entire ventral surface of the first four keels black, but this color not extending across sternite of the first segment as described for incisus, the color, however, running across the caudal border of the third segment.

Length, $7.5 \mathrm{~mm}$; width, $2 \mathrm{~mm}$.

Locality.-Toro Negro, Villalba.

Type.-One adult female taken by Rivero and Ramos, October 11, 1946.

Remarles.-Smaller form than species previously described.

\section{Genus LIOMUS, new}

Description.-A genus near Iomus in general form and structure, similarly broad and widely rounded at the ends. It differs in having the incisions between the lobes of the keels narrower, with marginal opening often showing the lobes in contact or nearly so, the lobes themselves truncate rather than rounded. Incisions of anterior border shallower and less pronounced. A conspicuous difference from Iomus is the lack of definite series of dorsal tubercles, represented only on the nineteenth tergite by a pair of low ridges.

Generotype.-Liomus albanus, new species.

\section{Liomus albanus, new species}

Description.-Dorsum variegated with brown and light brown or yellowish; a light median dorsal stripe bisected by a dark, often deltoid, darker mark on each tergite; the sides of dorsum brown, broken by lighter spots or areas; the keels lighter brown, with margins of incisions blackish from accumulated dirt. Ventral surface light, darker and brownish just outside the bases of legs. Head dark brown over the vertex, but white elsewhere. Antennae and legs white.

Antennae geniculate between the third and fourth joints; fifth article 


\section{Proceedings of the Biological Society of Washington}

abruptly crassate, much thicker than fourth, sixth, and seventh articles.

Collum with anterior margin evenly convex, the border showing ten long, radiating areas, but the margin with corresponding dividing notches scarcely or not at all evident; convex dorsal surface showing some slightly elevated or weakly separated areas, of which there are four in front of caudal margin and six in front and laterad of these, the lateral areas larger than the median.

Keels of the second tergite with lateral margins continuing evenly the curve of the collum as shown in fig. 1, which also shows the features of the lobes. Full width of tergites attained at the fifth segment. The features of the keels of the middle segments are indicated in fig. 2, representing the keel of the eighth segment.

Gonopods of the male as shown in fig. 3.

Length of the female allotype, $8 \mathrm{~mm}$., width, $2 \mathrm{~mm}$., the male a little smaller.

Localities.-Toro Negro, Villalba.

Maricao Insular Forest. One adult female and two young specimens taken September 25, 1948.

Ajuntas. A female differing from the other specimens in not having the median dorsal stripe geminate except at anterior and posterior ends.

Types.-Six specimens, including one adult male, taken October 11, by Rivero and Ramos.

Liomus obscurus, new species

Description.-A smaller form than albanus, from which it seems to differ conspicuously in lacking the median dorsal germinate light stripe; the brown coloration extending over the entire dorsal area between the lateral light areas.

The sixth article of the antennae is thicker relatively to the fifth than in albanus.

The collum differs in having the margin weakly, but more definitely, scalloped than in the other form.

Length, $6.2 \mathrm{~mm}$; width, $1.5 \mathrm{~mm}$.

Locality.-Maricao Insular Forest.

Type.-One female taken September 25, 1948.

\section{RHINOCRIDAE \\ Rhinocricus arboreus (Saussure)}

Julus arboreus Saussure, 1859, Linn. Ent., Vol. 13, p. 331; 1860, Mem. Mex. Myr., p. 98, fig. 28.

Spirobolus (Rhinocricus) arboreus Karsch, 1881, Zeit. Naturwiss., ser. 3 , vol. 6, p. 8 .

Rhinocricus arboreus Pocock, 1894, Journ. Linn. Soc., vol. 24, p. 493, pl. 38, fig. 4 .

Locality.-Maricao Insular Forest. One female taken September 25, 1948.

\section{SPIROBOLIDAE}

Microspirobolus insularis Silvestri

Microspirobolus insularis Silvestri, 1908, Bull. Amer. Museum Nat. Hist., vol. 24, p. 572, fig. VII, 1 and 2. 
Locality.-Adjuntas. One female taken in July, 1947. Maricao Insular Forest. One female taken September 23, 1948.

\section{Microspirobolus marmoratus Silvestri}

Microspirobolus marmoratus Silvestri, 1908, Bull. Amer. Mus. Nat. Hist., vol. 24, p. 57, figs. VI, 1-6.

Locality.-Toro Negro, Villalba. Two specimens taken October 11, 1946, by Rivero and Ramos.

\section{Microspirobolus mediolus, new species}

Description.-Body in general black. Antennae brown, legs reddish brown to clearer red.

Head smooth, the median sulcus distinct across vertex, then interrupted between antennae as usual and then deeply impressed down to labral margin. Clypal foveolae 4-4. Eyes composed of about 24 conspicuously developed ocelli.

Collum extended below on a level with the second tergite, the lower end free; smooth, the lower margining sulcus extending up the anterior side to the level of the eye.

Subsequent tergites with the segmental sulcus distinctly impressed and smooth throughout; tergites smooth dorsally and laterally, the metazonites crossed beneath with the usual series of deep longitudinal striae. Repugnatorial pores conspieuous, located far behind the sulcus and closer to the caudal margin than to the sulcus.

Anal tergite smooth, caudally rounded, exceeded by the valves. Valves smooth, their inner borders rounded, not compressed or elevated.

Coxae of third to sixth pairs of legs compressed and produced.

Gonopods of male as shown in figs. 4 and 5 .

Length, about $31 \mathrm{~mm}$; width, $3 \mathrm{~mm}$.

Locality.-Maricao Insular Forest.

Type.-One male taken September 25, 1948.

\section{Microspirobolus toronus, new species}

Description.-A much smaller form than the preceding, and lighter in its general color, which is light olive, darker in a caudal band or annulus. Antennae light brown, and the legs brick red. Anal scutum and valves black.

Head smooth. Median sulcus lightly impressed across vertex and deep down lower region as usual. Clypeal foveolae 3-3. Eyes well developed, composed of about 24 ocelli arranged in 5 transverse series.

Lower end of collum nearly straight or subtruncate; margining sulcus as usual.

The other tergites with an encircling furrow or culcus which is crossed by a series of short, rather coarse, longitudinal striae. The pore located midway between this sulcus and the caudal margin and lying upon a faint, pale encircling sutural line.

Anal scutum rounded behind, slightly exceeded by the valves which are smooth and evenly rounded, not at all compressed.

Coxae of third to sixth legs of male enlarged and compressed. Gonopods as shown in figs. 6 and 7.

Number of segments, 50 .

Length, $24 \mathrm{~mm}$; width, $2 \mathrm{~mm}$. 
Locality.-Toro Negro.

Type.-One male, taken October 11, 1946, by J. A. Rivero and J. B. Ramos. Distinguished from other species by size, sculpturing of tergites, clypeal foveolae, and details of gonopods.

\section{STEMMIULIDAE \\ Diopsiulus compressus (Karsch)}

Stemmiulus compressus Karsch, 1881, Zeits. Naturwiss., ser. 3, vol. 6, p. 11 ; Pocock, 1894, Journ. Linn. Soc. London, p. 478.

Diopsiulus compressus Silvestri, 1908, Bull. Amer. Mus. Nat. Hist., vol. 24, p. 566, figs. II, 1-8.

Locality.-Toro Negro, Villalba. Several females taken by J. A. Rivero and J. B. Ramos.

\section{Explanation of Figures}

1. Liomus albanus $\mathrm{n}$. sp. Right half of collum and right keels of tergites 2,3 and 4.

2. Liomus albanus $\mathrm{n}$. sp. Right keel of eighth segment.

3. Liomus albanus n. sp. Left gonopod, anterior view.

4. Microspirobolus mediolus $\mathrm{n}$. sp. Right anterior gonopod. and sternite.

5. Microspirobolus mediolus n. sp. Posterior gonopod.

6. Microspirobolus toronus $\mathrm{n}$. sp. Left anterior gonopod and sternite.

7. Microspirobolus toronus n. sp. Posterior gonopod. 

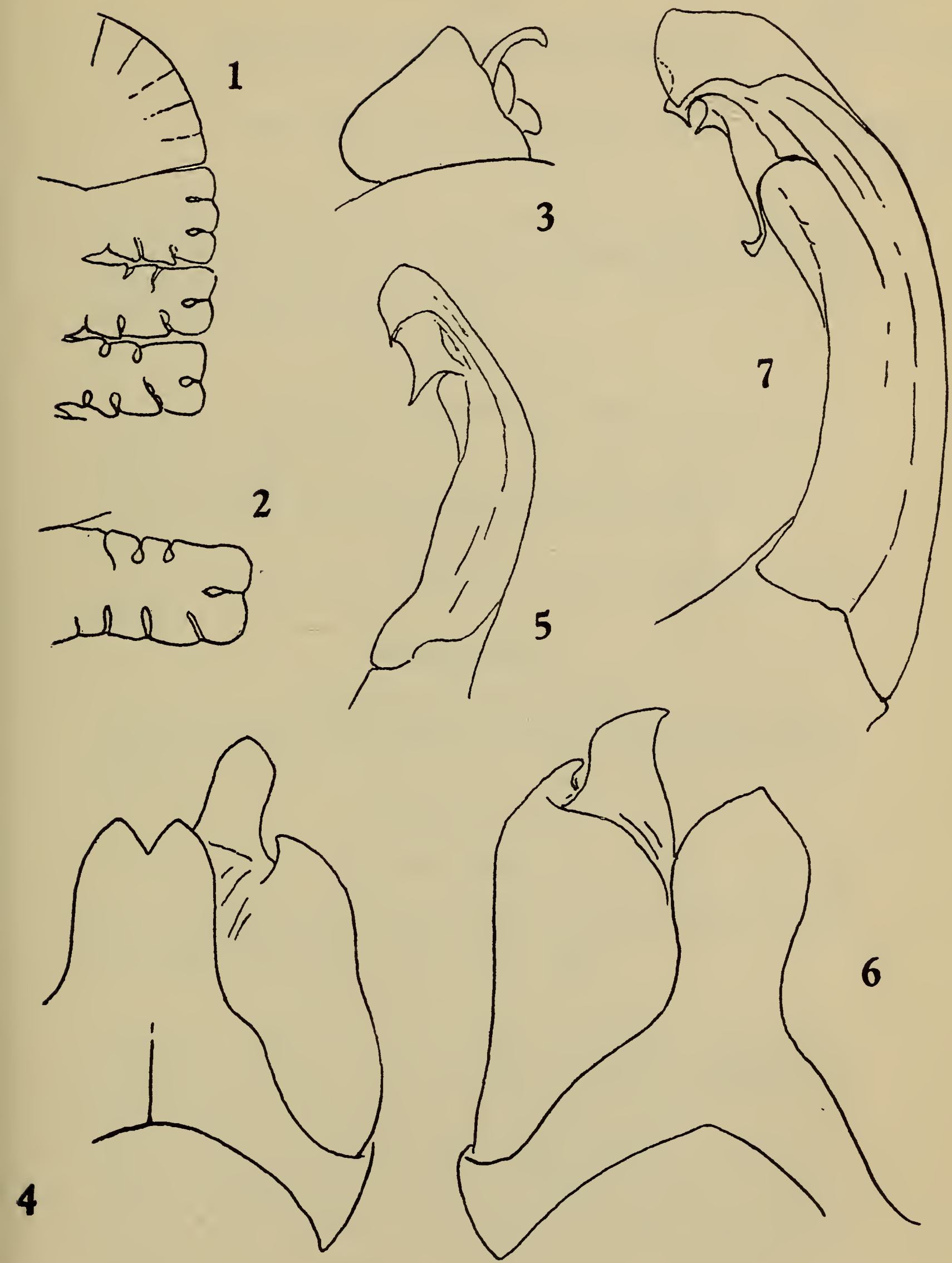
154 Proceedings of the Biological Society of Washington 
PROCEEDINCS OF THE

BIOLOGICAL SOCIETY OF WASHINCTON

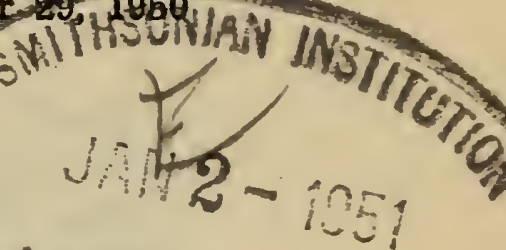

SOME CHILOPODS FROM PUERTO RICO

By RaLph V. Chamberdin

The notes and diagnoses here presented are based upon material collected and sent to me for identification by J. A. Rivero of the University of Puerto Rico. Types of the new species are retained by the author.

\section{SCOLOPENDRIDAE}

\section{Otocryptops melanostomus (Newport)}

Localities.-Toro Negro, Villalba, several partly grown specimens taken Oct. 11, 1946.

Maricao Insular Forest, young specimens taken Sept. 25, 1948.

Gilla de Guilarte, two young specimens taken Oct. 9, 1948.

\section{Newportia sp.}

Locality.-Maricao Insular Forest, one specimen which has lost the anal legs.

\section{OTOSTIGMIDAE}

\section{Otostigmus caraibicus Kraepelin}

Locality.-Maricao Insular Forest, one specimen taken Sept. 25, 1948. This species was previously known only from St. Thomas, the type locality.

\section{SCHENDYLIDAE}

Genus Schendylota, new

Agreeing in general structure with Schendylurus, but the anal legs shorter, the ultimate segment being reduced to a tubercle instead of having the elongate form typical of the latter genus.

Generotype.-Schendylota varipicta, new species.

\section{Schendylota varipicta, new species}

Description.-When in full color, yellow with a median geminate black band along the dorsum, this most distinct posteriorly, together with dusky blotches on the sides of the body and borders of the sternites; but in some specimens the pigment is partly or wholly absent.

Cephalic plate longer than broad, narrowing moderately caudad; overlapping the basal plate which is wide. Antennae filiform.

Claws of prehensors when closed not surpassing the anterior margin of the head; joints of prehensors all unarmed. Prosternum without chitinous lines.

Ventral pores in a subcircular area behind middle of plate, this area not sharply defined. Anterior sternites each with its posterior margin 
angularly produced at middle, the process fitting into a pocket in anterior border of succeeding plate.

Pairs of legs in male, 39. Anal legs strongly swollen, except the terminal, clawless article which is abruptly much reduced, tubercle-like, a total of six articles beyond the coxa.

Last ventral plate very broad, widely rounded behind. Two large coxal pits on each side covered by sides of sternite.

Length, $14 \mathrm{~mm}$.

Labrum widely and evenly concave, the margin armed with a series of stout, conical teeth, about ten in number, the lateral ones shorter, more rounded; later margins smooth or wavy. Inner branch of first maxillae with apical portion slenderly conical; outer branch long, biarticulate, arching over and meeting in front of inner branches, apex with a smooth, rounded lobe. Claws of palpus of second maxillae pectinate; pleurite not fused laterally with the coxosternum, within touching and partly covering the pore.

Localities.-Gilla de Guilarte, one male taken Oct. 9 by Rivero and G. Maldonado.

Adjuntas, one specimen taken in July, 1947.

Mariaco National Forest, two specimens taken Sept. 25, 1948.

Differing from known species of schendylurus in the small number of pairs of legs, in the great reduction of the last article of the anal legs, and in the typical presence of a pigmentation suggesting that of $\mathrm{Nan}$ nophilus melanostictus (Attems).

\section{Genus Portoricellus, new}

Characterized especially by having the coxae of the first maxillae free, not fused with each other at the middle line, and in having the telopodite of the anal legs composed of only five articles, with no trace of a praetarsus. Labrum incurved and armed with stout, separately rooted teeth. Ventral pores absent. Coxal pores homogeneous, 2-2.

Generotype.-Portoricellus mundus, new species.

Like Nannopodellus of the Galapagos Is. in the five-jointed telopodite of the anal legs, but readily distinguished, e.g., in lacking the strong serration on inner margin of claws or prehensors.

\section{Portoricellus mundus, new species}

Description.-Cephalic plate with sides widely convex; the posterior margin slightly convex, the anterior margin more strongly so.

Labrum widely and evenly concave, bearing some 16 or more stout conical teeth. The coxae of first maxillae not fused at middle, their inner margins well sclerotized. Claws of second maxillae large, pectinate.

Prehensors short, covered by cephalic plate; joints unarmed; claws slender. Prosternum without chitinous lines, its anterior margin concave or forming an obtuse reentrant angle.

Coxal pores homogeneous, two on each side.

Telopodite of anal legs composed of five joints; in the male conspicuously crassate, the terminal joint conically pointed.

Pairs of legs, 45.

Length, $12 \mathrm{~mm}$.

Locality.-Ajuntas. One male taken in July, 1947. 


\section{Genus Algunguis, new}

Related to Pectiniunguis in having the single large gland of each anal coxa heterogeneous or compound, but differing in having the anal legs with well developed claws.

Generotype.-Algunguis toronus, new species.

\section{Algunguis toronus, new species}

Description.-Cephalic plate short, broadest behind, narrowly rounded anteriorly; caudal margin truncate; overlapping the broad basal plate. Antennae filiform.

Labrum with margin convex at middle and laterally concave, the convex arc bearing six stout, conical teeth of which the medians are largest. Claws of palpi or second maxillae pectinate as usual; pleurite not fused with cozosternum.

Last ventral plate broad, somewhat semicircularly rounded behind. Each anal coxa presenting two large pits into which the simple glands or branches open. Anal legs with telopodite composed of six articles and ending in a distinct claw.

Pairs of legs of female, 69.

Length, about $30 \mathrm{~mm}$.

Locality.-Toro Negro, Villalba. One female taken October 11, by Rivero and Ramos.

\section{BALLOPHILIDAE}

\section{Ballophilus riveroi, new species}

Description.-Color pale throughout, no green or dark pigment evident in the preserved type.

Head small, broader than long. Antennae rather short, the joints much shorter than, e.g., in the species of Claviphilus and Ityphilus here listed; enlarged distal portion broad and somewhat flattended.

Body strongly constricted behind the first segment.

Ventral pores in a mostly subcircular area which is not sharply defined or elevated, the area sometimes somewhat wider transversely and sometimes longer than wide; the four last sternites apparently lacking pores.

The last ventral plate subtrapeziform, but the sides and caudal margin a little convex. Coxal pores 2-2, homogeneous.

Anal legs strongly crassate and of the usual form.

Pairs of legs 49-51.

Length, about $12 \mathrm{~mm}$.

Locality.-Adjuntas. Seven specimens taken in July, 1947, by J. A. Rivero.

This is the first species of the genus to be reported from the Western Hemisphere.

\section{Genus Clavophilus new}

Like Tanophilus in having only a single pore on each anal coxa, but the corresponding gland simple, homogeneous instead of consisting of several simple glands opening into the larger pit. Ventral pores more diffuse, the area large and neither elevated nor sharply limited. Prosternum of prehensors with chitinous lines complete and strongly marked. An- 


\section{8}

tennae geniculate, distally clavate. Anal legs much swollen, their telopodite with tarsus biarticulate and lacking a claw.

Generotype.-Clavophilus maricaonus, new species.

Clavophilus maricaonus, new species

Description.-Cephalic plate anteriorly semicircularly rounded, about equal in length and breadth. Antennae thickened as usual beyond the middle, the distal portion eylindrical, of nearly same width throughout.

Prehensors small, completely covered by head, much short of attain. ing anterior margin of latter. Prosternum with chitinous lines strongly developed and complete.

Dorsal plates strongly bisuleate.

Last ventral plate trapeziform, moderately narrowed caudad. Anal coxas each with one large, homogeneous pore almost completely covered by the sternite. Anal legs strongly crassate proximally, tapering distad, the terminal joint elongate conical.

Pairs of legs, 89.

Length, 20-24 $\mathrm{mm}$.

Locality.-Maricao Insular Forest. Two specimens taken September $25,1948$.

\section{Ityphilus lilacinus Cook}

Locality.-Maricao Insular Forest. One specimen apparently this species was taken by Mr. Rivero on September 25, 1948. The species was previously known only from the type locality, Sugar Loaf Key, Florida.

\section{ORYIDAE}

\section{Notiphilides erga, new species}

Description.-Cephalic plate less than three fourths as long as broad behind, strongly narrowed forward. Antennae with joints short and broad.

In agreement with the other known species of the genus in having the claws of the second maxillae pectinate.

Prehensors of the usual proportions. The basal plate a little shorter than the first dorsal plate.

The dorsal plates smooth throughout, not roughened as in maximiliani, at most but moderately uneven, lacking sulci or corresponding pits or these but vaguely indicated.

As usual, the spiraculiferous sclerite fused with the prescutelum, with three rows of suprascutella in the middle region, a single row anteriorly. Suprascutella of upper two rows single sclerites extending the full length of the segment, the sclerites of the lower series also single on each segment, this sclerite extending from caudal end to the prescutellum.

Last segment with sternite, coxae and telopodites of legs of the usual form.

Pairs of legs, 111.

Localtiy.-Gilla de Guilarte. One specimen taken October 9, 1948, by Biaggi and Rivero.

This species differs from maximiliani in having the lower suprascutellum undivided and completely separating the spiracular plate from the middle scutellum as well as in the larger number of legs,-111 pairs as against a maximum of 99 . 


\section{SOGONIDAE}

\section{Genus Portoricona, new}

Labrum entire, apparently fused with the clypeus at middle; caudal margin mesally convex and armed with stout teeth, laterally not fringed. Clypeus with a single median foveola. Coxae of first maxillae fused at middle; outer branch or palpus biarticulate, with a lappet. Second maxillae broadly connected at middle; claw of palpus smooth; chitinous pleurosternal suture not evident. Prosternum of prehensors with complete chitinous lines; claw armed at base, other joints unarmed. Anterior sternites each with a deep, broadly $v$-shaped impression. Coxal pores of anal segment several on each side, all free from sternite. Last legs with a well developed claw.

Generotype.-Portoricona adjunta, new species.

Among genera of the Sogonidae nearest to the Mexican Nuevona, with which it agrees in having several pores on the coxa of the anal legs. It differs from Nuevona in having a well-developed tooth at the base of claw of the prehensors, in having a single clypeal area instead of two, in lacking the conspicuous band of pres on caudal border of sternites, and in the narrower last ventral plate with more numerous pores on the adjacent last coxae.

\section{Portoricona adjunta, new species}

Description.-Cephalic plate longer than broad and narrower in front than behind; frontal suture absent. A single median clypeal area. Labrum strongly protruding at middle where its convex margin is armed with four stout, conical teeth of which the two medians are much largest; margin ectad of these teeth at most wavy but neither toothes nor pectinate. Lappet on first joint of palpus of first maxillae well developed.

Prebasal plate a little exposed at middle. Prosternum unarmed; first joints of prehensors unarmed; tooth at base of claw conspicuous, conical, black. Claws of prehensors when closed surpassing the head in front.

Impression on anterior sternites widely V-shaped, with angle somewhat rounded.

Spiracles all circular, the first one moderately enlarged.

Last ventral plate as wide anteriorly as the penult sternite at its posterior border, strongly narrowed caudad, rounded at end; coxal pores small, about 15 on each side, all free from the sternite. Anal legs crassate in the male.

Pairs of legs in female, 41 ; in male, 39.

Locality.-Adjuntas. Two females and a male taken in July, 1947.

\section{Portoricona socia, new species}

Description.-Color yellow, the legs paler.

The cephalic plate longer than broad, the sides straight between the oblique corners. Frontal suture absent. Prebasal plate exposed.

Mouthparts in general as in adjunta.

Claws of prehensors when closed extending well beyond the front margin of head; chitinous lines of prosternum moderately distinct; claw of prehensors armed at base with a small black tooth, the other joints unarmed.

Spiracles all circular. 


\section{Proceedings of the Biological Society of Washington}

Sternal impressions rather weak, evenly curved, not angled at middle. Last ventral plate narrowing caudad, the posterior margin rounded. Coxal pores small, free, present ventrally and laterally.

Pairs of legs, 51-53.

Length, about $20 \mathrm{~mm}$.

Locality.-Guánica Insular Forest. Two adult and three partly grown specimens.

Most readily separated from the preceding species in having the legs more numerous,-51-53 pairs as against 39-41. 
Chamberlin-Chilopods from Puerto Rico 
162 Proceedings of the Biological Society of Washington 


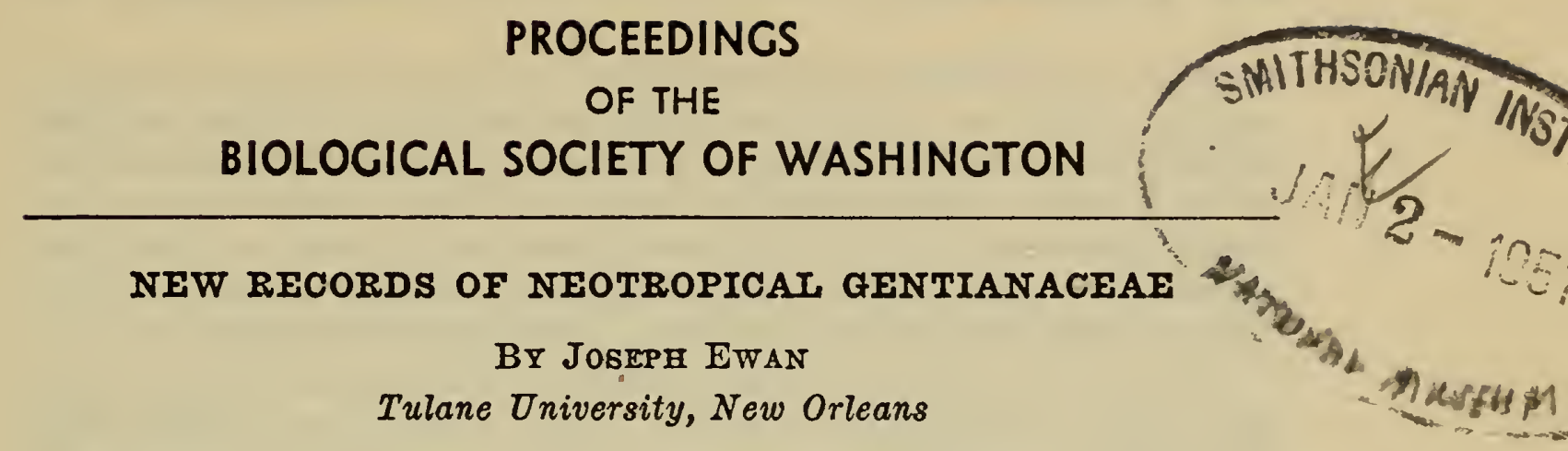

Miscellaneous notes on an undescribed species, nomenclatural transfers, and notable records in the four genera lisianthus, Macrocarpaea, Pagaea, and Symbolanthus constitute this short paper.

\section{LISIANTHUS}

1. Lisianthus arcuatus Perk., Engl. Bot. Jahrb. 31: 492. 1902.

With the discovery of this species in the lower Magdalena River region of Colombia by Oscar Haught (no. 4652; US), the genus Lisianthus, sensu stricto, may be reported for the South American continent. The taxonomy of the genus is poorly understood, chiefly for want of a broad systematic approach not confined to national boundaries, rather than a narrow geographic survey of a few species. It seems likely that Lisianthus seemannii (Griseb.) O. Kuntze1, based on H. Seemann 1064, Dec. 1847, from Piñas, Darien, Panama-locality corrected over "El Equa. dor"-represents the same species, judging from a photograph (MO) of the type in the Hooker Herbarium at Kew.

\section{MACROCARPAEA}

\section{Macrocarpaea affinis sp. nov.}

Shrub or small tree $2 \mathrm{~m}$. high; upper stems terete or subterete, sparingly leafy up to the panicle; leaves lanceolate, tapering to a subcuneate base and acuminate at apex, scarcely revolute, dark olive green above, paler beneath, the midrib and secondary veins impressed above, prominent, puberulent beneath with short curling hairs, the blades $15-19 \mathrm{~cm}$. long, $7-9 \mathrm{~cm}$. wide, the petioles $2.5-3 \mathrm{~cm}$. long, united by their bases into a collar-like ring; panicle ample, 16- to 20-flowered, the flowers greenishyellow, borne on arcuately spreading pedicels $2.0-3.5 \mathrm{~cm}$. long; calyx shortly and broadly campanulate $9.11 \mathrm{~mm}$. long, the lobes triangular, acute, but little overlapping, scarious-translucent or suberosulate, $4 \mathrm{~mm}$. long; corolla narrow campanulate, $40-45 \mathrm{~mm}$. long, eylindrical to summit of ovary, then gibbously flaring, the lobes ovate, $10-11 \mathrm{~mm}$. long, the two lateral lobes abruptly acuminate from a broadly triangular base; style and stamens included at anthesis but early exserted; immature capsule slender ovoid, glabrous, $20-22 \mathrm{~mm}$. long exclusive of stout persistent style; seeds unknown.

Frutex, parte superiore caulis subtereti laevi; foliis lanceolatis, acuminatis at subcuneatis margine vix revolutis, $15-19 \mathrm{~cm}$. longis, $7-9 \mathrm{~cm}$. lats, supra saturate viridibus, subtus pallidioribus, utrinque glabris sed

${ }^{1}$ Lisianthus seemannii (Griseb.) 0. Kuntze, Rev. Gen. Pl. 2: 429. 1891. 
costa et venis secondariis subtus manifestis puberulentibus, petiolis prominentibus, $2.5-3 \mathrm{~cm}$. longis, confluentibus ad basim similiter annulis; paniculis 16-20 floribus; floribus prominenter pedicellis, viridi-flavibus; calyce breviter lato-campanulato, $9-11 \mathrm{~mm}$. longo, lobis triangularibus, acutis, patentibus, $4 \mathrm{~mm}$. longis; corolla angusto-campanulata, $40-45 \mathrm{~mm}$. longis, lobis ovatis, 10-11 longis; stylo post anthesin exserto; capsula immatura angusto-ovoidea $20-22 \mathrm{~mm}$. longa; seminibus ignotis.

Type collected on old road between Sucre and Bolívar, 1,900-2,000 meters, Dept. of Santander, Colombia, August 7, 1949, by Lorenzo Oribe Uribe 1991 (type, US).

Compared with the two other Colombian Macrocarpaeae native to the Department of Santander, $M$. macrophylla and $M$. polyantha, this new species is most closely related to the former. Macrocarpaea affinis differs from $M$. macrophylla, however, in its petiolate acuminate leaves; its larger corollas with longer corolla lobes, and persistent style. In fact, $M$. affinis will key out ${ }^{2}$ on the basis of some of these characters to M. valerii, a Costa Rican species related to the Colombian $M$. macrophylla. Macrocarpaea affinis differs from $M$. valerii, on the other hand, in its much larger, longer, petiolate leaves, and larger corollas $(40-45 \mathrm{~mm}$. long; $25-35 \mathrm{~mm}$. long in $M$. valerii). The stigma in $M$. affinis is distinctly bilamellate-clavate; in $M$. valerii, clavate-thickened. Macrocarpaea affinis is a member of Section Tabacifoliae.

I am grateful to Señor Uribe for the opportunity to study this collection. I appreciate the assistance of Dr. G. W. Regenos of this University in preparing the Latin description.

3. Macrocarpaea arborea (Britton) Ewan, U. S. Nat. Herb. Contr. 29: 221. plate 1. 1948.

Chelonanthus arboreus Britton, Bull. Dept. Agric. Trin. \& Tob. 19: 230. 1922.

A synonym to be added is:

Lisianthus brittonii Williams \& Cheesm., Fl. Trin. \& Tob. 2: 183. 1947 , based on the last.

\section{Macrocarpaea sp.}

There is a collection provisionally labelled Macrocarpaea thamnoides in the New York Garden Botanical Herbarium, made at Santa Cruz, Trinidad, B. W. I., by J. Dannouse in 1904, which should be noticed. I did not refer to it in my revision of the genus (1948) 2 because the specimen was only in bud and different in certain morphological characters from any known Macrocarpaea. However, since Williams and Cheesman, in their account of the Gentianaceae of Trinidad and Tobago (1947) ${ }^{3}$, make no reference to such a specimen, it seems desirable to call attention to this curious collection in the hope that field botanists may watch for an anomalous Macrocarpaea in Trinidad.

Whereas Macrocarpaea thamnoides has the upper floral leaves reduced, in this Dannouse collection they are remarkably large $(20 \mathrm{~cm}$. long $x$ 7-8 cm. wide), petiolate and firm-coriaceous. The unopened corolla

2Ewan, J. Revision of Macrocarpaea, a neotropical genus of shrubby gentians. Contr. U. S. Nat. Herb. 29, 203-251. 5 pls. 1948.

WWilliams, R. O. and E. E. Cheesman, Flora of Trinidad and Tobago 2: [Gen. tianaceae] 179-184. Sept. 1947. 
suggests that the plant may prove to be a large flowered species, if, indeed, it proves to be of the genus Macrocarpaea.

The locality "Santa Cruz" is a village in a valley of Trinidad's Northern Range, five miles northeast of Port-of-Spain, and doubtless refers more precisely to the forests on the sides of the valley. Dr. John Beard informs me that Dannouse is a well-known Trinidad collector and there are many sheets taken by him in the Trinidad herbarium. $\mathrm{He}$ was a paid collector, supported, he believes, by W[alter]. E[lias]. Broadway (1863-1935), but certainly was not a trained botanist. Nevertheless he collected energetically, finding some very rare species, a number of which have not been collected by others. Most of his specimens have the vague locality "Arima," a town 16 miles east of Port-of-Spain. Since he was a paid collector, there is always the suspicion that he got some of his specimens elsewhere, but this is unlikely.

\section{$P A G A E A$}

5. Pagaea ramosissima (Benth.) Ewan, comb. nov.

Lisianthus ramosissimus Benth. in Hook. Journ. Bot. \& Kew Misc. 6: 200. 1854, based on $R$. Schomburgk 989 from the Rio Negro.

Helia ramosissima (Benth.) O. Ktze., Rev. Gen. Pl. 2: 428. 1891.

No Lisianthus collection from the Rio Negro is mentioned among the species listed in Richard Schomburgk's Reisen in Britisch-Guiana 3: 955-956, 1848, which was based on the explorations of the brothers Robert and Richard Schomburgk between 1840 and 1844 on the British Guiana-Venezuela Boundary Survey. Though no identifying date or other notation accompanies the first description, A. C. Smith suggests that the type was taken by Robert Schomburgk during his earlier survey of British Guiana for the Geographical Society of London, between 1835 and 1839, when he crossed into northernmost Brazil to the Rio Branco and the Rio Casiquiare of Venezuela.

\section{SYMBOLANTHUS}

6. Symbolanthus macranthus (Benth.) Ewan, comb. nov.

Lisianthus macranthus Benth., Pl. Hartw. 144. 1844 (Type: Loxa, Ecuador, Hartweg 799).

Helia macrantha (Benth.) O. Ktze., Rev. Gen. Pl. 2: 428. 1891.

Representative collection:

Ecuador: Carchi Prov.: Mexia 7562.

7. Symbolanthus nerioides (Griseb.) Ewan, comb. nov.

Lisianthus nerioides Griseb., Linnaea 22: 39. 1849 (Type: Las Lagunetas, State of Merida, Venezuela, Moritz 1189).

Helia nerio[i]des (Griseb.) O. Ktze., Rev. Gen. Pl. 2: 428. 1891. 
166 Proceedings of the Biological Society of Washington 


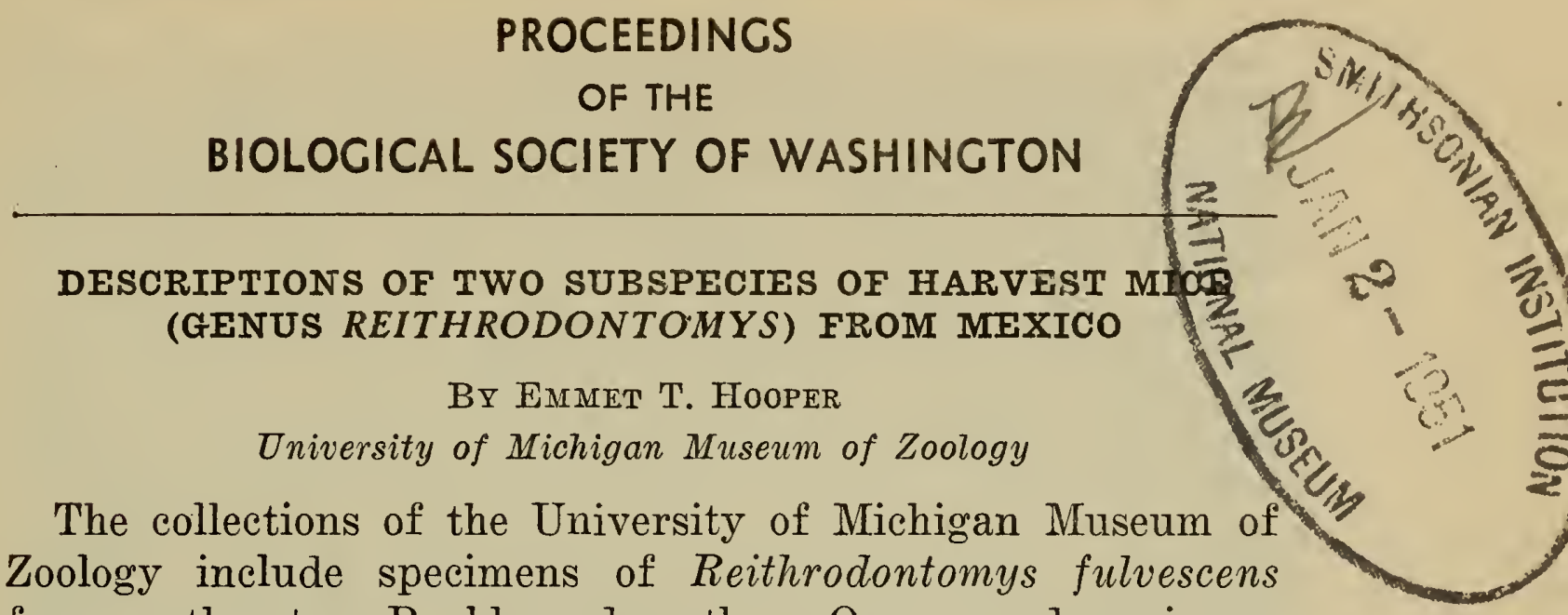
from southeastern Puebla and northern Oaxaca and specimens of $R$. microdon from Michoacán and the Federal District. By virtue of unique traits of skin and skull, each of those two series appears to represent a distinct, and heretofore unrecognized, geographic race. Most of the specimens were collected by Dr. H. O. Wagner. They constitute only a small segment of the total number of harvest mice secured by him in México for the Museum. He has helped me in many ways in my studies of the genus Reithrodontomys. It is a pleasure to name one of the subspecies in his honor.

Capitalized color terms are from Ridgway, Color Standards and Color Nomenclature, 1912. Certain measurements employed herein require explanation: Depth of eranium is measured from dorsal limit of the skull to the plane that passes through the tips of the incisors and the ventral surface of the auditory bullae. Length of rostrum is a measure of the distance from the tip of a nasal bone to the small notch, located near the lacrimal bone, on the anterior, orbital border of the zygomatic arch. Alveolar length of molar row is the length of the alveoli, not the teeth, measured from the anterior border of the alveolus of $\mathrm{M}^{1}$ to the posterior border of that of $\mathrm{M}^{3}$.

Reithrodontomys fulvescens infernatis, new subspecies

Type.- Young adult male (molar teeth slightly worn), skin and skull; Univ. Mich. Mus. Zool. No. 91,470; México, Oaxaca, Teotitlán, 3,100 feet elevation; collected 26 February 1947, by Helmuth O. Wagner; original No. 2,728.

Distribution.-Arid slopes of the Cañada de Cuicatlan (drainage of the ríos Salado and Quiotepec) in southern Puebla and northern Oaxaca. Known range from Tepanco, 5,700 feet, Puebla, south at least to the vicinity of Teotitlán, 3,100 feet, Oaxaca.

Characters and Comparisons. - A geographic race of $R$. fulvescens characterized by small body size, relatively long tail, pale coloration, strongly constricted frontal bones and relatively (with respect to depth of cranium) long, narrow rostrum. $R$. $f$. helvolus, which inhabits the highlands of central Oaxaca, is much larger (head and body length about $75 \mathrm{~mm}$. compared with about $65 \mathrm{~mm}$. in infernatis), rufescent instead of buffy dorsally, and longer-tailed (actually, but not relatively); 


\section{Proceedings of the Biological Society of Washington}

the frontal bones are flatter dorsally and are actually as well as relatively broader interorbitally; the rostrum and the molar teeth are broader and longer. $R$. $f$. mustelinus, which ranges in the Pacific slopes of Guerrero and possibly in the Balsas Basin, contrasts greatly with infernatis, particularly in coloration. It is much more rufescent and blackish dorsally, cinnamon-tinted ventrally, larger, and has relatively a broader rostrum and longer incisive foramina. $R$. $f$. difficilis, an inhabitant of the humid Gulf slopes fifteen or twenty miles to the east of (but on the opposite side of a mountain mass from) the range of infernatis, is similar in body size and tail length, but it is blackish and tawny dorsally and cinnamon ventrally; its brain case is larger and less constricted interorbitally. $R$. $f$. toltecus, of the central highlands to the northwest of the range of infernatis, is darker and rufescent dorsally and more intensely pigmented ventrally. It is much larger, actually longer-tailed (relatively shorter), and has a broader skull with relatively broader rostrum, shorter palate, and longer incisive foramina.

Color.-February specimen from Teotitlán: Upper parts CinnamonBuff, slightly intensified on the back with comparatively few black hairs and lightened on the shoulders with a grayish wash. Sides essentially pure Cinnamon-Buff, demarked sharply from the whitish or Pale Pinkish-Buff under parts. Ears Drab, clothed internally and externally with Cinnamon-Buff hairs. Tail Fuscous or Drab dorsally, with a sparse growth of whitish hairs; paler ventrally. Forefeet and hind feet whitish or Pale Pinkish-Buff, the ankles dusky bordered by a narrow stripe of Pinkish-Buff.

Measurements.-Averages and extremes, in millimeters, of five topotypes: total length, 161 (159-165); tail vertebrae, 94 (92-96); hind foot, 18 (17-20); ear from notch, 15 (13-16); greatest length of skull, 21.3 (20.9-22.1) ; zygomatic breadth, 10.6 (10.5-10.7); breadth of brain ease, 10.2 (9.9-10.5) ; depth of eranium, 8.4 (8.0-8.7) ; interorbital breadth, 3.1 (3.0-3.2); breadth of rostrum, $3.8(3.7-4.0)$; length of rostrum, 7.3 (7.2-7.8); length of palate, 3.6 (3.4-3.7); alveolar length of molar row, 3.3 (3.1-3.5); length of incisive foramina, 4.3 (4.1-4.6); breadth of zygomatic plate, 1.7 (1.5-1.8); breadth of mesopterygoid fossa, 1.2 (1.1-1.2).

Specimens examined.- Seventeen from the following localities in México: $O A X A C A$, Teotitlán, 3,100 feet, 8; PUEBLA, Tehuacán, 5,400 feet, 4, Tepanco, 5,700 feet 5 .

Remarks.-N. $f$. infernatis inhabits the basin in which lie Teotitlán and Cuicatlán. The basin is termed by Conzatti (Proc. Int. Cong. Plant Sci., 1: $534,1929)$ the Cañada de Cuicatlán and the botanical Estación del Tomellín. It is drained by several streams which join to form the Río Tuxtepec (Río Santo Domingo) and, much farther to the east, the Río Papaloapán. Lying in the rain shadow of Gulf on-shore winds, the valley is exceedingly dry and warm. Its flora and fauna reflect these desert-like conditions. Like several other froms known from the same valley, infernatis is pale; in this it contrasts greatly with the darker forms which inhabit neighboring areas. Among the subspecies of $R$. fulvescens, only canus and fulvescens equal or exceed it in pallor. The specimens from Tehuacán and Tepanco average slightly larger than those from Teotitlán; otherwise they are similar. 
Reithrodontomys microdon wagneri, new subspecies

Type.-Adult female (molar teeth well worn), skin and skull; Univ. Mich. Mus. Zool. No. 94,185; Michoacán, about ten miles northwest of Ciudad Hidalgo, western flanks of Cerro San Andrés, 9,400 feet elevation; collected 19 March 1949 by Helmuth O. Wagner; original No. 463, W. B. MeIntosh.

Distribution.-Known from only two localities, in the Distrito Federal and Michoacán, México, but probably occurring elsewhere on the mountains that rim the southern end of the Mexican Plateau. Known altitudinal range 9,200-10,000 feet in Cañón Contreras, near Mexico City.

Habitat.-Cool, moist situations supporting stands of fir, Abies religiosa. Specimens were obtained in situations as follows: In Cañón Contreras, one specimen at the base of a large fir with no other cover near by; another example on moist ground near spring seepages among sacatón and a mixed growth of shrubs, young fir and other trees. On Cerro San Andrés, a specimen at the base of a fir (one foot in diameter) in a mixed forest of fir, pine, and oak, with a moderately dense herbaceous understory; another specimen obtained in the same forest in an old nests of sticks five feet above ground in a crevice of a fir tree.

Characters and Comparisons.-A geographical race of Reithrodontomys microdon characterized by large ears, pale dorsal coloration, shallow brain case, long hard palate, and small auditory bullae. Slightly smaller and much paler dorsally than $R . m$. microdon; near Ochraceous-Tawny rather than Tawny or Cinnamon-Rufous in adult winter pelage and Cinnamon rather than Tawny or Russet in subadult pelage, and in both the subadult and adult coats with less blackish wash dorsally than in microdon; sides of face and body nearly pure Orchraceous-Tawny; underparts whitish or pale Pinkish-Buff, the bases of the hairs white throughout on the throat, elsewhere on the body Plumbeous-Black. Ears Fuscous, sparsely sprinkled internally and externally with brownish or blackish hairs, and longer than those of microdon (from notch about $19 \mathrm{~mm}$. fresh and $17 \mathrm{~mm}$. dry, compared with $17 \mathrm{~mm}$. fresh and $15 \mathrm{~mm}$. dry in microdon). Tail as in microdon, Fuscous dorsally, scarcely or not at all paler ventrally. Forefeet whitish, with or without a dusky stripe; toes white. Hind feet, from ankles to base of toes, Fuscous bordered by whitish, the Fuscous area usually wedge-shaped and covering much of the surface of the foot; toes white. Cranium small, the brain case shallower (absolutely and relative to the length of the skull), the palatelonger (its length equal to or greater than the interorbital diameter in wagneri, and less than that diameter in microdon), and the auditory bullae much smaller and disc-shaped rather than spherical.

$R$. m. wagneri differs from $R$. m. albilabris much as it does from $m i$ crodon; albilabris apparently is distinctly larger, has slightly darker upper parts, smaller ears, a deeper brain case, and larger, oval-shaped auditory bullae.

$R$. chrysopsis and $R$. rufescens, which may occur with $R . m$. wagneri, resemble that form in color of the upper parts and of the ears; but chrysopsis has a hairier and usually distinctly bicolored tail, and both it and rufescens have cinnamon-colored underparts. The species is distinguishable from all other species of the highlands of México in cranial characters, among which its long, narrow rostrum, bulbous brain case, 
narrow zygomatic plate, weak narrow zygomatic arches, and full mesolophs (ids) on all molar teeth are noteworthy.

Measurements.-Averages and extremes in millimeters, of the holo. type and a topotype, respectively (molars of both specimens well worn): total length, 169, 173; tail length, 101, 103; hind foot, 19, 19; ear from notch 18.5, 20.0; greatest length of skull, 21.6, 22.1; zygomatic breadth, 11.1, 11.0; breadth of brain case, 10.6, 10.9; depth of cranium, 8.3, 8.3; interorbital breadth, $3.6,3.4$; breadth of rostrum $3.8,3.9$; length of rostrum, 7.6, 7.9; length of palate, $3.6,3.5$; alveolar length of molar row, 3.0, 3.1; length of incisive foramina 4.0, 4.3; breadth of zygomatic plate, 1.4, 1.4; breadth of mesopterygoid fossa, 1.5, 1.6.

Remarks.-Reithrodontomys microdon is known from few specimens and localities. It is restricted to local pockets and apparently is uncommon even in its preferred habitat. It is an inhabitant of fir and short-needled pine forests of cool, shaded canyons and mountainous slopes of southern México and Guatemala. At least two of the ten known specimens were collected well above ground. It is probable that it spends much of its life in trees, for which reason it frequently may escape detection by collectors. Its spotty distribution, rarity, and probable arboreal habits suggest that the present populations of the species, in Guatemala, Oaxaca, Michoacán and the Federal District, are residuals from a time when the fir and pine forests were more widespread and continuous than they now are.

Specimens examined.-Five from the following localities in México: DISTRITO FEDERAL, $15 \mathrm{mi}$. SW of México City, Cañón Contreras, 9,200-10,000 ft., 3; MICHOACAN, $10 \mathrm{mi}$. NW. of Ciudad Hidalgo, Cerro San Andrés, 9,400 ft., 2. 


\title{
BIOLOOICAL SOCIETY OF WASHINGTON
}

\section{ADDITIONAL FORMS OF BIRDS FROM THE REPUBLICS OF PANAMA AND COLOMDIA}

\author{
BY ALEXANDER WETMORE
}

The subspecies described here have been separated during study of recently made collections in the areas indicated. The Colombian form is from the work of M. A. Carriker, Jr. The two races from Panamá were secured by the writer and W. M. Perrygo.

\section{FAMILY TINAMIDAE}

\section{Crypturellus saltuarius, sp. nov.}

Characters.-Generally similar to Crypturellus kerriae (Chapman ${ }^{1}$ ), but decidedly paler in color throughout; forepart of the crown dusky neutral gray (not black as in kerriae), merging into dull brown behind the center; dorsal surface, except the tail and upper tail coverts, duller brown, less rufescent; decidedly paler below, more buffy, less rufescent; grayish band on breast distinct; sides of head and neck bright brown (not blackish).

Description.-Type, male, U. S. Nat. Mus., Cat. no. 372,312, Ayacucho, elevation 500 feet, 25 kilometers east of La Gloria, Magdalena, Colombia, collected June 9, 1943, by M. A. Carriker, Jr. (orig. no. 4,245). Anterior half of crown deep neutral gray; lores hair brown; sides of crown in superciliary area drab; space in front of eye cinnamon, changing to sayal brown on sides of head and behind eye, the brown color extending indistinctly as a narrow line around the margin of the upper eyelid; a poorly defined malar stripe of sayal brown; auricular patch bone brown; hindneck warm sepia, changing to cinnamon brown on the sides of the neck, where those feathers adjacent to the malar stripe are tipped indistinctly with sayal brown; upper back Vandyke brown, the feathers of the lower portion with indistinct frecklings of dark neutral gray, perceivable only on close scutiny; lower back warm sepia, the feathers with subterminal bands of dull black and faint tips of verona brown, the black bands becoming progressively heavier over the rump to the upper tail coverts, with cross bands of pinkish buff; tail verona brown edged irregularly with black and pinkish buff; wing coverts dull black, with irregular bands of pinkish buff or light buff; tertials snuff brown, banded and blotched heavily with black; primaries and secondaries fuscous, the secondaries and innermost primaries with partial bars of pinkish buff on outer webs; the primaries edged centrally on the outer web, and tipped indistinctly, with cinnamon buff, except on the three outermost, where only the tipping, reduced in extent, is found; throat and upper foreneck white; lower foreneck mouse gray, with an

${ }^{1}$ Crypturus kerriae Chapman, Bull. Amer. Mus. Nat. Hist., vol. 34, December 80, 1915, p. 636 (Baudó, Choco, Colombia).

$$
\text { 31-Proo. BIOL. SOC. WAsh., VoL. 63, } 1950
$$


overwash of clay color that becomes stronger over the upper breast, becoming dull cinnamon-buff on the upper breast; sides of breast bister; center of abdomen dull white; sides, flanks and tibiae pinkish buff, the whole barred with dull black, the bars much heavier laterally; under tail coverts cinnamon buff, with heavy, irregular markings of black; under wing coverts centrally pale mouse gray, externally, including the bend of the wing, deep mouse gray; axillars mouse gray. Maxilla blackish brown, becoming olive-brown on the tomium; mandible ivory yellow, becoming olive-brown on the tomium; tarsus deep olive-buff, toes creambuff (from dried skin).

Measurements.-Male, type, wing 154.2 , tail 45.7 , culmen from base 26.8, tarsus $45.4 \mathrm{~mm}$.

Range.-Known only from the type locality, Ayacucho, in the hill country at the northwestern base of the Sierra de Ocaña, Departamento de Magdalena, Colombia.

Remarks.-This tinamou, represented only by the type, is one of the most interesting finds in the ornithological exploration of this area. It is completely distinct from any other, being closest to Crypturellus kerriae of the Baudo region of northwestern Colombia.

The type specimen of $C$. kerriae, Amer. Mus. Nat. Hist., Cat. No. 123,204 , is a female from Baudó, Chocó, collected at an elevation of 2,500 feet, July 3, 1912, by Mrs. E. L. Kerr (orig. no. 98). The bird is not quite fully adult, as the feathers of the upper foreneck and sides of the neck appear soft, with indistinct bars, while the white of the throat seems to be only partly developed, being restricted to the median line. It measures as follows: Wing 157.0, tail 35.3, culmen from base 29.2, tarsus $53.2 \mathrm{~mm}$. Another specimen, a male in the Academy of Natural Sciences in Philadelphia, an adult, is likewise very dark in color, especially on the head where the crown is completely black. The dark body color in this bird largely obscures the pattern markings found usually on the posterior parts of the body. This bird, examined through the courtesy of R. M. de Schauensee, has the following measurements: Wing 165 , tail 45.8 , culmen from base 28.0 , tarsus $56.4 \mathrm{~mm}$.

\section{Family COLUMBIDAE}

\section{Geotrygon goldmani oreas subsp. nov.}

Characters.-Similar to Geotrygon goldmani goldmani Nelson,2 but darker, especially on foreneck, breast and dorsal surface; foreneck and breast decidedly darker gray; upper abdomen darker; brown of crown, hindneck, wings, tail, rump and upper tail coverts darker, more chocolate; interscapular area darker, more purplish.

Description.-Type, U. S. N. M., Cat. no. 423,145, male, 1250 feet altitude, above Quebrada Cauchero, Cerro Chucantí, Serranía de Majé, eastern Provincia de Panamá, Panamá, collected March 18, 1950, by A. Wetmore and W. M. Perrygo (orig. no. 15,791). Forehead hazel, changing gradually to dark chestnut at the center of the crown, this color

2Geotrygon goldmani Nelson, Smiths. Misc. Coll., vol. 60, no. 3, September 27, 1912, p. 2 (5,000 feet elevation at head of Río Límon, Mt. Pirri, Darión, Pan. ama). 
becoming chestnut and continuing back over the hindneck, anteriorly shading to pinkish buff above the bare loral space; malar region and a broad stripe extending back over auricular region to the posterior end of the head pinkish buff shaded with cinnamon buff; a very narrow line of dusky neutral gray above and below the bare lores; and a slight mixture of neutral gray over the auricular region; a mark of dull black beginning as a narrow line at the base of the bare mandibular ramus, broadening immediately, and extending as a broad stripe to the posterior margin of the head; interscapular region slate-violet no. 1, each feather with the concealed portion and an indistinct terminal edge carob brown; tertials, back, rump and upper tail coverts carob brown; wing coverts chestnut brown, the ends of the greater coverts changing to hazel with a narrow subterminal bar of blackish slate; primaries and concealed areas of secondaries chaetura black, the outer webs of the secondaries cinnamon-brown, with an outer edging of ochraceous-tawny; middle rectrices and outer webs of others carob brown, the concealed portions of the lateral ones deep to dark neutral gray; throat and upper foreneck white, changing rather abruptly to light neutral gray on lower foreneck, which in turn becomes neutral gray and deep neutral gray on the breast; upper abdomen pale mouse gray; center of lower abdomen whitish; sides bister; flanks mouse gray, tipped with sepia anteriorly, and with pale drab-gray distally; under tail coverts mouse gray, edged terminally with pale drab-gray; under wing coverts dark to blackish mouse gray. Bill dull black; tarsus and toes Hay's brown (from dried skin).

Measurements.-Type, male adult, wing 138.2 , tail 85.8 , culmen from base 15.4, tarsus $40.5 \mathrm{~mm}$.

Range.-Known only from the lower slopes of Cerro Chucanti, in the eastern end of the Serranía de Majé, eastern Panamá.

Remarks.-At the present time Goldman's Quail-dove is one of the least known species of its group, so that it was of particular interest in the field season of 1950 to secure one in the little-known interior of the extreme eastern section of the Province of Panamá. On comparison with the seven skins of the species in the original series from Cerro Pirri and Cana in the U. S. National Museum, it was evident at a glance that the specimen from the isolated Serrania de Majé was decidedly darker, a difference that was borne out fully on check with four skins in the American Museum of Natural History from Mt. Tarcarcuna on the boundary between Colombia and Darién, and with two in the Academy of Natural Sciences of Philadelphia from Mt. Sapo back of Garachiné. The separation is so definite that description of a new form seems fully warranted though only a single skin is available. The bird seems to be rare, and the one secured was the only one seen. It was found on the ground in heavy forest near the crest of a high ridge.

While it has been customary in recent years to separate the quaildoves into two generic groups, Oreopeleia and Geotrygon, this does not seem justified. The only pertinent structural difference on which the two might be maintained apart from one another is found in the slightly stiffened, somewhat elongated feathers on the forehead of Geotrygon versicolor (Lafresnaye), type of Geotrygon. This is too slight a basis for generic separation; other characters that have been alleged do not hold. 


\section{Family CYCLARHIDAE}

Cyclarhis gujanensis flavens subsp. nov.

Characters.-Similar to Cyclarhis gujanensis perrygoi Wetmore ${ }^{3}$, but with yellow of undersurface brighter and more extensive posteriorly, covering most of the abdomen; upper surface brighter green; crown grayer, less brownish.

Description.-Type, U. S. Nat. Mus., no. 423,915, male, from Chimán (Punta Madroño), Province of Panamá, Panamá, taken March 31, 1950, by $A$. Wetmore and W. M. Perrygo (orig. no. 16,047). Crown and hindneck neutral gray; sides of head below eye, including auricular and malar regions, light neutral gray; scanty feathers on lores pallid neutral gray; broad superciliary extending from posterior margin of crown to nostril (the stripe on either side nearly united on the forehead), and a line on the lower eyelid, russet; back, rump, upper tail coverts and wing coverts serpentine green; secondaries and primaries with inner webs dark mouse gray, and outer webs serpentine green, becoming Roman green distally; rectrices olive-citrine, with a faint edging of yellowinsh citrine; foreneck, breast, sides, and upper abdomen between lemon chrome and lemon yellow; sides of upper breast washed with pyrite yellow; chin dull white; small area in center of abdomen white; under wing coverts pale lemon yellow; under surface of inner webs of remiges picric yellow anteriorly, changing to Martius yellow distally; flanks and under tail coverts pale lemon yellow. Maxilla snuff brown, becoming bister on the line of the culmen; tip of mandible drab-gray, rest plumbeous black; tarsus, toes and claws dull army brown (from dried skin).

Measurements.-Males (3 specimens), wing 69.2-73.8 (70.0), tail 49.052.3 (50.9), culmen from base 17.7-18.5 (18.1), tarsus 20.5-23.2 (21.7) $\mathrm{mm}$.

Female ( 1 specimen), wing 66.0 , tail 53.2 , culmen from base 17.3 , tarsus $21.1 \mathrm{~mm}$.

Type (male), wing 73.8, tail 51.6, culmen from base 18.5 , tarsus 21.6 $\mathrm{mm}$.

Range.-Known from coastal area of eastern Province of Panamá, Panamá (specimens from Chimán and Majé).

Remarks. - In the course of field work in eastern Panama in the dry season of $1950 \mathrm{I}$ was fortunate in securing specimens of the peppershrike, which on examination prove to represent an unrecognized form. The birds were found in small numbers in thickets back of the beach at the mouth of Río Majé, and at the mouth of the Río Chimán, near Punta Madroño opposite Chimán, these localities being on the coast of the eastern part of the Province of Panama a short distance from the western boundary of Darien. It is probable that the birds that I recorded in 1949 at Chepo on the lower Río Mamoní are this race, and it is practically certain that this is the form obtained in 1941 at Garachine by the Fifth George Vanderbilt Expedition ${ }^{5}$.

\footnotetext{
${ }^{3}$ Cyclarhis gujanensis perrygoi Wetmore, Prof. Biol. Soc. Washington, vol. 63, May 25, 1950, p. 61. (Ciénaga Macana, near El Rincón, Province of Herrera, Panamá).

${ }^{4}$ See Wetmore, l.c., p. 62.

'See Bond and de Schauensee, Acad. Nat. Sci. Philadelphia, Mon. no. 6, 1944, p. 40 .
} 


\title{
PROCEEDINGS
}

\author{
OF THE
}

BIOLOGICAL SOCIETY OF WASHINGTON

\section{A NEW VARICORHINUS FROM LAKE TANGANYIKA}

By J. T. Nichols and F. R. LaMonte

In cataloging accumulated fish material in the American Museum of Natural History, we have come across the following single specimen of an interesting, apparently undescribed Varicorhinus from Lake Tanganyika, with narrower, less specialized mouth than is usual in the genus, but obviously closely related to certain already described African species thereof.

\section{Varicorhinus chapini, new species}

Mouth small and narrow; minute posterior barbels (only) present; upper jaw with a conspicuous row of papillae. A long, strong, slender dorsal spine. Scales about 43.

Description of type.-No. 18,785, American Museum of Natural History, from Albertville, Lake Tanganyika, Africa, July 31, 1927, collected by James P. Chapin.

Length to base of caudal, $87 \mathrm{~mm}$. Depth in this length, 3.8 ; head, 3.4 . Eye in head, 3.2 ; snout, 3.2 ; interorbital, 3 ; maxillary, 3.3 ; width of mouth, 4 ; width of head, 1.9 ; depth of peduncle, 2.6 ; its length, 1.6 ; dorsal spine, 1 ; longest dorsal ray, 0.9 ; longest anal ray, 1.5 ; caudal, 1 (estimated, its tip broken); pectoral, 1.4; ventral, 1.5.

Dorsal, II, 9 ; Anal, 7 (5 branched rays). Scales, 43,7 between lateral-line and dorsal origin, $5 \frac{1}{2}$ between lateral line and ventrals, 16 around caudal peduncle.

Body slender, well compressed, top of the head somewhat broader than its lower part. Eye large, lateral, slightly before middle of head; interorbital concave; snout bluntly pointed. Mouth small, narrow, inferior, transversely rounded; the lower jaw with a sharp, firm but not cartilaginous, edge, a row of small, blunt papillae above the edge of the upper jaw, and a few below that of the lower. A slender rudimentary posterior barbel only, about one eighth the diameter of the eye. Dorsal and anal falcate, their margins concave; when depressed, their tips extending well beyond the short posterior rays; dorsal spine long, slender but strong. Caudal deeply forked, with pointed lobes; pectorals not reaching ventrals, ventrals not reaching anal.

Color pale, probably silvery in life, the end of the dorsal lobe dusky.

This species is unusually narrow-mouthed for Varicorhinus. It resembles $\nabla$. varicostoma Boulenger from Angola in appearance and is probably related thereto. It has fewer scales than $\nabla$. tanganicae Boulenger, more than $\nabla$. ruandae Pappenheim and Boulenger, both of which are recorded from Lake Tanganyika (Poll, 1946, Faune Ichthyol. du Lae Tanganika, in Ann. Mus. Congo Belge, p. 199). 
176 Proceedings of the Biological Society of Washington 


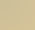

IRET NEW SPECIES OF SAIDIDAE (HEMIPTERA)

By C. J. Drake and F. C. Hottes

The present paper contains notes on four species of Saldidae, three of which are described as new. The disposition of types is given beneath the descriptions of the respective species. The left paramere of two species is figured.

\section{Saldula dixoni (Distant)}

Salda dixoni Distont, Fauna Brit. Ind., Heterop., 2:405, fig. 258. 1904. Salda dixoni Distant, Fauna Brit. Ind., 5:221. 1904.

Salda dixoni Breddin, Arch. fur Nat. 78A:86. 1912. (As subgenus of Chartoscrita.)

Acanthia balnearum Bergroth, Philip. Jr. Sci., 13(D3):123. 1918. (New Synonymy.)

A study of numerous specimens of $S$. balnearum Bergroth from Luzon (including specimens in Baker's collection bearing same label as type) and specimens of $S$. dixoni Distant from India (Brit. Mus.) has shown that these two names apply to the same species of shore bug. Since dixoni has priority by several years, it becomes the valid name of the species. Many other specimens have been examined, from Formosa, Japan, Philippines (Luzón, Mindanao, Mindoro and Sámar), Solomon Islands, Borneo, Celebes, Ceylon, Larut, and Africa (Senegal and Lake Chad). The type locality of dixoni is Siam. As pointed out by both Distant and Bergroth, the first and second antennal segments and the exocorium of the hemelytra occasionally vary somewhat in color. The color variety dixoni luteifusula Breddin (loc. cit., p. 86) is unknown. The type of the variety is not in the collection of Breddin in Berlin, and it may be lost. Its description does not fit any of the color variations seen by the authors.

\section{Saldula subsolans, new species}

Description.-Small, obovate, black with testaceous markings on corium of hemelytra; pubescence brown, dense, moderately long, brownish. Head black, strongly declivent in front, with very short pubescence; front longitudinally furrowed on median line, with apical callosites very large, greatly widened within, contiguous above clypeus; clypeus large, testaceous, strongly convex, nearly twice as long as wide, the callosity on each side of clypeus small, testaceous; gula short, black, with grayish hairs; ocelli brownish, placed on slightly raised area, approximate, separated by less than half of diameter of an ocellus; spot between each ocellus and eye large, nearly triangular in shape, yellowish, contiguous with inner margin of eye. Eyes large, dark fuscous, converging anteriorly, the area in subapical notch black. Rostrum very. long, brownish testaceous, extending between hind coxae. Legs testaceous, clothed with short pale hairs, the femora becoming dark brown or fuscous apically. Antennae 
long, slender, shortly pilose; segment I short, stout, largely testaceous; II brownish, longest; III and IV dark fuscous; proportions-I, 12; II (male) 23, (female) 26; III (male) 18, (female) 20; IV (male) 17, (female) 18.

Pronotum black. slightly shining, with moderately long, decumbent, brownish pubescence, deeply and broadly excavated behind, narrowed anteriorly, with margins moderately rounded and slightly reflexed, approximately two and one-half times as wide at base as median length $(52: 18)$; callus moderately swollen, convex, not extending on explanate margins, deeply and widely impressed on disc, extending a little behind middle of pronotum; furrow just back of callus rather deep, arcuate, pitted at bottom; hind lobe short, moderately convex, hardly as long as callus. Thorax beneath black, slightly shining. Abdomen beneath dark fuscous, elothed with short grayish hairs; last venter in female longer than two preceding segments, whitish apically. Scutellum subequal in width and length, black, transversely impressed before middle, finely transversely rugulose behind.

Hemelytra brownish black, a spot near apex of clavus, an apical spot and a long streak in front of middle along outer nervure of inner corium and most of exterior of outer corium flavous or testaceous; outer corium with small basal streak, an elongate spot in front of middle, a large spot within before apex and a small apical spot dark fuscous, the subapical, marginal testaceous area usually divided by a narrow, longitudinal, dark streak so as to form two large pale spots; clavus darker and more velvety than other parts of hemelytra; membrane clouded with brownish, non-hyaline, composed of four cells, the subapical spots in the cells tending to form a crossband. Legs testaceous, clothed with short, pale hairs; femora at times with slight indications of a brownish band before the apex; tibiae with usual dark spines; tarsi with last segment brown or dark fuscous.

Type (male) and allotype (female), Bandoeng, Java, Feb. 13, 1937, F. C. Drescher, in the collection of Rijksmuseum van Natuurlijke Historie, Leiden, Holland. Paratypes, 7 specimens, taken with type in Java, in collections of the writers and above-named Museum.

Remarks.-This species is much smaller than Saldula javanica (Jaczewski); it has the corium of hemelytra differently marked, and also different parameres. A right paramere of a paratype is figured.

\section{Saldula guamensis, new species}

Description.-Moderately large, male much smaller than female, ovate, the head, pronotum and scutellum somewhat shining, the hemelytra brown-fuscous, rather dull, with prominent white spots and prominent pale stripe on exterior margins; pubescence very long, with some short, dense, brown or golden hairs, Head black, broad, semi-vertical, slightly shining, with pale spot on each side next to eye opposite ocelli, with the usual six extremely long, upright, dark fuscous, bristly hairs; pubescence golden, dense, very short; ocelli slightly separated, with slight reddish tinge; front with median longitudinal furrow, on each side of furrow distinctly raised so as to form convex areas, with usual transverse callosities at apex, the callosities strongly swollen, yellowish, narrowed and meeting or nearly meeting within, distinctly arcuate, with hind surface 
concave; clypeus brownish, with pale hairs, nearly twice as long as wide; labrum brown; bucculae black, aerolate. Rostrum very long, brownish testaceous, reaching beyond middle of hind coxae. Antennae moderately long, dark fuscous, shortly, densely pilose, with a few scattered bristly hairs $\mathrm{n}$ third and fourth segments, the first and second segments paler, brownish or yellowish brown; proportions-I, 14; II, (male) 22, (female) 26 ; III, 19 ; IV, 20 . Eyes very large, converging anteriorly, with usual subapical notch on inuer side, black within notch.

Pronotum black, slightly shining, densely elothed with long, brownish or golden pubescence, deeply excavated behind, moderately narrowed anteriorly, more than two and one-half times as wide at base as median length (20:55), the side margins oblique, almost straight; callus moderately large, strongly convex, not reaching on expanded lateral margins, extending posteriorly a little beyond middle of pronotum, with large, deep discal impression at middle; furrow just behind callus deep, arcuate, pitted at the bottom; hind lobe convex, shorter than callus. Scutellum similar to pronotum in color, sheen and long pubescence or short hairs, scarcely longer than wide.

Hemelytra extending beyond tip of abdomen, largely pale brownish, typically with seven, rounded, white spots on each side, the pubescence very long, dense, nearly erect, brownish or golden; clavus black-fuscous, velvety, with whitish, subapical spot, the pubescence quite golden, very long, conspicuous; clavus brownish with some yellowish, with six conspicuous white spots (two subbasal, two near the middle and other two apical), the veins broadly dark fuscous; embolium pale, semi-transparent, with sometimes brown spot beyond the middle; membrane somewhat yellowish brown, subhyaline, the three first eells with brownish streak, the outermost cell without dark spot. Abdomen beneath black, with hind margins of segments narrowly testaceous, densely clothed with grayish pile; last venter of female much longer than other segments. Legs yellowish brown, clothed with short, pale hairs; femora tending to become a little darker apically; front tibiae with dark spot at base and apex of front surface; middle and hind tarsi with short, dark brown or fuscous spine; last tarsal segment darker.

Length, (male) $3.20 \mathrm{~mm} .$, (female), $4.00 \mathrm{~mm}$; width (male) $1.30 \mathrm{~mm}$., (female) $1.75 \mathrm{~mm}$.

Type (male), allotype (female), Mt. Chachao, Guam, May 16, 1936, R. L. Usinger. Type in Calif. Acad. Sciences.

Remarks.-This species was wrongly determined by Dr. R. L. Usinger, Insects of Guam-II, Bull. 189, Bernice Bishop Museum, Honolulu, 1946, p. 1, as Saldula balnearum Bergroth. It differs from balnearum in size, oblique pronotal margins, and color and markings of the hemelytra. In general. appearance, guamensis most closely resembles Saldula opacula (Zett.), but is distinguishable by its different shape, smaller size, vesture of short hairs or extremely long pubescence on dorsal surface of body. Both species have a pale marginal stripe on each hemelytron.

\section{Saldula scitula, new species}

Description.-Small, ovate, black, with pronotum and scutellum shining, the hemelytra brown-fuscous, with numerous rounded whitish spots and broad, pale, flavous stripe on outer margins. Head black, scarcely shining, with very short brownish pubescence, a spot between each ocellus 
and eye flavous; bucculae black, clothed with grayish hairs; apical callosities of front narrow, contiguous within, blackish, the outer ends yellowish; elypeus brownish, convex, the small calloses on each side yellowish; ocelli scarcely raised; reddish brown, separated by less than the diameter of one of them; subapical excavation of eyes black, shining. Eyes large, black-fuseous converging anteriorly.

Rostrum brownish, testaceous basally, extending between hind coxae. Legs testaceous, with short pale hairs, the femora becoming a little darker apically; coxae largely black-fuscous, somewhat testaceous apically; hind tarsi with scattered dark brown spines. Antennae moderately long, shortly pilose; segment I pale brown or testaceous stoutest; II black-fuscous, with dark pilosity; III black-fuscous, with longer, denser, whitish pilosity; IV very broadly banded with white, with only narrow basal and narrow apical portions black-fuscous; proportions-I, 13; II, 19 ; III, 17 ; IV, 19. Venter brownish black, with grayish hairs.

Pronotum deep black, quite shining, with short, brownish pubescence and interspersed with very short, brownish hairs, deeply excavated behind, three times as wide at base as median length $(54: 18)$; sides strongly narrowed anteriorly, the outer margins slightly sinuate (nearly straight), slightly reflexed; callus moderately swollen, convex, not extending on expanded margins, deeply and somewhat transversely im. pressed on the dise; furrow behind callus deep, arcuate, pitted at the bottom; hind lobe moderately convex, not as long as callus. Scutellum subequal in length and width, with impression in front of middle, the pubescence, lustre and color same as pronotum.

Hemelytra velvety black, rather dull, with rather wide, pale flavous stripe on outer margins, the pubescence longer, golden, semi-reclining, also interspersed with some short hairs; clavus with an oblong spot near apex; inner corium with four, rounded, whitish spots (two marginal near outer nervure in basal half and other two in inner apical corner); outer corium with two smaller, subapical, white spots near inner boundary, the flavous stripe on outer margin moderately wide, with base and narrow tip dark fuscous; membrane brown, non-transparent, composed of four cells, cells one, two and three each with three white spots (basal, apical and median), the outermost cell with only basal and apical white spots.

Length, $3.15 \mathrm{~mm}$. (male), $3.80 \mathrm{~mm}$. (female); width, $1.35 \mathrm{~mm}$. (male), $1.70 \mathrm{~mm}$. (female).

Type (male) and allotype (female), Nova Teutonia, Santa Catarina, Brasil, March 13, 1950, Fritz Plaumann, in collection of C. J. Drake.

Remarks. - Separated from S. ventralis (Stal) by its smaller size, subequal last three antennal segments, concolorous pronotum, and numerous prominent white spots on hemelytra. Both species have the terminal antennal segment broadly banded with white or flavous. S. ventralis has the pronotal margins flavous, and much longer second antennal segments. It is also larger and oblong in shape.

Paper by Drake and Hottes

Three New Species of Saldidae (Hemiptera)

Fig. 1. Right paramere S. dixoni (Distant)

Fig. 2. Right paramere S. scitula, new species 

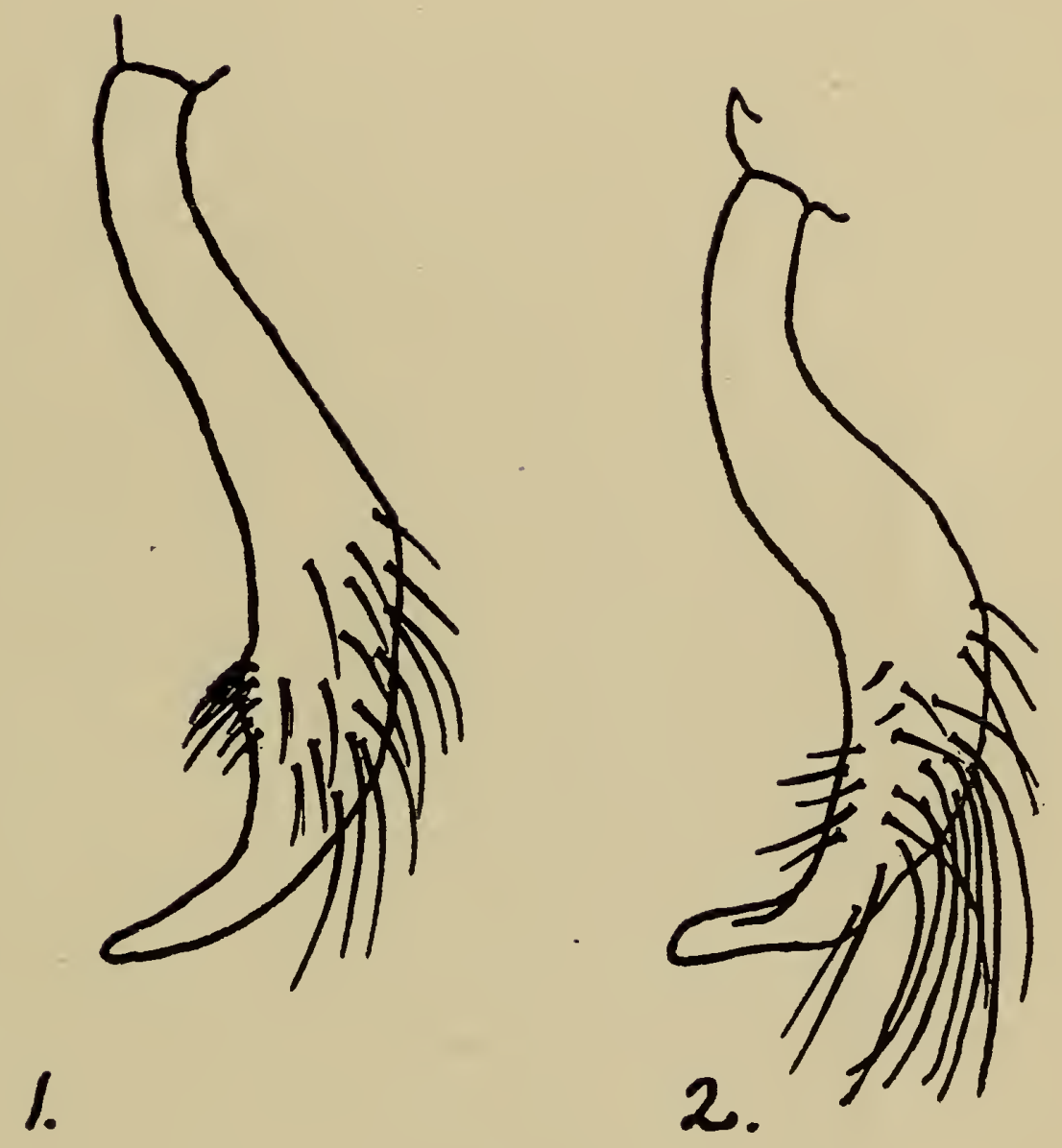
182 Proceedings of the Biological Society of Washington 
Drake and Hottes-A New Species of Saldidae 183 
184 Proceedings of the Biological Society of Washington 
earlier Eurydesmus, a Brazilian genus recently much enlarged by the work of Otto Schubart. The pertinent citations are as follows:

\section{Genus EURYDESMUS Saussure}

Eurydesmus Saussure, 1860, Mem. Soc. Phys. et d'Hist. nat. de Genève, vol. 15 , p. 335 (generotype, $E$. angulatus Saussure).

Chelodesmus Cook, 1895, Ann. N. Y. Acad. Sci., vol. 9, p. 4 (generotype, C. marxi Cook).

\section{Eurydesmus marxi (Cook)}

\section{Plate XIII}

Type specimen.-U. S. National Museum no. 1,881, labeled only "Therezopolis, Brazil, Dr. Goeldi, Marx Comm.", This locality is undoubtedly in or near the State of Rio de Janeiro.

Diagnosis.-Very close to $E$. agrestis Schubart, to which it runs in that author's key (1945, Arquivos do Museu Nacional, vol. 38, p. 78) but differing in a number of minor details of the male gonopod.

Description.-Similar to the species of Eurydesmus as described by Schubart. The following notes were made from the type:

Length, about $40 \mathrm{~mm}$. (much broken), width, $9 \mathrm{~mm}$.

Dorsum arched, almost smooth, finely coriaceous on keels. Latter medium in size, continuing slope of dorsum. Repugnatorial pores lateral, in a definite notch on side of keels.

Pleurites with an oblique, longitudinal ridge (directed cephaloventrad) just abore spiracular openings.

Sternites wide, smooth, glabrous; produced into spines at bases of legs. Sternite of 5th segment with four upright conical knobs, that of 6 th segment with two subtriangular laminae.

Legs rather short, stout; prefemora not spined; a small projection at the distal end of femora. Second tarsal joint with the usual long process ventrad of third. Terminal claw small, straight. Legs and body completely glabrous.

Color dark reddish-brown with underparts and edges of tergites lighter red. Legs red with a purplish cast.

Male gonopods as illustrated, projecting from a large, suboval, sternal aperture. Femoral process considerably larger than telopodite, forming a flat, shield-like development, bearing near the base a long slender spiniform projection. Femur of gonopod rather massive, tibiotarsus slender, distally flattened and twisted, its inner edges fimbriated. A little distad of midlength the tibiotarsus is widely slit, forming a long narrow sheath from which the solenomerite is exserted.

Remarks. - Comparison of the figure of marxi with that of agrestis given by Schubart (op. cit., fig. 60) reveals that the two species are extremely close, and that the latter may very well fall as a synonym of marxi. However, there are several minor differences which may be constant, or only individual variations, or may possibly reflect different interpretation of the structure. For instance, Schubart shows the solenomerite simply arising from the side of the tibiotarsus, and an adjacent secondary process originating independently above it. In the type of marxi, I satisfied myself that the solenomerite unquestionably projects from the inside of the tibiotarsus, and continues to the base of that por- 
tion as indicated in the drawing. In view of my particular attention to this detail, and of the fact that Dr. Schubart is a very careful worker, I think it best for the time being to retain the two species as distinct.

As to the family name to be applied to this group, $\mathrm{I}$ am retaining the name Chelodesmidae in anticipation of favorable action by the International Commission on a proposal now before it. This proposal asks that an established family name be continued in use even though the generic name upon which it is based has fallen into synonymy. Otherwise it would be necessary to introduce a new family name based on Eurydesmus.

The species of this family have been treated in detail by Attems in 1938 (Das Tierreich, Lief. 69, pp. 1-201); numerous genera and species have been since added by Chamberlin (Peruvian), Loomis (Antillean) and Schubart (Brazilian).

\section{Explanation of plate}

Eurydesmus marxi (Cook). Left gonopod of male holotype, cephalic or mesial aspect. 


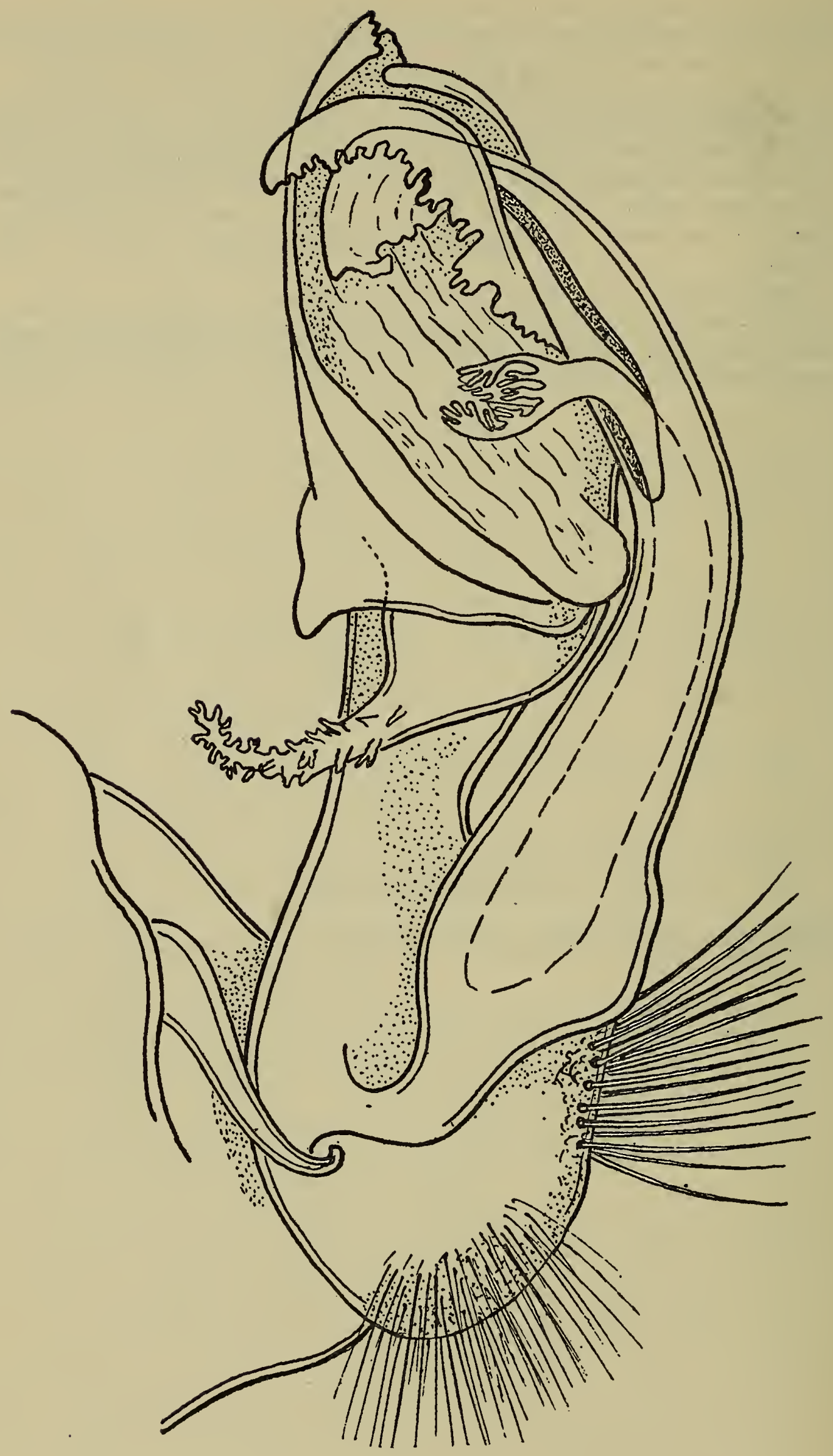


PROCEEDINCS

OF THE

\section{2 - $1.5: 1$ BIOLOCICAL SOCIETY OF WASHINCTON}

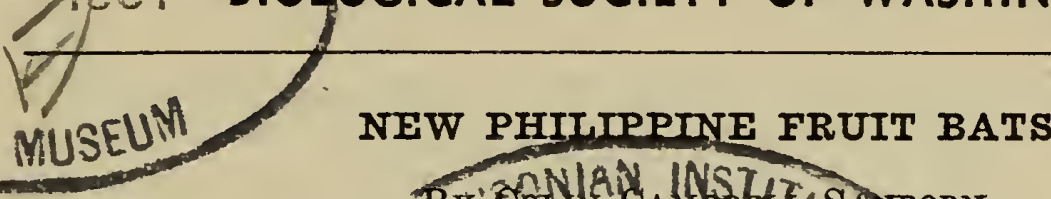

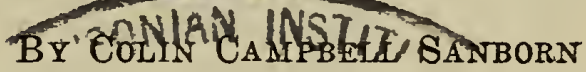

Curator of Mammals, Chicago Natural History Museum

The collections of the Philippines Zoological Expedition 1946-1947 of Chicago Natural History Museum include two undescribed fruit bats of the genus Pteropus. One of these was taken on Busuanga Island from which no fruit bats have been recorded, and the other comes from Paláwan Island,' where only Pteropus $v$. lanensis is found. These are described here as

Pteropus leucotis sp. nov.

Type from Singay, Busuanga Island, Calamianes Group, Philippine Islands. No. 63,736 Chicago Natural History Museum. Adult male. Collected March 24, 1947, by D. S. Rabor. Orig. No. 2,647.

Diagnosis.-Closely related to the samöensis and pselaphon group. Dentition much like that of $P t$. anetianus; male with well developed neck tufts. Size medium, color pale, with whitish ears.

Color.-Type: General color of mantle Clay Color (Ridgway, 1912) with neck tufts near Hay's Russet. Top of head between ears Deep Olive Buff darkened by black hairs on face between eyes. Back near Hair Brown. Throat Snuff Brown darkening on sides. Hairs of center of belly much darker and mixed with them many silvery-white hairs. Ears light, almost white when held against light.

In three female paratypes the mantle is (1) Cinnamon Buff and top of head Deep Olive Buff, (2) Sayal Brown and top of head Warm Buff. Back Dresden Brown in one, lighter in another and almost white in the third specimen. Under parts Verona Brown, darker in center of belly. Under parts lighter in two other females. Ears in all like those of the type.

Skull.-Typically pteropine, rostrum somewhat shortened. Postorbital processes long, but not quite reaching processes of zygoma. Front of orbit above hinder edge of $\mathrm{p}^{4}$. Coronoid process of mandible with front margin steeply ascending, but coronoid height less than length of lower tooth row, c-m

Teeth.-Similar to those of $P t$. anetianus aorensis but broader, heavier, and with other minor differences. Upper incisors narrow, inner pair longer than outer, narrower than in aorensis. Lower incisors unequal, $\mathrm{i}_{2}$ little more than twice the size of $i_{1}$. Upper canines short, not recurved, inner eingulum strong, the raised margin or shelf showing tendency to divide into small tubercles. Lower eanines short, slightly recurved, with broad shelf and strong inner eingulum. $\mathrm{P}^{1}$ absent or very minute. Posterior ledge of $\mathrm{p}^{3}$ not so sharply divided externally from main cusp nor is the postero-external tubercle so well formed as in aorensis. Antero- 
internal basal tubercle well developed in $\mathrm{p}^{3}$. In $\mathrm{p}^{4}$ the posterior ledge is not sharply separated externally by a notch from the main cusp but otherwise is very like that tooth in aorensis. The posterior ledge in $\mathrm{m}^{1}$ is little developed, the tooth being $2 / 3$ as wide as long instead of $1 / 2$ as wide as long as in aorensis. $\mathrm{M}^{2}$ is larger than $\mathrm{m}_{3}$ but smaller than $\mathrm{p}_{1}$. In the lower jaw $p_{1}$ is about twice the size of $i_{2}$. The large basal ledge in $\mathrm{p}_{3}, \mathrm{p}_{4}, \mathrm{~m}_{1}, \mathrm{~m}_{2}$, is marked by a notch postero-externally in the premolars but not so in the molars. This ledge forms a shelf on the interior side of $\mathrm{p}_{4}, \mathrm{~m}_{1}$ and $\mathrm{m}_{2}$. The projecting heel on the antero-internal portion of $\mathrm{p}_{3}$ is well marked but it does not appear in $\mathrm{p}_{4}$. The size of $m_{3}$ is greater than that of $i_{2}$.

Measurements of type (paratypes in parenthesis).-Forearm: broken (137-142 mm.); ear 23.8 dry. Skull: greatest length 67.7 (64.9-67.4); condylo-basal length (to front of canine) 60.1 (59.6-60); palatal length 32.9 (32-32.3); interorbital breadth 8.7 (8.5-9); intertemporal breadth 7.5 (6.8-7.1) ; zygomatic width 38.8 (36.8); mastoid width 22.3 (21.9); width of brain case at zygoma $24.4(23.5-23.9)$; orbit to nares $21.8(19.6$ 20.3 ) ; orbital diameter 14.3 (13.8-14.6); upper tooth row 25.7 (25-26.1); width across canines 13.5 (12.5-12.8); width across $\mathrm{m}^{1}-\mathrm{m}^{1} 19.5$ (19.3$20.5)$; coronoid height of mandible 26.5 (26.2-27) ; lower tooth row $\mathrm{c}-\mathrm{m}_{3}$ 29.2 (28.5). Teeth of type: length and width, $\mathrm{p}^{3} 4.7 \times 3.6 ; \mathrm{p}^{4} 5.1 \times 3.9$; $\mathrm{m}^{1} 5.3 \times 3.7 ; \mathrm{m}^{2} 2.5 \times 2 ; \mathrm{p}_{3} 4.8 \times 2.9 ; \mathrm{p}_{4} 5.2 \times 3.4 ; \mathrm{m}_{1} 5.1 \times 3.6 ; \mathrm{m}_{2} 4 \times$ $3.3 ; \mathrm{m}_{3} 2 \times 1.5$.

Specimens examined.-Type and three female paratypes.

Remarks.- "In high fruiting Ficus tree on mountain side."

Pteropus leucotis obscurus subsp. nov.

Type from Santiago, Iwahig, Paláwan Island, Philippine Islands. No. 63,741 Chicago Natural History Museum. Adult male. Collected May 7, 1947, by B. French. Orig. No. 3,063.

Diagnosis.-Like Pt. leucotis but larger and darker. Ears black.

Color.-Mantle Bister (Ridgway, 1912), top of head, general color Hair Brown, lighter between ears; black Fuscous, lighter on sides; throat Bister, darker on sides; center of belly black; neck tufts about color of mantle and not prominent. The one paratype is lighter.

Skull.-Like leucotis but larger with heavier teeth.

Measurements.-Forearm, type 142.5, paratype 145.4. Skull of type: greatest length 68.6 ; condylo-basal length to front of canine 61 ; palatal length 33.6 ; interorbital breadth 8.8 ; intertemporal breadth 7.2 ; zygomatic width 36.7 ; mastoid width 20.9 ; braincase at zygoma 24.3 ; front of orbit to nares $16.5 \pm$; orbital diameter 13.7 ; upper tooth row 26.5 ; width across canines 14 ; across $\mathrm{m}^{1}-\mathrm{m}^{1} 21.2$; coronoid height of mandible 26.2 ; lower tooth row $c-m_{3} 30.3$.

Teeth, length and width: $\mathrm{p}^{3} 5.1 \times 4 ; \mathrm{p}^{4} 5.7 \times 4.7 ; \mathrm{m}^{1} 5.9 \times 4.5 ; \mathrm{m}^{2}$ $2.9 \times 2.4 ; \mathrm{p}_{3} 5.4 \times 3.2 ; \mathrm{p}_{4} 5.6 \times 4.3 ; \mathrm{m}_{1} 5.7 \times 4.3 ; \mathrm{m}_{2} 4.3 \times 3.7 ; \mathrm{m}_{3} 2.2 \times$ 2.1 .

Specimens examined.-Type and one paratype. Skull of paratype without number but believed to belong to this specimen.

Remarks.- "Feeding on mango at night." 


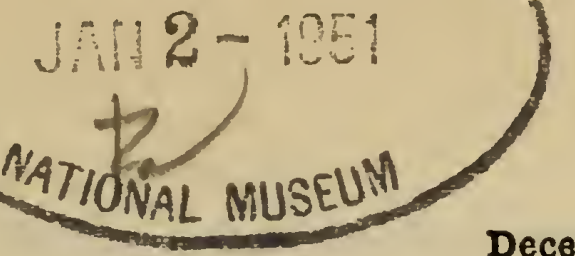

Vol. 63, pp. 191-194

December 29, 1950

\title{
PROCEEDINGS
}

\section{OF THE \\ BIOLOGICAL SOCIETY OF WASHINGTON}

\section{A NEW RACE OF SWAINSON'S WARBLER FROM THE APPALACHIAN MOUNTAINS}

\author{
By Brooke Meanley and Gorman M. Bond \\ Fish and Wildlife Service, U. S. Department of the Interior, \\ Washington, D. C.
}

Since Swainson's Warbler, Limnothlypis swainsonii (Audubon), has always been known as one of the characteristic breeding birds of the Coastal Plain of the southeastern United States, it was a matter of considerable interest to ornithologists when a mountain-breeding population was unexpectedly discovered by Legg (Legg, 1946) and Sims (Sims and DeGarmo, 1948) in the southwestern Allegheny Plateau region of West Virginia.

Considering the fact that the rhododendron-hemlock, hardwood, and cut-over dry hillside habitat of these birds, upwards to 2000 feet in the mountains, is so unlike the canebrake habitat of the coastal populations, the writers undertook an examination of specimens from both areas for the purpose of determining whether there was any evidence of subspecific difference between the two populations.

During this study, we have confined our examination to birds taken within recent years, inasmuch as old skins tend to be somewhat faded, foxed, or otherwise museum-worn.

As a result of a rather lengthy and painstaking examination of specimens from both areas, we are convinced that, in breeding plumage, birds from the mountains are separable from those of the Coastal Plain. We have been less successful, however, in separating birds taken at other times of the year. This has been due, in part, to our inability to obtain sufficient material from all parts of the range and at all times of the year. Then too, distinctions between adult and immature birds in first fall plumage have been complicated by the fact that most specimens are unmarked as to age. We have thought it advisable, nevertheless, to present the results of our study of color differences in ventral plumage, based on the specimens and data that were arailable to us.

In consideration of these factors, we have been particularly careful in our examination of Audubon's type, which was collected by the Rev. John Bachman, near Charleston, S. C., almost 120 years ago. Since there is no date on the label, our only indication of the time this bird was taken is based on Audubon's statement that the bird was collected in the Spring of 1832 (Audubon, 1834:564). While there is a possibility that Audubon's type may have been a migrant representative of the mountain breeding populations, the specimen is an old skin which may have undergone considerable post-mortem change in color. In addition, the original description gives the under parts as "Brownish-gray," while 
the plate in the Elephant Folio shows the under parts to have some faint trace of yellow. Therefore, the evidence is inconclusive as to the color of the under parts with respect to yellow or the absence of yellow. Since Edisto River, near Charleston, S. C., is the type locality of Limnothlypis swainsonii (Audubon), and since the species is known to breed in this area, Audubon's name is hereby restricted to the Coastal Plain breeding population. This leaves the mountain-breeding populations without a name, and they may be known as:

Limnothlypis swainsonii alta, new subspecies

Appalachian Swainson's Warbler

Type.-Adult ô, United States National Museum No. 362,424, Walhalla, S. C., June 25, 1940, collected by W. M. Perrygo and S. Y. Hoyt, original number 4,681 .

Subspecific characters. - Similar to Limnothlypis swainsonii swainsonii (Audubon) of the Atlantic and Gulf Coastal Plains, but in breeding plumage with under parts more whitish, less tinged with yellow. Upper parts variable, but tending to be generally more brownish, less greenish. There is no significant size difference.

Plumages.- (Colors listed in capital letters are taken from Ridgway's Color Standards and Color Nomenclature, Washington, 1912.)

COASTAL PLAIN FORM.-Adult in fall (5 specimens): Strongly yellowish below, approaching Citron. Breeding plumage (15 specimens): Primrose Yellow. Immature in fall (2 specimens): Similar to breeding birds. (Note: Some birds taken in early spring still display strongly yellowish underparts, as in the fall plumage, while others are paler. Obviously some of these birds may be migrants of the paler mountain form, but we feel that possibly there is also an age factor involved. Our material and data, however, have been inadequate for any positive statement concerning this correlation.)

MOUNTAIN FORM.-Adult in fall (2 specimens): About same shade of yellow below as Coastal Plain breeding birds, but possibly duller. Practically indistinguishable from juvenile coastal birds in fall plumage. Breeding plumage (5 specimens): Almost immaculate below, but with light suffusion of Naphthalene Yellow on breast and abdomen. Immature in fall ( 1 specimen): Ivory Yellow.

Geographic Distribution.-Breeds in the Appalachian Mountains from West Virginia south to Georgia. Winter range unknown at present, but probably very similar to winter range of the coastal populations.

Specimens Examined.-WEST VIRGINIA: Nicholas Co., Mt. Lookout, $1 \hat{o}$; Collison Creek, $1 \hat{o}$; Fourteen, 1ô. NORTH CAROLINA: Asheville, $1 \hat{\delta}, 1$; ; Pisgah National Forest, 1 q . GEORGIA: Roswell, $1 \hat{o}$; Atlanta, $2 \hat{o}$; Augusta, $1 \hat{\delta}, 2$ 우 ; Richmond County, 1 ; ; White County, Robertstown, $1 \hat{\delta}$; Beechton, $1 \hat{o}$; Macon, $2 \hat{o}$; LOUISIANA: University, $9 \hat{o}, 3 \hat{q}$; Baton Rouge, $2 \hat{\jmath}, 2$; B Baton Rouge Parish, $3 \hat{o}$; Magnolia Crossing, $1 \hat{o}$; Baines, $2 \hat{o}$; Denham Springs, $1 \hat{o}$; Grand Isle, 1 우 ; Kleinpeter, $1 \hat{o}$; New Orleans, $5 \hat{o}, 1$ ㅇ‥ MISSISSIPPI: Vicksburg, $4 \hat{o}$; Starkville, $1 \hat{\alpha}$. SOUTH CAROLINA: Mt. Pleasant, 1 ; ; Walhalla, $1 \hat{o}$; TENNESSEE: Shelby Co., Lucy, $4 \hat{\delta}, 1$ 웅 Memphis, $2 \hat{o}, 1$ 우 ; Germantown, $4 \hat{o}$; Shady Valley, $1 \hat{\delta}$. MARYLAND: Pocomoke City, $1 \hat{o}$, Pocomoke Swamp, $2 \hat{o}$. 
Acknowledgments.-The writers would like to express their appreciatian for the loan of critical material to the following persons and institutions: The American Museum of Natural History, the Carnegie $\mathrm{Mu}$ seum, the Charleston Museum, the Chicago Natural History Museum, the Louisiana State University Museum of Zoology, the Museum of Comparative Zoölogy, and to Messrs. J. Fred Denton, Ira N. Gabrielson, William W. Griffin, W. A. Lunk, Richard A. Parks, George M. Sutton, and M. G. Vaiden.

\section{LITERATURE CITED}

Audubon, John James

1834. Ornithological Biography, II

Audubon, John James

1834. Birds of America (folio), II

Legg, W. C.

1946. Swainson's Warbler Nests in Nicholas County

The Redstart (mimeo), XI, No. 12: 70-72.

Sims, Eleanor, and DeGarmo, W. R.

1948. A Study of Sfainson's Warbler in West Virginia

The Redstart (mimeo), XVI, No. 1: 1-8. 
194 Proceedings of the Biological Society of Washington 
Vol. 63, pp. 195-202

\title{
PROCEEDINCS
}

\author{
OF THE
}

\section{BIOLOGICAL SOCIETY OF WASHINGTON}

\section{NORTH AMERICAN ADDITIONS TO THE GENUS PTEROCHEILUS (HYMENOPTERA, VESPIDAE)}

\author{
By RICHARD M. BoHaRT \\ University of California, Davis
}

In the decade since publication of my revision ${ }^{1}$ of the genus Pterocheilus, 5 new species and 1 new subspecies have turned up, bringing the known total for America north of Mexico to 37. This includes the discovery that nigricaudus R. Bohart, described from the female, is synonymous with inyoensis $\mathrm{R}$. Bohart, described from the male. This was indicated by a series of both sexes from Yermo, San Bernardino Co. (E. G. Linsley, J. W. MacSwain) and Hopkins Well, San Bernardino Co. (J. E. Gillaspy, L. W. Quate) collected in April, 1949. Also, a long series of both sexes of acuceps $R$. Bohart was collected at Mendota, Fresno Co., April 23, 1949 (E. G. Linsley, J. W. MacSwain, R. F. Smith). The male of this species has not been previously described and its principal features are given below.

Pterocheilus acuceps R. Bohart

Pterocheilus (Micropterocheilus) acuceps R. Bohart, 1940. Ann. Ent. Soc. Amer. $33: 208$, female.

Male. - Similar to morrisoni Cresson, but last antennal segment smaller, more cone-shaped, not flattened beneath. Also, tergite II with a rather squarely U-shaped yellow margin, instead of curved as in morrisoni.

The puncturation, pubescence, clypeal shape and mid femur shape are much as in morrisoni. The genitalia are most similar to those of cyathopus $\mathrm{R}$. Bohart, with the paramere stout and obliquely truncate at the apex. In cyathopus, the clump of stout bristles at the inner apex is largely confined to the oblique apical margin, whereas in acuceps the bristles continue onto the inner margin. One additional locality is Coalinga, Fresno Co., California (M. Cazier).

Pterocheilus (Megapterocheilus) bradleyi, new species

Description of male.-Dark brown to black marked with ivory as follows: basal mandible spot, clypeus, face around antennal insertions, extenđing along lower orbits, spot along upper orbit opposite median ocellus, scape in front, postocular line, pronotum above, tegula except for a clear spot, mesopleural spot, parategula, 2 scutellar spots, postscutellum

${ }^{1}$ Bohart, R. M., 1940. A revision of the North American species of Pterocheilus and notes on related genera. Ann. Ent. Soc. Amer. 33:162-208. 


\section{Proceedings of the Biological Society of Washington}

mostly, spot on propodeal angle, legs partly, wavy apical margins of tergites I to VI and sternites II to VI, that on tergite II shaped roughly like a W. Antennal flagellum brownish beneath, legs partly brown. Wings lightly brown-tinted. Pubescence inconspicuous, pale, minute except on frons and propodeal angles; tergite II with a brownish pubescent sublateral spot. Puncturation moderate on head and thorax, fairly coarse and close on tergites; punctures of clypeus minute, those of frons small and well separated, those of pronotum moderate but well spaced, those of mesonotum mostly less than a puncture diameter apart, those at center of tergite II rather coarse and close. Clypeus weakly concave at apex which is about half as broad as length of antennal segment III; last antennal segment shaped like a curved cone, twothirds as long beneatli as segment XII but only about one-half as large; head broader than long, lateral ocellus not quite 2 diameters from compond eye; propodeal angles blunt, mid femur somewhat flattened beneath toward base; labial palpus with second segment as long as antennal segment XII, third segment as long as XIII. Genitalia about as in mirandus Cresson ${ }^{2}$ but aedeagus and parameres a little more slender, aedeagus with edge serrate between median prongs and paramere insertion, paramere with inner basal edge nearly straight. Length to apex of second tergite $10.0 \mathrm{~mm}$.

Types.-Type male and 1 male paratype, Nogales, Arizona, August 30, 1927 (J. C. Bradley). Type in Cornell University Collection; paratypo in collection of author.

Remarlos. - A female specimen with the same data as the type is probably the same species. However, it differs markedly in color, with an orange-red in place of black except at the petiole, along some sutures and in the ocellar area. The clypeus is somewhat produced apically and truncate.

The male of bradleyi runs between trichogaster $\mathrm{R}$. Bohart and decorus Cr. in the author's key to Pterocheilus. ${ }^{2}$ The last antennal segment is pointed but the first tergite has no long hair. The presumed female runs to texanus Cr. in the same key but lacks the dark brown wings of the latter and has the first tergite more narrow and gradually sloping.

\section{Pterocheilus (Onchopterocheilus) sculleni, new species}

Description of male.-Black, reddish and ivory (ivory to yellow in paratypes). Reddish are: mandible apex, antennal insertion, scape mostly, flagellum entirely, pronotum at sides below, mesopleuron partly, propodeum except for 2 large spots, stains on scutellum and postscutellum, legs partly (including most of femora), large square-ended mark on tergite I, $x$-shaped mark on tergite II, bases of tergites III to VI, tergite VII, sternites VI and VII. Ivory are: mandible mostly, clypous and labrum, frontal and orbital marks, postocular spot, scape in front, pronotum above, large mesopleural and propodeal spots, 2 pairs of spots laterally on mesonotum, tegula, 2 spots on scutellum, post-scutellum mostly, legs partly including most of tibiae, abdomen except for red marks. Costa mostly and other veins of forewing basally reddish, stigma reddish, membrane clouded toward apex. Pubescence pale and inconspicuous except on clypelis which is thickly covered with short silvery hair.

2Figured in Bohart, R M., 1940. Ann. Ent. Soc. Amer. $33: 177$, fig. 3. 
Puncturation sparse on clypeus, coarse and separated by less than a puncture diameter on pronotum, mesonotum and dorsum of tergites $I$ to III, a little less coarse on other tergites and rest of thorax; sternite II well punctured throughout, punctures mostly separated by a puncture diameter. Clypeus convex apically, head broader than long, last 2 anten. nal segments very small and largely retracted within $\mathrm{XI}$, mid femur with a moderate hump at base beneath, parategula broadly rounded, propodeal angles blunt. Aedeagus with about 15 subbasal lateral teeth; paramere roughly cone-shaped, longer than broad at base, apical one-half with many strong inward-pointing bristles, becoming more numerous toward apex. Length to apex of second tergite $9.0 \mathrm{~mm}$.

Description of female.-Clypeus varying from ivory with red mark toward apex to yellow to orange-red. Mesonotum as in male or with black largely replaced by reddish. Mandible mostly or all red, frons and legs mostly reddish. Pale markings ivory to yellow. Labial palpus light reddish. Clypeus obtusely pointed at apex, punctures distinct and 2 to 3 puncture diameters apart. Length to apex of second tergite about $9.0 \mathrm{~mm}$.

Types.-Male, California Academy of Sciences, Ent. No. 6,146, Doug. las, Arizona, June 16, 1942 (H. S. Scullen). Paratypes, 2 females, same data as type; 1 pair, Eckley, Colorado, June 30, 1925 (H. J. Grady); 4 males and 2 females, near El Paso, Texas, June 21, 1942 (E. C. Van Dyke and H. A. Scullen).

Remarks.-This species runs near laticeps in the key (Bohart, 1940) and makes the fourth known species of the group. They may be separated as follows:

1. Labial palpus of female yellow, legs black and yellow

Labial palpus of female red or reddish brown; legs with considerable reddish, at least on femur.

2. Clypeus in both sexes with a slight subapical depression filled with punctures coarser than those on rest of clypeus; mesonotum of female with a pair of nearly complete curved yellow stripes. Male mid femur with an acute basal knob, male paramere broad at apex and heavily bristled.

hurdi R. Bohart

Clypeus evenly convex and rather evenly punctured in both sexes; mesonotum of female without central marks or with a pair of dots only; male mid femur swollen at base but not distinctly knobbed; male paramere more slender and pointed toward apex, lightly bristled ______________achysomus $\mathrm{R}$. Bohart

3. Second tergite with lateral spots broadly attached to apical margin and extending obliquely inward so as to define a red or black $\mathrm{x}$-shaped mark; male paramere cone-shaped with many long and stout bristles sculleni R. Bohart

Second tergite with detached or pale spots; male paramere boatshaped and with weak bristles. laticeps Cresson

\section{Pterocheilus (Onchopterocheilus) hurdi, new species}

Pterocheilus trachysomus R. Bohart, 1940, in part, including allotype female and plate II, fig. 11. Ann. Ent. Soc. Amer. 33:193.

Description of male.-Black marked with yellow as follows: mandible mostly, clypeus, scape in front, interantennal spot, lower orbit, postocu- 
lar spot, pronotum except laterally, 2 large pleural spots, tegula and parategula, 2 spots on scutellum, postscutellum mostly, large spot on propodeal angle, legs mostly, apex of tergite I broadly and continued forward laterally to form a $U$-shaped mark, apical margins of tergites II to VI, enlarged medially and joined with lateral spot on II so that a black $\mathrm{X}$-shaped mark is defined, apical bands on sternites I to VI, those on $I$ and II U-shaped. Inner surface of flagellum, wing veins toward base and around stigma reddish. Wing membrane lightly stained. Pubescence moderate, silvery and appressed on clypeus, erect and fulvous on front, minute and inconspicuous elsewhere. Puncturation relatively coarse; clypeus with largest punctures in a slightly depressed subapical area, tergites closely punctured, tergite I roughened from middle toward apex. Clypeal apex somewhat convex; last two antennal segments largely enclosed in segment XI; parategula oval, propodeal angle blunt, outer surface of mid femur with an acute hump; paramere with a slanting, truncate apex, outer apical angle about $60^{\circ}$, inner apex with a tuft of stout bristles; aedeagus narrow apically and broad medially with a row of about 13 sharp teeth.

Description of female.-Clypeus with an irregular linear spot from middle to base sometimes present, labial palpus yellow, mesonotum with a pair of oblique lines, diverging and recurved anteriorly; clypeus convex at apex and with a slightly depressed subapical area filled with coarse punctures.

Types.-Male, California Academy of Sciences, Ent. No. 6,147, Hallelujah Junction, Lassen Co., California, July 4, 1949 (P. D. Hurd). Paratypes, 4 males and 9 females from the following California localities: Hallelujah Junction, Lassen Co.; La Crescenta, Los Angeles Co.; Mt. San Jacinto, Riverside Co. Collection dates are from May 10 to August 14.

Remarks.-A paratype female from Mt. San Jacinto and a paratype male from La Crescenta were paratypes of trachysomus R. Bohart. Also, the allotype female of trachysomus now in the California Academy of Sciences is actually hurdi, the true female of trachysomus differing as indicated in the foregoing key.

\section{Pterocheilus (Micropterocheilus) sparsipunctatus, new species}

Description of male.-Black, marked with yellow as follows: clypeus, labrum, mandible mostly, interantennal spot, lower orbital line, scape except for a small black apical spot, postorbital line, pronotum largely, 2 large spots on mesopleuron, tegula, squarish spots on scutellum, postscutellum mostly, parategula, propodeal spots, legs largely and including first 4 tarsal segments (last one brown), broad apical bands on abdominal segments, that on tergite II with anterior margin straight across middle and angled obtusely toward base, segment VII mostly black. Flagellum orange-yellow beneath with a black line above ex. tending around tip of last segment. Wings smoky, veins brown to black. Pubescence pale fulvous, upright, very short except on front where it is about 4 ocellus diameters, and propodeum where it is 1 to 2 ocellus diameters. Puncturation mostly fine, moderate and close on front, distinct but well separated on clypeus, granulate on mesonotum, fine and sparse on propodeum and abdominal apices, apparently absent in black-marked areas of abdomen which are finely granulate. Clypeus a nearly equal- 
sided heptagon, apex slightly concave and about as wide as length of antennal segment III; last antennal segment almost as long as XII, broadly rounded at apex, stoutly cone shaped; head broader than long; propodeum with cheeks bluntly angled; mid femur somewhat flattened toward base beneath but without an evident depression. Paramere enlarged triangularly toward apex and bearing 7 or 8 long briatles around inner angle, as well as 11 or 12 scattered shorter ones, longer bristles more than twice as long as distance across narrowest part of paramere. Length to apex of second tergite $6 \mathrm{~mm}$.

Description of female.-Clypeus black-bordered apicolaterally and light brownish across apex. Legs mostly yellow, tarsi roddish tinted. Clypeus almost twice as broad as long, apex slightly concave and with sharp lateral angles, head slightly broader than high. Length to apex of second tergite about $7.0 \mathrm{~mm}$.

Types.-Male, California Academy of Sciences, Ent. No. 6,148, Mt. Pinos, Ventura Co., California, May 31, 1942 (R. M. Bohart). Paratypes, 3 males and 4 females from the following California localities: Mt. Pinos, Ventura Co. (R. Bohart); Acton, Los Angeles Co. (E. G. Linsley), Claremont, Los Angeles Co.; Mt. San Jacinto, Riverside Co. (R. Bohart); Deep Creek, San Bernardino Co. (E. G. Linsley).

Remarks.-This species most closely resembles provancheri (Huard) and runs to it in my $1940 \mathrm{key}$. The more robust last antennal segment of the male, the broader clypeal apex in both sexes, and the practical absence of puncturation toward the bases of the abdominal segments all serve to distinguish sparsipunctatus. Details of the male genitalia, particularly the long bristles of the parameres, are also characteristic.

Pterocheilus (Micropterocheilus) provancheri albotinctus, new subspecies

Pterocheilus provancheri pruinosus Cameron, of R. Bohart, 1940 Ann. Ent. Soc. Amer. $33: 203$.

Description.-Marked as in typical provancheri (Hurd), except that yellow is largely replaced by white. Pale markings of legs, clypeus, and mandible tinted with yellow.

Types.-Male, California Academy of Sciences, Ent. No. 6,149, Summit Camp, Lassen Co., Calif., June 28, 1949 (J. W. MacSwain). Paratypes, 10 males and 9 females from the following localities: Summit Camp, Lassen Co., Calif. (J. W. MacSwain); Lake City, Modoc Co., Calif. (C. R. Fox); Elko Co., Nevada (T. E. Snyder, P. H. Baldwin); Gerlach, Nevada (P. C. Ting); Boardman, Oregon (G. R. Ferguson); Wagontire, Oregon (H. A. Scullen); Hatton, Washington (R. C. Shannon); Lind, Washington (F. W. Carlson); Toppenish, Washington (Spuler); Bridger Basin, Wyoming (S. Garman).

Remarks.-This subspecies is indicated in my $1940 \mathrm{key}$ to males as a whitish provancheri, and in the key to females as subspecies pruinosus. However, true pruinosus Cameron is a larger, more heavily punctured, species from Arizona, similar except in coloration to flavobalteatus Cameron. $P . \quad p$. albotinctus is similar in appearance to seneconis Rohwer, and the females of the latter are distinguished only by their finer puncturation. The males are separated by the depression at the base of the mid femur in seneconis and its absence in albotinotus. 


\section{Pterocheilus (Micropterocheilus) paenacuceps, new species}

Description of female.-Black, marked with orange as follows: clypeus except basally, mandible, labial palpus, antenna except segments $X$ to XII above, interantennal dot, lower orbital line, postocular spot, pronotum above, mesopleural spot, tegula mostly, wing veins mostly, 2 spots on scutellum, postscutellum mostly, legs except basally, broad apical bands on tergites I and II, narrow basal and apical bands on tergites V and VI, lateral spot on sternite I, sternite II mostly, sternite VI at base and apex. Wing membrane amber to dusky in apical cell, faint violet reflections. Pubescence fulvous, inconspicuous. Puncturation moderate to fine, clypeus somewhat strigose and moderately punctured, punctures of front and mesonotum small but close, abdominal tergites with fine punctures basally and a zone of coarser apical ones. Clypeus tapering to a rounded point, head slightly broader than long, propodeum rounded laterally, length to apex of second tergite $8.0 \mathrm{~mm}$.

Type.-Female, California Academy of Sciences, Ent. No. 6,150, Green River, Wyoming, July 2, 1920. Paratypes, 1 female, same data as type; 1 female, Rock Springs, Wyoming, June 29, 1920.

Remarles.-This species is the only one in the subgenus with black and orange color pattern. Structurally it resembles acuceps, particularly with respect to the pointed clypeus. However, paenacuceps has a rather definite apical zone of punctures on tergites I and II, whereas in acuceps the punctures become gradually finer toward the base on these tergites. Since the known males of this subgenus resemble the females in markings, the male of paenacuceps should be readily recognizable when found. 
202 Proceedings of the Biological Society of Washington 


\title{
PROCEEDINCS
}

\section{OF THE \\ BIOLOCICAL SOCIETY OF WASHINGTON}

\section{A NEW CACOMISTLE FROM SOUTHEASTERN CALIFORNIA}

\author{
Bt KENNETH E. StAger
}

A study of the distribution of the genus Bassariscus in southeastern California has disclosed the presence of a desert form which does not appear to have been previously recognized; it may be described as follows:

Bassariscus astutus willetti, subsp. nov.

Type.-Adult male, skin and skull no. 7,976, Los Angeles County Museum; Riverside Mountains, extreme northeastern corner of Riverside County, California; collected by Kenneth E. Stager, February 13, 1942.

Distribution.-Known from the type locality and southward to, and including, the Palo Verde Mountains, Imperial County, California.

General Characters.-Smaller than raptor and octavus, color light. Stands apart from nevadensis and yumanensis in color tone, due to the noticeable suffusion of pinkish buff, both dorsally and ventrally. Skull differs from those of both yumanensis and nevadensis in its shorter and more massive rostrum. Hairs of white tail rings noticeably pinkish buff at their bases.

Color of Type.-Color of upper parts near cinnamon buff (of Ridg. way, 1912), with the black guard hairs giving a somewhat darker appearance to the dorsal region, especially in the mid-dorsal area from the neck to base of tail. The black guard hairs thin out on the flanks, showing light ochraceous buff at point of junction with ventral surface proper. Forelegs bright pinkish buff on ventral surface, shading to a darker color on dorsal side due to presence of dark guard hairs. Paws a clear pinkish buff. Dorsal color of hind legs similar to forelegs, with paws showing the same pinkish buff. Ventral surface of feet dusky around margin of pads. Face of animal showing strong contrast of light and dark areas, with light patches predominant. Cheek patches under eyes ranging from pinkish buff above lips to almost white just under eye. A large postsupraocular patch of very pale pinkish buff abore each eye separated by a dark frontal patch. The type specimen possesses a blaze of pale pinkish buff on top of head between the ears, but this marking is not in evidence in any of the other specimens of the series. Ears pale whitish on distal ends, shading into smoky at bases posteriorly. Tail with characteristic eight alternating black rings and black tip. Three black rings at proximal end of tail suffused with ochraceous buff. On ventral surface of tail the black rings are incomplete, resulting in a continuous mid-ventral white line extending the entire length of the tail except for black tip. The hairs of the white tail rings are a noticeable pinkish buff at their bases throughout.

Skull.-Resembling that of arizonensis, but with rostrum proportionately shorter and more massive. Larger than yumanensis, with the mas- 


\section{Proceedings of the Biological Society of Washington}

siveness of the rostrum contrasting strongly with the more slender rostrum of yumanensis.

Measurements of Type.-Total length, $765 \mathrm{~mm}$; tail vertebrae, 400; hind foot, 60 ; ear, 53. Average of four adult male paratypes: 750 (758-745); $389(395-378) ; 64.5(66-62) ; 52$ (54-49). Skull (type); Greatest length, 78.3; condylobasal length, 74.8; zygomatic breadth, 50.7 ; breadth of rostrum (over root canine), 14.7 ; mastoid breadth, 33.7 ; interorbital constriction, 17.9 ; canine-molariform toothrow (alveoli), 31.7. Average of four adult male paratypes: greatest length, 78.4 (77.9-79.7); condylobasal length, 75.5 (75.1-76.7); zygomatic breadth, 47.7 (45.9-48.7); mastoid breadth, 33.5 (32.6-34.5); interorbital constriction, $17.2(16.5-17.8)$; canine-molariform toothrow, 30.7 (30.0-31.4).

Remarks.-The three specimens, 1 male (L.A.M. 8,397) and 2 females (L.A.M. 8,395 and 8,396), from the Palo Verde Mountains, show the same skull characters as those given for the type, but there is a reduction in the amount of pinkish buff in hair color, thus causing them to favor yumanensis in external appearance. This intergradation is to be expected, however, since the Palo Verde Mountains are situated close to the edge of the range of yumanensis as given by Huey. A specimen (MVZ 51,608) from near Laguna Dam, Imperial County, California, possesses a skull with characters almost identical with those of the skull of the type of yumanensis.

Specimens Examined.-Total number, 10, as follows: RIVERSIDE COUNTY: Riverside Mountains (type locality), 7; IMPERIAL COUNTY: Palo Verde Mountains, 3. 


\section{jiा12- ing \\ wational MUSEUM}

Vol. 63, pp. 205-208

December 29, 1950

\section{PROCEEDINCS}

OF THE

\section{BIOLOGICAL SOCIETY OF WASHINGTON}

\section{A NEW TYROGLYPHID MITE FROM PUERTO RICO}

By Irving Fox

Department of Microbiology, School of Medicine, School of Tropical Medicine, San Juan, Puerto Rico

The mite described here was first observed in 1946, when it appeared in Petri dishes containing wropods, which had been combed from rats in the course of an ectoparasite survey. For some time it was believed to be associated with rats. Later on, however, when light trap collections were under study, the mite was again noted, this time feeding voraciously on dead mosquitoes and other insects. It is therefore a feeder on dead insects, and a museum pest of no mean proportions, at least in Puerto Rico, where it can quickly destroy an insect collection not adequately protected with paradichlorobenzene.

\section{SUBFAMILY SUIDASINAE HUGHES}

Suidasia insectorum, new species

Male.-Length of idiosoma of holotype, .358 mm., greatest width, $.232 \mathrm{~mm}$; ; length of idiosoma of three paratypes, .316 mm., $.319 \mathrm{~mm}$., and $.336 \mathrm{~mm}$. The shape of the body and the texture of the cuticle is very much as described for $S$. nesbitti Hughes, except that certain specimens give a more broad-shouldered effect when alive, and the dorsal surface has distinct longitudinal grooves; the opisthosoma, too, seems to have on each side a more or less oval hyaline area (Fig. 1). After mounting on a slide in Berlese mixture, the body shape is broadly oval and the texture of the skin as when alive cannot be made out. Chelicera armed wtih prominent teeth as shown in Fig. 2. The internal vertical setae (Fig. 3) arise from conspicuous tubercles; the external verticals are very faint and located well anterior to the pseudostigmatic organs. External scapular setae large and robust; the internal scapulars very small as indeed are the other dorsal setae. Pseudostigmatic organ (Fig. 5) large and plumose. External posterior setae stout, about onehalf as long as the idiosoma; internal posteriors very small. On each side of the anus is a large oval area about which are three small setae, near the most anterior of these is an unidentified structure which is somewhat larger than a setal pit (Fig. 7). Genital area with a pair of suckers on each side (Fig. 9); the penis in its undisturbed position appears to be concave at the middle, but in some mounted specimens it is bent to one side or the other (Figs. 9A and 9B). Legs $I$ are longer and wider than the others; the average lengths of all legs (legs I, II, III 


\section{Proceedings of the Biological Society of Washington}

and IV) of four specimens when measured from the base of the trochanter to the end of the tarsus exclusive of the claws were in the following proportion, $49: 39: 43: 40$. Chatotaxy of tarsus I as shown in Fig. 10; the microsense seta does not appear to be present but there is a circumscribed area which may be its rudiments, the macrosense seta extends well beyond the dorsal median seta and the distal edge of the tarsus bears two spine-like seta. In tarsus II the macrosense seta is shorter and broader and does not extend beyond the dorsal median seta. Tarsus IV has two suckers of which the basal is located about equidistant from base to apex and the distal is located in the apical third as shown in Fig. 4. Tibiae I, II and III each with a long distal seta which is much shorter than its corresponding leg, being about threefifths as long on the first leg and about one-half as long on the other legs; tibia IV does not have such a seta but instead a stout spine (Fig. 4).

Female.-Length of idiosoma of female allotype, $.350 \mathrm{~mm}$, greatest width, $.218 \mathrm{~mm}$.; length of idiosoma of three other specimens, .358 mm., $.364 \mathrm{~mm}$., and $.372 \mathrm{~mm}$. In gencral the structure is as in the male. Anal region as shown in Fig. 8 ; the setal pit-like structures are more faint in the female than in the male. Legs as in the male with the first pair longer and broader than the others. Tibiae IV with long setae but they are shorter than those on the other tibiae. Tarsus $I$ is very much as in the male.

Immature stages.-Nymphs have the general structure of the adults, but the genital suckers are not on the same level as in the male or female, the pair on one side being nore anterior to the pair on the other side. Tibiae IV with long setae as in the female. In the larvae legs I are longer and wider than the others and the larval sense organ is bottleshaped, as shown in Fig. 6. Length of the idiosoma of a late stage nymph paratype, $.294 \mathrm{~mm}$., greatest width, $.176 \mathrm{~mm}$. Length of idiosoma of a larval paratype, .182 nim.

Type material.-Male holotype and three male paratypes taken August, 1950, feeding upon dead mosquitoes which had been collected by means of a light trap and stored in the School of Tropical Medicine building at San Juan, Puerto Rico; female allotype, one paratype late stage nymph and one paratype larva taken under the same circumstances August 15, 1950, and September 8, 1950. The types are in the entomological collection of the Department of Microbiology, School of Medicine, School of Tropical Medicine, San Juan, Puerto Rico.

Remarks. - In working up this mite, the writer was the fortunate reeipient of valuable advice from two distinguished authorities on the Tyroglyphidae, Dr. Herbert H. S. Nesbitt and Mrs. A. M. Huglies. Dr. Nesbitt, who had studied Oudemans' types, stated in personal correspondence dated March 16, 1949, "The specimens of Suidasia sp. are so close to $S$. medanensis (Oud.) that $I$ was tempted to call them a geographical variety of this. Because of the different habitats, though their presence on rats may be purely accidental, I refrained. You can do as you see fit." Mrs. A. M. Hughes, who was familiar with Dr. Nesbitt's study of the species, wrote in personal correspondence dated November 8,1949 , "I myself feel that it would be better to describe your species as a new one allied to $S$. nesbitti (which came from Istanbul, Turkey) 
and $S$. medanensis as Oudemans' original description leaves much to the imagination."

S. medanensis (Oudemans) has as its type habitat the nest of a bee, $X y$ locopa, and the type locality was Medan, Deli, Sumatra. The original description, in Entomologische Berichten 6:320, 1924, is meager and not illustrated, but certain phrases seem to show that a different species from the one described above was involved. Such phrases are, "Tibiae I, II, III met tasthaar bijna even lang als die poot. Pseudostigmatisch orgaan een gebogen borstel." "Larva ..... Ventraal. "Bauchtstiele" konisch; ..... Pooten \pm even lang." "Mas ..... Penis kort, recht." To the writer it is hard to believe that Oudemans could have been mistaken not only in the type habitat and locality but also in observing certain important characters.

\section{Explanation of Plate.}

Suidasia insectorum, new species. Fig. 1. Male, showing the body shape, dorsal grooves and in broken lines what appear to be hyaline plates on the opisthosoma. Fig. 2. Male, chelicera. Fig. 3. Male, internal vertical setae. Fig. 4. Male, distal portion of the tibia and tarsus IV. Fig. 5. Male, pseudostigmatic organ. Fig. 6. Larva, sternal area with the larval sense organ much enlarged. Fig. 7. Male, anal region. Fig. 8. Female, anal region. Fig. 9. Male, genitalia of the holotype; $9 \mathrm{~A}$, penis of a paratype; $9 \mathrm{~B}$, penis of another paratype. Fig. 10. Male, tarsus I. 

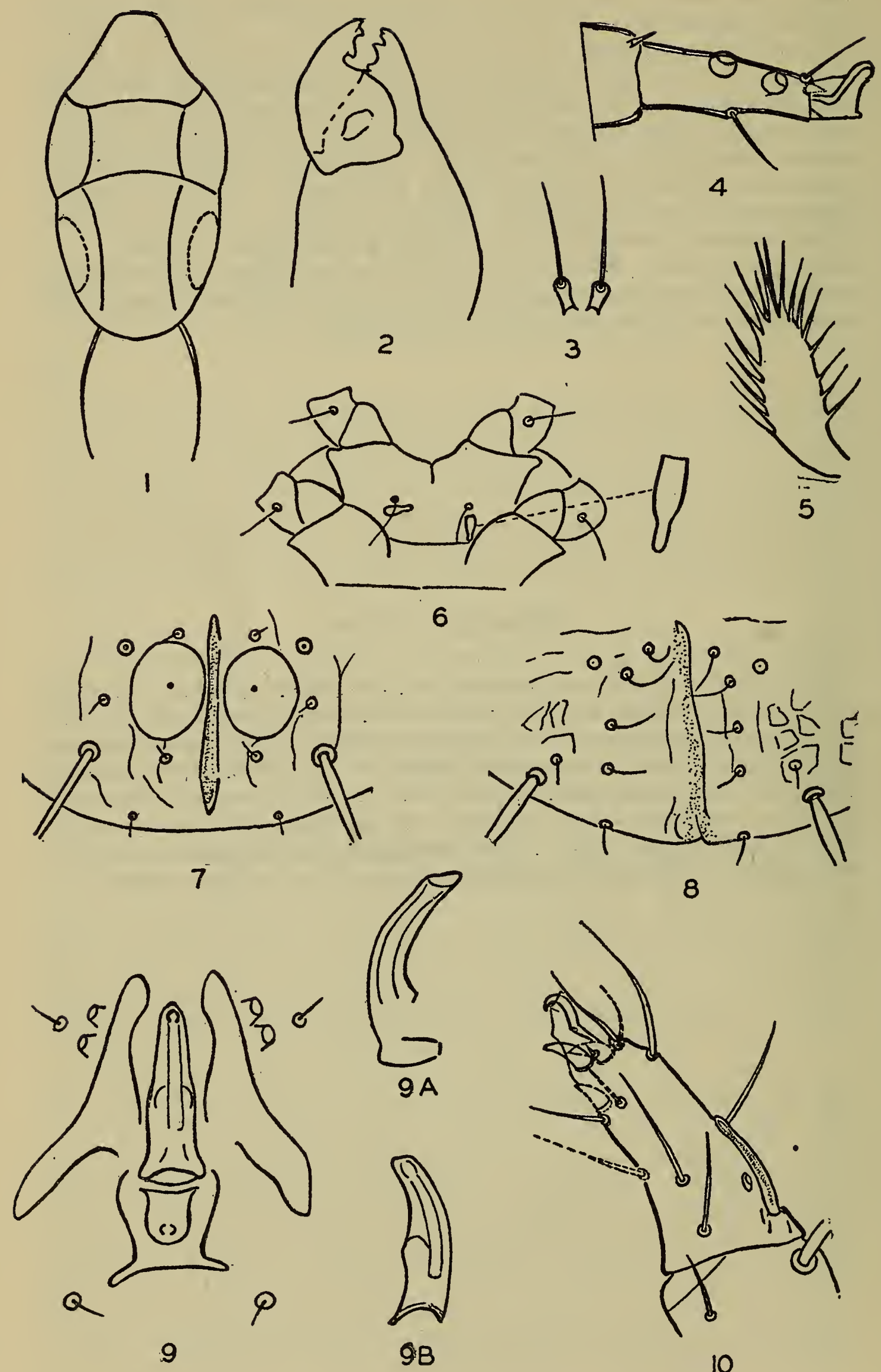

8

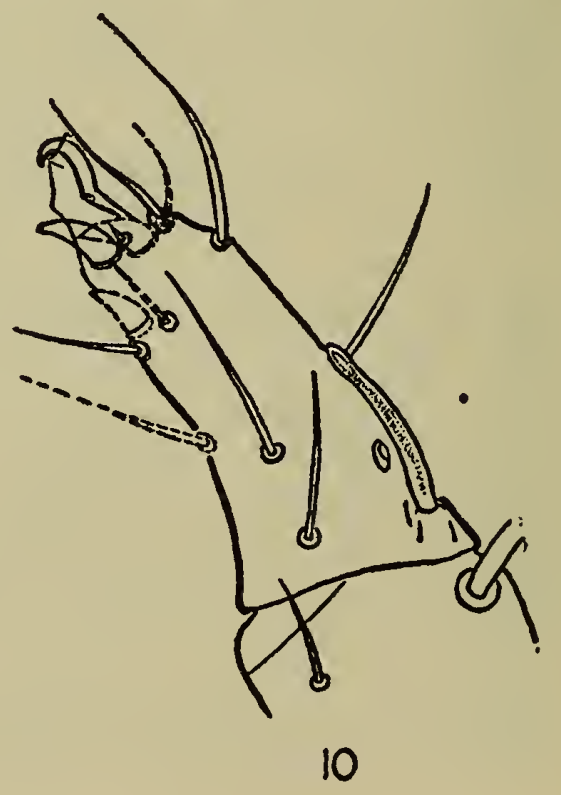




\section{INDEX}

New names are printed in heavy type.

A

Abbott, R. Tucker

Giant African snails

Acanthia balnearum

Achillea millefolium

aciculatus, Hoplothrips -...

Actinodura nipalensis

daflaensis

nipalensis
poliotis
vinctura
waldeni

acuceps, Pterocheilus -

Pterocheilus (Micropterocheilus)

adjunta, Portoricona
adiuntus, Glomeridesmus --.

adjuntus, Glomeridesm

Phylloscopus

Agama kirkii fitzsimonsi

mossambica

occipitalis

agathona, Aphis

agathonica, Amphorophora -

agrestis, Eurydesmus -

albanus, Liomus.

albescentior, Certhiaxis

cinnamomea

albilabris, Reithrodontomys

microdon

albopictus, Pseudomasaris

zonalis

albotinctus, Pterocheilus (Mi= cropterocheilus) provan=

$$
\text { cheri }
$$

Algunguis

$$
\text { toronus }
$$

alta, Limnothlypis swainsonii

amacurensis, Celeus undatus Amazilia beryllina

beryllina
devillei
lichtensteini
motaguae

americanus, Lepus ameri. canus

Ames, Oakes

Amphorophora agathonica .. kesocqua

rubi

tigwatensa

angulatus, Eurydesmus -

anguste, Dinopium shorii -...

annulus, Cyclorhabdus

aorensis, Pteropus

Pteropus anetianus -.....

Aphis agathona

erigoni

ribis

tahasa

tanahasa

urovaneta $\begin{array}{r}189 \\ -21,23 \\ \hline\end{array}$

23,26

100

35

100

24 approximans, Celeus elegans Rhinocricus

aquaticus, Scalopus aqua-

ticus

Sorex

arborea, Macrocarpaea

arboreus, Chelonanthus …... Julus

Rhinocricus

Spirobolus (Rhinocricus).-

arcanus, Phylloscopus

subaffinis

arcuatus, Dermanysus ...

Lisianthus

arizonensis, Bassariscus

astutus

Zethus (Zethusculus)

Artemisia dracunculoides -

Asthenes

wyatti mucuchiesi sanctae=martae wyatti

Atlapetes personatus parui collaris paraquensis personatus

21,23

186

$149,150,152$

199

157

157

192

117, 118

59,60

59,60

59,60

59

63,64

98,100

97

98,100

186

102

70

190

atripes, Macrosiphum

fuliginosa

Attila

Atwood, Earl L. -

urea, Hyla aurea

australis, Cyclora

B

bainensis, Dendrocincla

fuliginosa

bairdii, Lepus americanus

Baker, Rollin H., and Cockrum, E. Lendell.

A New Jumping Mouse (Genus Zapus) from Kan-

Baker, Rollin H., and Hankins, Robert M.

A New Subspecies of Snowshoe Rabbit from Wyoming

Ballard, R. C.

Ballophilus riverol

balnearum, Acanthia Saldula

Barber, H. S.

Bassariscus

astutus arizonensis

nevadensis _octavus

raptor

willetti y umanensis

Benyon, Wm. E

beryllina, Amazilia

Amazilia beryllina

beryllinus, Trochilus

(209)
116

69

65,66

65

164

164

150

150

150

105

31

163

203

77

26

85

86

85

46,47

47

47
47

18,27

119

$\mathrm{x}$
134

132

119

63,64

$1-4$

63.64

$x$
157

157
177

179

203

203

203

203

203

203, 204

$\mathrm{xi}$
59

59,60

59

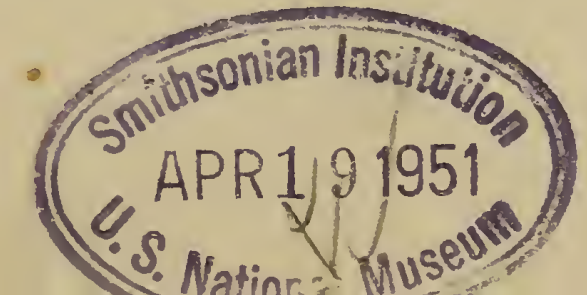


Bishop, Sherman C.

A New Cave Spider from North Carolina

bislineata, Eurycea -

Blake, S. F., reelected $\mathrm{Re}$ cording Secretary

appointed delegate of the Society to Seventh International Botanical Congress at Stockholm

Exhibition of specimens of Wolffia papulifera from Texas, and Wolffiella floridana and Leruna minor from Kenilworth Aquatic Gardens

Report of observation of about 50 Red - winged Blackbirds in Alexandria, including one female

Report of the voice of the Snowy Owl as described by various observers Report of finding three clumps of Solidago juncea in flower in Arlington, Va.

Blarina brevicauda carolinensis... kirtlandi

Bohart, Richard $\bar{M}$.

New species of Solitary Vespidae from North America (Hymenoptera, Vespidae)

North American Additions to the Genus Pterocheilus (Hymenoptera, Vespidae)

bolliformis, Eumenes cruci. fera

Bond, Gorman M., and

Meanley, Brooke

A New Race of Swainson's Warbler from the Appalachian Mountains

borealis, Lasiurus borealis... Vespertilio

Borthwick, H. A., Member of Council _........

Brachoria glendalea

bradleyi, Hoplothrips

bradleyi, Pterocheilus (Meg. apterocheilus)

Braggia echidna uncompahgrensis

breweri, Parascalops Scalops

brittonii, Lisianthus

bonitum, Macrosiphum brunneomarginatus, Mecocerculus leucophrys

Burger, W. Leslie, Smith, Hobart $M_{.,}$and Potter, Floyd E., J'r.

Another Neotenic Eurycea from the Edwards Plateau

C

californicus, Clethrionomys. Cambarellus diminutus ninae

puer

schmitti

shufeldtii

campestris, Zapus hudsonius caniceps, Megalaima zeyCapitophorus patonkus colo55, 96 Capitophorus patonkus colocaraibicus, Otostigmus _-_

x Carex _... 35, 36, 38, 39 caricis, Macrosiphum ___._._. carnifex, Hirstionyssus _-_ 32 carolinensis, Blarina brevicauda

carolinensis, Ivesia _ _ Sorex

cayannensis, Cotinga cayana

Celeus elegans approximans _...-. deltanus hellmayri leotaudi jumana

citreopygius _................ jumana

undatus amacurensis ............... multifasciatus undatus

centralis, Phylloscopus

maculipennis

68 Centurus chrysogenys

67 Certhia himalayana hima. layana

$$
\text { infima }
$$

9, 10

115, 116

115,116

117

116,117

116,117

117, 118

118

117,118

106

109

106

106

Certhiaxis cinnamonea albe. scentior valenciana

85
85

77.84 Chamberlin, Ralph V.

Some Chilopods from Puer. to Rico

195-202 Some Diplopods from Puerto Rico

chamberlini, Chondrodesmus chapini, Varicorhinus

Chartoscrita

Chelodesmus marxi

191-194

Chelonanthus arboreus

Chondrodesmus chamberlini. panamenus

chrysogenys, Centurus .............

Melanerpes

Melanerpes chrysogenys.

18,20

15

Cinara

Cinclodes fuscus

cineraceus, Lipaugus cinera. ceus

cinereus, Lasiurus

Sorex cinereus

Vespertilio

Cinclosoma rufimenta cinereiventris, Pachyram-

phus polychopterus

citreopygius, Celeus jumana

clarus, Cryptogonodesmus ...

Clavophilus

$$
\text { maricaonus }
$$

Cleidogona maculata _._.

Clethrionomys californicus -.. cockerelli, Macrosiphum --_Cockrum, E. Lendell, and Baker, Rollin $\mathrm{H}$.
32

89,92

89

89

89,92

$89,92,93$

$1,2,3$
(Genus Zapus) from Kan. sas

coibae, Cyclarhis gujanensis collaris, Atlapetes per-

sonatus

coloradensis, Capitophorus
$155 \cdot 162$

$147 \cdot 154$

70

175

177

185

185, 186

164

70

70
109

109

109

169

36

86

7

66

113

104

7

116,117

148

157

158

69

32
100

1.-4 
patonkus

compressus, Diopssiulus

Lepidocolaptes souleyetii Stemmiulus

Condylura cristata cristata contortus, Cyclorhabdus

Leptodesmus

Sola enorhabdus

Cook, Faxon IV.

cordobanus, Hexodontia ....

coronata, Hemiprocne longi-

pennis

corymboson, Eriognium ......

Corynorhinus

rafinesquii rafinesquii

Cotinga cayana cayennensis.

Cottam, Clarence

The National Wildlife Refuges

crassirostris, Oryzoborus

crassirostris

cristata, Condylura cristata cristatus, Sorex

crucifera, Eumenes crucifera cyathopus, Pterocheilus -...

Cryptogonodesmus clarus darlingtoni

Cryptotis parva elasson harlani parva

Crypturellus kerriae saltuarius

Cyclarhis gujanensis coibae

flavens

flaviventris

nicaraguae

perrygoi

subflavescens

Cyclora australis

Cyclorana slevini

Cyclorhabdus

annulus

contortus

cyclorhynchus, Hyla aurea...

$\mathrm{D}$

daflaensis, Actinodura nipalensis

darlingtoni, Cryptogonodes. mus

Davis, Malcolm, elected Vice President

Davis, Malcolm and McCabe, John

Exhibition of a live Snowy Owl

Day, Albert M.

Dayton, IV. A., reelected

Vice President

Deason, H. J., Member of Council

Deignan, H. G., reelected

$V$ ice President

deltana, Dendrocincla fuliginosa

deltanus, Celeus elegans

Dendrocincla fuliginosa atrirostris

barinensis
deltana
fuliginosa
lafresnayei
meruloides
phaeochroa
ridgwayi

rufo-olivacea

119

dentipes, Hirstionyssus

Dermanyssus arcuatus

devillei, Amazilia beryllina

diadema, Ochthoeca diadema

Didelphis virginiana virginiana

difficilis, Reithrodontomys

fulvescens

Diglossa duidae duidae ..... hitchcocki dilutior, Pipreola formosa Dinopium shorii auguste shorii

Diopssiulus compressus ___ 152

dispar, Lipaugus cineraceus. Sorex

dixiensis, Tamiascurus hudsonicus

dixoni, Saldula _-_______

Dolichodynerus tanynotus _. turgiceps vandykei

Donneily, Thomas W.

dracunculoides, Artemisia ...

Drake, C. J., and Hottes, F. C.

Three New Species of Sal. didae (Hemiptera)

dryas, Hemiprocne longipennis

duidae, Diglossa duidae...

Duvall, A. J reelected

Treasurer

61,62 $61,62,174$

62

131
70

70

70

134,135

105

148

$\mathrm{xi}$

118, 119

115,116

119

119

118, 119

119

119

119

118, 119

\section{E}

Eadie, G. L

Eklund, C R

Wildlife of the Ungava

Peninsula

erigoni, Aphis

echidna, Braggia

elegans, Celeus

elasson, Cryptotis parva__._.

electus, Hexodontia

esmeraldae, Lepidocolaptes

souleyetii

erga, Notiphilides

electus, Peridontodesmus

s, Philydo

eptesicus

fuscus fuscus

Eriogonium corymbosum

Eumenes crucifera bolli-

formis

crucifera.

flavitinctus

sculleni

verticalis tricinctus

Eurycea

latitans $51,52,53,54$

nana $51,53,55$

neotenes - $-51,52,53$

pterophila $\quad 51,52,53,55,56,57$

Eurydesmus $\quad 185,186,187$

agrestis —_ 186

angulatus $-186,187$

Euscarthmornis granadensis

federalis

120,121

granadensis

120,121 


\section{Proceedings of the Biological Society of Washington}

lehmanni
pyrrhops
Ewan, Joseph
New Records of Neotropi-
cal Gentianaceae

F

federalis, Euscarthmornis granadensis

fitzsimonsi, Agama kirkii ...

flavens, Cyclarhis gujanensis

flavicauda, Holothrips

flavinuchus, Melanerpes chrysogenys

flavitinctus, Eumenes cruci-

fera

flaviiventris, Cyclarhis gujanensis

flavobaltaetus, Pterocheilus

fontinalis, Sorex

Sorex cinereus

formosa, Pipreola formosa

Fox, Irving

A New Tyroglyphid Mite from Puerto Rico .........

frederici, Rhytipterna sim. plex

fremonti, Tamiasciurus

fuliginosa, Dendrocincla fuliginosa

fulvescens, Philydor

Reithrodontomys -......-.

fumeus, Sorex

Sorex fumeus

fungosus, Holothrips

furfurosus, Sclerurus rufigu. laris

fusca, Vaimosa

Cinclodes

fuscus, Eptesicus fuscus.......

\section{G}

Gardner, Marshall C.

A List of Maryland Mam. mals. (Part I. Marsupials and Insectivores.)

A List of Maryland Mammals. (Part II. Bats.)

Garrulax rufogularis gros=

venorl

occidentalis

rufogularis

striatus sikkim

striatus

vibex

Gee, Merle A

Big Game Management on the North Kaibab

geomydis, Hirstionyssus Geotrygon

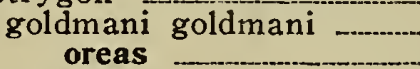
versicolor

gibbsii, Neurotrichus

Gilmore, Raymond M.

Whaling on the West

Coast

glabrum, Macrosiphum - -

glendalea, Brachoria

Glomeridesmus adjuntus

pectinatus

riveroi

trinidadensis
120,121

120,121

$163 \cdot 166$

120,121

127,128

174

142

109

79

62

199

66,68

66

$205 \cdot 208$

6
13,14

119

86

167,168

66

66
142

85

85
75

86

112

$65-68$

111-114

104

104

104

103

103

103

ix

31
173

173

172

173

32

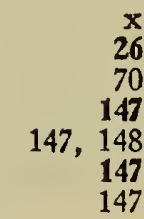

goldmani, Geotrygon goldmani

granadensis, Euscarthmornis granadensis

gratiosa, Ochthoeca diadema grosvenori, Garrulax rufogularis

guamensis, Saldula

guilarteus, Tridesmus

gujanensis, Cyclarhis

gularis, Mecocerculus leuco-

phrys

120,121

120

104

178, 179

148

61,62

122

$\mathrm{H}$

Hardy, Ross

A New Tree Squirrel from Central Utah

harlani, Cryptotis parva harterti, Mulleripicus pul-

verulentus

Helia nerio[i]des ramosissimus

hellmayri, Celeus elegans

helvolus, Reithrodomys fulvescens

Hemiprocne longipennis coronata

Herre, Albert W. C. T.

Two New Gobies from the Philippines with Notes on a Third Rare Goby

Hexodontia

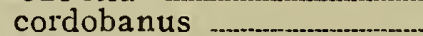

electus morelus

himalayana, Certhia himalayana

Hirstionyssus ................-. carnifex

dentipes

geomydis

hubbardi

obsoletus

occidentalis

hitchcocki, Diglossa duidae Hobbs, Horton $\mathrm{H}$.

A New Crayfish of the Genus Cambarellus from Texas (Decapoda, Astacidae)

hodgsoni, Megalaima _..........

Hoffman, Richard L.

Systematic Notes on Some Central American Milli-

peds

The Status of the Milliped Chelodesmus marxi Cook, and of the family name Chelodesmidae

Hood, J. Douglas

A New Hoplothrips from Cuba

Hooper, Emmet T.

Descriptions of Two Sub. species of Harvest Mice (Genus Reithrodontomys).. from Mexico

103

165

165

115,116

167

101

101

$73-76$

71

71

71

106

$31,32,33$

32

31

$31,32,34$

34
32

45

89.96

102

69-72

$185 \cdot 188$

139.146

Hoplothrips aciculatus bradleyi

flavicauda

fungosus

tyrannus

Hottes, F. C.

Descriptions of Western $\quad 167.170$

139, 142,142

143

142

142 
Colorado Aphididae

Descriptions of Some Aphididae from Carex

New Species of Aphididae

Hottes, F. C. and Drake,

C. J.

Three New Species of Saldidae (Hemiptera)

Howard, L. O.

hubbardi, Hirstionyssus -

Ichoronyssus

hudsonicus, Tamiasciurus -

hudsonius, Zapus

Zapus hudsonius

humeralis, Nycticeius hu. meralis

Vespertilio

hurdi, Pterocheilus (Onchoperocheilus)

Hyla aurea aurea

cyclorhynchus

ramiformes

ulongae

ulongensis

Hyla kinghorn latopalmata

\section{I}

Ichoronyssus hubbardi

incisus, Iomus ... infernatis, Reithrodontomys fulvescens

infima, Certhia himalayana... insectorum, Suidasia

insignis, Lepidocolaptes sou. leyetii

insularis, Microspirobolus.... intermedia, Rhytipterna simplex

Intonsagobius Van Clevei inyoensis, Pterocheilus .....Iodoplema isabellae isabellae

Iodopleura isabellae paraen= sis

Iomus

incisus

platanus

recentus

isabellae, Iodopreura isa

bellae

Ityphilus

lilacinus

Ivesia

carolinensis

tennesseensis

$\mathrm{J}$

Jameson, E. W., Jr.

Hirstionyssus obsoletus, a New Mesostigmatic Mite from Small Mammals of the Western United States (Acarina)

javanica, Saldula ... jesupi, Óchthoeca diadema Johnson, D. H., Member of Council

Jones, Thaddeus E.

Antarctic travelogue

Julus arboreus

jumana, Celeus

Celeus jumana
$15-30$

$35-42$

$97 \cdot 100$

$177 \cdot 184$

13

1,3

2,3

113

113

197, 198

134

134,135

134,135

131,133

134

131,132

132,133

31

149

167

106

205, 207

44

150

6
73

195

6

6

149

149

149

149

6

157

158

9
10
9

$31-34$

178,179

120

$\mathbf{x}$

ix

150

116

116, 117
K

kangrae, Megalaina zey.

lanica 102

kerriae, Crypturellus …_..._._.

kesocqua, Amphorophora _...

kinghorni, Hyla ___........ 131, 132

kirkii, Agama _..____ 127, 128

kirtlandi, Blarina brevicauda 67

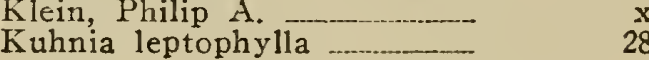

L

lafresnayei, Dendrocincla

fuliginosa

119

111

noctivagans

Lasiurus -

borealis borealis ___ 112

cinereus ................. 113

Lasser, Tobias - - - -

laticeps, Pterocheilus _-___ 197

latitans, Eurycea ____ $51,52,53,54$

latopalmata, Hyla ____ 132, 133

lehmanni, Euscarthmornis

grandensis Vespertilio compressus

esmeraldae ___

insignis

lineaticeps

littoralis

uaireni

Leptodesmus contortus

leptophylla, Kuhnia _

Lepus americanus americanus

$$
\text { bairdii }
$$$$
\text { seclusus }
$$

(eucophrys

lichtensteini, Amazilia beryl.

lina

lilacinus, Ityphilus _...................

Limnothlypis swainsonii _._. alta swainsonii reelected

Lincoln, F. C., reelected Exhibition of newspaper picture of a "sea monster," probably a whale, that had come ashore in Egypt Report of attendance at Tenth International Ornithological Congress

Report on conference on Alaska recently held in Washington

lineata Megalaima

lineaticeps, Lepidocolaptes

souleyetii

44
44

43,44

43,44

43,44

185

28

63,64

63,64

121

189,190

60

191, 158

192

192

$\mathbf{x}$

ix

$\mathrm{x}$

$x i$

102

Llomus

albanus

obscurus

43,44

149

Lipaugus cineraceus cineraceus

dispar
Liponyssus occidentalis wernecki 


\section{Proceedings of the Biological Society of Washington}

Lisianthus arcuatus brittonii macranthus nerioides ramosissimus

littoralis, Lepidocolaptes souleyetii

longirostris, Sorex

Sorex longirostris ....................

Lophoproctus

Loveridge, Arthur

A New Agamid Lizard (Agama kirkii fitzsimonsi) from Southern Rhodesia ... New Frogs of the Genera Cyclorana and Hyla from Southeastern Australia -... lucifugus, Myotis lucifugus. Vespertilio

M

macranthus, Lisianthus ..-.... Symbolanthus

Macrocarpaea

affinis

arborea

macrophylla

polyantha

thamnoides

valerii

macrophylla, Macrocarpaea.

Macrosiphum atripes

bonitum

caricis

cockerelii

glabrum

oljatae

rudbeckiarum

Mexiceuma

magnirostris, Oryzoborus

crassirostris

maniculatus, Peromyscus

marginalis, Pseudomasaris zonalis

maricaonus, Clayophilus

marmoratus, Microspiro-

bolus

marxi, Chelodesmus _-_._-_...

Eurydesmus

maxilimiani, Notiphilides

Oryzoborus crassirostris

McCabe, John and Davis,

Malcolm

Exhibition of a live Snowy Owl

Meanley, Brooke, and Bond, Gorman M.

A New Race of Swainson's Warbler from the Appalachian Mountains

Mecocerculus leucophrys...... brunneomarginatus . gularis

leucophrys ........-...-. nigriceps

notatus

palliditergum

parui

roraimae

setophagoides

medanensis, Suidasia

mediolus, Microspirobolus....

Megalaima hodgsoni
163,165

163

164

165

165

165

43,44

147

$127-130$

131-138

111

111

165

165

163

163,164

164

164

164

164

164
8,27

15

38

100

37,38

100

69

69

122, 124

32

78

151

185,186

186,187

158

123

ix

191-194

121,122 $121,122,123$

151, 152

102 lineata

zeylanica caniceps

kangrae

rana

Melanerpes chrysogenys ........ chrysogenys

flavinuchus mordensis

melanostictus, Nannophilus melanostomus, Otochryptops meridana, Ochthoeca dia.

dema

meruloides, Dendrocincla fuliginosa

Mexiceuma maculata

Mickey, Arthur B.

microdon, Reithrodontomys... Reithrodontomys micro-

Microsorex winnemana boyi winnemana

Microspirobolus insularis... marmoratus mediolus

toronus

millefolium Achilla

Miller, Alden $\mathrm{H}$.

mohun, Mulleripicus pul.

verulentus

Monarda

montaguae, Amazilia beryl-

lina

montana, Rudbeckia .............

Moore, Robert $\mathrm{T}$.

A New Race of the Spe. cies, Amazilia beryllina, from Southern Mexico. A New Race of Melanerpes chrysogenys from Central Mexico

morelensis, Melanerpes chry. sogenys

morelus, Hexodontia

morrisoni, Pterocheilus .....-...mossambica, Agama

mucuchiesi, Asthenes wyatti Mulleripicus pulverulentus harteri

mohun -

multifasciatus, Celeus undatus

mundus, Portoricellus.--..--..-

Myotis

lucifugus lucifugus

keenii septentrionalis sodalis

subulatus leibii

$\mathrm{N}$

nana, Eurycea

Nannophilus melanostictus.

Neoichoronyssus wernecki

nerio[i]des, Helia

nerioides, Symbolanthus

nesbitti, Suidasia -..-.-.-.-.

Nesticus

neotenes, Eurycea - -

Neurotrichus gibbsii

nerioides, Lisianthus ..............

nevadensis, Bassariscus as-

tutus

nicaraguae, Cyclarhis guja.
102

102

102

101, 102

109

109

109

109, 110

156

155

119, 120

119

69
69

69

167,170

169

67

67

150

151

151, 152

$151, \ldots 152$

125

103

39

59,60

100

59.60

109.110

109,11

71

195

127
86

103

103

118

156

111

111

111, 113

111

111

$51,53,55$

$31,32,33$

$31,32,33$

33
165

165

205, 206

$51,52,53$

32

165

203

155 
nensis

Nichols, J. T., and LaMonte, F. $\mathbf{R}$.

AeNew Varicorhinus from

61, 62 parui, Diglossa duidae parui, Mecocerculus

leucophrys

parva, Cryptotis parva Lake Tanganyika nigricaudus, Pterocheilus.... nigriceps, Mercocerculus leucophrys

ninae, 'Cambarellus

nipalensis, Actinodura nipa. lensis

noctivagans, Lasionycteris... noctivagans, V[espertilio] ... notatus Mercocerculus leu. cophrys

Notisorex

Notiphilides erga

Nuevona

i ...

$175-176$

$104,-105$

111

122

68

158

158 humeralis humeralis

\section{0}

obscurus, Llonus

Pipistrellus subfiavus --

Pteropus leucotis occidentalis, Garrulax rufogularis

Hirstionyssus

Liponyssus Ochthoeca diadema diadema gratiosa

\section{jesupi}

meridana

tovarensis

octavus, Bassariscus astutus

Odontopeltis

oljatae, Macrosiphum

O'Neill, Hugh, reelected

Vice President

opacula, Saldula

oreas, Geotrygon goldmani-

Oreopeleia

Ortiz de la Puente, Javier-

Oryzoborus crassirostris

crassirostris

magnirostris

maximiliani nuttingi

Otocryptops melanostomus

Otostigmus caraibicus

\section{$\mathrm{P}$}

Pachyramphus polychopterus cinereiventris

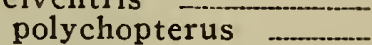

similis

tristis

paenacuceps, Pterocheilus

(Micropterocheilus)

Pagaea

ramosissima

palliditergum, Mecocerculus

leucophrys

pallidus, Zapus hudsonius....

palustris, Sorex

paraensis, Iodopleura

isabellae

panamenus, Chondrodesmus.

paraquensis, Atlapetes

personatus

parui, Atlapetes personatus.

$31,32,34$

104
32

$1,2,3,4$

47

46, 47
Nycticeius

obsoletus, Hirstlonyssus .......

Parascalops breweri parvus, Sorex

pauciflora, Stephanomeria -

pectinatus, Glomeridesmus...

Pectiniunguis

Peridontodesmus ...................... electus

Peromyscus maniculatus _...

perrygol, Cyclarhis

gujanensis

personatus, Atlapetes

personatus

phaeochroa, Dendrocincla
fuliginosa

Phelps, William H., and

Phelps, William H., Jr.

Three New Subspecies of

Birds from Venezuela

Seven New Subspecies of Venezuelan Birds

Philydor

erythronotus

fulvescens

subfulvus

phoenicurus, Pseudattila

Pipistrellus

hylloscopus affinis virens

subaffinis arcanus ........

subflavus obscurus subflavus

Pipreola formosa dilutior formosa rubidior

Pittier, Henry

platanus, Iomus

Plecotus rafinesquii ..........................

poliotis, Actinodura

nipalensis

polyantha, Macrocarpaea ..... polychopterus, Pachyram-

phus polychopterus

Portoricellus mundus

portoricensis, Tridesmus -

Portoricona adjunta socia

Potter, Floyd E., Jr., Burger, $W$. Leslie, and Potter, Floyd E.

Another Neotenic Eurycea from the Edwards Plateau

Priodesmus

7

Prothorax

projectus, Symmorphus

provancheri, Pterocheilus ... pruinosus, Pterocheilus Pterocheilus provancheri prunifoliae, Rhopalosiphum pselaphon, Pteropus

Pseudattila phoenicurus

Pseudomasaris zonalis albopictus marginalis

Pterocheilus

acuceps

albotinctus

cyathopus

flavobalteatus

inyoensis
45,46

121, 122

67

67

147, 148

157

71

118, 119

$43 \cdot 50$

115-126

85,87

87
86

86

87

112

106

106

105

112

112 


\section{Proceedings of the Biological Society of Washington}

acuceps
(Megapterocheilus)
bradleyi
(Micropterocheilus)
paenacuceps
provancheri albotinc-
tus
sparsipunctatus
morrisoni
nigricaudus
(Onchoperochellus)
hurdi
sculleni
provancheri
pruinosus
pruinosus
seneconis
texanus
trachysonus
trichogaster

pterophila, Eurycea ..51, 52, 53, 55, 56, 5

Pteropus

anetianus aorensis

aorensis

leucotis

obscurus

pselaphon

samöensis

$v$ [ampyrus] lanensis -

puer, Cambarellus

punctulatus, Sorex palustris

pyrrhops, Euscarthmornis

granadensis

\section{$\mathbf{R}$}

rafinesquei, Zapus hudsonius rafinesquii, Corynorhinus

rafinesquii

Plecotus

ramosissima, Pagaea

ramosissimus,

Lisianthus

ramiformes, Hyla aurea -

rana, Megalaima zeylanica..

raptor, Bassariscus astutus.

recentus, lomus

Rehder, H. A., elected Corresponding Secretary ...

Rhexiphloeus

Rhinocricidae

Rhinocricus approximans arboreus simulans

Reithrodontomys

chrysopis

fulvescens

helvolus

difficilis

infernatis

toltecus

microdon

albilabris
microdon
wagneri

rufescens

Rhacodesmus

Rhopalosiphum prunifoliae ...

Rhytipterna simplex

frederici

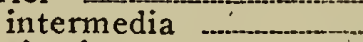
simplex

ribis, Aphis

richardsoni, Tamiasciurus ....

Tamiasciurus hudsonicus

ridgwayi, Dendrocincla

fuliginosa
195

195, 196

200

199

198

195

195

197, 198

196, 197

199

199

199

199

196

197, 198

196

189
189

189,190

189,190

190

189

189

189

89

67

120,121

$1,2,3$

113

113

165

165

165

134, 135

101, 102

203

149

$\mathbf{x}$

71

69

150

150
69

167

169

167, 168

167

168

167

168

167,170

169

169

169

169

185

35,36

6

6
6

100

14

14

119
Ripley, S. Dillon

New Birds from Nepal and the Indian Region

riveroi, Ballophilus Glomeridesmus

$101-108$

robusta, Shorea

103

roraimae, Mecocerculus

leucophrys

$121,122,123$

ruandae, Varicorhinus

rubi, Amphorophora -....

rubidior, Pipreola formosa

Rudbeckia montana

rudbeckiarum, Macrosiphum

rufescens, Reithrodontomys .

rufimenta, Cinclosoma

rufo-olivacea, Dendrocincla

fuliginosa

rufogularis, Garrulax

rufogularis

Russell, Ralph

Russell, Robert J., Jr. ........

98,100

6

100

100

169

104

119

104

xi

$x i$

S

Saldidae

Saldula balnearum _._._. dixoni

guamensis

javanica

opacula

scitula

subsolans

ventralis

saltuarius, Crypturellus

samöensis, Pteropus

Sanborn, Colin Campbell

New Philippine Fruit Bats

sanctae-martae, Asthenes

wyatti

Scalopus aquaticus aquaticus breweri

Schendylota

$$
\text { varipicta }
$$

sclimitti, Cambarellus .--

scitula, Saldula

Sclerurus rufigularis

furfurosus

Scott, Frederic R.

sculleni, Eumenes

Pterocheilus (Onchopterocheilus)

seclusus, Lepus americanus..

sectilis, Tridesmus

seneconis, Pterocheilu

septentrionalis, Myotis

$$
\text { keenii }
$$

Vespertilio gryphus var.

setophagoides, Mecocerculus

leucophrys

Shorea robusta

shorii, Dinopium

Dinopium shorii

shufeldtii, Cambarellus

sikkimensis, Garrulax

striatus

similis, Pachyramphus

polychopterus

Simmons, Edward A.

simplex, Rhytipterna

simplex

simulans, Rhinocricus _-

slevini, Cyclorana

Smith, Albert C.

A botanist in $\mathrm{Fiji}$

Smith, Hobart M., Burger,

W. Leslie, and Potter,

Floyd E., Jr.
177

179

177,180

178, 179

178,179

179

179, 180

177

180

171

189

189.190

85

65,66

66

155

89,92

179, 180

85

$x i$
78

196,_197

63,64

149

199

111, 113

111

12

103

102

102

$89,92,93$

103

7

6

69

131 
Another Neotenic Eurycea from the Edwards Plateau socia, Portoricona

sodalis, Myotis

Solaenorhabdus

contortus

Sorex aquaticus

carolinensis

cinereus cinereus fontinalis

cristatus

dispar

fontinalis ______._._.

fumeus

fumeus

longirostris

longirostris

palustris punctulatus

parvus

trowbridgii

sparsipunctatus, Pterochei-

lus (Micropterodheilus)

Spirobolus (Rhinocricus)

arboreus

Stager, Kenneth E.

A New Cacomistle from

Southeastern California ..

Stemmiulus compressus .....

Stephanomeria pauciflora..

Stickel, W. H., Member of

Council

striatus, Garrulax striatus

Strongylodesmus

subflavescens, Cyclarhis

gujanensis

subflavus, Pipistrellus

subflavus

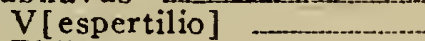
Philydor

subsolans, Saldula

subulatus leibii, Myotis _.....

Suidasia Insectorum

medanensis

nesbitti

swainsonii, Limnothlypis ... Limnothlysis swainsonii.

Swift, L. W., Member of

Council

Symbolanthus

macranthus

nerioides

Symmorphus projectus -

Synallaxis wyatti

$\mathrm{T}$

tahasa, Aphis

talavera, Tamanka

Tamiasciurus

freminti

hudsonicus

dixiensis

richardsoni

ventorum

wasatchensis

tanahasa, Aphis

tanganicae, Varicorhinus

Tanophilus ......

tanynotus, Dolichodynerus -

tennesseensis, Ivesia

texanus, Pterocheilus

thamnoides, Macrocarpaea ...

Thone, Frank

tigwatensa, Amphorophora....

timpanogos, Utamphara.

phora
$51 \cdot 58$

159

111

70

70

65

67

66
66

66

66,68

66

66

67

67
Todd, W. E. Clyde

Critical Notes on the

Cotingas

Two Apparently New

Oven-Birds from Colombia

toltecus, Reithrodontomys

fulvescens

toronus, Algunguis

Microspirobolus

tovarensis, Ochthoeca diadema

Toxoptera viridi-rubra

Trachyphloeus

trachysomus, Pterocheilus -

trichogaster, Pterocheilus _..

tricinctus, Eumenes

verticalis

Tridesmus guilarteus

portoricensis sectilis .

trinidadensis, Glomerides-

mus

tristis, Pachyramphus

polychopterus

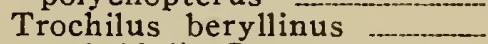

trowbridgii, Sorex

turgiceps, Dolichodynerus -.

tyrannus, Hoplothrips

U

uaireni, Lepidocolaptes

souleyetii

ulongae, $\mathrm{Hyla}$ area

ulongensis,

uncompahgrensis, Braggia -.

undatus, Celeus undatus .....

urovaneta, Aphis

Utamphorophora timpanogos

85.88

168

157

151, 152

120

36

71

197, 198

196

79
148

149

149

147

7

59

80,81

142

43, 44

131,133

134

18,20

117, 118

38,39

V

Vaimosa fusca zebrinus

valenciana, Certhiaxis

cinnamonea

valerii, Macrocarpaea

Van Clevel, Intonsagobins...

vandykei, Dolichodynerus ...

Varicorhinus chapini

ruandae

tanganicae

variplcta, Schendylota

ventorum, Tamiasciurus

hudsonicus

ventralis, Saldula

versicolor, Geotrygon _-__

Vespertilio

borealis

cinereus ........-

gryphus var. septentrionalis

humeralis

leibii

lucifugus ....................

$V$ [espertilio], noctivagans_ subflavus

vibex, Garrulax striatus ....

viola, Amazilia beryllina ....

vinctura, Actinodura

nipalensis

virens, Phylloscopus

maculipennis

virginiana, Didelphis

Didelphis virginiana .....

viridi-rubra.. Toxoptera 
218 Proceedings of the Biological Society of Washington

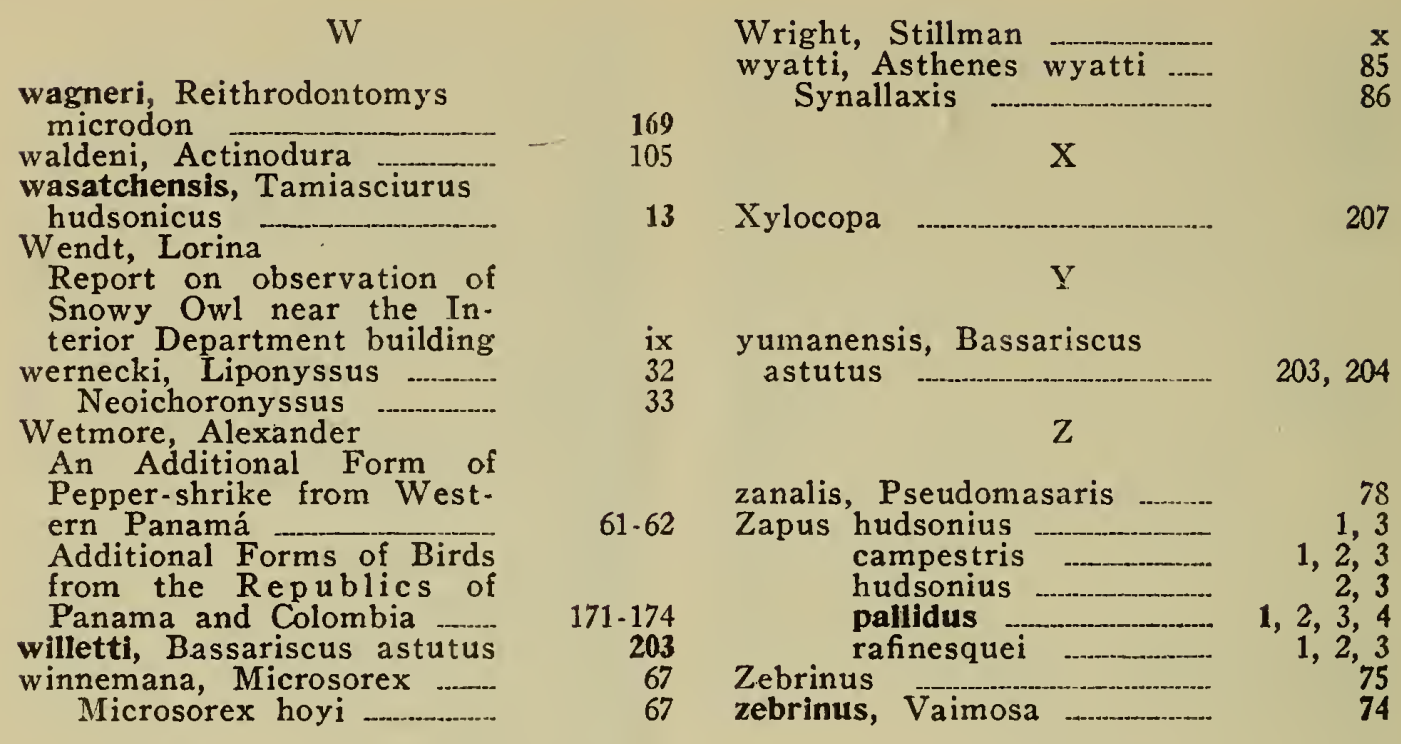








SMITHSONIAN INSTITUTION LIBRARIES

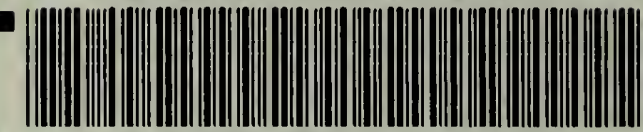
39088012051892 